National Water-Quality Assessment Program

Nutrient Concentrations and Loads

in the Northeastern United States -

Status and Trends, 1975-2003

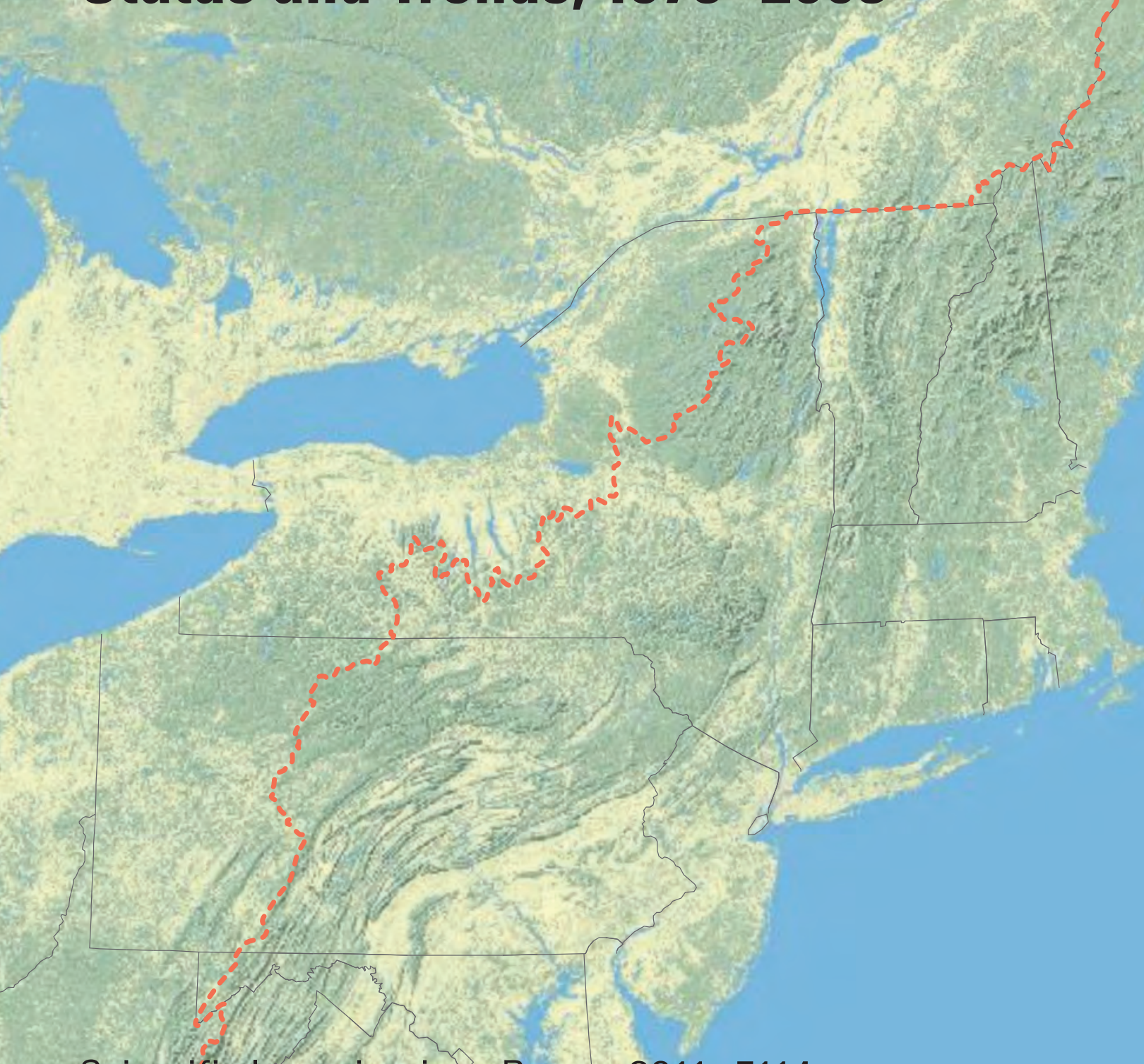

Scientific Investigations Report 2011-5114

U.S. Department of the Interior

U.S. Geological Survey 
Cover. The northeastern United States and southeastern Canada, from the Natural Earth physical map for the world, U.S. National Park Service; with state lines and study area boundary added. 


\section{Nutrient Concentrations and Loads in the Northeastern United States- Status and Trends, 1975-2003}

By Elaine C. Todd Trench, Richard B. Moore, Elizabeth A. Ahearn, John R. Mullaney, R. Edward Hickman, and Gregory E. Schwarz

National Water-Quality Assessment Program

Scientific Investigations Report 2011-5114 


\section{U.S. Department of the Interior \\ KEN SALAZAR, Secretary \\ U.S. Geological Survey \\ Marcia K. McNutt, Director}

U.S. Geological Survey, Reston, Virginia: 2012

For more information on the USGS - the Federal source for science about the Earth, its natural and living resources, natural hazards, and the environment, visit http://www.usgs.gov or call 1-888-ASK-USGS.

For an overview of USGS information products, including maps, imagery, and publications, visit http://www.usgs.gov/pubprod

To order this and other USGS information products, visit http://store.usgs.gov

Any use of trade, product, or firm names is for descriptive purposes only and does not imply endorsement by the U.S. Government.

Although this report is in the public domain, permission must be secured from the individual copyright owners to reproduce any copyrighted materials contained within this report.

Suggested citation:

Trench, E.C.T., Moore, R.B., Ahearn, E.A., Mullaney, J.R., Hickman, R.E., and Schwarz, G.E., 2012, Nutrient concentrations and loads in the northeastern United States-Status and trends, 1975-2003: U.S. Geological Survey Scientific Investigations Report 2011-5114, 169 p. (Also available at http://pubs.usgs.gov/sir/2011/5114.) 


\section{Foreword}

The U.S. Geological Survey (USGS) is committed to providing the Nation with reliable scientific information that helps to enhance and protect the overall quality of life and that facilitates effective management of water, biological, energy, and mineral resources (http://www.usgs.gov/). Information on the Nation's water resources is critical to ensuring long-term availability of water that is safe for drinking and recreation and is suitable for industry, irrigation, and fish and wildlife. Population growth and increasing demands for water make the availability of that water, measured in terms of quantity and quality, even more essential to the long-term sustainability of our communities and ecosystems.

The USGS implemented the National Water-Quality Assessment (NAWOA) Program in 1991 to support national, regional, State, and local information needs and decisions related to water-quality management and policy (http://water.usgs.gov/nawqa). The NAWQA Program is designed to answer: What is the quality of our Nation's streams and groundwater? How are conditions changing over time? How do natural features and human activities affect the quality of streams and groundwater, and where are those effects most pronounced? By combining information on water chemistry, physical characteristics, stream habitat, and aquatic life, the NAWQA Program aims to provide science-based insights for current and emerging water issues and priorities. From 1991 to 2001, the NAWQA Program completed interdisciplinary assessments and established a baseline understanding of water-quality conditions in 51 of the Nation's river basins and aquifers, referred to as Study Units (http://water.usgs.gov/nawqa/studies/ study_units.html ).

In the second decade of the Program (2001-2012), a major focus is on regional assessments of waterquality conditions and trends. These regional assessments are based on major river basins and principal aquifers, which encompass larger regions of the country than the Study Units. Regional assessments extend the findings in the Study Units by filling critical gaps in characterizing the quality of surface water and groundwater, and by determining water-quality status and trends at sites that have been consistently monitored for more than a decade. In addition, the regional assessments continue to build an understanding of how natural features and human activities affect water quality. Many of the regional assessments employ modeling and other scientific tools, developed on the basis of data collected at individual sites, to help extend knowledge of water quality to unmonitored, yet comparable areas within the regions. The models thereby enhance the value of our existing data and our understanding of the hydrologic system. In addition, the models are useful in evaluating various resource-management scenarios and in predicting how our actions, such as reducing or managing nonpoint and point sources of contamination, land conversion, and altering flow and (or) pumping regimes, are likely to affect water conditions within a region.

Other activities planned during the second decade include continuing national syntheses of information on pesticides, volatile organic compounds (VOCs), nutrients, trace elements, and aquatic ecology; and continuing national topical studies on the fate of agricultural chemicals, effects of urbanization on stream ecosystems, bioaccumulation of mercury in stream ecosystems, effects of nutrient enrichment on stream ecosystems, and transport of contaminants to production wells.

The USGS aims to disseminate credible, timely, and relevant science information to address practical and effective water-resource management and strategies that protect and restore water quality. We hope this NAWQA publication will provide you with insights and information to meet your needs, and will foster increased citizen awareness and involvement in the protection and restoration of our Nation's waters.

The USGS recognizes that a national assessment by a single program cannot address all water-resource issues of interest. External coordination at all levels is critical for cost-effective management, regulation, and conservation of our Nation's water resources. The NAWQA Program, therefore, depends on advice and information from other agencies_-Federal, State, regional, interstate, Tribal, and local-as well as nongovernmental organizations, industry, academia, and other stakeholder groups. Your assistance and suggestions are greatly appreciated. 
THIS PAGE INTENTIONALLY LEFT BLANK 


\section{Contents}

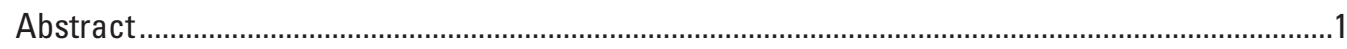

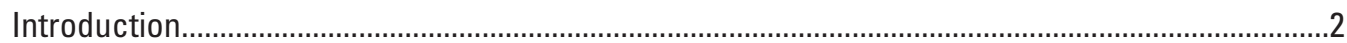

Regional Synthesis Studies of the U.S. Geological Survey National Water Quality

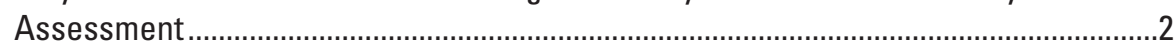

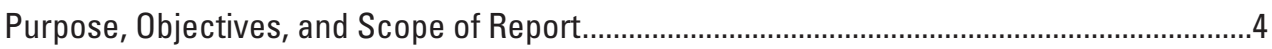

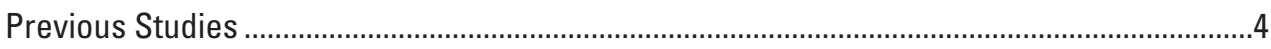

Environmental Setting of the Northeastern United States ............................................................

Population Density and Land Use .....................................................................................

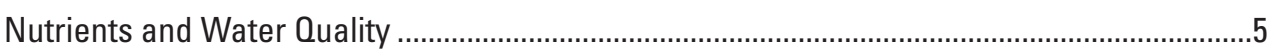

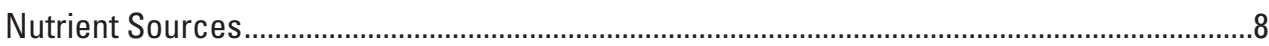

Management Context for Nutrient-Related Water-Quality Impairments ........................................8

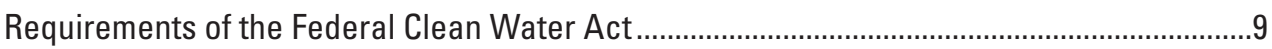

Water-Quality Criteria and Standards for Nutrients ............................................................

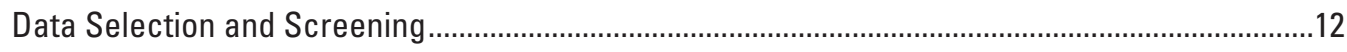

Data from U.S. Geological Survey Monitoring Programs ...................................................12

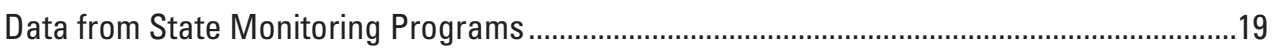

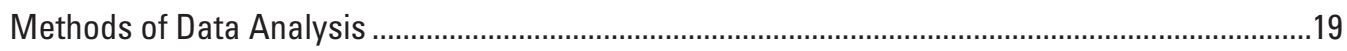

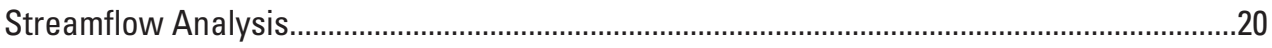

Analysis of Trends in Nutrient Concentrations, Nutrient Loads, and Streamflow ..................21

Flow-Adjusted Trend Analysis with Tobit Regression ...................................................21

Instream Trend Analysis with Coupled Statistical Streamflow and Water-

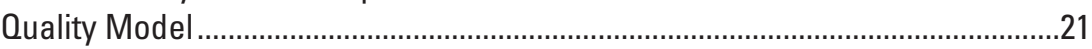

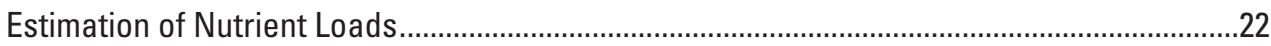

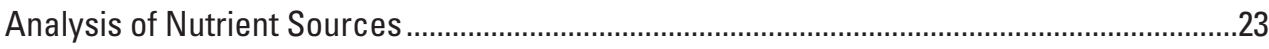

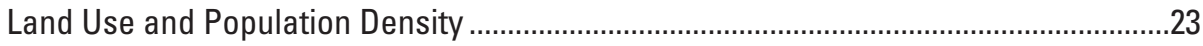

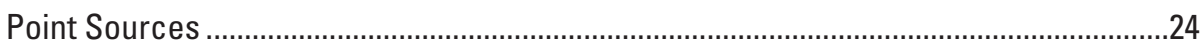

Streamflow Conditions in the Northeastern United States ........................................................26

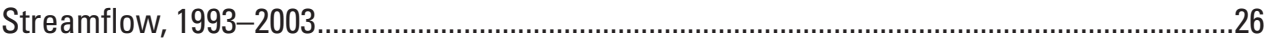

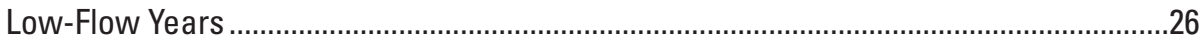

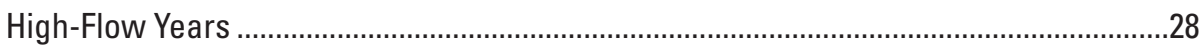

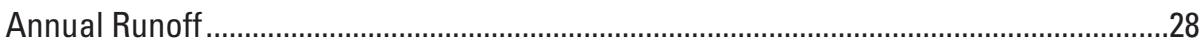

Streamflow During Sampling Years in National USGS Programs ..................................28

Comparison of 1993-2003 Period to Long-Term Streamflows ................................................29

Long-Term Variability in Annual Mean Streamflow ....................................................29

Regional and Temporal Variability in Runoff ................................................................

Effects of Streamflow on Water-Quality Variability ..............................................................

Effects of Streamflow Conditions on Trend Analysis .......................................................36

Effects of Streamflow Conditions on Load Estimation.....................................................37

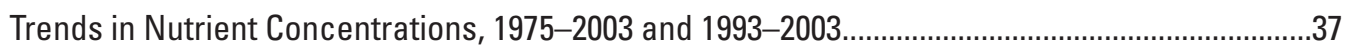

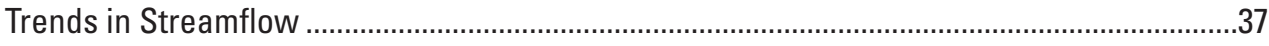

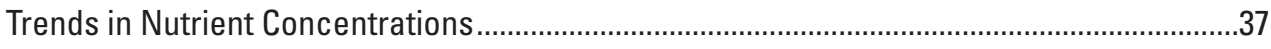

Trends in Flow-Adjusted Nutrient Concentrations ..........................................................38

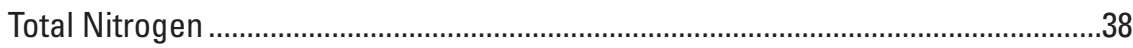


Dissolved Ammonia Nitrogen and Total Kjeldahl Nitrogen.......................................38

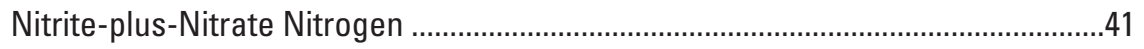

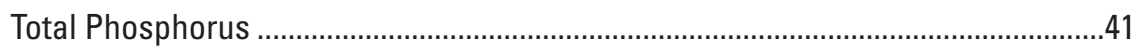

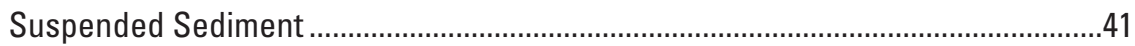

Trends in Flow-Adjusted Concentrations of Nutrients in Large Drainage Basins.

Trends in Modeled Instream Nutrient Concentrations....................................................46

Nutrient Concentrations in Undeveloped Drainage Basins ...................................46

Modeled Instream Nutrient Concentrations in Relation to Proposed Nutrient Criteria

Modeled Instream Nutrient Concentrations and Trends in Large Drainage Basins.....

Comparing Trend Results from Different Periods of Record ...................................................56

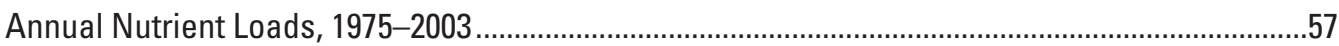

Relation of Nutrient Loads to Stream Discharge Conditions, 1975-2003 ...............................57

Effects of Calibration Period on Load Estimates ....................................................................63

Effects of Storms on Annual Nutrient Loads .......................................................................63

Trends in Nutrient Loads, 1975-2003 and 1993-2003 …......................................................64

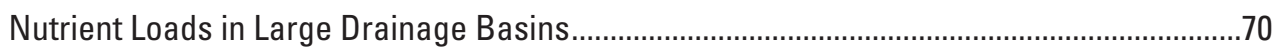

Relation of Nutrient Trends, Loads, and Yields to Nutrient Sources..............................................77

Land Use and Population Density .....................................................................................

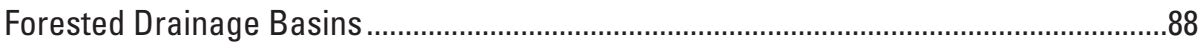

Agricultural Drainage Basins ...............................................................................99

Urbanized Drainage Basins .........................................................................................

Overall Effects of Urban and Agricultural Development...............................................95

Large Drainage Basins that Integrate Numerous Land Uses and Nutrient Sources.....95

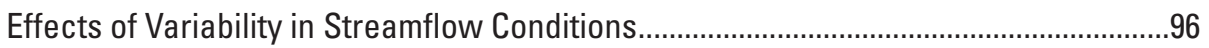

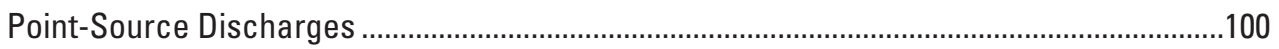

Quinebaug River Basin in Connecticut, Massachusetts, and Rhode Island ................105

Raritan River Basin in Northern New Jersey.................................................................109

Patuxent River Basin in Maryland …….....................................................................117

James River Basin in Central Virginia ...........................................................................121

Summary, Conclusions, and Challenges for Management of Water Resources ...........................124

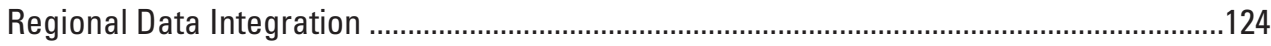

Trends in Flow-Adjusted Nutrient Concentrations............................................................124

Instream Concentration Trends in Relation to Proposed Nutrient Criteria ............................125

Annual Nutrient Loads and Trends in Loads ..................................................................125

Effects of Land Use and Population Density on Nutrient Yields ..........................................126

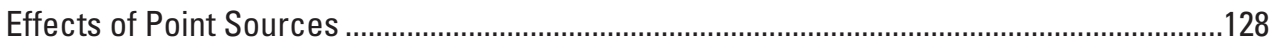

Challenges for Management of Nutrients in the Northeastern United States......................129

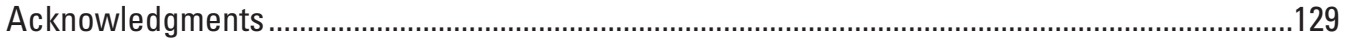

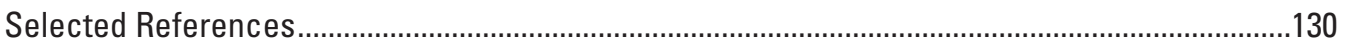

Appendix 1. Methods-Data Retrieval, Screening, and Modification ......................................149

Appendix 2. Methods-Stations Used in Analysis of Discharge Conditions (CD-ROM) ...........153

Appendix 3. Methods-Flow-Adjusted Trend Analysis with Tobit Regression in the 
Appendix 4. Methods-Trend Analysis Using Coupled Statistical Model of Streamflow and Water Quality.....

Appendix 5. Results - Trends in Streamflow, 1975-2003 and 1993-2003 (CD-ROM) .................163

Appendix 6. Results-Trend Analysis on Flow-Adjusted Nutrient Concentrations, 1975-2003

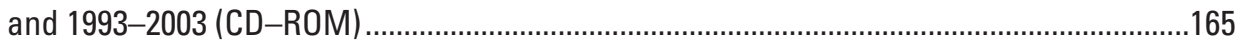

Appendix 7. Results-Annual Load Estimates, 1975-2003, 1993-2003, and Varied Periods

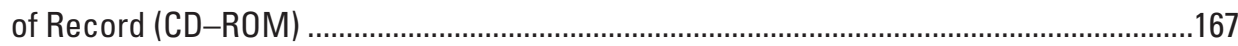

Appendix 8. Results-Trend Analysis on Nutrient Loads, 1975-2003 and 1993-2003 (CD-ROM).

\section{Figures}

1. Map showing major features of the northeastern region study area, including study area boundary, state lines, major coastal features, major cities, major rivers, and National Water Quality Assessment (NAWOA) study units 3

2. Map showing regional land-use and land-cover characteristics...................................6

3. Map showing nutrient ecoregions in the northeastern United States ............................11

4. Map showing locations of 130 U.S. Geological Survey water-quality monitoring stations evaluated in this study.

5. Bar graphs of long-term annual mean streamflows at selected stations, 1970-2004 ....30

6. Graphs showing characteristic plots of nutrient concentration as a function of discharge at selected stations, showing land-use and point-source effects..................32

7. Maps showing trends in flow-adjusted concentrations of total nitrogen, (A) 1975-2003 and (B) 1993-2003

8. Maps showing trends in flow-adjusted concentrations of nitrite-plus-nitrate nitrogen, (A) 1975-2003 and (B) 1993-2003...

9. Maps showing trends in flow-adjusted concentrations of total phosphorus, (A) 1975-2003 and (B) 1993-2003.

10. Graph showing total phosphorus concentrations as a function of time, Patuxent River near Bowie, Md., 1979-2003.

11. Graphs of nitrogen constituent concentrations as a function of time at selected stations

12. Graphs of total phosphorus concentrations as a function of time at selected stations

13. Graph of nitrite-plus-nitrate concentrations as a function of time, Potomac River at Chain Bridge, Washington, D.C.

14. Bar graphs of annual mean discharges and annual nutrient loads for selected stations and constituents with no trend in load....

15. Bar graphs of long-term annual nutrient loads at selected stations with significant trends in load.

16. Bar graphs of long-term annual nutrient loads in the five largest drainage basins of the region, 1975-2003

17. Graphs showing ranges for minimum, median, and maximum nutrient yields in relation to the percentage of developed land in a drainage basin

18. Boxplots showing annual yields for $(A)$ total nitrogen and $(B)$ total phosphorus for 46 stations during 1993-2003

19. Graphs showing annual nutrient yields in selected water years, including 2000 (median flow year), 2002 (dry year), and 2003 (wet year), as a function of the percentage of developed land in a drainage basin . 
20. Map showing drainage basins selected for analysis of point sources in relation to nutrient concentrations, loads, and yields

21. Map showing monitoring stations and point-source locations in the Quinebaug River Basin.

22. Bar graphs showing annual stream loads of nutrients and point-source loads of total phosphorus in the Quinebaug River Basin

23. Map showing monitoring stations and point-source locations in the Raritan River Basin

24. Bar graphs showing annual stream loads and point-source loads of nutrients in the Raritan River Basin

25. Map showing monitoring stations and point-source locations in the Patuxent and James River Basins

26. Bar graphs showing annual stream loads and point-source loads of nutrients in the Patuxent River Basin

27. Bar graphs showing annual stream loads and point source loads of nutrients in the James River Basin

\section{Tables}

1. Population density of states in the northeastern United States ........................................

2. Land-use characteristics of the northeastern region of the United States.......................7

3. Land-use characteristics of selected major drainage basins in the northeastern United States

4. Nutrient criteria proposed by the U.S. Environmental Protection Agency for ecoregions in the northeastern United States.

5. Characteristics of 130 U.S. Geological Survey (USGS) water-quality monitoring stations evaluated in this study.....

6. Water-quality constituents retrieved for study, including constituent name, parameter code, and listing of parameter codes used in analyses in this report.

7. Land-use categories for $\mathbf{1 3 0}$ drainage basins evaluated for trends, loads, and yields in the northeastern United States

8. Land-use and population characteristics for $\mathbf{1 3 0}$ monitored drainage basins in the northeastern United States

9. Estimated numbers of point sources discharging nutrients in the northeastern United States study area

10. Summary of data sources and availability of point-source data for selected drainage basins

11. New minimum and maximum annual mean flows during 1993-2003 for selected stations with 60 or more years of record.

12. Sampling years in NAWQA study units and ending water years at NASOAN stations in the Northeast.

13. Summary of trend results for flow-adjusted concentrations of nutrients and suspended sediment, 1975-2003 and 1993-2003

14. Trends in flow-adjusted nutrient concentrations and nutrient loads in large drainage basins, 1975-2003 and 1993-2003

15. Trend results for modeled instream nutrient concentrations, proposed criteria for total nitrogen and total phosphorus, modeled reference concentrations for nutrients, and modeled changes in concentration for 47 streams in the northeastern region, 
16. Summary of trend results for modeled instream concentrations, 1975-2003 and 1993-2003.

17. Flow-weighted nutrient concentrations and nutrient yields in undeveloped basins evaluated in a national study...

18. Summary of trends in nutrient and suspended sediment loads, 1975-2003 and 1993-2003

19. Summary statistics for total nitrogen loads in the five largest drainage basins in

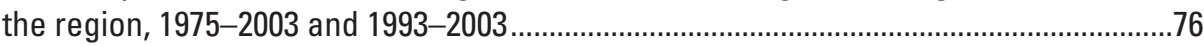

20. Summary statistics for total nitrogen yields by station, 1993-2003...................................78

21. Summary statistics for total phosphorus yields by station, 1993-2003 ...........................81

22. Summary statistics for total nitrogen and total phosphorus yields for all stations

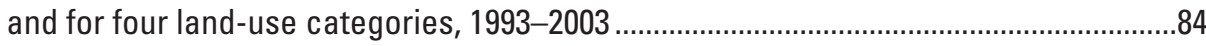

23. Summary statistics for total nitrogen yields by water year, 1993-2003...........................96

24. Summary statistics for total phosphorus yields by water year, 1993-2003.....................97

25. Summary of point source information and basin characteristics in drainage basins selected for analysis 101

26. Summary of trends in flow-adjusted nutrient concentrations in drainage basins selected for analysis of point sources 103

27. Summary of trends in nutrient loads in drainage basins selected for analysis of point sources. 


\section{Conversion Factors, Datum, and Acronyms}

\begin{tabular}{|c|c|c|}
\hline Multiply & By & To obtain \\
\hline \multicolumn{3}{|c|}{ Length } \\
\hline inch (in.) & 2.54 & centimeter $(\mathrm{cm})$ \\
\hline inch (in.) & 25.4 & millimeter (mm) \\
\hline foot $(\mathrm{ft})$ & 0.3048 & meter $(\mathrm{m})$ \\
\hline mile (mi) & 1.609 & kilometer (km) \\
\hline \multicolumn{3}{|c|}{ Area } \\
\hline square mile $\left(\mathrm{mi}^{2}\right)$ & 259.0 & hectare (ha) \\
\hline square mile $\left(\mathrm{mi}^{2}\right)$ & 2.590 & square kilometer $\left(\mathrm{km}^{2}\right)$ \\
\hline \multicolumn{3}{|c|}{ Volume } \\
\hline gallon (gal) & 3.785 & liter (L) \\
\hline gallon (gal) & 0.003785 & cubic meter $\left(\mathrm{m}^{3}\right)$ \\
\hline gallon (gal) & 3.785 & cubic decimeter $\left(\mathrm{dm}^{3}\right)$ \\
\hline million gallons (Mgal) & 3,785 & cubic meter $\left(\mathrm{m}^{3}\right)$ \\
\hline cubic foot $\left(\mathrm{ft}^{3}\right)$ & 28.32 & cubic decimeter $\left(\mathrm{dm}^{3}\right)$ \\
\hline cubic foot $\left(\mathrm{ft}^{3}\right)$ & 0.02832 & cubic meter $\left(\mathrm{m}^{3}\right)$ \\
\hline \multicolumn{3}{|c|}{ Flow rate } \\
\hline cubic foot per second $\left(\mathrm{ft}^{3} / \mathrm{s}\right)$ & 0.02832 & cubic meter per second $\left(\mathrm{m}^{3} / \mathrm{s}\right)$ \\
\hline $\begin{array}{l}\text { cubic foot per second per square mile } \\
{\left[\left(\mathrm{ft}^{3} / \mathrm{s}\right) / \mathrm{mi}^{2}\right]}\end{array}$ & 0.01093 & $\begin{array}{l}\text { cubic meter per second per square } \\
\text { kilometer }\left[\left(\mathrm{m}^{3} / \mathrm{s}\right) / \mathrm{km}^{2}\right]\end{array}$ \\
\hline million gallons per day (Mgal/d) & 0.04381 & cubic meter per second $\left(\mathrm{m}^{3} / \mathrm{s}\right)$ \\
\hline inch per year (in/yr) & 25.4 & millimeter per year (mm/yr) \\
\hline \multicolumn{3}{|c|}{ Mass } \\
\hline pound, avoirdupois (lb) & 0.4536 & kilogram (kg) \\
\hline ton, short $(2,000 \mathrm{lb})$ & 0.9072 & megagram (Mg) \\
\hline ton per year (ton/yr) & 0.9072 & megagram per year $(\mathrm{Mg} / \mathrm{yr})$ \\
\hline ton per year (ton/yr) & 0.9072 & metric ton per year \\
\hline
\end{tabular}

Temperature in degrees Celsius $\left({ }^{\circ} \mathrm{C}\right)$ may be converted to degrees Fahrenheit $\left({ }^{\circ} \mathrm{F}\right)$ as follows:

$$
{ }^{\circ} \mathrm{F}=\left(1.8 \times{ }^{\circ} \mathrm{C}\right)+32
$$

Temperature in degrees Fahrenheit $\left({ }^{\circ} \mathrm{F}\right)$ may be converted to degrees Celsius $\left({ }^{\circ} \mathrm{C}\right)$ as follows:

$$
{ }^{\circ} \mathrm{C}=\left({ }^{\circ} \mathrm{F}-32\right) / 1.8
$$

Vertical coordinate information is referenced to the North American Vertical Datum of 1988 (NAVD 88).

Horizontal coordinate information is referenced to the North American Datum of 1983 (NAD 83). Altitude, as used in this report, refers to distance above the vertical datum.

Concentrations of chemical constituents in water are given either in milligrams per liter (mg/L) or micrograms per liter $(\mu \mathrm{g} / \mathrm{L})$. 


\section{List of Acronyms}

\begin{tabular}{|c|c|}
\hline AG & Agricultural \\
\hline AMLE & Adjusted Maximum Likelihood Estimation \\
\hline AU & Agricultural/Urban \\
\hline BASINS & Better Assessment Science Integrating point \& Non-point Sources \\
\hline BNR & Biological Nitrogen Removal \\
\hline CBP & Chesapeake Bay Program \\
\hline CTDEP & Connecticut Department of Environmental Protection \\
\hline CWA & Clean Water Act \\
\hline DMR & Discharge Monitoring Report \\
\hline ESTREND & Estimate Trend \\
\hline HBN & Hydrologic Benchmark Network \\
\hline HUC & Hydrologic Unit Code, or Hydrologic Unit \\
\hline LAD & Least Absolute Deviation \\
\hline LOADEST & Load Estimator \\
\hline LOESS & Locally Weighted Scatterplot Smoothing \\
\hline MCL & Maximum Contaminant Level \\
\hline MLE & Maximum Likelihood Estimation \\
\hline NASQAN & National Stream Quality Accounting Network \\
\hline NAWQA & National Water Quality Assessment \\
\hline NJDEP & New Jersey Department of Environmental Protection \\
\hline NLCDe & 1992 National Land Cover Dataset, enhanced 2005 \\
\hline NOAA & National Oceanic and Atmospheric Administration \\
\hline NPDES & National Pollutant Discharge Elimination System \\
\hline NWIS & National Water Information System \\
\hline PCS & Permit Compliance System \\
\hline RIM & River Input Monitoring \\
\hline SIC & Standard Industrial Classification \\
\hline TMDL & Total Maximum Daily Load \\
\hline UA & Urban/Agricultural \\
\hline UN & Undeveloped \\
\hline UR & Urban \\
\hline USEPA & United States Environmental Protection Agency \\
\hline USGS & U.S. Geological Survey \\
\hline VOC & Volatile organic compound \\
\hline
\end{tabular}


THIS PAGE INTENTIONALLY LEFT BLANK 


\title{
Nutrient Concentrations and Loads in the Northeastern United States-Status and Trends, 1975-2003
}

\author{
By Elaine C. Todd Trench, Richard B. Moore, Elizabeth A. Ahearn, John R. Mullaney, R. Edward Hickman, and \\ Gregory E. Schwarz
}

\section{Abstract}

The U.S. Geological Survey (USGS) National Water Quality Assessment Program (NAWQA) began regional studies in 2003 to synthesize information on nutrient concentrations, trends, stream loads, and sources. In the northeastern United States, a study area that extends from Maine to central Virginia, nutrient data were evaluated for 130 USGS waterquality monitoring stations.

Nutrient data were analyzed for trends in flow-adjusted concentrations, modeled instream (non-flow-adjusted) concentrations, and stream loads for 32 stations with 22 to 29 years of water-quality and daily mean streamflow record during 19752003 (termed the long-term period), and for 46 stations during 1993-2003 (termed the recent period), by using a coupled statistical model of streamflow and water quality developed by the USGS. Recent trends in flow-adjusted concentrations of one or more nutrients also were analyzed for 90 stations by using Tobit regression.

Annual stream nutrient loads were estimated, and annual nutrient yields were calculated, for 47 stations for the longterm and recent periods, and for 37 additional stations that did not have a complete streamflow and water-quality record for 1993-2003. Nutrient yield information was incorporated for 9 drainage basins evaluated in a national NAWQA study, for a total of 93 stations evaluated for nutrient yields.

Long-term downward trends in flow-adjusted concentrations of total nitrogen and total phosphorus (18 and 19 of 32 stations, respectively) indicate regional improvements in nutrient-related water-quality conditions. Most of the recent trends detected for total phosphorus were upward (17 of 83 stations), indicating possible reversals to the longterm improvements.

Concentrations of nutrients in many streams persist at levels that are likely to affect aquatic habitat adversely and promote freshwater or coastal eutrophication. Recent trends for modeled instream concentrations, and modeled reference concentrations, were evaluated relative to ecoregionbased nutrient criteria proposed by the U.S. Environmental Protection Agency. Instream concentrations of total nitrogen and total phosphorus persist at levels higher than proposed criteria at more than one-third and about one-half, respectively, of the 46 stations analyzed.

Long-term trends in nutrient loads were primarily downward, with downward trends in total nitrogen and total phosphorus loads detected at 12 and 17 of 32 stations, respectively. Upward trends were rare, with one upward trend for total nitrogen loads and none for total phosphorus. Trends in loads of nitrite-plus-nitrate nitrogen included 7 upward and 8 downward trends among 32 stations. Downward trends in loads of ammonia nitrogen and total Kjeldahl nitrogen were detected at all six stations evaluated. Long-term downward trends detected in four of the five largest drainage basins evaluated include: total nitrogen loads for the Connecticut, Delaware, and James Rivers; total Kjeldahl nitrogen and ammonia nitrogen loads for the Susquehanna River; ammonia nitrogen and nitrite-plus-nitrate nitrogen loads for the James River; and total phosphorus loads for the Connecticut and Delaware Rivers. No trends in load were detected for the Potomac River.

Nutrient yields were evaluated relative to the extent of land development in 93 drainage basins. The undeveloped land-use category included forested drainage basins with undeveloped land ranging from 75 to 100 percent of basin area. Median total nitrogen yields for the 27 undeveloped drainage basins evaluated, including 9 basins evaluated in a national NAWQA study, ranged from 290 to 4,800 pounds per square mile per year $\left(\mathrm{lb} / \mathrm{mi}^{2} / \mathrm{yr}\right)$. Total nitrogen yields even in the most pristine drainage basins may be elevated relative to natural conditions, because of high rates of atmospheric deposition of nitrogen in parts of the northeastern United States. Median total phosphorus yields ranged from 12 to $330 \mathrm{lb} / \mathrm{mi}^{2} / \mathrm{yr}$ for the 26 undeveloped basins evaluated. The undeveloped category includes some large drainage basins with point-source discharges and small percentages of developed land; in these basins, streamflow from undeveloped headwater areas dilutes streamflow in more urbanized reaches, and dampens but does not eliminate the point-source "signal" of higher nutrient loads. Median total nitrogen yields generally do not exceed $1,700 \mathrm{lb} / \mathrm{mi}^{2} / \mathrm{yr}$, and median total phosphorus yields generally do not exceed $100 \mathrm{lb} / \mathrm{mi}^{2} / \mathrm{yr}$, in the drainage basins that are least affected by human land-use and wastedisposal practices. 
Agricultural and urban land use has increased nutrient yields substantially relative to undeveloped drainage basins. Median total nitrogen yields for 24 agricultural basins ranged from 1,700 to $26,000 \mathrm{lb} / \mathrm{mi}^{2} / \mathrm{yr}$, and median total phosphorus yields ranged from 94 to $1,000 \mathrm{lb} / \mathrm{mi}^{2} / \mathrm{yr}$. The maximum estimated total nitrogen and total phosphorus yields, 32,000 and $16,000 \mathrm{lb} / \mathrm{mi}^{2} / \mathrm{yr}$, respectively, for all stations in the region were in small (less than 50 square miles $\left(\mathrm{mi}^{2}\right)$ ) agricultural drainage basins. Median total nitrogen yields ranged from 1,400 to $17,000 \mathrm{lb} / \mathrm{mi}^{2} / \mathrm{yr}$ in 26 urbanized drainage basins, and median total phosphorus yields ranged from 43 to $1,900 \mathrm{lb} / \mathrm{mi}^{2} / \mathrm{yr}$. Urbanized drainage basins with the highest nutrient yields are generally small (less than $300 \mathrm{mi}^{2}$ ) and are drained by streams that receive major point-source discharges.

Instream nutrient loads were evaluated relative to loads from point-source discharges in four drainage basins: the Quinebaug River Basin in Connecticut, Massachusetts, and Rhode Island; the Raritan River Basin in New Jersey; the Patuxent River Basin in Maryland; and the James River Basin in Virginia. Long-term downward trends in nutrient loads, coupled with similar trends in flow-adjusted nutrient concentrations, indicate long-term reductions in the delivery of most nutrients to these streams. However, the absence of recent downward trends in load for most nutrients, coupled with instream concentrations that exceed proposed nutrient criteria in several of these waste-receiving streams, indicates that challenges remain in reducing delivery of nutrients to streams from point sources. During dry years, the total nutrient load from point sources in some of the drainage basins approached or equaled the nutrient load transported by the stream.

\section{Introduction}

River basins of the northeastern United States, from Maine to central Virginia, encompassed 21 percent of the population of the United States in the year 2000, although constituting only about 5 percent of the land area (4.7 percent of the total land area, and 5.5 percent of the conterminous 48 states). Despite large public expenditures for water-quality improvements, nutrient-related water-quality problems continue to cause substantial impairments in freshwater and estuarine areas. Estuarine areas adversely affected by nutrients include nationally prominent areas such as Chesapeake Bay and Long Island Sound, and many smaller estuaries. Estuaries that have historically had highly valued commercial fisheries, and aesthetic and recreational value, have been adversely affected by nutrients. With continued population growth and land development in the region, water-quality managers and public officials likely will continue to struggle with managing the effects of excess nutrients in rivers, lakes, and estuaries.

The link between human presence and water-quality impairments is very strong in the northeastern United States. This link requires examination from multiple perspectives to understand and solve nutrient-related problems. Management decisions of increasing complexity require information suitable for protection and restoration of water quality, aquatic life, and habitat in rivers, lakes, and estuaries. Water-quality problems resulting from excessive nutrients in freshwater and estuaries are among the most widespread and complex issues currently facing water managers.

Effective action to address nutrient-related water-quality problems in the northeastern United States requires scientific information on the sources, distribution, cycling, and transport of nutrients in the environment. Water-resources scientists and managers need to know the geographic and temporal distribution of nutrient concentrations and loads to evaluate the importance of various nutrient sources as factors causing water-quality impairments in the streams and estuaries of the region. Resource managers can use this information in designing programs to control nutrient sources and improve water quality.

\section{Regional Synthesis Studies of the U.S. Geological Survey National Water Quality Assessment}

Nutrient conditions in the river basins of the northeastern United States (fig. 1) have been monitored and investigated by the U.S. Geological Survey (USGS), State agencies, and regional agencies since the early 1900s, and more intensively since the 1960s. The USGS began the National Water Quality Assessment (NAWQA) Program in 1991, with nutrients as a major focus. Seven NAWQA study units are in the regional study area of this report: New England Coastal Basins; Connecticut, Housatonic, and Thames River Basins; Hudson River Basin; Long Island-New Jersey Coastal Drainages; Delaware River Basin; Lower Susquehanna River Basin; and Potomac River Basin and Delmarva Peninsula (fig. 1).

As part of the continuing effort to understand and improve water quality in the United States, the USGS NAWQA Program began regional studies in 2003 to synthesize information on nutrient concentrations, trends, loads, and sources. This study of nutrients in the northeastern United States is one of several regional synthesis studies nationwide. 


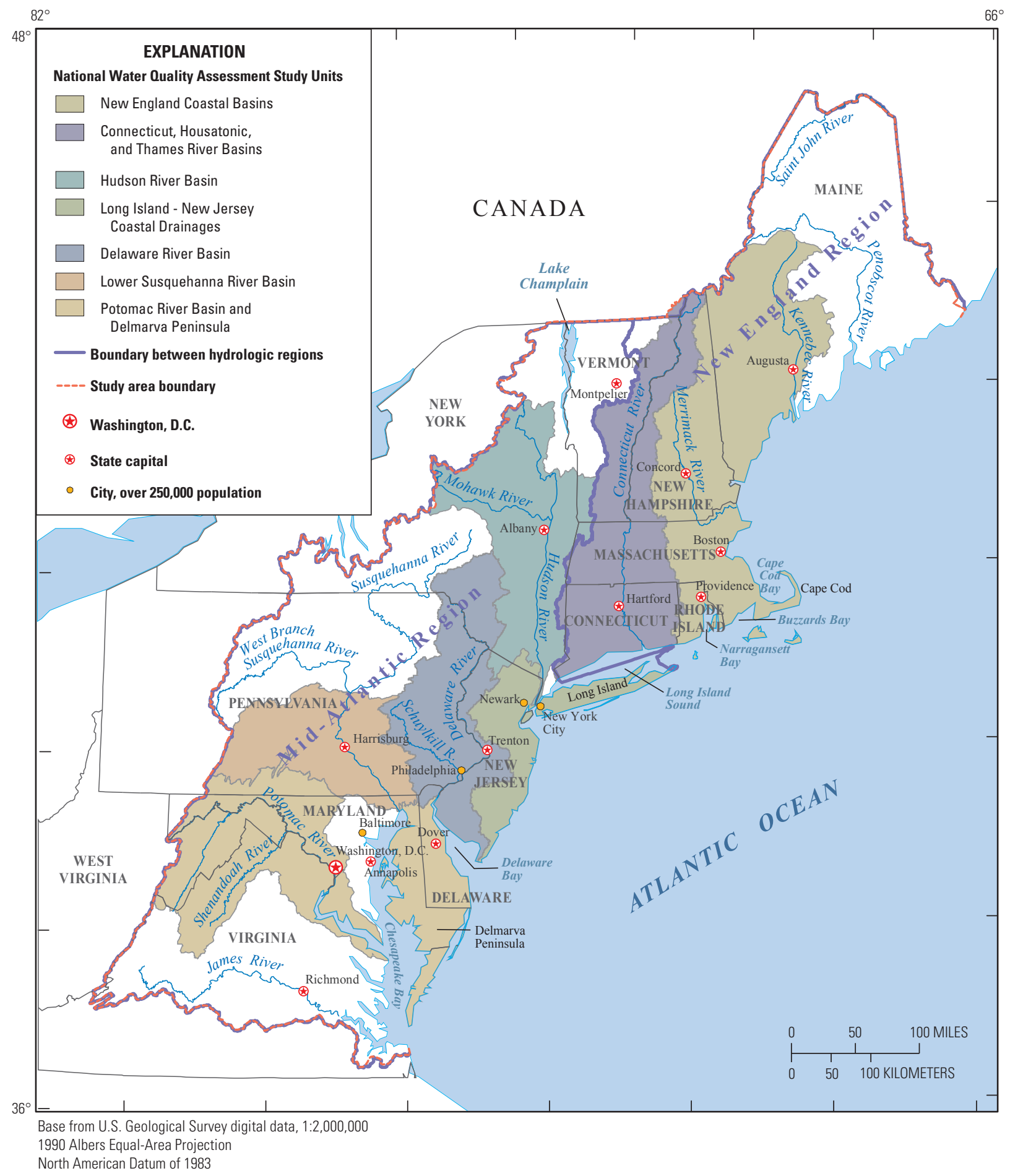

Figure 1. Major features of the northeastern region study area, including study area boundary, state lines, major coastal features, major cities, major rivers, and National Water Quality Assessment (NAWQA) study units. 


\section{Purpose, Objectives, and Scope of Report}

The purpose of this report is to provide water managers, scientists, policymakers, and citizens with a regional perspective on nitrogen and phosphorus concentrations (nutrients) in streams, the changes (trends) in nutrient concentrations, the amounts of these nutrients (loads) transported by streams, and the sources of these nutrients in drainage basins. Specific objectives of the report are to present, evaluate, and synthesize:

1. Information on recent (1993-2003) and long-term (1975-2003) trends in nutrient concentrations;

2. Information on observed nutrient concentrations relative to water-quality criteria and benchmarks;

3. Recent and long-term annual nutrient load estimates, and information on trends in annual loads;

4. Selected information on nutrient sources, including regional land use and population density data, and point-source information for four selected drainage basins.

The geographic scope of the report includes the drainage basins of rivers in the New England and the mid-Atlantic states that drain to the Atlantic Ocean and an area in Vermont and New York where rivers drain northward to Canada. The study area is coincident with, and includes all river basin units in, Hydrologic Region 01, the New England region, and Hydrologic Region 02, the mid-Atlantic region, as originally defined by the USGS and the U.S. Water Resources Council (Seaber and others, 1987), and refined for digital standards in the 1990s and 2000s under the Federal Geographic Data Committee (Natural Resources Conservation Service, 2009). The New England region includes most river basins in the New England states (fig. 1). The mid-Atlantic region includes drainage basins from eastern New York to central Virginia, including the Lake Champlain area along the VermontNew York border, from which rivers drain northward to Canada (fig. 1).

\section{Previous Studies}

Nutrient conditions in many parts of the region have been studied over a period of several decades. Information from several of these studies is cited in this report, and additional relevant publications are listed in the references.

\section{Environmental Setting of the Northeastern United States}

The area of the northeastern United States covered by this study includes river basins in the New England and midAtlantic hydrologic regions (fig. 1). The hydrologic landscape is composed of many small river basins drained by streams flowing generally southward or eastward toward estuaries of the Atlantic Ocean. An area along the Lake Champlain Valley in northern New York and Vermont drains northward toward Canada. The Susquehanna River is the largest river in the region, with a monitored drainage area of 27,100 square miles $\left(\mathrm{mi}^{2}\right)$ and a total drainage area of $27,500 \mathrm{mi}^{2}$ (Sprague and others, 2000, p. 13, 15). Most major streams have drainage areas of about $10,000 \mathrm{mi}^{2}$ or less, and many have drainage areas less than $1,000 \mathrm{mi}^{2}$. The study area encompasses $166,000 \mathrm{mi}^{2}$ and a population of 59 million.

\section{Population Density and Land Use}

The area of the northeastern United States covered by this study is one of the most densely populated regions of the country. Six of the seven most densely populated states in the nation are entirely, or almost entirely, in the study area, and the most densely populated areas of the seventh, New York, also are in the study area (table 1; U.S. Census Bureau, 2001). The areas of highest population density are along the coast, in metropolitan areas from Boston, Massachusetts, to Washington, D.C. (figs. 1, 2).

Despite the high population density of parts of the region, the region as a whole is largely forested (65 percent, table 2 ). In general, mountainous and hilly areas in the interior of the region are forested, and coastal areas are more highly urbanized (fig. 2). Major rivers in the region flow from interior highlands toward the coast, and consequently the land-use characteristics of major river basins are similar to the general landscape pattern of the region (table 3). Although most large river basins encompass densely populated areas near the coast, urbanized areas often constitute less than 10 percent of the monitored drainage area, and the large drainage basins as a whole are primarily forested.

Agricultural areas constitute about 18 percent of the region, but are primarily in the central and southern parts of the study area. Agricultural land generally constitutes less than 10 percent of the land in most of the large drainage basins of northern New England (table 3), with larger percentages in drainage basins from the Lake Champlain Valley and central New York south to Virginia.

Changes in land use and population distribution over time have not been evaluated quantitatively for this study. However, some general patterns are evident, and may be major factors in future water-quality changes. During the second half of the 20th century, the period of greatest percentage increases in population took place during the 1950s and 1960s in the eight most densely populated states of the region (table 1) (Hobbs and Stoops, 2002, Appendix A; Forstall, 1995). Population has continued to grow, at a slower rate, in most states of the region, and population growth rates have increased in the latter decades of the 20th century in some rural states, including New Hampshire. The distribution of population also has changed. Residential and commercial development pressure in 
Table 1. Population density of states in the northeastern United States.

[Sources for population data: U.S. Census Bureau, 2000, 2001; Hobbs and Stoops, 2002, appendix A; mi², square mile; NA, not applicable]

\begin{tabular}{|c|c|c|c|c|c|c|c|c|}
\hline \multirow{2}{*}{ State or district } & \multirow{2}{*}{$\begin{array}{l}\text { Area } \\
\left(\mathrm{mi}^{2}\right)\end{array}$} & \multicolumn{2}{|c|}{ Population } & \multirow{2}{*}{$\begin{array}{l}\text { Population } \\
\text { rank in } 2000\end{array}$} & \multicolumn{2}{|c|}{$\begin{array}{c}\text { Population density per } \\
\text { square mile }\end{array}$} & \multicolumn{2}{|c|}{ National density rank } \\
\hline & & 1990 & 2000 & & 1990 & 2000 & 1990 & 2000 \\
\hline New Jersey & 7,419 & $7,730,188$ & $8,414,350$ & 9 & 1,042 & 1,134 & 1 & 1 \\
\hline Rhode Island & 1,045 & $1,003,464$ & $1,048,319$ & 43 & 960 & 1,003 & 2 & 2 \\
\hline Massachusetts & 7,838 & $6,016,425$ & $6,349,097$ & 13 & 768 & 810 & 3 & 3 \\
\hline Connecticut & 4,845 & $3,287,116$ & $3,405,565$ & 29 & 678 & 703 & 4 & 4 \\
\hline Maryland & 9,775 & $4,781,468$ & $5,296,486$ & 19 & 489 & 542 & 5 & 5 \\
\hline New York & 47,224 & $17,990,455$ & $18,976,457$ & 3 & 381 & 402 & 6 & 6 \\
\hline Delaware & 1,955 & 666,168 & 783,600 & 45 & 341 & 401 & 7 & 7 \\
\hline Pennsylvania & 44,820 & $11,881,643$ & $12,281,054$ & 6 & 265 & 274 & 8 & 10 \\
\hline Virginia & 39,598 & $6,187,358$ & $7,078,515$ & 12 & 156 & 179 & 15 & 14 \\
\hline New Hampshire & 8,969 & $1,109,252$ & $1,235,786$ & 41 & 124 & 138 & 18 & 20 \\
\hline West Virginia & 24,087 & $1,793,477$ & $1,808,344$ & 37 & 75 & 75 & 26 & 29 \\
\hline Vermont & 9,249 & 562,758 & 608,827 & 49 & 61 & 66 & 30 & 30 \\
\hline Maine & 30,865 & $1,227,928$ & $1,274,923$ & 40 & 40 & 41 & 36 & 38 \\
\hline District of Columbia & 61 & 606,900 & 572,059 & NA & 9,883 & 9,317 & NA & NA \\
\hline
\end{tabular}

formerly rural or forested areas has increased in recent years, and the rate at which land is developed also has increased, in a process commonly called "suburban sprawl." Development of vacation communities in coastal areas and mountain regions also has increased. All these factors are likely to affect future trends in nutrient-related water-quality conditions.

Although the region as a whole is largely forested, a large proportion of the forested area has already been fragmented or otherwise affected by nearby development. A study of forest fragmentation in Connecticut found that about 59 percent of the state was forested in 2006, but only 46 percent of these forested lands were considered "core" forest, the least disturbed of the forested categories in the study (Center for Land Use Education and Research, 2009).

\section{Nutrients and Water Quality}

Phosphorus and nitrogen are essential nutrients for plant growth. Free-floating aquatic plants such as algae depend on dissolved nitrogen and phosphorus compounds for nutrients (Hem, 1985, p. 128). Nitrogen availability rarely limits aquatic plant growth in freshwater, whereas phosphorus concentrations in natural or near-natural streams are generally low enough to limit plant growth. Excessive phosphorus concentrations in freshwater promote the growth of aquatic algae and resulting eutrophic conditions (Hem, 1985, p. 128; Litke, 1999), whereas excessive nitrogen concentrations promote algal growth and eutrophication in estuarine environments (National Research Council, 2000, p. 63-112).

Decomposition of aquatic plants contributes to a condition called hypoxia, or low dissolved oxygen, in freshwater and marine environments. As algal blooms die, organic decomposition releases nutrients to the water column, depletes oxygen from the water, and leaves nutrient-rich organic material that settles to the bottom of the stream, reservoir, or estuary. Freshwater algal blooms may be transported downstream to the estuarine environment, where algal decomposition depletes oxygen and contributes organic material and nutrients to the water column and sediments.

Elevated concentrations of nitrogen and phosphorus have been reported historically and in recent years at water-quality monitoring stations operated cooperatively by the USGS and state agencies in the northeastern United States. Nuisance algal blooms develop annually during summer and autumn months in impoundments, streams, and estuarine areas in some parts of the region. Elevated instream phosphorus concentrations, in conjunction with other hydrologic and climatic factors, are the likely cause of freshwater algal blooms. Seasonal algal blooms and hypoxia are serious long-term problems in the Chesapeake Bay, Long Island Sound, and other estuaries. Elevated concentrations of nitrogen constituents from multiple sources are believed to promote estuarine algal blooms and contribute to high levels of biochemical oxygen demand, resulting in low dissolved oxygen concentrations in Narragansett Bay in Rhode 


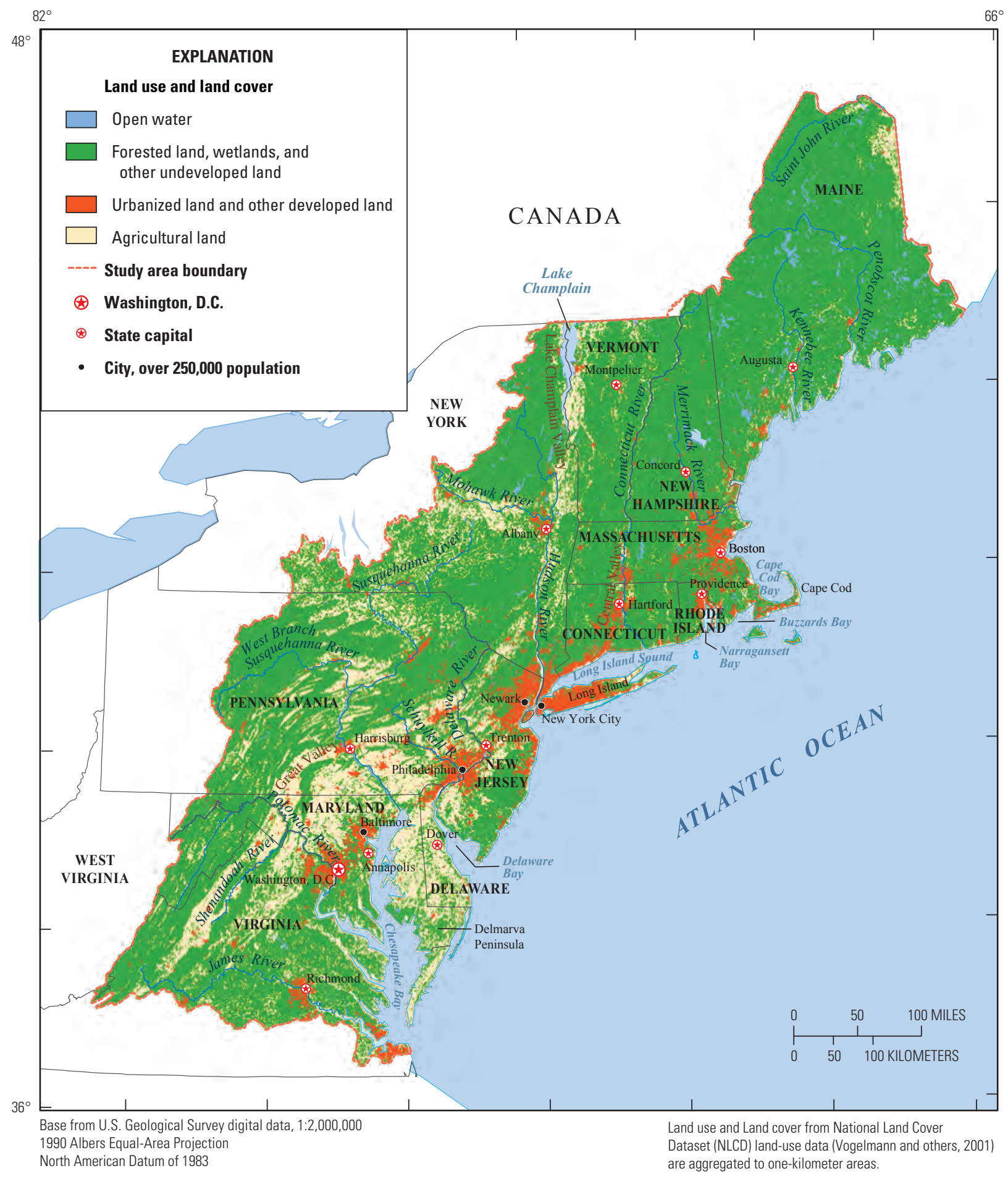

Figure 2. Regional land-use and land-cover characteristics. [Source for land-use data: 1992 National Land Cover Dataset (NLCDe 92) (Vogelmann and others, 1998; enhanced as described by Nakagaki and Wolock, 2005)] 
Table 2. Land-use characteristics of the northeastern region of the United States.

[Source: 1992 National Land Cover Dataset (NLCDe 92) (Vogelmann and others, 1998; enhanced as described by Nakagaki and Wolock, 2005). Other land uses constitute the remaining small percentage of the region]

\begin{tabular}{lc}
\hline \multicolumn{1}{c}{ Land use } & Percentage of region \\
\hline Urban & 8.3 \\
Agricultural & 18 \\
Forested & 65 \\
Water & 3.5 \\
Wetland & 4.0 \\
\hline
\end{tabular}

Island, Long Island Sound in Connecticut and New York, and Chesapeake Bay in Maryland and Virginia, as well as in many smaller harbors, estuaries, and bays throughout the region (Ely, 2002, p. 6; Connecticut Department of Environmental Protection, 2001, p. 1; Chesapeake Bay Program, 2004, p. 13; Bricker and others, 2007, p. 40-54).

The National Oceanic and Atmospheric Administration (NOAA) has evaluated eutrophic conditions, assessed changes in eutrophic conditions from the early 1990s to 2004, evaluated the effectiveness of management actions to reduce eutrophic conditions, and assessed the future outlook for eutrophic conditions in the Nation's estuaries, through the National Estuarine Eutrophication Assessment (Bricker and others, 2007). The North Atlantic region and the mid-Atlantic region of the NOAA assessment correspond closely to the geographic area encompassed by this study.
The North Atlantic region defined by NOAA, encompassing the coasts of Maine, New Hampshire, and eastern Massachusetts (including Cape Cod), was the least eutrophic region in the nation, with most assessed systems having a low or moderate overall eutrophic condition (Bricker and others, 2007, p. 40-46). This condition is believed to be the result of low freshwater nitrogen loads relative to oceanic nitrogen inputs, generally sparse population, high tidal flushing, and moderate to good dilution capabilities of estuarine systems. Only one assessed system, the Merrimack River in New Hampshire and Massachusetts, was found to have high nitrogen loads relative to oceanic inputs. However, about one-third of the systems had insufficient monitoring data for assessment of eutrophic conditions. The NOAA assessment predicted worsening conditions in most systems that were evaluated in the North Atlantic region, as a result of anticipated increases in nutrient loads from treated wastewater, urban runoff, septic systems, combined sewer overflows, atmospheric deposition, increasing impervious surfaces, and fertilizer use in one or more of the estuarine systems, with increases in coastal population expected to increase nutrient loads from all these sources. NAWQA studies have found that concentrations of nutrients in streams and shallow groundwater generally increase with increasing amounts of agricultural and urban land in a drainage basin (U.S. Geological Survey, 1999, p. 15). A national NAWQA study of nutrient trends in streams and rivers from 1993 to 2003 concluded that nutrient enrichment has increased in many streams that were among the least impaired by nutrients in 1993, and that the Nation's least impaired streams are increasingly being affected by population growth (Sprague and others, 2009, p. 93, 101). These large-scale findings support the NOAA conclusion that coastal population increases are likely to result in increased nutrient loads to coastal areas.

Table 3. Land-use characteristics of selected major drainage basins in the northeastern United States.

[Source: 1992 National Land Cover Dataset (NLCDe 92) (Vogelmann and others, 1998; enhanced as described by Nakagaki and Wolock, 2005). Other lands uses constitute the remaining small percentage of each drainage area. Forested land includes wooded wetlands; water includes herbaceous wetlands; $\mathrm{mi}^{2}$, square miles]

\begin{tabular}{|c|c|c|c|c|c|}
\hline \multirow{2}{*}{ River } & \multirow{2}{*}{$\begin{array}{c}\text { Monitored } \\
\text { drainage area } \\
\left(\mathrm{mi}^{2}\right)\end{array}$} & \multicolumn{4}{|c|}{ Land-use percentages of monitored drainage area } \\
\hline & & Urban & Agricultural & Forested & Water \\
\hline Kennebec River at North Sidney, Maine & 5,403 & 1.4 & 5.6 & 82.1 & 7.3 \\
\hline Merrimack River below Concord River at Lowell, Mass. & 4,635 & 11.5 & 6.7 & 74.7 & 6.5 \\
\hline Connecticut River at Thompsonville, Conn. & 9,660 & 5.0 & 8.3 & 81.0 & 3.5 \\
\hline Mohawk River at Cohoes, N.Y. & 3,450 & 5.8 & 27.2 & 65.2 & 1.8 \\
\hline Delaware River at Trenton, N.J. & 6,780 & 5.3 & 16.4 & 75.2 & 2.8 \\
\hline Susquehanna River at Conowingo, Md. & 27,100 & 3.2 & 28.2 & 66.6 & 1.3 \\
\hline Potomac River at Chain Bridge, at Washington, D.C. & 11,570 & 4.5 & 33.8 & 60.1 & 0.9 \\
\hline James River at Cartersville, Va. & 6,252 & 3.5 & 15.0 & 79.6 & 0.8 \\
\hline
\end{tabular}


The mid-Atlantic region of the NOAA assessment encompasses coastal areas from Buzzards Bay on the south side of Cape Cod in Massachusetts to the James River Basin at the southern end of Chesapeake Bay in Virginia. Nationally, the estuaries of the mid-Atlantic region were the most affected by eutrophication, with most assessed estuarine systems having a moderate-high or high overall eutrophic condition (Bricker and others, 2007, p. 47-54). Watershed nitrogen loads to these estuaries are high relative to oceanic inputs, major population centers are present, agriculture is a major source of nutrients, and many estuaries have low flushing capabilities. The future outlook described for this region is mixed, with improvements expected in some estuarine systems and worsening conditions predicted in others. Anticipated changes show a regional pattern, with predicted improvements more common in the northern part of the region and deterioration more likely in the southern part of the region. Coastal population increases are expected to result in increased nutrient loads. Details of the NOAA assessment for individual estuaries in the North Atlantic and mid-Atlantic regions are available (Bricker and others, 2007, p. 40-54).

\section{Nutrient Sources}

Nitrogen and phosphorus constituents in streams of the northeastern United States are derived from natural sources and from many human uses of land and water resources. Sources of contamination that transmit nutrients or other contaminants through a pipe, such as effluent from a wastewatertreatment plant or an industrial facility, are referred to as point sources. By contrast, sources that are spread over large areas, such as fertilizer applications or septic systems, are referred to as nonpoint sources. Natural sources, including decaying plants and animal wastes, are the major nutrient sources in forested, undeveloped areas, and are also present in developed areas. Animal wastes, fertilizers, and decaying plants are major sources in agricultural areas. Nitrogen and phosphorus constituents from nonpoint sources are carried to streams by runoff during and after periods of rainfall or snowmelt, or are transported through groundwater and eventually discharged to streams. Municipal and industrial wastewater, residential and commercial fertilizers, local sources of atmospheric deposition, and urban runoff are major nutrient sources in urban areas. Historically, detergents have contributed large amounts of phosphorus to streams through municipal wastewater discharges (Litke, 1999).

Atmospheric deposition contributes nitrogen constituents and minor amounts of phosphorus to the land surface. Some nutrients are deposited directly in streams and other water bodies from atmospheric deposition. Nitrogen deposited from the atmosphere is derived either naturally from chemical reactions or from the combustion of fossil fuels. The area of the northeastern United States covered by this report is in the air-shed of the larger industrialized northeast, and atmospheric deposition is a regionally important nonpoint source of nitrogen (Castro and others, 2001). Ammonia emissions to the atmosphere, primarily from animal agriculture, are considered to be a major source of nitrogen to land and water ecosystems in the Chesapeake Bay watershed (Chesapeake Bay Program, 2002, p. 44).

Groundwater inflow may contribute major or minor quantities of nutrients to streams, depending on hydrogeologic conditions and land-use effects. A study of base flow and groundwater nitrate loads in the Chesapeake Bay watershed determined that groundwater is a major source of water to total streamflow and a major source of nitrate to total stream nitrate loads (Bachman and others, 1998). Nitrogen constituents, which may infiltrate to groundwater from fertilizers, manure, septic systems, or other nonpoint sources, are generally unreactive in oxygenated groundwater, and consequently may reach streams with little attenuation. By contrast, some forms of phosphorus are chemically reactive, and may be filtered out of groundwater and retained by particulate materials. Minerals in rocks and soil are not major sources of nitrogen in the region, but phosphorus from rocks and soil is locally important in some areas.

Point sources in urban areas are major nutrient sources in the northeast, where many of the Nation's largest cities are located and where smaller urban areas are also numerous. Estimates made for this report indicate that more than 11,000 point sources discharge effluent to rivers and streams of the region, and of these 11,000 sources, about 6,000 facilities discharge nutrients.

Many of the largest municipal point discharges in the region are from large metropolitan areas on the coast, and the facilities discharge directly to estuarine or tidal areas. All water-quality data analyzed for this report come from monitoring stations on freshwater streams, upstream from the point of tidal influence. Consequently, the water-quality effects of many major point sources in the region are not encompassed by this analysis, as this report focuses on sources upstream from stream-quality monitoring stations.

Surface-water and groundwater diversions and interbasin transfers of water are common in many drainage basins of the northeast. The use, transfer, and disposal of water affect nutrient concentrations and loads in many streams, and complicate the assessment of nutrient sources.

\section{Management Context for Nutrient- Related Water-Quality Impairments}

Nutrient-related water-quality impairments are among the water contamination problems regulated under Federal law. The U.S. Environmental Protection Agency (USEPA) is responsible for implementing the Clean Water Act, Safe Drinking Water Act, and parts of other statutes related 
to prevention, control, and abatement of pollution (U.S. Environmental Protection Agency, 2010). The USEPA delegates many water programs to State and tribal agencies, provides guidance, develops water-quality assessments and inventories, and develops strategies and criteria for waterquality restoration.

\section{Requirements of the Federal Clean Water Act}

The Federal Water Pollution Control Act Amendments of 1972 (Clean Water Act, or CWA) established two complementary approaches to water pollution control: the existing interstate water-quality standards program was extended to intrastate waters, and technology-based discharge permits were required (U.S. Environmental Protection Agency, 2006). The CWA, and subsequent amendments, requires States and Tribes to adopt water-quality standards and sets requirements for these standards. Water-quality standards, established under Section 303 (c) of the CWA, define goals for a water body by designating uses for the water body, setting water-quality criteria to protect those uses, and establishing an antidegradation policy (U.S. Environmental Protection Agency, 2006). The CWA established the National Pollutant Discharge Elimination System (NPDES), which requires a discharge permit for each point-source facility that discharges wastewater to waters of the United States. The NPDES process has been a critical factor supporting many waterquality improvements that have taken place during the 1970s and 1980s in the northeastern United States, a region with many urban areas, municipal discharges, and industries.

Water-quality assessments are reported periodically by the States in a document referred to as the 305 (b) Report, or the Water Quality Report to Congress, as required under Section 305 (b) of the CWA. Water bodies that have been identified as not meeting designated uses are reported periodically in a document called the 303 (d) List, as required under Section 303 (d) of the CWA (U.S. Environmental Protection Agency, 2007). Despite substantial waterquality improvements in many areas of the region, some impoundments, stream reaches, and estuaries continue to be listed as not meeting standards of the CWA because of elevated nutrient and chlorophyll-a concentrations, excessive algal growth, and persistent organic enrichment that causes high levels of biochemical oxygen demand and low dissolved oxygen concentrations (Connecticut Department of Environmental Protection, 2008; Maryland Department of the Environment, 2008; Massachusetts Department of Environmental Protection, 2008; New Jersey Department of Environmental Protection, 2007; Pennsylvania Department of Environmental Protection, 2008; Rhode Island Department of Environmental Management, 2008; Virginia Department of Environmental Quality, 2008).

The CWA requires that states, territories, and authorized tribes establish priority rankings for waters on the 303 (d) lists and develop Total Maximum Daily Load (TMDL) analyses for these water bodies (U.S. Environmental Protection Agency, 2007). The TMDL process provides a framework to restore impaired waters by establishing the maximum amount of a contaminant that a water body can assimilate from all sources and still support uses designated by the water-quality standards. Water-quality restoration is an interstate concern in many areas of the northeastern United States, with major nutrient sources in multiple states contributing nutrients to streams with interstate watersheds.

\section{Water-Quality Criteria and Standards for Nutrients}

National Water Quality Inventories produced periodically by the USEPA have repeatedly shown that nutrients are a major cause of water-quality use impairments, including failure to support aquatic life (U.S. Environmental Protection Agency, 2000d, 2002). To address this problem, the USEPA developed a National Strategy for the Development of Regional Nutrient Criteria (U.S. Environmental Protection Agency, 1998), under Section 304 (a) of the CWA (U.S. Environmental Protection Agency, 2000d, 2002). The National Strategy emphasizes development of guidance for specific water bodies and ecological regions, and the use of measured nutrient concentrations in pristine or minimally impaired waters as a basis for formulating nutrient criteria. Guidance has been or will be developed for four types of waters: lakes and reservoirs, rivers and streams, estuaries and coastal waters, and wetlands.

This process has resulted in the development of proposed criteria for total nitrogen and total phosphorus for rivers and streams in 14 nutrient ecoregions in the United States (U.S. Environmental Protection Agency, 2002). Nutrient concentrations that exceed proposed criteria are likely to promote eutrophic conditions. These criteria provide benchmarks for evaluating the nutrient concentrations and trends presented in this report. Criteria for five ecoregions are applicable to the study area of this report (table 4, fig. 3) (U.S. Environmental Protection Agency, 2000a-d, 2001).

The USEPA has established a Federal drinking-water standard, or Maximum Contaminant Level (MCL), of 10 milligrams per liter $(\mathrm{mg} / \mathrm{L})$ for nitrate as nitrogen (U.S. Environmental Protection Agency, 2003). An MCL is a concentration above which adverse human health effects may occur. The USEPA also has established criteria for nonionic ammonia in surface water because of toxicity to fish (U.S. Geological Survey, 1999, p. 35). The chronic criteria for total ammonia (applicable to persistent rather than short-term conditions) vary from 0.07 to $2.1 \mathrm{mg} / \mathrm{L}$, depending on the $\mathrm{pH}$ and temperature of the water (U.S. Environmental Protection Agency, 1986). 
Table 4. Nutrient criteria proposed by the U.S. Environmental Protection Agency for ecoregions in the northeastern United States.

[Source for proposed ecoregional nutrient criteria: U.S. Environmental Protection Agency (2000a, 2000b, 2000c, 2000d, 2001; mg/L, milligrams per liter]

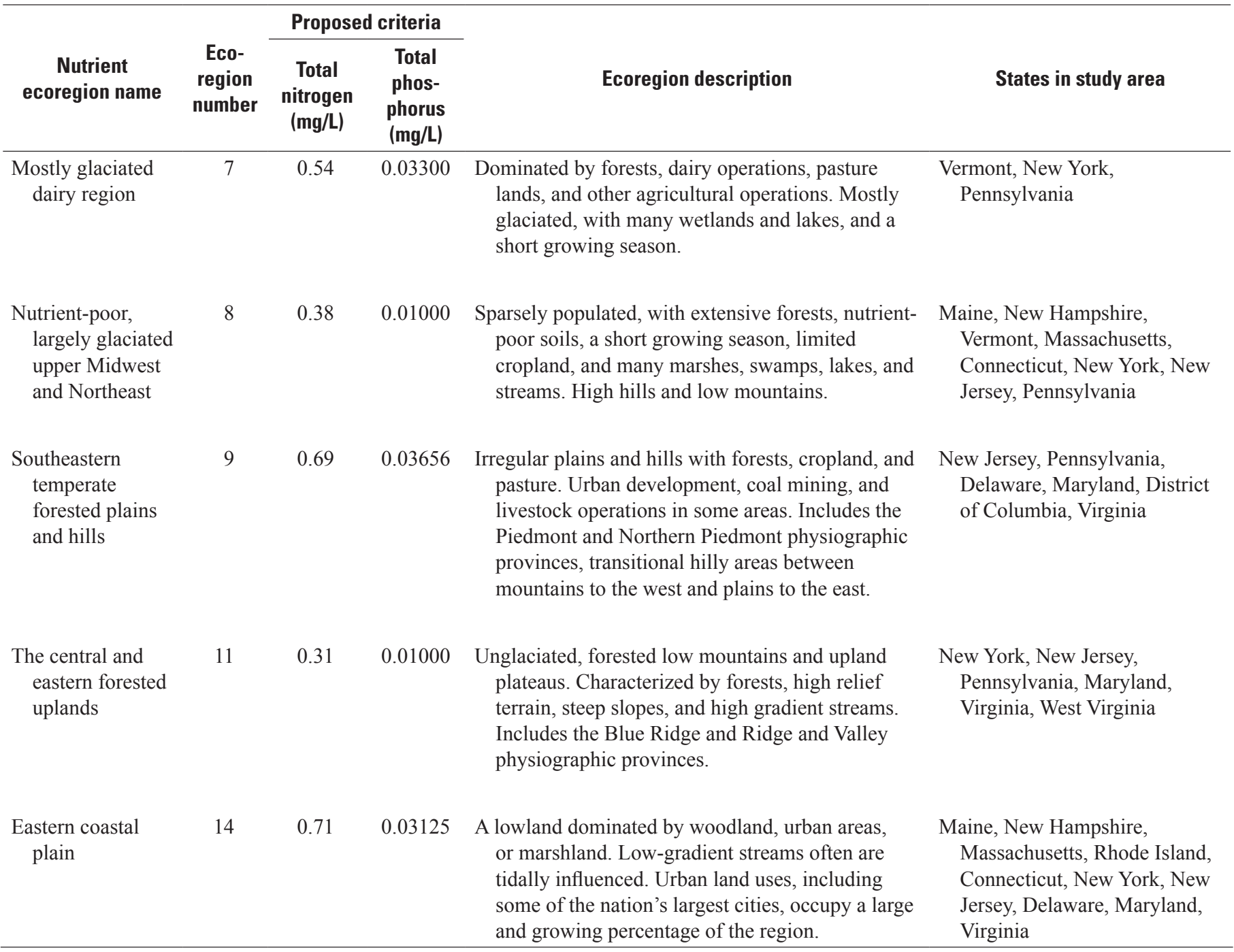




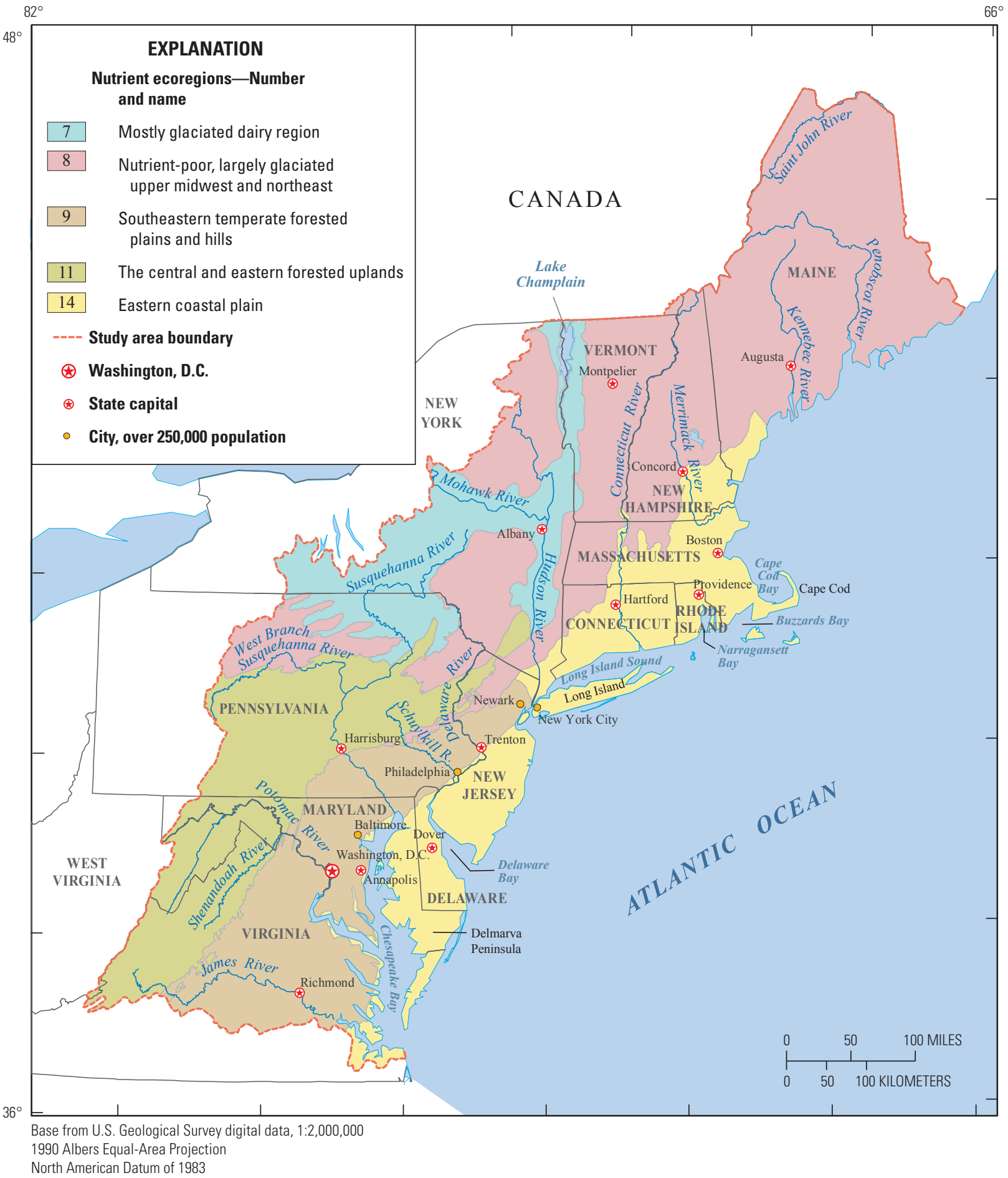

Figure 3. Nutrient ecoregions in the northeastern United States. (Source for ecoregions: Rohm and others, 2002) 


\section{Data Selection and Screening}

Water-quality and streamflow data were investigated, retrieved, and evaluated for long-term and recent periods. Water-quality data were retrieved for a long-term period of analysis, 1975-2003. For some stations, the long-term period starts in 1979 or 1982 . Nutrient data for the recent period, 1993-2003, are used to describe and evaluate the most recent nutrient conditions in the region, within the longer-term period evaluated in this study. The 1993-2003 period was selected as a period of analysis for several regional NAWQA nutrient studies, to have a common basis for comparing trend results in different regions of the country. The 1993-2003 period also has been evaluated in a National synthesis of nutrient data by the NAWQA Program (Sprague and others, 2009). Stream discharge data were retrieved for the period 1970-2004, and for the full period of record for stations with discharge data prior to 1970. Unless otherwise specified, data were retrieved and analyzed by water year. A water year is defined as the 12-month period from October 1 through September 30 and is designated by the calendar year in which the water year ends.

\section{Data from U.S. Geological Survey Monitoring Programs}

Water-quality data and associated streamflow data for 1975-2003 were retrieved from several USGS programs, including the NAWQA Program study units (fig. 1); the National Stream Quality Accounting Network (NASQAN); the Hydrologic Benchmark Network (HBN); State monitoring programs conducted by the USGS under the Federal-State cooperative program; and special projects conducted by USGS Water Science Centers in several states.

Water-quality data for USGS National Stream WaterQuality Monitoring Networks, including NASQAN and $\mathrm{HBN}$, were retrieved from a published CD-ROM (Alexander and others, 1996, 1997). Water-quality data for all USGS stations monitoring drainage areas greater than $1 \mathrm{mi}^{2}$ were retrieved on a state-by-state basis from the USGS National Water Information System (NWIS), through the online source NWISWeb (U.S. Geological Survey, 2002; 2009b). Additional details of data retrievals and data screening are provided in appendix 1 .

Data were evaluated for more than 450 stations with at least 20 nutrient samples during the 1975-2003 period. These stations were screened to select stations with sufficient data and appropriate annual data distribution for trend analysis or load estimation during selected periods of interest. More than 200 stations have data sufficient for trend analysis during the 1993-2003 period or for load estimation during at least two years of the 1993-2003 period. Additional stations have long-term records in the period from the mid-1970s to the mid-1990s. Trend analyses for this report were restricted to stations with data for 8 to 11 years of the 1993-2003 period, and load estimation focused on stations with data for the entire 1993-2003 period and stations with longer-term records that included the entire 1993-2003 period. Annual loads were estimated for selected additional stations with less than the full 1993-2003 period of record to ensure geographic coverage of the region and representation of specific land uses in the results. One or more analyses were performed on nutrient data for 121 stations (table 5; fig. 4). In addition, nutrient concentration and yield information for nine drainage basins evaluated in a national NAWQA study of undeveloped drainage basins (Clark and others, 2000) is included in this study for comparison (table 5; fig. 4). Station sequence numbers have been assigned to the 130 stations included in this report (table 5; fig. 4), and sequence numbers are shown in parentheses when specific monitoring stations or drainage basins are discussed.

Geographic coverage of the region by USGS waterquality monitoring programs is not complete, and the period of water-quality record available varies in different parts of the region. The NASQAN Program was established in 1973 to compile long-term, consistent, baseline water-chemistry data for major streams of the United States (Ficke and Hawkinson, 1975). The NASQAN Program was redesigned in 1995, and water-quality monitoring was discontinued on several major streams in the Northeast during the early 1990s (Alexander and others, 1996). State monitoring programs are conducted by the USGS in some states, and by State regulatory agencies in other states. In some areas of the region, responsibility for water-quality monitoring has transferred between the USGS and State agencies at several points, and no single source provides continuous monitoring data. For these reasons, some major drainage areas of the region are not fully represented in the analyses in this report.

Water-quality constituents evaluated in this report include several nitrogen constituents, total phosphorus, and suspended sediment (table 6). Analytical methods for determining nutrient concentrations have changed during the period of time covered in this report. Methods for calculating "total" constituent concentrations also have changed for some constituents. Consequently, long-term records evaluated in this study may combine data from more than one parameter code for a waterquality constituent (appendix 1).

Changes in analytical methods may affect the interpretation of some reported concentrations and time trends. A positive analytical bias of about $0.1 \mathrm{mg} / \mathrm{L}$ in total Kjeldahl nitrogen concentrations (as nitrogen), in samples analyzed by the USGS National Water Quality Laboratory from 1986 to the time of a method change in 1991, has been reported in a methods evaluation by Patton and Truitt (2000, p. 1, 29). The study further reports that nitrite-plus-nitrate concentrations greater than $1 \mathrm{mg} / \mathrm{L}$ (as nitrogen) may have caused either positive or negative interference in Kjeldahl nitrogen determinations during that period of time. The magnitude of the bias, however, is believed to be small relative to total nitrogen concentrations in most of the streams evaluated in this study. Additional discussion of the effects of changes in laboratory methods on historical nutrient data in the study area can be found in Zimmerman and others (1996, p. 29-30) and Trench (2000, p. 15). 


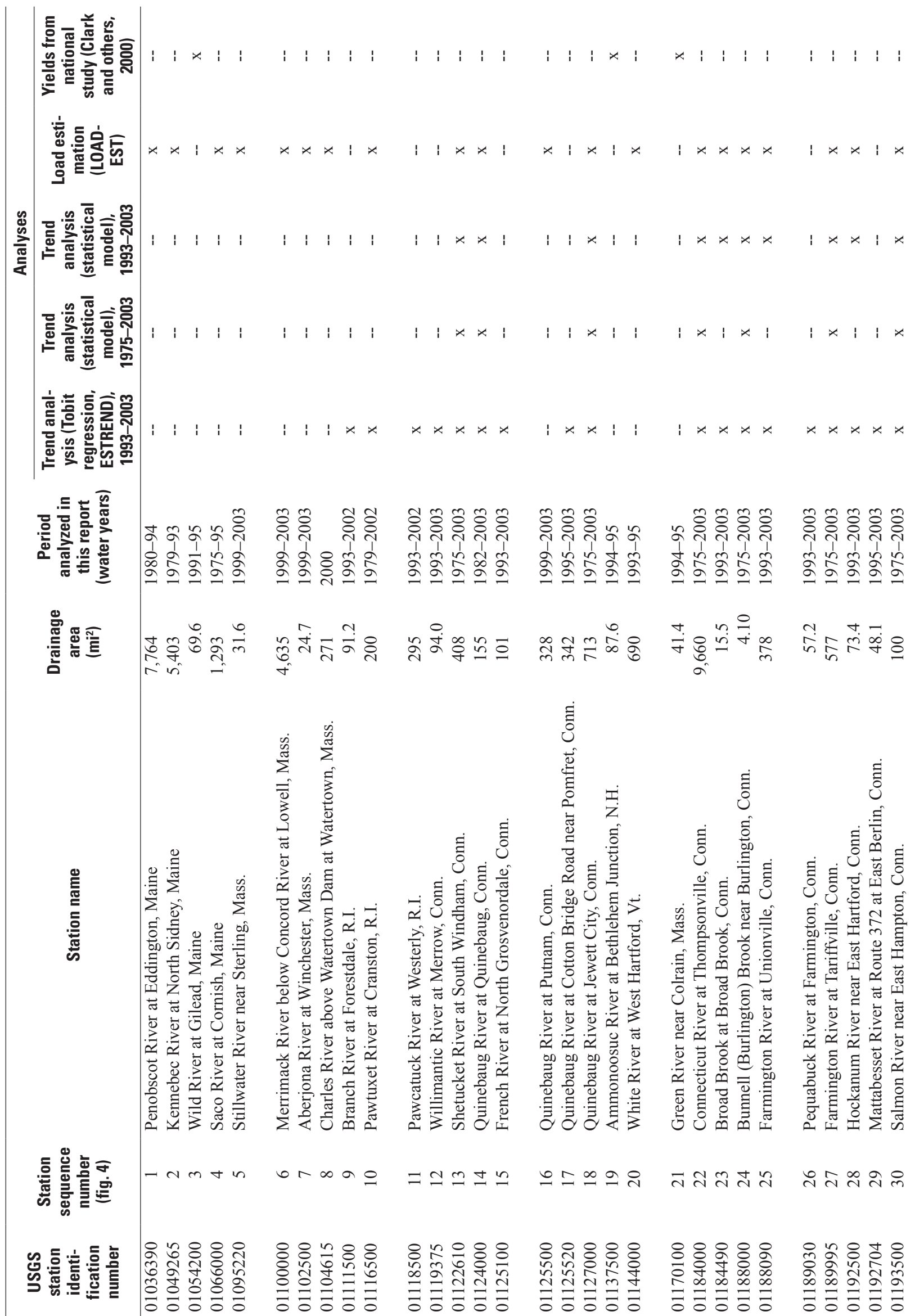




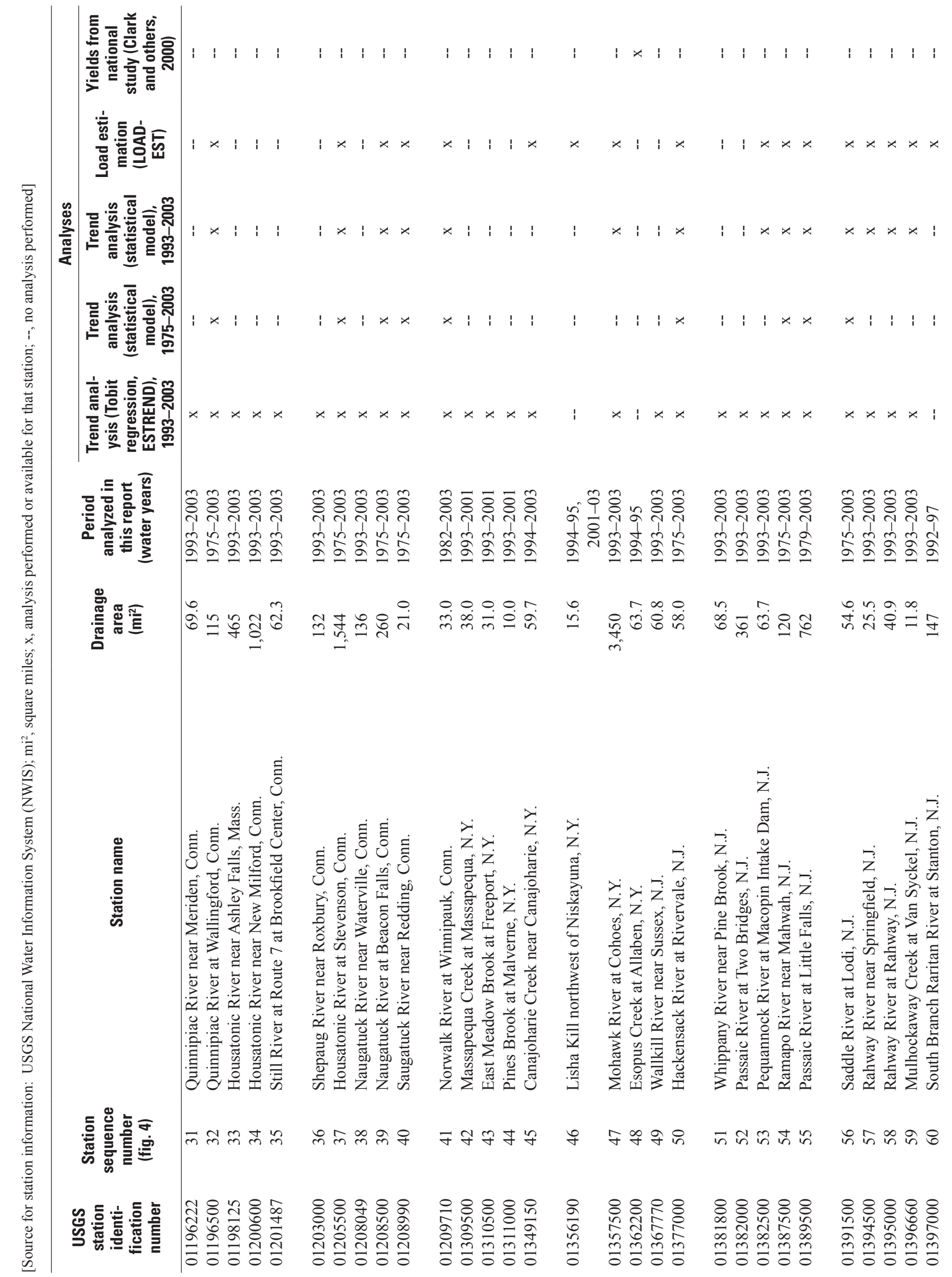




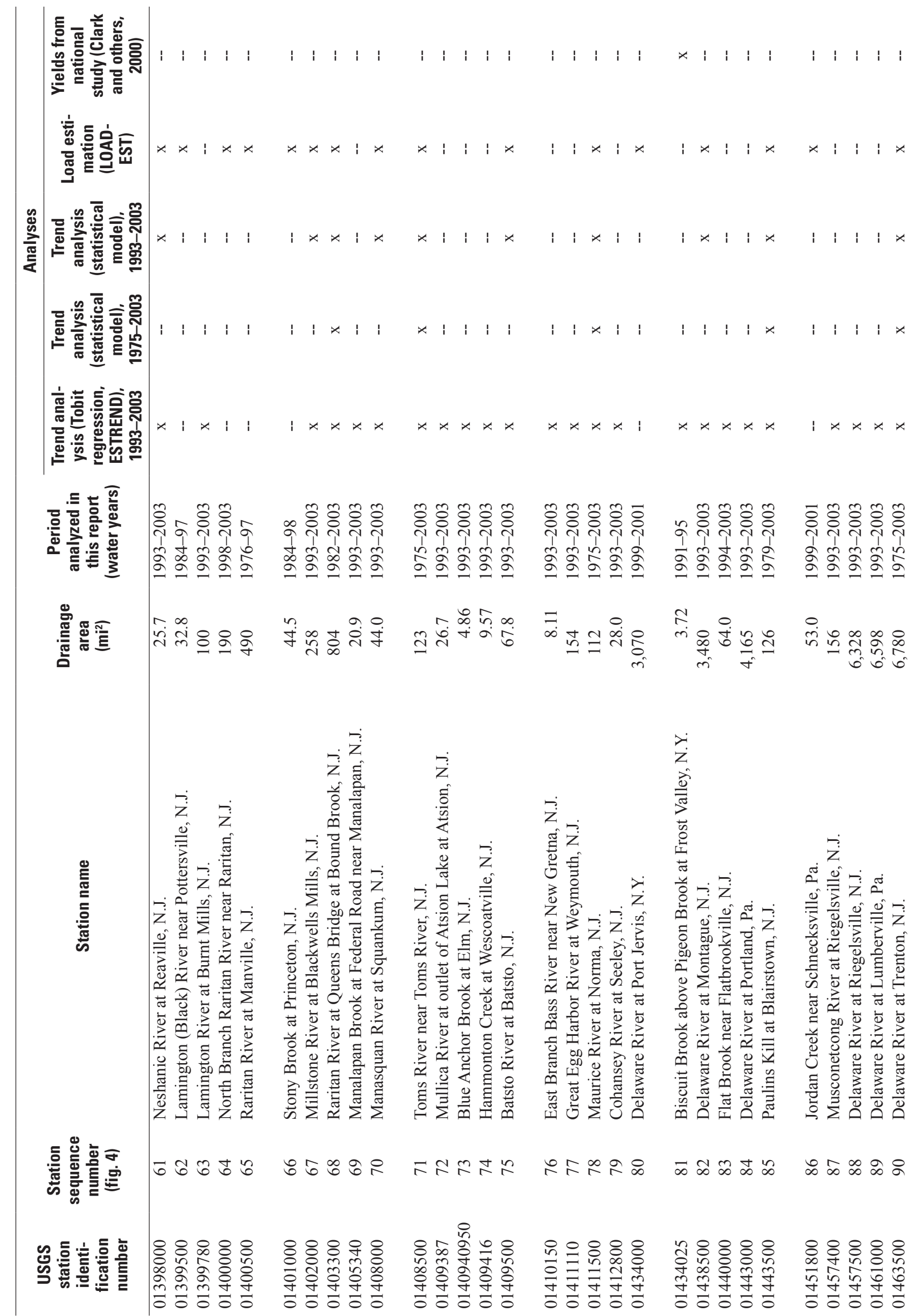




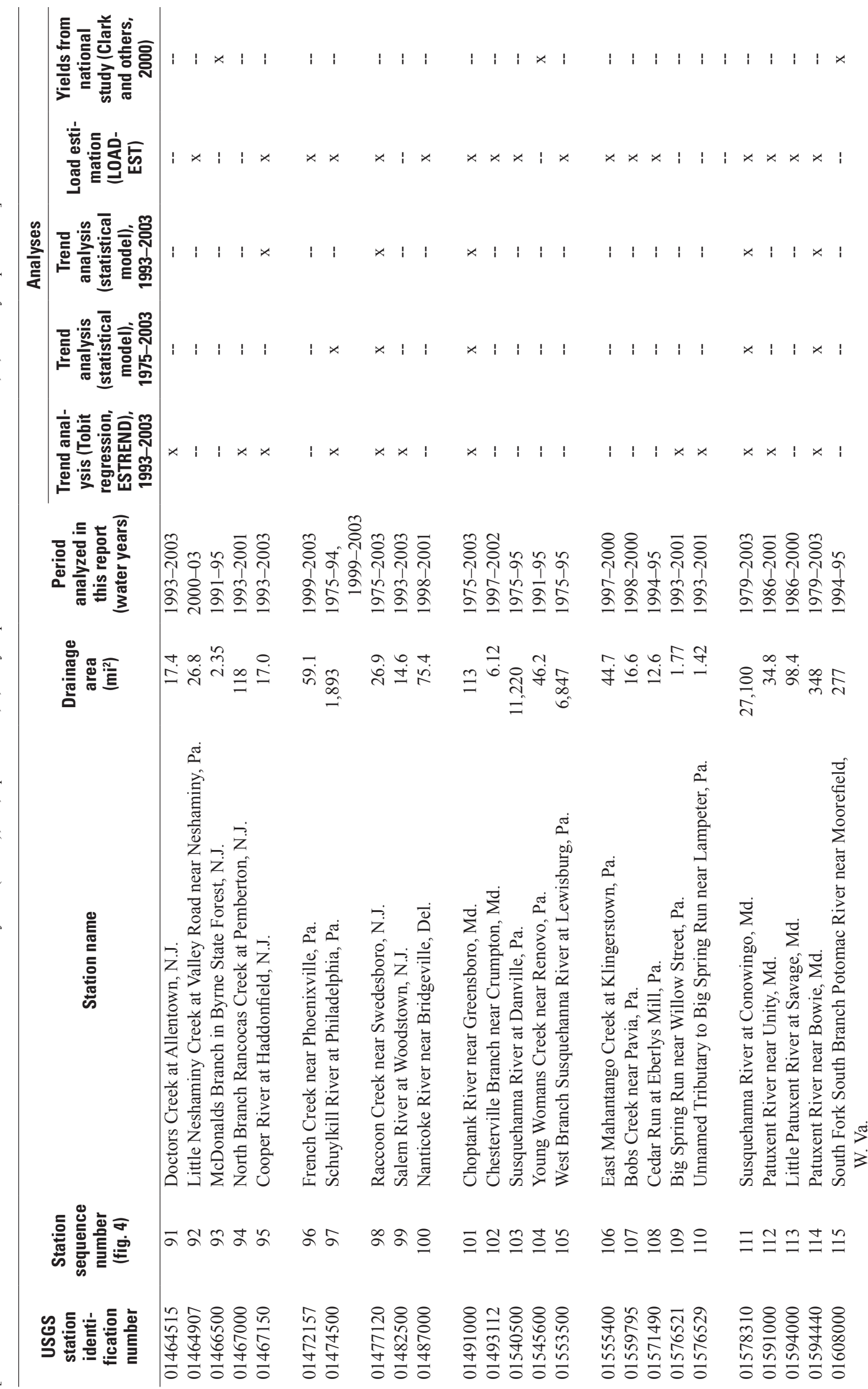




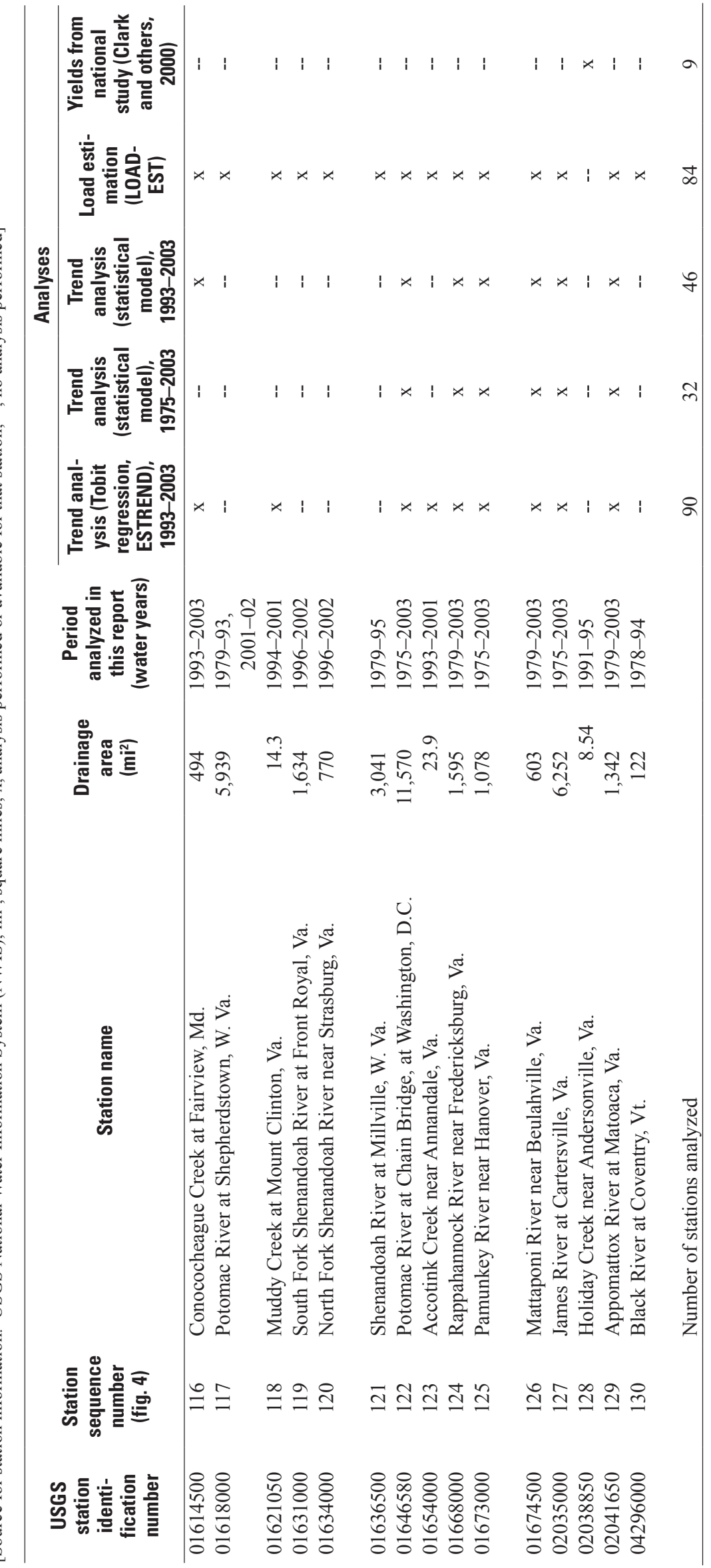




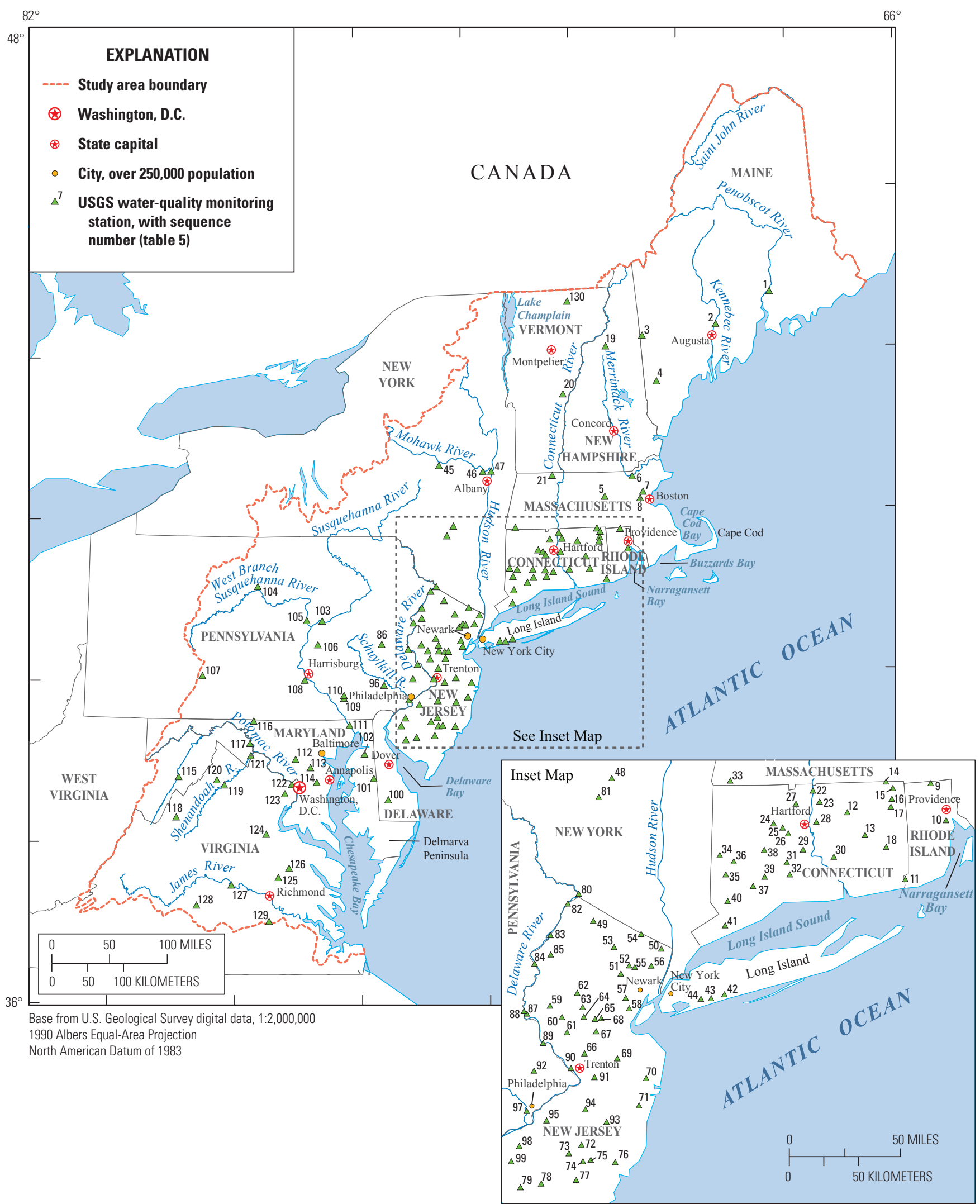

Figure 4. Locations of 130 U.S. Geological Survey water-quality monitoring stations evaluated in this study (with station sequence numbers keyed to table 5). 
Table 6. Water-quality constituents retrieved for study, including constituent name, parameter code, and listing of parameter codes used in analyses in this report.

[Water-quality constituents evaluated shown in bold. Parameter codes refer to laboratory methods for determining constituent concentrations. $\mathrm{mg} / \mathrm{L}$, milligrams per liter; N, nitrogen; P, phosphorus]

\begin{tabular}{|c|c|c|}
\hline Water-quality constituent & $\begin{array}{l}\text { Parameter } \\
\text { code }\end{array}$ & $\begin{array}{l}\text { Parameter codes used in analyses } \\
\text { (shown in order of priority for each constituent) }\end{array}$ \\
\hline Nitrogen, total, as $\mathrm{N}, \mathrm{mg} / \mathrm{L}$ & & $00600,(00625+00631),(00623+49570+00631)$ \\
\hline Nitrogen, total, as $\mathrm{N}, \mathrm{mg} / \mathrm{L}$ & 00600 & \\
\hline Ammonia, dissolved, as $\mathrm{N}, \mathrm{mg} / \mathrm{L}$ & 00608 & 00608 \\
\hline Nitrate, dissolved, as $\mathrm{N}, \mathrm{mg} / \mathrm{L}$ & 00618 & \\
\hline Nitrate, total, as $\mathrm{N}, \mathrm{mg} / \mathrm{L}$ & 00620 & \\
\hline Ammonia-plus-organic nitrogen, dissolved, as $\mathrm{N}, \mathrm{mg} / \mathrm{L}$ & 00623 & \\
\hline Ammonia-plus-organic nitrogen, total, as $\mathrm{N}, \mathrm{mg} / \mathrm{L}$ & 00625 & 00625 \\
\hline Nitrite-plus-nitrate, dissolved, as $\mathrm{N}, \mathrm{mg} / \mathrm{L}$ & & $00631,00630,00618,00620$ \\
\hline Nitrite-plus-nitrate, dissolved, as $\mathrm{N}, \mathrm{mg} / \mathrm{L}$ & 00631 & \\
\hline Nitrite-plus-nitrate, total, as $\mathrm{N}, \mathrm{mg} / \mathrm{L}$ & 00630 & \\
\hline Nitrogen, particulate, as $\mathrm{N}, \mathrm{mg} / \mathrm{L}$ & 49570 & \\
\hline Phosphorus, total, as $\mathrm{P}, \mathrm{mg} / \mathrm{L}$ & & $00665,(00667+00666)$ \\
\hline Phosphorus, total, as $\mathrm{P}, \mathrm{mg} / \mathrm{L}$ & 00665 & \\
\hline Phosphorus, dissolved, as $\mathrm{P}, \mathrm{mg} / \mathrm{L}$ & 00666 & \\
\hline Phosphorus, particulate, as $\mathrm{P}, \mathrm{mg} / \mathrm{L}$ & 00667 & \\
\hline Suspended sediment, mg/L & 80154 & 80154 \\
\hline
\end{tabular}

\section{Data from State Monitoring Programs}

State nutrient data sets, and some municipal datasets for drinking water sources, were investigated during the initial phase of this study, but compilation, screening, and analysis of these data were beyond the scope of this report. These datasets represent a valuable resource for understanding nutrient conditions in the streams of the region, and provide coverage for some geographic areas that are not monitored through USGS programs. State nutrient datasets have been incorporated in a USGS NAWQA study that is modeling regional nutrient loads (R.M. Moore, U.S. Geological Survey, oral commun., 2008), and also are used in studies of the USGS Chesapeake Bay Program (CBP) (Langland and others, 2006).

\section{Methods of Data Analysis}

USGS streamflow and water-quality data for the region were evaluated and analyzed by using several methods. Streamflow conditions were characterized for several time periods to evaluate streamflow during periods of water-quality analyses, and streamflow data were analyzed for trends. Streamgages used in the streamflow analysis, and a table of analyses performed, are shown in appendix 2 . Nutrient data, and a small amount of suspended sediment data, were analyzed for flow-adjusted and non-flow-adjusted trends in concentrations. Annual constituent loads were estimated, and annual loads were analyzed for trends. All the methods for analysis of nutrient trends and loads involve relating nutrient concentrations to variables of streamflow, time, and season. The methods are described in more detail in the following sections and in appendixes 3 and 4. Results of trend analyses and other statistical tests were considered significant if the attained significance level of the test ( $p$-value) was less than or equal to 0.05 , and were considered highly significant if the $p$-value was less than or equal to 0.01 . Trend counts summarized in this report include both significant and highly significant trends, unless otherwise specified.

Exploratory analyses for water-quality data included: tabular compilations of water-quality samples by year for each constituent of interest at each water-quality station; plots of concentration as a function of time; and plots of concentration 
as a function of stream discharge. A LOESS smoothing procedure in S-Plus (Insightful Corporation, 2002; TIBCO Software, Inc., 2008) has been used to identify generalized time trends, or other relations between variables, in the plots in this report. Outliers (values substantially outside the expected range) were identified and checked for validity by using several approaches. A small number of outliers were omitted from the analyses, on the basis of information that indicated the values were inaccurate.

Selected ancillary datasets were analyzed to evaluate the effects of land use, population density, and point-source discharges on nutrient trends and loads. Compilation and analysis of point-source data for the whole region was beyond the scope of this report. Four drainage basins were selected for analysis of point-source information: the Quinebaug River Basin in Connecticut, the Raritan River Basin in New Jersey, the Patuxent River Basin in Maryland, and the James River Basin in Virginia.

\section{Streamflow Analysis}

Streamflow data for 96 USGS streamgages in the region were analyzed to evaluate annual variability; to define low, average, and high flow years; to evaluate changes over time; to compare streamflow conditions during the recent period, 1993 to 2003, to a reference period of 1970-2003; and to place the recent period in the context of longer-term data (records extending back to 1944 or earlier). Statistical analyses for selected streamgages included: (1) computing streamflow statistics such as the averages and percentiles of daily and annual mean flows, and (2) evaluating time-series plots of annual mean streamflow for the full period of record, with the annual median flow statistics computed for each of the three periods. Exploratory data analysis included review of flow-duration curves for each of the three periods for selected streamgages. The network of 96 streamgages used to summarize and evaluate streamflow represents a wide range of stream types and drainage basins - from steep, mountainous streams to lowgradient, meandering streams; from small streams to large rivers; and from mostly forested basins to urban environments (appendix 2, table 2-1).

Daily-mean streamflow data were retrieved from the USGS National Water Information System (NWIS) and were used to generate annual mean and annual median flow statistics by water year (U.S. Geological Survey, 2009b; 2002). In general, annual mean flow is larger than the annual median flow because high flows often associated with storms affect the mean more than the median. Typically, high annual median flow results from an overall wet year. Percentiles calculated from the annual mean and annual median flows were used to identify low, average, and high annual mean and annual median flow years for selected streamgages. Annual mean and annual median flows from the 25th to the 75th percentiles were considered average (normal) flow years; flows less than the 25th percentile were considered low-flow years; and flows exceeding the 75th percentile were considered high-flow years. In addition, annual mean and annual median flows less than the 10th percentile were considered extremely low-flow years and flows greater than the 90th percentile were considered extremely high-flow years. Flow-duration curves constructed by using the daily-mean streamflow values were reviewed to compare how flow characteristics during the recent period differ from the reference period of 1970-2003 and the long-term (60 years or more) full period of record. Flow-duration curves show the percentage of time during which a specified streamflow was equaled or exceeded in a given time period.

Annual statistics of runoff from 1901 to 2003 were retrieved from the USGS WaterWatch web site for Hydrologic Region 01, the New England region, and Hydrologic Region 02, the mid-Atlantic region (U.S. Geological Survey, 2009c; Jian and others, 2008) and were used to summarize regional runoff. Hydrologic Regions are also referred to as Hydrologic Units, because all drainage areas in this system of classification are identified by Hydrologic Unit Codes (HUCs) on a scale from large regions to smaller local drainage basins (Natural Resources Conservation Service, 2009). The New England region is identified as HUC 01 and the mid-Atlantic region as HUC 02.

Runoff is the amount of water running off a drainage area, measured in units that can be compared from one drainage area to another, and is expressed as the depth to which the drainage area would be covered by water (in inches), if all the water flowing from the basin were uniformly distributed over the drainage basin. Runoff for HUC 01 and HUC 02 was determined by averaging the runoff from the basins in each HUC that had complete records of daily mean flow for the water year. The number of basins with daily mean flow data used to estimate annual runoff varies from year to year because certain time periods had fewer gaged basins. Annual runoff for each basin is determined for each water year by dividing the average daily flow for the water year by the basin drainage area. Annual runoff for each HUC is then determined by averaging the runoff from all the basins within each HUC, to provide a regional estimate of runoff.

Streamflows also were compared regionally and over time by using the coefficient of variation. The coefficient of variation for annual runoff is defined as the standard deviation divided by the mean. The result is a ratio, or percentage. For comparison of streamflow conditions, the coefficient of variation equals the standard deviation divided by the mean of the annual runoff dataset for each period. The coefficient of variation was computed for the three periods of record for each group of streamgages evaluated. This statistic allows for direct comparisons in the variability of the annual runoff between periods of record for a given geographic area, and between regions with differences in annual runoff values during the same time period. Time periods or geographic areas with the lowest coefficient of variation have the least variability in the annual runoff. When comparing statistical results among different periods for a group of streamgages, a longer 
time period generally includes more extreme climatic years and has a higher coefficient of variation. Other statistics used to characterize and compare streamflows include the mean and median of the annual runoff, and standard deviation.

Streamflow data also were evaluated for trend, for the stations that were evaluated for trends in nutrient concentrations and loads. Long-term and recent records of daily mean streamflow for these streamgages were analyzed for trends by using methods described in the section entitled "Instream Trend Analysis with Coupled Statistical Streamflow and Water-Quality Model.”

\section{Analysis of Trends in Nutrient Concentrations, Nutrient Loads, and Streamflow}

Trends in nutrient concentrations, nutrient loads, and streamflow were identified by using two approaches described in the following sections. Tobit regression in the ESTREND system (Slack and others, 2003) was used to analyze flowadjusted trends in constituent concentrations during the 1993-2003 period. A statistical modeling program has been developed by the USGS to analyze trends in streamflow, flow-adjusted constituent concentrations, non-flow-adjusted constituent concentrations, and stream constituent loads (G.E. Schwarz, U.S. Geological Survey, written commun., 2006). This statistical modeling program was used to analyze trends during the 1993-2003 and 1975-2003 periods. The two programs provide different capabilities that expanded the range of the analysis for this report.

Flow-adjusted trends account for (or remove) the effects of natural fluctuations in streamflow on concentrations.

Because the results are unaffected by these streamflow variations, flow-adjusted trend results provide an indication of water-quality changes resulting from changes in a watershed, such as implementation of management and pollution-control measures or changes in land use. Non-flow-adjusted trend results provide an indication of changes in the actual instream water-quality conditions that affect aquatic habitat and other resource uses.

The parametric methods of trend analysis used in this study assume the presence of linear (monotonic) trends. A significant trend refers to a linear change between the beginning and the end of the period of record analyzed. During long periods of time, however, many constituent trends are nonmonotonic. The assumption that any trend is linear oversimplifies the reality of changes in streamflow, constituent concentration, flow-adjusted concentration, or constituent load over time. Although a nonlinear trend violates the linearity assumption of the trend methods, and may introduce some bias into the results, the presence of a nonlinear trend does not invalidate the trend results. Without knowledge of the true form of the trend, any trend function, including functions that incorporate nonlinearities, may overestimate or underestimate the trend (G.E. Schwarz, U.S. Geological Survey, written commun., 2010). Trend results reported for this study, particularly trends for the long-term period, should be evaluated with the understanding that there may be some bias in the attained significance level of the trend tests ( $p$-values) where the direction, or slope, of the trend has varied over time. Constituent concentrations or loads have changed substantially during the period of analysis at many stations, and simple plots of these values over time add strength to the argument that significant trends are, in fact, present. More detailed and intensive methods of analysis for individual stations and constituents could refine the identification of variable changes over time, but these methods are beyond the scope of this study, in which a large number of stations and constituents are evaluated to provide a broad picture of regional conditions.

\section{Flow-Adjusted Trend Analysis with Tobit Regression}

USGS water-quality stations were selected for analysis of flow-adjusted trends in total nitrogen and total phosphorus based on the availability of nutrient concentration data during water years 1993-2003 and the availability of a streamflow measurement associated with each water-quality value. Trends in dissolved nitrite-plus-nitrate and dissolved ammonia were analyzed at stations in the four basins selected for analysis of point source information.

Trends in flow-adjusted nutrient concentrations were identified with the S-PLUS version of the ESTREND system (Insightful Corporation, 2002; Slack and others, 2003; TIBCO Software, Inc., 2008). The Estimate Trend (ESTREND) Program (Schertz and others, 1991) was developed by the USGS to identify trends in water quality in streams. The ESTREND system provides three methods to identify trends, and Tobit regression was the method selected for this study. For each nutrient at each station, an equation was developed relating water quality to year, streamflow, and season. Aspects of the Tobit regression method are described by Helsel and Hirsch (2000, p. 372), and details of the application in this study are provided in appendix 3.

Nutrient data for 90 stations were analyzed for trend, for periods ranging from 8 to 11 water years, depending on the amount and distribution of data. Trend tests for a station are reported if the dataset contained sufficient nutrient measurements to start the period of analysis during water years 1993 , 1994 , or 1995 and end the period of analysis during water years 2001, 2002, or 2003.

\section{Instream Trend Analysis with Coupled Statistical Streamflow and Water-Quality Model}

Determination of trends in instream water quality requires an approach that accommodates data with multiple changes in water-quality sampling intervals and in the types of streamflow conditions sampled. In many previous trend studies, trend analysis programs such as ESTREND have been applied to the reported instream concentrations during the period of interest, 
to understand water-quality changes that riverine habitats have actually experienced. Applying this type of trend analysis is an acceptable practice where monitoring programs collect waterquality samples at fixed intervals, without regard to streamflow, and the resulting samples represent a range of streamflow conditions during a period of several years. However, many monitoring programs have sampled streams intensively during high streamflow or low streamflow to evaluate specific conditions, and thus the range of constituent concentrations sampled during some parts of the period of record may be biased. Consequently, trend analyses on instream concentrations can be biased as well.

A different approach for assessing instream waterquality changes is necessary because of the potential for biased trend results when trend programs are applied to data from sampling programs focused on specific hydrologic conditions. The approach developed for this study, and for similar nutrient studies in other regions of the country, uses a coupled streamflow model and water-quality model to derive a non-flow-adjusted trend in concentration (G.E. Schwarz, U.S. Geological Survey, written commun., 2006). The streamflow model and the water-quality model are estimated in natural logarithm space. The non-flow-adjusted trend in concentration derived from these models is referred to as the "modeled instream concentration trend" in this report. Because the water-quality model used to derive these trends includes streamflow as a predictor, the estimates of trend are immune to the bias arising from preferential water-quality sampling during extreme streamflow.

This coupled statistical model provides trend results for streamflow, flow-adjusted constituent concentrations, nonflow-adjusted constituent concentrations ("modeled instream concentrations"), and constituent loads. A narrative explanation of this modeling approach is provided in appendix 4, and the detailed mathematical basis for the model has been presented by Sprague and others (2007, p. 10-12). In simplest terms, the streamflow model, which is estimated from all daily streamflow measurements during the period of analysis, relates the logarithm of daily streamflow to an intercept, a linear trend term (decimal time), sine and cosine functions of decimal time (to describe the seasonal component of flow), and a serially correlated error term; the streamflow residual is assumed to follow an autoregressive process of order 30 (AR(30)) (Fuller, 1996). The streamflow model is estimated by using maximumlikelihood estimation methods as employed by the AUTOREG procedure in SAS 9, version 1, release 2 (SAS Institute, Inc., 2004). The high-order autoregressive process is necessary to remove as much serial correlation as possible from the flow residuals, thereby reducing bias in the estimated coefficient covariance matrix of the streamflow model.

The water-quality model, estimated from constituent concentrations measured during the analysis period, relates the logarithm of constituent concentration to the terms in the streamflow model and also to functions of the logarithm of streamflow. Model results also include estimates of unit trends, that is, trends expressed in units of concentration or load per year, and also the reference concentrations and reference loads that are used to derive the unit trends. Reference flows, computed from streamflow model results, are essentially estimates of median daily streamflow for the period of analysis (G.E. Schwarz, U.S. Geological Survey, written commun., 2006).

\section{Estimation of Nutrient Loads}

USGS water-quality stations were selected for estimation of annual nutrient loads on the basis of the availability of nutrient concentration data during water years 1975-2003 or 1993-2003 and the availability of a complete record of daily mean stream discharge values for each year of interest. Annual stream nutrient loads were estimated for 32 water-quality monitoring stations for the period 1975-2003 and for 46 stations for the period 1993-2003 (table 5). Annual loads were estimated for 31 of these stations for both periods of record. One station, the Schuylkill River at Philadelphia, was included in the long-term period, but data for the station did not meet criteria for the recent period because of a four-year break in the water-quality record during water years 1995-98. For the recent period all stations had water-quality and discharge records beginning with the 1993 water year and ending with the 2003 water year. A few stations had one missing year of water-quality record during that period. For the long-term period, the beginning year of water-quality record varied among stations, and stations were grouped for load estimation with initial years of 1975, 1979, and 1982. All long-term annual load estimates ended with the 2003 water year. Annual loads were estimated for all years in the 1975-2003 period for the Schuylkill River at Philadelphia, including the four-year break in the water-quality record.

Annual loads were estimated for 37 additional stations that had less than the full 1993-2003 period of record, to provide better geographic coverage of the region and representation of specific land uses in the results. Criteria for selection of additional stations were as follows: at least one integrator drainage basin (station monitoring a large drainage basin with varied land uses), one urban basin, one agricultural basin, and one forested basin in each of the NAWQA study units, where available; large drainage basins in under-represented areas of the region; small drainage basins with no point sources in under-represented areas of the region; and recommendations of NAWQA study unit staff. Water-quality records for these 37 stations ranged in length from 1 to 10 years during the 1993-2003 period and from 14 to 24 years during the 19752003 period. Annual loads were estimated for all available years of record during the 1975-2003 period.

Annual nutrient loads for all stations analyzed were normalized by drainage area and converted to annual yields in pounds per square mile for comparison among drainage basins. Mean annual nutrient yields for undeveloped drainage basins have been estimated in a national study by Clark and others (2000). Nine of the basins in the national study are in the northeastern region covered by this report. Mean annual 
nutrient yields for these nine basins are presented in this report as a benchmark of conditions in relatively undeveloped and near-pristine watersheds of the region.

Annual stream nutrient loads were estimated by using a multiple-linear-regression model contained in the computer program LOADEST, applied in the S-PLUS version of the program (Insightful Corporation, 2002; Runkel and others, 2004; TIBCO Software, Inc., 2008). Given a time series of streamflow, additional data variables, and constituent concentration for a monitoring station, LOADEST assists the user in developing a regression model for estimating the stream load of a specific constituent at that location. This step is the calibration phase of the model. Explanatory variables in the regression model include various functions of streamflow, decimal time, and season, and can include additional userspecified data variables. The formulated regression model then is used in the estimation phase of the model, to estimate annual constituent loads during a user-specified time interval. Mean load estimates, standard errors, and 95-percent confidence intervals are developed on an annual basis.

The calibration and estimation procedures in LOADEST are based on three statistical estimation methods. The first two methods, Adjusted Maximum Likelihood Estimation (AMLE) and Maximum Likelihood Estimation (MLE), are appropriate when the calibration model errors (residuals) are normally distributed. AMLE is the method of choice when the calibration dataset (time series of streamflow, additional data variables, and concentration) contains censored data. The third method, Least Absolute Deviation (LAD), is an alternative to maximum likelihood estimation when the residuals are not normally distributed and the dataset contains no censored data (Runkel and others, 2004). The AMLE method was used for all load estimates in this report because of censored data in most of the nutrient datasets.

The LOADEST Program includes several predefined models that specify the form of the regression equation (Runkel and others, 2004, p. 12, table 7). A model may be selected by the user, on the basis of the user's knowledge of the hydrologic and biogeochemical system of the stream. Alternatively, the software provides an automated model selection option to select the "best" model from the set of predefined models, on the basis of statistics computed for the full set of models (Runkel and others, 2004, p. 7). The "best" model option was used for most of the stations and constituents analyzed in this report.

\section{Analysis of Nutrient Sources}

Nutrient sources in the region are numerous and complex, and a comprehensive evaluation of sources was beyond the scope of this report. Selected information on land use and population density for the region, and information on point sources in a small number of drainage basins, was compiled to provide an overview of some of the critical nutrient sources affecting stream nutrient conditions in the region.

\section{Land Use and Population Density}

Land use and population data used in this report were developed by the USGS to support the analyses of surfacewater quality and aquatic ecological data by NAWQA regional studies (N. Nakagaki, U.S. Geological Survey, written commun., 2005). Population data were also obtained from the U.S. Census Bureau (Forstall, 1995; Hobbs and Stoops, 2002; U.S. Census Bureau, 2000, 2001). The land use dataset is the August 2005 enhanced version of the circa 1992 National Land Cover Dataset, known as the "NLCDe 92" dataset (Vogelmann and others, 1998; enhanced as described by Nakagaki and Wolock, 2005). The 25 detailed land-cover categories in this dataset have been aggregated into the following major categories for use in this report: total urban land, total agricultural land, total developed land (includes urban land, agricultural land, and other miscellaneous developed land uses), total forested land, and total undeveloped land (includes forested land).

Monitored drainage basins have been assigned to the following five land-use categories on the basis of percentages of urban and agricultural land in the drainage basin upstream from each monitoring station: Undeveloped (UN), Urban (UR), Urban/Agricultural (UA), Agricultural (AG), and Agricultural/Urban (AU) (table 7). Effects on water quality from agricultural and urban land uses are generally much more pronounced than the effects of undeveloped land. Consequently, in this report, developed land uses covering less than half of a drainage basin are used to identify the predominant land use affecting water quality, even though the land use is not predominant in a spatial context. Most monitored drainage areas in the northeastern United States include mixed land uses, and consequently nutrient impairments are derived from multiple sources.

Land-use categories defined for this report differ from the categories used by the NAWQA Program in national studies (described by Mueller and Spahr, 2006, p. 7-8), although both classification schemes are based on the land cover with the predominant effect on water quality in a drainage basin. For example, an Urban drainage basin as defined by the NAWQA Program is usually more than 25 percent urban and less than 25 percent agricultural. In the northeastern United States, however, many streams with more than about 10 percent urban land in their watersheds also are receiving waters for one or more municipal point sources, and urbanized land is concentrated close to rivers and streams. The urban point-source signature is generally apparent in various measures of water quality in these streams, and consequently, the presence of 10 percent urbanized land is considered a reasonable threshold for urban effects. Likewise, an Agricultural drainage basin as defined by the NAWQA Program is generally more than 50 percent agricultural and less than 5 percent urban. Only a few of the stations for which nutrient loads were estimated in this report have drainage basins that meet this definition, and yet many other drainage basins in the region with lower percentages of agricultural land are affected by agricultural 
Table 7. Land-use categories for 130 drainage basins evaluated for trends, loads, and yields in the northeastern United States.

[Some stations were evaluated for trends only, some for loads only, and some for both. Counts include undeveloped basins from national study (Clark and others, 2000) (table 5). <, less than; >, greater than; \%, percent; =, equal]

\begin{tabular}{|c|c|c|c|c|c|}
\hline \multirow{2}{*}{ Category } & \multirow{2}{*}{$\begin{array}{l}\text { Land-use } \\
\text { code }\end{array}$} & \multirow{2}{*}{ Land-use percentages in drainage basin } & \multicolumn{2}{|c|}{ Maximum number of stations evaluated } & \multirow{2}{*}{$\begin{array}{c}\text { Total } \\
\text { number of } \\
\text { stations }\end{array}$} \\
\hline & & & Trend analysis & Load and yield estimation & \\
\hline Undeveloped & UN & $\mathrm{UR}<10 \%$ and $\mathrm{AG}<20 \%$ & 22 & 28 & 38 \\
\hline Urban & UR & $\mathrm{UR}>$ or $=10 \%$ and $\mathrm{AG}<20 \%$ & 37 & 26 & 43 \\
\hline Urban/agricultural & UA & $\mathrm{UR}>$ or $=10 \%$ and $\mathrm{AG}>$ or $=20 \%$ and $<50 \%$ & 10 & 14 & 17 \\
\hline Agricultural & $\mathrm{AG}$ & $\mathrm{AG}>$ or $=20 \%$ and $\mathrm{UR}<10 \%$ & 19 & 25 & 30 \\
\hline Agricultural/urban & AU & $\mathrm{UR}>$ or $=10 \%$ and $\mathrm{AG}>$ or $=50 \%$ & 2 & 0 & 2 \\
\hline Total: & & & 90 & 93 & 130 \\
\hline
\end{tabular}

nutrient sources. Consequently, a lower threshold of 20 percent agricultural land (with urban land less than 10 percent) was used in this report to define a drainage basin as Agricultural. The threshold percentage for defining a drainage basin as urban is lower than the threshold percentage for defining a drainage basin as agricultural in both classification schemes. Likewise in both classification schemes, Undeveloped drainage basins have more than 70 percent undeveloped land.

Undeveloped land is almost entirely forested land in the northeastern United States. The undeveloped land-use category in this report includes drainage basins with undeveloped land ranging from 74.1 to 100 percent of basin area.

The NAWQA Program also defines a category of Large drainage basins, on the basis of a combination of drainage area (generally greater than about $600 \mathrm{mi}^{2}$ ) and long-term mean annual streamflow, to account for the effects of a complex mixture of land cover, multiple point sources, and temporally variable sources of streamflow in these drainage basins. This category of size distinction has not been included in this report. Many large drainage basins, including some with multiple point sources, are classified as Undeveloped on the basis of land-use percentages. For example, the drainage area of the Connecticut River at Thompsonville, Conn., is 5 percent urban, 8.3 percent agricultural, and about 85 percent undeveloped, and is classified as Undeveloped, although there are major municipal point-source discharges in the basin (table 8, in back of report). Conversely, some large drainage basins are classified as Urban or Agricultural, even though more than half of their drainage areas are forested. For example, the drainage area of the Susquehanna River at Conowingo, Md., is largely undeveloped (about 68 percent) (table 8 , in back of report). However, agricultural lands account for about 28 percent of the drainage area, most agricultural land is located in downstream areas of the drainage basin nearest the monitoring station, and agricultural land use provides the most pronounced effects on the observed water quality. Therefore, this basin is classified as Agricultural. The complex nature of nutrient sources in large drainage basins is discussed in this report.
Land use and population characteristics have been summarized for 130 stations evaluated in this report (table 8, in back of report). The undeveloped category includes nine stations in the northeastern region that were evaluated in a national study of undeveloped drainage basins (Clark and others, 2000). These nine stations are identified in the "Undeveloped site" column in table 8 (in back of report).

\section{Point Sources}

Information used for the analysis of point sources was initially developed from the USEPA Permit Compliance System (PCS). Facility locations (coordinates for latitude and longitude) were obtained from the PCS data distributed with the USEPA "Better Assessment Science Integrating point \& Non-point Sources" (BASINS) ArcView system (U.S. Environmental Protection Agency, 2005). The BASINS system includes information for 11,584 PCS sites in the study area of this report. Records for only 624 of these 11,584 PCS sites included annual estimates for total phosphorus loads (parameter code 00665) for any year from 1992 to 1999. Additionally, records for only 123 sites included annual estimates for total nitrogen loads (parameter code 00600). Many more sites must actually discharge nitrogen and phosphorus. By using the Standard Industrial Classification (SIC) Codes that are included with the PCS facility data, sites were identified that are likely to be discharging nutrient loads to streams in the region (table 9). A listing of these SIC codes and related criteria (McMahon and others, 2007, p. 5) were used in conjunction with PCS data to estimate the number of major and minor facilities discharging nutrients in each state of the study area (table 9). Major municipal facilities are defined by the U.S. Environmental Protection Agency (2008) as facilities that discharge at least 1 million gallons per day of effluent. Major non-municipal facilities are defined by a rating code formula. 
Table 9. Estimated numbers of point sources discharging nutrients in the northeastern United States study area.

[Nutrient point-source locations were identified by using the reported Permit Compliance System (PCS) facility locations, in conjunction with Standard Industrial Classification (SIC) Codes. Sources: U.S. Environmental Protection Agency, 2005; McMahon and others, 2007, p. 5]

\begin{tabular}{|c|c|c|}
\hline \multirow[t]{2}{*}{ State or district } & \multicolumn{2}{|c|}{$\begin{array}{l}\text { Nutrient point sources in the } \\
\text { northeastern United States study area }\end{array}$} \\
\hline & Major facilities & Minor facilities \\
\hline Connecticut & 78 & 40 \\
\hline Delaware & 20 & 22 \\
\hline District of Columbia & 3 & 2 \\
\hline Maine & 82 & 154 \\
\hline Maryland & 74 & 328 \\
\hline Massachusetts & 117 & 235 \\
\hline New Hampshire & 58 & 52 \\
\hline New Jersey & 160 & 593 \\
\hline New York & 152 & 623 \\
\hline Pennsylvania & 201 & 1,973 \\
\hline Rhode Island & 22 & 46 \\
\hline Vermont & 31 & 45 \\
\hline Virginia & 84 & 682 \\
\hline West Virginia & 7 & 267 \\
\hline Total & 1,089 & 5,062 \\
\hline
\end{tabular}

Additional state and regional programs were investigated for data on point-source nutrient loads because of the insufficient annual estimates for total nitrogen and total phosphorus loads provided with the PCS data. Sources of nutrient data for point sources in selected areas of the region include the Connecticut Department of Environmental Protection (CTDEP), the New Jersey Department of Environmental Protection (NJDEP), and the Chesapeake Bay Program (table 10). These data sources were analyzed to identify watersheds where the nutrient point-source data were adequate for detailed analysis. Analysis of all point sources in the region was beyond the scope of this project. Consequently, a small number of watersheds were selected for analysis, to represent major geographic areas in the region, and to take advantage of the extensive water-quality and point-source data available in some areas. Four watersheds were selected: the Quinebaug River Basin in Connecticut, Rhode Island, and Massachusetts; the Raritan River Basin in New Jersey; the Patuxent River Basin in Maryland; and the James River Basin in Virginia, which includes the Appomattox River Basin (table 10).

Total nitrogen loads for point sources in the Quinebaug River Basin were provided by the CTDEP (Paul Stacey, Connecticut Department of Environmental Protection, written commun., 2006). Annual loads of total phosphorus for point sources in the Quinebaug River Basin (1990 through 1999) were obtained directly from the PCS database accessed through the BASINS Program (Better Assessment Science Integrating point \& Non-point Sources; U.S. Environmental Protection Agency, 2005).

Annual loads for nitrogen constituents for point sources in the Raritan River Basin were obtained from TRC Omni Environmental Corporation for the period 1991-97 (James Cosgrove, TRC Omni Environmental Corporation, written commun., 2006). These data on point-source loads of nitrogen constituents were derived primarily from the discharge monitoring report (DMR) database of NJDEP, and were compiled in a point-source pollutant analysis (TRC Omni Environmental Corporation, 2001). Annual load compilations from this analysis were used subsequently to compute average point-source loads for the 1991-97 period (Reiser, 2004).

Table 10. Summary of data sources and availability of point-source data for selected drainage basins.

[Sources: Stacey, Paul, Connecticut Department of Environmental Protection, written commun., 2006; U.S. Environmental Protection Agency, 2005; Cosgrove, James, TRC Omni Environmental Corporation, written commun., 2006; Reiser, 2004; Robinson and others, 1996; Chesapeake Bay Program Data Hub (http://www.chesapeakebay.net/data/index.htm); mi², square miles; CTDEP, Connecticut Department of Environmental Protection; NJDEP, New Jersey Department of Environmental Protection; CBP, Chesapeake Bay Program]

\begin{tabular}{lcllcc}
\hline Drainage basin & $\begin{array}{c}\text { Monitored } \\
\text { drainage area } \\
\left(\mathbf{m i}^{2}\right)\end{array}$ & & States & Source for point- & \multicolumn{2}{c}{ Time period for point-source data } \\
\cline { 5 - 6 } & 713 & Rhource data & Total nitrogen & Total phosphorus \\
\hline Quinebaug & 804 & New Jersey & CTDEP & $2002-2004$ & $1990-1998^{*}$ \\
Raritan & 348 & Maryland & NJDEP & $1991-1997$ & $1991-1997$ \\
Patuxent & 6,252 & Virginia & CBP & $1990-2003$ & $1990-2003$ \\
James & 1,342 & Virginia & CBP & $1990-2003$ & $1990-2003$ \\
Appomattox & & CBP & $1990-1999$ & $1990-2003$ \\
\hline
\end{tabular}

${ }^{*}$ No total phosphorus data for Quinebaug River at Jewett City, Conn. 
Total nitrogen loads for this report were calculated from the loads of nitrogen constituents, which were reported separately in the analysis by TRC Omni Environmental Corporation. Total nitrogen loads were calculated from annual loads of Kjeldahl nitrogen (ammonia, ammonium, and organic nitrogen), nitrate, and nitrite. Annual loads of total phosphorus for facilities in the Raritan River Basin were obtained directly from the PCS database.

Nutrient loads for point sources in the Patuxent River and James River Basins were obtained from the Chesapeake Bay Program Data Hub (http://www.chesapeakebay.net/data/index. htm, accessed February 16, 2006). Annual point-source loads for total nitrogen and total phosphorus (1990 to 2003) were provided from this source.

Total point-source nutrient loads upstream from selected USGS water-quality monitoring stations were summed and plotted along with the total estimated stream nutrient loads for selected monitoring stations throughout the basins selected for analysis. Observations and inferences were then made regarding the role of point sources in the total annual stream loads. Point-source loads are reported for calendar years, whereas stream loads are reported by water year (October 1 through September 30). Although the comparison is for slightly different timeframes, with a three month offset, observations and inferences can be made.

Additional information on point-source locations and return flows in the New England states is from Medalie (1996). Additional information for point-source locations in New Jersey is from Robinson and others (1996), and from Reiser (2004) for locations in the Raritan River Basin in New Jersey.

\section{Streamflow Conditions in the Northeastern United States}

Nutrient concentrations and loads are often closely correlated with streamflow conditions, and consequently information on streamflow is necessary for interpreting and understanding these measures of stream nutrient conditions. Annual mean streamflows at most stations evaluated have varied substantially during the recent and long-term periods of record considered in this report. Substantial spatial variation in streamflow also is common in the region.

Stream discharges were evaluated at 96 stations (appendix 2, table 2-1), for the period 1993-2003, the period 1970-2003, if available, and the full period of record at stations with record prior to 1970 . Several statistics were used to characterize streamflow, to compare the recent period to the reference period of 1970 to 2003 , and to place the recent period in the context of longer-term data (records extending back to 1944 or earlier). Graphical methods also were used to evaluate and characterize streamflow for selected stations during the recent and long-term periods.

\section{Streamflow, 1993-2003}

Annual mean flows and annual runoff during 1993-2003 varied substantially from year to year, with extremely low annual mean flows and annual runoff in 2002 and high annual mean flows and annual runoff in 1996 and 2003, depending on the geographic area. New minimum or maximum annual mean flows were recorded at 18 of 51 stations with 60 or more years of record (appendix 2). Water-quality records were evaluated in this report for 13 of these 18 stations (table 11). Five water-quality stations with record lengths ranging from 62 to 75 years experienced both new minimum and new maximum annual mean flows during 1993-2003: Ammonoosuc River, N.H.; Neshanic River, N.J.; Conococheague Creek, Md.; Shenandoah River, W. Va.; and Pamunkey River, Va. (station numbers $19,61,116,121$, and 125 , respectively, in fig. 4 and table 5).

Annual mean flow during 1993-2003 was fairly evenly distributed among high and low flows at all 51 stations, with about one-third of the annual mean flows greater than the 75th percentile, one-third of the annual mean flows less than the 25th percentile, and one-third of the annual mean flows within the interquartile range (the 25th to 75 th percentiles of flow). Across the region, only water year 2000 was near the long-term annual average. During 2002, annual mean flow was below normal (less than 25 th percentile) at 90 percent (46 of 51) of the stations with long-term streamflow records (60+ years). During 1996 and 2003, annual mean flow was above normal (greater than 75 th percentile) at 76 percent (39 of 51) and 69 percent (35 of 51) of the stations, respectively.

The five largest rivers in the region with long-term data for both stream discharge and water quality are the Connecticut River $\left(9,660 \mathrm{mi}^{2}\right)$, Delaware River $\left(6,780 \mathrm{mi}^{2}\right)$, Susquehanna River $\left(24,100 \mathrm{mi}^{2}\right.$ at Harrisburg, Pa., for long-term streamflow; 27,100 $\mathrm{mi}^{2}$ at Conowingo, Md., for water quality), Potomac River (11,570 $\left.\mathrm{mi}^{2}\right)$, and James River $\left(6,252 \mathrm{mi}^{2}\right)$ (numbers $22,90,111,122$, and 127 in fig. 4 and table 5). The combined annual median flow of these five rivers during 2002 (with streamflow for the Susquehanna based on the Harrisburg station) was 41 percent less than the long-term median flow. In contrast to the dry conditions of water year 2002, the combined flow of these five rivers was 53 percent more than the long-term median flow during 1996 and 64 percent more than the long-term median flow during 2003, the two wettest water years in the recent period.

\section{Low-Flow Years}

In water years 1995, 1999, and 2001, notable regional differences in the annual mean flow were observed among the 51 long-term surface-water stations. Conditions were drier in the northern part of the study area in 1995. During 1995, annual mean flows were below normal (less than 25th percentile) or well below normal (less than 10th percentile) at 82 percent of the stations in New England (14 of 17 stations) and at all 23 stations in the central part of the region (New 


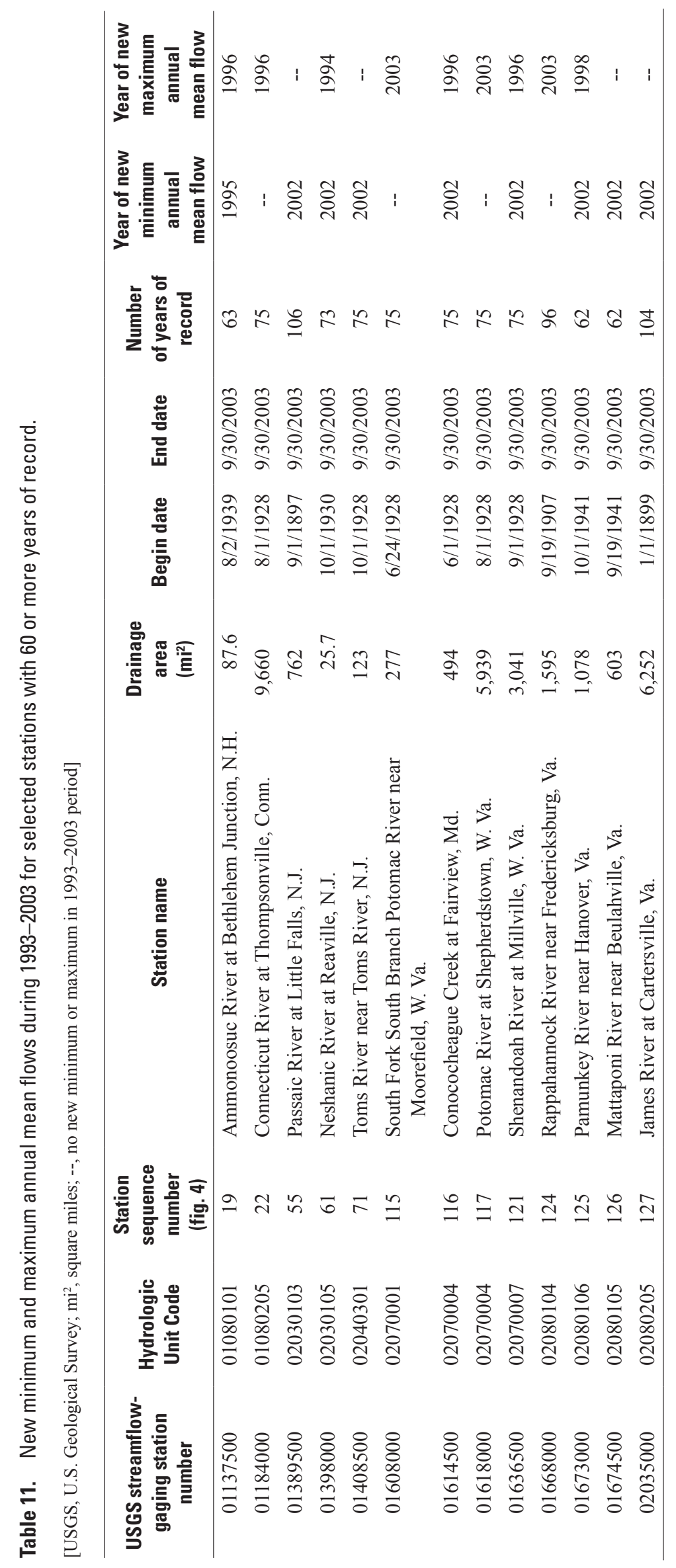


York, New Jersey, and Pennsylvania). At one long-term surface-water and water-quality station in New Hampshire, a new minimum annual mean flow was recorded (table 11). By contrast, annual mean flows were normal (the 25th to 75 th percentiles) for 6 of 11 stations, and below normal (less than 25th percentile) for 5 of 11 stations, during 1995 in the southern part of the region (Virginia, West Virginia, and Maryland).

A hydrologic drought characterized most of the southern part of the region, including areas of Virginia, West Virginia, and Maryland, from water year 1999 to 2002. Annual mean flows were well below normal (less than 10th percentile) during 1999, 2001, and 2002, and were below normal (between the 10th and 25th percentiles) at fewer stations in 2000 than in 1999, 2001, and 2002. Dry conditions also affected the central part of the region during 1999. Annual mean flows were below normal and well below normal for stations in New Jersey, New York, and Pennsylvania during water year 1999. Exceptionally dry conditions during 2002 affected, in varying degrees, a broad area from Maine to Virginia. At stations in the central and southern parts of the region, including stations in New Jersey, Maryland, Virginia, and West Virginia, annual mean flows during 2002 were the lowest of record. New minimum annual mean flow was recorded during 2002 at 9 of 51 long-term streamflow stations evaluated, including 8 stations evaluated for water quality in this report. Two of these water-quality stations had more than 100 years of record, the Passaic River at Little Falls, N.J. (drainage area $762 \mathrm{mi}^{2}$ ), and the James River at Cartersville, Va. (drainage area $6,252 \mathrm{mi}^{2}$ ). The dry conditions of 2002, characterized by a substantial shortfall in precipitation and warmer than normal temperatures, affected annual mean flows in the northeastern part of the region less than in the southern part of the region. Annual mean flows were below normal (less than the 25th percentile) at 83 percent of the streamflow stations (19 of 23) in the northeastern part of the region (New York and the New England states); whereas annual mean flows were below normal at 96 percent of the streamflow stations (27 of 28) in the southern part of the region (New Jersey, Pennsylvania, West Virginia, Virginia, and Maryland). New minimum annual mean flows were recorded during 2002 at eight water-quality stations with long-term surface-water records in the southern part of the region, whereas no new minimum annual mean flow was recorded during 2002 in the northeastern part of the region (table 11).

\section{High-Flow Years}

Generally, water years 1996 and 2003 were the wettest years in the period 1993-2003. New maximum annual mean flow was recorded at 14 of 51 long-term surface-water stations evaluated, with all but 2 of the 14 new maximums occurring in 1996 or 2003. An exceptionally wet pattern occurred across the region from 1996 through 1998. Annual mean flow was above normal (greater than 75th percentile) for 76 percent of the long-term stations during 1996 (39 of 51 stations),
59 percent (30 of 51) during 1997, and 65 percent (33 of 51) during 1998. More stations in the northern part of the region experienced annual mean flows above normal during 1997 than in the southern part of the region. New maximum annual mean flow was recorded during 2003 at three long-term stations evaluated for water quality in the southern part of the region (table 11). The Potomac River at Shepherdstown, W. Va. (number 117, fig. 4 and table 5) experienced the highest annual mean flow since 1928. Across the entire study area, annual mean flows were well above normal (greater than the 90th percentile) during 2003 for 35 percent of the longterm surface-water stations evaluated (18 of 51 stations). All streamflow stations in Pennsylvania, West Virginia, Virginia, and Maryland, with the exception of one station in Virginia, experienced annual mean flows well above normal during 2003.

\section{Annual Runoff}

The 11 water years in the recent period were identified as low, average, or high runoff years by Hydrologic Unit. In the New England region (HUC 01, fig. 1), 6 of 11 water years $(1993-94,1999,2000-01,2003)$ were considered as average runoff years (in the 25 th to 75 th percentiles). The 1996-98 water years were considered high runoff years (greater than the 75th percentile), whereas the 1995 and 2002 water years were considered low runoff years (less than the 25th percentile).

In the mid-Atlantic region (HUC 02, fig. 1), records for most water years (10 of 11) indicate runoff in the upper and lower percentile ranges: either greater than the 75 th percentile (high runoff, or wet conditions), or less than the 25th percentile (low runoff, or dry conditions). Only one water year (2000) was considered as an average runoff year. High runoff years include 1993-94, 1996-98, and 2003. Low runoff years include 1995, 1999, and 2001-2002. Water year 2002 set a new all-time low record for annual runoff. Water year 2002 was the driest year in more than 80 years of record and was followed by an extremely high runoff water year (2003). Water year 2003 ranked as the second highest runoff year on record, on the basis of records for groups of stations dating back to 1900. Overall, the median of the annual runoff (reported in units of inches per year) for the 11 water years of the 1993-2003 period was greater in the New England region (HUC 01, median of 25.05 inches per year (in/yr)) than in the mid-Atlantic region (HUC 02, median of $22.84 \mathrm{in} / \mathrm{yr}$ ).

\section{Streamflow During Sampling Years in National USGS Programs}

The duration of water-quality sampling at USGS monitoring stations in the region has varied considerably in both national programs and in programs and projects conducted in cooperation with individual states. Variation in the period of 
record among stations complicates comparison of water-quality conditions among different drainage basins.

The NAWQA Program is designed to have 3 years of high-intensity sampling at water-quality stations in each study unit, followed by 6 years of low-intensity sampling at a smaller number of stations, followed by 3 more years of highintensity sampling (Gilliom and others, 1995, p. 2). Nationally, the NAWQA study unit projects have been started in a phased approach, so that the high-intensity sampling period does not coincide for all study units (table 12). Funding constraints have played a role in the number of stations sampled or continued in the program. There has been no high-intensity sampling in the Lower Susquehanna River Basin Study Unit since the mid-1990s (M.J. Langland, U.S. Geological Survey, written commun., 2011). In the Hudson River Basin Study Unit, long-term sampling at a limited number of stations in the early 2000s is not comparable to the 1993-95 high-intensity period, in terms of numbers of stations or duration of sampling (P.J. Phillips, U.S. Geological Survey, written commun., 2011). High-intensity sampling in 2002 and 2003 in the Connecticut, Housatonic, and Thames River Basins Study Unit is at a small number of stations, relative to the 1993-95 sampling period (C.J. Brown, U.S. Geological Survey, written commun., 2011).

Program changes or periodic sampling may result in a situation where the sampling period misses extreme high- or low-flow years that help to define the range of expected stream nutrient loads, or misses more typical flow years that would help to define average stream nutrient loads. For example, the 1999-2001 high-intensity sampling period for the New England Coastal Basins NAWQA study unit misses the more extreme high and low flows of recent years, whereas the same period for the Potomac-Delmarva NAWQA study unit encompasses an extended dry period for some stations (tables 11,
12). The 1996-98 sampling period for the Long Island-New Jersey NAWQA study unit is a period of generally high annual mean flows, and includes one of the highest flow years in the 1993-2003 period.

As noted in the section on Data Selection and Screening, water-quality monitoring through the NASQAN Program was discontinued on many major streams in the northeast in the early- to mid-1990s (tables 5, 12). Records for NASQAN stations that end in the early 1990s do not include several extreme flow years for the 1993-2003 period.

\section{Comparison of 1993-2003 Period to Long-Term Streamflows}

Streamflows for the reference period of 1970-2003 were evaluated for 96 stations (appendix 2, table 2-1), and for longterm periods with initial dates ranging from 1890 to 1944 for 51 of these stations. Long-term station records were evaluated in terms of annual mean streamflow, and regional patterns of annual runoff were identified.

\section{Long-Term Variability in Annual Mean Streamflow}

Long-term annual mean streamflows for nine streamgages (fig. 5) provide an overview of long-term conditions in the region, with the understanding that streamflow at each location represents a unique combination of climate, geology, and geography. Streamgages from three subregions of the study area are shown: the northeastern part of the region, encompassing most of the New England states (figs. 5A, B,

Table 12. Sampling years in NAWQA study units and ending water years at NASQAN stations in the Northeast.

[Shaded blocks show intensive sampling years for NAWQA stations or ending water years for NASQAN stations in the study area. NAWQA study units shown in figure 1. NAWQA, National Water Quality Assessment; NASQAN, National Stream Quality Accounting Network]

\begin{tabular}{|c|c|c|c|c|c|c|c|c|c|c|c|c|}
\hline $\begin{array}{c}\text { Study unit } \\
\text { abbrevia- } \\
\text { tion }\end{array}$ & Study unit name & 1993 & 1994 & 1995 & 1996 & 1997 & 1998 & 1999 & 2000 & 2001 & 2002 & 2003 \\
\hline \multicolumn{13}{|c|}{ NAWOA Program } \\
\hline NECB & New England Coastal Basins & & & & & & & & & & & \\
\hline CONN & Connecticut, Housatonic, and Thames River Basins & & & & & & & & & & & \\
\hline HDSN & Hudson River Basin & & & & & & & & & & & \\
\hline DELR & Delaware River Basin & & & & & & & & & & & \\
\hline LSUS & Lower Susquehanna River Basin & & & & & & & & & & & \\
\hline PODL & Potomac River Basin and Delmarva Peninsula & & & & & & & & & & & \\
\hline \multicolumn{13}{|c|}{ NASQAN Program } \\
\hline
\end{tabular}



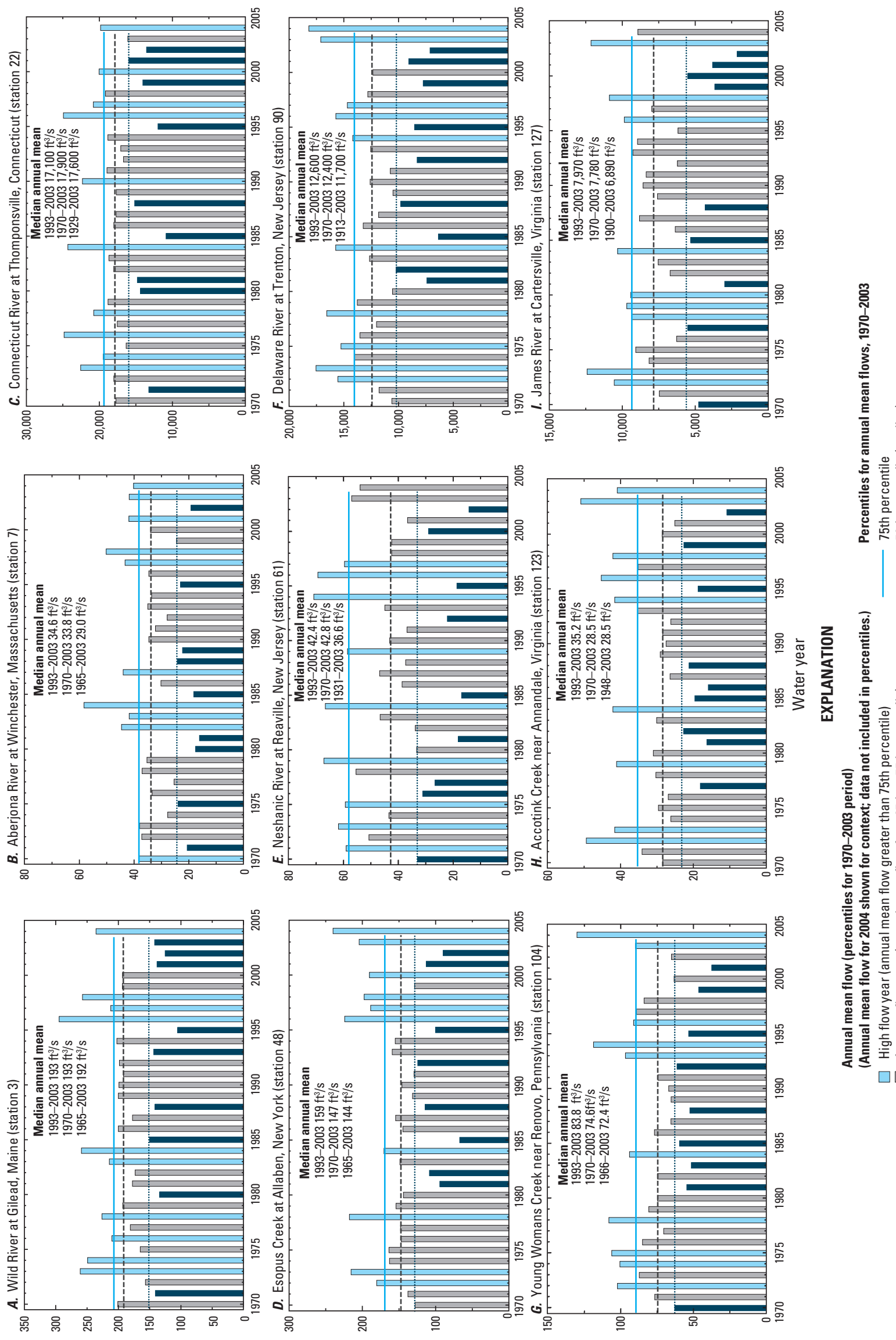

ำ

苛 வ

.

링

ㄷํㅇ ه

ज़ ฮั

के

$\sum^{\pi} \frac{1}{U}$

ذั

\&

인

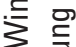

히응

ఫ̄

:

룰

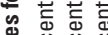

这

点念念

운

믄

बi

言

흔 인

造

중

这

这

可 严

\高

过

흘 吉

षீ

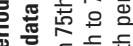

只

要䓌

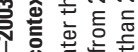

잉 Ф)

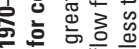

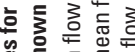

边 穴完

क口 is

(2)

으 즏

跑苏

엉 닣

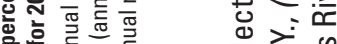

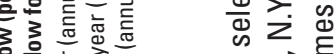

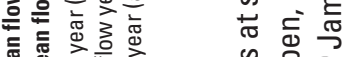

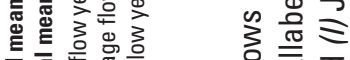

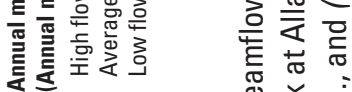

离 范

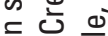

(ᄄ)

릉 등

졸 虫

高

E ¿̇

Фั) 등

อิ

으 옳

เก ธิํำ

는

흠응

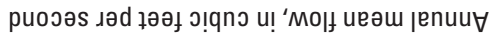

证卡 
C); the central part of the region, including the Hudson and Delaware River Basins and adjacent coastal basins (figs. 5D, E, F); and the southwestern part of the region, including the Susquehanna and Potomac River Basins, and drainage basins in Maryland and Virginia (figs. 5G, H, I). The northern subregion is equivalent to Hydrologic Region 01, and the central and southwestern subregions constitute Hydrologic Region 02 (fig. 1). Local and regional patterns of streamflow for the three subregions in the study area are illustrated by graphs of annual mean flows for small, undeveloped upland drainage basins (less than $100 \mathrm{mi}^{2}$ ) (figs. 5A, D, G); small, developed coastal drainage basins (less than $50 \mathrm{mi}^{2}$ ) (figs. 5B, E, H); and large drainage basins (greater than 5,000 $\mathrm{mi}^{2}$ ) (figs. 5C, F, I).

Graphs of annual mean streamflow for the nine example basins illustrate some of the extreme hydrologic conditions during 1993-2003. Drier than normal conditions during 19992002 affected streamflow for large drainage basins, particularly in the southwestern subregion, as illustrated by the James River (fig. 5I), where water years 1999-2002 represent the longest period of low annual mean flows from 1970 to 2003. For the Connecticut River (table 5; fig. 4, station 22), the 1996 annual mean flow was the highest for the 1970 to 2003 period (fig. 5C). For the Delaware River at Trenton, N.J., (station 90), and James River (station 127), the 2003 annual mean flow almost equaled the annual mean flow of 1973, which was the highest annual mean flow as far back as 1970 (figs. 5F, I).

For small, undeveloped upland drainage basins, the highest annual mean flows for the 1993-2003 period exceeded previous record high annual means for 1970-1992 (figs. 5A, D, G). The lowest annual mean flows during 1993-2003 were lower than previous record low annual means for the Wild River at Gilead, Maine, and Young Womans Creek near Renovo, Pa. (figs. 5A, G). Similarly, among the three small, developed coastal drainage basins, the highest and lowest annual mean flows during the 1993-2003 period were higher and lower than annual mean flows from 1970 to 1992 for the Neshanic River at Reaville, N.J., and Accotink Creek near Annadale, Va. (figs. 5E, H).

Although water year 2004 is not part of the period of analysis for streamflow and water quality in this report, water year 2004 is included in the graphs of annual mean flows (fig. 5), to provide another point of reference for evaluating streamflow in the 1993-2003 period. Water year 2003 represents the highest, or one of the highest, annual mean flows for several stations in the study area, but annual mean flows in water year 2004 exceeded annual mean flows in water year 2003 at some stations, including Esopus Creek at Allaben, N.Y., the Delaware River at Trenton, N.J., and Young Womans Creek near Renovo, Pa. (figs. 5D, F, G).

\section{Regional and Temporal Variability in Runoff}

The coefficient of variation for runoff, which equals the standard deviation divided by the mean of the annual runoff dataset, was used to compare the variability of the annual runoff between different periods of record for a hydrologic region, and between regions with differences in annual runoff values during the same time period. This statistic was computed for each of three periods for the two hydrologic regions in the study area, the New England region (HUC 01) and the mid-Atlantic region (HUC 02).

The average annual runoff in the New England region (HUC 01), varied within a range of 1.5 inches (in.) for the three periods: an average of $24.4 \mathrm{in} / \mathrm{yr}$ from 1993 to 2003, 25.5 in. from 1970 to 2003 (highest runoff period), and $24.0 \mathrm{in}$. from 1930 to 2003 . The coefficient of variation varied within a range of 1.1 percent for the three periods: 21.8 percent (1993-2003); 22.9 percent (1970-2003); 22.5 percent (1930-2003). The small range in the coefficients of variation for the New England region illustrates that the characteristics of annual runoff during 1993-2003 were very similar to the characteristics of annual runoff for 1970-2003 and 1930-2003.

The average annual runoff in the mid-Atlantic region (HUC 02) varied within a range of 1.3 in. for the 3 periods: $20.0 \mathrm{in} / \mathrm{yr}$ for 1993-2003, $20.1 \mathrm{in} / \mathrm{yr}$ for 1970-2003 (highest runoff period), and $18.8 \mathrm{in} / \mathrm{yr}$ for 1930-2003. The coefficient of variation varied within a range of 6.7 percent among the three periods: 31.2 percent (1993-2003); 25.9 percent (1970-2003); 24.5 percent (1930-2003). The coefficient of variation was highest for the stations in the mid-Atlantic region during 1993-2003, indicating that variability in annual runoff was greater during 1993-2003 than during 1970-2003 or 1930-2003. This result is consistent with the finding of new record maximum and minimum annual mean flows at a substantial number of stations in the mid-Atlantic region during the 1993-2003 period (table 11). This variability during the 1993-2003 period also can be seen in plots of annual mean flows for several stations in the mid-Atlantic region, where few annual mean flows are near the long-term median (figs. 5D, F, G, H, I).

\section{Effects of Streamflow on Water-Quality Variability}

The concentrations of many water-quality constituents are correlated with streamflow (fig. 6), and consequently a large part of the variability in constituent concentration over time may be caused by variability in streamflow, both seasonally and from year to year. A LOESS smoothing procedure, referenced in the section on Methods of Data Analysis, has been used to identify generalized relations between constituent concentration and daily mean streamflow (fig. 6), and also has been used to show relations between concentration and time in plots in subsequent sections of this report.

The correlation between concentration and streamflow may be more pronounced in streams that are influenced by developed land uses or waste-disposal practices. Streams in small drainage basins (less than about 1,000 $\mathrm{mi}^{2}$ ) with point-source discharges often have high nutrient concentrations at low flows, when point-source effluent constitutes a 

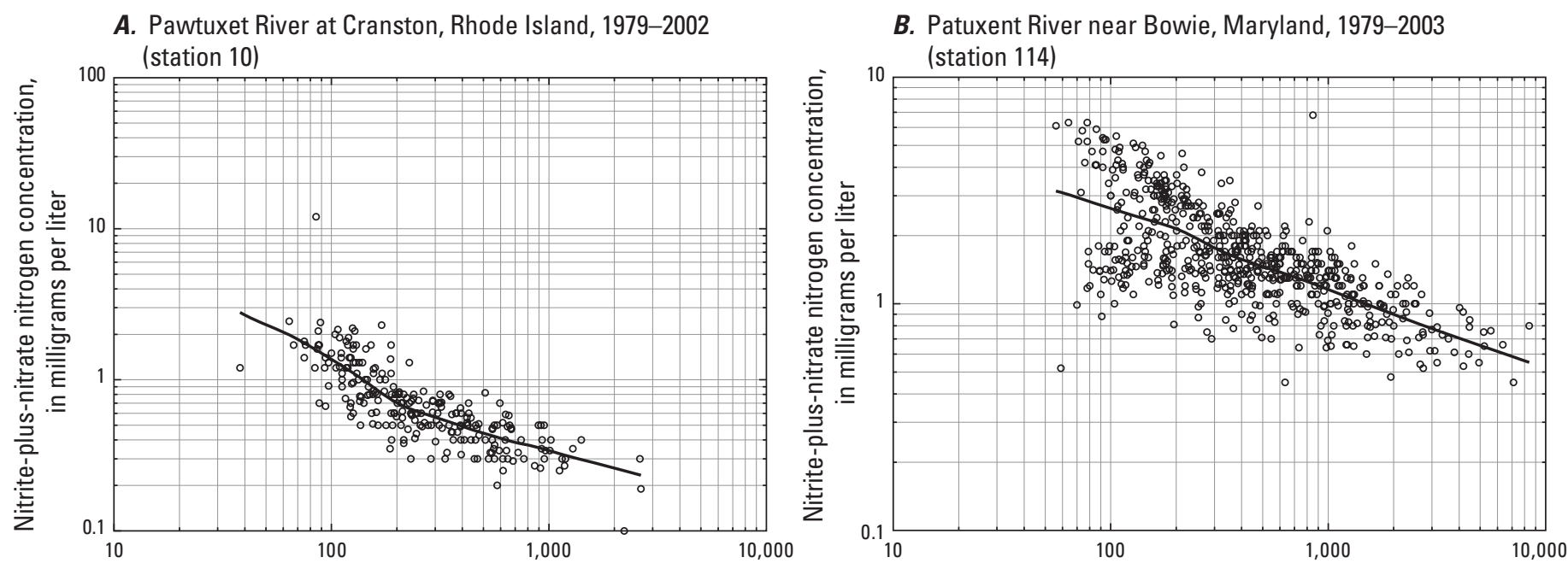

C. Pawtuxet River at Cranston, Rhode Island, 1979-2002 (station 10)

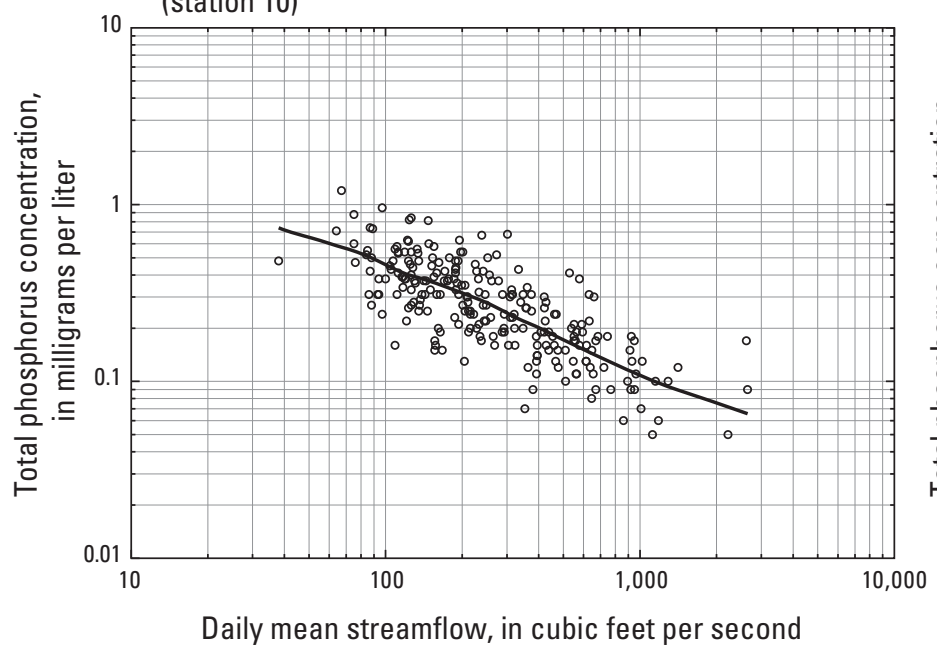

D. Naugatuck River at Beacon Falls, Connecticut, 1975-2003 (station 39)

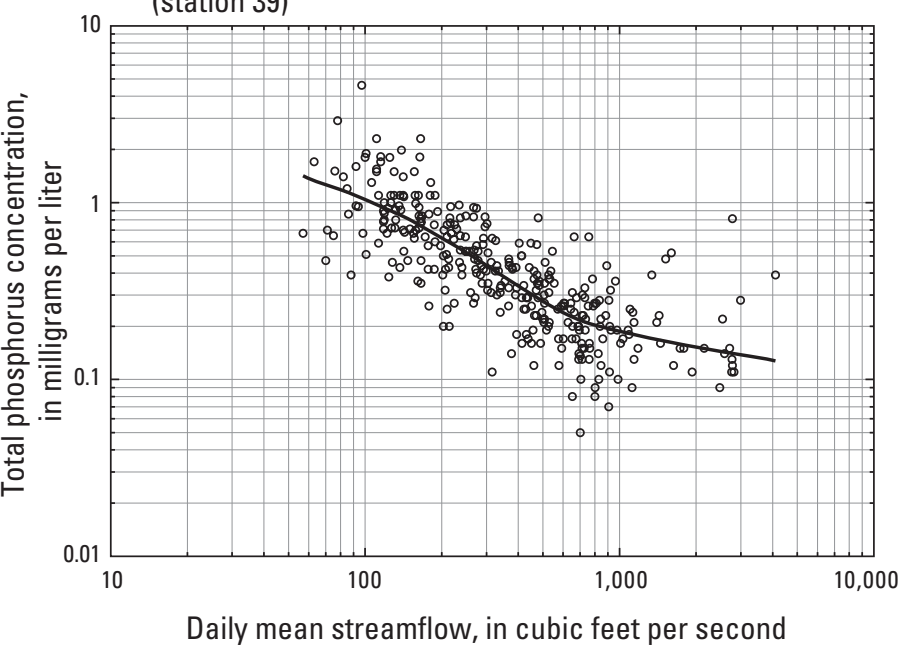

\section{EXPLANATION}

— LOESS smooth line

- Constituent concentration

Figure 6. Characteristic plots of nutrient concentration as a function of discharge at selected stations, showing land-use and point-source effects. (A) Pawtuxet River at Cranston, R.I., nitrite-plus-nitrate concentrations, 1979-2002, (B) Patuxent River near Bowie, Md., nitriteplus-nitrate concentrations, 1979-2003, (C) Pawtuxet River at Cranston, R.I., total phosphorus concentrations, 1979-2002, (D) Naugatuck River at Beacon Falls, Conn., total phosphorus concentrations, 1975-2003, (E) Canajoharie Creek near Canajoharie, N.Y., total nitrogen concentrations, 1994-2003, (F) Canajoharie Creek near Canajoharie, N.Y., nitrite-plus-nitrate concentrations, 1994-2003, (G) Choptank River near Greensboro, Md., nitrite-plus-nitrate concentrations, 1975-2003, (H) Canajoharie Creek near Canajoharie, N.Y., total phosphorus concentrations, 1994-2003, (I) Connecticut River at Thompsonville, Conn., total nitrogen concentrations, 1975-2003, (J) Connecticut River at Thompsonville, Conn., total phosphorus concentrations, 1975-2003, (K) Susquehanna River at Conowingo, Md., total nitrogen concentrations, 1979-2003, (L) James River at Cartersville, Va., total nitrogen concentrations, 1975-2003, (M) Susquehanna River at Conowingo, Md., total phosphorus concentrations, 1979-2003, and (N) James River at Cartersville, Va., total phosphorus concentrations, $1975-2003$. 

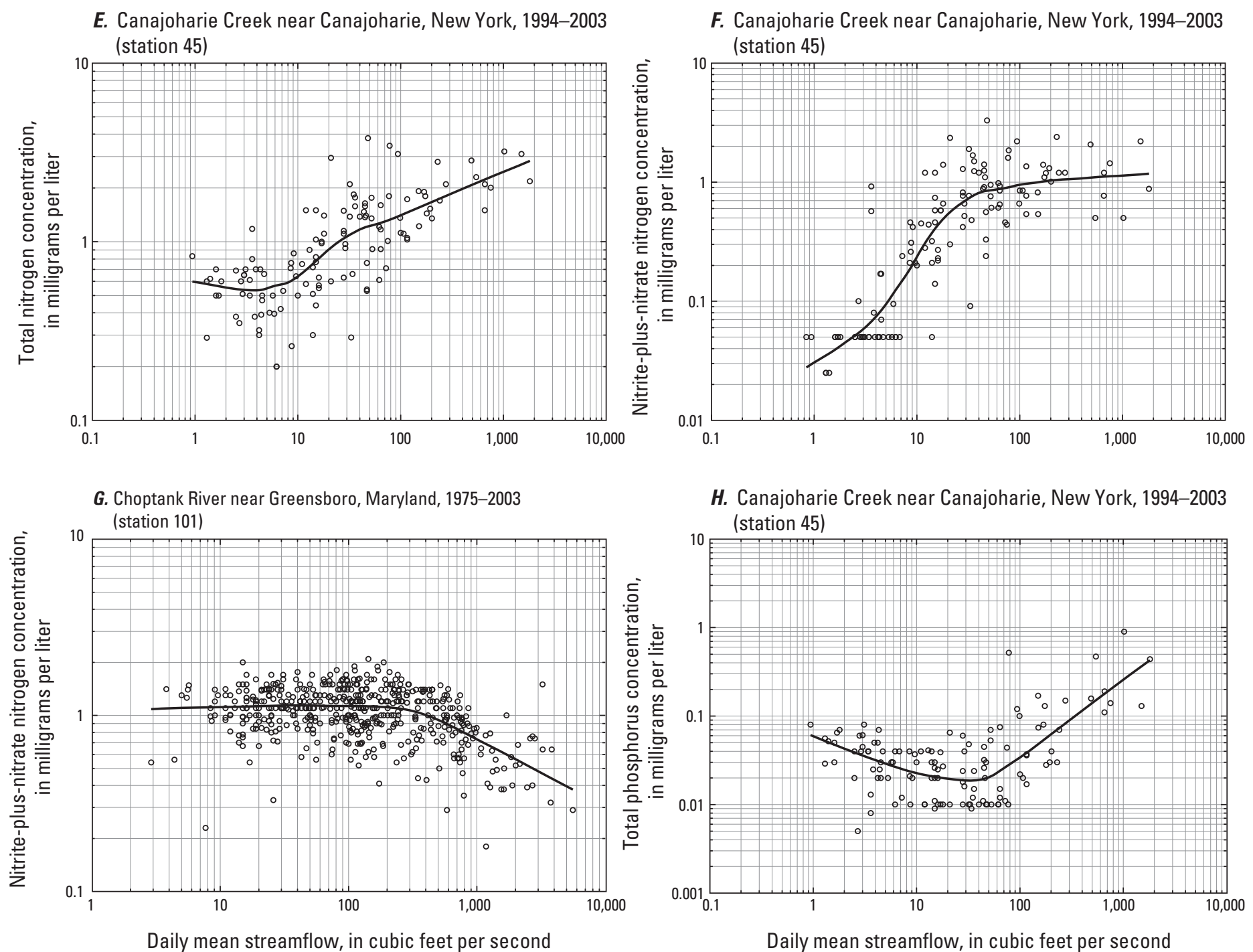

\section{EXPLANATION}

— LOESS smooth line

- Constituent concentration

Figure 6. Characteristic plots of nutrient concentration as a function of discharge at selected stations, showing land-use and point-source effects. (A) Pawtuxet River at Cranston, R.I., nitrite-plus-nitrate concentrations, 1979-2002, (B) Patuxent River near Bowie, Md., nitriteplus-nitrate concentrations, 1979-2003, (C) Pawtuxet River at Cranston, R.I., total phosphorus concentrations, 1979-2002, (D) Naugatuck River at Beacon Falls, Conn., total phosphorus concentrations, 1975-2003, (E) Canajoharie Creek near Canajoharie, N.Y., total nitrogen concentrations, 1994-2003, (F) Canajoharie Creek near Canajoharie, N.Y., nitrite-plus-nitrate concentrations, 1994-2003, (G) Choptank River near Greensboro, Md., nitrite-plus-nitrate concentrations, 1975-2003, (H) Canajoharie Creek near Canajoharie, N.Y., total phosphorus concentrations, 1994-2003, (I) Connecticut River at Thompsonville, Conn., total nitrogen concentrations, 1975-2003, (J) Connecticut River at Thompsonville, Conn., total phosphorus concentrations, 1975-2003, (K) Susquehanna River at Conowingo, Md., total nitrogen concentrations, 1979-2003, (L) James River at Cartersville, Va., total nitrogen concentrations, 1975-2003, (M) Susquehanna River at Conowingo, Md., total phosphorus concentrations, 1979-2003, and (N) James River at Cartersville, Va., total phosphorus concentrations, 1975-2003.—Continued 


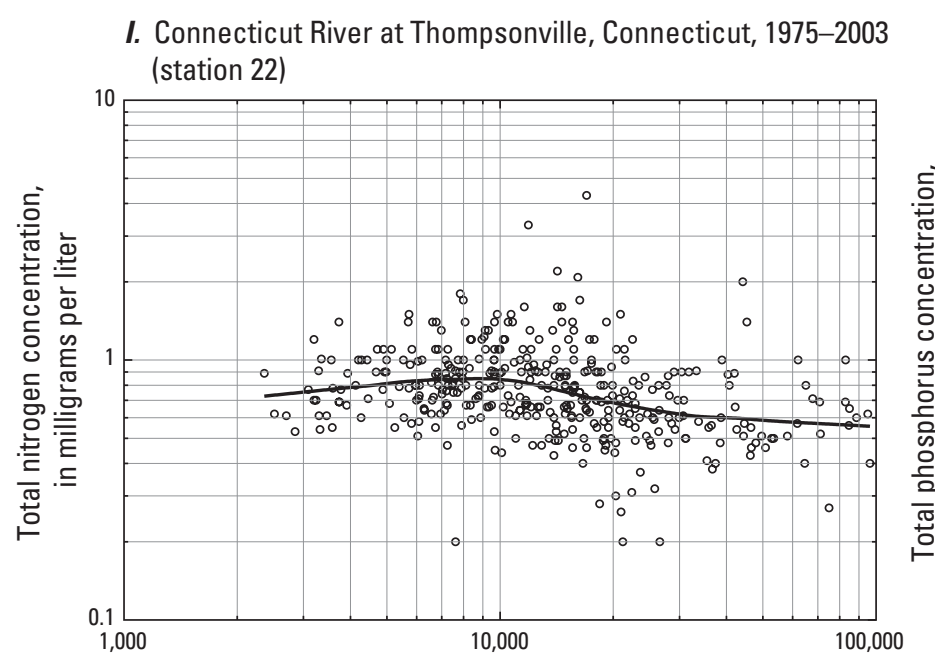

Daily mean streamflow, in cubic feet per second
J. Connecticut River at Thompsonville, Connecticut, 1975-2003 (station 22)

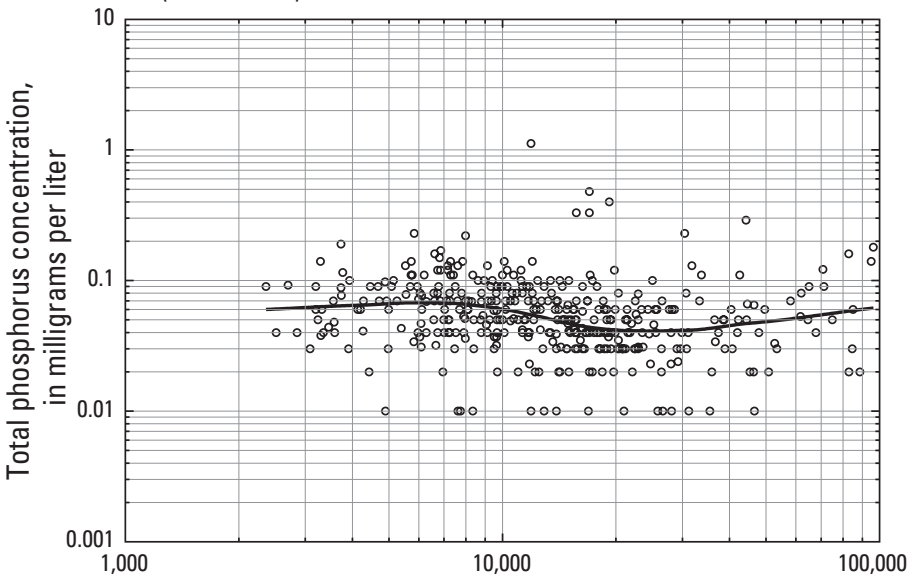

Daily mean streamflow, in cubic feet per second

\section{EXPLANATION}

LOESS smooth line

- Constituent concentration

Figure 6. Characteristic plots of nutrient concentration as a function of discharge at selected stations, showing land-use and point-source effects. (A) Pawtuxet River at Cranston, R.I., nitrite-plus-nitrate concentrations, 1979-2002, (B) Patuxent River near Bowie, Md., nitriteplus-nitrate concentrations, 1979-2003, (C) Pawtuxet River at Cranston, R.I., total phosphorus concentrations, 1979-2002, (D) Naugatuck River at Beacon Falls, Conn., total phosphorus concentrations, 1975-2003, (E) Canajoharie Creek near Canajoharie, N.Y., total nitrogen concentrations, 1994-2003, (F) Canajoharie Creek near Canajoharie, N.Y., nitrite-plus-nitrate concentrations, 1994-2003, (G) Choptank River near Greensboro, Md., nitrite-plus-nitrate concentrations, 1975-2003, (H) Canajoharie Creek near Canajoharie, N.Y., total phosphorus concentrations, 1994-2003, (I) Connecticut River at Thompsonville, Conn., total nitrogen concentrations, 1975-2003, (J) Connecticut River at Thompsonville, Conn., total phosphorus concentrations, 1975-2003, (K) Susquehanna River at Conowingo, Md., total nitrogen concentrations, 1979-2003, (L) James River at Cartersville, Va., total nitrogen concentrations, 1975-2003, (M) Susquehanna River at Conowingo, Md., total phosphorus concentrations, 1979-2003, and (N) James River at Cartersville, Va., total phosphorus concentrations, 1975-2003.-Continued 

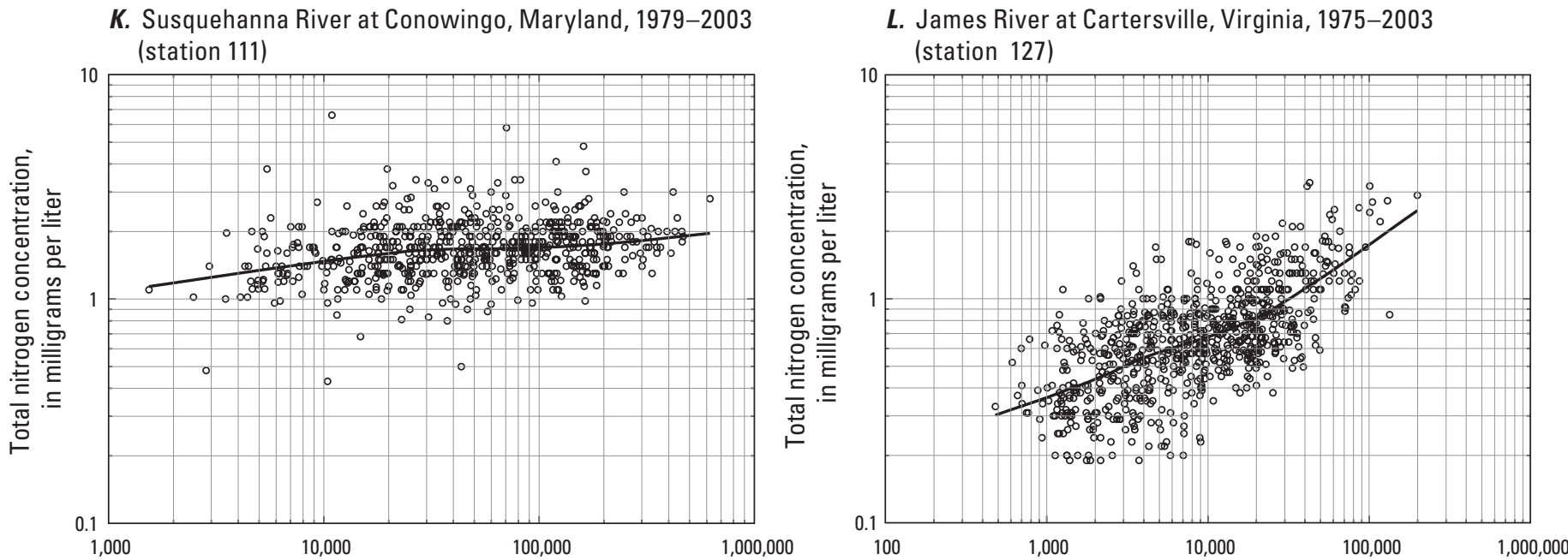

M. Susquehanna River at Conowingo, Maryland, 1979-2003 (station 111)
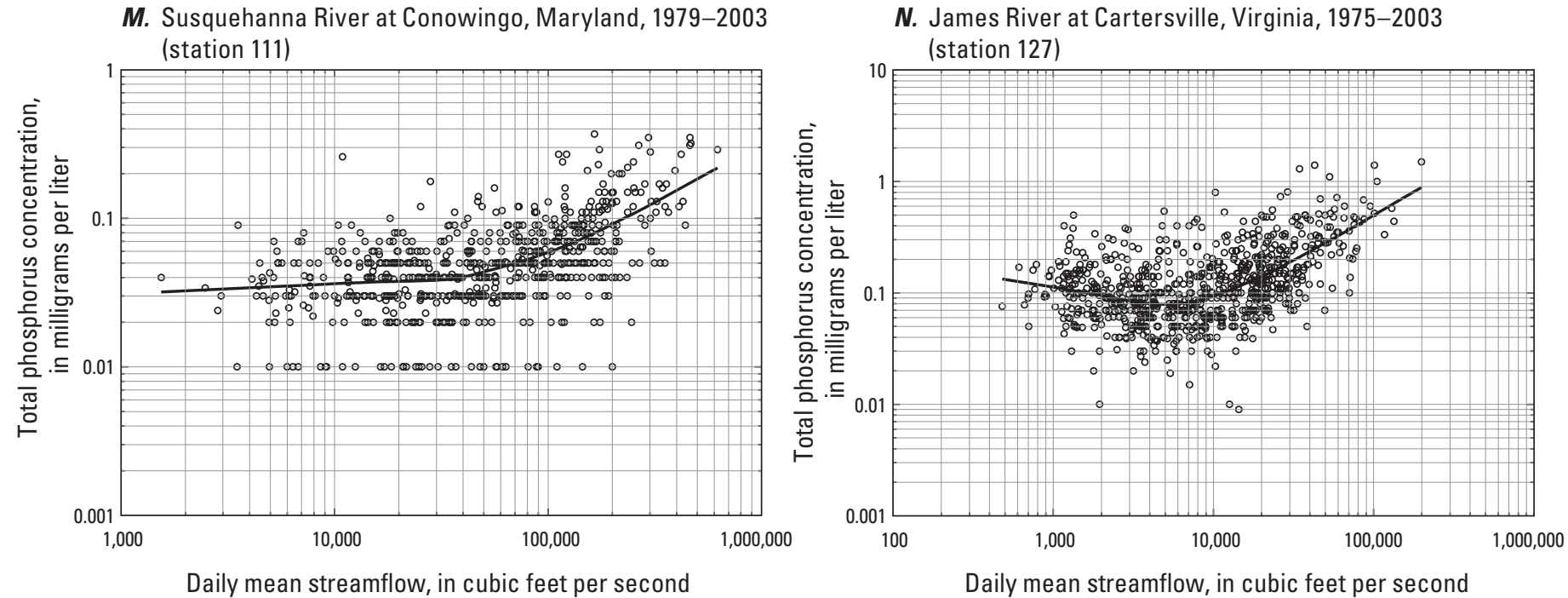

EXPLANATION

LOESS smooth line

- Constituent concentration

Figure 6. Characteristic plots of nutrient concentration as a function of discharge at selected stations, showing land-use and point-source effects. (A) Pawtuxet River at Cranston, R.I., nitrite-plus-nitrate concentrations, 1979-2002, (B) Patuxent River near Bowie, Md., nitriteplus-nitrate concentrations, 1979-2003, (C) Pawtuxet River at Cranston, R.I., total phosphorus concentrations, 1979-2002, (D) Naugatuck River at Beacon Falls, Conn., total phosphorus concentrations, 1975-2003, (E) Canajoharie Creek near Canajoharie, N.Y., total nitrogen concentrations, 1994-2003, (F) Canajoharie Creek near Canajoharie, N.Y., nitrite-plus-nitrate concentrations, 1994-2003, (G) Choptank River near Greensboro, Md., nitrite-plus-nitrate concentrations, 1975-2003, (H) Canajoharie Creek near Canajoharie, N.Y., total phosphorus concentrations, 1994-2003, (I) Connecticut River at Thompsonville, Conn., total nitrogen concentrations, 1975-2003, (J) Connecticut River at Thompsonville, Conn., total phosphorus concentrations, 1975-2003, (K) Susquehanna River at Conowingo, Md., total nitrogen concentrations, 1979-2003, (L) James River at Cartersville, Va., total nitrogen concentrations, 1975-2003, (M) Susquehanna River at Conowingo, Md., total phosphorus concentrations, 1979-2003, and (N) James River at Cartersville, Va., total phosphorus concentrations, 1975-2003. - Continued 
large percentage of streamflow, and often have lower nutrient concentrations at high streamflows, when point-source effluent is diluted by storm runoff. Water-quality data for the Pawtuxet River in Rhode Island, the Patuxent River in Maryland, and the Naugatuck River in Connecticut demonstrate the relationship of nitrite-plus-nitrate and total phosphorus concentrations to streamflow under these conditions (stations 10, 114, 39) (figs. 6A-D).

Nutrient concentrations in small agricultural drainage basins may have a variety of responses to increases in stream discharge. In Canajoharie Creek in New York, total nitrogen and nitrite-plus-nitrate concentrations increase with moderate increases in stream discharge, as storm runoff transports nutrients from agricultural areas to streams (station 45, figs. 6E-F). Total nitrogen concentrations continue to increase at high discharges, whereas nitrite-plus-nitrate concentrations level off. This difference in response indicates that particulate forms of nitrogen predominate at high discharges on Canajoharie Creek. In the Choptank River in Maryland (station 101, fig. 6G), nitrite-plus-nitrate concentrations remain within a similar range at low to moderate stream discharges, and concentrations decrease at high discharges. Decreasing nitrite-plus-nitrate concentrations at high streamflows may indicate the effects of dilution, or may indicate that available nonpoint sources of the constituent have been depleted during earlier stages of increasing discharge. Concentrations of total phosphorus may decrease with moderate increases in streamflow as a result of dilution, as in the case of Canajoharie Creek (fig. 6H). By contrast, total phosphorus concentrations increase gradually with moderate increases in stream discharge in the Choptank River (not shown in fig. 6). Total phosphorus concentrations increase steeply at very high rates of streamflow in Canajoharie Creek (fig. 6H) and the Choptank River, probably as a result of sediment-borne phosphorus at very high flows.

The relation between nutrient concentrations and streamflow is affected by multiple factors in the large drainage basins of the region, most of which have numerous point sources, urban and agricultural areas, and large forested areas. No consistent patterns were evident among the large drainage basins evaluated (figs. 6I-N). Total nitrogen and total phosphorus concentrations increase with moderate increases in discharges in the Connecticut River in Connecticut (station 22, figs. 6I, J). At higher discharges, concentrations of both constituents decrease, with increases in total phosphorus concentrations at very high discharges. The Connecticut River has the largest percentage of undeveloped land (about 85 percent, table 8 , in back of report) and the least agricultural land (about 8 percent) of the three large basins shown in figure 6. The largest drainage basin evaluated in this study, the Susquehanna River at Conowingo, Md. (station 111), is about 28 percent agricultural, with much of the agricultural land concentrated in the downstream parts of the basin. Plots of nutrient concentration as a function of streamflow for the Susquehanna River and the James River (station 127, 15 percent agricultural) show some similarities to smaller agricultural drainage basins. Overall, total nitrogen concentrations on the Susquehanna increase gradually over a range from low to high stream discharges (fig. 6K). Total nitrogen concentrations in the James River (fig. 6L) increase steeply with increases in stream discharge. Nitrite-plus-nitrate concentrations in the James River (not shown in fig. 6) increase with increasing discharges and then level off at high discharges, in a similar pattern to Canajoharie Creek (fig. 6F). Increasing concentrations of total nitrogen at high stream discharges on the Susquehanna and James Rivers probably indicate the predominance of particulate forms of nitrogen in the total nitrogen concentration at very high discharges. Total phosphorus concentrations in the Susquehanna increase gradually from low to moderate stream discharges (fig. 6M), and then increase steeply at very high discharges. Total phosphorus concentrations on the James River (fig. $6 \mathrm{~N}$ ) decrease as streamflow increases from low to moderate streamflows, and concentrations increase steeply at very high streamflows, in a pattern similar to that of Canajoharie Creek (fig. 6H).

In small, primarily forested drainage basins, such as the Stillwater River in Massachusetts, Bunnell (Burlington) Brook in Connecticut, and Bobs Creek in Pennsylvania (not shown in fig. 6), nutrient concentrations may not be clearly correlated with streamflow. Drainage basins that are undeveloped or relatively undeveloped also may not be sampled as frequently as impaired streams, and consequently the relation of concentration to streamflow may not be as well defined.

\section{Effects of Streamflow Conditions on Trend Analysis}

In trend analysis, flow-adjustment procedures may be used to remove that part of concentration variability that is caused by variability in streamflow. Trend analysis is often performed on flow-adjusted concentrations, because the trend results show changes in constituent concentration that are independent of streamflow conditions during the period of interest. Some cause other than streamflow has produced the trend. Consequently, flow-adjusted trend results are useful in evaluating changes in water quality that arise from changes in contamination sources or management activities in a watershed. For example, downward trends in flow-adjusted nutrient concentrations may indicate a decrease in the delivery of nutrients to streams from various sources, whereas upward trends may indicate an increase.

Water managers and scientists also want to understand what trends are taking place in the instream concentrations of constituents, the actual concentrations that affect the habitat and life processes of aquatic organisms. These instream concentrations or values, reported from field or laboratory analyses of the water-quality samples collected, represent the real environmental conditions. The modeled instream concentration trends in this report provide an indication of changes in the actual water quality in streams of the region, and provide a measure of whether aquatic habitat conditions are improving, deteriorating, or not changing significantly over time. 
In the absence of a trend in streamflow, results for the analyses of flow-adjusted and modeled instream concentration trends should be about the same. However, even a small trend in streamflow that is not statistically significant may be sufficient to cause different trend results for the flow-adjusted and instream trend analyses. Consequently, the results for these two forms of analysis are not identical in all cases.

\section{Effects of Streamflow Conditions on Load Estimation}

Annual nutrient load estimates typically vary according to the stream discharge conditions during each year, in the absence of a trend in constituent load. Larger loads are transported in years of high annual mean streamflow and smaller loads in years of low annual mean streamflow. In this report, most of the discussion of the effects of streamflow on load estimates refers to annual mean streamflow.

Extreme high flows may transport a large part of the total annual stream load, even if concentrations are low during high flows. The load estimation procedure relates concentration values for a small number of water-quality sampling days to a large series of daily mean streamflow values, and predicts loads on unsampled days based on this relation. Consequently, the accuracy of annual load estimates for a stream depends on availability of water-quality data over a wide range of streamflows. Although water-quality monitoring during high flows has received increased emphasis in recent years, waterquality data for extreme high flows are often lacking for a variety of logistical reasons, including cost, unpredictability, planned deployment of resources, and safety. Constituent concentrations during streamflows on the rising limb of a storm hydrograph are often very different from concentrations during equivalent streamflows on the falling limb of the storm hydrograph, a phenomenon termed "hysteresis." This phenomenon further complicates load estimation if concentrations are not known for the streamflows immediately preceding and following flood peaks. Estimated loads that include streamflows exceeding the range for which constituent concentrations have been measured will have larger measures of uncertainty (error bars) than loads based on known conditions. Additional information on the effects of stormflow samples on constituent load estimation can be found in Robertson and Roerish (1999) and Sprague (2001).

\section{Trends in Nutrient Concentrations, 1975-2003 and 1993-2003}

Water-quality data for selected USGS monitoring stations were analyzed for trends in flow-adjusted nutrient concentrations and modeled instream (non-flow-adjusted) concentrations during long-term (1975-2003) and recent (1993-2003) periods. Stream discharges also were analyzed for trends during these two periods. Results of trend tests, and results of associated statistical tests, were considered significant if the attained significance level of the test ( $p$-value) was less than or equal to 0.05 , and were considered highly significant if the $p$-value was less than or equal to 0.01 .

The trend analysis techniques used in this study are all parametric techniques, which assume a linear trend during the period of analysis. In many cases, the trends discussed here have not been linear, particularly during the long-term period. Consideration of nonlinear trends as part of the evaluation of trend results is discussed in more detail in the "Methods" section of this report.

\section{Trends in Streamflow}

Trends in stream discharge were analyzed by the streamflow model component of the statistical modeling approach described in the "Methods" section (results in appendix 5). The streamflow trend evaluated by the model is the trend in daily median flow. Trends in streamflow were detected at only two stations during the periods of analysis. Downward trends in streamflow were detected for the Quinebaug River at Jewett City, Conn., for the long-term period, and for the Cooper River at Haddonfield, N.J., during the recent period (stations 18 and 95 , fig. 4, table 5).

About half of the stations analyzed (15 of 32) for the long-term period had significant serial correlation in the flow residuals, and 10 of the 15 stations had highly significant serial correlation. About one-fourth of the stations analyzed (12 of 46) for the recent period had significant serial correlation, with highly significant serial correlation at 6 of the 12 stations (appendix 5, table 5-1). This finding in the streamflow trend results means that some additional serial correlation in the residuals was not removed by the autoregressive component of the streamflow model. The practical importance of this circumstance for the statistical significance of water-quality trend estimates is likely to be small (G.E. Schwarz, U.S. Geological Survey, written commun., 2006). Serial correlation in the streamflow residuals is likely to decrease the $p$-value associated with the trend coefficient in the streamflow model, thus increasing the likelihood of observing a significant trend in streamflow. However, this possible outcome was not observed in the analyses included in this report. Among the stations with significant serial correlation in the flow residuals, only one station, the Quinebaug River at Jewett City, Conn., also had a significant trend in streamflow.

\section{Trends in Nutrient Concentrations}

Trends in flow-adjusted nutrient concentrations and modeled instream (non-flow-adjusted) concentrations were analyzed for 32 stations during 1975-2003 and for 46 stations during 1993-2003 by using the coupled statistical model of streamflow and water quality; 31 stations were analyzed for both periods. Flow-adjusted trends in one or more nutrient concentrations also were analyzed for 90 stations during 1993-2003 by using Tobit regression in ESTREND. The 
statistical model requires a continuous record of daily mean streamflow, whereas ESTREND requires only instantaneous streamflow measurements at the time of water-quality sampling. Consequently, use of ESTREND enabled evaluation of a larger group of stations. Some water-quality stations were evaluated with both programs. Altogether, 90 stations were analyzed for trends in flow-adjusted concentrations of one or more nutrients during the two periods (appendix 6, table 6-1).

Stations analyzed for trend during the long-term period have varied initial dates for water-quality data. The longterm period selected for analysis started in 1975 for 22 of the 32 stations analyzed, in 1979 for 7 stations, and in 1982 for 3 stations ( 22 to 29 water years). All stations evaluated with the coupled statistical model during the recent period of 1993-2003 had records beginning in 1993 and ending in 2003 (11 water years). Stations evaluated with Tobit regression had records of 8 to 11 years in the 1993-2003 period.

\section{Trends in Flow-Adjusted Nutrient Concentrations}

Significant trends in flow-adjusted nutrient concentrations were more frequent during the long-term period than during the recent period (table 13). About two-thirds of the 32 stations analyzed for trends in total nitrogen, nitrite-plus-nitrate, and total phosphorus during 1975-2003 had significant trends in one or more of these nutrients. By contrast, significant trends in these nutrients were detected in about one-quarter to one-third of the 52 to 83 stations analyzed for trends in these three constituents during 1993-2003. In some cases, findings of no trend during the recent period may result from decreased sensitivity of the trend test to detect subtle trends during a shorter period with fewer samples.

In general, downward trends in flow-adjusted nutrient concentrations were more frequently detected than upward trends during both periods of analysis, with two major exceptions that are discussed in the following sections. Numerous downward trends in flow-adjusted concentrations of nitrogen and phosphorus constituents are an indication of regional improvements in nutrient-related water-quality conditions.

\section{Total Nitrogen}

Significant long-term downward trends in flow-adjusted concentrations of total nitrogen were detected at about half (18) of the 32 stations analyzed; 4 stations had upward trends. By contrast, during the recent period, about two-thirds of the 81 stations analyzed had no significant trend, and the remaining stations were about equally divided between upward and downward trends (fig. 7, table 13).

Numerous nonlinear trends in flow-adjusted concentrations of total nitrogen were identified. Of the 31 stations that were analyzed during both the long-term and recent periods, 11 had downward trends during 1975-2003 and no significant trend during 1993-2003, and 4 had downward trends during 1975-2003 and upward trends during 1993-2003. These results may indicate that at a little less than half of the stations evaluated, the major decreases in flow-adjusted total nitrogen concentrations took place prior to 1993, with flow-adjusted concentrations remaining stable, or in some cases increasing, in the more recent period.

Downward trends in flow-adjusted concentrations of total nitrogen were detected during both periods of analysis at three stations: the Naugatuck River at Beacon Falls, Conn., the Passaic River at Little Falls, N.J., and the Delaware River at Trenton, N.J. (stations 39, 55, and 90). Upward trends in total nitrogen were detected during both periods of analysis at four stations: the Saddle River at Lodi, N.J., Toms River near Toms River, N.J., the Choptank River near Greensboro, Md., and the Pamunkey River near Hanover, Va. (stations 56, 71, 101, 125).

\section{Dissolved Ammonia Nitrogen and Total Kjeldahl Nitrogen}

Trends in ammonia nitrogen and total Kjeldahl nitrogen (total-ammonia-plus-organic nitrogen in unfiltered or whole

Table 13. Summary of trend results for flow-adjusted concentrations of nutrients and suspended sediment, 1975-2003 and 1993-2003.

[Long-term period for trend analysis spans 22-29 water years at different stations, all ending in 2003; recent period for trend analysis spans 8 to 11 water years within the 1993-2003 period at different stations. Significant trend: $p$-value less than or equal to 0.05 ; highly significant trend: $p$-value less than or equal to $0.01 ;--$, not analyzed]

\begin{tabular}{|c|c|c|c|c|c|c|c|c|}
\hline \multirow[b]{2}{*}{ Water-quality constituent } & \multicolumn{4}{|c|}{ 1975-2003, 1979-2003, or 1982-2003 } & \multicolumn{4}{|c|}{ 1993-2003 } \\
\hline & $\begin{array}{l}\text { Number of } \\
\text { stations } \\
\text { analyzed }\end{array}$ & $\begin{array}{l}\text { Upward } \\
\text { trend }\end{array}$ & $\begin{array}{l}\text { Downward } \\
\text { trend }\end{array}$ & $\begin{array}{l}\text { No significant } \\
\text { trend }\end{array}$ & $\begin{array}{l}\text { Number of } \\
\text { stations } \\
\text { analyzed }\end{array}$ & $\begin{array}{l}\text { Upward } \\
\text { trend }\end{array}$ & $\begin{array}{l}\text { Downward } \\
\text { trend }\end{array}$ & $\begin{array}{l}\text { No significant } \\
\text { trend }\end{array}$ \\
\hline Ammonia nitrogen & 6 & 0 & 6 & 0 & 15 & 2 & 6 & 7 \\
\hline Total Kjeldahl nitrogen & 6 & 0 & 6 & 0 & 0 & -- & -- & -- \\
\hline Suspended sediment & 4 & 0 & 4 & 0 & 8 & 1 & 2 & 5 \\
\hline
\end{tabular}




\section{$A$}

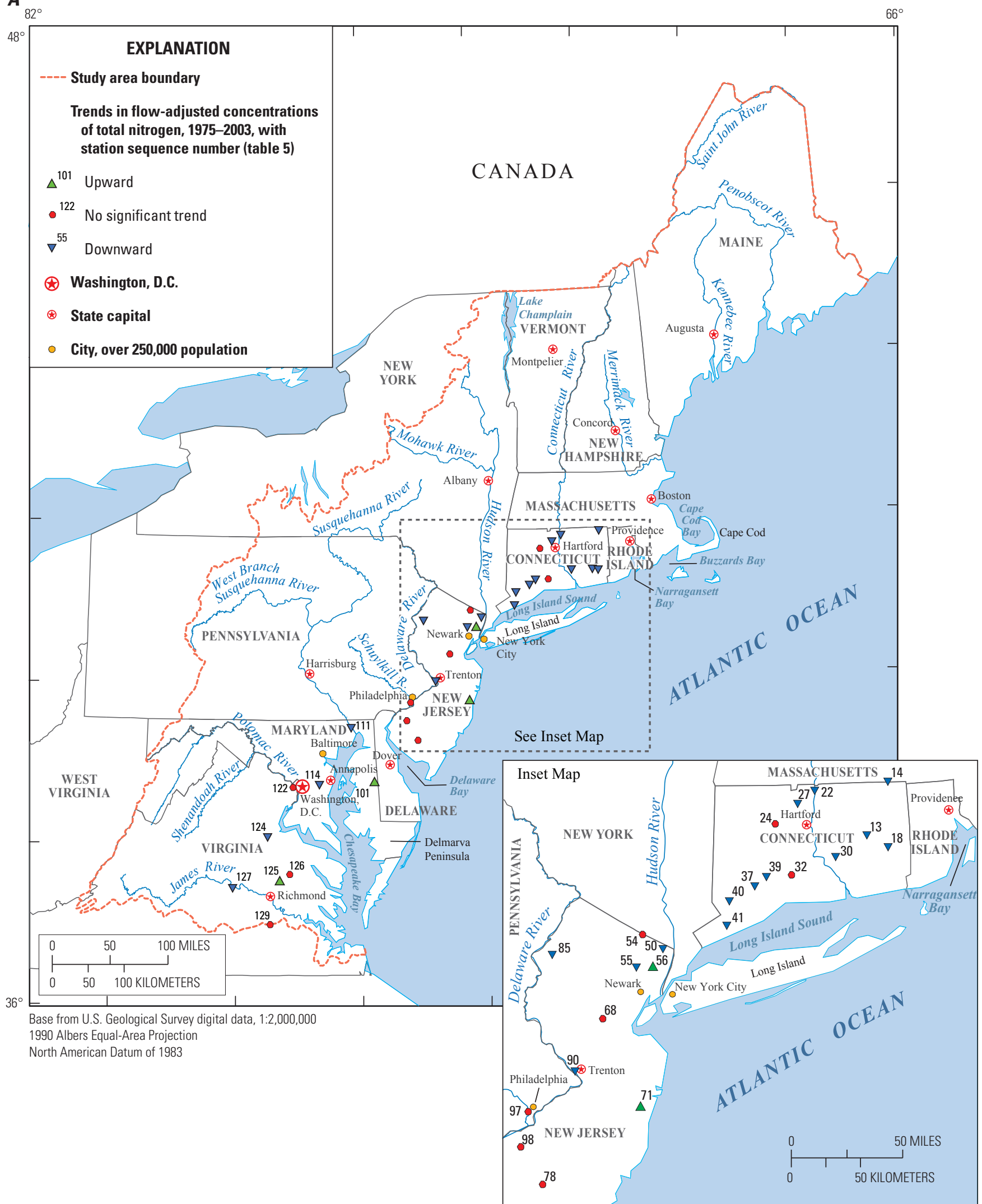

Figure 7. Trends in flow-adjusted concentrations of total nitrogen, (A) 1975-2003 and (B) 1993-2003. 


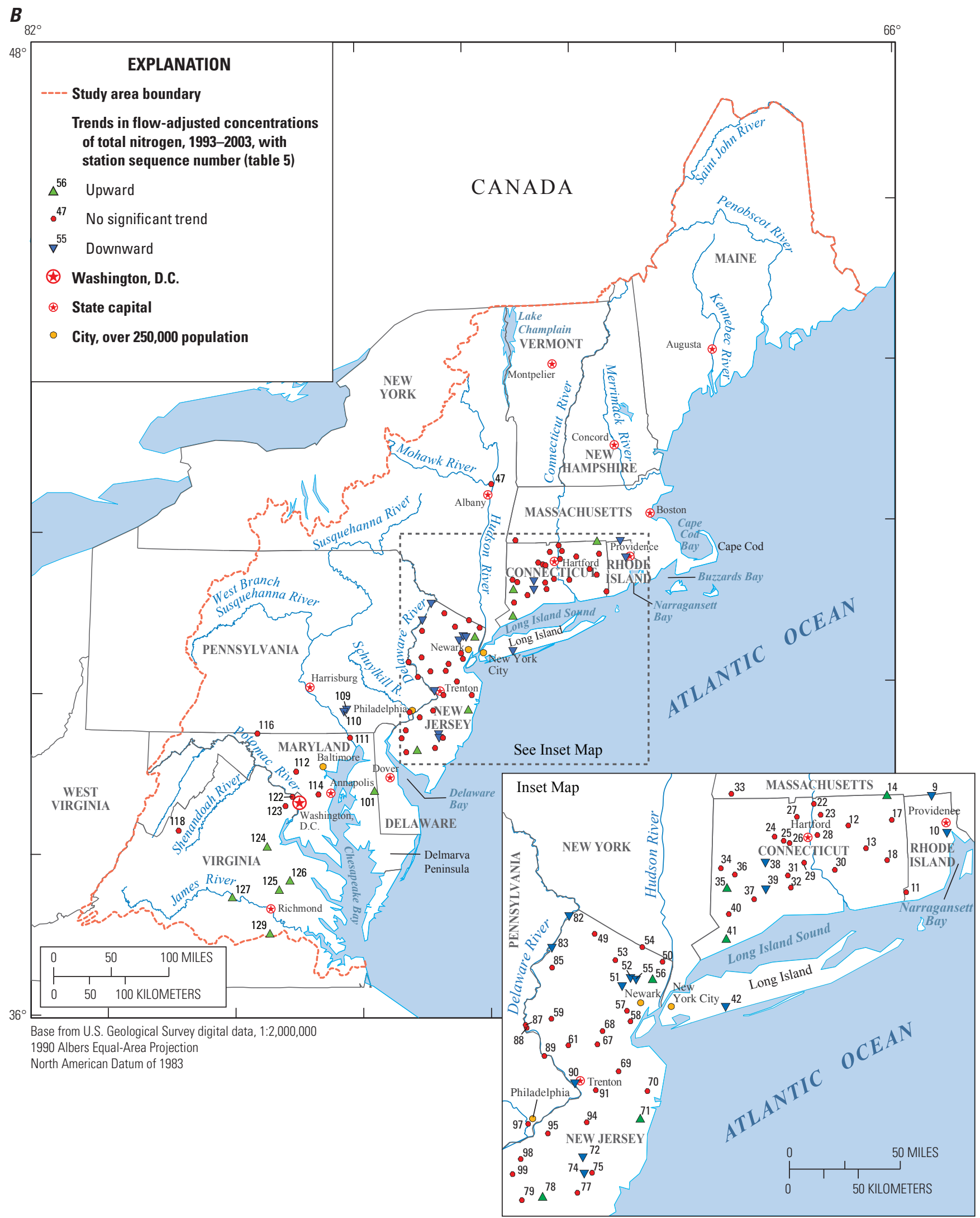

Figure 7. Trends in flow-adjusted concentrations of total nitrogen, (A) 1975-2003 and (B) 1993-2003. - Continued 
water samples) were analyzed at a small number of stations, primarily in drainage basins where point sources have been evaluated for this report. The long-term record for the Susquehanna River at Conowingo, Md., also was analyzed for trends in these constituents, because of the regional importance of this drainage basin.

Downward trends in flow-adjusted concentrations of ammonia nitrogen and total Kjeldahl nitrogen were detected at the six stations analyzed for the long-term period (table 13). During the recent period, downward trends in ammonia nitrogen were detected at 6 of the 15 stations evaluated, and 2 stations, both in the Raritan River Basin in New Jersey, had upward trends.

\section{Nitrite-plus-Nitrate Nitrogen}

Long-term flow-adjusted concentrations of nitrite-plusnitrate nitrogen increased at about one-third of the 32 stations analyzed, decreased at about one-third of the stations, and had no significant trend at about one-third of the stations (table 13, fig. 8A). During the recent period, three-quarters of the stations had no trend in nitrite-plus-nitrate, and only one station had an upward trend (table 13, fig. 8B). The Saddle River at Lodi, N.J. (station 56), was the only station with upward trends detected during both periods of analysis. Downward trends in flow-adjusted concentrations of nitriteplus-nitrate were detected at four stations during both the long-term and recent periods: the Naugatuck River at Beacon Falls, Conn.; the Delaware River at Trenton, N.J.; the Patuxent River near Bowie, Md.; and the Appomattox River at Matoaca, Va. (stations 39, 90, 114, 129).

\section{Total Phosphorus}

Downward trends in flow-adjusted concentrations of total phosphorus were detected at more than half the stations analyzed (19 of 32) during the long-term period (table 13, fig. 9A). During the recent period, however, most of the significant trends detected (17 of 83 stations) were upward trends (table 13, fig. 9B), indicating possible reversals to the overall long-term water-quality improvements relative to total phosphorus concentrations. Seven stations where downward trends in flow-adjusted concentrations of total phosphorus were detected during 1975-2003 had upward trends during 1993-2003. These results indicate that the long-term trends at these stations were not monotonic; that is, flow-adjusted concentrations generally decreased from the late 1970s to the early 1990s, and then increased from the early 1990s to 2003, although flow-adjusted concentrations in the early 2000s were still lower than in the late 1970s. This general pattern is apparent in a plot of unadjusted total phosphorus concentrations for the Patuxent River near Bowie, Md. (station 114, fig. 10), a station with a highly significant longterm downward trend in flow-adjusted concentrations of total phosphorus, and a highly significant upward trend in the more recent part of the period of record.

Most of the 17 stations with upward trends in flowadjusted concentrations of total phosphorus during 1993-2003 monitor streams that receive municipal wastewater effluent, but a few monitor streams in basins with agricultural or urban land use and no point sources. The Pamunkey River near Hanover, Va., was the only station with upward trends detected for both periods of analysis (station 125).

\section{Suspended Sediment}

All four stations analyzed for trends in flow-adjusted concentrations of suspended sediment during 1975-2003 had downward trends (table 13). The Susquehanna River at Conowingo, Md., had downward trends during both the longterm and recent periods (station 111). Sediment carried by the Susquehanna River tends to settle behind the Conowingo Dam and in other reservoirs on the lower reaches of the river (Langland and Hainly, 1997). Of eight stations analyzed for the recent period, the only station with an upward trend in flow-adjusted concentrations of suspended sediment was Conococheague Creek at Fairview, Md. (station 116); two stations had downward trends.

\section{Trends in Flow-Adjusted Concentrations of Nutrients in Large Drainage Basins}

Flow-adjusted trend results for the 11 largest drainage basins evaluated in the study, with drainage areas greater than 1,000 $\mathrm{mi}^{2}$, showed many long-term improvements in nutrient conditions, and also some indications of long-term or recent deterioration in water quality (table 14). Monitored drainage areas for these 11 basins encompass $72,275 \mathrm{mi}^{2}$, or about 44 percent of the region. The six largest drainage basins, with drainage areas greater than $3,000 \mathrm{mi}^{2}$, encompass about 39 percent of the region.

Long-term downward trends in flow-adjusted concentrations of nutrients predominated at 7 of the 10 stations with long-term records; 20 downward trends were detected out of 35 analyses for these 10 stations (table 14). During the recent period, 19 of 36 trend analyses for 10 stations showed no significant trend; the remaining analyses were about equally divided between upward and downward trends. Four upward trends in total nitrogen and four upward trends in total phosphorus were detected during the recent period. Four downward trends in nitrite-plus-nitrate were detected during the recent period, and no upward trends were detected.

Trend results indicate that progress has been made in reducing flow-adjusted nutrient concentrations in the largest drainage basins of the region. Downward trends in flowadjusted concentrations also may indicate progress in reducing nutrient delivery to streams from various sources. The 1993-2003 results, however, also indicate increases in nutrient concentrations in some drainage basins during the most recent part of the period analyzed in this study. The preponderance of downward trends during the long-term period, viewed in conjunction with the absence of significant trends for about half of the analyses in these large basins for the recent period, may indicate that the largest reductions in flow-adjusted nutrient concentrations took place prior to the 1990s. 


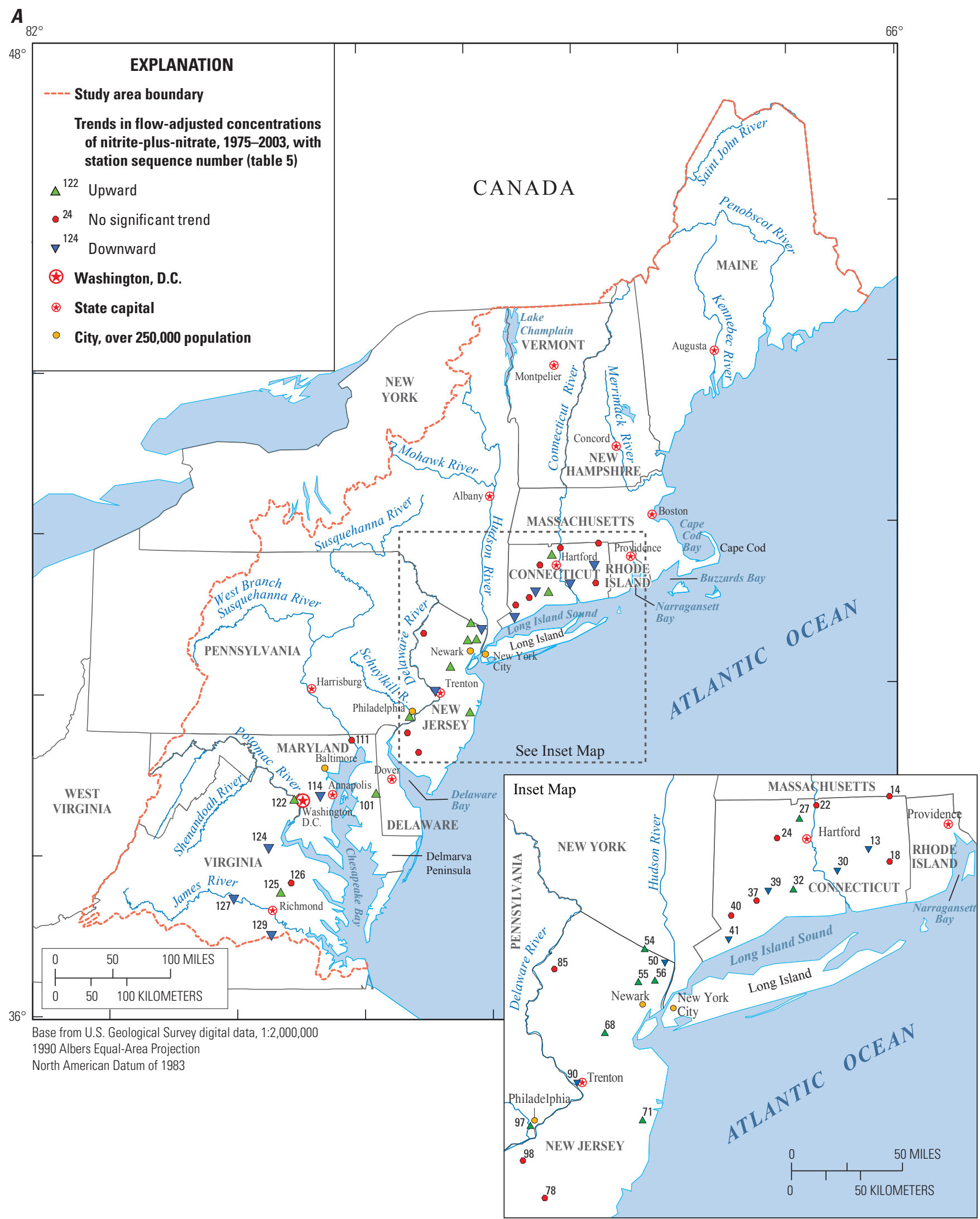

Figure 8. Trends in flow-adjusted concentrations of nitrite-plus-nitrate nitrogen, (A) 1975-2003 and (B) 1993-2003. 


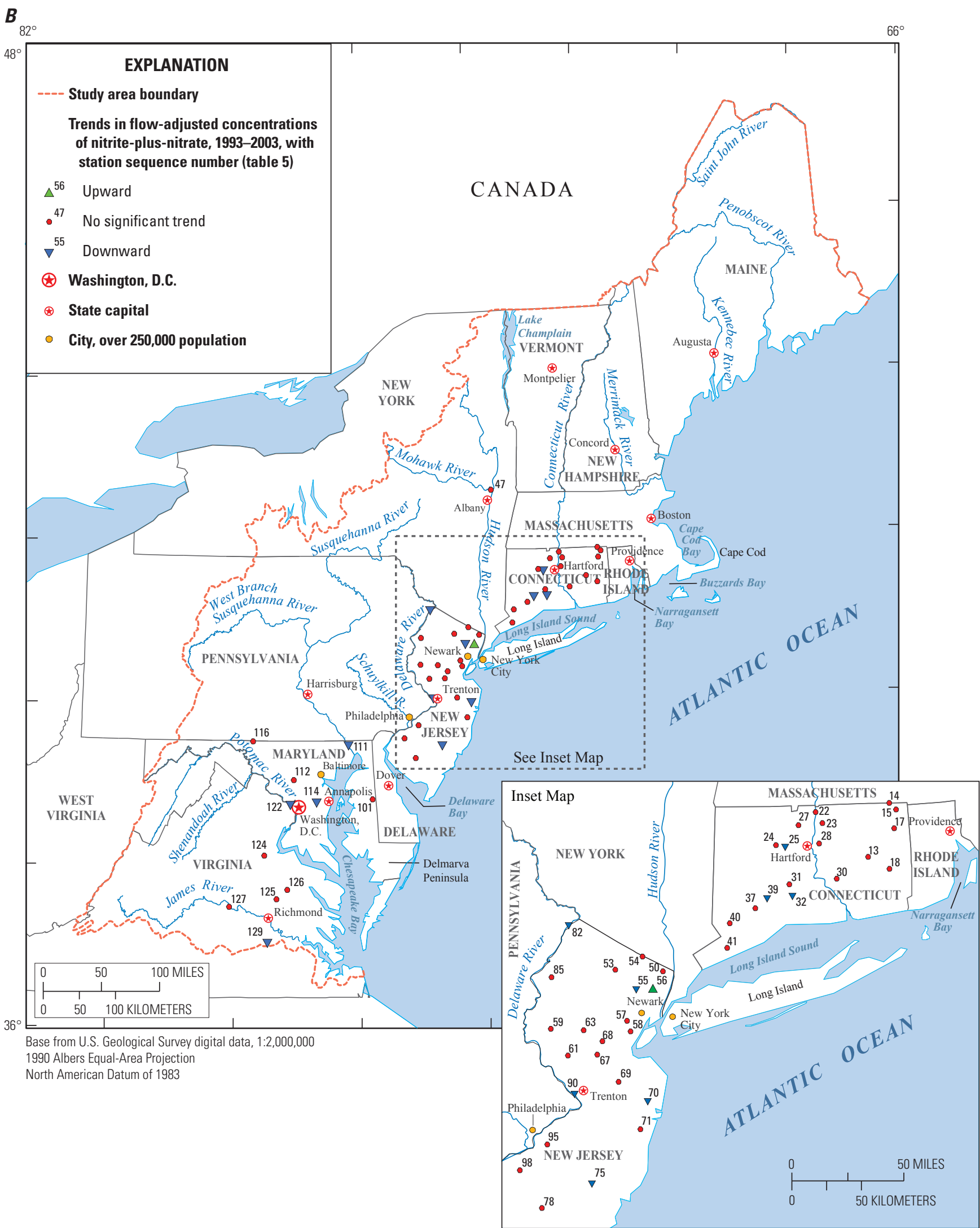

Figure 8. Trends in flow-adjusted concentrations of nitrite-plus-nitrate nitrogen, (A) 1975-2003 and (B) 1993-2003. - Continued 


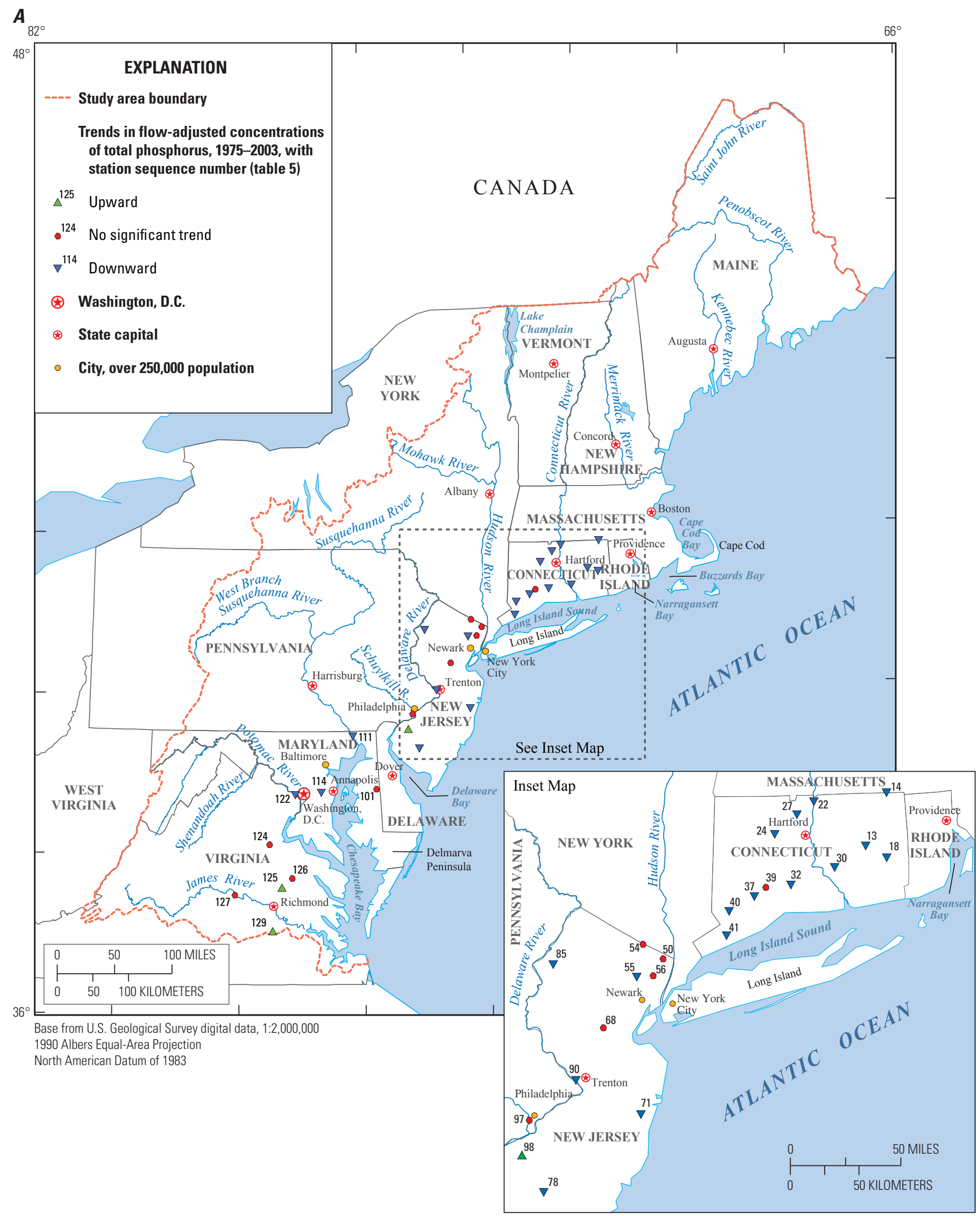

Figure 9. Trends in flow-adjusted concentrations of total phosphorus, (A) 1975-2003 and (B) 1993-2003. 
$B$

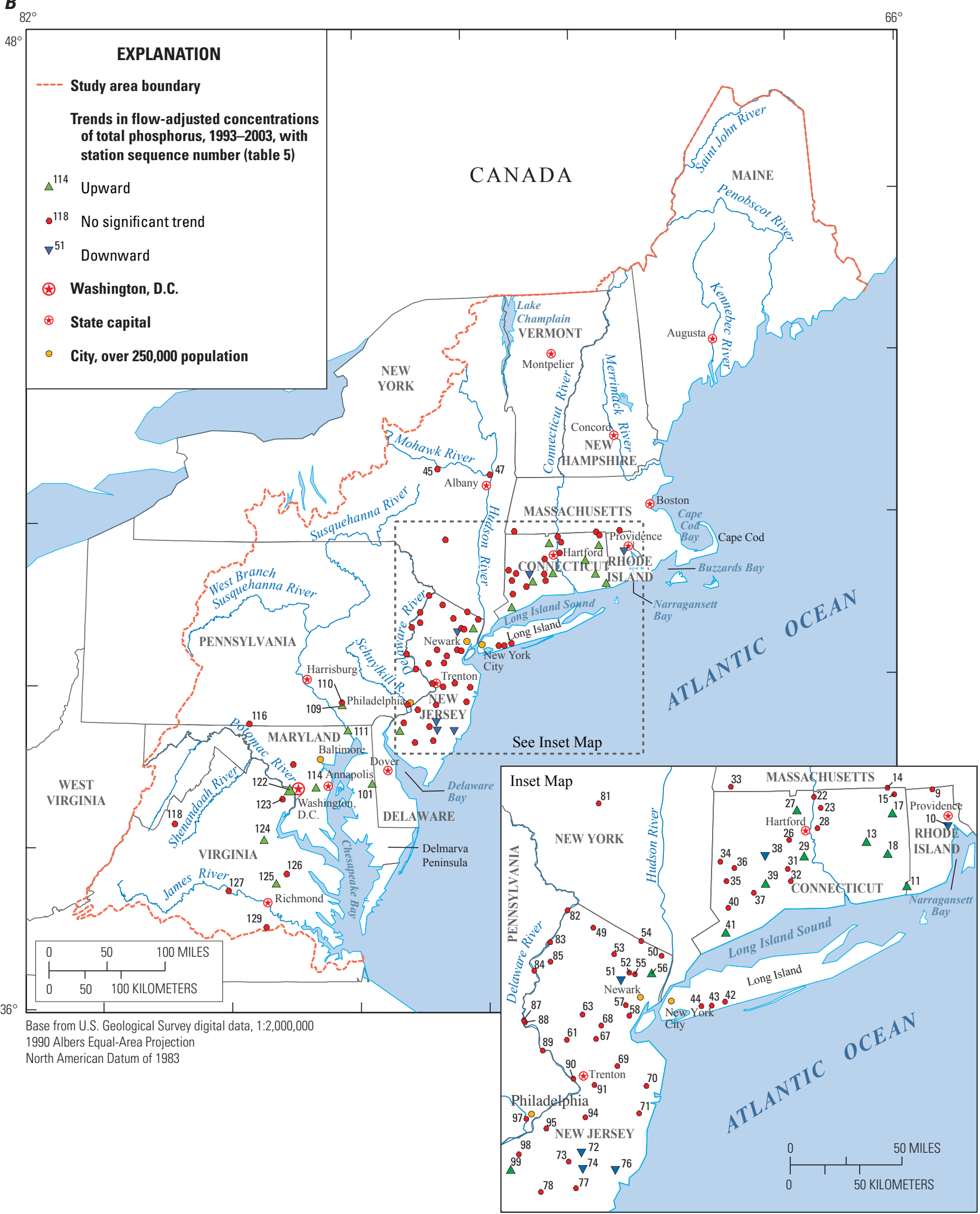

Figure 9. Trends in flow-adjusted concentrations of total phosphorus, $(A)$ 1975-2003 and (B) 1993-2003.-Continued 


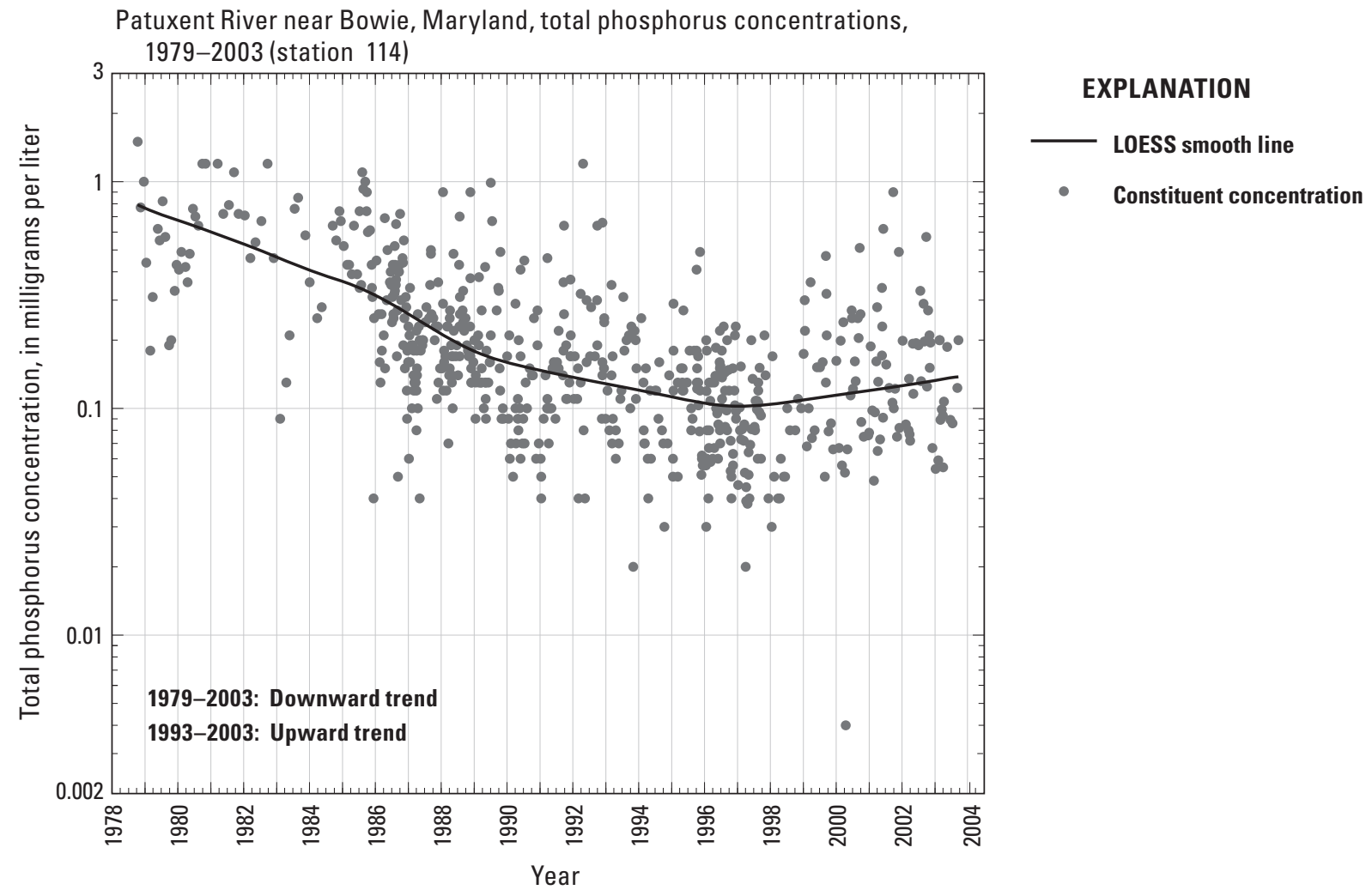

Figure 10. Total phosphorus concentrations as a function of time, Patuxent River near Bowie, Md., 1979-2003.

\section{Trends in Modeled Instream Nutrient Concentrations}

Trends in modeled instream nutrient concentrations for the long-term and recent periods were analyzed by using the coupled statistical model of streamflow and water quality (table 15, in back of report, and table 16). This method of analysis provides a modeled "reference concentration" for a constituent at the beginning of a period of analysis, that is, a central tendency in the concentration data for the initial year of the analysis that is not affected by seasonal variability or by fluctuations in annual streamflow (G.E. Schwarz, U.S. Geological Survey, written commun., 2006). These reference concentrations, in conjunction with trend results for the periods of analysis, provide a useful indicator for assessing the status of instream water quality, in terms of habitat conditions for aquatic life and in terms of conditions that may promote freshwater eutrophication or downstream eutrophication in estuarine areas.
Trends in modeled instream concentrations (non-flowadjusted concentrations) are likely to be the same as or similar to trends in flow-adjusted concentrations, in the absence of trends in streamflow. This is the case for the trend results reported in this study, where the direction of change, upward or downward, was similar for instream (non-flow-adjusted) and flow-adjusted trends in concentration at most monitoring stations (table 15, in back of report; appendix 6, table 6-1).

\section{Nutrient Concentrations in Undeveloped Drainage Basins}

Flow-weighted nutrient concentrations for undeveloped drainage basins have been evaluated in a national study by Clark and others (2000). Nine drainage basins evaluated in the national study are in the northeastern region encompassed by this study. Information for these nine streams and their drainage basins provides another useful reference point for evaluating nutrient concentrations and trends in the northeastern United States (table 17). 
Table 14. Trends in flow-adjusted nutrient concentrations and nutrient loads in large drainage basins, 1975-2003 and 1993-2003.

[No long-term record for Mohawk River at Cohoes, N.Y. Schuylkill River at Philadelphia not analyzed for 1993-2003 period because of gap in waterquality record. Significant trend: $p$-value less than or equal to 0.05 ; highly significant trend: $p$-value less than or equal to 0.01 ; $\mathrm{mi}^{2}$, square miles;

*, highly significant trend; N, no significant trend; --, data unavailable for period or not analyzed]

\begin{tabular}{|c|c|c|c|c|c|c|}
\hline \multirow{2}{*}{$\begin{array}{c}\text { Station } \\
\text { sequence number } \\
\text { (fig. 4) }\end{array}$} & \multirow{2}{*}{ Water-quality constituent } & \multirow{2}{*}{$\begin{array}{c}\text { Initial } \\
\text { water year }\end{array}$} & \multicolumn{2}{|c|}{ Flow-adjusted concentration trend } & \multicolumn{2}{|c|}{ Trend in load } \\
\hline & & & 1975-2003 & $1993-2003$ & $1975-2003$ & 1993-2003 \\
\hline \multicolumn{7}{|c|}{ Susquehanna River at Conowingo, Md. $\left(27,100 \mathrm{mi}^{2}\right)$} \\
\hline 111 & Total nitrogen & 1979 & *Down & $\mathrm{N}$ & $\mathrm{N}$ & $\mathrm{N}$ \\
\hline 111 & Ammonia nitrogen & 1979 & *Down & -- & *Down & -- \\
\hline 111 & Total Kjeldahl nitrogen & 1979 & $*$ Down & -- & Down & -- \\
\hline 111 & Nitrite-plus-nitrate nitrogen & 1979 & $\mathrm{~N}$ & *Down & $\mathrm{N}$ & $\mathrm{N}$ \\
\hline 111 & Total phosphorus & 1979 & *Down & $* U p$ & $\mathrm{~N}$ & $\mathrm{~N}$ \\
\hline 111 & Suspended sediment & 1979 & *Down & *Down & $\mathrm{N}$ & $\mathrm{N}$ \\
\hline \multicolumn{7}{|c|}{ Potomac River at Chain Bridge, at Washington, D.C. $\left(11,570 \mathrm{mi}^{2}\right)$} \\
\hline 122 & Total nitrogen & 1975 & $\mathrm{~N}$ & $\mathrm{~N}$ & $\mathrm{~N}$ & $\mathrm{~N}$ \\
\hline 122 & Nitrite-plus-nitrate nitrogen & 1975 & $* \mathrm{Up}$ & *Down & $\mathrm{N}$ & $\mathrm{N}$ \\
\hline 122 & Total phosphorus & 1975 & Down & $* \mathrm{Up}$ & $\mathrm{N}$ & $\mathrm{N}$ \\
\hline 122 & Suspended sediment & 1993 & -- & $\mathrm{N}$ & -- & $\mathrm{N}$ \\
\hline \multicolumn{7}{|c|}{ Connecticut River at Thompsonville, Conn. $\left(9,660 \mathrm{mi}^{2}\right)$} \\
\hline 22 & Total nitrogen & 1975 & *Down & $\mathrm{N}$ & *Down & $\mathrm{N}$ \\
\hline 22 & Nitrite-plus-nitrate nitrogen & 1975 & $\mathrm{~N}$ & $\mathrm{~N}$ & $\mathrm{~N}$ & $\mathrm{~N}$ \\
\hline 22 & Total phosphorus & 1975 & *Down & $\mathrm{N}$ & *Down & $\mathrm{N}$ \\
\hline 22 & Suspended sediment & 1993 & -- & $\mathrm{N}$ & -- & $\mathrm{N}$ \\
\hline \multicolumn{7}{|c|}{ Delaware River at Trenton, N.J. $\left(6,780 \mathrm{mi}^{2}\right)$} \\
\hline 90 & Total nitrogen & 1975 & *Down & Down & Down & $\mathrm{N}$ \\
\hline 90 & Nitrite-plus-nitrate nitrogen & 1975 & *Down & *Down & $\mathrm{N}$ & $\mathrm{N}$ \\
\hline 90 & Total phosphorus & 1975 & *Down & $\mathrm{N}$ & *Down & $\mathrm{N}$ \\
\hline \multicolumn{7}{|c|}{ James River at Cartersville, Va. $\left(6,252 \mathrm{mi}^{2}\right)$} \\
\hline 127 & Total nitrogen & 1975 & *Down & $* \mathrm{Up}$ & Down & $\mathrm{N}$ \\
\hline 127 & Ammonia nitrogen & 1979 & *Down & *Down & *Down & Down \\
\hline 127 & Nitrite-plus-nitrate nitrogen & 1975 & *Down & $\mathrm{N}$ & *Down & $\mathrm{N}$ \\
\hline 127 & Total phosphorus & 1975 & $\mathrm{~N}$ & $\mathrm{~N}$ & $\mathrm{~N}$ & $\mathrm{~N}$ \\
\hline \multicolumn{7}{|c|}{ Mohawk River at Cohoes, N.Y. $\left(3,450 \mathrm{mi}^{2}\right)$} \\
\hline 47 & Total nitrogen & 1993 & -- & $\mathrm{N}$ & -- & $\mathrm{N}$ \\
\hline 47 & Nitrite-plus-nitrate nitrogen & 1993 & -- & $\mathrm{N}$ & -- & $\mathrm{N}$ \\
\hline 47 & Total phosphorus & 1993 & -- & $\mathrm{N}$ & -- & $\mathrm{N}$ \\
\hline 47 & Suspended sediment & 1993 & -- & *Down & -- & $\mathrm{N}$ \\
\hline \multicolumn{7}{|c|}{ Schuylkill River at Philadelphia, Pa. $\left(1,893 \mathrm{mi}^{2}\right)$} \\
\hline 97 & Total nitrogen & 1975 & $\mathrm{~N}$ & -- & $\mathrm{N}$ & -- \\
\hline 97 & Nitrite-plus-nitrate nitrogen & 1975 & $* \mathrm{Up}$ & -- & $\mathrm{N}$ & -- \\
\hline 97 & Total phosphorus & 1975 & $\mathrm{~N}$ & -- & $\mathrm{N}$ & -- \\
\hline \multicolumn{7}{|c|}{ Rappahannock River near Fredericksburg, Va. (1,595 mi²) } \\
\hline 124 & Total nitrogen & 1979 & Down & $* \mathrm{Up}$ & $\mathrm{N}$ & $\mathrm{N}$ \\
\hline 124 & Nitrite-plus-nitrate nitrogen & 1979 & *Down & $\mathrm{N}$ & $\mathrm{N}$ & $\mathrm{N}$ \\
\hline 124 & Total phosphorus & 1979 & $\mathrm{~N}$ & $*$ Up & $\mathrm{N}$ & $\mathrm{N}$ \\
\hline
\end{tabular}


Table 14. Trends in flow-adjusted nutrient concentrations and nutrient loads in large drainage basins, 1975-2003 and 1993-2003.-Continued

[No long-term record for Mohawk River at Cohoes, N.Y. Schuylkill River at Philadelphia not analyzed for 1993-2003 period because of gap in waterquality record. Significant trend: $p$-value less than or equal to 0.05 ; highly significant trend: $p$-value less than or equal to $0.01 ; \mathrm{mi}^{2}$, square miles;

*, highly significant trend; N, no significant trend; --, data unavailable for period or not analyzed]

\begin{tabular}{|c|c|c|c|c|c|c|}
\hline \multirow{2}{*}{$\begin{array}{c}\text { Station } \\
\text { sequence number } \\
\text { (fig. } 4 \text { ) }\end{array}$} & \multirow{2}{*}{ Water-quality constituent } & \multirow{2}{*}{$\begin{array}{c}\text { Initial } \\
\text { water year }\end{array}$} & \multicolumn{2}{|c|}{ Flow-adjusted concentration trend } & \multicolumn{2}{|c|}{ Trend in load } \\
\hline & & & 1975-2003 & 1993-2003 & $1975-2003$ & $1993-2003$ \\
\hline \multicolumn{7}{|c|}{ Housatonic River at Stevenson, Conn. $\left(1,544 \mathrm{mi}^{2}\right)$} \\
\hline 37 & Total nitrogen & 1975 & *Down & $\mathrm{N}$ & $\mathrm{N}$ & $\mathrm{N}$ \\
\hline 37 & Nitrite-plus-nitrate nitrogen & 1975 & $\mathrm{~N}$ & $\mathrm{~N}$ & $\mathrm{~N}$ & $\mathrm{~N}$ \\
\hline 37 & Total phosphorus & 1975 & *Down & $\mathrm{N}$ & *Down & $\mathrm{N}$ \\
\hline \multicolumn{7}{|c|}{ Appomattox River at Matoaca, Va. $\left(1,342 \mathrm{mi}^{2}\right)$} \\
\hline 129 & Total nitrogen & 1979 & $\mathrm{~N}$ & $* \mathrm{Up}$ & $\mathrm{N}$ & $\mathrm{N}$ \\
\hline 129 & Ammonia nitrogen & 1980 & *Down & $*$ Down & *Down & $\mathrm{N}$ \\
\hline 129 & Nitrite-plus-nitrate nitrogen & 1979 & Down & Down & Down & $\mathrm{N}$ \\
\hline 129 & Total phosphorus & 1979 & Up & $\mathrm{N}$ & $\mathrm{N}$ & $\mathrm{N}$ \\
\hline \multicolumn{7}{|c|}{ Pamunkey River near Hanover, Va. (1,078 mi²) } \\
\hline 125 & Total nitrogen & 1975 & $* U p$ & $* \mathrm{Up}$ & $\mathrm{N}$ & $\mathrm{N}$ \\
\hline 125 & Nitrite-plus-nitrate nitrogen & 1975 & $* \mathrm{Up}$ & $\mathrm{N}$ & $\mathrm{N}$ & $\mathrm{N}$ \\
\hline 125 & Total phosphorus & 1975 & $* U p$ & $* \mathrm{Up}$ & $\mathrm{N}$ & $\mathrm{N}$ \\
\hline
\end{tabular}

Flow-weighted concentrations are not identical to timeweighted concentrations, and comparisons should be made with caution. These measures may differ because of short periods of high streamflow, where dilution or runoff enrichment may have a strong effect on flow-weighted concentrations. However, flow-weighted and time-weighted concentrations are likely to be much more similar in streams with undeveloped watersheds than in streams with substantial development and nutrient inputs (J.D. Blomquist, U.S. Geological Survey, written commun., 2010).
In the national study, flow-weighted concentration, in milligrams per liter $(\mathrm{mg} / \mathrm{L})$, was estimated as the total stream load of a constituent during the entire estimation period divided by the total stream discharge during the estimation period (Clark and others, 2000). Flow-weighted concentration can be thought of as the concentration of a constituent that would be present in a giant storage tank holding all the discharge from the stream (G.E. Schwarz, U.S. Geological Survey, written commun., 2007). A day with more streamflow has more weight in determining the flow-weighted

Table 16. Summary of trend results for modeled instream concentrations, 1975-2003 and 1993-2003.

[Long-term period for trend analysis spans 22-29 water years at different stations, all ending in 2003; recent period for trend analysis spans 11 water years at all stations. Significant trend: $p$-value less than or equal to 0.05 ; highly significant trend: $p$-value less than or equal to 0.01 ; --, not analyzed]

\begin{tabular}{|c|c|c|c|c|c|c|c|c|}
\hline \multirow[b]{2}{*}{ Water-quality constituent } & \multicolumn{4}{|c|}{$1975-2003,1979-2003$, or $1982-2003$} & \multicolumn{4}{|c|}{ 1993-2003 } \\
\hline & $\begin{array}{c}\text { Number of } \\
\text { stations } \\
\text { analyzed }\end{array}$ & $\begin{array}{c}\text { Upward } \\
\text { trend }\end{array}$ & $\begin{array}{l}\text { Downward } \\
\text { trend }\end{array}$ & $\begin{array}{l}\text { No signifi- } \\
\text { cant trend }\end{array}$ & $\begin{array}{l}\text { Number of } \\
\text { stations } \\
\text { analyzed }\end{array}$ & $\begin{array}{c}\text { Upward } \\
\text { trend }\end{array}$ & $\begin{array}{c}\text { Downward } \\
\text { trend }\end{array}$ & $\begin{array}{l}\text { No signifi- } \\
\text { cant trend }\end{array}$ \\
\hline Total nitrogen & 32 & 4 & 16 & 12 & 46 & 6 & 4 & 36 \\
\hline Ammonia nitrogen & 6 & 0 & 5 & 1 & 9 & 1 & 4 & 4 \\
\hline Total Kjeldahl nitrogen & 6 & 0 & 6 & 0 & 0 & -- & -- & -- \\
\hline Nitrite-plus-nitrate nitrogen & 32 & 11 & 7 & 14 & 46 & 0 & 8 & 38 \\
\hline Total phosphorus & 32 & 2 & 18 & 12 & 46 & 11 & 0 & 35 \\
\hline Suspended sediment & 4 & 0 & 4 & 0 & 8 & 0 & 2 & 6 \\
\hline
\end{tabular}




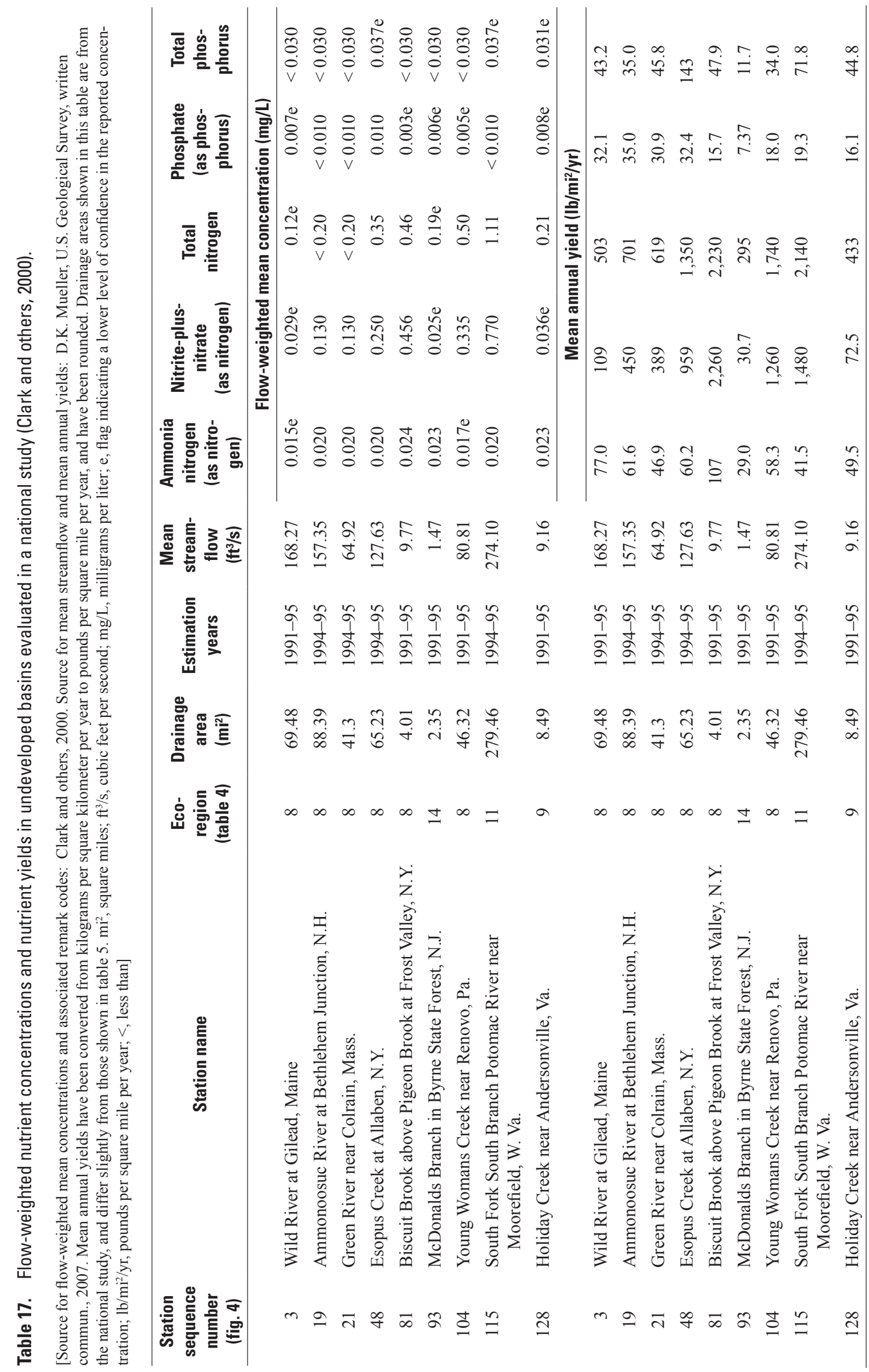


concentration than a day with less streamflow. By contrast, time-weighted concentration puts equal weight on each water-quality observation, or more specifically, puts equal weight on the time span between samples. Sampling schemes with some kind of regularity are acceptable for determining time-weighted concentration, with sample concentrations representing an average over time (D.L. Lorenz, U.S. Geological Survey, written commun., 2009). Time-weighted concentrations are commonly the basis of regulatory standards, because regulations address the issue of whether water-quality conditions are adverse on a daily basis. A flow-weighted concentration may be less than regulatory limits over time, but on a given day, a standard or criterion may be exceeded, creating adverse conditions for aquatic life. The difference between flow-weighted and time-weighted concentrations depends on the relation between the constituent concentration and streamflow (D.L. Lorenz, U.S. Geological Survey, written commun., 2009). For example, if concentration increases as streamflow increases, then the flow-weighted concentration could exceed regulatory limits, but on a typical day (during lower streamflow), the concentration could be less than the limit. Conversely, if concentration decreases as streamflow increases, then the flow-weighted concentration could be less than regulatory limits, but concentrations could exceed limits on days of lower streamflow.

\section{Modeled Instream Nutrient Concentrations in Relation to Proposed Nutrient Criteria}

Trend results for modeled instream concentrations, along with modeled reference concentrations for streams, can be evaluated relative to nutrient criteria proposed for rivers and streams by the USEPA (table 4) and relative to flow-weighted concentrations from the national study for streams with relatively undeveloped or near-pristine drainage areas (table 15, in back of report, and table 17), as a means of assessing the status of nutrient conditions in the study area. Nutrient criteria have been proposed by the USEPA for total nitrogen and total phosphorus for 14 ecoregions in the United States (table 4).

Several cautionary notes should be considered when making comparisons between modeled instream concentrations and proposed nutrient criteria. The coupled statistical model of streamflow and water quality does not provide a measure of uncertainty for the modeled instream concentrations, and consequently, comparisons with proposed nutrient criteria are considered qualitative rather than quantitative. Additionally, the USEPA has stated that nutrient criteria recommendations "serve as a starting point for States and Tribes to develop more refined criteria, as appropriate, to reflect local conditions," and also states that the values presented in nutrient criteria documents "generally represent nutrient levels that protect against the adverse effects of nutrient overenrichment" (U.S. Environmental Protection Agency, 2001, p. iv). Nutrient criteria adopted in the future for specific streams in the region may differ from the proposed criteria shown here (tables 4,15 , in back of report). Finally, many drainage basins, particularly the larger drainage basins, encompass parts of more than one nutrient ecoregion, and consequently the nutrient criteria proposed for a single ecoregion may not represent all conditions in a given drainage basin. For drainage basins that encompass parts of more than one ecoregion, the nutrient criteria shown in table 15 (in back of report) either reflect ecoregional assignments made in the NAWQA Program (D.K. Mueller, U.S. Geological Survey, written commun., 2003), or represent the ecoregion with the highest criterion (highest concentration) in that drainage basin. The overall range in proposed criteria is small enough that these comparisons, although qualitative, provide a useful indicator of water-quality status.

The national study of nutrients in undeveloped drainage basins presents flow-weighted concentrations for total nitrogen, ammonia nitrogen, nitrite-plus-nitrate nitrogen (referred to as nitrate in the national report), phosphate, and total phosphorus (table 17; Clark and others, 2000). This national study found that "concentrations and yields of nitrate tended to be highest in northeastern and mid-Atlantic coastal states and correlated well with areas of high atmospheric nitrogen deposition" (Clark and others, 2000, p. 1). Nitrate constitutes from at least 65 percent to almost 100 percent of the flow-weighted mean concentration of total nitrogen in six of the nine streams evaluated in the national study, and only 13 to 24 percent in three of the streams (table 17). The streams where nitrate constitutes a high proportion of total nitrogen are generally in upland areas with high concentrations of nitrate in precipitation (Clark and others, 2000, p. 14, fig. 2). Total nitrogen concentrations exceed proposed criteria in three of the nine drainage basins, including Biscuit Brook in New York, Young Womans Creek in Pennsylvania, and the South Fork South Branch of the Potomac River in West Virginia (tables 4, 17).

Elevated concentrations of nutrients persist in many of the streams evaluated in this study. Modeled reference concentrations for total nitrogen at the start of the 1993-2003 period exceeded proposed criteria for total nitrogen by a factor of two or more at 21 of the 46 stations analyzed (table 15, in back of report). Concentrations exceeded proposed criteria by a factor of five or more at 4 of the 21 stations. No trend in modeled instream concentration of total nitrogen was detected for 1993-2003 at 17 of these 21 stations, downward trends were detected at 3 stations, and an upward trend was detected at 1 station, indicating persistence of elevated concentrations during the period of analysis at more than one-third of the stations analyzed. Although criteria have not been proposed for nitrite-plus-nitrate, elevated concentrations of this constituent are indicated at several stations where modeled reference concentrations for the 1993-2003 period exceed proposed criteria for total nitrogen (table 15, in back of report).

Modeled reference concentrations for total phosphorus at the start of the 1993-2003 period exceeded proposed criteria for total phosphorus by a factor of two or more at 24 of the 46 stations analyzed for trends (table 15, in back of report). At 4 of the 24 stations, modeled reference concentrations exceeded proposed criteria by an order of magnitude. No significant trends in the modeled instream concentration of 
total phosphorus were detected for 1993-2003 at 19 of these 24 stations, and upward trends were detected at 5 stations, indicating persistence of elevated instream total phosphorus concentrations during the period of analysis at about one-half of the stations analyzed.

Modeled reference concentrations for total nitrogen and total phosphorus at the start of the long-term period provide a useful indication of historical instream nutrient conditions, and the starting point for long-term trends. Graphs of nutrient concentrations as a function of time at selected stations show some of these long-term changes (figs. 11, 12). Numerous long-term downward trends in flow-adjusted and modeled instream nutrient concentrations indicate that at many stations, the reference concentrations for the late 1970s are no longer representative of conditions in the mid-2000s. For example, long-term downward trends in concentrations of total nitrogen were detected for the Naugatuck River in Connecticut (station 39) and the Delaware River at Trenton, N.J. (station 90) (figs. 11A, B). The trends in total nitrogen for the Naugatuck and Delaware Rivers are nonlinear, with an increase in concentration from the mid-1970s to the mid1980s, and a decrease in concentration from the mid-1980s to the mid-2000s; overall, concentrations in the mid-2000s are lower than in the mid-1970s. Long-term downward trends in all nitrogen constituents evaluated, including total nitrogen, nitrite-plus-nitrate nitrogen, ammonia nitrogen, and total Kjeldahl nitrogen, were detected for the Patuxent River in Maryland (station 114) (figs. 11C-F), with the largest decreases in instream concentration taking place prior to the early 1990s. Elevated total nitrogen concentrations in the late 1980s in these and other streams may be affected to some extent by a positive analytical bias in total Kjeldahl nitrogen concentrations (Patton and Truitt, 2000), as discussed in the "Methods" section of this report. The magnitude of the bias is believed to be small relative to total nitrogen concentrations in streams with substantial urban and agricultural influences. In some rivers, such as the Naugatuck and Patuxent, recent instream concentrations of total nitrogen substantially exceed proposed criteria, despite significant long-term downward trends in total nitrogen (figs. 11 A, C), and in some rivers, recent instream concentrations of nitrite-plus-nitrate nitrogen also exceed proposed criteria for total nitrogen (figs. 11D, H).

At stations with no long-term trend in a constituent, reference concentrations modeled for the beginning of the long-term period also may be indicative of more recent conditions. No significant long-term trend in instream concentrations of total nitrogen was detected for the Raritan River in New Jersey, although short-term changes are apparent during the period of record, with concentrations generally decreasing from 1982 to 1995, and then increasing from the mid-1990s to the early 2000s (fig. 11G). Although no trend in total nitrogen was detected for the 1993-2003 period at the significance level selected for this study ( $p$-value $=0.05$ ), possible upward trends in flow-adjusted and instream concentrations of total nitrogen are indicated by trend test results for the 1993-2003 period, with $p$-values of 0.125 and 0.116 , respectively. A long-term upward trend in nitrite-plus-nitrate nitrogen was detected for the Raritan River (fig. 11H). Many recent concentrations of total nitrogen and nitrite-plus-nitrate nitrogen exceed the proposed criterion for total nitrogen at this location (figs. 11G, H). By contrast, long-term downward trends in instream concentrations of ammonia nitrogen and total Kjeldahl nitrogen were detected, indicating overall improvement in the quality of water in the Raritan River (figs. 11I, J).

Long-term upward trends in instream concentrations of total nitrogen and nitrite-plus-nitrate nitrogen were detected for some rivers, including the Saddle River in New Jersey and the Choptank River in Maryland (figs. 11K-N). Many of the most recent concentrations of both total nitrogen and nitrite-plus-nitrate nitrogen in the Choptank River exceed the proposed criterion for total nitrogen, and all recent concentrations of these constituents in the Saddle River exceed the proposed criterion.

Instream concentrations of total phosphorus decreased during the long-term period in several rivers, including the Connecticut River in Connecticut and the Delaware River in New Jersey (figs. 12A, B); no trends were detected during the recent period at these stations. At six locations, including the Patuxent River (fig. 10), instream concentrations of total phosphorus decreased during the long term, but increased during the recent period. Long-term increases in total phosphorus were detected at only two locations, on Raccoon Creek in New Jersey and the Pamunkey River in Virginia (figs. 12C, D). Despite the number of long-term downward trends detected, many of the most recent concentrations of total phosphorus substantially exceed proposed criteria in a number of streams.

\section{Modeled Instream Nutrient Concentrations and Trends in Large Drainage Basins}

Evaluation of the 11 largest drainage basins analyzed for trends shows mixed results in terms of proposed nutrient criteria. Modeled reference concentrations for either total nitrogen or total phosphorus or both constituents exceed proposed nutrient criteria by a factor of at least two at the start of the recent period in the Connecticut, Housatonic, Delaware, Potomac, and James Rivers (table 15, in back of report). The Schuylkill River was not analyzed for the 1993-2003 period, but modeled reference concentrations for both constituents at the start of the 1975-2003 period exceed proposed criteria, and no long-term trend was detected in either constituent.

The largest drainage basin, the Susquehanna, incorporates several ecoregions, with proposed nutrient criteria at low concentrations in upland headwater areas and at somewhat higher concentrations downstream where the monitoring station is located. If the highest concentration criteria for ecoregions within its drainage area are applied to the Susquehanna River at Conowingo, Md. (station 111), the modeled reference concentration for total nitrogen exceeds the proposed criterion by a factor of two, and the modeled reference concentration for total phosphorus is slightly higher than the proposed criterion (table 15, in back of report). A downward trend in the modeled 
A. Naugatuck River at Beacon Falls, Connecticut, 1975-2003 (station 39)

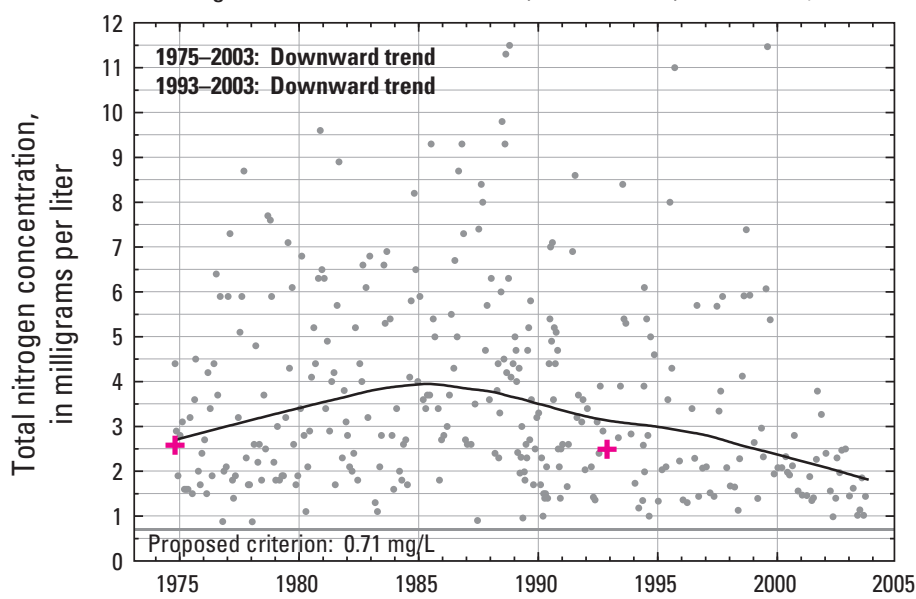

C. Patuxent River near Bowie, Maryland, 1979-2003 (station 114)

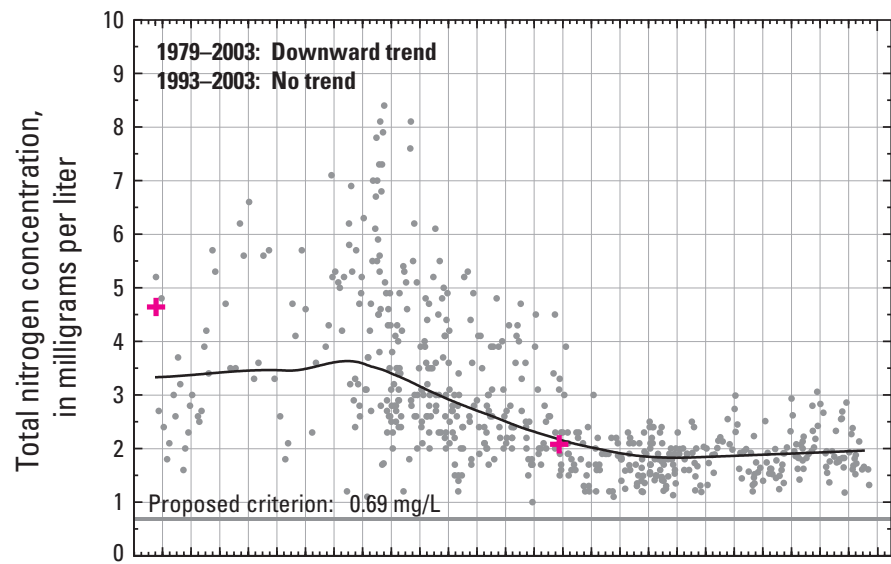

$1978 \quad 1980198219841986 \quad 1988199019921994 \quad 1996 \quad 199820002002 \quad 2004$

E. Patuxent River near Bowie, Maryland, 1980-2003 (station 114)

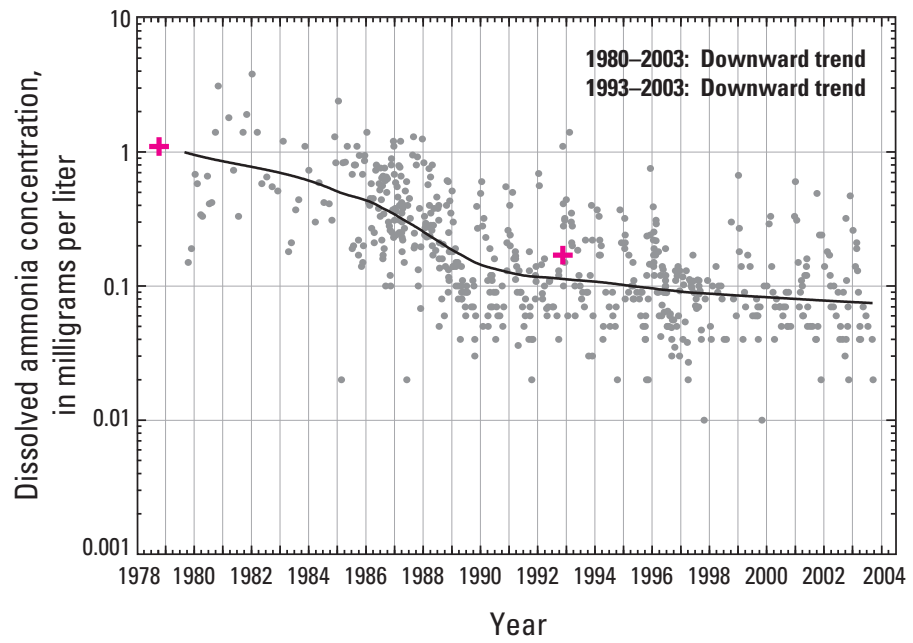

B. Delaware River at Trenton, New Jersey, 1975-2003 (station 90)

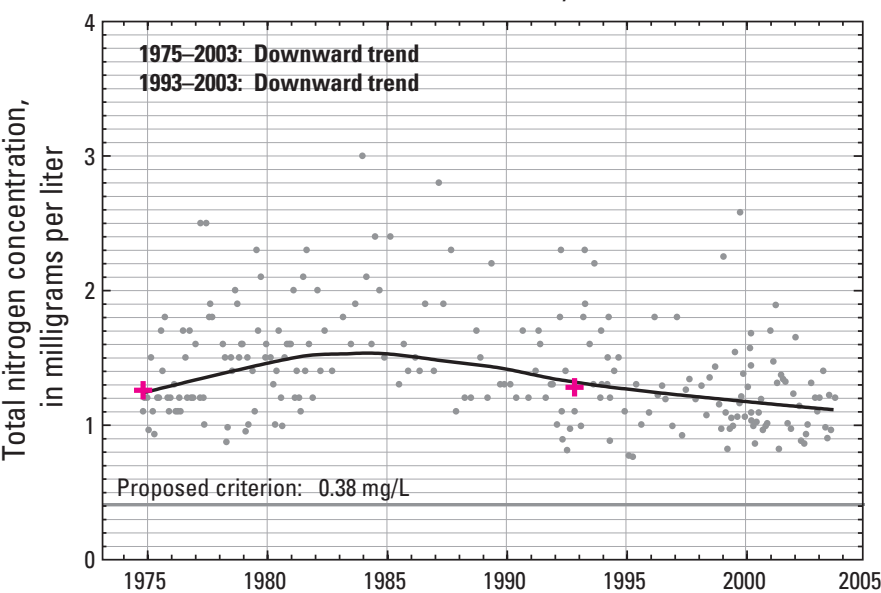

D. Patuxent River near Bowie, Maryland, 1979-2003 (station 114)

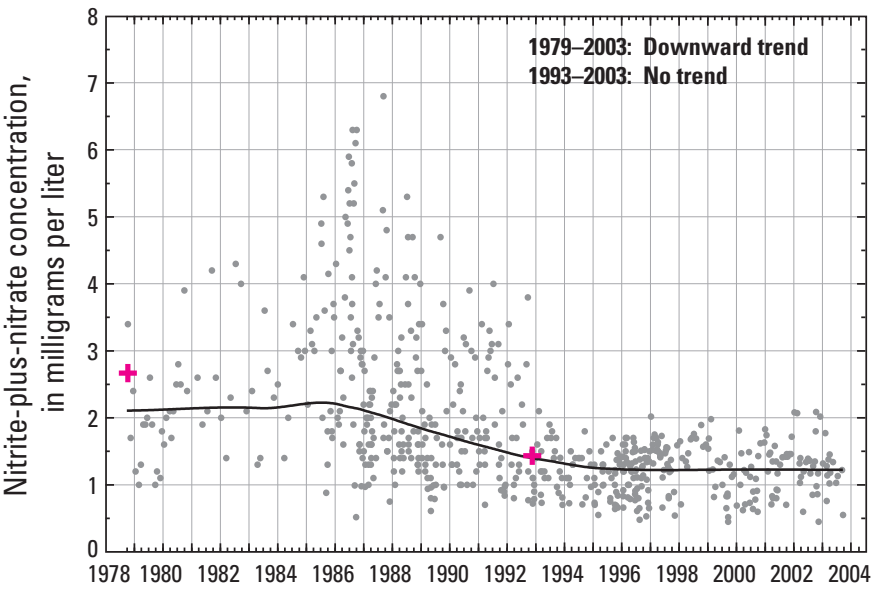

F. Patuxent River near Bowie, Maryland, 1979-2003 (station 114)

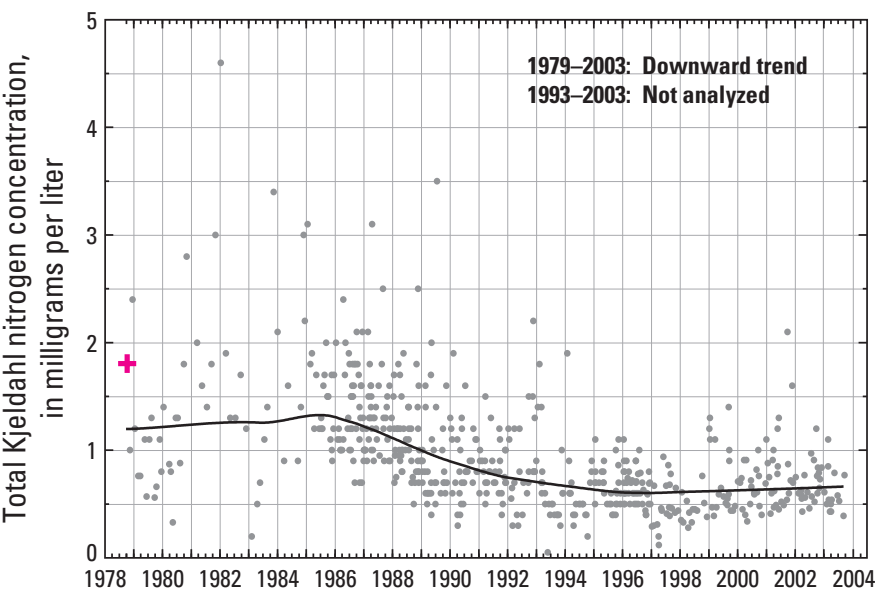

Year

\section{EXPLANATION}

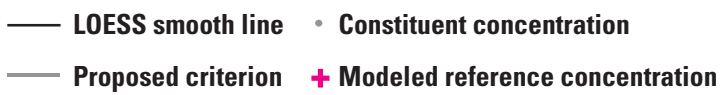

Figure 11. Nitrogen constituent concentrations as a function of time at selected stations. (See facing page for explanations of $(A-F))$ 

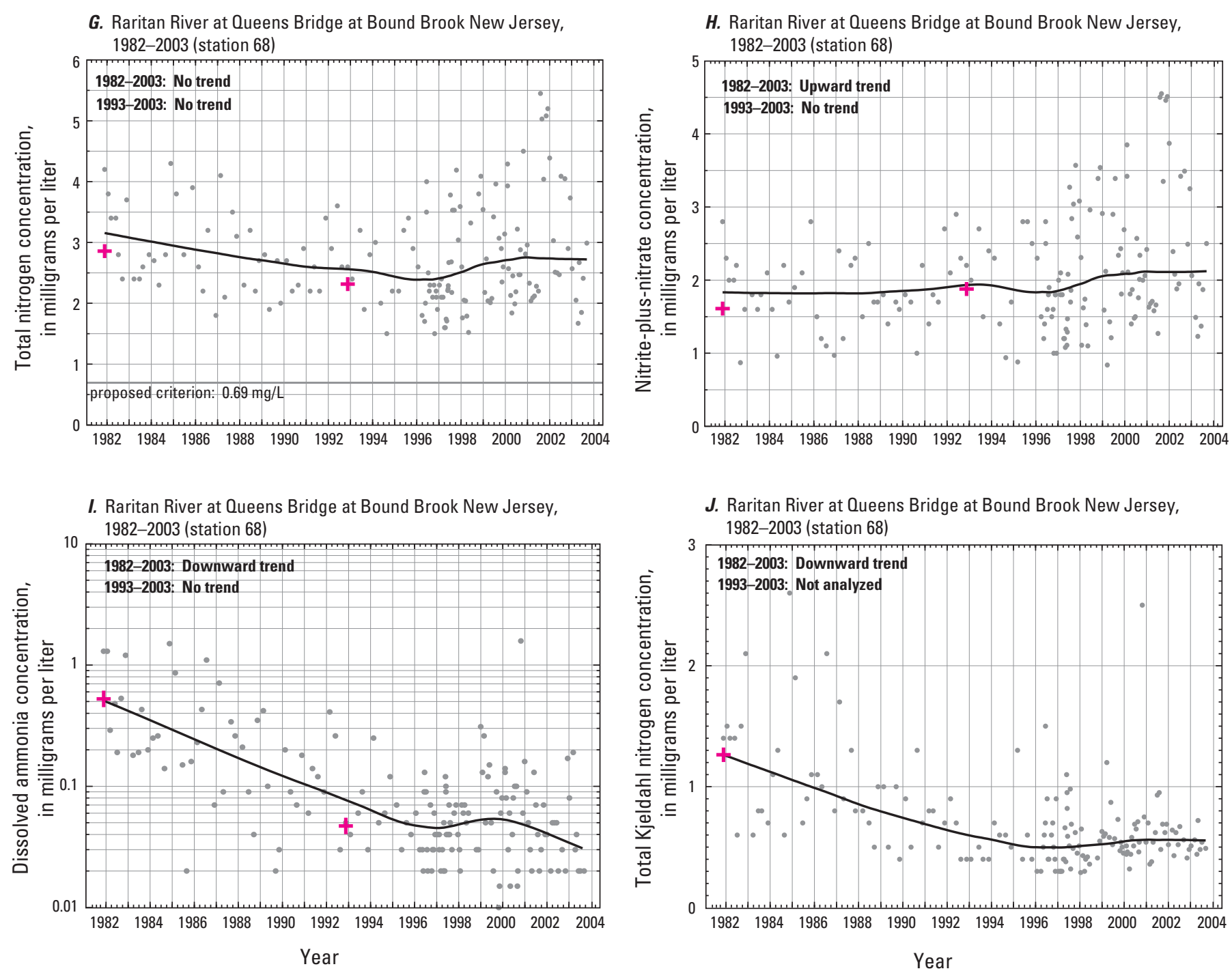

EXPLANATION

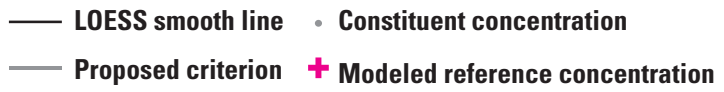

Figure 11. Nitrogen constituent concentrations as a function of time at selected stations. (A) Naugatuck River at Beacon Falls, Conn., total nitrogen concentrations, 1975-2003, (B) Delaware River at Trenton, N.J., total nitrogen concentrations, 1975-2003, (C) Patuxent River near Bowie, Md., total nitrogen concentrations, 1979-2003, (D) Patuxent River near Bowie, Md., nitrite-plus-nitrate concentrations, 1979-2003, (E) Patuxent River near Bowie, Md., dissolved ammonia concentrations, 1980-2003, (F) Patuxent River near Bowie, Md., total Kjeldahl nitrogen concentrations, 1979-2003, (G) Raritan River at Queens Bridge at Bound Brook, N.J., total nitrogen concentrations, 1982-2003, (H) Raritan River at Queens Bridge at Bound Brook, N.J., nitrite-plus-nitrate concentrations, 1982-2003, (I) Raritan River at Queens Bridge at Bound Brook, N.J., dissolved ammonia concentrations, 1982-2003, (J) Raritan River at Queens Bridge at Bound Brook, N.J., total Kjeldahl nitrogen concentrations, 1982-2003, (K) Saddle River at Lodi, N.J., total nitrogen concentrations, 1975-2003, (L) Saddle River at Lodi, N.J., nitrite-plus-nitrate concentrations, 1975-2003, (M) Choptank River near Greensboro, Md., total nitrogen concentrations, 1975-2003, and (N) Choptank River near Greensboro, Md., nitrite-plus-nitrate concentrations, 1975-2003. - Continued 

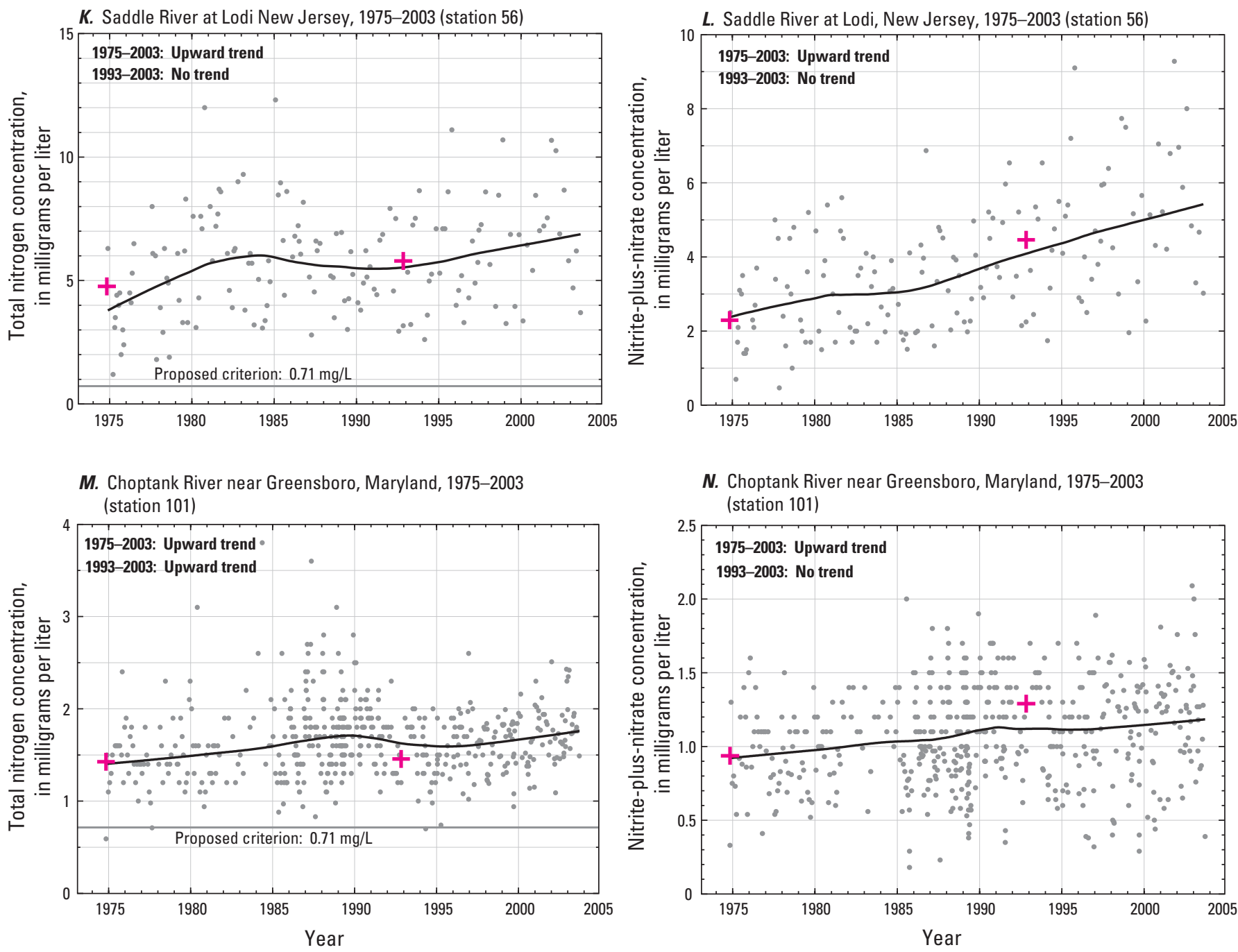

\section{EXPLANATION}

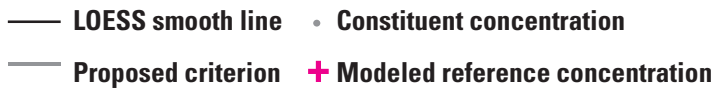

Figure 11. Nitrogen constituent concentrations as a function of time at selected stations. (A) Naugatuck River at Beacon Falls, Conn., total nitrogen concentrations, 1975-2003, (B) Delaware River at Trenton, N.J., total nitrogen concentrations, 1975-2003, (C) Patuxent River near Bowie, Md., total nitrogen concentrations, 1979-2003, (D) Patuxent River near Bowie, Md., nitrite-plus-nitrate concentrations, 1979-2003, (E) Patuxent River near Bowie, Md., dissolved ammonia concentrations, 1980-2003, (F) Patuxent River near Bowie, Md., total Kjeldahl nitrogen concentrations, 1979-2003, (G) Raritan River at Queens Bridge at Bound Brook, N.J., total nitrogen concentrations, 1982-2003, (H) Raritan River at Queens Bridge at Bound Brook, N.J., nitrite-plus-nitrate concentrations, 1982-2003, (I) Raritan River at Queens Bridge at Bound Brook, N.J., dissolved ammonia concentrations, 1982-2003, (J) Raritan River at Queens Bridge at Bound Brook, N.J., total Kjeldahl nitrogen concentrations, 1982-2003, (K) Saddle River at Lodi, N.J., total nitrogen concentrations, 1975-2003, (L) Saddle River at Lodi, N.J., nitrite-plus-nitrate concentrations, 1975-2003, (M) Choptank River near Greensboro, Md., total nitrogen concentrations, 1975-2003, and (N) Choptank River near Greensboro, Md., nitrite-plus-nitrate concentrations, 1975-2003.-Continued 
A. Connecticut River at Thompsonville, Connecticut, (station 22), 1975-2003

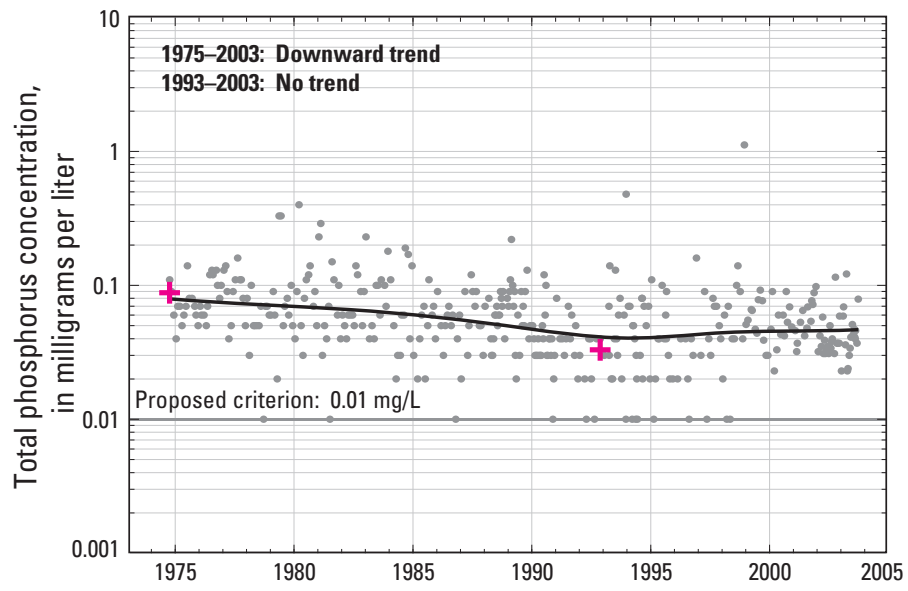

C. Raccoon Creek near Swedesboro, New Jersey, (station 98), 1975-2003

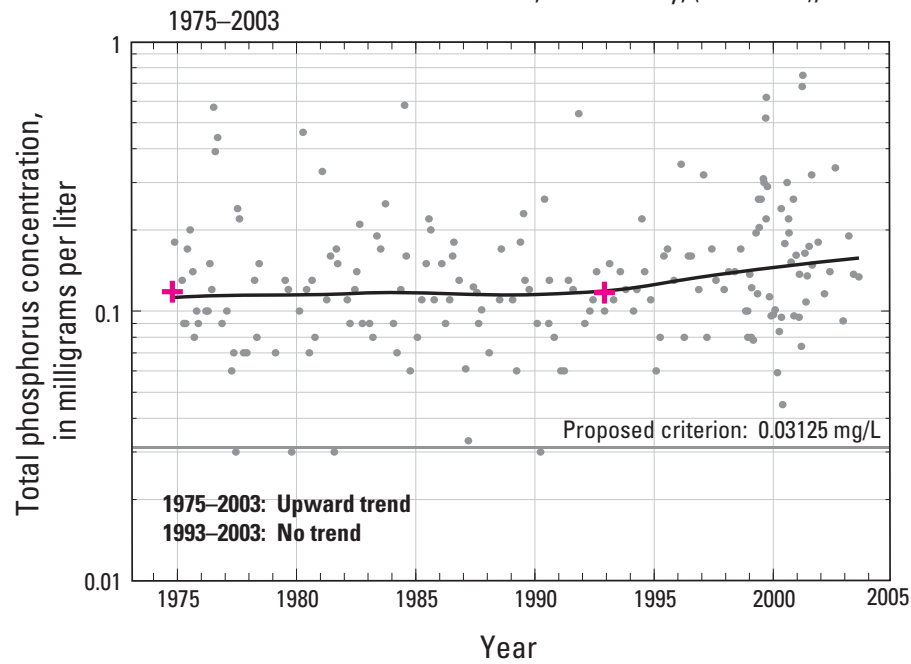

B. Delaware River at Trenton, New Jersey, (station 90), 1975-2003

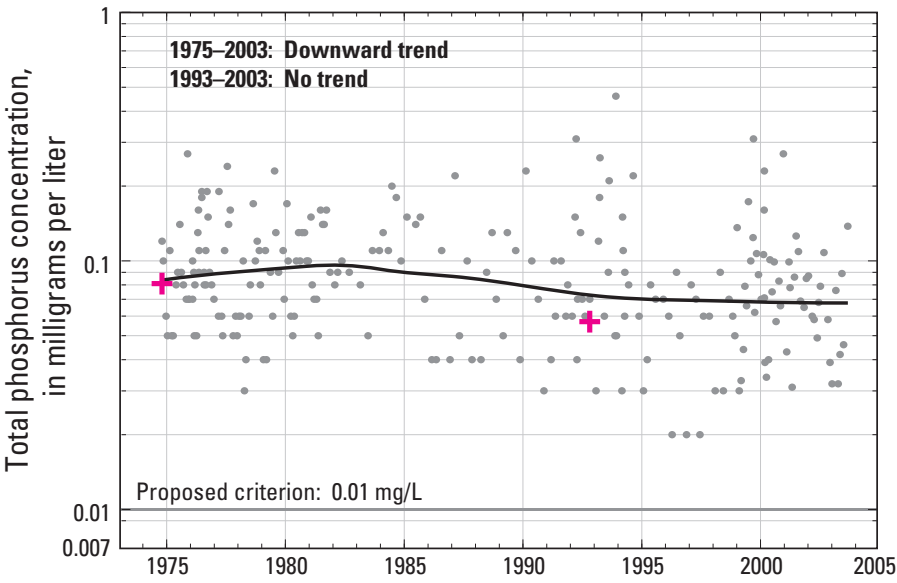

D. Pamunkey River near Hanover, Virginia, (station 125), 1975-2003

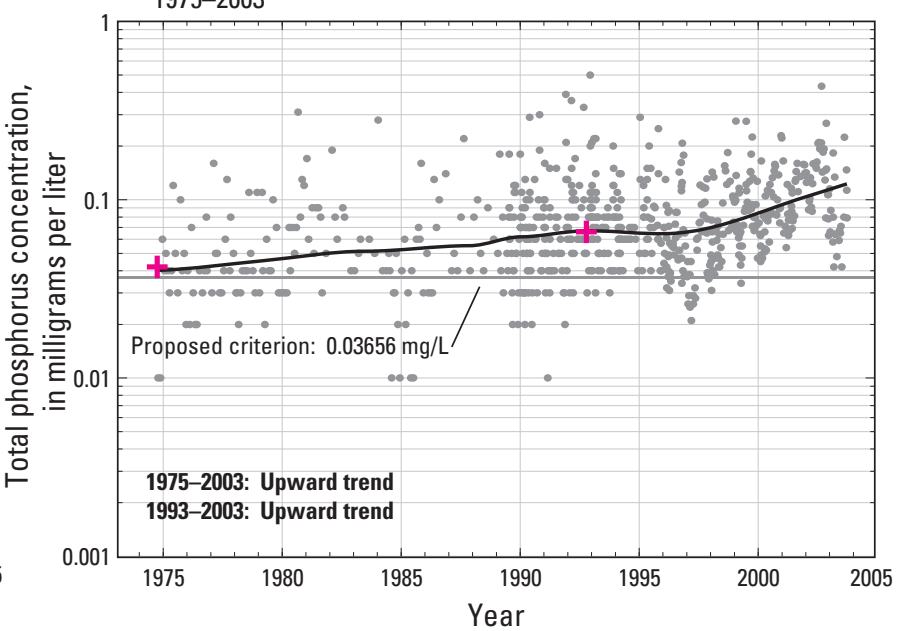

EXPLANATION

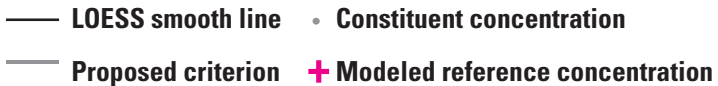

Figure 12. Total phosphorus concentrations as a function of time at selected stations. (A) Connecticut River at Thompsonville, Conn., 1975-2003, (B) Delaware River at Trenton, N.J., 1975-2003, (C) Raccoon Creek near Swedesboro, N.J., 1975-2003, and (D) Pamunkey River near Hanover, Va., 1975-2003. 
instream concentration of total nitrogen, indicating improvement relative to reference conditions, and an upward trend in total phosphorus, indicating deterioration, were detected for the recent period for the Susquehanna River.

Large drainage basins in the region generally have sparsely developed headwater basins in upland or mountainous areas, with highly developed and densely populated areas near the coast, where monitoring stations are located. Nutrient criteria for some large basins are based on forested headwater areas that constitute most of the drainage area, and are generally more stringent than criteria for smaller nearby coastal basins, even though the downstream reaches share the dense population and urban land use characteristics of the coastal area. The criteria exceedances reported here may appear to contradict the positive results shown by the many long-term downward trends in flow-adjusted nutrient concentrations in large drainage basins (table 14). However, both analyses contain useful information. Progress has been made in reducing nutrient delivery to large streams in the region, as shown by numerous long-term downward trends in flow-adjusted concentrations of nutrients. The starting point for these trends was high, however, and instream concentrations still exceed proposed criteria in several major streams.

\section{Comparing Trend Results from Different Periods of Record}

Trend results in this report, and in many trend studies, refer to linear trends, sometimes called monotonic trends. That is, a significant trend refers to a linear change in concentration or flow-adjusted concentration between the beginning and the end of the period of record analyzed. During long periods of time, however, many constituent trends are nonmonotonic, with increases, plateaus, and decreases in concentration during different periods of time. Typically, the longer the period of record, the more likely it is that nonmonotonic trends will be present.
Considering the period of record is always critical when evaluating and comparing any trend results. Because longterm trends are often nonmonotonic, different studies might report trend results that may appear contradictory, whereas the different results are actually attributable to differences in the period of record analyzed. Results for different periods of record may even appear contradictory in the same study. For example, trend analyses for this study determined that flowadjusted and modeled instream concentrations of nitrite-plusnitrate nitrogen in the Potomac River at Washington, D.C., increased during the 1975-2003 period and decreased during the 1993-2003 period. A study of nutrient trends and loads in the Chesapeake Bay watershed found that flow-adjusted concentrations of nitrite-plus-nitrate nitrogen at this station decreased during the 1985-2004 period, and that modeled instream concentrations had no trend (Langland and others, 2006). A plot of nitrite-plus-nitrate concentrations over time clarifies why all these results can be accurate representations of water-quality changes in the Potomac River (fig. 13). A smooth line through the plot shows the general tendency of concentration over time. Concentrations are generally higher at the end of the period of record (2003) than at the beginning (1975), supporting the finding of a long-term increase in flow-adjusted and modeled instream concentrations. No trend in streamflow was detected during either period. The steepest increase in nitrite-plus-nitrate concentrations occurred from about 1975 to 1985, after which the smooth line is closer to horizontal. The position of the smooth line is consistent with the finding of no trend in modeled instream concentration for 1985-2004 (Langland and others, 2006). The downward trend in flow-adjusted concentrations detected for the 1985-2004 period may reflect streamflow variability over time, although no trend in streamflow was detected. The smooth line (fig. 13) shows a gradual decline during the 1990s and early 2000s, consistent with the finding in this study of downward trends in flow-adjusted and modeled instream concentrations during the 1993-2003 period.

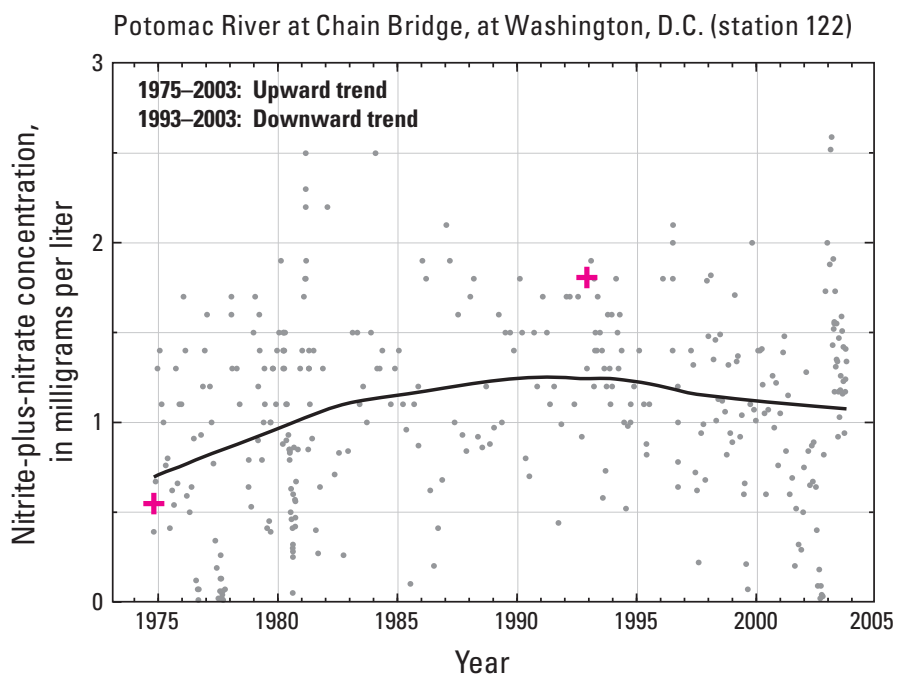

\section{EXPLANATION}

LOESS smooth line

+ Modeled reference

concentration

- Constituent concentration
Figure 13. Nitrite-plus-nitrate concentrations as a function of time, Potomac River at Chain Bridge, Washington, D.C. 


\section{Annual Nutrient Loads, 1975-2003}

Annual stream loads of total nitrogen, nitrite-plus-nitrate nitrogen, and total phosphorus were estimated for 32 stations for the period 1975-2003 and for 46 stations for the period 1993-2003 (table 5); 31 of these stations were evaluated during both periods. Long-term and recent trends in nutrient loads were evaluated for these stations by using the coupled statistical model of streamflow and water quality. Load estimation and analysis of trends in load were performed for a smaller number of stations for ammonia nitrogen, total Kjeldahl nitrogen, and suspended sediment. Results of tests for trends in load were considered significant if the attained significance level of the test ( $p$-value) was less than or equal to 0.05 , and were considered highly significant if the $p$-value was less than or equal to 0.01 .

Annual loads of total nitrogen and total phosphorus were estimated for 37 additional stations that did not have a complete streamflow or water-quality record during the 1993-2003 period (table 5), to provide better geographic coverage of the region and representation of specific land uses in the results. Trends in load were not evaluated for these stations because of the short and varied periods of record available. Altogether, annual loads were estimated for 84 stations. Annual nutrient loads, confidence intervals, and annual yields have been compiled for all stations analyzed (appendix 7, table 7-1).

\section{Relation of Nutrient Loads to Stream Discharge Conditions, 1975-2003}

Stream discharge has varied substantially from year to year during the period of record evaluated in this report, and annual nutrient loads have varied accordingly (fig. 14). Stations with no long-term or recent trends in annual loads have been selected to illustrate the relation of annual loads to annual streamflow variability; in one case, the Kennebec River at North Sidney, Maine (figs. 14A, B), trends in annual loads were not analyzed because of the incomplete record for 1993-2003. Stations also have been included to illustrate annual loads in years of new minimum or maximum annual mean flows in the recent period (table 11). The absence of a trend in constituent load means that for similar annual mean discharges in different years, the annual constituent load also would be similar.

In many parts of the region, water years 1981,1985 , 1992, 1995, and 2002 were extremely dry years, and water years 1978, 1979, 1984, 1994, 1996, and 2003 were extremely wet years (fig. 5). These years represent the minimum and maximum ranges for annual nutrient loads estimated for many stations in the region during the 1993-2003 or 1975-2003 periods (fig. 14). Maximum annual loads are often three to five times the minimum annual loads during the period of record. For example, on the Schuylkill River at Philadelphia, Pa. (figs. 14E, F), water years 1984 and 2003 are the first and second highest annual mean flows; the first and second highest annual loads of total nitrogen and total phosphorus also were estimated for those years. Water years 2002 and 1981 are the first and second lowest annual mean flows; the first and second lowest annual loads of total nitrogen and total phosphorus on the Schuylkill River also were estimated for those years. The annual load of total nitrogen in 1984 was 3.2 times the annual load in 2002 on the Schuylkill River, and the annual load of total phosphorus in 1984 was 2.7 times the annual load in 2002. The interannual difference in loads was much greater on Conococheague Creek in Maryland (figs. 14G, H), where the maximum annual load of total nitrogen in 2003 was 7.0 times the minimum load in 2002, and the maximum total phosphorus load in 1996 was 11.5 times the minimum load in 2002. Water year 1996 represented a new maximum annual mean flow on Conococheague Creek in 75 years of record, and water year 2002 represented a new minimum (table 11), and this large difference in streamflow contributed to the order-of-magnitude difference in total phosphorus loads between the two years.

Annual loads of total nitrogen are typically several times greater than annual loads of total phosphorus at a given station. For example, on the Schuylkill River, the maximum total nitrogen load is 15.7 times the maximum total phosphorus load, and the minimum total nitrogen load is 13.5 times the minimum total phosphorus load. Error ranges for annual total phosphorus loads are often much larger than error ranges for total nitrogen at many stations. Phosphorus concentrations vary over orders of magnitude relative to nitrogen concentrations; therefore, phosphorus loads can be expected to have larger error ranges. The larger variability in the concentration data for total phosphorus may be affected by several factors, including the transport of particulate phosphorus during high streamflows. Error ranges for nutrient loads are typically larger in high flow years with major storms than in low flow years characterized by a higher proportion of base flow in the total streamflow, and this difference is more pronounced for total phosphorus than for total nitrogen, as illustrated by annual loads for the Rappahannock River in Virginia (figs. 14I, J). Error ranges for total phosphorus may be smaller on streams that receive large or numerous point-source discharges, such as the Schuylkill River (fig. 14F), because the relatively uniform point-source contribution of nutrients throughout the year results in a relatively narrow concentration range (less scatter in the data). Error ranges for total phosphorus may be much larger in drainage basins that have few or no point sources and large percentages of agricultural land, such as the Choptank, Rappahannock (fig. 14J), and Pamunkey Rivers, because of the more varied amounts of nutrients in runoff during extreme storms.

Annual loads of total nitrogen and total phosphorus in the recent period were generally substantially greater in 2003 than in 2002, particularly in southern parts of the region (figs. 14G-J). Annual loads of total nitrogen or total phosphorus or both differ by an order of magnitude for those two years in some locations, including the Choptank River (not shown), Conococheague Creek (figs. 14G, H), the Rappahannock River (figs. 14I, J), and the Pamunkey River 
A. Kennebec River at North Sidney, Maine (station 2)

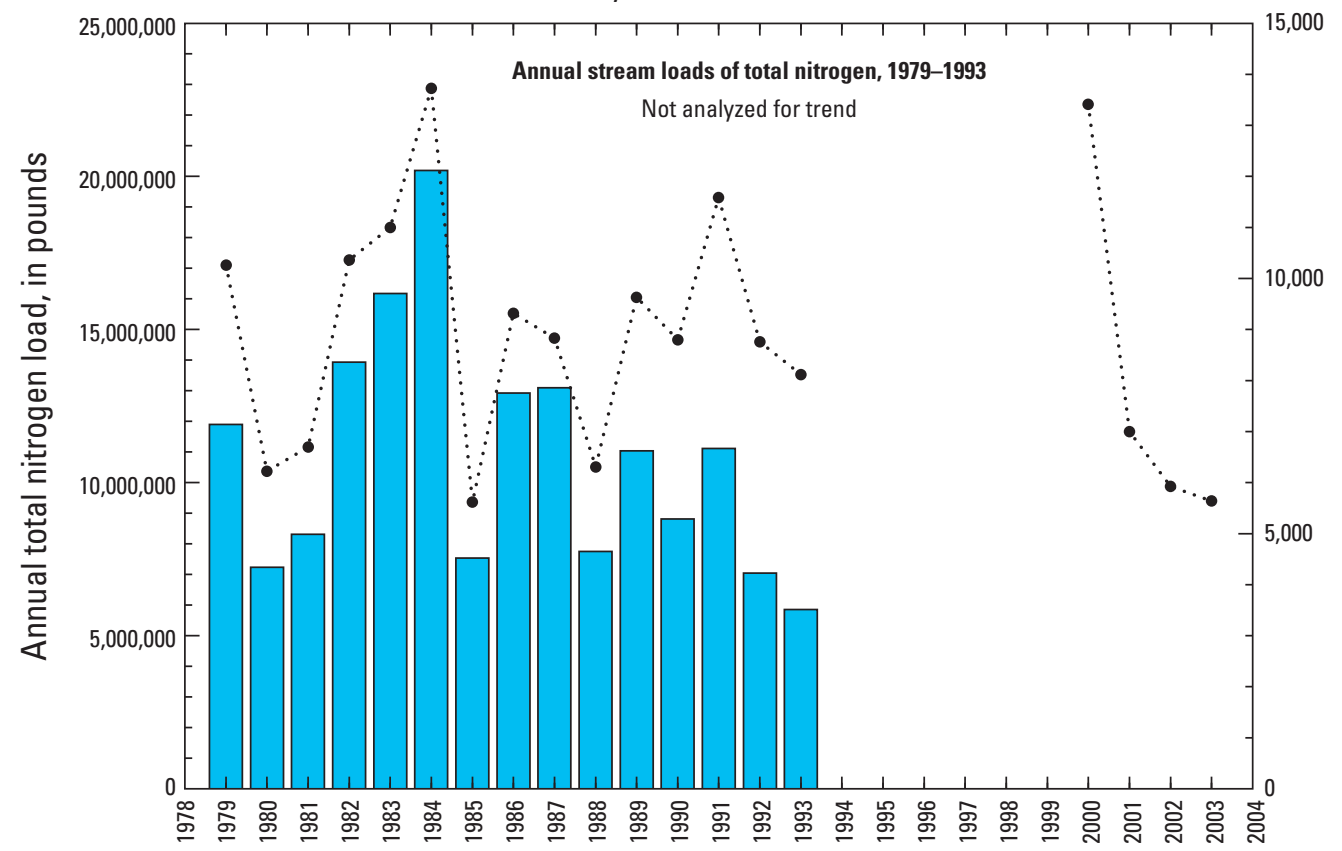

\section{EXPLANATION}

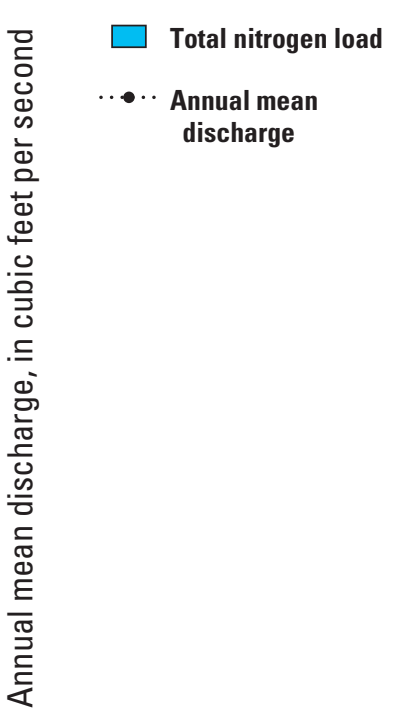

B. Kennebec River at North Sidney, Maine (station 2)

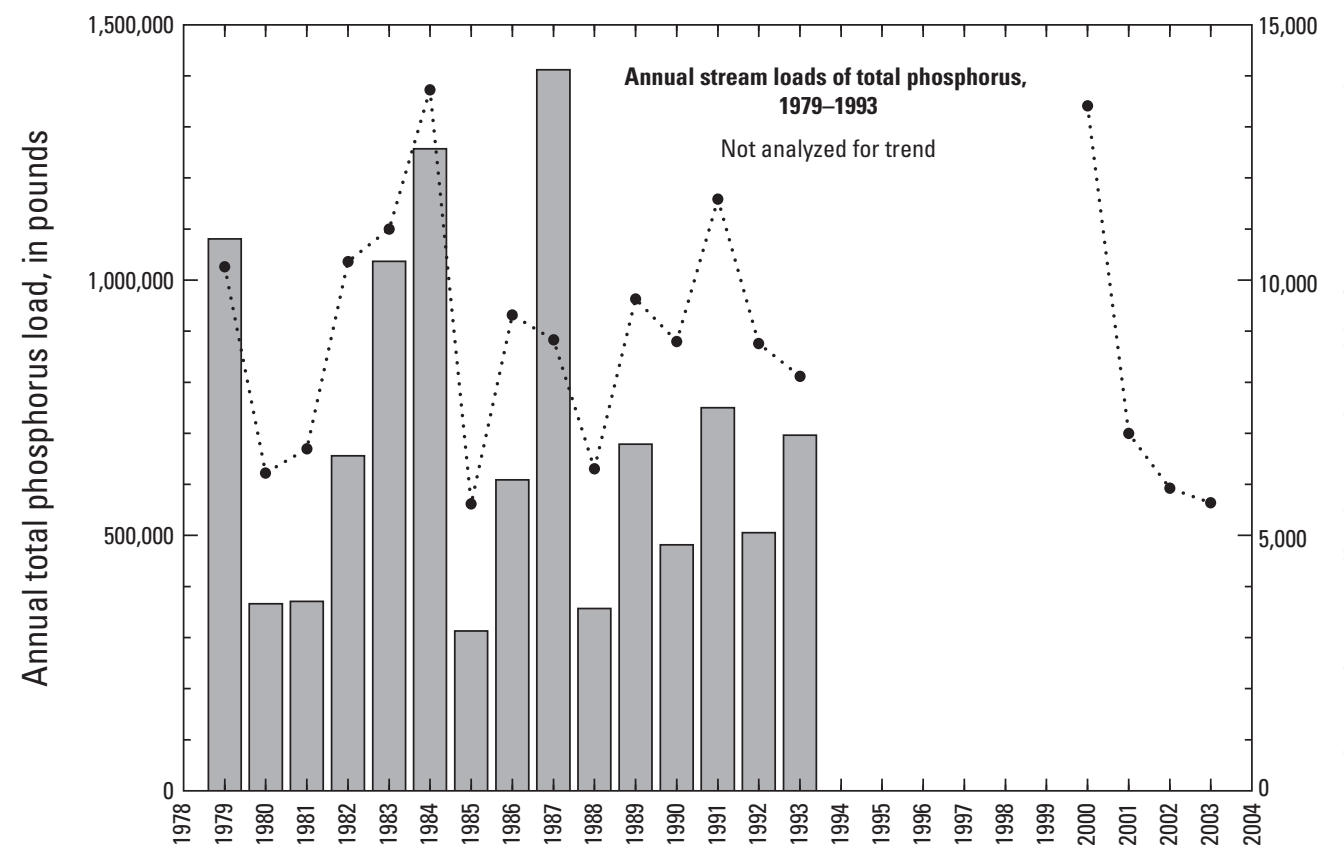

EXPLANATION

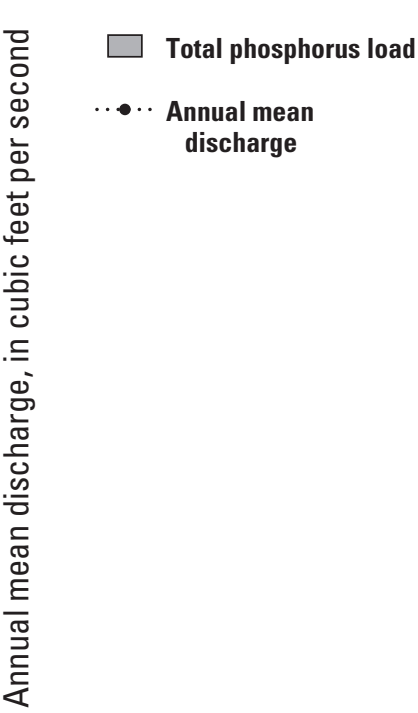

Water Year

Figure 14. Annual mean discharges and annual nutrient loads for selected stations and constituents with no trend in load. (A) Kennebec River at North Sidney, Maine, total nitrogen loads, 1979-1993, (B) Kennebec River at North Sidney, Maine, total phosphorus loads, 1979-1993, (C) Neshanic River at Reaville, N.J., total nitrogen loads, 1993-2003, (D) Neshanic River at Reaville, N.J., total phosphorus loads, 1993-2003, (E) Schuylkill River at Philadelphia, Pa., total nitrogen loads, 1975-2003, (F) Schuylkill River at Philadelphia, Pa., total phosphorus loads, 1975-2003, (G) Conococheague Creek at Fairview, Md., total nitrogen loads, 1993-2003, (H) Conococheague Creek at Fairview, Md., total phosphorus loads, 1993-2003, (I) Rappahannock River near Fredericksburg, Va., total nitrogen loads, 1979-2003, and (J) Rappahannock River near Fredericksburg, Va., total phosphorus loads, $1979-2003$. 
C. Neshanic River at Reaville, New Jersey (station 61)

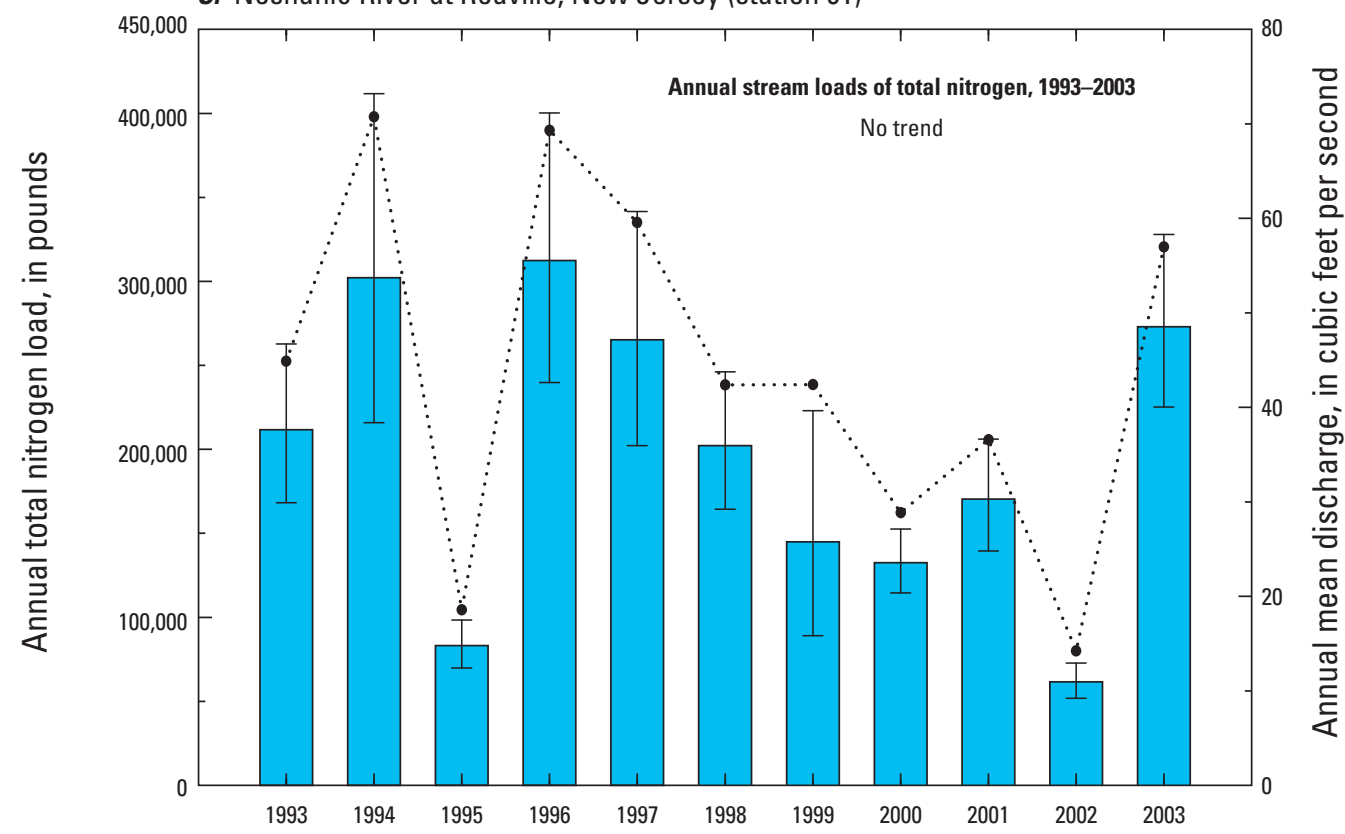

\section{EXPLANATION}

Total nitrogen load

.... Annual mean discharge

I 95-percent confidence interval of load estimate
D. Neshanic River at Reaville, New Jersey (station 61)

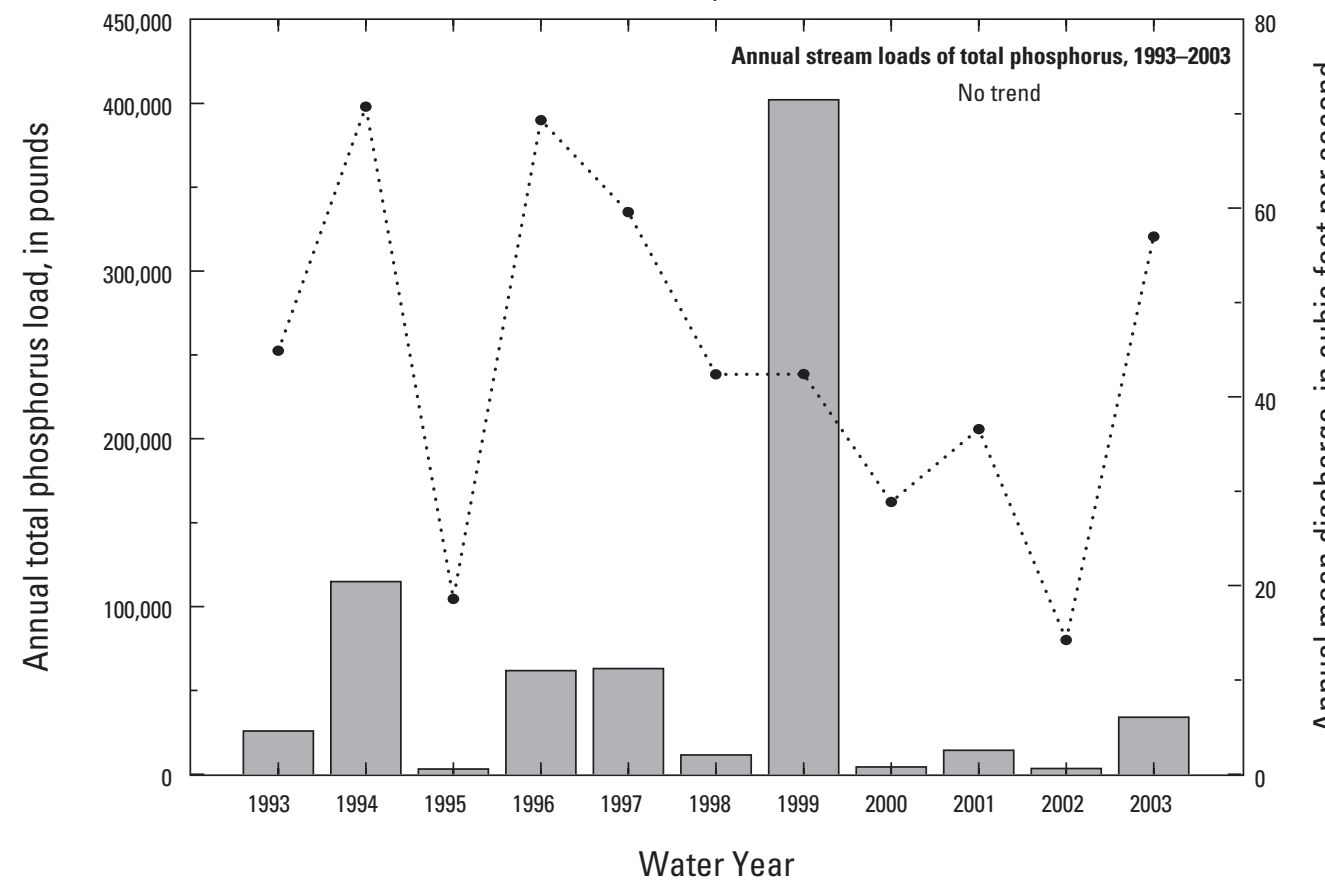

\section{EXPLANATION}

Total phosphorus load

-. Annual mean discharge

Figure 14. Annual mean discharges and annual nutrient loads for selected stations and constituents with no trend in load. (A) Kennebec River at North Sidney, Maine, total nitrogen loads, 1979-1993, (B) Kennebec River at North Sidney, Maine, total phosphorus loads, 1979-1993, (C) Neshanic River at Reaville, N.J., total nitrogen loads, 1993-2003, (D) Neshanic River at Reaville, N.J., total phosphorus loads, 1993-2003, (E) Schuylkill River at Philadelphia, Pa., total nitrogen loads, 1975-2003, (F) Schuylkill River at Philadelphia, Pa., total phosphorus loads, 1975-2003, (G) Conococheague Creek at Fairview, Md., total nitrogen loads, 1993-2003, (H) Conococheague Creek at Fairview, Md., total phosphorus loads, 1993-2003, (I) Rappahannock River near Fredericksburg, Va., total nitrogen loads, 1979-2003, and (J) Rappahannock River near Fredericksburg, Va., total phosphorus loads, 1979-2003.—Continued 


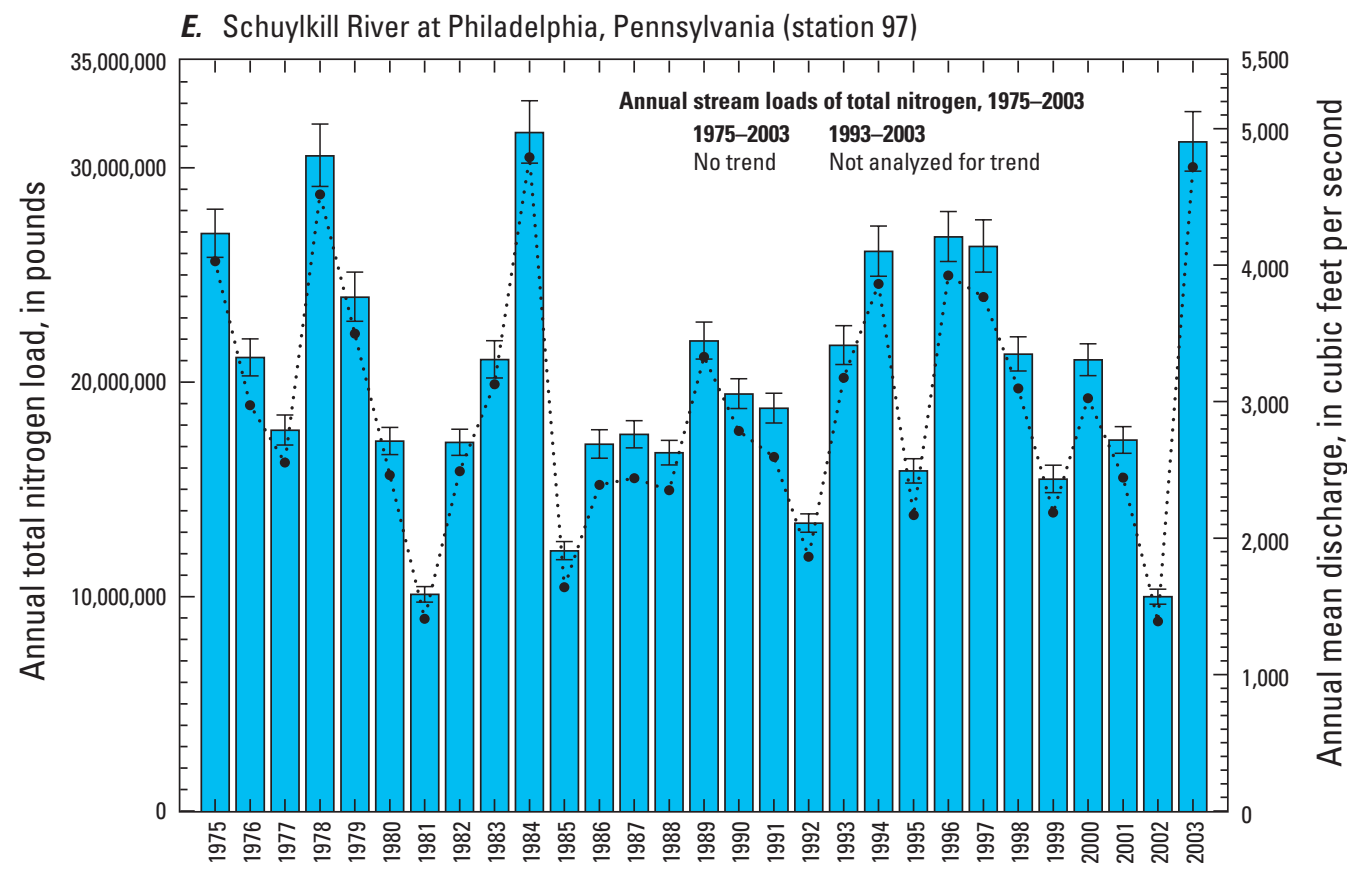

\author{
EXPLANATION \\ Total nitrogen load \\ -. Annual mean \\ discharge \\ I 95-percent confidence \\ interval of load estimate
}

\section{F. Schuylkill River at Philadelphia, Pennsylvania (station 97)}

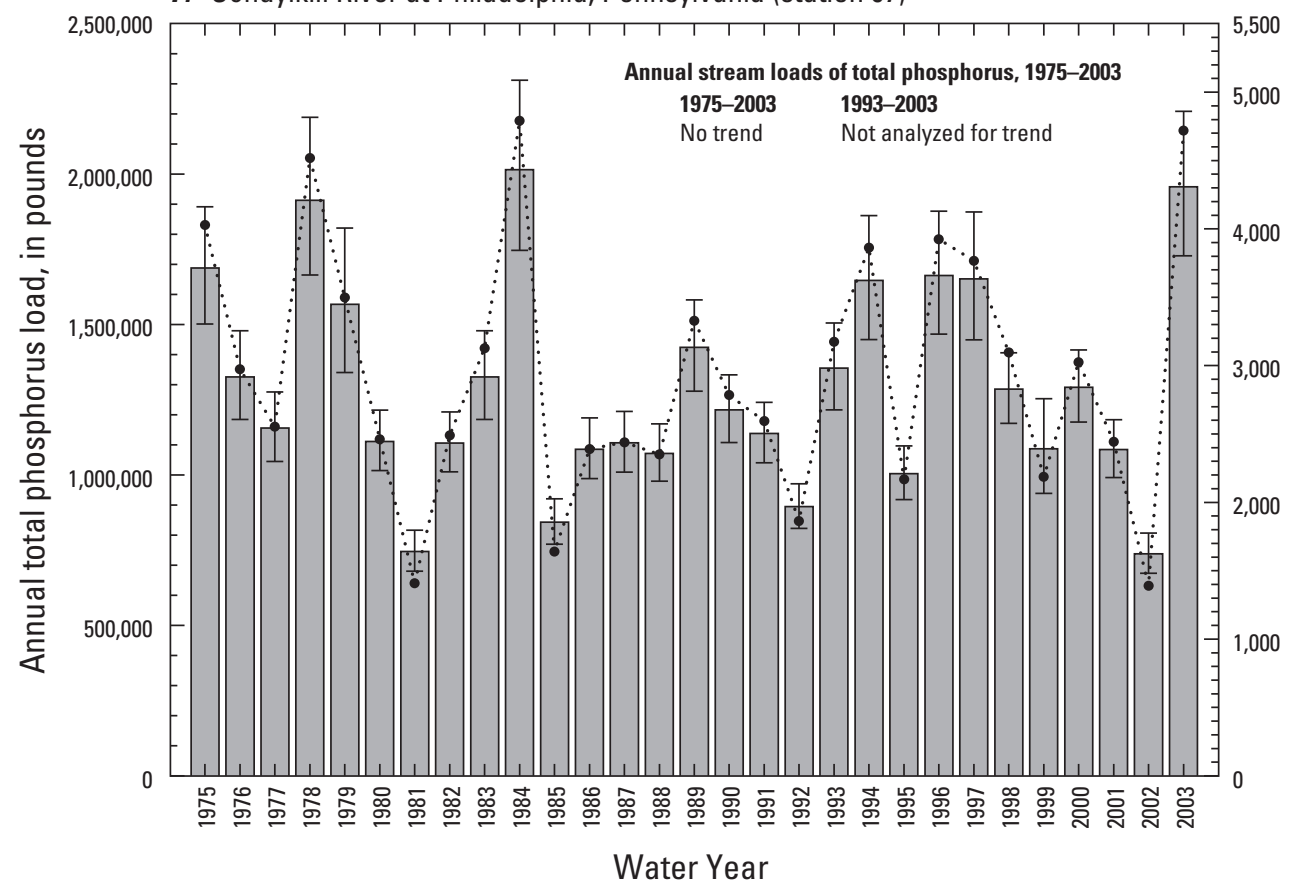

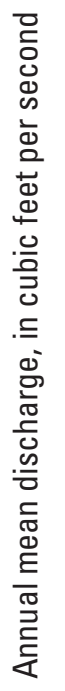

EXPLANATION

Total phosphorus load

... Annual mean discharge

I 95-percent confidence interval of load estimate

Figure 14. Annual mean discharges and annual nutrient loads for selected stations and constituents with no trend in load. (A) Kennebec River at North Sidney, Maine, total nitrogen loads, 1979-1993, (B) Kennebec River at North Sidney, Maine, total phosphorus loads, 1979-1993, (C) Neshanic River at Reaville, N.J., total nitrogen loads, 1993-2003, (D) Neshanic River at Reaville, N.J., total phosphorus loads, 1993-2003, (E) Schuylkill River at Philadelphia, Pa., total nitrogen loads, 1975-2003, (F) Schuylkill River at Philadelphia, Pa., total phosphorus loads, 1975-2003, (G) Conococheague Creek at Fairview, Md., total nitrogen loads, 1993-2003, (H) Conococheague Creek at Fairview, Md., total phosphorus loads, 1993-2003, (I) Rappahannock River near Fredericksburg, Va., total nitrogen loads, 1979-2003, and (J) Rappahannock River near Fredericksburg, Va., total phosphorus loads, 1979-2003. —Continued 
G. Conococheague Creek at Fairview, Maryland (station 116)

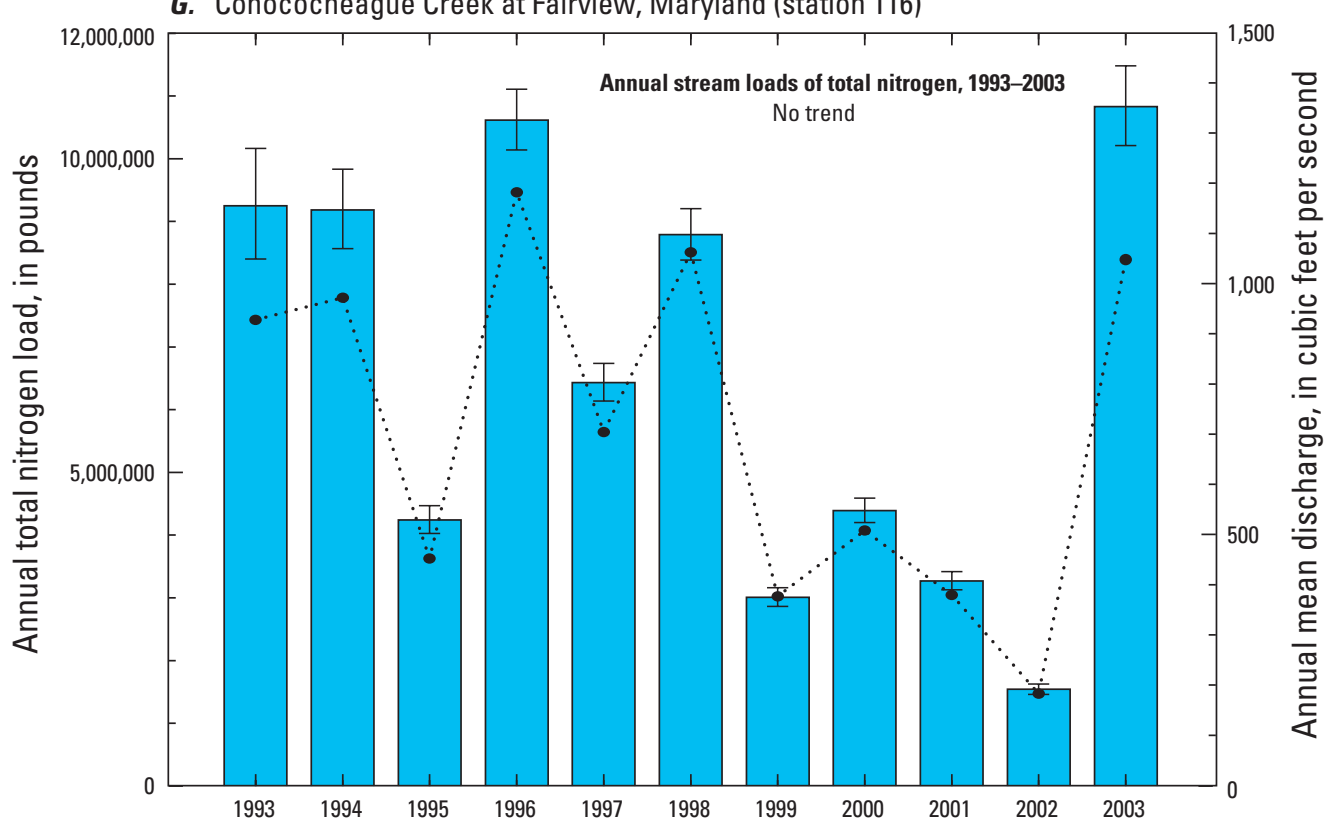

H. Conococheague Creek at Fairview, Maryland (station 116)

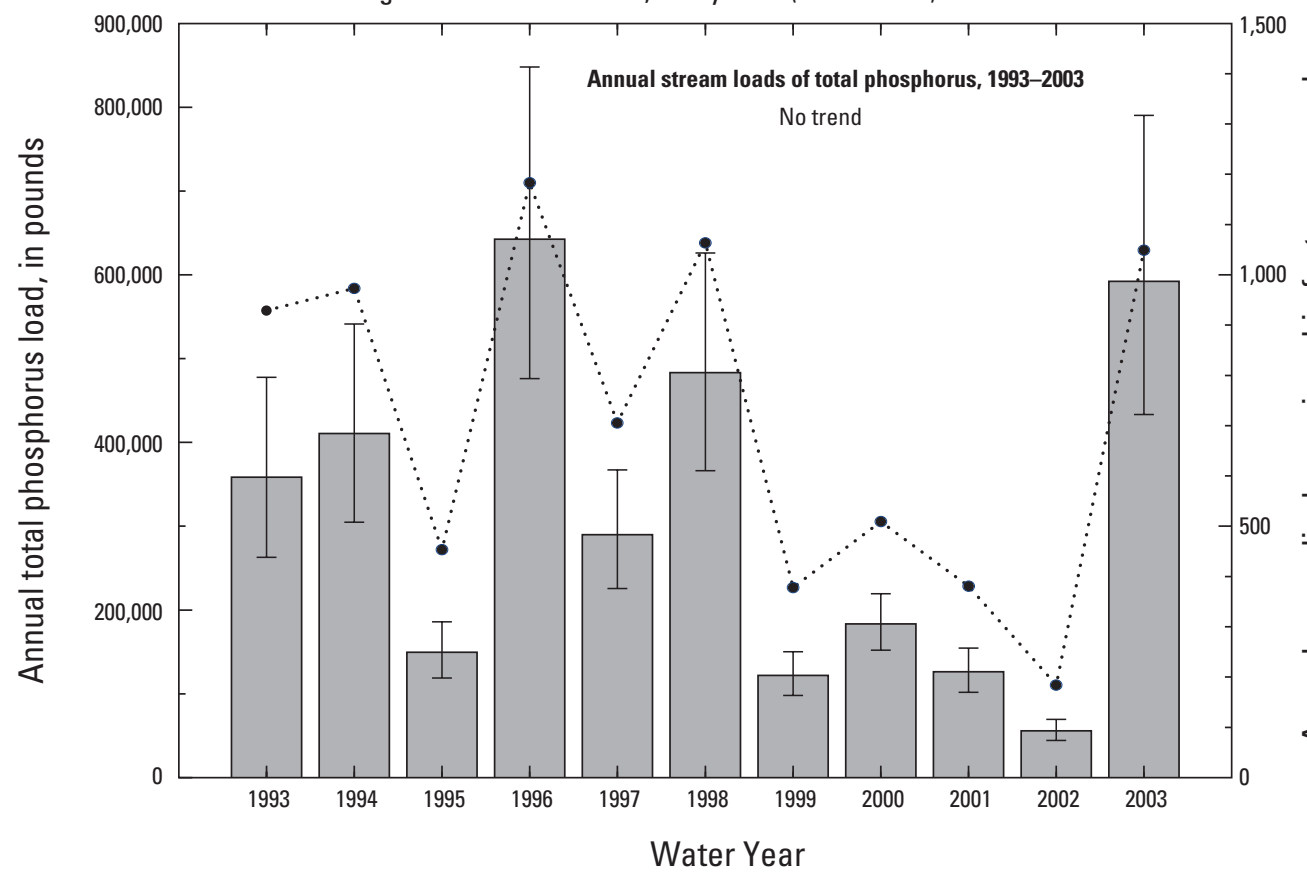

EXPLANATION

Total nitrogen load

Annual mean discharge

95-percent confidence interval of load estimate

EXPLANATION

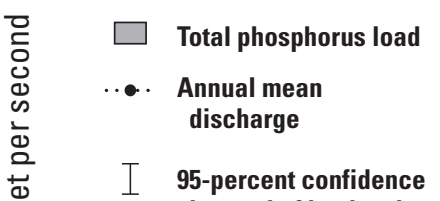
interval of load estimate

Figure 14. Annual mean discharges and annual nutrient loads for selected stations and constituents with no trend in load. (A) Kennebec River at North Sidney, Maine, total nitrogen loads, 1979-1993, (B) Kennebec River at North Sidney, Maine, total phosphorus loads, 1979-1993, (C) Neshanic River at Reaville, N.J., total nitrogen loads, 1993-2003, (D) Neshanic River at Reaville, N.J., total phosphorus loads, 1993-2003, (E) Schuylkill River at Philadelphia, Pa., total nitrogen loads, 1975-2003, (F) Schuylkill River at Philadelphia, Pa., total phosphorus loads, 1975-2003, (G) Conococheague Creek at Fairview, Md., total nitrogen loads, 1993-2003, (H) Conococheague Creek at Fairview, Md., total phosphorus loads, 1993-2003, (I) Rappahannock River near Fredericksburg, Va., total nitrogen loads, 1979-2003, and (J) Rappahannock River near Fredericksburg, Va., total phosphorus loads, 1979-2003.—Continued 


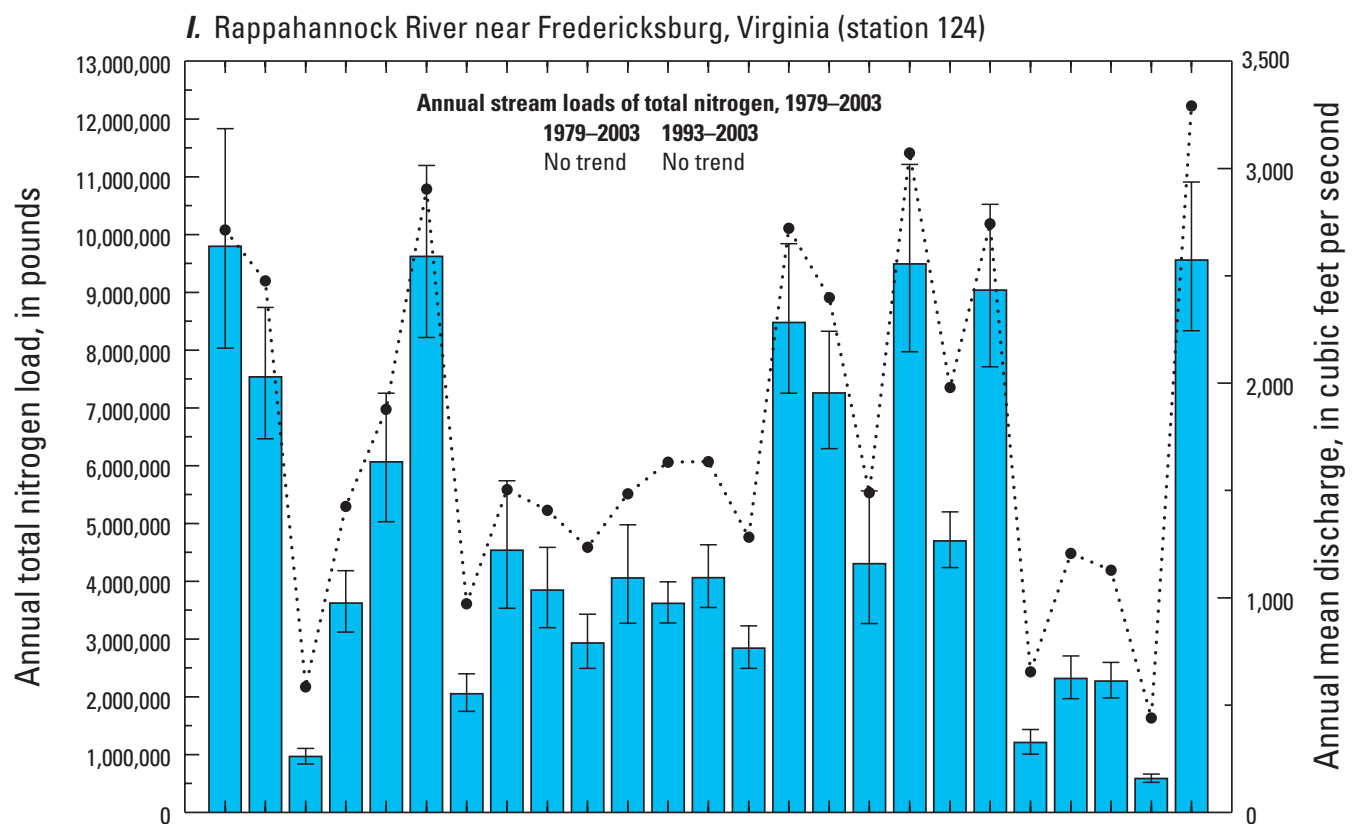

\section{EXPLANATION}

Total nitrogen load

Annual mean discharge

95-percent confidence interval of load estimate

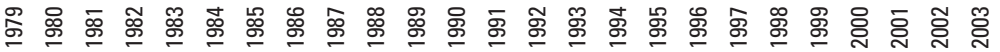
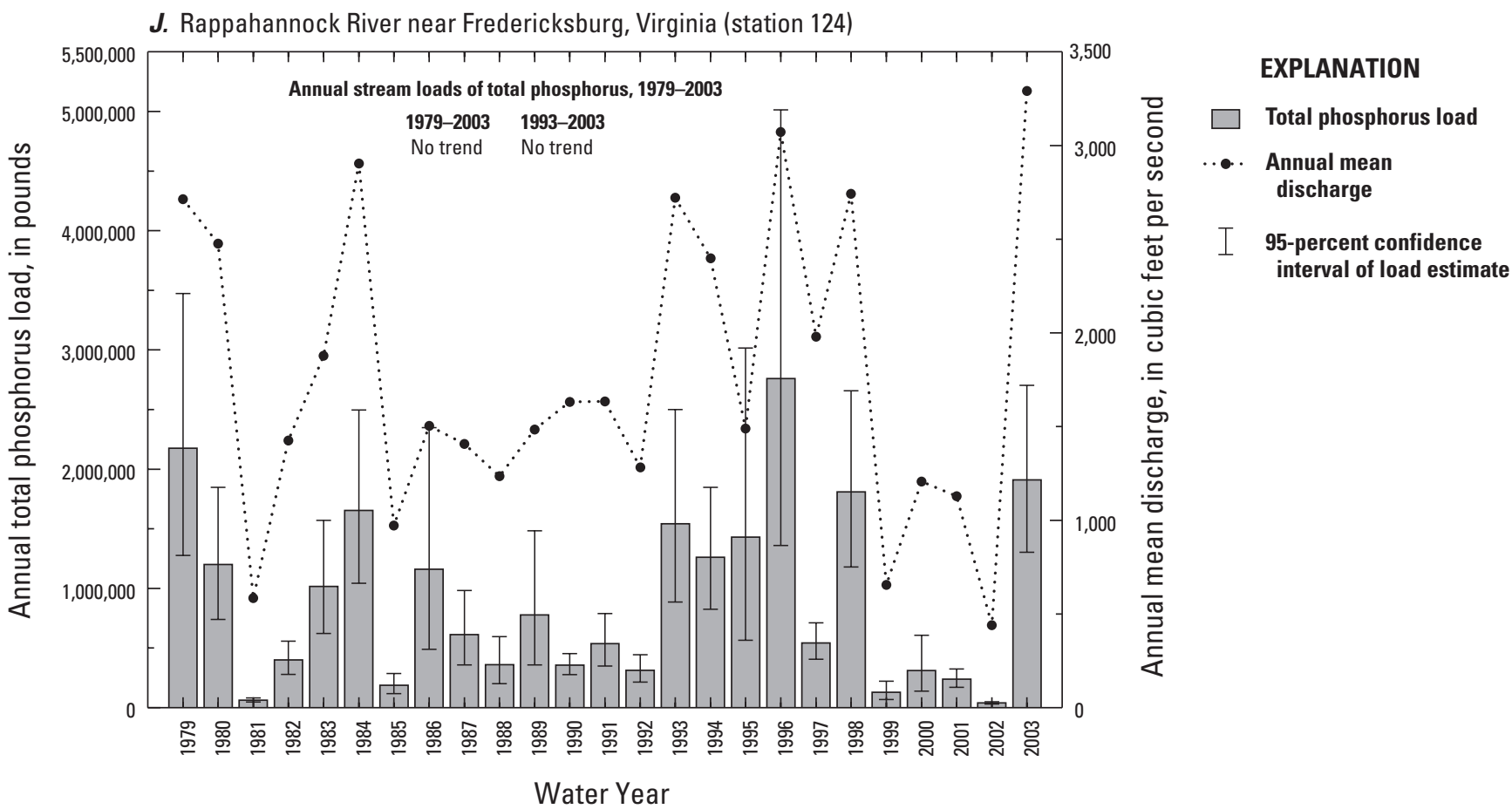

Figure 14. Annual mean discharges and annual nutrient loads for selected stations and constituents with no trend in load. (A) Kennebec River at North Sidney, Maine, total nitrogen loads, 1979-1993, (B) Kennebec River at North Sidney, Maine, total phosphorus loads, 1979-1993, (C) Neshanic River at Reaville, N.J., total nitrogen loads, 1993-2003, (D) Neshanic River at Reaville, N.J., total phosphorus loads, 1993-2003, (E) Schuylkill River at Philadelphia, Pa., total nitrogen loads, 1975-2003, (F) Schuylkill River at Philadelphia, Pa., total phosphorus loads, 1975-2003, (G) Conococheague Creek at Fairview, Md., total nitrogen loads, 1993-2003, (H) Conococheague Creek at Fairview, Md., total phosphorus loads, 1993-2003, (I) Rappahannock River near Fredericksburg, Va., total nitrogen loads, 1979-2003, and (J) Rappahannock River near Fredericksburg, Va., total phosphorus loads, 1979-2003.—Continued 
(not shown). Differences in annual loads between the two years were generally more pronounced for total phosphorus than for total nitrogen at some stations. The total phosphorus load estimated for the Rappahannock River for 2003 was 48 times the load estimated for 2002. The 2003 load, however, was not the maximum for the period of record at this station; the total phosphorus load for 1996 was 70 times the 2002 load (fig. 14J). In some drainage basins, exceptionally dry antecedent conditions in 2002 may have resulted in retention of nutrients that would have been transported to streams under normal conditions, thus creating a reservoir or backlog of nutrients that contributed to the exceptionally high nutrient loads in 2003.

The drought of 2002 persisted into 2003 in parts of northern New England, and consequently water year 2003 does not represent an extreme high flow year for the Kennebec River in Maine (fig. 14A), the Connecticut River in Connecticut (fig. 5C), and other streams in the northern part of the region. In fact, the annual mean flow for 2002 on the Kennebec River exceeded the annual mean flow for 2003. Consequently, water year 2003 is typically not the peak nutrient load year for the more northerly drainage basins in the region.

Annual mean flows during 1993-2003 varied substantially from year to year, with extremely low annual mean flows in 1995 and 2002, and high annual mean flows in 1996 and 2003, depending on the geographic area (fig. 5). Consequently this period of record provides a good indication of recent annual nutrient loads under a wide range of conditions. In some parts of the region, particularly drainage basins in the southernmost areas, few annual mean flows near long-term median flows occurred during this period of record (fig. 5I), and consequently annual nutrient loads that represent more typical conditions are less readily identified. Annual nutrient loads for years with typical annual mean streamflows earlier in the period of record may not be representative of more recent conditions in drainage basins where long-term trends in nutrient loads have taken place.

\section{Effects of Calibration Period on Load Estimates}

Annual load estimates often must be considered provisional, because load estimation programs are sensitive to data at the ends of the period of record, particularly the final year in the load estimation period. The USGS Chesapeake Bay River Input Monitoring (RIM) Program has used a nine-year "moving window" approach to evaluate changes in annual load estimates related to changes in the calibration period. Results from this evaluation showed that annual load estimates for the years at the center of each nine-year load estimation period were typically more accurate than the estimates for years at either end of the period (Yochum, 2000). The final (ninth) year of estimation showed the most change when that year became the eighth year in the next nine-year "window," and this change approached a minimum when that year became the fifth, or center, year of a subsequent calibration period. Based on this information from the RIM evaluation, and the extreme hydrologic conditions in 2002 and 2003 at some locations, the annual load estimates in this report for those years are considered provisional. Accurate annual load estimates generally can be considered a "moving target" that requires repeated analyses in future years to verify or modify existing estimates.

Annual loads for 31 stations have been estimated for both the long term period (1975-2003, 1979-2003, or 1982-2003) and recent period (1993-2003). Annual loads estimated for years in the 1993-2003 period may differ depending on the calibration period used, and the years of maximum or minimum loads also may differ. Where annual loads for the longterm period are shown (for example, fig. 14), the calibration period used is the long-term period.

\section{Effects of Storms on Annual Nutrient Loads}

Although the magnitude of annual nutrient loads often follows the magnitude of annual mean discharge fairly closely, individual floods may contribute to peak annual loads in years that are otherwise unremarkable in terms of annual mean streamflow, and multiple storms may result in a year with higher than average annual mean flow. Storms can contribute to peak loads in any season, and short-term peak seasonal loads can result in high annual constituent load estimates. The effects of major storms on constituent loads may differ for different constituents, depending on a number of factors. For example, on the Kennebec River in Maine, the peak total nitrogen load occurred in 1984, which was also the peak year for annual mean flow for the 1979-1993 period (fig. 14A). By contrast, the peak total phosphorus load was estimated for 1987, a year in which the annual mean discharge is close to median conditions (fig. 14B). A major flood in April 1987, with associated transport of sediment and particulate materials, is a likely cause for the unusually high estimated annual load of total phosphorus. According to a study of this storm, "snowmelt and precipitation from two storms caused record flooding in April 1987 in central and southwestern Maine" (Fontaine and Nielsen, 1994, p. 1). The flood flow for the Kennebec River at North Sidney had a greater than 100-year recurrence interval (Fontaine and Nielsen, 1994, p. 24, table 11).

Three major floods occurred in the Potomac River Basin in 1996 (Ator and others, 1998, p. 14). Intense rainfall and rapid snowmelt in January resulted in a record high flow for a single day on the Potomac River at Washington, D.C.; intense rainfall during a five-day period in June caused flooding in drainage basins in Maryland, including Conococheague Creek (figs. 14G, H); and a tropical storm in September caused flooding in the Shenandoah River Basin (Ator and others, 1998 , p. 14). These floods were regional in nature, and annual mean flows and annual nutrient loads for 1996 are among the highest for the 1993-2003 period at many monitoring stations (figs. 5, 14). 
A new maximum annual mean flow for a 73-year period occurred in 1994 on the Neshanic River at Reaville, N.J. (table 11). The second highest total nitrogen load for the 1993-2003 period was estimated for 1994 (fig. 14C). However, the peak total phosphorus load for this station was in 1999, a year in which the annual mean flow was near the longterm median (fig. 14D). The annual load of total phosphorus estimated for 1999 is more than an order of magnitude higher than annual loads estimated for other years with annual mean flows similar to 1999. The total phosphorus load estimated for 1999 was 3.5 times the second highest load, which occurred in 1994, and was 130 times the minimum load, which occurred in 1995. The peak phosphorus load estimated for 1999 is likely the result of heavy rainfall from Tropical Storm Floyd, which, combined with a western storm system, produced as much as 14 in. of rain in New Jersey during September 15-17, 1999, resulting in flooding of historical proportions in many areas of the state (Reed and others, 2000, p. 2, 4). Maximum annual peak streamflows were measured for several long-term streamgages in the Raritan River Basin on September 16 or 17, 1999, including the Neshanic River at Reaville, where the peak streamflow on September 16 was the maximum annual peak for the period 1931-2007 (U.S. Geological Survey, 2009a).

\section{Trends in Nutrient Loads, 1975-2003 and 1993-2003}

Trends in nutrient loads were detected much more frequently during the long-term period than during the recent period (table 18). Detected trends in nutrient loads were primarily downward during 1975-2003, and few statistically significant trends in nutrient loads were detected during the recent period (table 18). Results of trend analyses for nutrient loads for all stations and constituents analyzed, including $p$-values (significance level of trend tests), are shown in appendix 8 (table $8-1$ ). Total phosphorus data for five stations monitoring undeveloped drainage basins were considered insufficient for evaluating trends in load during the recent period (appendix 8, table 8-1).

Some of the long-term trends in nutrient loads that illustrate changing conditions in the region are shown in figure 15. Long-term trends in nutrient loads, coupled with similar trends in flow-adjusted concentrations, are likely to indicate long-term changes in the delivery of nutrients to some streams in the region, and are not likely to be caused by changes in streamflow, because trends in streamflow were detected at only two stations, one in each of the two periods analyzed.

Many of the long-term records available for load estimation and trend analysis are for drainage basins with large percentages of urban or agricultural land, and most of these drainage basins receive point-source discharges. Most of the significant trends in load have been detected in the more developed drainage basins of the region, where changes in land use and point-source loadings have a major effect on nitrogen and phosphorus delivery to streams.

Comparison of trends in load among different forms of nitrogen often provides some insight into long-term effects of wastewater-treatment improvements. Long-term trends of nitrogen constituent loads in the Quinnipiac River in Connecticut (fig. 15A) illustrate a pattern that could be typical for streams where improvements in wastewater treatment have taken place. Previous analyses for this river have shown that over the long term, stream loads of total Kjeldahl nitrogen have decreased, nitrite-plus-nitrate loads have increased, and total nitrogen loads have shown no trend (J.R. Mullaney, U.S. Geological Survey, written commun.,

Table 18. Summary of trends in nutrient and suspended sediment loads, 1975-2003 and 1993-2003.

[Long-term period for trend analysis spans 22-29 water years at different stations, all ending in 2003; recent period for trend analysis spans 11 water years at all stations. Significant trend: $p$-value less than or equal to 0.05 ; highly significant trend: $p$-value less than or equal to 0.01 ; --, not analyzed]

\begin{tabular}{|c|c|c|c|c|c|c|c|c|}
\hline \multirow[b]{2}{*}{ Water-quality constituent } & \multicolumn{4}{|c|}{$1975-2003,1979-2003$, or $1982-2003$} & \multicolumn{4}{|c|}{ 1993-2003 } \\
\hline & $\begin{array}{l}\text { Number of } \\
\text { stations } \\
\text { analyzed }\end{array}$ & $\begin{array}{c}\text { Upward } \\
\text { trend }\end{array}$ & $\begin{array}{l}\text { Downward } \\
\text { trend }\end{array}$ & $\begin{array}{l}\text { No signifi- } \\
\text { cant trend }\end{array}$ & $\begin{array}{l}\text { Number of } \\
\text { stations } \\
\text { analyzed }\end{array}$ & $\begin{array}{l}\text { Upward } \\
\text { trend }\end{array}$ & $\begin{array}{c}\text { Downward } \\
\text { trend }\end{array}$ & $\begin{array}{l}\text { No signifi- } \\
\text { cant trend }\end{array}$ \\
\hline Total nitrogen & 32 & 1 & 12 & 19 & 46 & 0 & 1 & 45 \\
\hline Ammonia nitrogen & 6 & 0 & 6 & 0 & 9 & 0 & 3 & 6 \\
\hline Total Kjeldahl nitrogen & 6 & 0 & 6 & 0 & 0 & -- & -- & -- \\
\hline Nitrite-plus-nitrate nitrogen & 32 & 7 & 8 & 17 & 46 & 0 & 4 & 42 \\
\hline Total phosphorus & 32 & 0 & 17 & 15 & 41 & 2 & 1 & 38 \\
\hline Suspended sediment & 4 & 0 & 1 & 3 & 8 & 0 & 0 & 8 \\
\hline
\end{tabular}


2006). These trend results for nitrogen constituent loads in the Quinnipiac River have persisted in the period analyzed in this study (fig. 15A), with total Kjeldahl nitrogen representing a decreasing proportion of the total nitrogen load over time, and nitrite-plus-nitrate nitrogen representing an increasing proportion. This pattern of trends in load is consistent with implementation of wastewater-treatment improvements that remove organic material and convert ammonia nitrogen to nitrite and nitrate. Based on this information for the Quinnipiac River, a working hypothesis for this study was that a similar pattern of nitrogen constituent loads would be likely in other streams that receive municipal wastewater effluent. No consistent pattern was found, however, among other rivers with similar land use or point-source discharge conditions. Trends and loads for ammonia nitrogen and total Kjeldahl nitrogen were only evaluated for a small number of stations.

Downward trends in total nitrogen loads were detected at more than one-third of the stations analyzed (12 of 32) during the long-term period (table 18), and 10 of these trends were highly significant (appendix 8 ). Of the 12 stations with downward trends, nine stations monitor streams that receive major point-source discharges, including the Naugatuck River in Connecticut (fig. 15C) and the Passaic River in New Jersey (fig. 15E), both of which had highly significant downward trends. The Naugatuck River also had a highly significant downward trend in total nitrogen load for the recent period. Only one long-term upward trend in total nitrogen load was detected, at Toms River near Toms River, N.J. (fig. 15G), a stream that receives small amounts of nitrogen from minor point-source discharges.

Long-term trends in loads of nitrite-plus-nitrate nitrogen were detected at almost half the stations analyzed (15 of 32), with results about evenly divided between upward (7) and downward (8) trends (table 18). Of the seven rivers with longterm upward trends in loads of nitrite-plus-nitrate nitrogen, five receive major municipal point-source discharges, including the Quinnipiac River in Connecticut (fig. 15A) and the Passaic River in New Jersey (fig. 15E); Toms River in New Jersey (fig. 15G) receives minor point-source discharges. The seventh station with an upward trend, the Choptank River in Maryland, drains an agricultural drainage basin (48 percent agricultural land) with no major or minor point sources. Of the eight rivers with long-term downward trends in loads of nitrite-plus-nitrate nitrogen, five receive major point-source discharges, including the Naugatuck River in Connecticut (fig. 15C), the Patuxent River in Maryland, and the James River in Virginia. Stations with downward trends in load and no major point discharges include the Hackensack River (67 percent urbanized) and Raccoon Creek (66 percent agricultural; fig. 15I), both in New Jersey, and the Salmon River in Connecticut (about 24 percent developed land) (table 8, in back of report). In some streams that are receiving waters for major point-source discharges, downward trends in nitriteplus-nitrate nitrogen loads, and also total nitrogen loads, may result in part from advanced wastewater-treatment practices such as Biological Nitrogen Removal (BNR), which has been implemented in treatment plants in the Patuxent River Basin (Maryland Department of Natural Resources, 2009).

Long-term downward trends in loads of ammonia nitrogen and total Kjeldahl nitrogen were detected at the six stations evaluated for these constituents (table 18; appendix 8 ), and most of the downward trends were highly significant. Three downward trends in loads of ammonia nitrogen were detected for the recent period, and no upward trends were detected. Nine of the 10 streams evaluated for ammonia nitrogen or total Kjeldahl nitrogen receive major pointsource discharges.

Downward trends in total phosphorus loads were detected at slightly more than half of the stations analyzed (17 of 32) during the long-term period (table 18). Of the 17 stations with downward trends, 14 stations monitor streams that receive major or minor point-source discharges, including the Quinnipiac River in Connecticut (fig. 15B) and the Passaic River and Toms River in New Jersey (figs. 15F, H).

Several long-term trends in nutrient loads were detected at stations in drainage basins evaluated for point-source loads. These trends are discussed in the "Point Sources" section.

Long-term downward trends in loads of one or more nutrients were detected for three streams with relatively undeveloped drainage basins and no major or minor point discharges: Bunnell (Burlington) Brook, the Salmon River, and the Saugatuck River in Connecticut. The drainage basins for these streams are largely undeveloped $(75,76$, and 74 percent, respectively), although the Salmon and Saugatuck River Basins have been classified as urban (table 8, in back of report). Highly significant long-term downward trends in total nitrogen loads and nitrite-plus-nitrate nitrogen loads were detected for the Salmon River. Downward trends in nitrogen constituents in undeveloped areas could be related to changes in atmospheric deposition of nitrogen. Long-term downward trends in total phosphorus loads also were detected for all three streams. Additional investigation would be necessary to evaluate possible causes for downward trends in nutrient loads in these drainage basins.

A small number of stations were evaluated for trends in suspended sediment load, four in the long-term period and eight in the recent period (table 18). The only significant trend was a downward trend in load for the Raritan River at Bound Brook in New Jersey. 
A. Quinnipiac River at Wallingford, Connecticut (station 32)

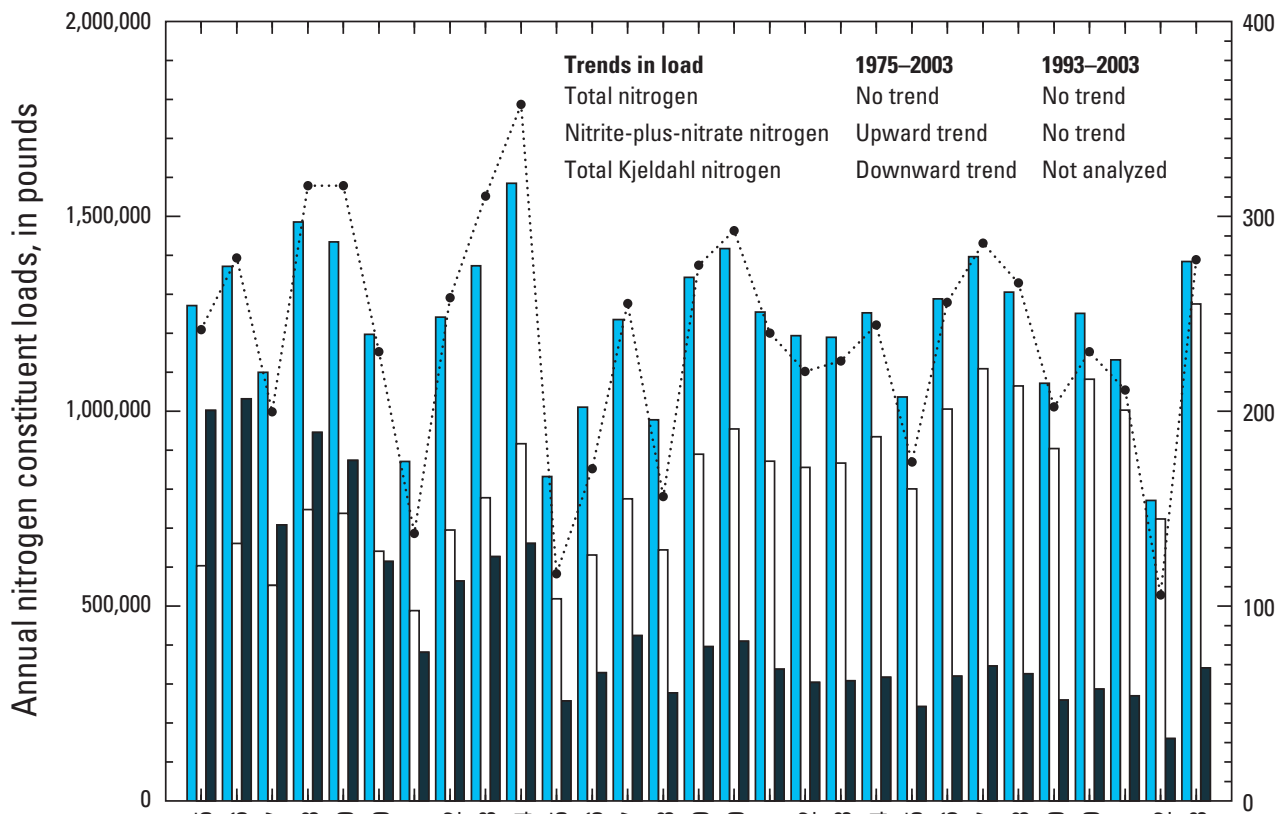

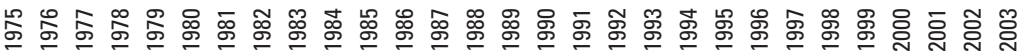

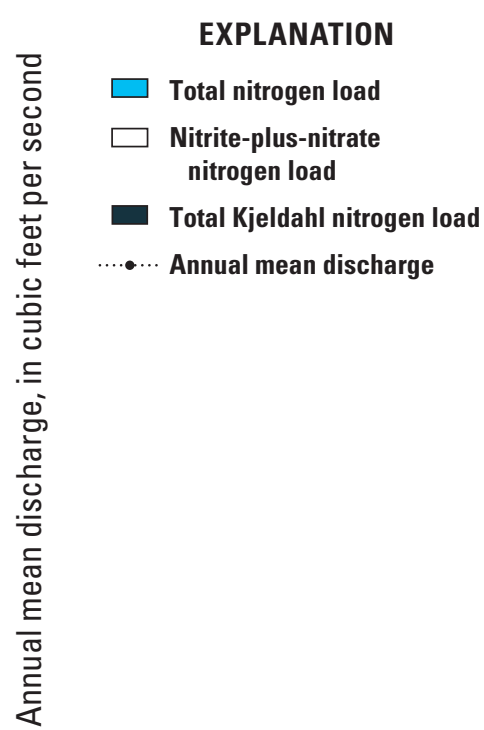

EXPLANATION

Total phosphorus load

Annual mean discharge

Figure 15. Long-term annual nutrient loads at selected stations with significant trends in load. (A) Quinnipiac River at Wallingford, Conn., total nitrogen, nitrite-plus-nitrate nitrogen, and total Kjeldahl nitrogen, 1975-2003, (B) Quinnipiac River at Wallingford, Conn., total phosphorus, 1975-2003, (C) Naugatuck River at Beacon Falls, Conn., total nitrogen and nitrite-plus-nitrate nitrogen, 1975-2003, (D) Naugatuck River at Beacon Falls, Conn., total phosphorus, 1975-2003, (E) Passaic River at Little Falls, N.J., total nitrogen and nitriteplus-nitrate nitrogen, 1979-2003, (F) Passaic River at Little Falls, N.J., total phosphorus, 1979-2003, (G) Toms River near Toms River, N.J., total nitrogen and nitrite-plus-nitrate nitrogen, 1975-2003, (H) Toms River near Toms River, N.J., total phosphorus, 1975-2003, and (I) Raccoon Creek near Swedesboro, N.J., total nitrogen and nitrite-plus-nitrate nitrogen, 1975-2003. 

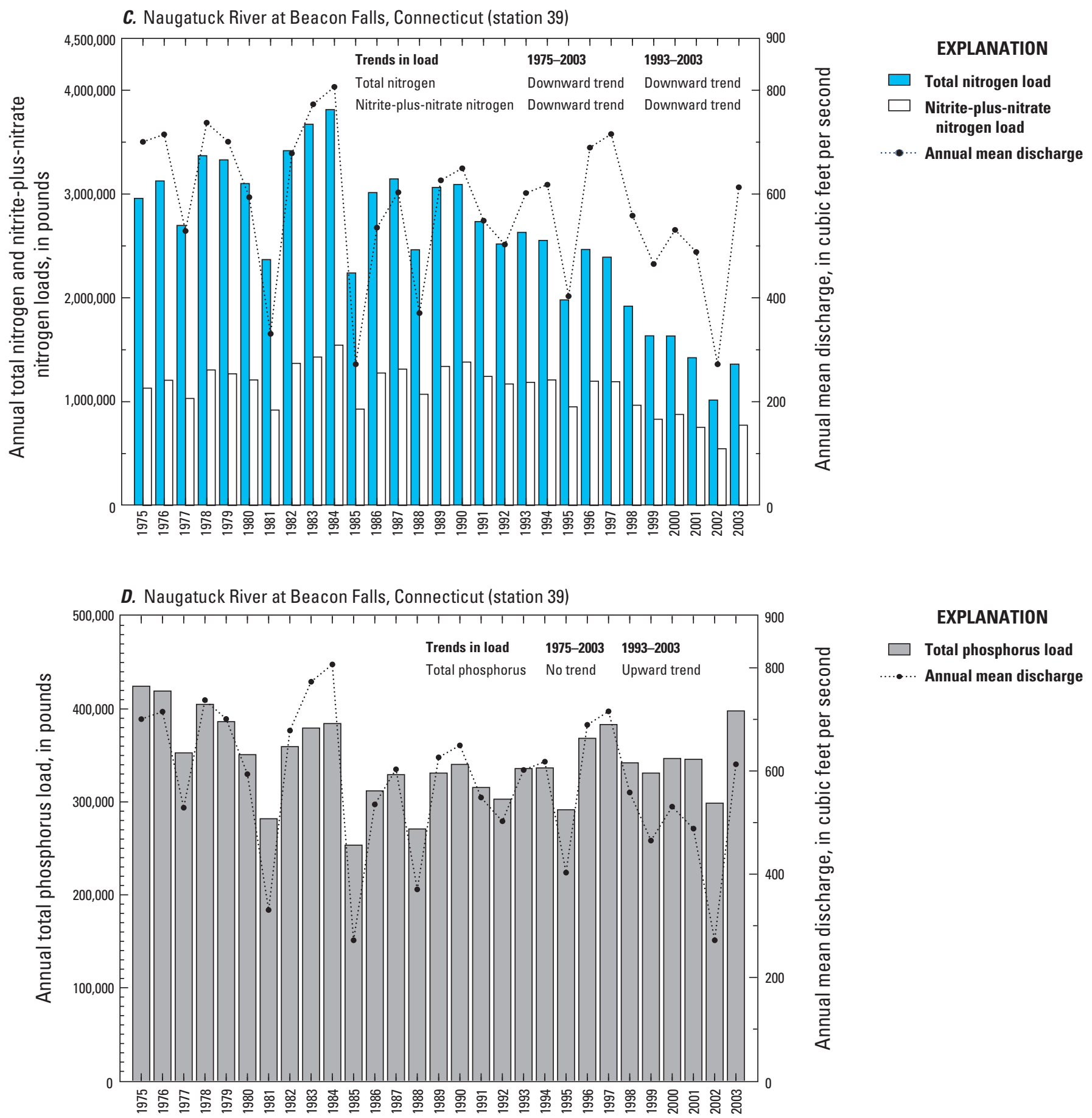

Water Year

Figure 15. Long-term annual nutrient loads at selected stations with significant trends in load. (A) Quinnipiac River at Wallingford, Conn., total nitrogen, nitrite-plus-nitrate nitrogen, and total Kjeldahl nitrogen, 1975-2003, (B) Quinnipiac River at Wallingford, Conn., total phosphorus, 1975-2003, (C) Naugatuck River at Beacon Falls, Conn., total nitrogen and nitrite-plus-nitrate nitrogen, 1975-2003, (D) Naugatuck River at Beacon Falls, Conn., total phosphorus, 1975-2003, (E) Passaic River at Little Falls, N.J., total nitrogen and nitriteplus-nitrate nitrogen, 1979-2003, (F) Passaic River at Little Falls, N.J., total phosphorus, 1979-2003, (G) Toms River near Toms River, N.J., total nitrogen and nitrite-plus-nitrate nitrogen, 1975-2003, (H) Toms River near Toms River, N.J., total phosphorus, 1975-2003, and (I) Raccoon Creek near Swedesboro, N.J., total nitrogen and nitrite-plus-nitrate nitrogen, 1975-2003.-Continued 

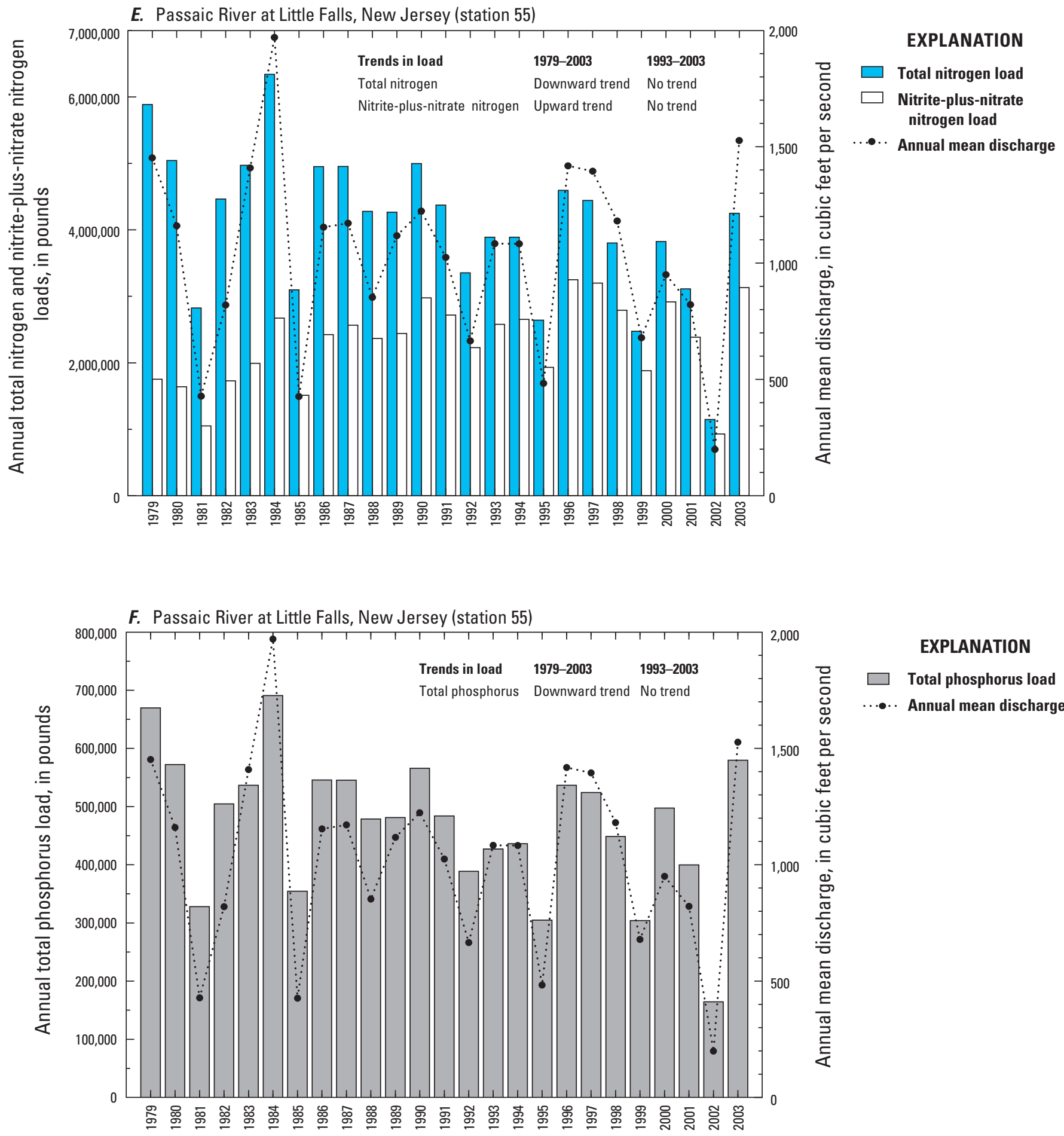

EXPLANATION

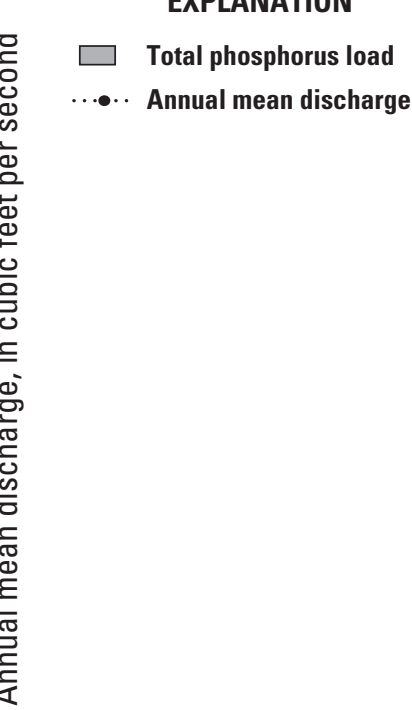

Water Year

Figure 15. Long-term annual nutrient loads at selected stations with significant trends in load. (A) Quinnipiac River at Wallingford, Conn., total nitrogen, nitrite-plus-nitrate nitrogen, and total Kjeldahl nitrogen, 1975-2003, (B) Quinnipiac River at Wallingford, Conn., total phosphorus, 1975-2003, (C) Naugatuck River at Beacon Falls, Conn., total nitrogen and nitrite-plus-nitrate nitrogen, 1975-2003, (D) Naugatuck River at Beacon Falls, Conn., total phosphorus, 1975-2003, (E) Passaic River at Little Falls, N.J., total nitrogen and nitriteplus-nitrate nitrogen, 1979-2003, (F) Passaic River at Little Falls, N.J., total phosphorus, 1979-2003, (G) Toms River near Toms River, N.J., total nitrogen and nitrite-plus-nitrate nitrogen, 1975-2003, (H) Toms River near Toms River, N.J., total phosphorus, 1975-2003, and (I) Raccoon Creek near Swedesboro, N.J., total nitrogen and nitrite-plus-nitrate nitrogen, 1975-2003.-Continued 

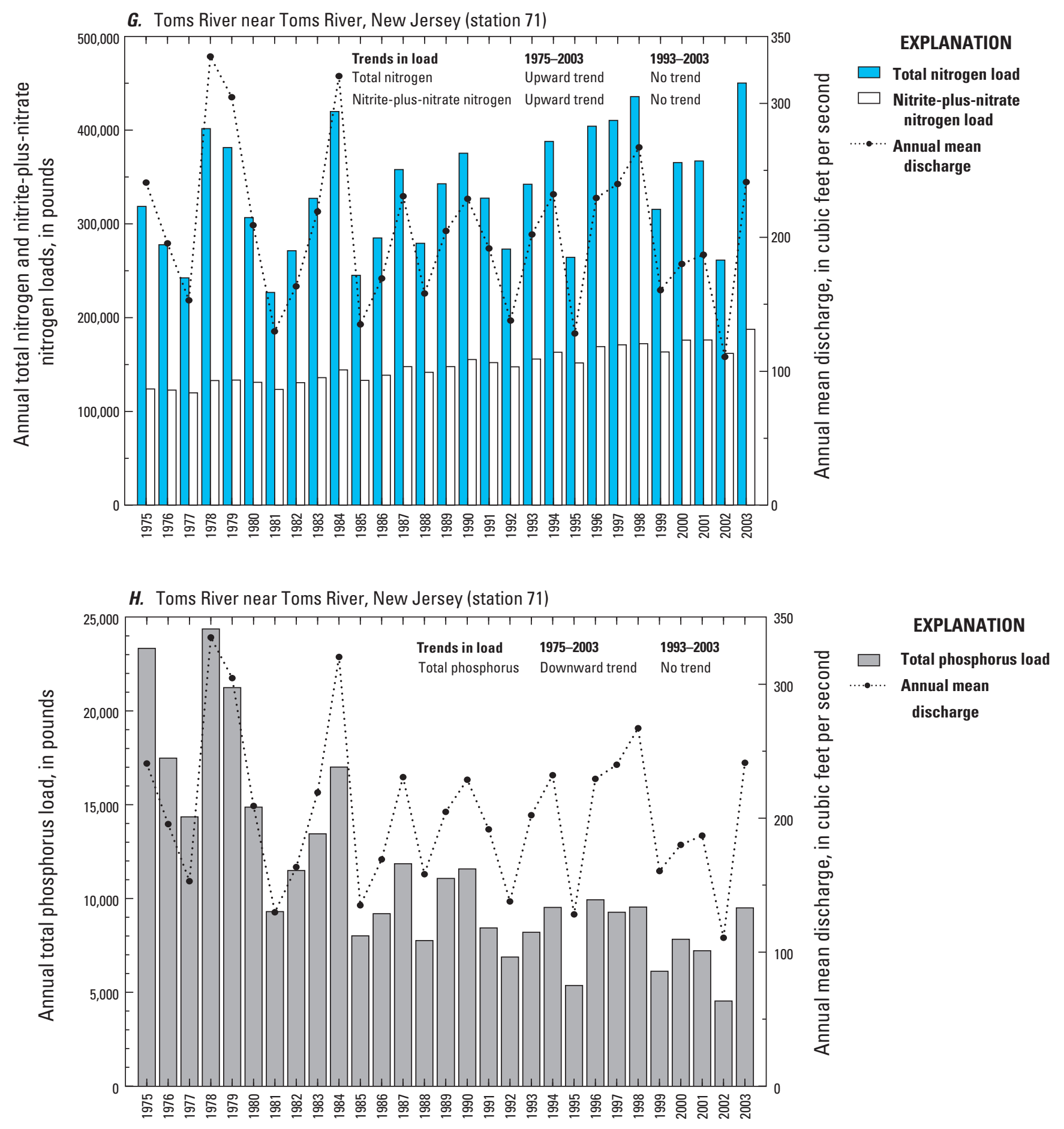

Water Year

Figure 15. Long-term annual nutrient loads at selected stations with significant trends in load. (A) Quinnipiac River at Wallingford, Conn., total nitrogen, nitrite-plus-nitrate nitrogen, and total Kjeldahl nitrogen, 1975-2003, (B) Quinnipiac River at Wallingford, Conn., total phosphorus, 1975-2003, (C) Naugatuck River at Beacon Falls, Conn., total nitrogen and nitrite-plus-nitrate nitrogen, 1975-2003, (D) Naugatuck River at Beacon Falls, Conn., total phosphorus, 1975-2003, (E) Passaic River at Little Falls, N.J., total nitrogen and nitriteplus-nitrate nitrogen, 1979-2003, (F) Passaic River at Little Falls, N.J., total phosphorus, 1979-2003, (G) Toms River near Toms River, N.J., total nitrogen and nitrite-plus-nitrate nitrogen, 1975-2003, (H) Toms River near Toms River, N.J., total phosphorus, 1975-2003, and (I) Raccoon Creek near Swedesboro, N.J., total nitrogen and nitrite-plus-nitrate nitrogen, 1975-2003.-Continued 

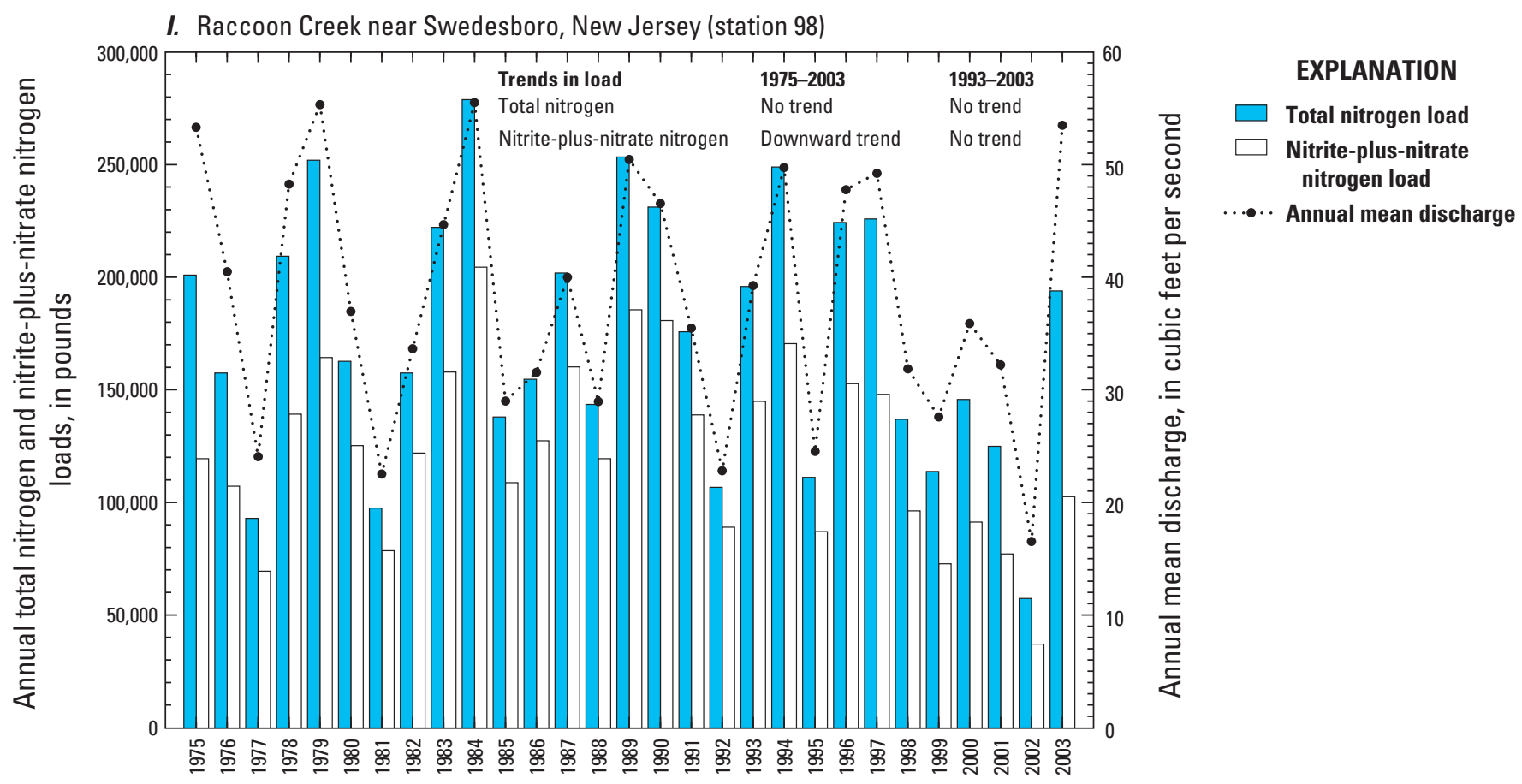

Water Year

Figure 15. Long-term annual nutrient loads at selected stations with significant trends in load. (A) Quinnipiac River at Wallingford, Conn., total nitrogen, nitrite-plus-nitrate nitrogen, and total Kjeldahl nitrogen, 1975-2003, (B) Quinnipiac River at Wallingford, Conn., total phosphorus, 1975-2003, (C) Naugatuck River at Beacon Falls, Conn., total nitrogen and nitrite-plus-nitrate nitrogen, 1975-2003, (D) Naugatuck River at Beacon Falls, Conn., total phosphorus, 1975-2003, (E) Passaic River at Little Falls, N.J., total nitrogen and nitriteplus-nitrate nitrogen, 1979-2003, (F) Passaic River at Little Falls, N.J., total phosphorus, 1979-2003, (G) Toms River near Toms River, N.J., total nitrogen and nitrite-plus-nitrate nitrogen, 1975-2003, (H) Toms River near Toms River, N.J., total phosphorus, 1975-2003, and (I) Raccoon Creek near Swedesboro, N.J., total nitrogen and nitrite-plus-nitrate nitrogen, 1975-2003.—Continued

\section{Nutrient Loads in Large Drainage Basins}

No upward trends in nutrient loads were detected in the 11 largest drainage basins during either the long-term or recent periods, although some upward trends in flow-adjusted concentrations were detected during both periods (table 14). The 10 drainage basins with nutrient data for the long-term period either had downward trends in load or no trends in load (table 14). Some of the long-term downward trends were highly significant ( $p$-value less than or equal to 0.01 ).

Collectively and individually, the 11 largest rivers evaluated in this study deliver the largest freshwater inflows and nutrient loads to major estuaries on the northeast coast, including Long Island Sound, the Hudson River Estuary, Delaware Bay, and Chesapeake Bay. Consequently, long-term downward trends in nutrient loads represent major regional water-quality improvements.

The Susquehanna, Potomac, Connecticut, Delaware, and James River Basins (in descending order of size) are the largest monitored basins for which long-term water-quality records were available for evaluation of trends in nutrient loads. The Susquehanna, Potomac, and James Rivers are the three largest sources of streamflow and nutrients to Chesapeake Bay from the nontidal part of the Chesapeake Bay drainage basin (Belval and Sprague, 1999, p. 3-4). Nutrient trends and loads for these and numerous other streams in the Chesapeake Bay drainage basin are evaluated annually by the USGS in cooperation with federal, state, and regional agencies of the Chesapeake Bay Program (Langland and others, 2006). The Susquehanna River, with a monitored drainage area 
encompassing 42 percent of the $64,000 \mathrm{mi}^{2}$ drainage basin for Chesapeake Bay, contributes about 60 percent of the total streamflow, 62 percent of the total nitrogen load, and 34 percent of the total phosphorus load from the nontidal part of the Chesapeake Bay drainage basin. The Potomac River Basin, encompassing 18 percent of the Bay drainage area, contributes about 20 percent of the total streamflow, 28 percent of the total nitrogen load, and 33 percent of the total phosphorus load, and the James River, encompassing 9.8 percent of the Bay drainage area, contributes about 12 percent of the streamflow, 5 percent of the total nitrogen load, and 20 percent of the total phosphorus load (Belval and Sprague, 1999, p. 4-5). The Connecticut River is the largest source of freshwater inflow and a major nutrient source to Long Island Sound, and the Delaware River is the major freshwater inflow to Delaware Bay.

Long-term downward trends in total nitrogen loads were detected for the Connecticut, Delaware, and James Rivers, and no trends in total nitrogen loads were detected for the Susquehanna or Potomac Rivers (figs. 16A, C, E, G, H). The downward trends are more apparent in graphs of annual loads for the Connecticut and Delaware Rivers than for the James River, where the extended dry period from 1999 to 2002 represents a long-term anomaly (figs. 16A, C, H). Mean, median, and maximum total nitrogen loads were lower during the recent period than during the long-term period for all three rivers (table 19). Although no trend in total nitrogen load was detected for the Potomac for either the long-term period or the recent period, the 1993-2003 period contains both extreme high and extreme low annual loads, and five of the six highest annual loads are in the 1993-2003 period (fig. 16G). Mean and median total nitrogen loads for the Potomac River were higher during the recent period than during the long-term period (table 19).

Although no long-term or recent trend in total nitrogen load was detected for the Susquehanna River, a downward trend in total Kjeldahl nitrogen load and a highly significant downward trend in ammonia nitrogen load were detected for the long-term (1979-2003) period (fig. 16F; table 14). No long-term or recent trend in nitrite-plus-nitrate nitrogen load was identified for the Susquehanna at the 0.05 significance level used in this study, but a likely downward trend in this constituent for the recent period is present $(p$-value $=0.07)$ (fig. 16F).

Highly significant long-term downward trends in total phosphorus loads were detected for the Connecticut and Delaware Rivers (table 14, figs. 16B, D). No long-term trends in total phosphorus loads were detected for the Susquehanna, Potomac, and James Rivers (table 14; not shown in fig. 16). A downward trend in ammonia nitrogen load for the James River was the only trend in load detected for any of the nutrients analyzed for the five largest drainage basins during the 1993-2003 period (table 14).

Four of the 11 largest drainage basins were evaluated for trends in suspended sediment load during the recent period: the Susquehanna, Potomac, Connecticut, and Mohawk Rivers (table 14). No trends in load were detected. Although not significant at the level selected for this study, data for the Susquehanna River showed a possible downward trend in suspended sediment load for the 1993-2003 period $(p$-value $=0.100)$.

The Susquehanna River, as the largest freshwater inflow to the Chesapeake Bay, transports a large amount of the suspended sediment and nutrient load that enters the Bay. Suspended sediment loads, total phosphorus loads, and to a lesser extent, total nitrogen loads entering Chesapeake Bay from the Susquehanna River are affected by three hydroelectric dams, and associated reservoirs, on the lower reaches of the Susquehanna in Pennsylvania and Maryland. The three reservoirs trap a large amount of the sediment transported by the river, and some associated nutrients (Langland, 2009). The Conowingo Reservoir is the largest and farthest downstream of the three reservoirs. The USGS conducted bathymetric surveys in 2008 to estimate the remaining sediment storage capacity in the three reservoirs (Langland, 2009, p. 1). Although it is difficult to estimate the length of time until the remaining sediment storage capacity of the Conowingo Reservoir is reached, the remaining capacity may be filled in 15 to 20 years, depending on sediment transport rates, sediment deposition rates, and the absence of major sediment scours resulting from floods. When the remaining sediment storage capacity is reached, then the sediment loads and associated phosphorus loads transported by the Susquehanna River into the Chesapeake Bay are expected to increase (Langland, 2009, p. 1, 19).

Large drainage basins of the region integrate streamflow and nutrient sources from many smaller basins that experience a wide range of conditions in any one year. Although streamflow has not been uniform across the region, high annual streamflows, and consequently high nutrient loads, have been measured in many parts of the region in the late 1970s, 1984, 1993-94, 1996, and 2003. Low annual streamflows, and consequently low nutrient loads, have been measured in many parts of the region in 1981, 1985, 1988, 1992, 1995, 1999, and 2001-2002. Maximum total nitrogen loads for the 1993-2003 period (with estimation based on the 1975-2003 calibration period) were transported by the Connecticut, Delaware, and Potomac Rivers in 1996; by the Susquehanna River in 1994; and by the James River in 2003 (figs. 16A, C, G, E, H). Minimum total nitrogen loads for the 1993-2003 period were transported by the Connecticut, Delaware, Potomac, and James Rivers in 2002, and by the Susquehanna River in 2001. 

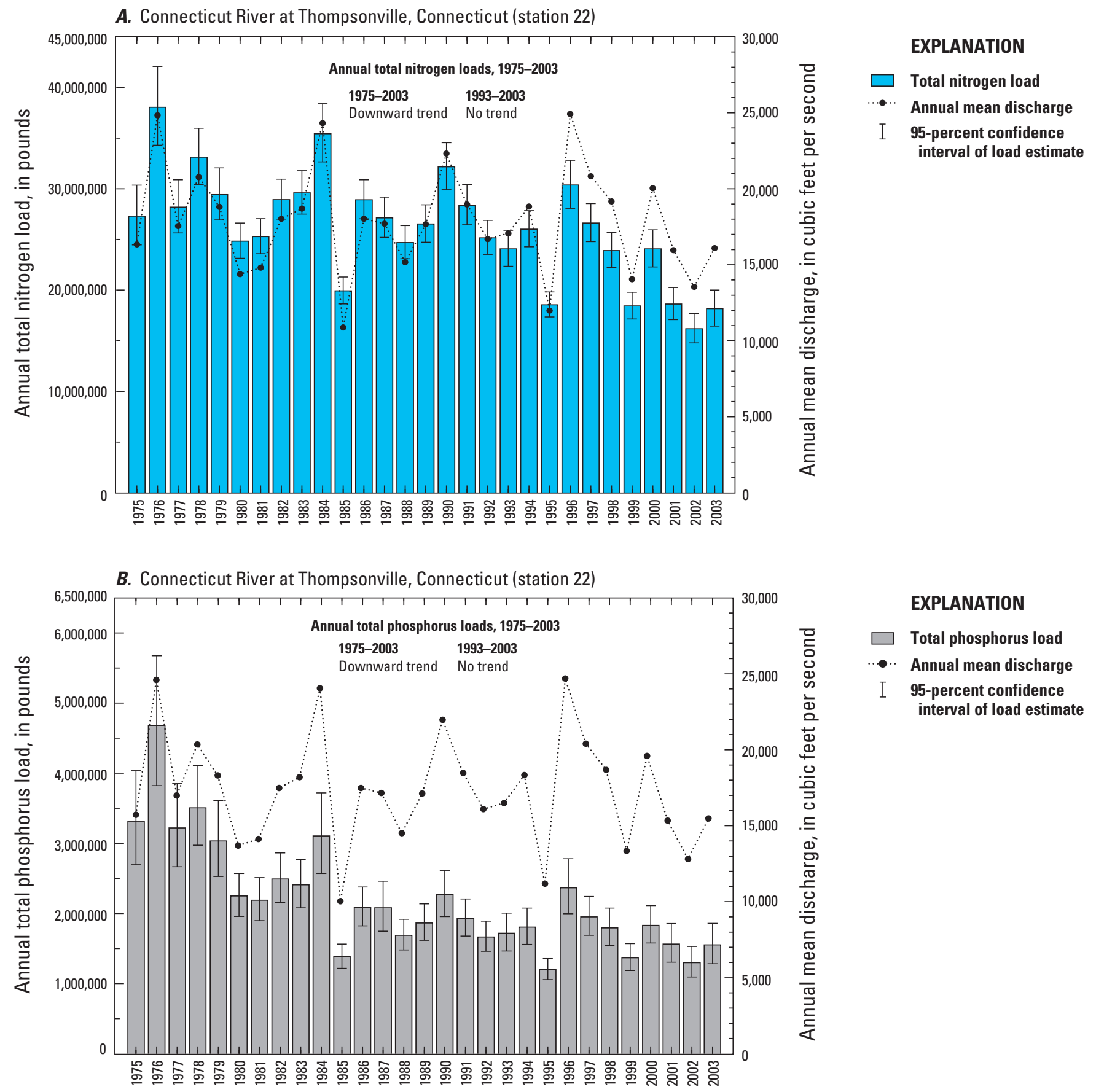

Water Year

Figure 16. Long-term annual nutrient loads in the five largest drainage basins of the region, 1975-2003. (A) Total nitrogen, Connecticut River at Thompsonville, Conn., 1975-2003, (B) total phosphorus, Connecticut River at Thompsonville, Conn., 1975-2003, (C) total nitrogen, Delaware River at Trenton, N.J., 1975-2003, (D) total phosphorus, Delaware River at Trenton, N.J., 1975-2003, (E) total nitrogen, Susquehanna River at Conowingo, Md., 1979-2003, (F) nitrite-plus-nitrate nitrogen, total Kjeldahl nitrogen, and ammonia nitrogen, Susquehanna River at Conowingo, Md., 1979-2003, (G) total nitrogen, Potomac River at Chain Bridge, at Washington, D.C., 1975-2003, and $(H)$ total nitrogen, James River at Cartersville, Va., 1975-2003. 

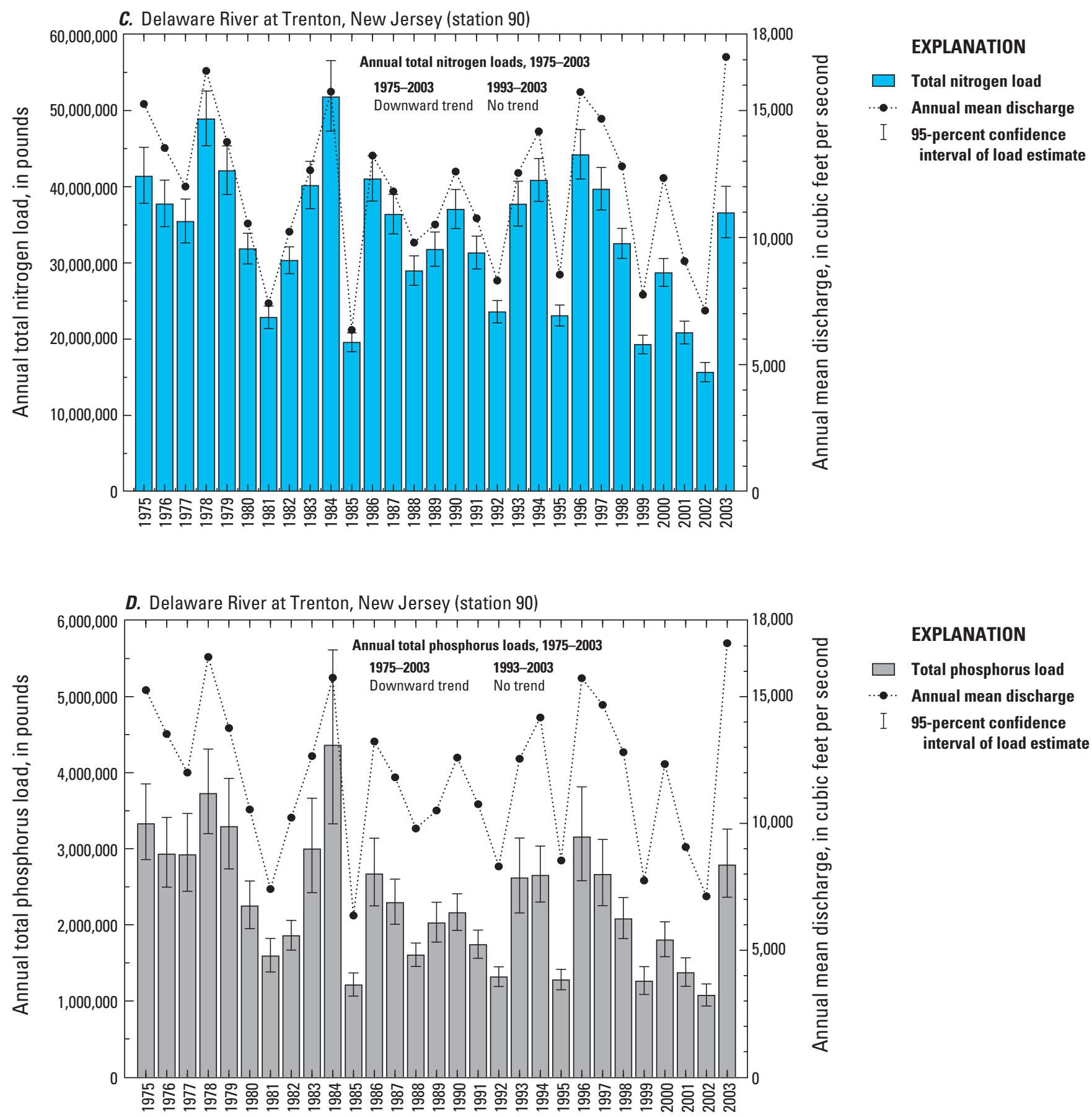

Figure 16. Long-term annual nutrient loads in the five largest drainage basins of the region, 1975-2003. (A) Total nitrogen, Connecticut River at Thompsonville, Conn., 1975-2003, (B) total phosphorus, Connecticut River at Thompsonville, Conn., 1975-2003, (C) total nitrogen, Delaware River at Trenton, N.J., 1975-2003, (D) total phosphorus, Delaware River at Trenton, N.J., 1975-2003, (E) total nitrogen, Susquehanna River at Conowingo, Md., 1979-2003, (F) nitrite-plus-nitrate nitrogen, total Kjeldahl nitrogen, and ammonia nitrogen, Susquehanna River at Conowingo, Md., 1979-2003, (G) total nitrogen, Potomac River at Chain Bridge, at Washington, D.C., 1975-2003, and $(H)$ total nitrogen, James River at Cartersville, Va., 1975-2003.-Continued 

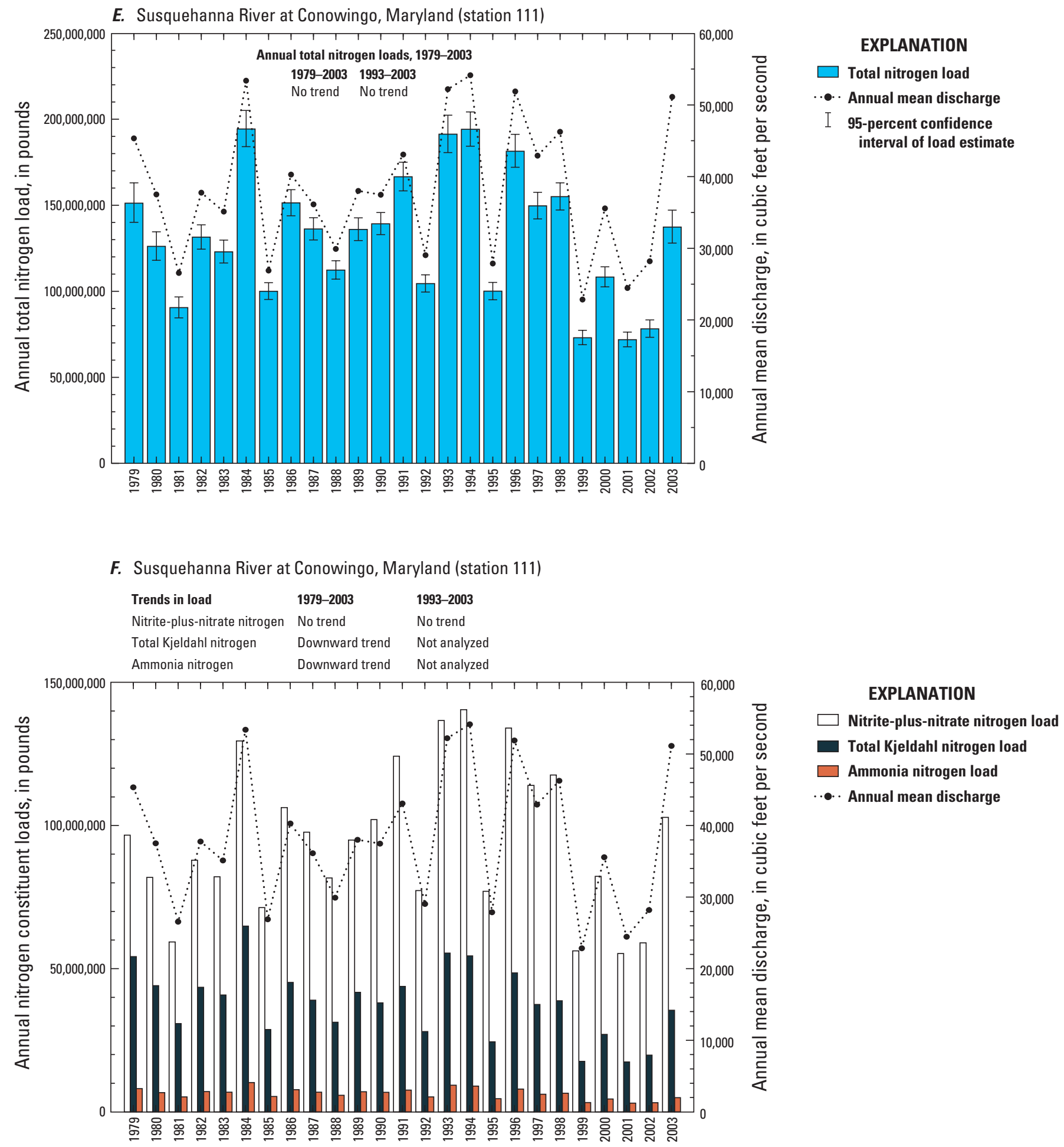

Water Year

Figure 16. Long-term annual nutrient loads in the five largest drainage basins of the region, 1975-2003. (A) Total nitrogen, Connecticut River at Thompsonville, Conn., 1975-2003, (B) total phosphorus, Connecticut River at Thompsonville, Conn., 1975-2003, (C) total nitrogen, Delaware River at Trenton, N.J., 1975-2003, (D) total phosphorus, Delaware River at Trenton, N.J., 1975-2003, (E) total nitrogen, Susquehanna River at Conowingo, Md., 1979-2003, (F) nitrite-plus-nitrate nitrogen, total Kjeldahl nitrogen, and ammonia nitrogen, Susquehanna River at Conowingo, Md., 1979-2003, (G) total nitrogen, Potomac River at Chain Bridge, at Washington, D.C., 1975-2003, and $(H)$ total nitrogen, James River at Cartersville, Va., 1975-2003.-Continued 

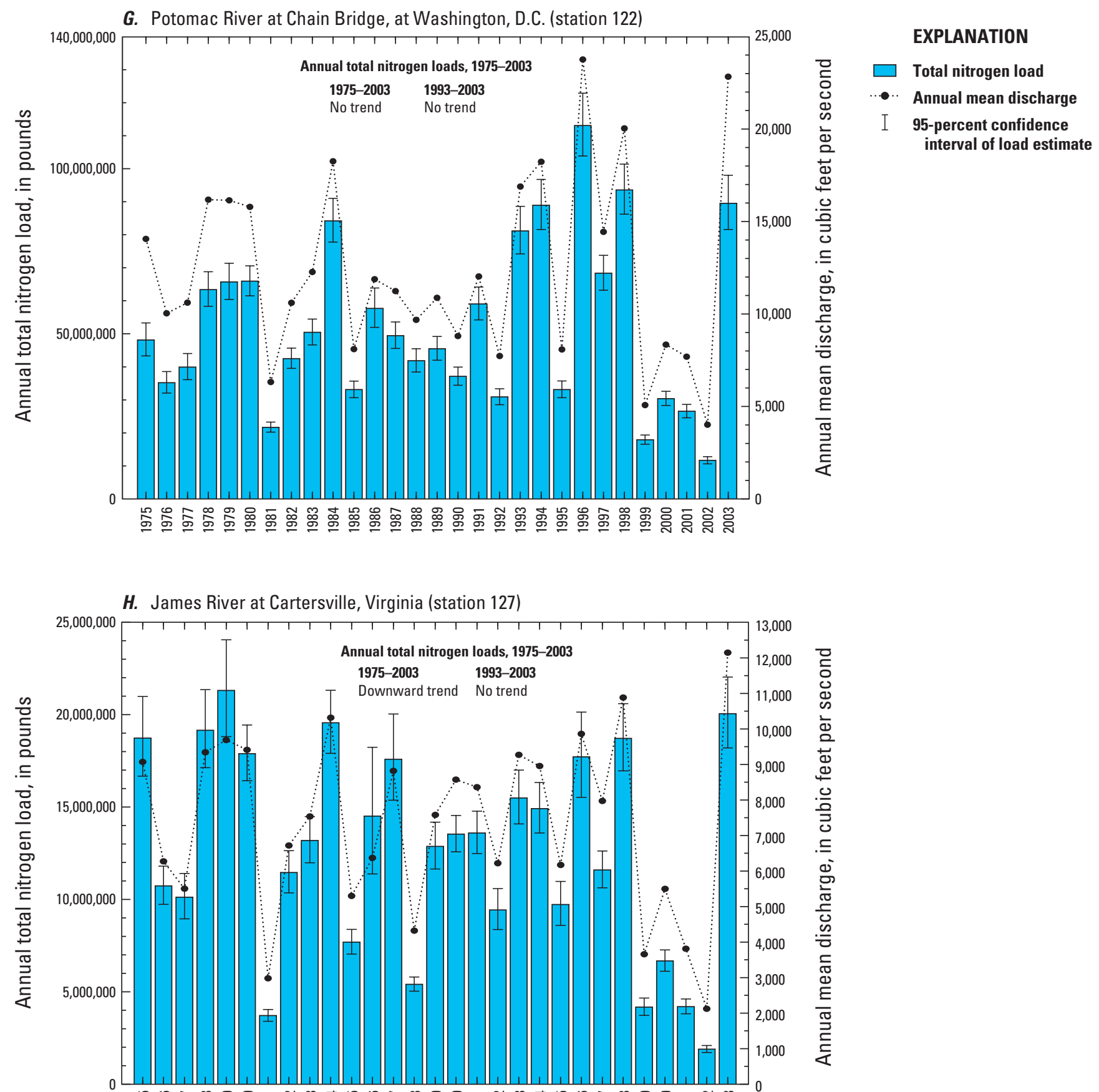

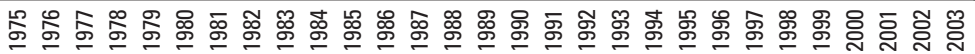

\section{Water Year}

Figure 16. Long-term annual nutrient loads in the five largest drainage basins of the region, 1975-2003. (A) Total nitrogen, Connecticut River at Thompsonville, Conn., 1975-2003, (B) total phosphorus, Connecticut River at Thompsonville, Conn., 1975-2003, (C) total nitrogen, Delaware River at Trenton, N.J., 1975-2003, (D) total phosphorus, Delaware River at Trenton, N.J., 1975-2003, (E) total nitrogen, Susquehanna River at Conowingo, Md., 1979-2003, (F) nitrite-plus-nitrate nitrogen, total Kjeldahl nitrogen, and ammonia nitrogen, Susquehanna River at Conowingo, Md., 1979-2003, (G) total nitrogen, Potomac River at Chain Bridge, at Washington, D.C., 1975-2003, and (H) total nitrogen, James River at Cartersville, Va., 1975-2003.-Continued 


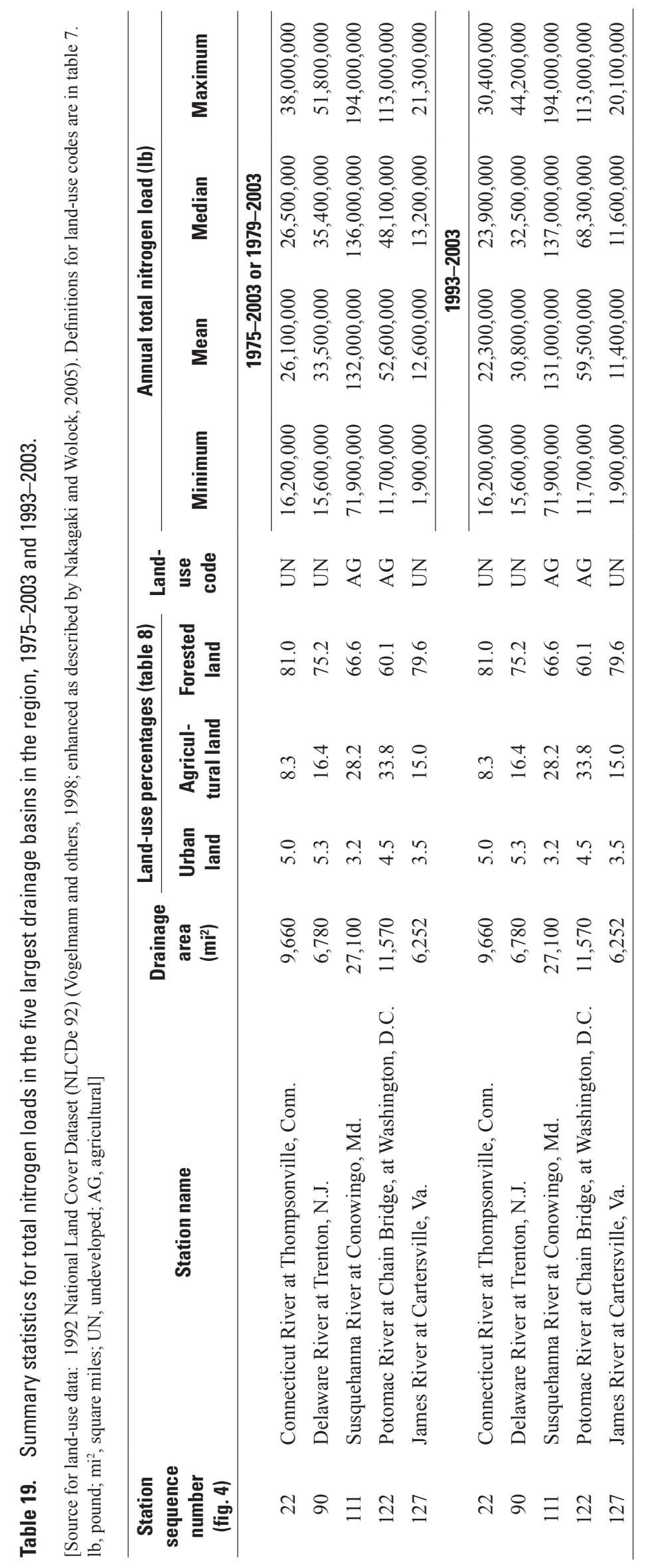




\section{Relation of Nutrient Trends, Loads, and Yields to Nutrient Sources}

Land use and land cover in many drainage basins of the northeastern United States constitute a complex and changing mosaic, often with many nutrient sources contributing to the nutrient concentrations and loads measured or estimated for a stream. A full evaluation of the effects of these sources on nutrient trends, loads, and yields is beyond the scope of this report. Some general relations observed between nutrient conditions and basin land use, population density, and hydrologic conditions are discussed, and effects of point sources are evaluated for selected drainage basins.

\section{Land Use and Population Density}

Land use in drainage basins evaluated for this report ranges from 96 percent developed land (urban or agricultural land) to 100 percent undeveloped land (primarily forested) (table 8 , in back of report). Although the region as a whole is 65 percent forested, urban nutrient sources dominate water quality in many areas, particularly near the coast, and agricultural nutrient sources predominate in some areas, particularly in central and southern parts of the region.

Annual nutrient yields have been used to compare the effects of major land uses in the region on stream nutrient transport. Annual nutrient yields (annual loads divided by drainage basin area) are a convenient measure for comparing the relative nutrient contributions from drainage basins with a wide range in total basin size and a wide range in basin characteristics. Nutrient yields vary seasonally, annually, and regionally, on the basis of hydrologic conditions, natural drainage basin characteristics, and nutrient sources associated with various land uses and waste-disposal practices.

Annual yields have been evaluated and summary statistics have been calculated for 93 stations for total nitrogen (table 20) and for 92 stations for total phosphorus (table 21). The White River at West Hartford, Vt. (station 20, table 20), had sufficient data for estimation of total nitrogen loads, but had insufficient uncensored data for estimation of total phosphorus loads. Annual yields of total nitrogen and total phosphorus were evaluated for stations with annual load estimates for all or some of the 11 water years in the 19932003 period, including: 46 stations with annual load estimates for the full 11-year period; one station, the Schuylkill River at Philadelphia, Pa., with annual load estimates for the 1993-2003 period based on the 1975-2003 load estimation; and 37 additional stations that had from 1 to 10 years of annual load estimates in the 1993-2003 period (table 5, load estimation column). In addition, mean annual yields for nine basins evaluated in a national study of undeveloped basins were included (Clark and others, 2000; D.K. Mueller, U.S. Geological Survey, written commun., 2007).

Summary statistics for the individual stations have been further summarized into statistics for minimum, median, and maximum yields for all stations and for four land use categories (table 22). Stations with annual yield estimates for three or fewer years generally do not have records that cover a full range of annual mean streamflows. Consequently, these stations have been included only in selected summary statistics for all stations or for the four land use categories (table 22), on the basis of an evaluation of annual mean flows during the years of available yield estimates. Ranges in annual yields for stations with 1 to 10 years of yield estimates in the 1993-2003 period are not exactly comparable to yield ranges for stations with estimates for the full 11-year period, because of differences in hydrologic conditions during different calibration periods. Additional years of data would be required to define the yield ranges more accurately for these stations with short periods of record. However, the analyses for these stations provide information on yields for geographic areas and land uses that are not fully covered by the stations with more complete records, and thus extend the understanding of nutrient yields in the region. Mean annual yields for the nine basins evaluated in a national study of undeveloped basins (Clark and others, 2000; D.K. Mueller, U.S. Geological Survey, written commun., 2007) are included only in the summary statistics for median yields for all basins and median yields for undeveloped basins (table 22).

Estimated total nitrogen yields for all drainage basins and all years evaluated during the recent period ranged over four orders of magnitude, from 41 pounds per square mile per year $\left(\mathrm{lb} / \mathrm{mi}^{2} / \mathrm{yr}\right.$ ) to $32,000 \mathrm{lb} / \mathrm{mi}^{2} / \mathrm{yr}$ (table 22 , fig. 17). Minimum yields ranged from 41 to $15,000 \mathrm{lb} / \mathrm{mi}^{2} / \mathrm{yr}$, median yields ranged from 290 to $26,000 \mathrm{lb} / \mathrm{mi}^{2} / \mathrm{yr}$, and maximum yields ranged from 1,300 to $32,000 \mathrm{lb} / \mathrm{mi}^{2} / \mathrm{yr}$.

Estimated total phosphorus yields for all drainage basins and years evaluated ranged over five orders of magnitude, from 1.4 to $16,000 \mathrm{lb} / \mathrm{mi}^{2} / \mathrm{yr}$ (table 22, fig. 17). Minimum yields ranged from 1.4 to $900 \mathrm{lb} / \mathrm{mi}^{2} / \mathrm{yr}$, median yields ranged from 12 to $1,900 \mathrm{lb} / \mathrm{mi}^{2} / \mathrm{yr}$, and maximum yields ranged from less than 100 to $16,000 \mathrm{lb} / \mathrm{mi}^{2} / \mathrm{yr}$. A maximum total phosphorus yield of more than $100,000 \mathrm{lb} / \mathrm{mi}^{2} / \mathrm{yr}$ was estimated for water year 1996, a year of extremely high streamflow, for Muddy Creek at Mount Clinton, Va., (table 21). This maximum has not been included in the summary statistics (table 22) and graph (fig. 17F) for reasons described in the section on Effects of Variability in Streamflow Conditions. 
Table 20. Summary statistics for total nitrogen yields by station, 1993-2003.

[Definitions for land-use codes are in table 7. Stations with drainage areas greater than or equal to 1,000 $\mathrm{mi}^{2}$ are shaded. Annual loads and yields for the Schuylkill River at Philadelphia, Pa. (station 97) based on load estimation for 1975-2003 period. $\mathrm{mi}^{2}$, square miles; $1 \mathrm{~b} / \mathrm{mi}^{2} / \mathrm{yr}$, pounds per square mile per year; NA, not available; UN, undeveloped; UR, urban; UA, urban/agricultural; AG, agricultural]

\begin{tabular}{|c|c|c|c|c|c|c|c|c|}
\hline \multirow{2}{*}{$\begin{array}{l}\text { Station } \\
\text { se- } \\
\text { quence } \\
\text { number }\end{array}$} & \multirow{2}{*}{ Station name } & \multirow{2}{*}{$\begin{array}{c}\text { Drainage } \\
\text { area } \\
\left(\mathrm{mi}^{2}\right)\end{array}$} & \multirow{2}{*}{$\begin{array}{c}\text { Num- } \\
\text { ber of } \\
\text { years of } \\
\text { record in } \\
1993-2003\end{array}$} & \multicolumn{4}{|c|}{$\begin{array}{l}\text { Total nitrogen yields } \\
\text { (lb/mi²/yr) }\end{array}$} & \multirow{2}{*}{$\begin{array}{l}\text { Land- } \\
\text { use } \\
\text { code }\end{array}$} \\
\hline & & & & $\begin{array}{l}\text { Mini- } \\
\text { mum }\end{array}$ & Mean & Median & $\begin{array}{l}\text { Maxi- } \\
\text { mum }\end{array}$ & \\
\hline 1 & Penobscot River at Eddington, Maine & 7,764 & 2 & NA & 1,600 & 1,600 & NA & $\mathrm{UN}$ \\
\hline 2 & Kennebec River at North Sidney, Maine & 5,403 & 1 & NA & 1,100 & 1,100 & NA & UN \\
\hline 3 & Wild River at Gilead, Maine & 69.6 & 3 & NA & 500 & 500 & NA & UN \\
\hline 4 & Saco River at Cornish, Maine & 1,293 & 3 & 330 & 500 & 580 & NA & UN \\
\hline 5 & Stillwater River near Sterling, Mass. & 31.6 & 5 & 620 & 1,100 & 1,200 & 1,600 & UN \\
\hline 6 & $\begin{array}{l}\text { Merrimack River below Concord River at } \\
\text { Lowell, Mass. }\end{array}$ & 4,635 & 5 & 1,700 & 2,400 & 2,400 & 2,900 & UR \\
\hline 7 & Aberjona River at Winchester, Mass. & 24.7 & 5 & 4,400 & 7,000 & 7,600 & 9,100 & UR \\
\hline 8 & $\begin{array}{l}\text { Charles River above Watertown Dam at } \\
\text { Watertown, Mass. }\end{array}$ & 271 & 1 & NA & 4,900 & 4,900 & NA & UR \\
\hline 10 & Pawtuxet River at Cranston, R.I. & 200 & 10 & 2,900 & 5,100 & 5,100 & 7,100 & UR \\
\hline 13 & Shetucket River at South Windham, Conn. & 408 & 11 & 1,200 & 2,200 & 2,400 & 2,800 & UR \\
\hline 14 & Quinebaug River at Quinebaug, Conn. & 155 & 11 & 1,200 & 1,800 & 2,000 & 2,300 & UR \\
\hline 16 & Quinebaug River at Putnam, Conn. & 328 & 5 & 1,700 & 2,400 & 2,400 & 3,300 & UR \\
\hline 18 & Quinebaug River at Jewett City, Conn. & 713 & 11 & 1,600 & 3,000 & 3,200 & 3,700 & UN \\
\hline 19 & Ammonoosuc River at Bethlehem Junction, N.H. & 87.6 & 2 & NA & 700 & 700 & NA & UN \\
\hline 20 & White River at West Hartford, Vt. & 690 & 3 & 800 & 1,100 & 1,200 & NA & UN \\
\hline 21 & Green River near Colrain, Mass. & 41.4 & 2 & NA & 620 & 620 & NA & UN \\
\hline 22 & Connecticut River at Thompsonville, Conn. & 9,660 & 11 & 1,700 & 2,200 & 2,200 & 2,900 & UN \\
\hline 23 & Broad Brook at Broad Brook, Conn. & 15.5 & 11 & 7,500 & 14,000 & 15,000 & 17,000 & UA \\
\hline 24 & Bunnell (Burlington) Brook near Burlington, Conn. & 4.10 & 11 & 730 & 1,300 & 1,400 & 1,700 & UN \\
\hline 25 & Farmington River at Unionville, Conn. & 378 & 11 & 610 & 1,100 & 1,100 & 1,400 & UN \\
\hline 27 & Farmington River at Tariffville, Conn. & 577 & 11 & 2,200 & 3,300 & 3,500 & 4,000 & UR \\
\hline 28 & Hockanum River near East Hartford, Conn. & 73.4 & 11 & 7,200 & 11,000 & 11,000 & 12,000 & UR \\
\hline 30 & Salmon River near East Hampton, Conn. & 100 & 11 & 780 & 1,500 & 1,500 & 2,400 & UR \\
\hline 32 & Quinnipiac River at Wallingford, Conn. & 115 & 11 & 6,600 & 10,000 & 11,000 & 12,000 & UR \\
\hline 37 & Housatonic River at Stevenson, Conn. & 1,544 & 11 & 1,200 & 2,500 & 2,600 & 3,600 & UR \\
\hline 39 & Naugatuck River at Beacon Falls, Conn. & 260 & 11 & 3,700 & 7,300 & 7,700 & 9,900 & UR \\
\hline 40 & Saugatuck River near Redding, Conn. & 21.0 & 11 & 810 & 1,400 & 1,400 & 2,000 & UR \\
\hline 41 & Norwalk River at Winnipauk, Conn. & 33.0 & 11 & 1,500 & 2,600 & 2,400 & 3,700 & UR \\
\hline 45 & Canajoharie Creek near Canajoharie, N.Y. & 59.7 & 10 & 1,900 & 5,700 & 5,800 & 9,400 & AG \\
\hline 46 & Lisha Kill northwest of Niskayuna, N.Y. & 15.6 & 5 & 770 & 1,600 & 1,500 & 2,900 & UR \\
\hline 47 & Mohawk River at Cohoes, N.Y. & 3,450 & 11 & 2,200 & 4,200 & 4,600 & 5,400 & AG \\
\hline 48 & Esopus Creek at Allaben, N.Y. & 63.7 & 2 & NA & 1,300 & 1,300 & NA & UN \\
\hline 50 & Hackensack River at Rivervale, N.J. & 58.0 & 11 & 1,400 & 2,900 & 3,100 & 3,800 & UR \\
\hline 53 & Pequannock River at Macopin Intake Dam, N.J. & 63.7 & 11 & 41 & 700 & 820 & 1,300 & $\mathrm{UN}$ \\
\hline 54 & Ramapo River near Mahwah, N.J. & 120 & 11 & 2,200 & 4,100 & 4,200 & 5,700 & UR \\
\hline
\end{tabular}


Table 20. Summary statistics for total nitrogen yields by station, 1993-2003.—Continued

[Definitions for land-use codes are in table 7. Stations with drainage areas greater than or equal to 1,000 $\mathrm{mi}^{2}$ are shaded. Annual loads and yields for the Schuylkill River at Philadelphia, Pa. (station 97) based on load estimation for 1975-2003 period. $\mathrm{mi}^{2}$, square miles; lb/mi²/yr, pounds per square mile per year; NA, not available; UN, undeveloped; UR, urban; UA, urban/agricultural; AG, agricultural]

\begin{tabular}{|c|c|c|c|c|c|c|c|c|}
\hline \multirow{2}{*}{$\begin{array}{l}\text { Station } \\
\text { se- } \\
\text { quence } \\
\text { number }\end{array}$} & \multirow{2}{*}{ Station name } & \multirow{2}{*}{$\begin{array}{c}\text { Drainage } \\
\text { area } \\
\left(\mathrm{mi}^{2}\right)\end{array}$} & \multirow{2}{*}{$\begin{array}{c}\text { Num- } \\
\text { ber of } \\
\text { years of } \\
\text { record in } \\
\text { 1993-2003 }\end{array}$} & \multicolumn{4}{|c|}{$\begin{array}{l}\text { Total nitrogen yields } \\
\left(\mathrm{lb} / \mathrm{mi}^{2} / \mathrm{yr}\right)\end{array}$} & \multirow{2}{*}{$\begin{array}{c}\text { Land- } \\
\text { use } \\
\text { code }\end{array}$} \\
\hline & & & & $\begin{array}{l}\text { Mini- } \\
\text { mum }\end{array}$ & Mean & Median & $\begin{array}{l}\text { Maxi- } \\
\text { mum }\end{array}$ & \\
\hline 55 & Passaic River at Little Falls, N.J. & 762 & 11 & 1,500 & 4,400 & 5,000 & 5,900 & UR \\
\hline 56 & Saddle River at Lodi, N.J. & 54.6 & 11 & 12,000 & 16,000 & 17,000 & 22,000 & UR \\
\hline 57 & Rahway River near Springfield, N.J. & 25.5 & 11 & 2,700 & 5,700 & 5,700 & 8,200 & UR \\
\hline 58 & Rahway River at Rahway, N.J. & 40.9 & 11 & 2,000 & 4,800 & 5,000 & 7,800 & UR \\
\hline 59 & Mulhockaway Creek at Van Syckel, N.J. & 11.8 & 11 & 1,500 & 3,300 & 3,100 & 5,500 & AG \\
\hline 60 & South Branch Raritan River at Stanton, N.J. & 147 & 5 & 3,300 & 6,500 & 7,200 & 7,600 & UA \\
\hline 61 & Neshanic River at Reaville, N.J. & 25.7 & 11 & 2,400 & 7,600 & 7,900 & 12,000 & $\mathrm{AG}$ \\
\hline 62 & Lamington (Black) River near Pottersville, N.J. & 32.8 & 5 & 2,600 & 4,300 & 4,700 & 4,800 & UR \\
\hline 64 & North Branch Raritan River near Raritan, N.J. & 190 & 6 & 2,100 & 3,500 & 3,400 & 4,700 & UA \\
\hline 65 & Raritan River at Manville, N.J. & 490 & 5 & 3,300 & 7,500 & 8,500 & 9,300 & UA \\
\hline 66 & Stony Brook at Princeton, N.J. & 44.5 & 6 & 1,900 & 6,000 & 6,400 & 8,600 & UA \\
\hline 67 & Millstone River at Blackwells Mills, N.J. & 258 & 11 & 4,200 & 7,700 & 8,000 & 10,000 & UA \\
\hline 68 & Raritan River at Queens Bridge at Bound Brook, N.J. & 804 & 11 & 3,000 & 6,500 & 6,700 & 9,000 & UA \\
\hline 70 & Manasquan River at Squankum, N.J. & 44.0 & 11 & 930 & 2,900 & 3,500 & 5,100 & UA \\
\hline 71 & Toms River near Toms River, N.J. & 123 & 11 & 2,100 & 2,800 & 2,900 & 3,600 & UR \\
\hline 75 & Batsto River at Batsto, N.J. & 67.8 & 11 & 460 & 1,300 & 1,600 & 1,900 & UN \\
\hline 78 & Maurice River at Norma, N.J. & 112 & 11 & 2,700 & 4,700 & 4,800 & 6,500 & UA \\
\hline 80 & Delaware River at Port Jervis, N.Y. & 3,070 & 3 & 900 & 1,400 & 1,400 & NA & UN \\
\hline 81 & Biscuit Brook above Pigeon Brook at Frost Valley, N.Y. & 3.72 & 3 & NA & 2,200 & 2,200 & NA & UN \\
\hline 82 & Delaware River at Montague, N.J. & 3,480 & 11 & 990 & 2,400 & 2,400 & 4,500 & UN \\
\hline 85 & Paulins Kill at Blairstown, N.J. & 126 & 11 & 1,100 & 3,400 & 3,200 & 5,000 & $\mathrm{AG}$ \\
\hline 86 & Jordan Creek near Schnecksville, Pa. & 53.0 & 3 & 9,400 & 12,000 & 12,000 & NA & $\mathrm{AG}$ \\
\hline 90 & Delaware River at Trenton, N.J. & 6,780 & 11 & 2,400 & 4,600 & 4,800 & 6,400 & UN \\
\hline 92 & $\begin{array}{l}\text { Little Neshaminy Creek at Valley Road near } \\
\text { Neshaminy, Pa. }\end{array}$ & 26.8 & 4 & 2,300 & 6,000 & 6,600 & 8,300 & UA \\
\hline 93 & McDonalds Branch in Byrne State Forest, N.J. & 2.35 & 3 & NA & 290 & 290 & NA & UN \\
\hline 95 & Cooper River at Haddonfield, N.J. & 17.0 & 11 & 2,100 & 3,900 & 3,800 & 6,400 & UR \\
\hline 96 & French Creek near Phoenixville, Pa. & 59.1 & 5 & 1,500 & 4,400 & 4,100 & 8,300 & AG \\
\hline 97 & Schuylkill River at Philadelphia, Pa. & 1,893 & 11 & 5,300 & 11,000 & 11,000 & 16,000 & UA \\
\hline 98 & Raccoon Creek near Swedesboro, N.J. & 26.9 & 11 & 2,500 & 5,200 & 5,100 & 7,300 & $\mathrm{AG}$ \\
\hline 100 & Nanticoke River near Bridgeville, Del. & 75.4 & 4 & 8,400 & 13,000 & 13,000 & 15,000 & AG \\
\hline 101 & Choptank River near Greensboro, Md. & 113 & 11 & 1,400 & 4,600 & 4,900 & 9,300 & AG \\
\hline 102 & Chesterville Branch near Crumpton, Md. & 6.12 & 6 & 9,800 & 14,000 & 15,000 & 17,000 & $\mathrm{AG}$ \\
\hline 103 & Susquehanna River at Danville, $\mathrm{Pa}$. & 11,220 & 3 & 2,500 & 4,500 & NA & 5,600 & $\mathrm{AG}$ \\
\hline 104 & Young Womans Creek near Renovo, Pa. & 46.2 & 3 & NA & 1,700 & 1,700 & NA & UN \\
\hline 105 & West Branch Susquehanna River at Lewisburg, Pa. & 6,847 & 3 & 2,000 & 3,500 & NA & 4,300 & UN \\
\hline
\end{tabular}


Table 20. Summary statistics for total nitrogen yields by station, 1993-2003.—Continued

[Definitions for land-use codes are in table 7. Stations with drainage areas greater than or equal to 1,000 $\mathrm{mi}^{2}$ are shaded. Annual loads and yields for the Schuylkill River at Philadelphia, Pa. (station 97) based on load estimation for 1975-2003 period. $\mathrm{mi}^{2}$, square miles; lb/mi²/yr, pounds per square mile per year; NA, not available; UN, undeveloped; UR, urban; UA, urban/agricultural; AG, agricultural]

\begin{tabular}{|c|c|c|c|c|c|c|c|c|}
\hline \multirow{2}{*}{$\begin{array}{c}\text { Station } \\
\text { se- } \\
\text { quence } \\
\text { number }\end{array}$} & \multirow{2}{*}{ Station name } & \multirow{2}{*}{$\begin{array}{c}\text { Drainage } \\
\text { area } \\
\left(\mathrm{mi}^{2}\right)\end{array}$} & \multirow{2}{*}{$\begin{array}{c}\text { Num- } \\
\text { ber of } \\
\text { years of } \\
\text { record in } \\
\text { 1993-2003 }\end{array}$} & \multicolumn{4}{|c|}{$\begin{array}{l}\text { Total nitrogen yields } \\
\left(\mathrm{lb} / \mathrm{mi}^{2} / \mathrm{yr}\right)\end{array}$} & \multirow{2}{*}{$\begin{array}{c}\text { Land- } \\
\text { use } \\
\text { code }\end{array}$} \\
\hline & & & & $\begin{array}{l}\text { Mini- } \\
\text { mum }\end{array}$ & Mean & Median & $\begin{array}{c}\text { Maxi- } \\
\text { mum }\end{array}$ & \\
\hline 106 & East Mahantango Creek at Klingerstown, $\mathrm{Pa}$. & 44.7 & 4 & 15,000 & 25,000 & 26,000 & 32,000 & $\mathrm{AG}$ \\
\hline 107 & Bobs Creek near Pavia, $\mathrm{Pa}$. & 16.6 & 3 & 2,200 & 3,000 & 2,700 & 3,900 & UN \\
\hline 108 & Cedar Run at Eberlys Mill, Pa. & 12.6 & 2 & 7,000 & 11,000 & 11,000 & 14,000 & UA \\
\hline 111 & Susquehanna River at Conowingo, Md. & 27,100 & 11 & 2,600 & 4,600 & 5,200 & 6,500 & $\mathrm{AG}$ \\
\hline 112 & Patuxent River near Unity, Md. & 34.8 & 9 & 2,800 & 6,800 & 7,100 & 11,000 & AG \\
\hline 113 & Little Patuxent River at Savage, Md. & 98.4 & 8 & 3,300 & 6,600 & 7,300 & 9,400 & UA \\
\hline 114 & Patuxent River near Bowie, Md. & 348 & 11 & 2,000 & 4,300 & 4,700 & 6,700 & UA \\
\hline 115 & $\begin{array}{l}\text { South Fork South Branch Potomac River near } \\
\text { Moorefield, W. Va. }\end{array}$ & 277 & 2 & NA & 2,100 & 2,100 & NA & UN \\
\hline 116 & Conococheague Creek at Fairview, Md. & 494 & 11 & 3,100 & 13,000 & 13,000 & 22,000 & $\mathrm{AG}$ \\
\hline 117 & Potomac River at Shepherdstown, W. Va. & 5,939 & 3 & 1,300 & 3,400 & 2,200 & 6,700 & AG \\
\hline 118 & Muddy Creek at Mount Clinton, Va. & 14.3 & 8 & 2,100 & 9,200 & 8,500 & 19,000 & AG \\
\hline 119 & South Fork Shenandoah River at Front Royal, Va. & 1,634 & 7 & 530 & 3,300 & 2,000 & 7,500 & $\mathrm{AG}$ \\
\hline 120 & North Fork Shenandoah River near Strasburg, Va. & 770 & 7 & 1,200 & 3,600 & 2,700 & 7,100 & $\mathrm{AG}$ \\
\hline 121 & Shenandoah River at Millville, W. Va. & 3,041 & 3 & 2,200 & 4,100 & 4,900 & 5,100 & AG \\
\hline 122 & Potomac River at Chain Bridge, at Washington, D.C. & 11,570 & 11 & 1,000 & 4,700 & 5,100 & 8,400 & AG \\
\hline 123 & Accotink Creek near Annandale, Va. & 23.9 & 9 & 2,700 & 6,100 & 6,400 & 8,900 & UR \\
\hline 124 & Rappahannock River near Fredericksburg, Va. & 1,595 & 11 & 410 & 3,300 & 2,700 & 7,400 & AG \\
\hline 125 & Pamunkey River near Hanover, Va. & 1,078 & 11 & 200 & 1,500 & 1,700 & 3,000 & $\mathrm{AG}$ \\
\hline 126 & Mattaponi River near Beulahville, Va. & 603 & 11 & 150 & 1,000 & 1,200 & 2,000 & UN \\
\hline 127 & James River at Cartersville, Va. & 6,252 & 11 & 310 & 1,900 & 1,800 & 4,200 & UN \\
\hline 128 & Holiday Creek near Andersonville, Va. & 8.54 & 3 & NA & 430 & 430 & NA & $\mathrm{UN}$ \\
\hline 129 & Appomattox River at Matoaca, Va. & 1,342 & 11 & 220 & 1,200 & 1,200 & 3,200 & UN \\
\hline 130 & Black River at Coventry, Vt. & 122 & 2 & 1,500 & 1,700 & 1,700 & NA & $\mathrm{AG}$ \\
\hline
\end{tabular}


Table 21. Summary statistics for total phosphorus yields by station, 1993-2003.

[Definitions for land-use codes are in table 7. Stations with drainage areas greater than or equal to 1,000 $\mathrm{mi}^{2}$ are shaded. Annual loads and yields for the Schuylkill River at Philadelphia, Pa. (station 97) based on load estimation for 1975-2003 period. $\mathrm{mi}^{2}$, square miles; lb/mi²/yr, pounds per square mile per year; NA, not available; UN, undeveloped; UR, urban; UA, urban/agricultural; AG, agricultural]

\begin{tabular}{|c|c|c|c|c|c|c|c|c|}
\hline \multirow{2}{*}{$\begin{array}{c}\text { Station } \\
\text { se- } \\
\text { quence } \\
\text { number }\end{array}$} & \multirow{2}{*}{ Station name } & \multirow{2}{*}{$\begin{array}{c}\text { Drainage } \\
\text { area } \\
\left(\mathrm{mi}^{2}\right)\end{array}$} & \multirow{2}{*}{$\begin{array}{c}\text { Num- } \\
\text { ber of } \\
\text { years of } \\
\text { record in } \\
\text { 1993-2003 }\end{array}$} & \multicolumn{4}{|c|}{$\begin{array}{l}\text { Total phosphorus yields } \\
\left(\mathrm{lb} / \mathrm{mi}^{2} / \mathrm{yr}\right)\end{array}$} & \multirow{2}{*}{$\begin{array}{l}\text { Land- } \\
\text { use } \\
\text { code }\end{array}$} \\
\hline & & & & $\begin{array}{l}\text { Mini- } \\
\text { mum }\end{array}$ & Mean & Median & $\begin{array}{c}\text { Maxi- } \\
\text { mum }\end{array}$ & \\
\hline 1 & Penobscot River at Eddington, Maine & 7,764 & 2 & NA & 91 & 91 & NA & UN \\
\hline 2 & Kennebec River at North Sidney, Maine & 5,403 & 1 & NA & 130 & 130 & NA & UN \\
\hline 3 & Wild River at Gilead, Maine & 69.6 & 3 & NA & 43 & 43 & NA & UN \\
\hline 4 & Saco River at Cornish, Maine & 1,293 & 3 & 48 & 62 & 63 & NA & UN \\
\hline 5 & Stillwater River near Sterling, Mass. & 31.6 & 5 & 27 & 52 & 56 & 74 & $\mathrm{UN}$ \\
\hline 6 & $\begin{array}{l}\text { Merrimack River below Concord River at } \\
\text { Lowell, Mass. }\end{array}$ & 4,635 & 5 & 140 & 210 & 220 & 280 & UR \\
\hline 7 & Aberjona River at Winchester, Mass. & 24.7 & 5 & 69 & 140 & 140 & 230 & UR \\
\hline 8 & $\begin{array}{l}\text { Charles River above Watertown Dam at } \\
\text { Watertown, Mass. }\end{array}$ & 271 & 1 & NA & 210 & 210 & NA & UR \\
\hline 10 & Pawtuxet River at Cranston, R.I. & 200 & 10 & 370 & 550 & 550 & 720 & UR \\
\hline 13 & Shetucket River at South Windham, Conn. & 408 & 11 & 68 & 110 & 110 & 150 & UR \\
\hline 14 & Quinebaug River at Quinebaug, Conn. & 155 & 11 & 64 & 100 & 100 & 170 & UR \\
\hline 16 & Quinebaug River at Putnam, Conn. & 328 & 5 & 89 & 130 & 120 & 200 & UR \\
\hline 18 & Quinebaug River at Jewett City, Conn. & 713 & 11 & 100 & 180 & 180 & 350 & UN \\
\hline 19 & Ammonoosuc River at Bethlehem Junction, N.H. & 87.6 & 2 & NA & 35 & 35 & NA & UN \\
\hline 21 & Green River near Colrain, Mass. & 41.4 & 2 & NA & 46 & 46 & NA & $\mathrm{UN}$ \\
\hline 22 & Connecticut River at Thompsonville, Conn. & 9,660 & 11 & 120 & 190 & 190 & 280 & UN \\
\hline 23 & Broad Brook at Broad Brook, Conn. & 15.5 & 11 & 150 & 490 & 510 & 820 & UA \\
\hline 24 & Bunnell (Burlington) Brook near Burlington, Conn. & 4.10 & 11 & 25 & 62 & 63 & 83 & UN \\
\hline 25 & Farmington River at Unionville, Conn. & 378 & 11 & 26 & 51 & 53 & 67 & UN \\
\hline 27 & Farmington River at Tariffville, Conn. & 577 & 11 & 230 & 310 & 310 & 450 & UR \\
\hline 28 & Hockanum River near East Hartford, Conn. & 73.4 & 11 & 730 & 1,000 & 1,000 & 1,200 & UR \\
\hline 30 & Salmon River near East Hampton, Conn. & 100 & 11 & 23 & 54 & 43 & 110 & UR \\
\hline 32 & Quinnipiac River at Wallingford, Conn. & 115 & 11 & 550 & 1,000 & 1,100 & 1,500 & UR \\
\hline 37 & Housatonic River at Stevenson, Conn. & 1,544 & 11 & 50 & 110 & 110 & 150 & UR \\
\hline 39 & Naugatuck River at Beacon Falls, Conn. & 260 & 11 & 720 & 1,200 & 1,300 & 1,600 & UR \\
\hline 40 & Saugatuck River near Redding, Conn. & 21.0 & 11 & 30 & 55 & 55 & 75 & UR \\
\hline 41 & Norwalk River at Winnipauk, Conn. & 33.0 & 11 & 64 & 130 & 120 & 220 & UR \\
\hline 45 & Canajoharie Creek near Canajoharie, N.Y. & 59.7 & 10 & 75 & 580 & 540 & 1,100 & AG \\
\hline 46 & Lisha Kill northwest of Niskayuna, N.Y. & 15.6 & 5 & 32 & 86 & 68 & 190 & UR \\
\hline 47 & Mohawk River at Cohoes, N.Y. & 3,450 & 11 & 110 & 380 & 420 & 540 & AG \\
\hline 48 & Esopus Creek at Allaben, N.Y. & 63.7 & 2 & NA & 140 & 140 & NA & UN \\
\hline 50 & Hackensack River at Rivervale, N.J. & 58.0 & 11 & 90 & 140 & 120 & 260 & UR \\
\hline 53 & Pequannock River at Macopin Intake Dam, N.J. & 63.7 & 11 & 1.4 & 38 & 32 & 77 & UN \\
\hline 54 & Ramapo River near Mahwah, N.J. & 120 & 11 & 190 & 340 & 350 & 480 & UR \\
\hline 55 & Passaic River at Little Falls, N.J. & 762 & 11 & 210 & 520 & 530 & 690 & UR \\
\hline
\end{tabular}


Table 21. Summary statistics for total phosphorus yields by station, 1993-2003.—Continued

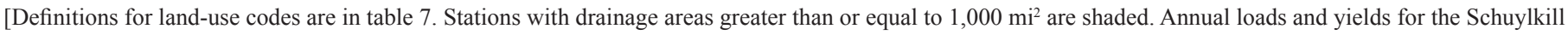

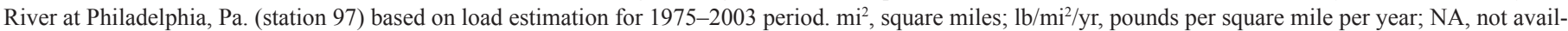
able; UN, undeveloped; UR, urban; UA, urban/agricultural; AG, agricultural]

\begin{tabular}{|c|c|c|c|c|c|c|c|c|}
\hline \multirow{2}{*}{$\begin{array}{l}\text { Station } \\
\text { se- } \\
\text { quence } \\
\text { number }\end{array}$} & \multirow{2}{*}{ Station name } & \multirow{2}{*}{$\begin{array}{c}\text { Drainage } \\
\text { area } \\
\left(\mathrm{mi}^{2}\right)\end{array}$} & \multirow{2}{*}{$\begin{array}{c}\text { Num- } \\
\text { ber of } \\
\text { years of } \\
\text { record in } \\
\text { 1993-2003 }\end{array}$} & \multicolumn{4}{|c|}{$\begin{array}{c}\text { Total phosphorus yields } \\
\left(\mathrm{lb} / \mathrm{mi}^{2} / \mathrm{yr}\right)\end{array}$} & \multirow{2}{*}{$\begin{array}{c}\text { Land- } \\
\text { use } \\
\text { code }\end{array}$} \\
\hline & & & & $\begin{array}{l}\text { Mini- } \\
\text { mum }\end{array}$ & Mean & Median & $\begin{array}{l}\text { Maxi- } \\
\text { mum }\end{array}$ & \\
\hline 56 & Saddle River at Lodi, N.J. & 54.6 & 11 & 900 & 1,800 & 1,900 & 2,600 & UR \\
\hline 57 & Rahway River near Springfield, N.J. & 25.5 & 11 & 200 & 1,500 & 800 & 6,300 & UR \\
\hline 58 & Rahway River at Rahway, N.J. & 40.9 & 11 & 160 & 490 & 380 & 1,100 & UR \\
\hline 59 & Mulhockaway Creek at Van Syckel, N.J. & 11.8 & 11 & 40 & 110 & 94 & 180 & $\mathrm{AG}$ \\
\hline 60 & South Branch Raritan River at Stanton, N.J. & 147 & 5 & 82 & 190 & 140 & 400 & UA \\
\hline 61 & Neshanic River at Reaville, N.J. & 25.7 & 11 & 120 & 2,600 & 1,000 & 16,000 & $\mathrm{AG}$ \\
\hline 62 & Lamington (Black) River near Pottersville, N.J. & 32.8 & 5 & 76 & 140 & 160 & 180 & UR \\
\hline 64 & North Branch Raritan River near Raritan, N.J. & 190 & 6 & 150 & 320 & 260 & 700 & UA \\
\hline 65 & Raritan River at Manville, N.J. & 490 & 5 & 130 & 320 & 350 & 420 & UA \\
\hline 66 & Stony Brook at Princeton, N.J. & 44.5 & 6 & 120 & 590 & 580 & 980 & UA \\
\hline 67 & Millstone River at Blackwells Mills, N.J. & 258 & 11 & 410 & 840 & 860 & 1,300 & UA \\
\hline 68 & Raritan River at Queens Bridge at Bound Brook, N.J. & 804 & 11 & 290 & 710 & 610 & 1,900 & UA \\
\hline 70 & Manasquan River at Squankum, N.J. & 44.0 & 11 & 89 & 290 & 250 & 670 & UA \\
\hline 71 & Toms River near Toms River, N.J. & 123 & 11 & 38 & 75 & 71 & 170 & UR \\
\hline 75 & Batsto River at Batsto, N.J. & 67.8 & 11 & 14 & 39 & 23 & 120 & $\mathrm{UN}$ \\
\hline 78 & Maurice River at Norma, N.J. & 112 & 11 & 23 & 55 & 54 & 91 & UA \\
\hline 80 & Delaware River at Port Jervis, N.Y. & 3,070 & 3 & 48 & 89 & 100 & NA & UN \\
\hline 81 & Biscuit Brook above Pigeon Brook at Frost Valley, N.Y. & 3.72 & 3 & NA & 48 & 48 & NA & UN \\
\hline 82 & Delaware River at Montague, N.J. & 3,480 & 11 & 37 & 130 & 97 & 290 & UN \\
\hline 85 & Paulins Kill at Blairstown, N.J. & 126 & 11 & 44 & 120 & 120 & 230 & AG \\
\hline 86 & Jordan Creek near Schnecksville, Pa. & 53.0 & 3 & 150 & 200 & 200 & NA & $\mathrm{AG}$ \\
\hline 90 & Delaware River at Trenton, N.J. & 6,780 & 11 & 160 & 340 & 330 & 580 & UN \\
\hline 92 & $\begin{array}{l}\text { Little Neshaminy Creek at Valley Road near } \\
\text { Neshaminy, Pa. }\end{array}$ & 26.8 & 4 & 170 & 680 & 690 & 1,200 & UA \\
\hline 93 & McDonalds Branch in Byrne State Forest, N.J. & 2.35 & 3 & NA & 12 & 12 & NA & UN \\
\hline 95 & Cooper River at Haddonfield, N.J. & 17.0 & 11 & 560 & 1,200 & 1,100 & 2,100 & UR \\
\hline 96 & French Creek near Phoenixville, Pa. & 59.1 & 5 & 43 & 260 & 200 & 590 & $\mathrm{AG}$ \\
\hline 97 & Schuylkill River at Philadelphia, Pa. & 1,893 & 11 & 390 & 710 & 680 & 1,000 & UA \\
\hline 98 & Raccoon Creek near Swedesboro, N.J. & 26.9 & 11 & 190 & 580 & 610 & 1,000 & $\mathrm{AG}$ \\
\hline 100 & Nanticoke River near Bridgeville, Del. & 75.4 & 4 & 280 & 520 & 570 & 640 & $\mathrm{AG}$ \\
\hline 101 & Choptank River near Greensboro, Md. & 113 & 11 & 67 & 330 & 290 & 1,000 & AG \\
\hline 102 & Chesterville Branch near Crumpton, Md. & 6.12 & 6 & 98 & 480 & 510 & 860 & $\mathrm{AG}$ \\
\hline 103 & Susquehanna River at Danville, $\mathrm{Pa}$. & 11,220 & 3 & 120 & 320 & NA & 460 & $\mathrm{AG}$ \\
\hline 104 & Young Womans Creek near Renovo, Pa. & 46.2 & 3 & NA & 34 & 34 & NA & UN \\
\hline 105 & West Branch Susquehanna River at Lewisburg, Pa. & 6,847 & 3 & 110 & 250 & NA & 320 & UN \\
\hline 106 & East Mahantango Creek at Klingerstown, Pa. & 44.7 & 4 & 170 & 220 & 220 & 270 & $\mathrm{AG}$ \\
\hline
\end{tabular}


Table 21. Summary statistics for total phosphorus yields by station, 1993-2003.-Continued

[Definitions for land-use codes are in table 7. Stations with drainage areas greater than or equal to 1,000 $\mathrm{mi}^{2}$ are shaded. Annual loads and yields for the Schuylkill River at Philadelphia, Pa. (station 97) based on load estimation for 1975-2003 period. $\mathrm{mi}^{2}$, square miles; lb/mi²/yr, pounds per square mile per year; NA, not available; UN, undeveloped; UR, urban; UA, urban/agricultural; AG, agricultural]

\begin{tabular}{|c|c|c|c|c|c|c|c|c|}
\hline \multirow{2}{*}{$\begin{array}{l}\text { Station } \\
\text { se- } \\
\text { quence } \\
\text { number }\end{array}$} & \multirow{2}{*}{ Station name } & \multirow{2}{*}{$\begin{array}{c}\text { Drainage } \\
\text { area } \\
\left(\mathrm{mi}^{2}\right)\end{array}$} & \multirow{2}{*}{$\begin{array}{c}\text { Num- } \\
\text { ber of } \\
\text { years of } \\
\text { record in } \\
\text { 1993-2003 }\end{array}$} & \multicolumn{4}{|c|}{$\begin{array}{c}\text { Total phosphorus yields } \\
\text { (lb/mi2/yr) }\end{array}$} & \multirow{2}{*}{$\begin{array}{c}\text { Land- } \\
\text { use } \\
\text { code }\end{array}$} \\
\hline & & & & $\begin{array}{l}\text { Mini- } \\
\text { mum }\end{array}$ & Mean & Median & $\begin{array}{l}\text { Maxi- } \\
\text { mum }\end{array}$ & \\
\hline 107 & Bobs Creek near Pavia, $\mathrm{Pa}$. & 16.6 & 3 & 39 & 58 & 52 & 84 & $\mathrm{UN}$ \\
\hline 108 & Cedar Run at Eberlys Mill, Pa. & 12.6 & 2 & 68 & 130 & 130 & 190 & UA \\
\hline 111 & Susquehanna River at Conowingo, Md. & 27,100 & 11 & 71 & 160 & 190 & 270 & $\mathrm{AG}$ \\
\hline 112 & Patuxent River near Unity, Md. & 34.8 & 9 & 60 & 320 & 200 & 1,100 & AG \\
\hline 113 & Little Patuxent River at Savage, Md. & 98.4 & 8 & 180 & 1,400 & 1,300 & 3,000 & UA \\
\hline 114 & Patuxent River near Bowie, Md. & 348 & 11 & 130 & 330 & 280 & 890 & UA \\
\hline 115 & $\begin{array}{l}\text { South Fork South Branch Potomac River near } \\
\text { Moorefield, W. Va. }\end{array}$ & 277 & 2 & NA & 72 & 72 & NA & $\mathrm{UN}$ \\
\hline 116 & Conococheague Creek at Fairview, Md. & 494 & 11 & 110 & 630 & 590 & 1,300 & AG \\
\hline 117 & Potomac River at Shepherdstown, W. Va. & 5,939 & 3 & 92 & 200 & 100 & 420 & $\mathrm{AG}$ \\
\hline 118 & Muddy Creek at Mount Clinton, Va. & 14.3 & 8 & 68 & 14,000 & 500 & 110,000 & AG \\
\hline 119 & South Fork Shenandoah River at Front Royal, Va. & 1,634 & 7 & 85 & 280 & 220 & 550 & AG \\
\hline 120 & North Fork Shenandoah River near Strasburg, Va. & 770 & 7 & 130 & 340 & 280 & 630 & $\mathrm{AG}$ \\
\hline 121 & Shenandoah River at Millville, W. Va. & 3,041 & 3 & 130 & 250 & 310 & 320 & AG \\
\hline 122 & Potomac River at Chain Bridge, at Washington, D.C. & 11,570 & 11 & 61 & 330 & 280 & 870 & $\mathrm{AG}$ \\
\hline 123 & Accotink Creek near Annandale, Va. & 23.9 & 9 & 160 & 880 & 980 & 1,800 & UR \\
\hline 124 & Rappahannock River near Fredericksburg, Va. & 1,595 & 11 & 24 & 610 & 630 & 1,500 & $\mathrm{AG}$ \\
\hline 125 & Pamunkey River near Hanover, Va. & 1,078 & 11 & 29 & 180 & 190 & 440 & AG \\
\hline 126 & Mattaponi River near Beulahville, Va. & 603 & 11 & 12 & 99 & 120 & 180 & UN \\
\hline 127 & James River at Cartersville, Va. & 6,252 & 11 & 61 & 380 & 320 & 860 & UN \\
\hline 128 & Holiday Creek near Andersonville, Va. & 8.54 & 3 & NA & 45 & 45 & NA & UN \\
\hline 129 & Appomattox River at Matoaca, Va. & 1,342 & 11 & 16 & 130 & 120 & 350 & UN \\
\hline 130 & Black River at Coventry, Vt. & 122 & 2 & 140 & 220 & 220 & NA & AG \\
\hline
\end{tabular}


Table 22. Summary statistics for total nitrogen and total phosphorus yields for all stations and for four land-use categories, 1993-2003.

[Definitions for land-use categories are in table $7.1 \mathrm{~b} / \mathrm{mi}^{2} / \mathrm{yr}$, pounds per square mile per year]

\begin{tabular}{|c|c|c|c|c|}
\hline & \multirow{2}{*}{$\begin{array}{l}\text { Number of } \\
\text { stations }\end{array}$} & \multicolumn{3}{|c|}{$\begin{array}{c}\text { Yield } \\
\text { (lb/mi²/yr) }\end{array}$} \\
\hline & & Minimum & Median & Maximum \\
\hline \multicolumn{5}{|c|}{ All basins } \\
\hline Minimum total nitrogen yields & 81 & 41 & 2,000 & 15,000 \\
\hline Median total nitrogen yields & 91 & 290 & 3,400 & 26,000 \\
\hline Maximum total nitrogen yields & 76 & 1,300 & 6,400 & 32,000 \\
\hline Minimum total phosphorus yields & 80 & 1.4 & 91 & 900 \\
\hline Median total phosphorus yields & 90 & 12 & 200 & 1,900 \\
\hline Maximum total phosphorus yields & 75 & 67 & 460 & 16,000 \\
\hline \multicolumn{5}{|c|}{ Undeveloped basins } \\
\hline Minimum total nitrogen yields & 17 & 41 & 730 & 2,400 \\
\hline Median total nitrogen yields & 27 & 290 & 1,300 & 4,800 \\
\hline Maximum total nitrogen yields & 14 & 1,300 & 3,100 & 6,400 \\
\hline Minimum total phosphorus yields & 16 & 1.4 & 38 & 160 \\
\hline Median total phosphorus yields & 26 & 12 & 63 & 330 \\
\hline Maximum total phosphorus yields & 14 & 67 & 230 & 860 \\
\hline \multicolumn{5}{|c|}{ Urban basins } \\
\hline Minimum total nitrogen yields & 25 & 770 & 2,100 & 12,000 \\
\hline Median total nitrogen yields & 26 & 1,400 & 4,000 & 17,000 \\
\hline Maximum total nitrogen yields & 25 & 2,000 & 4,800 & 22,000 \\
\hline Minimum total phosphorus yields & 25 & 23 & 140 & 900 \\
\hline Median total phosphorus yields & 26 & 43 & 210 & 1,900 \\
\hline Maximum total phosphorus yields & 25 & 75 & 280 & 6,300 \\
\hline \multicolumn{5}{|c|}{ Urban/agricultural basins } \\
\hline Minimum total nitrogen yields & 14 & 930 & 3,100 & 7,500 \\
\hline Median total nitrogen yields & 14 & 3,400 & 7,000 & 15,000 \\
\hline Maximum total nitrogen yields & 14 & 4,700 & 8,800 & 17,000 \\
\hline Minimum total phosphorus yields & 14 & 23 & 140 & 410 \\
\hline Median total phosphorus yields & 14 & 54 & 430 & 1,300 \\
\hline Maximum total phosphorus yields & 14 & 91 & 850 & 3,000 \\
\hline \multicolumn{5}{|c|}{ Agricultural basins } \\
\hline Minimum total nitrogen yields & 25 & 200 & 2,100 & 15,000 \\
\hline Median total nitrogen yields & 24 & 1,700 & 5,000 & 26,000 \\
\hline Maximum total nitrogen yields & 23 & 3,000 & 7,500 & 32,000 \\
\hline Minimum total phosphorus yields & 25 & 24 & 92 & 280 \\
\hline Median total phosphorus yields & 24 & 94 & 280 & 1,000 \\
\hline Maximum total phosphorus yields & 22 & 180 & 610 & 16,000 \\
\hline
\end{tabular}




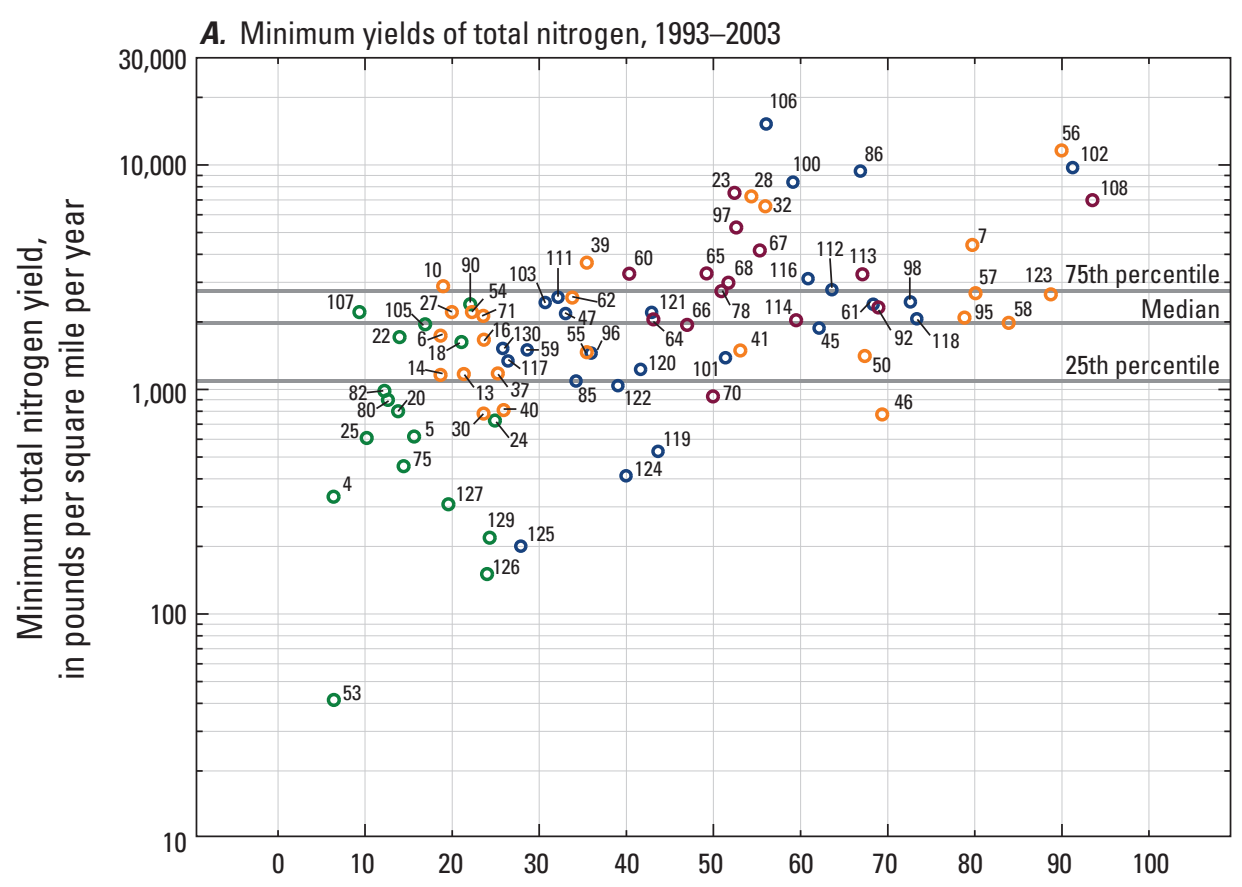

\section{EXPLANATION}

- Agricultural basin

- Urban/agricultural basin

- Undeveloped basin

- Urban basin

32 Station sequence number

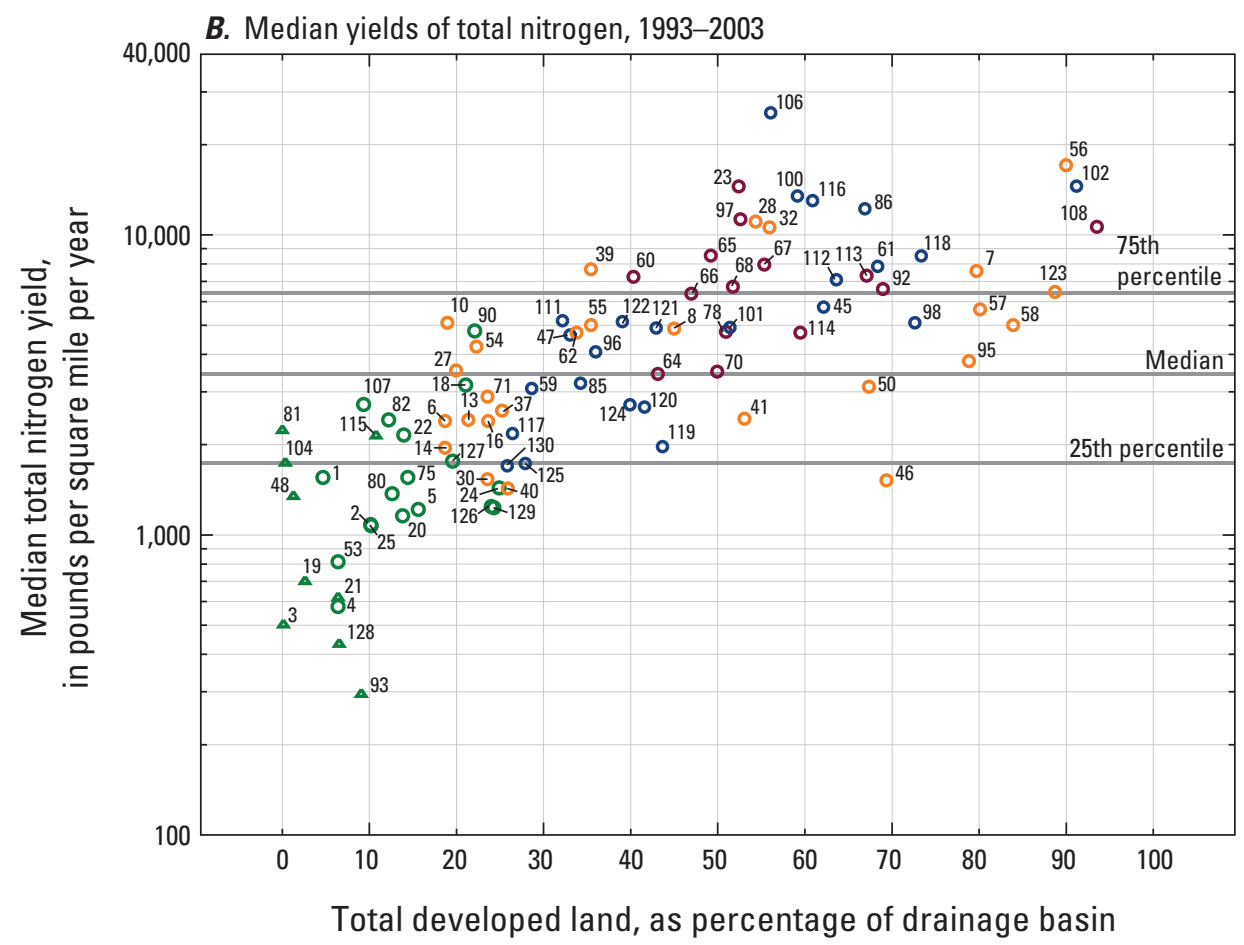

\section{EXPLANATION}

- Northeastern region study site

$\Delta$ Undeveloped basin (mean from national study)

- Agricultural basin

- Urban/agricultural basin

- Undeveloped basin

○ Urban basin

19 Station sequence number

Figure 17. Ranges for minimum, median, and maximum nutrient yields in relation to the percentage of developed land in a drainage basin. (A) Minimum yields of total nitrogen for 81 stations, 1993-2003, (B) median yields of total nitrogen for 91 stations, 1993-2003, (C) maximum yields of total nitrogen for 76 stations, 1993-2003, (D) minimum yields of total phosphorus for 80 stations, 1993-2003, (E) median yields of total phosphorus for 90 stations, 1993-2003, and (F) maximum yields of total phosphorus for 75 stations, 1993-2003. 


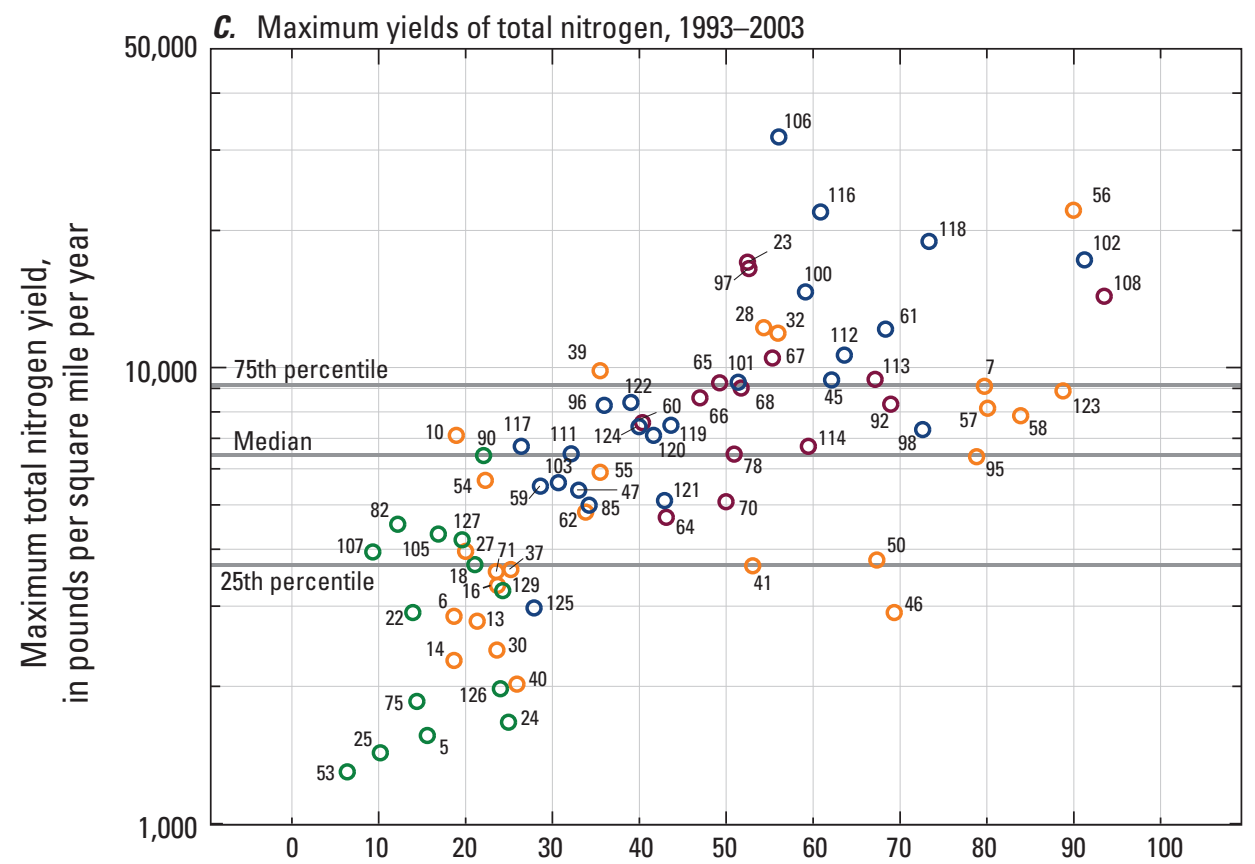

\section{EXPLANATION}

- Agricultural basin

○ Urban/agricultural basin

○ Undeveloped basin

○ Urban basin
D. Minimum yields for total phosphorus, 1993-2003

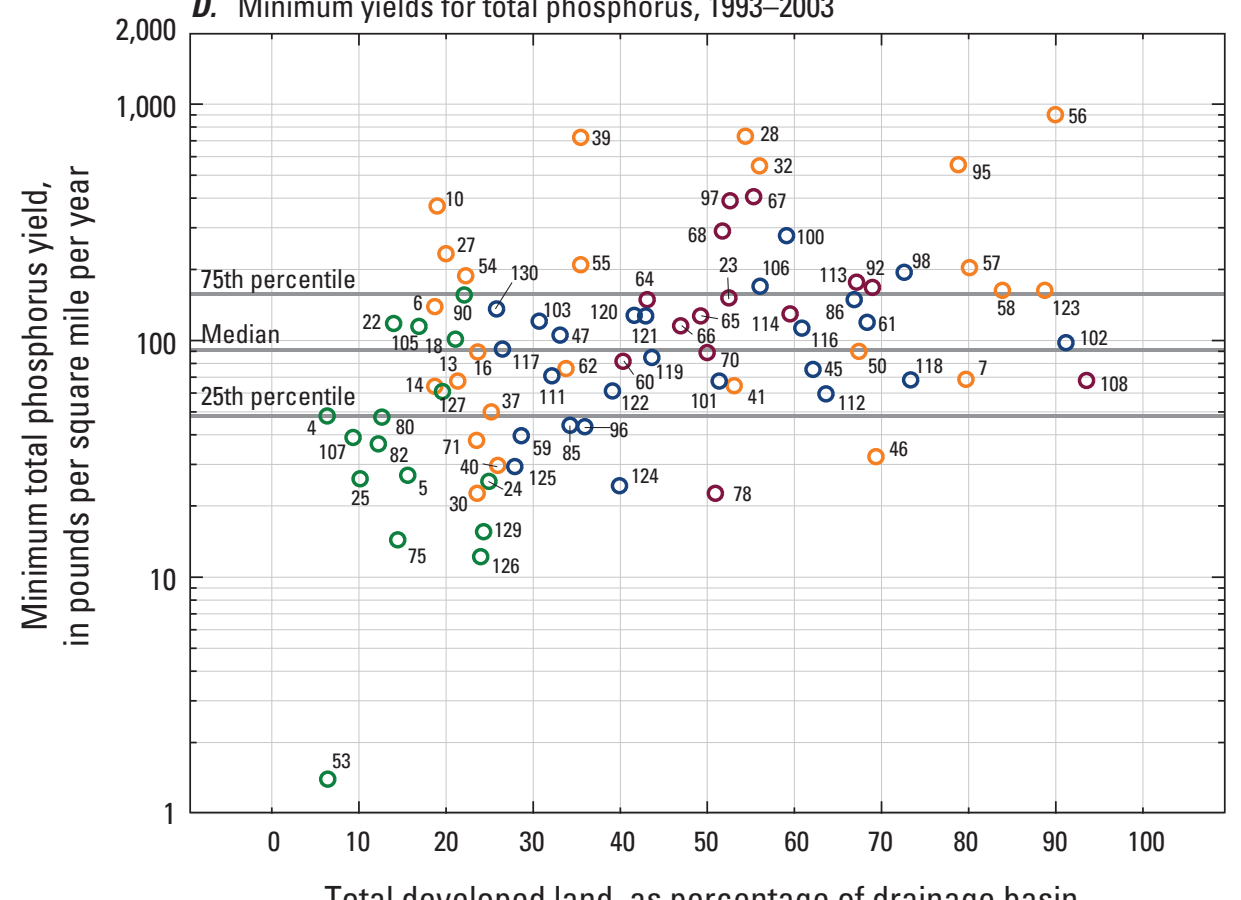

EXPLANATION

○ Agricultural basin

○ Urban/agricultural basin

○ Undeveloped basin

○ Urban basin

${ }_{46}$ Station sequence number

Figure 17. Ranges for minimum, median, and maximum nutrient yields in relation to the percentage of developed land in a drainage basin. (A) Minimum yields of total nitrogen for 81 stations, 1993-2003, (B) median yields of total nitrogen for 91 stations, 1993-2003, (C) maximum yields of total nitrogen for 76 stations, 1993-2003, (D) minimum yields of total phosphorus for 80 stations, 1993-2003, (E) median yields of total phosphorus for 90 stations, 1993-2003, and (F) maximum yields of total phosphorus for 75 stations, 1993-2003.-Continued 


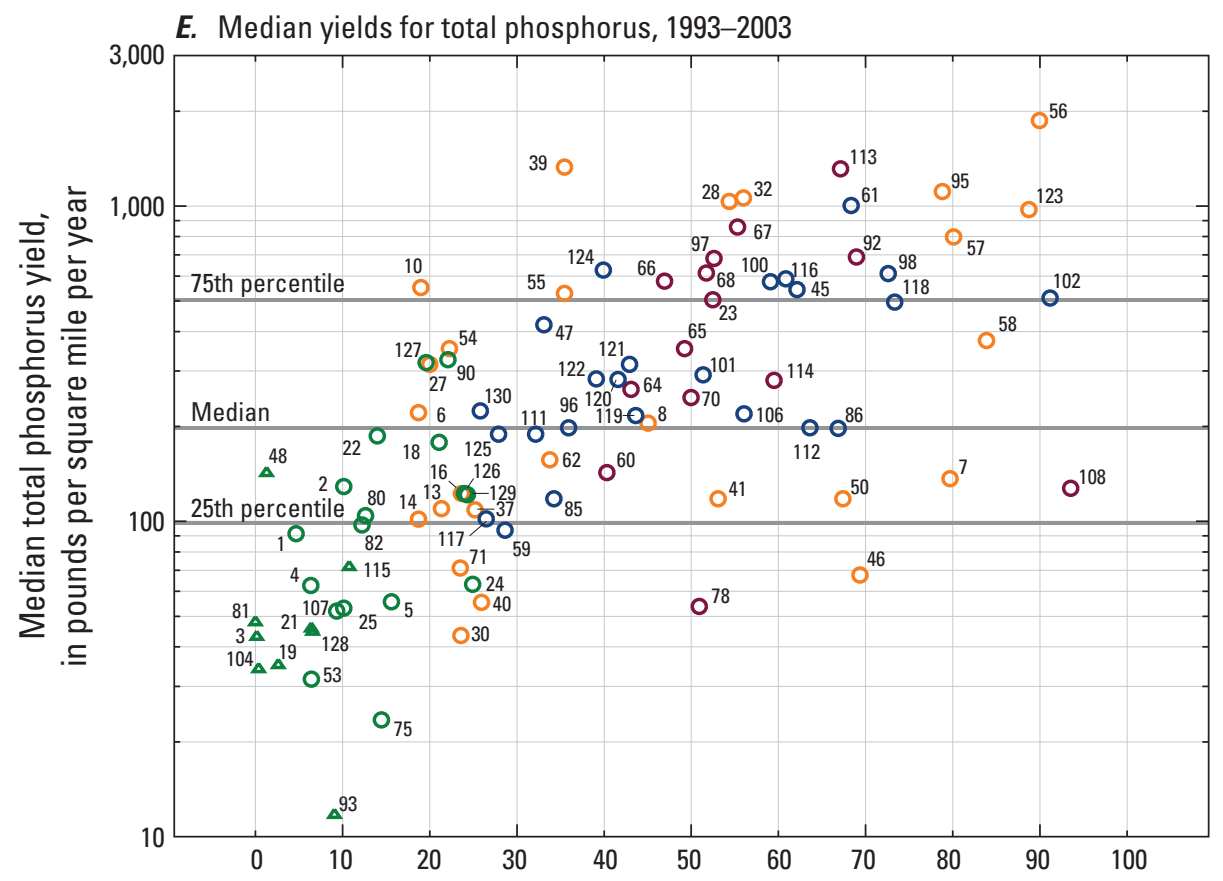

\section{EXPLANATION}

- Northeastern region study site

s Undeveloped basin (mean from national study)

- Agricultural basin

- Urban/agricultural basin

○ Undeveloped basin

○ Urban basin

39 Station sequence number

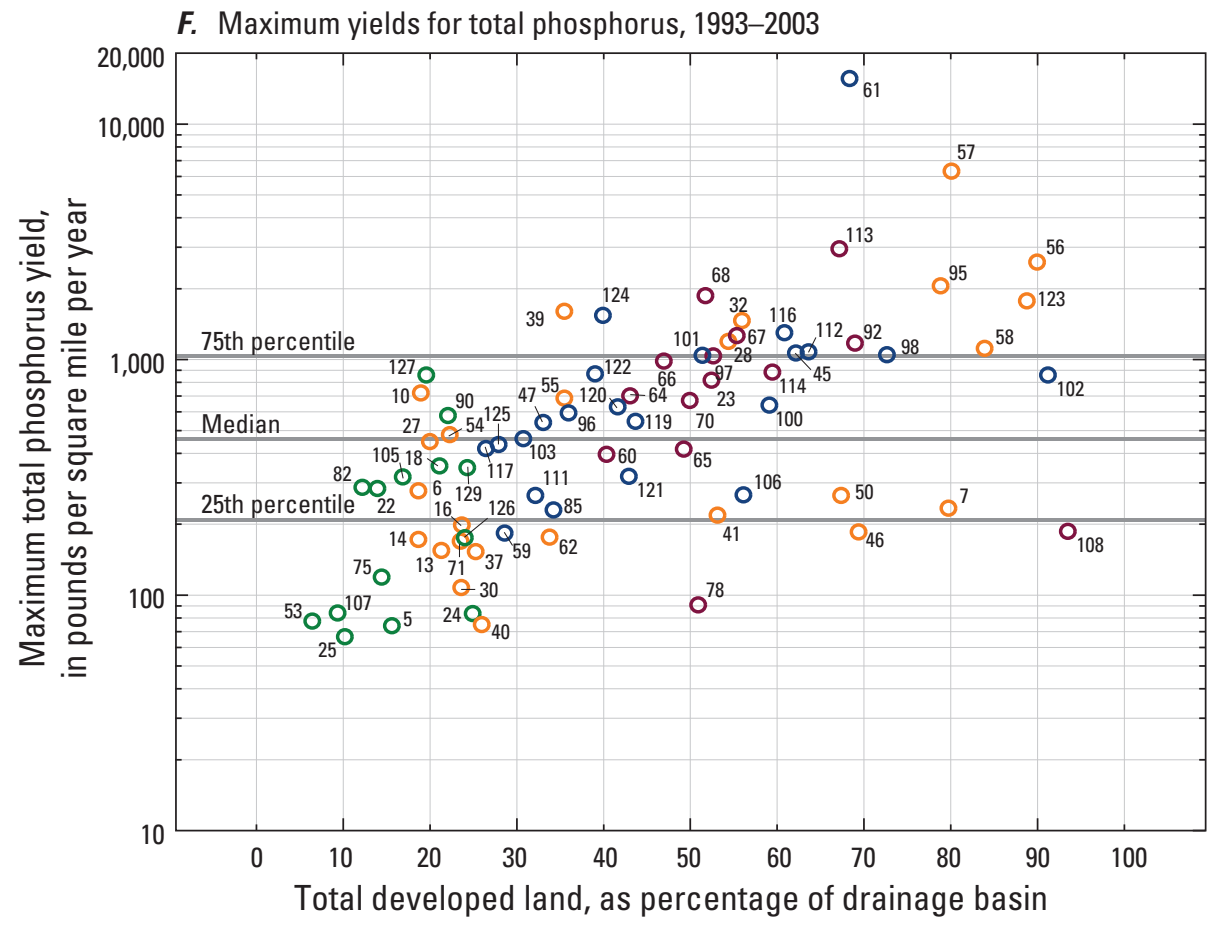

EXPLANATION

- Agricultural basin

○ Urban/agricultural basin

○ Undeveloped basin

○ Urban basin

61 Station sequence number

Figure 17. Ranges for minimum, median, and maximum nutrient yields in relation to the percentage of developed land in a drainage basin. (A) Minimum yields of total nitrogen for 81 stations, 1993-2003, (B) median yields of total nitrogen for 91 stations, 1993-2003, (C) maximum yields of total nitrogen for 76 stations, 1993-2003, (D) minimum yields of total phosphorus for 80 stations, 1993-2003, (E) median yields of total phosphorus for 90 stations, 1993-2003, and (F) maximum yields of total phosphorus for 75 stations, 1993-2003.-Continued 
Annual nutrient yields for total nitrogen and total phosphorus have been summarized in boxplots for the 46 stations with annual load estimates for all years in the 1993-2003 period, to show the distribution of yields in individual basins in more detail (fig. 18). In addition to the large station-tostation variations in nutrient yields, large total ranges and large interquartile ranges for some stations also demonstrate that large variations in yield take place from year to year at some locations. Yield estimates are generally low for drainage basins with large percentages of undeveloped land (more than 70 percent of the basin) and few or no point sources; the total range is compact, with minimal interannual variation. For example, total nitrogen yields for Bunnell (Burlington) Brook in Connecticut (station 24, about 75 percent undeveloped), the Pequannock River at Macopin Intake Dam in New Jersey (station 53, about 94 percent undeveloped), and the Batsto River in New Jersey (station 75, about 86 percent undeveloped) are all low (less than $2,000 \mathrm{lb} / \mathrm{mi}^{2} / \mathrm{yr}$ ), with narrow total ranges and narrow interquartile ranges (table 5, and fig. 18A). By contrast, drainage basins with large percentages of developed land, or major point-source influences, generally have high nutrient yields, large total ranges, and large interquartile ranges. The large interquartile ranges indicate substantial variation in yields, and consequently large variations in water quality, from year to year. Examples of stations with high total nitrogen yields (medians from 11,000 to $17,000 \mathrm{lb} / \mathrm{mi}^{2} / \mathrm{yr}$ ), large total ranges, and large interquartile ranges include: Broad Brook in Connecticut, an urbanagricultural basin (station 23, about 48 percent undeveloped); the Hockanum River in Connecticut, an urbanized basin with major point sources (station 28, about 46 percent undeveloped); the Saddle River in New Jersey, an urbanized basin with point sources (station 56, 10 percent undeveloped), and Conococheague Creek in Maryland, an agricultural basin with point sources (station 116, about 39 percent undeveloped) (table 5, and fig. 18A). Differences in yield related to land-use characteristics are discussed in more detail in the sections on Forested, Agricultural, and Urbanized Drainage Basins.

\section{Forested Drainage Basins}

Headwater tributaries have a profound influence on downstream water quality, water quantity, and habitat, as noted in a series of papers on the hydrologic connections between headwater streams and downstream waters (Nadeau and Rains, 2007; Alexander and others, 2007). As one researcher observes, "Every important aspect of the river ecosystem, the river geomorphic system, and the river chemical system begins in headwater streams" (Freeman and others, 2007). These findings have major implications for future water quality in the river basins of the northeastern United States, where most of the land is still forested, where major river basins have relatively pristine headwater areas and impaired downstream reaches, and where development pressures in the late 20th and early 21 st centuries have increased in previously undeveloped areas of many drainage basins.
A study of the influence of headwater streams on downstream water quality (Alexander and others, 2007) emphasizes that the hydrologic modifications accompanying urbanization in headwater streams accelerate and increase the delivery of nutrients to downstream reaches, independent of increases in the nutrient sources. Based on the understanding of nitrogen transport processes,

"Land-use changes or modifications to stream channels that increase the rates of flow in headwater streams may heighten their influence on the chemical quality of downstream receiving waters. For example, increases in the peak discharge and flashiness of flows that are often associated with urbanization would be likely to reduce the natural processing of nitrogen in low-order streams, increasing the distance over which nitrogen is transported downstream. In addition, stream channelization projects that straighten channels and remove natural pools and riffles are likely to shorten the water travel time in stream reaches; this would also be likely to reduce nitrogen losses and increase downstream transport" (Alexander and others, 2007, p. 46).

These conclusions underscore the importance of understanding baseline nutrient concentrations, trends, and loads in the relatively pristine headwater drainage basins of the region, and the changes that may be occurring in sparsely developed basins that are undergoing increased urbanization.

Nutrient yields have been evaluated for 28 drainage basins classified as undeveloped in this report (table 20), ranging in size from slightly more than $2 \mathrm{mi}^{2}$ to almost $10,000 \mathrm{mi}^{2}$, and with undeveloped land ranging from 75 to 100 percent of basin area. Undeveloped drainage basins include small, largely forested and sparsely populated basins, and large basins that meet the land-use criteria for undeveloped basins as applied in this study (table 7 , and table 8 , in back of report), but nevertheless include large urban areas and major point-source discharges. Nine undeveloped basins from a national study (Clark and others, 2000; D.K. Mueller, U.S. Geological Survey, written commun., 2007) are included in the summary statistics for median yields for undeveloped basins and all basins, but are excluded from the summary statistics for minimum and maximum yields (table 22). The yields calculated for undeveloped basins in the national study (table 17) are mean annual yields based on estimates for years in the early 1990s, made by using a different methodology from the load estimation procedure used in this report. Although the mean annual yields for these nine basins are not equivalent to the median yields estimated for other undeveloped basins analyzed in this report, these basins represent a useful comparison, and an additional source of information for understanding likely nutrient yields in undeveloped drainage areas of the region. One undeveloped drainage basin, the West Branch Susquehanna in Pennsylvania (station 105, table 20), has been excluded from median yield statistics, because the available years of load 


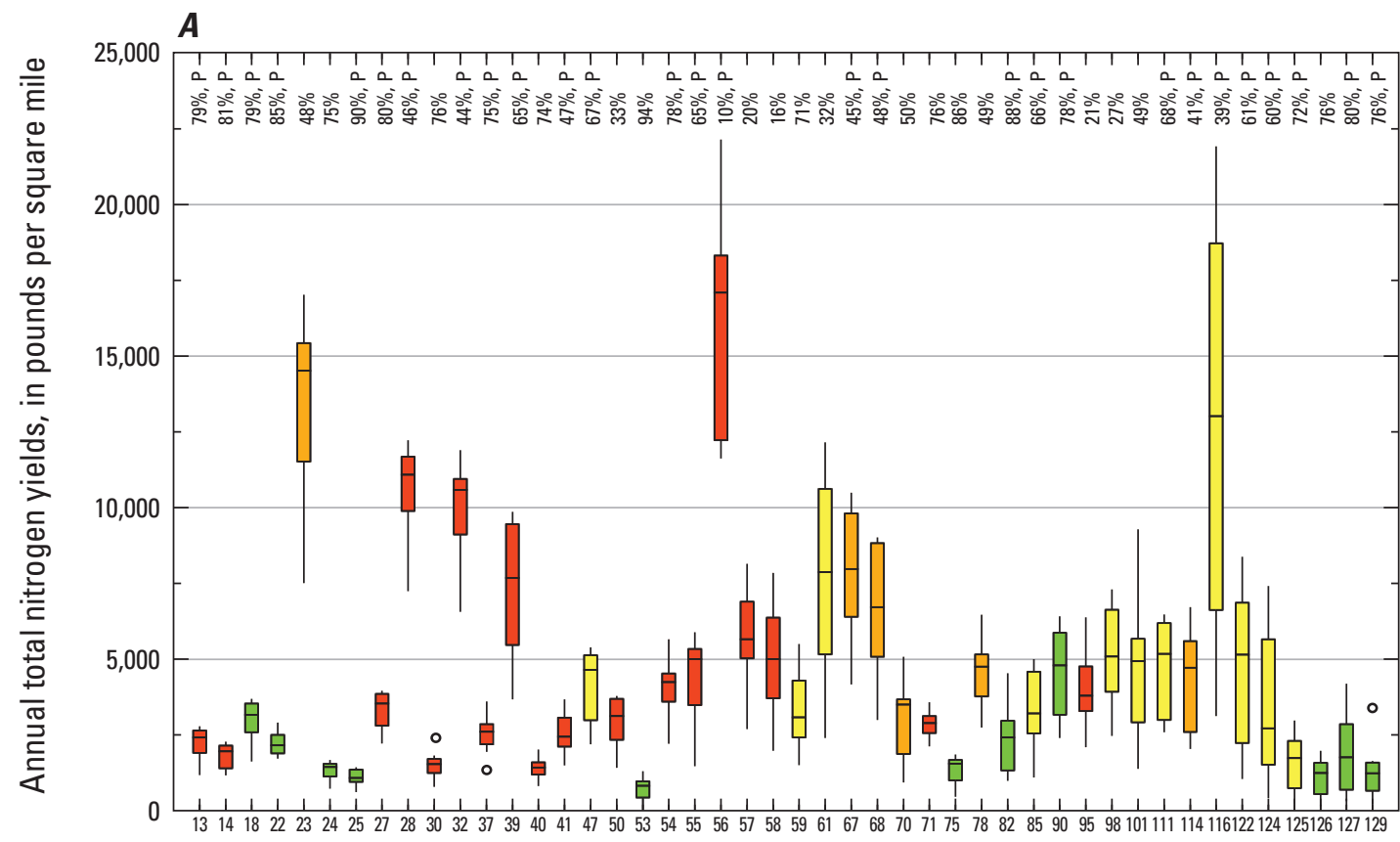

EXPLANATION

$\square \quad$ Undeveloped

$\square$ Urban

$\square \quad$ Agricultural

$\square \quad$ Urban/agricultural

$P \quad$ Point source

Schematic boxplot

- Outlier

- Outlier within 1.5 times the interquartile range

- 75th percentile

- Median

25th percentile

Outlier within 1.5 times the interquartile range

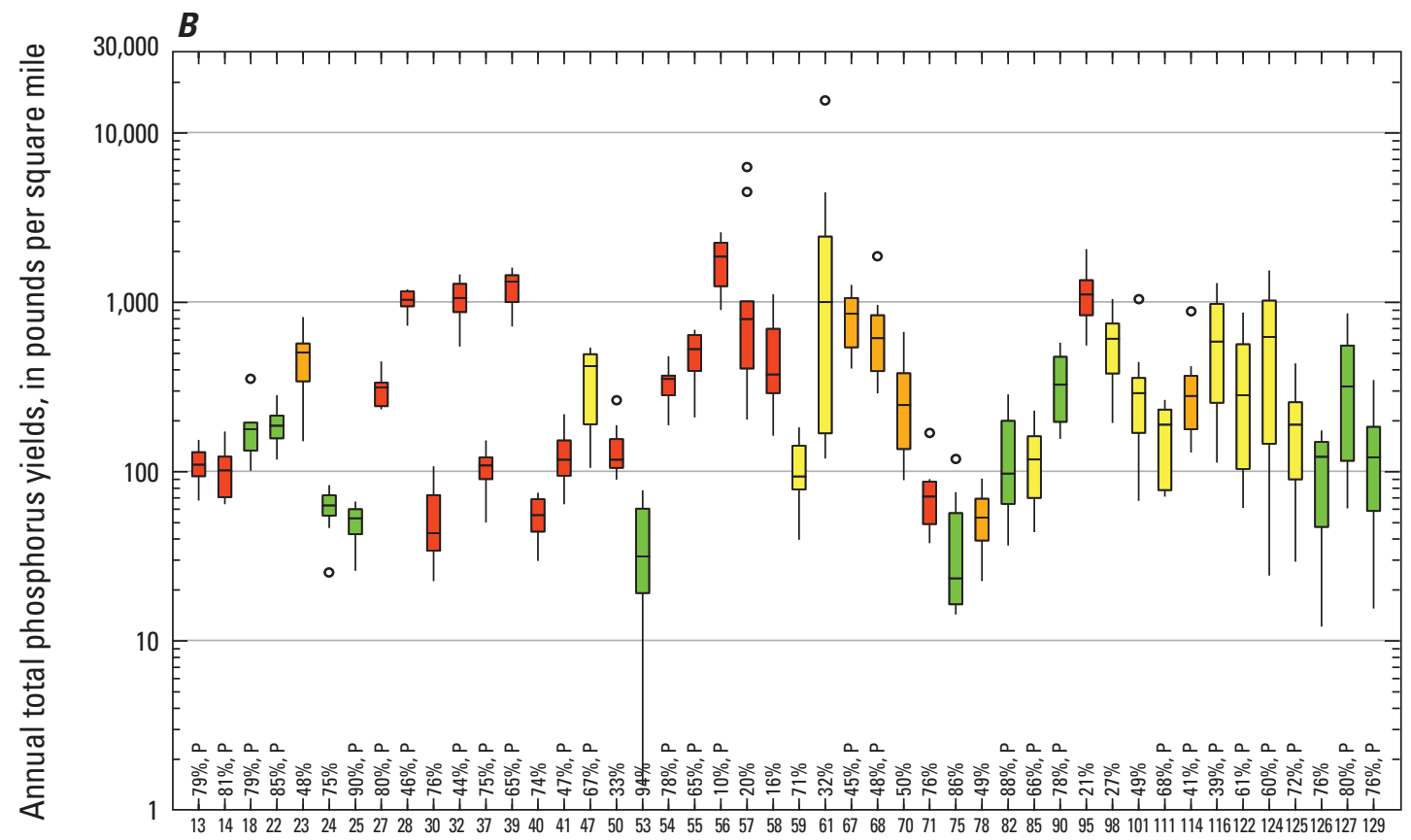

Station sequence number (table 5)

(With percent of undeveloped land, land-use classification (table 7), and presence of major point sources (P))

Figure 18. Annual yields for $(A)$ total nitrogen and $(B)$ total phosphorus for 46 stations during 1993-2003. 
estimation in the 1993-2003 period include 1 year of very low annual mean flow, and 2 years of high annual mean flow.

Median total nitrogen yields for 27 undeveloped (generally forested) drainage basins in the region during the 19932003 period range from 290 to $4,800 \mathrm{lb} / \mathrm{mi}^{2} / \mathrm{yr}$, with a median of $1,300 \mathrm{lb} / \mathrm{mi}^{2} / \mathrm{yr}$ (table 22). Mean annual total nitrogen yields for the nine undeveloped basins evaluated in the national study (Clark and others, 2000; D.K. Mueller, U.S. Geological Survey, written commun., 2007; table 17) range from about 300 to $2,200 \mathrm{lb} / \mathrm{mi}^{2} / \mathrm{yr}$ (shown as green triangular symbols in fig. 17B). The lowest median (or mean) annual total nitrogen yields, less than $1,000 \mathrm{lb} / \mathrm{mi}^{2} / \mathrm{yr}$, are found in drainage basins with more than 90 percent undeveloped land, including the Wild and Saco Rivers in Maine, the Ammonoosuc River in New Hampshire, the Green River in Massachusetts, the Pequannock River and McDonalds Branch in New Jersey, and Holiday Creek in Virginia (table 20; fig. 17B, stations 3, 4, 19, 21, 53, 93, and 128).

The national study of nutrients in undeveloped basins found that concentrations and yields of nitrate were generally highest in northeastern and mid-Atlantic coastal states, and that these high concentrations and yields correlated well with areas of high atmospheric nitrogen deposition (Clark and others, 2000, p. 1). Total nitrogen concentrations and yields for several stations evaluated in the national study (table 17) are composed largely of nitrate, and these basins are in the areas with high rates of atmospheric deposition of inorganic nitrogen (Clark and others, 2000, p. 14, fig. 2). Thus it is likely that even the most pristine drainage basins in the study area of this report have total nitrogen yields that are elevated relative to natural conditions. Undeveloped basins from the national study with mean annual total nitrogen yields that exceed $1,000 \mathrm{lb} / \mathrm{mi}^{2} / \mathrm{yr}$ include Esopus Creek and Biscuit Brook in New York, Young Womans Creek in Pennsylvania, and the South Fork South Branch of the Potomac River in West Virginia (table 20; fig. 17B, stations 48, 81, 104, and 115). These four drainage basins, and the drainage basins of the Pequannock River and McDonalds Branch in New Jersey, are in the area of highest total atmospheric deposition of inorganic nitrogen, based on data for 1994 (Clark and others, 2000, p. 14, fig. 2). The national analyses for these drainage basins are based on data for 1991-95, and trends in the atmospheric deposition of nitrogen would affect expectable current yields in these and other drainage basins. All streams in the region are affected by the atmospheric deposition of nitrogen to some extent.

Drainage basins are classified as undeveloped for 11 of the 46 monitoring stations with annual load estimates for all years in the 1993-2003 period. Undeveloped land encompasses about 75 to 94 percent of the drainage basin areas of these streams. Among these 11 stations, 7 monitor streams that receive major point-source discharges, including the Quinebaug River at Jewett City, the Connecticut River at Thompsonville, and the Farmington River at Unionville in Connecticut; the Delaware River at Montague and at Trenton in New Jersey, and the James and Appomattox Rivers in
Virginia (table 8, in back of report; figs. 17, 18A, stations 18, $22,25,82,90,127,129)$. The four streams without major point-source discharges are Bunnell (Burlington) Brook in Connecticut, the Pequannock and Batsto Rivers in New Jersey, and the Mattaponi River in Virginia (table 8, in back of report; figs. 17, 18A, stations $24,53,75,126$ ).

Boxplots of annual total nitrogen yields for the recent period show that median yields are less than or equal to about $4,800 \mathrm{lb} / \mathrm{mi}^{2} / \mathrm{yr}$ for all 11 undeveloped drainage basins, and are less than $2,000 \mathrm{lb} / \mathrm{mi}^{2} / \mathrm{yr}$ for 7 of these basins (fig. 18A; undeveloped basins shown in green). Interquartile ranges for yields in the undeveloped drainage basins evaluated in this report are generally narrow, less than $1,000 \mathrm{lb} / \mathrm{mi}^{2} / \mathrm{yr}$ for 8 of the 11 undeveloped basins; that is, the yield at the 75th percentile exceeds the yield at the 25 th percentile by less than $1,000 \mathrm{lb}$ (fig. 18A). Total range in yield generally is narrow, with a difference between minimum and maximum yields ranging from about 800 to $2,100 \mathrm{lb} / \mathrm{mi}^{2} / \mathrm{yr}$ in 7 of the 11 basins. The range in total nitrogen yields equals or exceeds $3,000 \mathrm{lb} / \mathrm{mi}^{2} / \mathrm{yr}$ in the drainage basins of the Delaware River at Montague (range of about 3,500 lb/ $\left.\mathrm{mi}^{2} / \mathrm{yr}\right)$ and at Trenton $\left(4,000 \mathrm{lb} / \mathrm{mi}^{2} / \mathrm{yr}\right)$, New Jersey, and the James $\left(3,900 \mathrm{lb} / \mathrm{mi}^{2} / \mathrm{yr}\right)$ and Appomattox

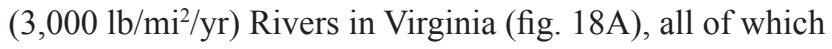
receive major point-source discharges. The Delaware River at Trenton, N.J., has the highest median $\left(4,800 \mathrm{lb} / \mathrm{mi}^{2} / \mathrm{yr}\right)$, largest interquartile range $\left(2,600 \mathrm{lb} / \mathrm{mi}^{2} / \mathrm{yr}\right)$, largest range in total nitrogen yields $\left(4,000 \mathrm{lb} / \mathrm{mi}^{2} / \mathrm{yr}\right)$, and highest maximum yield $\left(6,400 \mathrm{lb} / \mathrm{mi}^{2} / \mathrm{yr}\right)$ of these 11 undeveloped drainage basins (figs. 17, 18A, table 20; station 90). The Pequannock River in New Jersey (no major point-source discharges) has the lowest median total nitrogen yield $\left(820 \mathrm{lb} / \mathrm{mi}^{2} / \mathrm{yr}\right)$, and the Farmington River at Unionville, Conn. (one major point-source discharge), has the narrowest interquartile range $\left(350 \mathrm{lb} / \mathrm{mi}^{2} / \mathrm{yr}\right)$ and the narrowest total range in yields $\left(790 \mathrm{lb} / \mathrm{mi}^{2} / \mathrm{yr}\right)$ among these 11 undeveloped drainage basins (figs. 17, 18A, table 20; stations 53, 25).

Minimum total nitrogen yields for 17 undeveloped drainage basins range from less than 100 to $2,400 \mathrm{lb} / \mathrm{mi}^{2} / \mathrm{yr}$, with a median value for minimum yields of $730 \mathrm{lb} / \mathrm{mi}^{2} / \mathrm{yr}$ (table 22 , fig. 17A). Minimum yields of total nitrogen are less than about $1,600 \mathrm{lb} / \mathrm{mi}^{2} / \mathrm{yr}$ in 75 percent of the undeveloped drainage basins. Maximum total nitrogen yields for 14 undeveloped drainage basins range from 1,300 to $6,400 \mathrm{lb} / \mathrm{mi}^{2} / \mathrm{yr}$, with a median value for maximum yields of $3,100 \mathrm{lb} / \mathrm{mi}^{2} / \mathrm{yr}$ (table 22 , fig. 17C).

Median total phosphorus yields range from 12 to $330 \mathrm{lb} / \mathrm{mi}^{2} / \mathrm{yr}$ for the 26 undeveloped basins evaluated, with a median of $63 \mathrm{lb} / \mathrm{mi}^{2} / \mathrm{yr}$ (table 22). Mean annual total phosphorus yields for undeveloped basins evaluated in the national study (Clark and others, 2000; D.K. Mueller, U.S. Geological Survey, written commun., 2007) range from about 12 to $140 \mathrm{lb} / \mathrm{mi}^{2} / \mathrm{yr}$ (table 17), and were generally less than $75 \mathrm{lb} / \mathrm{mi}^{2} / \mathrm{yr}$ (shown as green triangular symbols in fig. 17E).

Boxplots of annual total phosphorus yields for the recent period show that median yields are less than or equal to about $330 \mathrm{lb} / \mathrm{mi}^{2} / \mathrm{yr}$ for the 11 undeveloped drainage basins with 
annual load estimates for all years in the 1993-2003 period (fig. 18B, undeveloped basins shown in green; table 21). Median total phosphorus yields are less than $200 \mathrm{lb} / \mathrm{mi}^{2} / \mathrm{yr}$ for 9 of the 11 undeveloped basins, and less than $100 \mathrm{lb} / \mathrm{mi}^{2} / \mathrm{yr}$ for 5 of the 11 basins. The five undeveloped drainage basins with median total phosphorus yields less than $100 \mathrm{lb} / \mathrm{mi}^{2} / \mathrm{yr}$ are Bunnell (Burlington) Brook and the Farmington River at Unionville in Connecticut, and the Pequannock, Batsto, and Delaware (at Montague) Rivers in New Jersey (figs. 17, 18B, table 21; stations $24,25,53,75,82$ ). Undeveloped basins with medians greater than $100 \mathrm{lb} / \mathrm{mi}^{2} / \mathrm{yr}$ are generally larger drainage basins that receive at least some point source discharges. As in the case of total nitrogen, interquartile ranges for total phosphorus yields in the undeveloped drainage basins are generally narrow, relative to the more developed drainage basins, although this narrow range is less obvious on the logarithmic scale used for total phosphorus (fig. 18B) than on the linear scale used for total nitrogen (fig. 18A).

Minimum total phosphorus yields for 16 undeveloped basins range from 1.4 to $160 \mathrm{lb} / \mathrm{mi}^{2} / \mathrm{yr}$, with a median of $38 \mathrm{lb} / \mathrm{mi}^{2} / \mathrm{yr}$ (table 22, fig. 17D). Maximum total phosphorus yields range from 67 to $860 \mathrm{lb} / \mathrm{mi}^{2} / \mathrm{yr}$ for 14 undeveloped basins, with a median of $230 \mathrm{lb} / \mathrm{mi}^{2} / \mathrm{yr}$ (table 22, fig. 17F). Undeveloped drainage basins with maximum total phosphorus yields that exceed about $200 \mathrm{lb} / \mathrm{mi}^{2} / \mathrm{yr}$ are generally drained by streams that receive point-source discharges (table 8 , in back of report, and table 21).

Total nitrogen and total phosphorus yields for drainage basins with 90 percent or more undeveloped land and no point sources provide an indication of nutrient yields under the least developed conditions in the study area, although this information is incomplete, in terms of both geographic distribution and years of record. The drainage basins that are least affected by human land-use and waste-disposal practices (although not totally unaffected) generally have median total nitrogen yields in the range of 300 to $1,700 \mathrm{lb} / \mathrm{mi}^{2} / \mathrm{yr}$ (fig. 17B) and median total phosphorus yields in the range of 30 to $100 \mathrm{lb} / \mathrm{mi}^{2} / \mathrm{yr}$ (fig. 17E). In the large drainage basins that receive pointsource discharges and have large percentages of undeveloped land, streamflow with low nutrient loads from relatively undeveloped headwater areas dilutes streamflow in the more urbanized downstream reaches, and dampens but does not eliminate the point-source "signal" of higher nutrient loads.

\section{Agricultural Drainage Basins}

Drainage basins with substantial agricultural influences on water quality are concentrated primarily in the mid-Atlantic hydrologic region, that is, the central and southern parts of the study area, largely because of favorable climatic, geologic, and geomorphic conditions, although monitoring priorities also may play a part in the distribution of monitored basins. Agricultural and urban/agricultural drainage basins are common in the Delaware River Basin, the lower Susquehanna River Basin, coastal basins of Maryland, Delaware, and Virginia, and the Potomac River Basin (fig. 2, table 8, in back of report; fig. 18).

The most extensive areas of agricultural land are in three ecoregions of the study area (figs. 2, 3): the Eastern Coastal Plain (ecoregion 14), in the Delmarva Peninsula and southern New Jersey; parts of the Southeastern Temperate Forested Plains and Hills (ecoregion 9), in areas extending from northeastern Virginia through central Maryland and southeastern Pennsylvania and into north-central New Jersey; and the Great Valley in the Central and Eastern Forested Uplands (ecoregion 11). The Great Valley, underlain by fractured carbonate bedrock in many areas, is a major physiographic feature in the study area, extending along the southeastern edge of the Central and Eastern Forested Uplands from the Shenandoah River valley in west-central Virginia through western Maryland and southeastern Pennsylvania and into northern New Jersey (visible as a distinct band of agricultural land that passes through Harrisburg, Pa., in fig. 2).

Agricultural drainage basins have some of the highest total nitrogen yields in the region (table 22). Several agricultural and urban/agricultural basins in the study area have median total nitrogen yields that equal or exceed $10,000 \mathrm{lb} / \mathrm{mi}^{2} / \mathrm{yr}$ (substantially more than the 75 th percentile of about $6,400 \mathrm{lb} / \mathrm{mi}^{2} / \mathrm{yr}$ for all drainage basins evaluated), including Broad Brook in the Connecticut River Basin, Jordan Creek and the Schuylkill River in the Delaware River Basin, the Nanticoke River and Chesterville Branch in the Eastern Coastal Plain of Delaware and Maryland, East Mahantango Creek and Cedar Run in the lower Susquehanna River Basin, and Conococheague Creek in the Potomac River Basin (table 20; fig. 17B, stations 23, 86, 97, 100, 102, 106, 108, 116; agricultural basins shown in blue, urban/agricultural basins in purple). Broad Brook is in an area known as the Central Valley (in central Connecticut and western Massachusetts), a former agricultural region that has become progressively more urbanized since the mid-20th century. Jordan Creek, parts of the Schuylkill River Basin, and Cedar Run in Pennsylvania, and Conococheague Creek in Maryland, are in the Great Valley. High median total nitrogen yields for these drainage basins, as well as high minimum yields (figs. 17A, B), indicate that high total nitrogen yields are common on an annual basis in these basins. Periods of record are short for some of these stations, however, and additional years of record would be necessary to identify yield ranges and typical conditions.

Median total nitrogen yields for 24 agricultural basins range from 1,700 to $26,000 \mathrm{lb} / \mathrm{mi}^{2} / \mathrm{yr}$ (table 22), with a median for all 24 basins of $5,000 \mathrm{lb} / \mathrm{mi}^{2} / \mathrm{yr}$. Median total phosphorus yields range from 94 to $1,000 \mathrm{lb} / \mathrm{mi}^{2} / \mathrm{yr}$ for the 24 agricultural basins evaluated, with a median yield of $280 \mathrm{lb} / \mathrm{mi}^{2} / \mathrm{yr}$ (table 22).

The maximum total nitrogen yield and maximum total phosphorus yield estimated for all stations in the region are both in small (less than $50 \mathrm{mi}^{2}$ ) agricultural drainage basins that do not receive any major point-source discharges. The maximum total nitrogen yield, $32,000 \mathrm{lb} / \mathrm{mi}^{2} / \mathrm{yr}$, was estimated 
for East Mahantango Creek, in the lower Susquehanna River Basin in Pennsylvania (about 55 percent agricultural land; table 8 , in back of report, and table 20 ; fig. $17 \mathrm{C}$, station 106). The maximum total phosphorus yield included in the summary statistics, $16,000 \mathrm{lb} / \mathrm{mi}^{2} / \mathrm{yr}$, was estimated for the Neshanic River Basin, a subbasin of the Raritan River Basin in New Jersey (about 60 percent agricultural land; table 8 , in back of report, and table 21; fig. 17F, station 61).

Among the 46 stations with records for the full 19932003 period, agricultural land is a major source of nutrients in two of the five basins with median total nitrogen yields exceeding 10,000 lb/ $\mathrm{mi}^{2} / \mathrm{yr}$. (The other three are small urban basins with major point-source discharges and high population densities, discussed in the section on Urbanized Drainage Basins). Among these 46 stations, the second highest total nitrogen yield, $22,000 \mathrm{lb} / \mathrm{mi}^{2} / \mathrm{yr}$, and the largest range in total nitrogen yields, were estimated for an agricultural basin that also receives point-source discharges, Conococheague Creek in Maryland (about 57 percent agricultural land, table 8, in back of report) (fig. 18A, table 20; station 116). The maximum total phosphorus yield was estimated for the agricultural Neshanic River Basin in New Jersey (fig. 18B, table 21; station 61). Annual variability in nutrient yields can be large, as indicated by relatively large interquartile ranges and large total ranges in yield for several agricultural and urban/agricultural basins (fig. 18; agricultural basins shown in yellow, urban/ agricultural basins in orange).

Nutrient yields in agricultural and urban/agricultural drainage basins generally increase with increasing percentages of developed land in a drainage basin, although there is a wide range in yields at most levels of development (fig. 17), and point-source effects in some basins complicate interpretations. Nutrient yields for the Raritan River Basin $\left(804 \mathrm{mi}^{2}\right)$ and its agricultural and urban/agricultural subbasins (11.8 to $490 \mathrm{mi}^{2}$ ) show a somewhat varied but steady increase with increasing percentages of developed land, particularly in the median and maximum yields of total nitrogen (figs. 17B, C; stations 59-61, 64-68). Five of these eight Raritan basins receive major point-source discharges; the Stony Brook Basin receives minor point-source discharges (fig. 17; station 66), and Mulhockaway Creek and the Neshanic River are nonpoint-source basins (fig. 17; stations 59, 61). The Potomac River Basin $\left(11,570 \mathrm{mi}^{2}\right)$ and most of its agricultural subbasins (770 to $5,939 \mathrm{mi}^{2}$ ), have large percentages of undeveloped land. Yields for these streams generally are between the 25th and 75th percentiles for all drainage basins, with no clear relation to increases in developed land (fig. 17; stations 117 , 119-122); all these streams receive major point-source discharges (table 8, in back of report). However, the median total nitrogen yield for the small Muddy Creek Basin (14.3 $\mathrm{mi}^{2}$, about 68 percent agricultural), located in the Great Valley in the headwaters of the Potomac River Basin, exceeds the 75th percentile for all stations, and the maximum total nitrogen yield in this basin of nonpoint sources is one of the highest in the study area (station 118, figs. 17B, C). Median and maximum yields for total nitrogen and total phosphorus in the
Conococheague Creek Basin (about 57 percent agricultural), which receives major point-source discharges, exceed the 75th percentile for all drainage basins (figs. 17B, C, E, F; station 116). The high total nitrogen yields estimated for the Muddy and Conococheague Creek basins support findings from the 1992-96 NAWQA study in the Potomac River Basin (fig. 1), which concluded that elevated concentrations of nitrogen were common in streams and groundwater in the northeastern part of the drainage basin (ecoregion 9) and areas underlain by carbonate bedrock, such as the Great Valley (ecoregion 11, figs. 2, 3) (Ator and others, 1998, p. 2, 8).

The Susquehanna and the Potomac River Basins are the largest monitored drainage basins in the region with complete records for the 1993-2003 period (stations 111 and 122, figs. 17 and 18), and provide the largest freshwater inflows to the Chesapeake Bay. Although both drainage basins are more than 60 percent undeveloped, stream quality in both basins is affected by agricultural influences. A NAWQA study of the Lower Susquehanna River Basin concluded that the main source of nitrogen in the study unit is animal manure used as agricultural fertilizer (Lindsey and others, 1998, p. 2, 9). Similarly, a NAWQA study of the Potomac River Basin concluded that commercial fertilizers and manure were major sources of nitrogen and phosphorus to the basin in 1990, and that tributary streams draining agricultural areas yielded the greatest quantities of nitrogen to the Potomac River (Ator and others, 1998, p. 2, 6-9). The Susquehanna and Potomac River Basins are classified as agricultural drainage basins in this report, with about 28 and 34 percent agricultural land, respectively, and less than 10 percent urbanized land (table 8, in back of report). Median total nitrogen yields for the Susquehanna $\left(5,200 \mathrm{lb} / \mathrm{mi}^{2} / \mathrm{yr}\right)$ and Potomac $\left(5,100 \mathrm{lb} / \mathrm{mi}^{2} / \mathrm{yr}\right)$ are close to the median (of all medians) for total nitrogen yields for all agricultural drainage basins $\left(5,000 \mathrm{lb} / \mathrm{mi}^{2} / \mathrm{yr}\right)$ (tables 20,22$)$. The median total phosphorus yield for the Potomac $\left(280 \mathrm{lb} / \mathrm{mi}^{2} / \mathrm{yr}\right)$ is similar to the median (of all medians) for all agricultural basins (tables 21, 22). The median for the Susquehanna, by contrast, is somewhat lower $\left(190 \mathrm{lb} / \mathrm{mi}^{2} / \mathrm{yr}\right)$, possibly because phosphorus tends to bind to sediment particles that settle and are retained behind the Conowingo Dam (Belval and Sprague, 1999, p. 5). Maximum total nitrogen yields for the Susquehanna and Potomac, and maximum total phosphorus yields for the Potomac, are near the median (of the maximums) for all agricultural basins, whereas the maximum total phosphorus yield for the Susquehanna is substantially lower than the median (of the maximums) for all agricultural basins (tables 20, 21, 22).

Although the northeastern United States is one of the most highly urbanized areas in the nation, agricultural land is a major source of nutrients. Nutrients derived from agricultural land contribute to some of the highest total nitrogen yields in the study area. High nutrient yields related to agricultural land are most common in smaller drainage basins of the midAtlantic hydrologic region. Overall, maximum total nitrogen yields show a pronounced increase when the agricultural land in a drainage basin exceeds 50 percent (fig. 17C; agricultural 
basins shown in blue; urban/agricultural basins in purple). Agricultural and urban/agricultural drainage basins dominate the highest maximum yields for total nitrogen (greater than the 75th percentile for all stations), whereas urban drainage basins are more numerous among the highest yields for total phosphorus (figs. 17C, F).

Land-use percentages and generalized land-use categories for this report are based on the 1992 National Land Cover Dataset. Agricultural land has been converted to residential developments and other forms of urbanized land in some parts of the study area during the 1993-2003 period for which nutrient yields have been analyzed. Consequently, annual nutrient yields are likely to have been affected by changing sources of nutrients in some drainage basins.

\section{Urbanized Drainage Basins}

Drainage basins with substantial urban influences on water quality are concentrated in the Eastern Coastal Plain (ecoregion 14) in New England and southern New Jersey, and in parts of the Southeastern Temperate Forested Plains and Hills (ecoregion 9) in northern New Jersey, southeastern Pennsylvania, and central Maryland (figs. 2, 3; table 8, in back of report). Urbanized drainage basins encompass a wide range of total developed land, and a wide range in the predominant type of urban development. Consequently, nutrient yields vary over a wide range in drainage basins classified as urbanized in this report. Differences among urbanized drainage basins have not been evaluated quantitatively in this study, but qualitative observations of nutrient yields in urbanized drainage basins provide an indication of the conditions that have the greatest effect on these yields. Conditions affecting nutrient yields in urbanized drainage basins include the presence or absence of point sources, the size of the drainage basin relative to the magnitude of the point sources, population density, percentages of urbanized versus undeveloped land, and nonpoint source water-quality effects related to the intensity of the urbanized land development. Point sources have not been evaluated quantitatively for most drainage basins in the region, and the magnitude of point-source effluents relative to drainage basin size or measures of streamflow in the receiving water have not been evaluated. Consequently, the discussion of the effects of point sources is qualitative. As noted in the section on Agricultural Drainage Basins, some drainage basins are affected by both urban and agricultural nutrient sources, further complicating the evaluation of nutrient yields.

Median total nitrogen yields range from 1,400 to $17,000 \mathrm{lb} / \mathrm{mi}^{2} / \mathrm{yr}$ in 26 urbanized drainage basins, with a median (of all medians) of 4,000 lb/ $\mathrm{mi}^{2} / \mathrm{yr}$ (table 22). Median total nitrogen yields in agricultural basins $\left(5,000 \mathrm{lb} / \mathrm{mi}^{2} / \mathrm{yr}\right)$ and urban/agricultural basins $\left(7,000 \mathrm{lb} / \mathrm{mi}^{2} / \mathrm{yr}\right)$ exceed median total nitrogen yields in urban basins $\left(4,000 \mathrm{lb} / \mathrm{mi}^{2} / \mathrm{yr}\right)$

(table 22). Among the 46 stations with records for the full 1993-2003 period, three of the five basins with median total nitrogen yields exceeding $10,000 \mathrm{lb} / \mathrm{mi}^{2} / \mathrm{yr}$ are small urban basins with major point-source discharges and high population densities: the Hockanum (station 28, $73.4 \mathrm{mi}^{2}$, 1,331 people/ $\mathrm{mi}^{2}$ ) and Quinnipiac (station 32, $115 \mathrm{mi}^{2}, 1,396$ people $/ \mathrm{mi}^{2}$ )

River Basins in Connecticut, and the Saddle River Basin (station 56, $54.6 \mathrm{mi}^{2}, 2,624$ people/ $\mathrm{mi}^{2}$ ) in New Jersey (figs. 17B, urban basins shown in orange; fig. 18A, urban basins shown in red; table 8 , in back of report).

Median total phosphorus yields in 26 urbanized drainage basins range from 43 to $1,900 \mathrm{lb} / \mathrm{mi}^{2} / \mathrm{yr}$, with a median of $210 \mathrm{lb} / \mathrm{mi}^{2} / \mathrm{yr}$ (table 22). As in the case of total nitrogen, median total phosphorus yields (median of all medians) in agricultural basins (280 lb/mi²/yr) and urban/agricultural basins $\left(430 \mathrm{lb} / \mathrm{mi}^{2} / \mathrm{yr}\right.$ ) exceed median total phosphorus yields of urban basins $\left(210 \mathrm{lb} / \mathrm{mi}^{2} / \mathrm{yr}\right)$ (table 22). However, the highest median total phosphorus yield, 1,900 lb/mi²/yr, was estimated for an urban drainage basin, the Saddle River at Lodi, N.J. (figs. 17E, 18B, station 56; table 8, in back of report, about 89 percent urbanized land). Among stations with records for the full 1993-2003 period, five of the six basins with median total phosphorus yields equaling or exceeding $1,000 \mathrm{lb} / \mathrm{mi}^{2} / \mathrm{yr}$ are small urban basins with major or minor point-source discharges: the Hockanum, Quinnipiac, and Naugatuck River Basins in Connecticut, and the Saddle and Cooper River Basins in New Jersey (figs. 17E, urban drainage basins shown in orange; $18 \mathrm{~B}$, urban basins in red; stations 28 , $32,39,56,95)$.

Total nitrogen yields are consistently high in several small drainage basins that have major urban influences on water quality in the form of large percentages of urbanized land, high population densities, or major point-source discharges. Minimum total nitrogen yields in eight urbanized drainage basins exceed or are about equal to the 75 th percentile for all minimum yields $\left(2,700 \mathrm{lb} / \mathrm{mi}^{2} / \mathrm{yr}\right)$ (fig. 17A). Total developed land exceeds 50 percent of the drainage basin in six of the eight basins, major point sources discharge to streams in five of the eight basins, and population densities exceed $1,000 / \mathrm{mi}^{2}$ in six of the eight basins. The drainage basins range in size from about 24 to $260 \mathrm{mi}^{2}$, and five are less than $100 \mathrm{mi}^{2}$. The Pawtuxet River in Rhode Island, the Hockanum, Quinnipiac, and Naugatuck Rivers in Connecticut, and the Saddle River in New Jersey all receive major pointsource discharges (table 8 , in back of report; fig. 17A, stations $10,28,32,39,56$; urban basins shown in orange). In the three drainage basins where nonpoint sources determine water quality, population densities are high and the percentage of urbanized land is high: the Aberjona River in Massachusetts (station 7, 2,955/ $\mathrm{mi}^{2}$, about 79 percent urbanized land), the Rahway River near Springfield, N.J. (station 57, 4,372/mi², about 80 percent urbanized land), and Accotink Creek in Virginia (station $123,4,170 / \mathrm{mi}^{2}$, about 85 percent urbanized land) (table 8, in back of report; fig. 17A).

Total phosphorus yields are consistently high in many urbanized drainage basins, as indicated by high minimum yields (fig. 17D, urban basins shown in orange). Minimum total phosphorus yields exceeding $200 \mathrm{lb} / \mathrm{mi}^{2} / \mathrm{yr}$ were estimated for 13 stations during 1993-2003 (fig. 17D). Of these 13 stations, all but 1 monitor streams that drain urban basins 
(9 stations) or urban/agricultural basins ( 3 stations). Twelve of the 13 drainage basins, including the agricultural Nanticoke River Basin in Delaware (fig. 17D, station 100), receive major or minor municipal point discharges. These 12 basins are typical of the older urbanized drainage basins of the northeast: the Pawtuxet River Basin in Rhode Island; the Farmington (at Tariffville), Hockanum, Quinnipiac, and Naugatuck Rivers in Connecticut; the Passaic, Saddle, Rahway (at Springfield), Millstone, Raritan, and Cooper River Basins in New Jersey; and the Schuylkill River Basin in Pennsylvania (fig. 17D, stations $10,27,28,32,39,55,56,57,67,68,95,97)$. All but the Schuylkill Basin are less than $1,000 \mathrm{mi}^{2}$ in area, and several are less than $100 \mathrm{mi}^{2}$. Consequently, for most of these streams, wastewater discharges constitute a substantial part of the stream nutrient loads under most conditions, and minimum total phosphorus yields are high relative to other land-use categories. The maximum values for minimum and median total phosphorus yields are in urbanized drainage basins (table 22). Among these 12 drainage basins, the Millstone, Raritan, and Schuylkill are classified as urban/agricultural basins, and nutrient yields reflect agricultural and urban nutrient sources.

Maximum total nitrogen yields for urbanized basins range from 2,000 to $22,000 \mathrm{lb} / \mathrm{mi}^{2} / \mathrm{yr}$, with a median of $4,800 \mathrm{lb} / \mathrm{mi}^{2} / \mathrm{yr}$ (table 22). Urbanized drainage basins with maximum total nitrogen yields near or less than the 25th percentile for maximum yields for all stations (about $3,700 \mathrm{lb} / \mathrm{mi}^{2} / \mathrm{yr}$ ) include larger drainage basins with major point sources and a high percentage of undeveloped land, such as the Merrimack River in Massachusetts and the Shetucket, Quinebaug, and Farmington Rivers in Connecticut (fig. 17C, stations $6,13,16,27$; urban basins shown in orange; table 8 , in back of report); small drainage basins with minor point sources and a large percentage of undeveloped land, such as Toms River in New Jersey (station 71); and small drainage basins with low-density development, no point sources, and a large percentage of undeveloped land, such as the Salmon and Saugatuck Rivers in Connecticut (stations 30, 40). However, three urbanized basins with large percentages of developed land, moderate to high population densities, and in one case, point sources, also have maximum total nitrogen yields at or less than the 25th percentile for all stations: the Norwalk River in Connecticut (about 47 percent undeveloped, with a major point source), Lisha Kill in New York (about 31 percent undeveloped), and the Hackensack River in New Jersey (about 33 percent undeveloped) (fig. 17C, stations 41, 46, 50). Detailed land-use classifications show that low-intensity residential development and forested residential development dominate the urbanized land in these drainage basins, constituting 79 percent of the urbanized land in the Norwalk River Basin, 55 percent in the Lisha Kill Basin, and 78 percent in the Hackensack River Basin. These results indicate the complexities of factors affecting nutrient yields in urbanized drainage basins, including the type and intensity of development, and possibly the location and level of treatment of point source discharges.
Maximum total nitrogen yields in six urbanized drainage basins exceed or are about equal to the 75th percentile for maximum yields for all stations (about $9,100 \mathrm{lb} / \mathrm{mi}^{2} / \mathrm{yr}$; fig. 17C; urban basins shown in orange). Five of these drainage basins are small (about $100 \mathrm{mi}^{2}$ or less), and all six are located in or encompass older highly urbanized areas of the region: the Aberjona River in Massachusetts; the Hockanum, Quinnipiac, and Naugatuck Rivers in Connecticut; the Saddle River in New Jersey; and Accotink Creek in Virginia (fig. 17C, stations 7, 28, 32, 39, 56, 123; urban basins shown in orange). The Hockanum, Quinnipiac, Naugatuck, and Saddle Rivers are all receiving waters for major pointsource discharges. The maximum total nitrogen yield among 25 urbanized drainage basins, $22,000 \mathrm{lb} / \mathrm{mi}^{2} / \mathrm{yr}$, was estimated for the Saddle River in New Jersey (tables 20, 22). The routinely high annual total nitrogen yields in these drainage basins (figs. 17A-C) illustrate the challenges of managing nutrients in the older urbanized drainage basins of the region.

Maximum total phosphorus yields for urbanized basins encompass a wide range, from less than 100 to more than $6,000 \mathrm{lb} / \mathrm{mi}^{2} / \mathrm{yr}$ (table 22). As in the case of total nitrogen, the lower maximum total phosphorus yields in urbanized basins (less than about $200 \mathrm{lb} / \mathrm{mi}^{2} / \mathrm{yr}$ ) are generally in larger drainage basins with major point sources and a high percentage of undeveloped land, or in smaller drainage basins with minor or no point sources and a high percentage of undeveloped land (fig. 18B, urban basins shown in red; table 8, in back of report, and table 21). Maximum yields exceed $1,000 \mathrm{lb} / \mathrm{mi}^{2} / \mathrm{yr}$ in eight urban basins, including the Hockanum, Quinnipiac, and Naugatuck Rivers in Connecticut; the Saddle, Rahway (near Springfield and at Rahway), and Cooper Rivers in New Jersey; and Accotink Creek in Virginia (fig. 17F, stations 28, 32, 39, $56,57,58,95,123$; urban basins shown in orange). Although the monitored areas of the Rahway River, the Cooper River, and Accotink Creek do not receive major point-source discharges, the drainage areas have some of the highest population densities in the study area (table 8 , in back of report).

Nine of the 26 drainage basins classified as urban have median total nitrogen yields ranging from about 5,000 to $17,000 \mathrm{lb} / \mathrm{mi}^{2} / \mathrm{yr}$ and maximum total nitrogen yields ranging from about 7,000 to $22,000 \mathrm{lb} / \mathrm{mi}^{2} / \mathrm{yr}$ (figs. $17 \mathrm{~B}, \mathrm{C}$, table 20 ). The drainage areas for these nine basins are small, less than $300 \mathrm{mi}^{2}$; drainage areas for six of the nine basins are less than $100 \mathrm{mi}^{2}$. Nine urban basins have median total phosphorus yields ranging from about 500 to $1,900 \mathrm{lb} / \mathrm{mi}^{2} / \mathrm{yr}$, and maximum yields ranging from about 700 to $6,300 \mathrm{lb} / \mathrm{mi}^{2} / \mathrm{yr}$ (table 21, figs. 17E, F). Drainage areas for these nine basins are less than $800 \mathrm{mi}^{2}$, and drainage areas for seven of the nine are $200 \mathrm{mi}^{2}$ or less. Most of the urban drainage basins with these very high nutrient yields are drained by streams that are receiving waters for major pointsource discharges.

Ten of the 26 drainage basins classified as urban have no major point-source discharges: the Aberjona River in Massachusetts (fig. 17, station 7); the Salmon and Saugatuck Rivers in Connecticut (stations 30, 40); Lisha Kill in New 
York (station 46); the Hackensack, Rahway (near Springfield, and at Rahway), Toms, and Cooper Rivers in New Jersey (stations 50, 57, 58, 71, 95); and Accotink Creek in Virginia (station 123) (table 8, in back of report). The drainage basins of Toms River and Cooper River receive minor point-source discharges. These 10 basins range in size from 15.6 to $123 \mathrm{mi}^{2}$, and 7 of these basins are less than $50 \mathrm{mi}^{2}$. Nutrient yields generally increase with increasing percentages of developed land in urbanized drainage basins where water quality is influenced primarily by nonpoint sources (fig. 17; urban basins shown in orange). This relation differs for total nitrogen and total phosphorus. Median and maximum total nitrogen yields for the Rahway and Cooper Rivers and Accotink Creek, which are among the most highly developed drainage basins evaluated, fall approximately between the median and 75th percentile for all stations (figs. 17B, C; stations 57, 58, 95, 123), whereas median total phosphorus yields for three of these drainage basins exceed the 75th percentile for all stations, and maximum total phosphorus yields for all four basins exceed the 75th percentile for all stations (figs. 17E, F). This relation indicates that high total phosphorus yields are likely in small, highly urbanized drainage basins. Nutrient yields for Lisha Kill (station 46) are generally low relative to the extent of development in the drainage basin (fig. 17). Total nitrogen yields for Toms River (figs. 17A, B, C; station 71) are somewhat high, relative to the large percentage of undeveloped land in the drainage basin; this relatively high yield may be caused by minor point-source discharges. Total nitrogen yields for the Aberjona River Basin are at or above the 75th percentile for all drainage basins, and are in a range similar to that of the other highly developed nonpoint urban basins (figs. 17A, B, C; station 7). By contrast, total phosphorus yields for the Aberjona are relatively low, between the 25th percentile and the median for all stations (figs. 17D, E, F). These nutrient yield variations among small urbanized basins indicate that identification of specific urban nonpoint sources and land-use conditions may be necessary to address nutrient management in urbanized drainage basins, particularly in the older urbanized areas of the northeastern United States.

Nutrient yields for urbanized drainage basins demonstrate that streams draining highly urbanized areas of the region are major nutrient sources, delivering nutrient loads to the main stems of major rivers and in some cases directly to estuaries and coastal areas. Smaller urbanized drainage basins (less than about $300 \mathrm{mi}^{2}$ ), including drainage basins with and without point sources, have some of the highest nutrient yields in the study area (fig. 17).

\section{Overall Effects of Urban and Agricultural Development}

The extent of developed land in a drainage basin has a profound effect on the magnitude of nutrient yields. Most drainage basins with more than 30 percent developed land have maximum total nitrogen yields that equal or exceed
$5,000 \mathrm{lb} / \mathrm{mi}^{2} / \mathrm{yr}$, and 14 of 31 basins with more than 50 percent developed land have maximum total nitrogen yields that equal or exceed 10,000 lb/mi²/yr (fig. 17C). Of these 14 drainage basins, 3 are classified as urban, 4 as urban/agricultural, and 7 as agricultural. Most drainage basins with more than 50 percent developed land ( 23 of 31 basins) have maximum total phosphorus yields that exceed $600 \mathrm{lb} / \mathrm{mi}^{2} / \mathrm{yr}$, and in 18 of these basins, maximum total phosphorus yields equal or exceed $1,000 \mathrm{lb} / \mathrm{mi}^{2} / \mathrm{yr}$ (fig. 17F). Of these 18 basins, 7 are classified as urban, 5 as urban/agricultural, and 6 as agricultural. Where more than about 50 percent of a drainage area is developed, in either agricultural or urban land or both, the potential for very high maximum yields is present (figs. 17C, F).

Summary statistics for total nitrogen and total phosphorus yields for drainage basins in the northeastern United States indicate that urban and agricultural land use (more than 20 to 30 percent of a drainage basin) has increased median total nitrogen yields by factors of three to five and has increased median total phosphorus yields by factors of three to six, relative to undeveloped drainage basins, although the yield ranges for both constituents are large for all land use categories (table 22, figs. 17B, E). Median yields increase as the percentage of developed land in a drainage basin increases, and the increase in yield is notable in the range of 20 to 40 percent developed land (figs. 17B, E). Major point-source discharges contribute to elevated nutrient yields throughout the study area (fig. 18, table 8 , in back of report), in agricultural, urban/agricultural, and forested basins, as well as in urban basins.

The type of development, the extent of developed land, and the intensity of urban or agricultural development varies in the region. Percentages of agricultural land are higher in the central and southern drainage basins of the region (the mid-Atlantic hydrologic region), and most developed drainage basins in these areas are classified as agricultural or urban/agricultural. Only one drainage basin south and west of southern New Jersey is classified as urban, among the basins evaluated in this study (Accotink Creek in Virginia, station 123 , table 8 , in back of report). Consequently, conclusions and generalizations about the contributions of agricultural or urban land to nutrient yields may be applicable to subregions in the study area, but not applicable to the entire region.

\section{Large Drainage Basins that Integrate Numerous Land Uses and Nutrient Sources}

Water quality in large drainage basins of the northeastern United States integrates the effects of numerous and varied land uses and nutrient sources. Nutrient yields in 21 of the 22 large drainage basins evaluated (about $1,000 \mathrm{mi}^{2}$ or larger; highlighted in gray, tables 20,21 ) are affected by major pointsource discharges. Nutrient yields in large drainage basins with point sources are generally substantially lower than nutrient yields in smaller drainage basins with point sources. Ranges for nutrient yields in some large drainage basins with 
point sources are similar to ranges for yields in undeveloped basins with no point sources (fig. 18). For example, the Connecticut River in Connecticut, the Delaware River (at Montague) in New Jersey, and the James and Appomattox Rivers in Virginia (table 8, in back of report; numbers 22, 82, 127, and 129), are all classified as undeveloped on the basis of land use percentages (less than 10 percent urban and less than 20 percent agricultural). These drainage basins are about 76 to 88 percent undeveloped, and all these streams receive major point-source discharges. Drainage basin size for these four rivers ranges from about 1,300 to almost 10,000 $\mathrm{mi}^{2}$. Median total nitrogen yields for these four rivers range from 1,200 to $2,400 \mathrm{lb} / \mathrm{mi}^{2} / \mathrm{yr}$, and 75 percent of the annual yields for these rivers are less than $3,000 \mathrm{lb} / \mathrm{mi}^{2} / \mathrm{yr}$ (fig. $18 \mathrm{~A}$, table 20 ). By contrast, total nitrogen yields for the Delaware River at Trenton (table 8, in back of report; fig. 18A; station 90), also classified as undeveloped, are substantially higher than for these four basins, possibly because of higher population density or the size and distribution of point sources. Median total phosphorus yields are less than $200 \mathrm{lb} / \mathrm{mi}^{2} / \mathrm{yr}$ for the Connecticut, Delaware (at Montague), and Appomattox Rivers, and more than $300 \mathrm{lb} / \mathrm{mi}^{2} / \mathrm{yr}$ for the Delaware (at Trenton) and James Rivers (table 21).

The Susquehanna, Potomac, Connecticut, Delaware (at Trenton), and James Rivers are the five largest monitored drainage basins with complete records for the 1993-2003 period (stations 111, 122, 22, 90, and 127, figs. 17 and 18). Total nitrogen and total phosphorus yields for these drainage basins generally fall in the interquartile range for all stations (fig. 17). Median total nitrogen yields for the Susquehanna, Potomac, and Delaware River Basins are more than two times the median yields for the Connecticut and James River Basins (fig. 17B, table 20). In the case of the Susquehanna and Potomac River Basins, this difference may be attributable to the much larger percentage of developed (agricultural) land. Median total phosphorus yields for the Potomac, Delaware, and James River Basins exceed median yields for the

Susquehanna and Connecticut River Basins, but only by about 50 percent (fig. 17E, table 21). Total phosphorus yields in the James River Basin are relatively higher than total nitrogen yields, compared to the other four basins, possibly because of natural phosphorus sources in the drainage basin (Belval and Sprague, 1999). The very low minimum total nitrogen yield for the James River Basin (fig. 17A) occurred during the drought conditions of 2002.

Forested land constitutes 65 percent or more of the drainage area in 17 of the 22 large drainage basins evaluated for nutrient yields (table 8 , in back of report). Cleaner streamflow from forested areas is a source of dilution for the more impaired waters downstream. The relation of upstream nutrient contributions to main stem rivers is complex, however, as described in the evaluation of headwater streams and transport processes (Alexander and others, 2007). Development in forested areas of large drainage basins may contribute to future increases in nutrient yields, both through the increases in nutrient sources and the changes in hydrologic processes in headwater streams.

\section{Effects of Variability in Streamflow Conditions}

Annual nutrient yields vary considerably from year to year in response to changing hydrologic conditions, as shown in the previous discussion of nutrient loads. These effects are more pronounced in small drainage basins, and also may be related to basin land use. For the period analyzed, maximum total nitrogen yields in wet years, such as 1996 and 2003, are generally about two times larger than maximum yields in dry years, such as 1995 and 2002 (table 23). Maximum total phosphorus yields in wet years, such as 1994, 1996, and 2003, are generally two to four times larger than maximum yields in dry years, such as 1995 and 2002 (table 24). Differences between wet and dry years in individual drainage basins may be much greater. Maximum nutrient yields in any one year may be affected by one or more localized storms that do not affect the entire region. Regional variations in the same year also may be pronounced.

None of the water years in the 1993-2003 period represents a truly median streamflow year (on the basis of annual mean streamflows) for the entire region (fig. 5). In particular, drainage basins in the southern part of the study area generally experienced annual precipitation and streamflows during 1993-2003 that were either substantially more than or substantially less than median conditions. Drought conditions prevailed in the southern part of the study area during much of the 1999-2002 period. Nutrient yields for water year 2000 are presented as the year most closely representing median

Table 23. Summary statistics for total nitrogen yields by water year, 1993-2003.

[Undeveloped stations from Clark and others (2000) not included in statistics. $1 \mathrm{~b} / \mathrm{mi}^{2} / \mathrm{yr}$, pounds per square mile per year]

\begin{tabular}{cccccc}
\hline \multirow{2}{*}{$\begin{array}{c}\text { Water } \\
\text { year }\end{array}$} & $\begin{array}{c}\text { Number of } \\
\text { stations }\end{array}$ & \multicolumn{4}{c}{$\begin{array}{c}\text { Total nitrogen yield } \\
\left(\mathbf{I b} / \mathbf{m i}^{2} / \mathbf{y r}\right)\end{array}$} \\
\cline { 3 - 6 } & & Minimum & Mean & Median & Maximum \\
\hline 1993 & 64 & 580 & 5,000 & 4,400 & 19,000 \\
1994 & 66 & 590 & 5,600 & 4,800 & 19,000 \\
1995 & 64 & 330 & 3,100 & 2,400 & 12,000 \\
1996 & 59 & 1,300 & 6,500 & 5,700 & 21,000 \\
1997 & 61 & 1,200 & 6,500 & 5,100 & 31,000 \\
1998 & 61 & 960 & 6,200 & 4,800 & 32,000 \\
1999 & 67 & 220 & 3,700 & 2,600 & 15,000 \\
2000 & 69 & 550 & 4,900 & 3,700 & 20,000 \\
2001 & 67 & 480 & 4,300 & 3,000 & 17,000 \\
2002 & 61 & 41 & 2,300 & 1,700 & 12,000 \\
2003 & 56 & 840 & 6,100 & 4,800 & 22,000 \\
\hline
\end{tabular}


Table 24. Summary statistics for total phosphorus yields by water year, 1993-2003.

[Undeveloped stations from Clark and others (2000) not included in statistics. $\mathrm{lb} / \mathrm{mi}^{2} / \mathrm{yr}$, pounds per square mile per year]

\begin{tabular}{cccccc}
\hline \multirow{2}{*}{$\begin{array}{c}\text { Water } \\
\text { year }\end{array}$} & $\begin{array}{c}\text { Number of } \\
\text { stations }\end{array}$ & \multicolumn{4}{c}{$\begin{array}{c}\text { Total phosphorus yield } \\
\left(\mathbf{l b} / \mathbf{m i}^{2} / \mathbf{y r}\right)\end{array}$} \\
\cline { 3 - 6 } & & Minimum & Mean & Median & Maximum \\
\hline 1993 & 63 & 48 & 390 & 320 & 1,300 \\
1994 & 65 & 60 & 520 & 330 & 4,500 \\
1995 & 63 & 22 & 210 & 110 & 1,100 \\
1996 & 59 & 32 & 2,400 & 440 & 110,000 \\
1997 & 61 & 29 & 580 & 300 & 4,500 \\
1998 & 61 & 23 & 470 & 330 & 2,300 \\
1999 & 67 & 8.5 & 660 & 140 & 16,000 \\
2000 & 69 & 16 & 340 & 200 & 2,600 \\
2001 & 67 & 19 & 340 & 200 & 2,200 \\
2002 & 61 & 1.4 & 180 & 99 & 1,700 \\
2003 & 56 & 32 & 550 & 420 & 2,400 \\
\hline
\end{tabular}

conditions in large parts of the region, particularly central and northern areas (figs. 19A, B).

In water year 2000, a year with fairly typical hydrologic conditions, nutrient yields are high in all types of highly developed drainage basins: small urbanized drainage basins that receive point sources, small highly urbanized nonpoint source basins, agricultural basins with large percentages of agricultural land, and agricultural and urban/agricultural basins that receive point sources (figs. 19A, B). As in the case for minimum, median, and maximum nutrient yields (fig. 17), the range in yields in water year 2000 is large, with a more compact range for total nitrogen yields (fig. 19A) and greater scatter in total phosphorus yields (fig. 19B). The high total phosphorus yield for the agricultural Canajoharie Creek Basin in New York (fig. 19B; station 45) illustrates regional variability in conditions. The total phosphorus yield for Canajoharie Creek in 2000 is the maximum yield for that station for the 1994-2003 period; the median total phosphorus yield is $540 \mathrm{lb} / \mathrm{mi}^{2} / \mathrm{yr}$ (table 21). Annual mean streamflows in water year 2000 exceeded the 75 th percentile in some drainage basins in this part of the study area (fig. 5D).

Streamflows and nutrient yields in water year 2000 varied considerably among the five largest drainage basins with records for the complete 1993-2003 period. Total nitrogen yields in 2000 generally follow a gradient from higher streamflow in the northern part of the study area to lower streamflow in the southern part of the study area (figs. 5C, F, I). The total nitrogen yield in 2000 for the Connecticut River Basin (fig. 19A, station 22; 2,500 lb/mi2/yr) was relatively high, about equal to the 75 th percentile for that station. The yield for the Delaware River at Trenton in 2000 (station $90 ; 4,300 \mathrm{lb} / \mathrm{mi}^{2} / \mathrm{yr}$ ) was close to the station median $\left(4,800 \mathrm{lb} / \mathrm{mi}^{2} / \mathrm{yr}\right.$, table 20$)$, whereas the yield in 2000 for the Susquehanna River Basin (station 111; 3,900 lb/mi²/yr) was 75 percent of the median for that station $\left(5,200 \mathrm{lb} / \mathrm{mi}^{2} / \mathrm{yr}\right)$. The yield for the Potomac River Basin in 2000 (station 122; $\left.2,500 \mathrm{lb} / \mathrm{mi}^{2} / \mathrm{yr}\right)$ was about half of the median $\left(5,100 \mathrm{lb} / \mathrm{mi}^{2} / \mathrm{yr}\right)$ and slightly greater than the 25 th percentile $\left(2,300 \mathrm{lb} / \mathrm{mi}^{2} / \mathrm{yr}\right)$ for that station. Similarly, the total nitrogen yield for the James

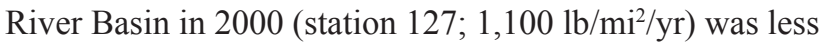
than two-thirds of the median $\left(1,800 \mathrm{lb} / \mathrm{mi}^{2} / \mathrm{yr}\right)$ and slightly greater than the 25 th percentile $\left(890 \mathrm{lb} / \mathrm{mi}^{2} / \mathrm{yr}\right)$ for that station.

Water years 2002, a very dry year throughout the region, and 2003, a very wet year in many parts of the region, represent extreme streamflow conditions for many drainage basins, with large differences in maximum yields for both total nitrogen and total phosphorus between the two years (figs. 19C, D). Differences in yield were less pronounced in the northern part of the study area, where the dry conditions of 2002 persisted into 2003 in some areas (figs. 5A, C). Regional hydrologic differences are the likely cause of regional differences in the extent of variation in yield between the two years, with more extreme streamflow conditions prevailing during both 2002 and 2003 in the southern part of the study area. However, predominant land use also may be a factor in the regional differences. Agricultural basins, more prevalent in the southern part of the study area, have large differences in yield between the two years, presumably because nonpoint sources are the predominant nutrient sources in these basins, and yields are largely dependent on varying hydrologic conditions. In the northeastern part of the study area, by contrast, urbanized drainage basins are more prevalent, and nutrient yields generally have less year-to-year variability because point-source discharges in many of these basins contribute to relatively constant annual nutrient yields.

Total nitrogen yields in 2003 generally exceeded yields in 2002 by a factor of 2.0 or less in most drainage basins in New England and New York, including large drainage basins such as the Merrimack and Connecticut (fig. 19C, stations 6, 22), and small drainage basins with point sources, (stations 28, 32). Differences in yield between the two years were greater in the central and southern parts of the study area. The Pequannock River Basin in New Jersey (station 53) had the greatest difference in yields among the 56 stations with estimates for both years, with a 2003 total nitrogen yield that was 20 times the yield estimated for 2002. All stations in Virginia had an orderof-magnitude difference in total nitrogen yields between the two years (2003 yields ranging from 13 to 18 times the 2002 yields), including the Rappahannock, Pamunkey, Mattaponi, James, and Appomattox River Basins (fig. 19C; stations 124, $125,126,127$, and 129). The large differences in yield for the Virginia drainage basins may be caused in large part by differences in hydrologic conditions between the two years (figs. $5 \mathrm{H}, \mathrm{I}$ ), and to the nonpoint nutrient contributions from agricultural land related to the hydrologic conditions in each year. Antecedent conditions also may be a factor in the large 


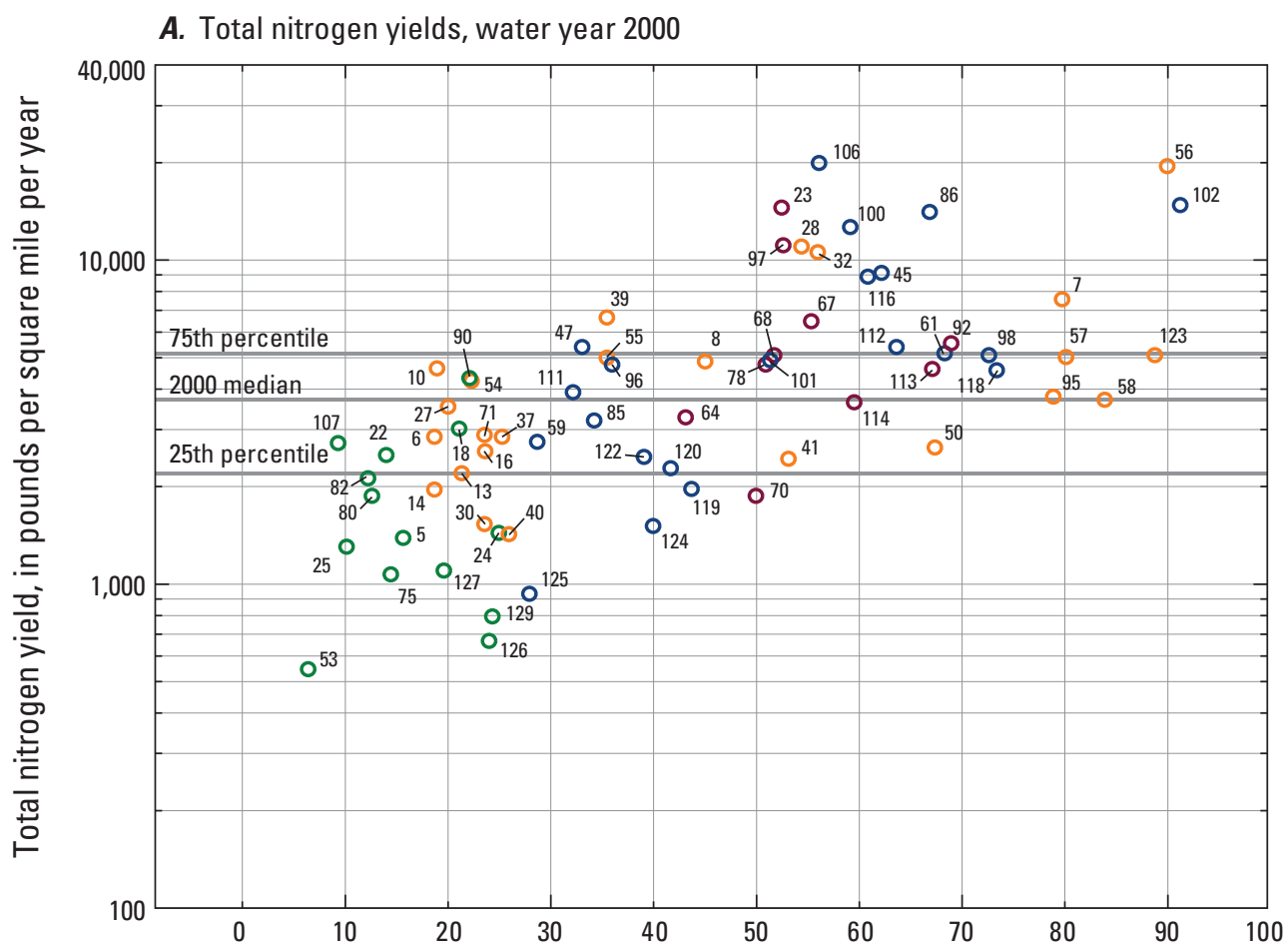

\section{EXPLANATION}

○ Agricultural basin

○ Urban/agricultural basin

○ Undeveloped basin

- Urban basin

23 Station sequence number

B. Total phosphorus yields, water year 2000

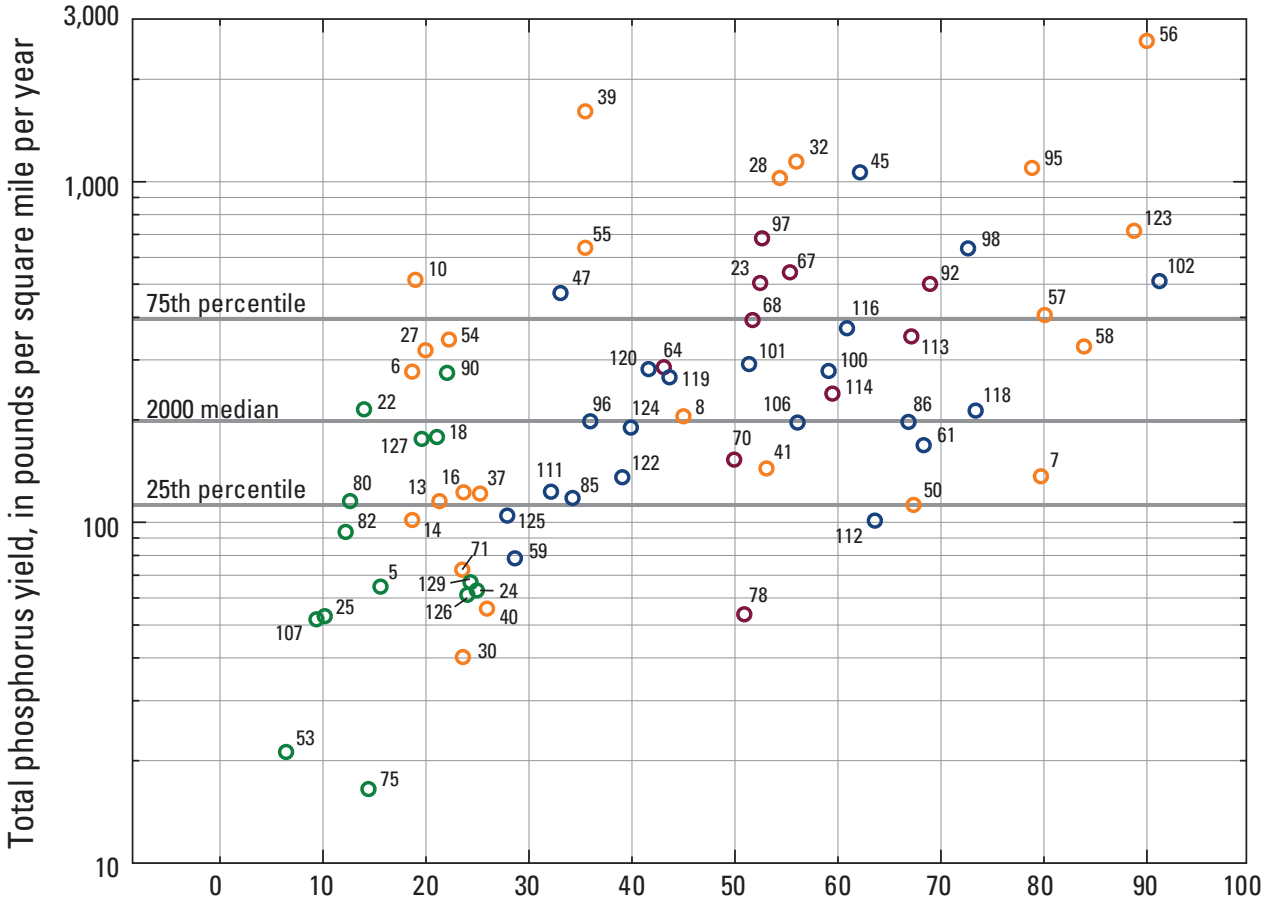

Total developed land, as percentage of drainage basin

Figure 19. Annual nutrient yields in selected water years, including 2000 (median flow year), 2002 (dry year), and 2003 (wet year), as a function of the percentage of developed land in a drainage basin. (A) Total nitrogen yields for 69 stations, water year $2000,(B)$ total phosphorus yields for 69 stations, water year 2000, (C) total nitrogen yields for 56 stations, water years 2002 and 2003, and (D) total phosphorus yields for 56 stations, water years 2002 and 2003. 


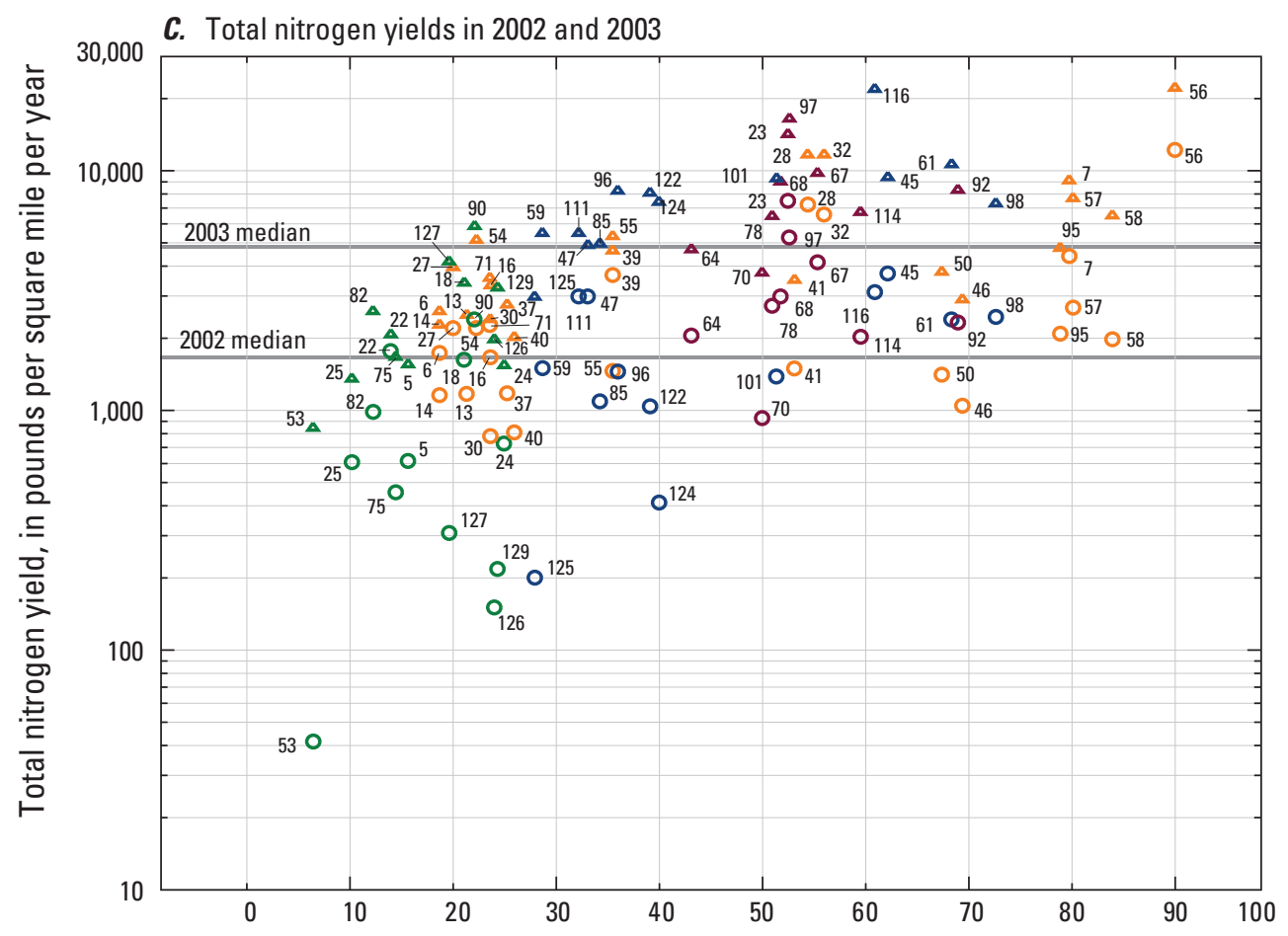

\section{EXPLANATION}

\section{2}

- Agricultural basin

- Urban/agricultural basin

- Undeveloped basin

- Urban basin

90 Station sequence number

2003

$\Delta$ Agricultural basin

A Urban/agricultural basin

$\Delta$ Undeveloped basin

$\triangle$ Urban basin

90 Station sequence number

D. Total phosphorus yields in 2002 and 2003

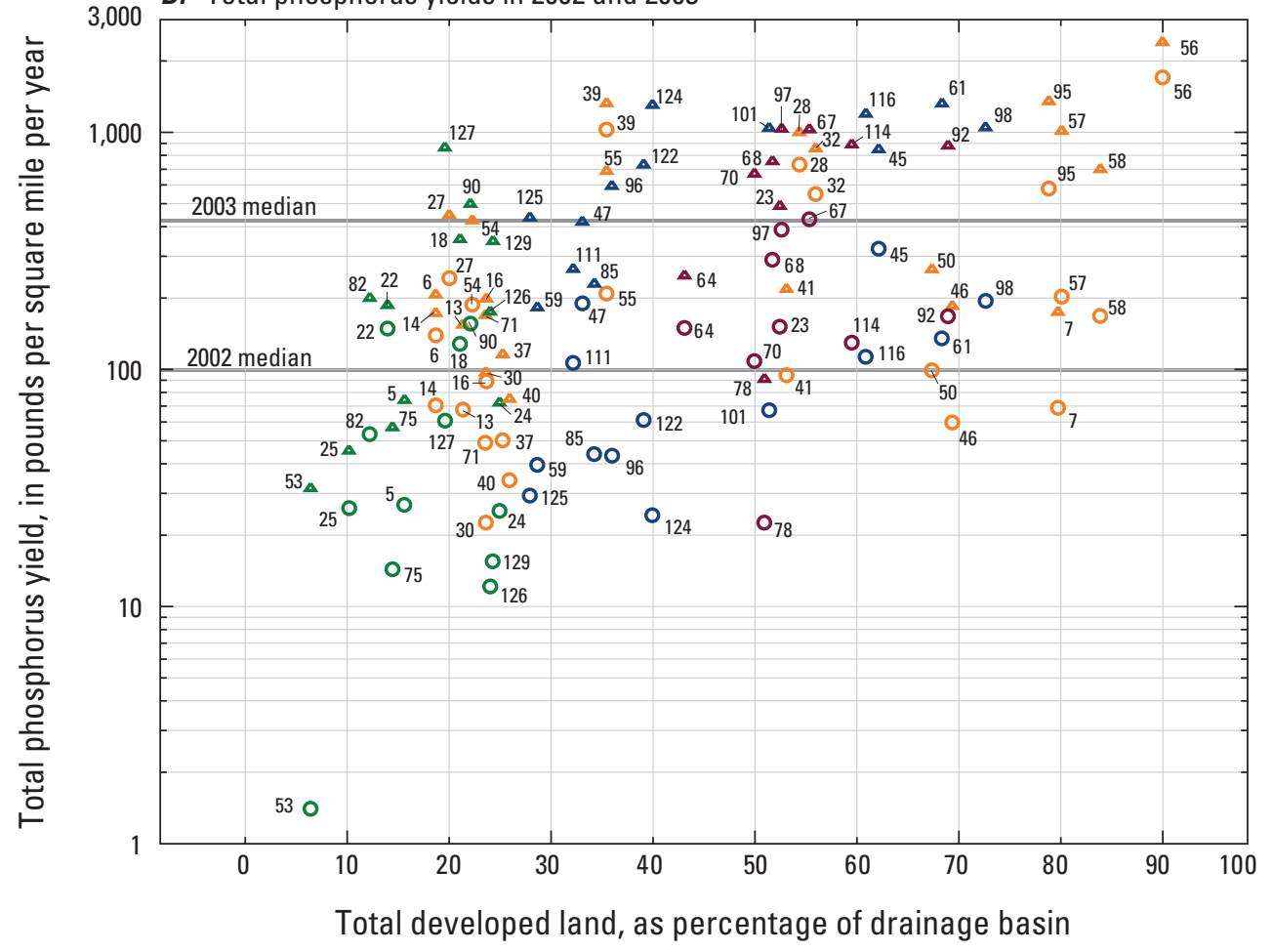

Figure 19. Annual nutrient yields in selected water years, including 2000 (median flow year), 2002 (dry year), and 2003 (wet year), as a function of the percentage of developed land in a drainage basin. (A)Total nitrogen yields for 69 stations, water year $2000,(B)$ total phosphorus yields for 69 stations, water year 2000, (C) total nitrogen yields for 56 stations, water years 2002 and 2003, and (D) total phosphorus yields for 56 stations, water years 2002 and 2003.-Continued 
differences between the two years. Wet conditions and high streamflow during 2003 may have removed and transported nutrients delivered to drainage basins in 2002, nutrients which might have been transported out of the basins if normal hydrologic conditions had prevailed during 2002, but which were retained in the basins because of extremely dry conditions.

Differences in total phosphorus yields between 2002 and 2003 followed a similar regional pattern to that of total nitrogen, with even greater differences observed for total phosphorus in some parts of the study area. The maximum differences in total phosphorus yields between the two years were observed in the Rappahannock River Basin in Virginia (fig. 19D, station 124; 2003 yield 54 times greater than the 2002 yield), the Pequannock River Basin in New Jersey (station 53; 2003:2002 ratio of 23), the Appomattox River Basin in Virginia (station 129; ratio of 22), the Choptank River Basin in Maryland (station 101; ratio of 15.5), and the Pamunkey River in Virginia (station 125; ratio of 14.9). In general, differences in total phosphorus yields between the two years were greatest in drainage basins from New Jersey to Virginia, particularly in small agricultural drainage basins and in some larger drainage basins with agricultural influences in Maryland and Virginia. Ratios of total phosphorus yields for the five largest drainage basins varied widely along a general north-south gradient in the study area: the Connecticut River Basin (fig. 19D, station 22; ratio of 1.3), the Delaware River Basin (station 90; ratio of 3.2), the Susquehanna River Basin (station 111; ratio of 2.5), the Potomac River Basin (station 122; ratio of 12), and the James River Basin (station 127; ratio of 14).

Evaluation of nutrient yields in high, low, and "typical" streamflow years indicates that substantial annual variations in nutrient yields are the norm in the study area, particularly in smaller drainage basins and drainage basins in which nonpoint sources of nutrients predominate. This large interannual variability has implications for management of nutrients to restore receiving waters, in both freshwater reaches and estuarine areas. Management strategies targeted to address average nutrient yield conditions may not be adequate to address more extreme, but nevertheless moderately frequent, conditions.

A maximum total phosphorus yield of more than $100,000 \mathrm{lb} / \mathrm{mi}^{2} / \mathrm{yr}$ is shown for water year 1996 (table 24), a wet year. This estimate is included as an example of conditions in small agricultural basins and also as an example of uncertainties in load estimation beyond the range of known hydrologic and water-quality conditions. This maximum yield is based on the annual load estimated for 1996 for Muddy Creek at Mount Clinton, Va., a drainage basin of about 14 $\mathrm{mi}^{2}$ with about 68 percent agricultural land (table 8 , in back of report, station 118; table 21). Annual loads were estimated for the period 1994-2001; however, no water-quality data were collected during 1996, which included several peak streamflows for the period. The highest daily mean streamflow value paired with water-quality data during 1994-2001 is 92 cubic feet per second $\left(\mathrm{ft}^{3} / \mathrm{s}\right)$, and most daily mean streamflow values are less than $100 \mathrm{ft}^{3} / \mathrm{s}$. Water year 1996 included the five highest daily mean stream discharge values in the 1994-2001 period, ranging from 290 to $1,760 \mathrm{ft}^{3} / \mathrm{s}$. Consequently, the load estimate for 1996 is based on extreme streamflows that are well beyond the range of the known concentration-discharge relation. The 1996 yield estimate for Muddy Creek is not included in the graph of maximum total phosphorus yields (fig. 17F) or the summary statistics for total phosphorus yields (table 22) because of the high degree of uncertainty associated with the estimate, and also because the range of yields for all stations is illustrated more clearly without the distortion introduced by this extreme outlier. Additional monitoring of high streamflows would be necessary to determine how high maximum total phosphorus yields might be in this and other small agricultural drainage basins.

\section{Point-Source Discharges}

Numerous regional improvements in municipal wastewater treatment took place during the time period covered by this study, including upgrades of primary treatment facilities to secondary treatment after passage of the Clean Water Act in 1972, and implementation of subsequent regulations. Some secondary treatment processes are designed to remove biodegradable organic material and material that contains organic nitrogen prior to discharge, by converting ammonia nitrogen to nitrate in a process called nitrification (U.S. Environmental Protection Agency, 2004, p. 12). During the same period, implementation of phosphate detergent bans reduced the discharge of phosphorus in treatment plant effluent (Litke, 1999). Implementation of phosphate detergent bans in the northeastern United States took place during a period ranging from 1972 to 1995 (Litke, 1999, p. 6, table 1). Nationally, the detergent industry phased out the use of phosphorus in domestic laundry detergent by about 1994 . Detergent bans, however, typically limited phosphorus only in household laundry detergent during the time period covered by this study; phosphate was still allowed in dishwashing detergents and commercial cleaning products (Litke, 1999, p. 5-6). Implementation of secondary treatment, and in some cases tertiary treatment, has also reduced phosphorus concentrations in the effluent from wastewater-treatment plants during the period of this study (Litke, 1999, p. 8-9).

Four drainage basins were evaluated for nutrient loads from point source discharges: the Quinebaug River Basin in Connecticut, Massachusetts, and Rhode Island; the Raritan River Basin in New Jersey; the Patuxent River Basin in Maryland; and the James River Basin (including the Appomattox River Basin) in Virginia (table 25, fig. 20). In these four drainage basins, trends in flow-adjusted nutrient concentrations were analyzed for 14 stations during the recent period and 6 stations during the long-term period (table 26). Trends in nutrient loads were analyzed and annual loads of nutrients were estimated for nine stations during the recent period and six stations during the long-term period (table 27). 


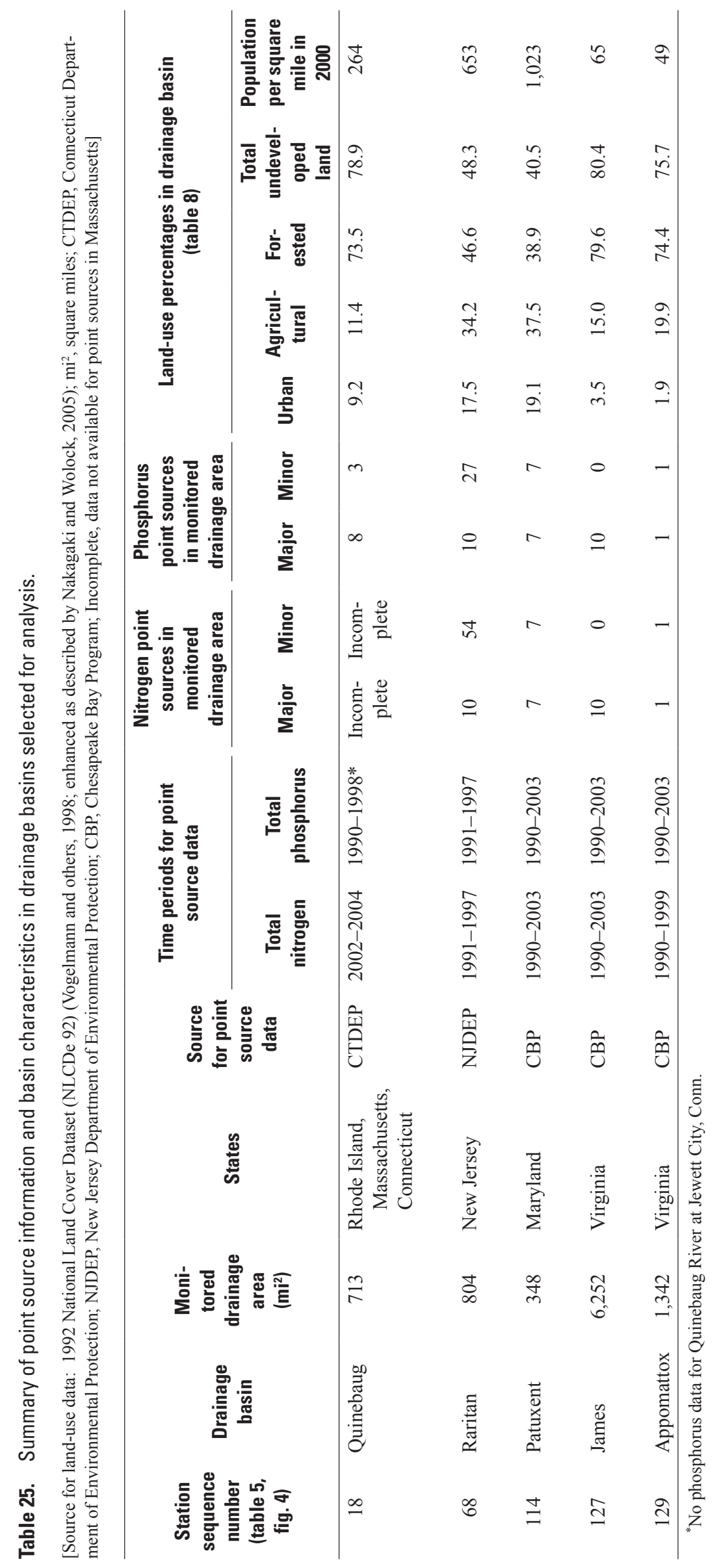




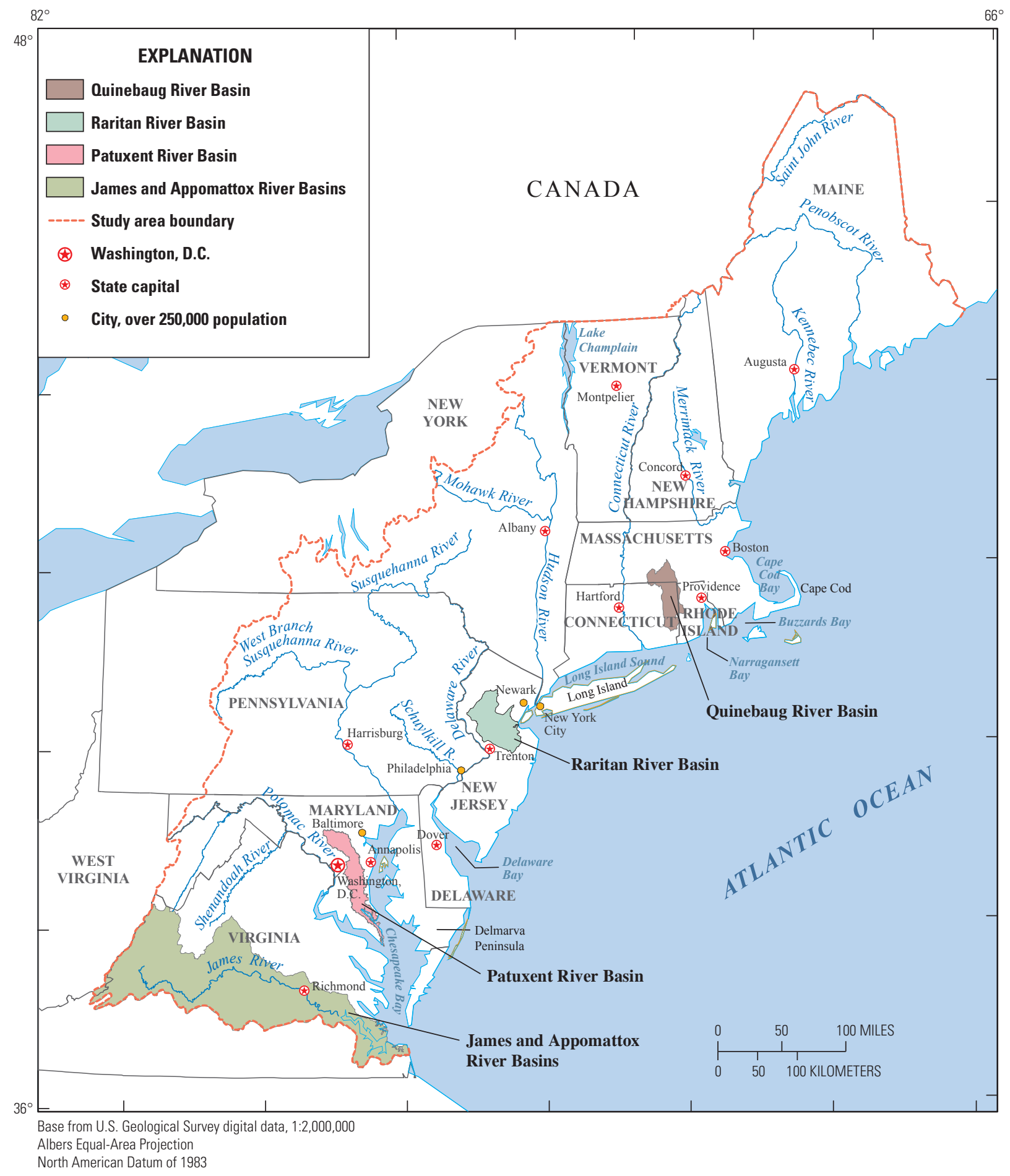

Figure 20. Drainage basins selected for analysis of point sources in relation to nutrient concentrations, loads, and yields. 
Table 26. Summary of trends in flow-adjusted nutrient concentrations in drainage basins selected for analysis of point sources.

[Station sequence numbers shown in table 5. Significant trend: $p$-value less than or equal to 0.05 ; highly significant trend: $p$-value less than or equal to 0.01 . $\mathrm{mi}^{2}$, square miles; *, highly significant trend; N, no significant trend; --, data not available or not analyzed]

\begin{tabular}{|c|c|c|c|}
\hline \multirow{2}{*}{$\begin{array}{c}\text { Initial } \\
\text { water qual- } \\
\text { ity date, } \\
\text { 1975-2003 }\end{array}$} & \multirow[b]{2}{*}{ Water-quality constituent } & \multicolumn{2}{|c|}{$\begin{array}{c}\text { Flow-adjusted } \\
\text { concentration trend }\end{array}$} \\
\hline & & $\begin{array}{c}\text { Water } \\
\text { years } \\
\text { 1975-2003 }\end{array}$ & $\begin{array}{c}\text { Water } \\
\text { years } \\
\text { 1993-2003 }\end{array}$ \\
\hline \multicolumn{4}{|c|}{ Quinebaug River Basin } \\
\hline \multicolumn{4}{|c|}{ Quinebaug River at Quinebaug, Conn. (station 14) (155 mi²) } \\
\hline $10 / 26 / 1981$ & Total nitrogen & *Down & $* U p$ \\
\hline $2 / 10 / 1993$ & Ammonia nitrogen & -- & Down \\
\hline 10/26/1981 & Total Kjeldahl nitrogen & *Down & -- \\
\hline $10 / 26 / 1981$ & Nitrite-plus-nitrate nitrogen & $\mathrm{N}$ & $\mathrm{N}$ \\
\hline $10 / 26 / 1981$ & Total phosphorus & *Down & $\mathrm{N}$ \\
\hline \multicolumn{4}{|c|}{ French River at North Grosvenordale, Conn. (station 15) (101 mi²) } \\
\hline $2 / 10 / 1993$ & Ammonia nitrogen & -- & $\mathrm{N}$ \\
\hline $10 / 20 / 1992$ & Nitrite-plus-nitrate nitrogen & -- & $\mathrm{N}$ \\
\hline 10/20/1992 & Total phosphorus & -- & $\mathrm{N}$ \\
\hline \multicolumn{4}{|c|}{$\begin{array}{l}\text { Quinebaug River at Cotton Bridge Road near Pomfret, Conn. } \\
\left.\qquad \text { (station 17) (342 } \mathrm{mi}^{2}\right)\end{array}$} \\
\hline 3/8/1995 & Total nitrogen & -- & $\mathrm{N}$ \\
\hline $3 / 8 / 1995$ & Ammonia nitrogen & -- & $\mathrm{N}$ \\
\hline 3/8/1995 & Nitrite-plus-nitrate nitrogen & -- & $\mathrm{N}$ \\
\hline 3/8/1995 & Total phosphorus & -- & $* \mathrm{Up}$ \\
\hline \multicolumn{4}{|c|}{ Quinebaug River at Jewett City, Conn. (station 18) (713 mi²) } \\
\hline 10/22/1974 & Total nitrogen & *Down & $\mathrm{N}$ \\
\hline 10/22/1974 & Ammonia nitrogen & Down & $\mathrm{N}$ \\
\hline 10/22/1974 & Total Kjeldahl nitrogen & *Down & -- \\
\hline $10 / 22 / 1974$ & Nitrite-plus-nitrate nitrogen & $\mathrm{N}$ & $\mathrm{N}$ \\
\hline $10 / 22 / 1974$ & Total phosphorus & *Down & $* U p$ \\
\hline
\end{tabular}

\section{Raritan River Basin}

\begin{tabular}{clcc}
\hline \multicolumn{4}{c}{ Mulhockaway Creek at Van Syckel, N.J. (station 59) $\left(11.8 \mathrm{mi}^{2}\right)$} \\
\hline $11 / 5 / 1992$ & Total nitrogen & $\mathrm{N}$ \\
$11 / 5 / 1992$ & Nitrite-plus-nitrate nitrogen & -- & $\mathrm{N}$ \\
\hline \multicolumn{4}{c}{ Neshanic River at Reaville, N.J. (station 61) (25.7 $\left.\mathrm{mi}^{2}\right)$} \\
\hline $11 / 5 / 1992$ & Total nitrogen & -- & $\mathrm{N}$ \\
$11 / 5 / 1992$ & Ammonia nitrogen & -- & $\mathrm{N}$ \\
$11 / 5 / 1992$ & Nitrite-plus-nitrate nitrogen & -- & $\mathrm{N}$ \\
$11 / 5 / 1992$ & Total phosphorus & -- & $\mathrm{N}$ \\
\hline \multicolumn{4}{c}{ Lamington River at Burnt Mills, N.J. (station 63) (100 mi²) } \\
\hline $11 / 18 / 1992$ & Ammonia nitrogen & -- & $\mathrm{Down}$ \\
$11 / 18 / 1992$ & Nitrite-plus-nitrate nitrogen & -- & $\mathrm{N}$ \\
$11 / 18 / 1992$ & Total phosphorus & -- & $\mathrm{N}$ \\
\hline Millstone & River at Blackwells Mills, N.J. (station 67) (258 $\left.\mathrm{mi}^{2}\right)$ \\
\hline $11 / 19 / 1992$ & Total nitrogen & -- & $\mathrm{N}$ \\
$11 / 19 / 1992$ & Ammonia nitrogen & -- & $\mathrm{Up}$ \\
$2 / 17 / 1993$ & Nitrite-plus-nitrate nitrogen & -- & $\mathrm{N}$ \\
$2 / 17 / 1993$ & Total phosphorus & -- & $\mathrm{N}$
\end{tabular}

\begin{tabular}{cccc}
\hline \multirow{2}{*}{$\begin{array}{c}\text { Initial } \\
\text { water qual- } \\
\text { ity date, }\end{array}$} & \multicolumn{2}{c}{$\begin{array}{c}\text { Flow-adjusted } \\
\text { concentration trend }\end{array}$} \\
\cline { 3 - 4 } 1975-2003 & Water-quality constituent & Water & Water \\
& & years & years \\
& & $1975-2003$ & $1993-2003$ \\
\hline
\end{tabular}

Raritan River Basin-Continued

Raritan River at Queens Bridge at Bound Brook, N.J. (station 68) (804 $\mathrm{mi}^{2}$ )

\begin{tabular}{llcc}
\hline $11 / 23 / 1981$ & Total nitrogen & $\mathrm{N}$ & $\mathrm{N}$ \\
$11 / 23 / 1981$ & Ammonia nitrogen & *Down & $\mathrm{N}$ \\
$11 / 23 / 1981$ & Total Kjeldahl nitrogen & *Down & -- \\
$11 / 23 / 1981$ & Nitrite-plus-nitrate nitrogen & *Up & $\mathrm{N}$ \\
$11 / 23 / 1981$ & Total phosphorus & $\mathrm{N}$ & $\mathrm{N}$ \\
$11 / 23 / 1981$ & Suspended sediment & *Down & $\mathrm{N}$ \\
\hline
\end{tabular}

Manalapan Brook at Federal Road near Manalapan, N.J. (station 69) $\left(20.9 \mathrm{mi}^{2}\right)$

\begin{tabular}{lllc}
\hline $11 / 10 / 1992$ & Total nitrogen & -- & $\mathrm{N}$ \\
$11 / 10 / 1992$ & Ammonia nitrogen & -- & $\mathrm{Up}$ \\
$11 / 10 / 1992$ & Nitrite-plus-nitrate nitrogen & -- & $\mathrm{N}$ \\
$11 / 10 / 1992$ & Total phosphorus & -- & $\mathrm{N}$ \\
\hline
\end{tabular}

\section{Patuxent River Basin}

Patuxent River near Unity, Md. (station 112) (34.8 mi²)

10/5/1992 Total nitrogen -- $\quad \mathrm{N}$

10/6/1992 Ammonia nitrogen -- $\quad$ N

10/5/1992 Nitrite-plus-nitrate nitrogen -- $\quad$ N

10/5/1992 Total phosphorus -- $\quad N$

Patuxent River near Bowie, Md. (station 114) (348 mi²)

10/10/1978 Total nitrogen *Down N

10/17/1979 Ammonia nitrogen *Down *Down

10/10/1978 Total Kjeldahl nitrogen *Down --

10/10/1978 Nitrite-plus-nitrate nitrogen *Down Down

10/10/1978 Total phosphorus *Down *Up

10/10/1978 Suspended sediment *Down N

\section{James River Basin}

James River at Cartersville, Va. (station 127) $\left(6,252 \mathrm{mi}^{2}\right)$

10/7/1974 Total nitrogen *Down *Up

8/21/1979 Ammonia nitrogen *Down *Down

10/1/1974 Nitrite-plus-nitrate nitrogen *Down N

10/7/1974 Total phosphorus N N

Appomattox River at Matoaca, Va. (station 129) (1,342 $\left.\mathrm{mi}^{2}\right)$

10/11/1978 Total nitrogen $\quad \mathrm{N} * \mathrm{Up}$

10/10/1979 Ammonia nitrogen *Down *Down

10/11/1978 Nitrite-plus-nitrate nitrogen Down Down

10/11/1978 Total phosphorus Up N 
Table 27. Summary of trends in nutrient loads in drainage basins selected for analysis of point sources.

[Significant trend: $p$-value less than or equal to 0.05 ; highly significant trend: $p$-value less than or equal to 0.01 . N, no significant trend; *, highly significant trend; --, data not available or not analyzed]

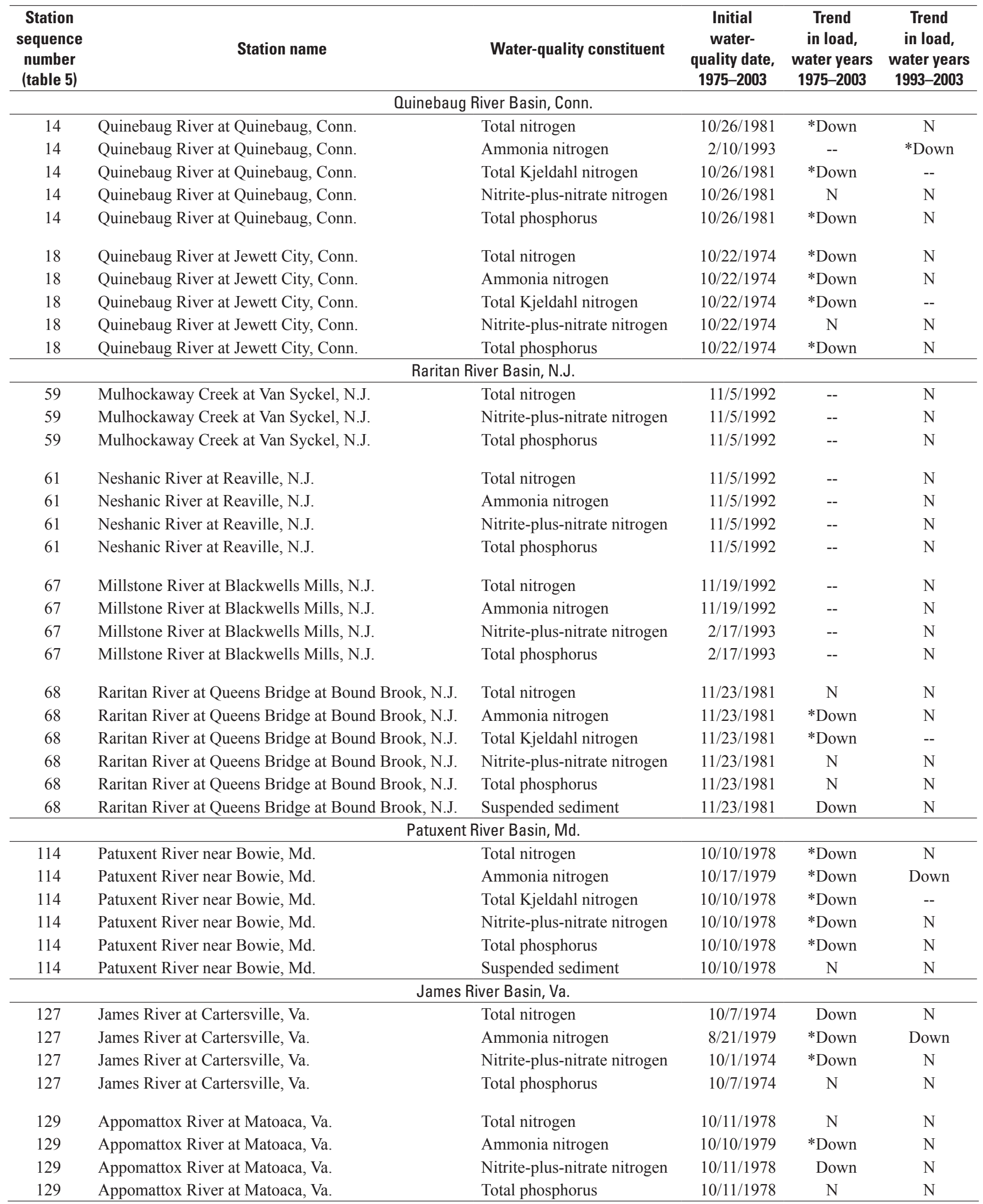


During the long-term period, numerous downward trends in nutrient loads were detected (table 27). Long-term downward trends in total nitrogen loads were detected at four stations, with no significant trend at two stations. Highly significant long-term downward trends in ammonia nitrogen loads were detected at the five stations analyzed for this constituent. Highly significant downward trends in loads of total Kjeldahl nitrogen were detected at the four stations with long-term data for this constituent. Long-term downward trends in nitriteplus-nitrate nitrogen were detected at three stations, and three stations had no significant trend. Highly significant long-term downward trends in total phosphorus loads were detected at three stations, and three stations had no significant trend. The only significant trends in nutrient loads detected during the recent period were downward trends in dissolved ammonia at three stations.

No consistent pattern was found in terms of trends in load among different forms of nitrogen, in streams that receive point-source discharges. The long-term effects of wastewatertreatment improvements have varied in different drainage basins, including the small number of basins evaluated for the effects of point sources.

The prevalence of long-term downward trends in nutrient loads in the drainage basins evaluated for point-source influences indicates substantial improvements in nutrient-related water-quality conditions. The finding of long-term downward trends in ammonia or total Kjeldahl nitrogen loads is consistent with wastewater-treatment processes that have reduced aquatic toxicity problems by converting ammonia to nitrate prior to discharge, and by removing organic material from wastewater. Long-term downward trends in total phosphorus loads in some drainage basins are consistent with implementation of phosphate detergent bans (Litke, 1999, p. 6, table 1). The absence of trends in load for most nutrients during the recent period (table 27), coupled with modeled instream concentrations for the early 1990s that exceed proposed nutrient criteria in many streams that receive wastewater effluent (table 15, in back of report), indicates that additional challenges remain in reducing the delivery of nutrients to streams from point sources.

Long-term downward trends in flow-adjusted concentrations of most nutrients (table 26) indicate reductions in the delivery of nutrients to streams, in the absence of trends in streamflow. Comparison of long-term and recent trends in flow-adjusted nutrient concentrations and trends in nutrient loads indicates that in the basins evaluated, the major reductions in delivery of nutrients to streams, whether from point sources or other sources, may have taken place prior to the 1993-2003 period of analysis. The reduction in delivery of nutrients is consistent with the history of improvements in wastewater-treatment facilities in the region, although this relation has not been documented quantitatively or in historical detail. Trends in nutrient loads, for most stations, coupled with similar trends in flow-adjusted concentrations of nutrients, appear to indicate changes in the delivery of nutrients to streams, with long-term reductions in nutrients detected for most nutrients evaluated. During the recent period, however, upward trends in flow-adjusted concentrations of some nutrients at a few locations indicate processes or changes that have increased nutrient delivery to some streams since 1993 (table 26).

\section{Quinebaug River Basin in Connecticut, Massachusetts, and Rhode Island}

The Quinebaug River Basin is in eastern Connecticut and adjoining areas of Massachusetts and Rhode Island, a relatively undeveloped area of the Boston-to-Washington urban corridor (fig. 21). Annual stream nutrient loads were estimated, trends in nutrient loads were evaluated, and pointsource loads of total phosphorus were estimated for two monitoring stations in the Quinebaug River Basin, both in Connecticut: the Quinebaug River at Quinebaug $\left(155 \mathrm{mi}^{2}\right)$, near the state line with Massachusetts, and the Quinebaug River at Jewett City $\left(713 \mathrm{mi}^{2}\right)$, near the mouth of the river (fig. 21; stations 14, 18). The Quinebaug River Basin at the Jewett City monitoring station is largely forested, with about 9 percent urbanized land, about 11 percent agricultural land, and about 79 percent undeveloped land (table 8, in back of report). Comparisons between point-source loads and stream loads of total nitrogen could not be made because nitrogen data were unavailable for point sources in Massachusetts that discharge to the Quinebaug River Basin. Nitrogen pointsource data for the Quinebaug River Basin are limited to data from the State of Connecticut (table 25).

Highly significant long-term downward trends in stream loads of total nitrogen and total Kjeldahl nitrogen were detected for the Quinebaug River at Quinebaug (fig. 22A, table 27). No trends in loads of nitrite-plus-nitrate nitrogen were detected for either the long-term (1982-2003) or recent period (fig. 22A). A highly significant downward trend in ammonia nitrogen load was detected for the recent period; data for ammonia nitrogen were not available for the longterm period (fig. 22A).

The drainage area of the Quinebaug River at Quinebaug (table 8, in back of report, station 14) includes three major point-source discharges in Massachusetts with phosphorus loads identified in the PCS database. Comparison of total phosphorus point-source loads with estimated annual stream loads for the Quinebaug River at Quinebaug (fig. 22B) shows that the total point-source load was substantially less than the total stream load for all years from 1993 to 1999, with pointsource loads generally representing 9 to 34 percent of the stream load. A substantial decrease in phosphorus point-source loads appears to have taken place between 1990 and 1993, and this decrease is reflected in a decrease in estimated stream loads during the mid- to late-1990s. In 1999, a dry year, the total point-source load of phosphorus represented 53 percent of the estimated stream phosphorus load. Point-source loads of total phosphorus as a percentage of stream phosphorus loads have decreased during the mid- to late-1990s. Stream 


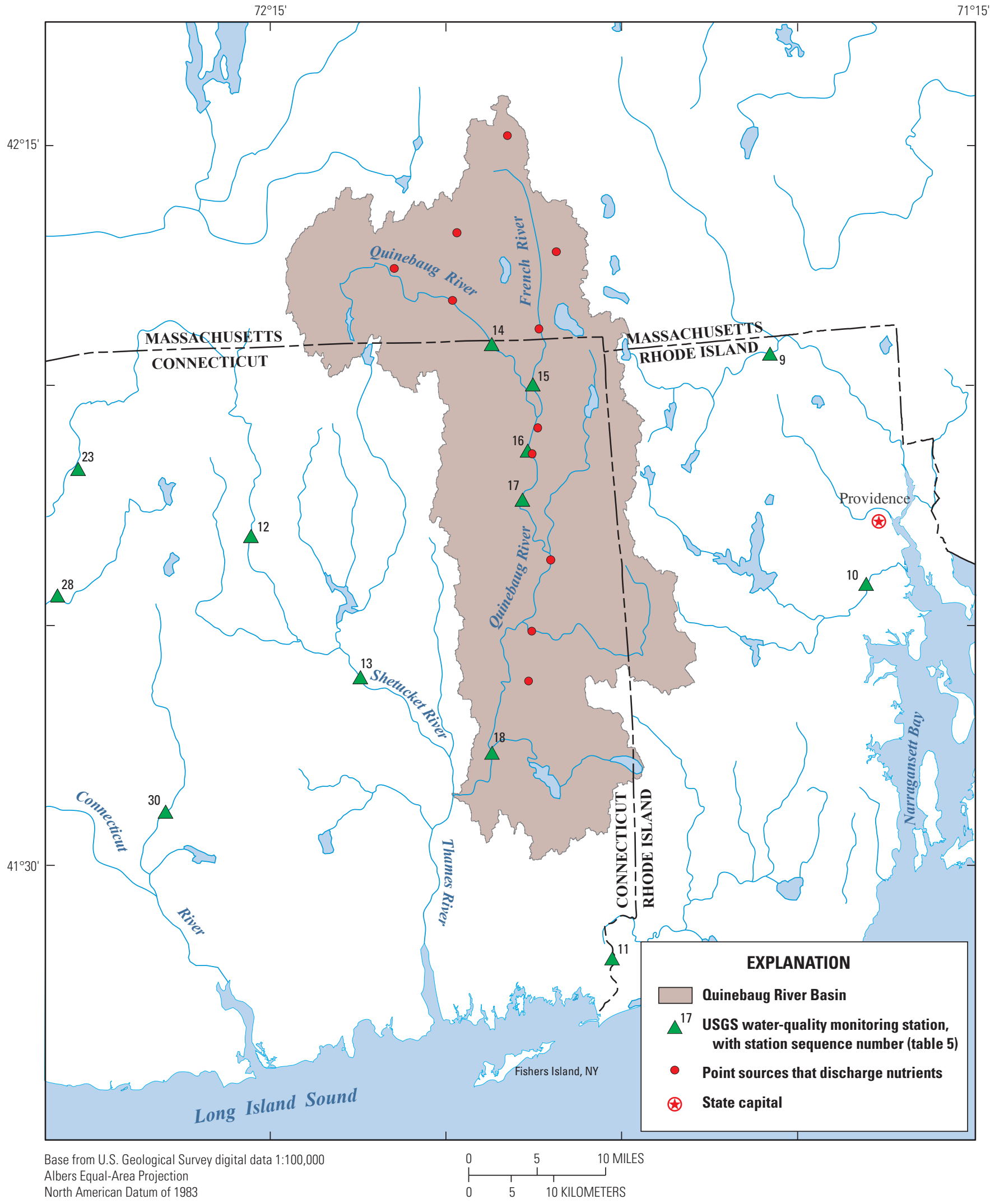

Figure 21. Monitoring stations and point-source locations in the Quinebaug River Basin. 
A. Quinebaug River at Quinebaug, Connecticut (station 14)
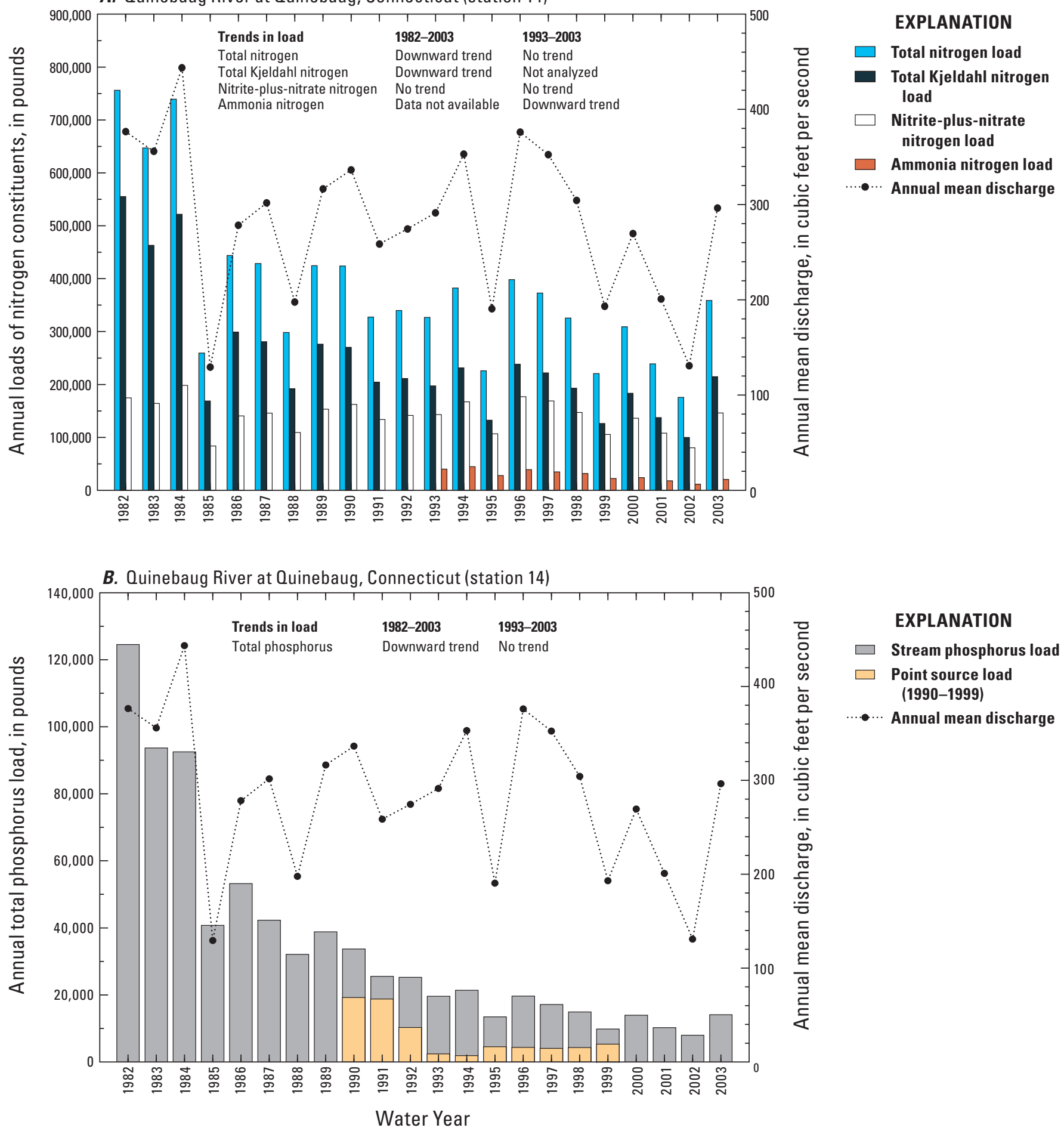

Figure 22. Annual stream loads of nutrients and point-source loads of total phosphorus in the Quinebaug River Basin. (A) Nitrogen constituents, Quinebaug River at Quinebaug, Conn., 1982-2003, (B) total phosphorus, Quinebaug River at Quinebaug, Conn., 1982-2003, (C) nitrogen constituents, Quinebaug River at Jewett City, Conn., 1975-2003, and (D) total phosphorus, Quinebaug River at Jewett City, Conn., 1975-2003. 
C. Quinebaug River at Jewett City, Connecticut (station 18)

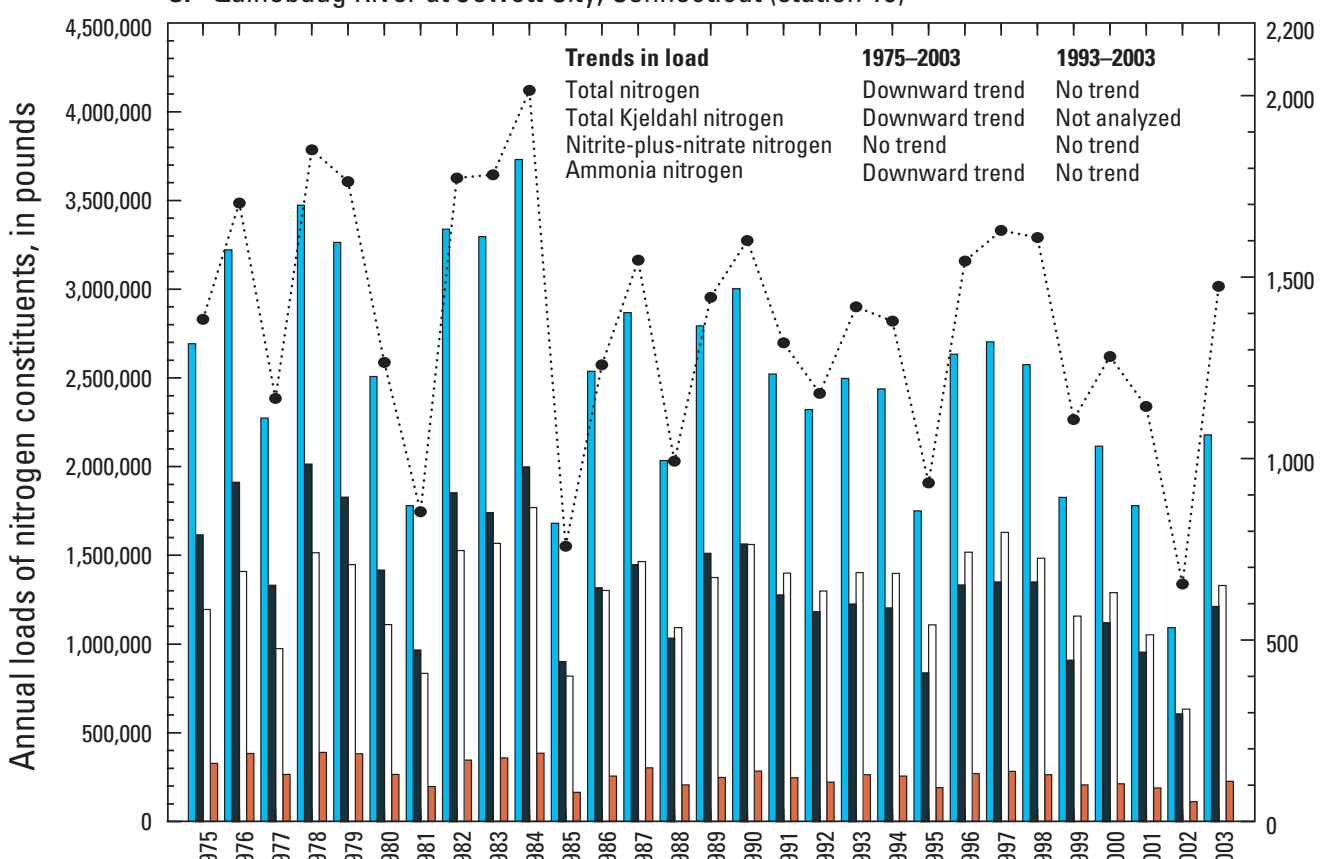

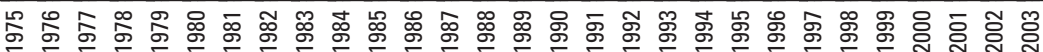
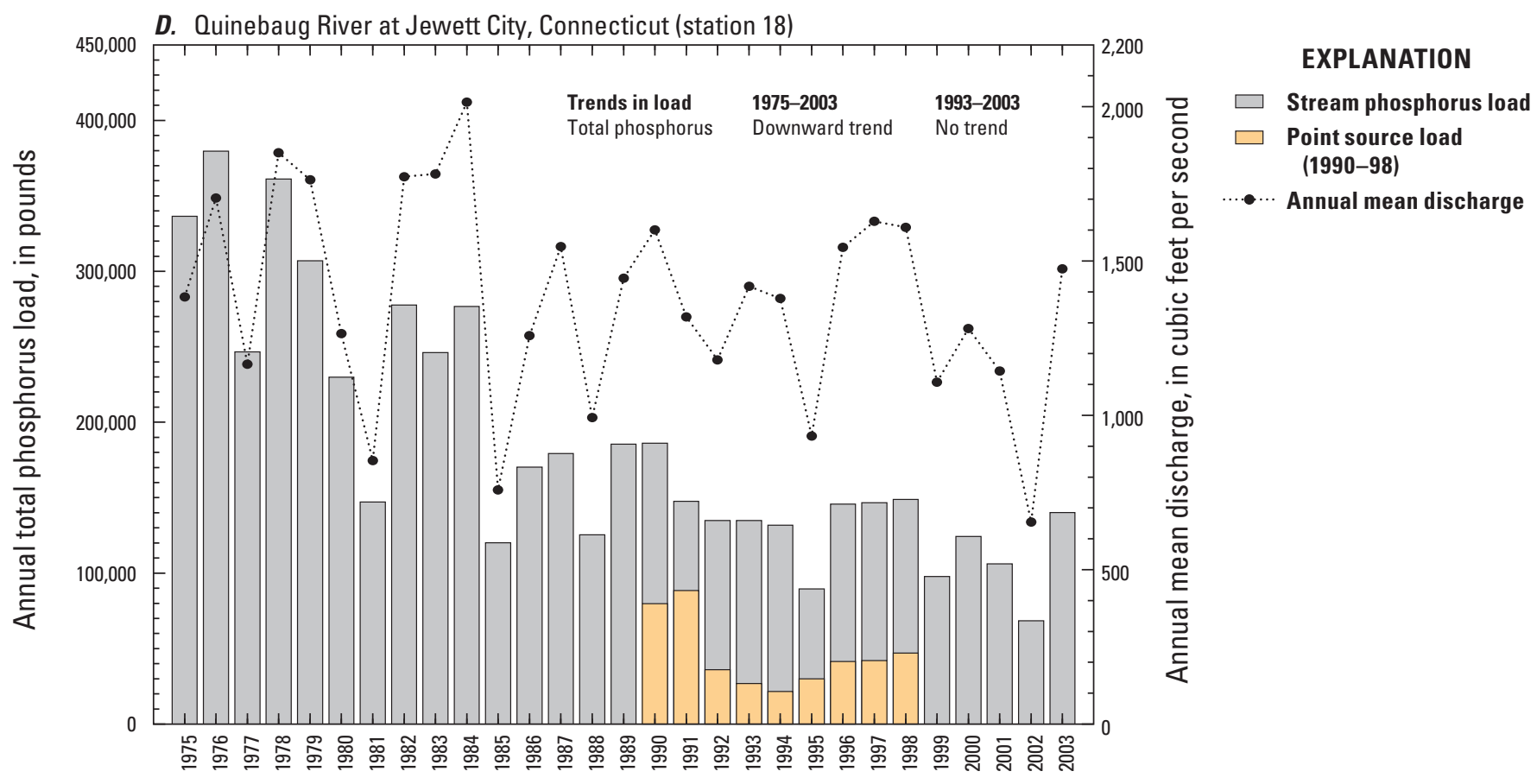

Figure 22. Annual stream loads of nutrients and point-source loads of total phosphorus in the Quinebaug River Basin. (A) Nitrogen constituents, Quinebaug River at Quinebaug, Conn., 1982-2003, (B) total phosphorus, Quinebaug River at Quinebaug, Conn., 1982-2003, (C) nitrogen constituents, Quinebaug River at Jewett City, Conn., 1975-2003, and (D) total phosphorus, Quinebaug River at Jewett City, Conn., 1975-2003.-Continued 
loads of total phosphorus have a highly significant downward trend for the 1982-2003 period, and no trend for the 19932003 period (table 27, fig. 22B).

A long-term downward trend in stream discharge was detected for the Quinebaug River at Jewett City (appendix 5, table 5-1). Consequently, the highly significant long-term downward trends in loads of total nitrogen, ammonia nitrogen, total Kjeldahl nitrogen, and total phosphorus detected for this station (table 27, figs. 22C, D) may be caused in part by decreases in streamflow. However, plots of annual mean discharge and annual loads of total nitrogen and total phosphorus (figs. 22C, D) indicate that for a given annual mean discharge, annual loads of these two constituents were lower in the 1990s and early 2000s than in the 1970s and 1980s. This decrease in loads can be attributed in part to the long-term downward trends in flow-adjusted concentrations of these constituents (table 26), which indicate that a reduction in the delivery of nutrients to the Quinebaug River has taken place, in addition to the likely effects of the downward trend in streamflow.

The drainage area of the Quinebaug River at Jewett City (table 8, in back of report, station 18; table 25), has 11 upstream point sources with phosphorus loads identified in the PCS database. Eight of these point sources are identified as major point-source discharges. The borough of Jewett City, which discharges effluent directly upstream from the monitoring station, does not have reported phosphorus loads for the 1990s in the PCS database; consequently, data for this municipality are not included in the point-source load estimate. Jewett City has a population of 3,053 (in 2000) and is not identified in PCS as a major point-source facility. Total phosphorus point-source loads were highest in 1990 and 1991 (fig. 22D), and represented the largest percentage of stream loads in those years, 43 and 60 percent, respectively. Annual point-source loads were substantially less than annual stream loads estimated for the Jewett City monitoring station from 1992 to 1998 , representing 16 to 33 percent of the stream loads for that period (fig. 22D).

Decreases in point-source loads of total phosphorus may have contributed to the large decreases in stream loads prior to the 1990s (figs. 22B, D), but point-source data for this early period were not readily available. Long-term downward trends in total phosphorus loads for the Quinebaug River Basin are consistent with implementation of phosphate detergent bans in Connecticut in 1972 (Litke, 1999, p. 6, table 1).

A few trends in flow-adjusted nutrient concentrations for the 1993-2003 period may indicate processes or changes that are increasing nutrient delivery to the Quinebaug River in recent years (table 26). An upward trend in flow-adjusted total nitrogen concentrations was detected for the Quinebaug River at Quinebaug, and upward trends in flow-adjusted concentrations of total phosphorus were detected for Quinebaug River stations near Pomfret and at Jewett City.

\section{Raritan River Basin in Northern New Jersey}

The Raritan River Basin encompasses a highly developed area of northern New Jersey (fig. 23). Stream quality in the Raritan River Basin has been studied extensively by the USGS in cooperation with the New Jersey Department of Environmental Protection and the New Jersey Water Supply Authority (Reiser, 2004, p. 3, 9-10). Streamflow, water quality, and permitted (point source) and nonpermitted (nonpoint source) loads and yields were evaluated for water years 1991-98 (Reiser, 2004). Water-quality constituents evaluated included the following nutrients: total Kjeldahl nitrogen, nitrite-plus-nitrate nitrogen, and total phosphorus. Concentrations, loads, and yields were evaluated at low, median, and high streamflows. In evaluating the effects of point-source loads on stream loads, adjustments were made to point-source loads for time-of-travel from point discharges to monitoring locations and for constituent attenuation rates (Reiser, 2004, p. 20-21, p. 127-133). Readers are referred to the New Jersey study for detailed information. This study evaluates point-source nutrient loads in the Raritan Basin in the long-term context of stream nutrient loads and trends in load, and provides regional comparisons.

Annual stream nutrient loads were estimated for nine monitoring stations in the Raritan River Basin, all in New Jersey: the Raritan River at Queens Bridge at Bound Brook, N.J., and eight subbasins, including Mulhockaway Creek at Van Syckel, South Branch Raritan River at Stanton, Neshanic River at Reaville, Lamington (Black) River near Pottersville, North Branch Raritan River near Raritan, Raritan River at Manville, Stony Brook at Princeton, and Millstone River at Blackwells Mills (stations 59-62 and 64-68, table 5; fig. 23). Trends in nutrient loads were evaluated for four of these stations (table 27), and point-source nutrient loads were estimated for eight of the nine stations.

The drainage area of the Raritan River at Queens Bridge at Bound Brook $\left(804 \mathrm{mi}^{2}\right)$, includes 64 point sources with nitrogen loads reported in the New Jersey Department of Environmental Protection database and 37 point sources with phosphorus loads reported in the PCS database. Ten of these point sources (nitrogen and phosphorus) are identified as major point sources (table 25). The Raritan River Basin, measured at the Bound Brook monitoring station, is one of the most highly developed of the watersheds selected for analysis of point sources, with about 17 percent of the drainage area in urbanized land, about 34 percent in agricultural land, and about 48 percent in undeveloped land (table 8 , in back of report, station 68).

Total point-source loads of nitrogen for the Raritan River at Bound Brook ranged from 32 to 79 percent of the estimated annual stream loads from 1991 to 1997 (fig. 24A). During years with annual mean flows that were above average, including 1994, 1996, and 1997, the point-source load of total nitrogen constituted 32 to 42 percent of the stream load. In 1993, an average flow year, the point-source load was about 


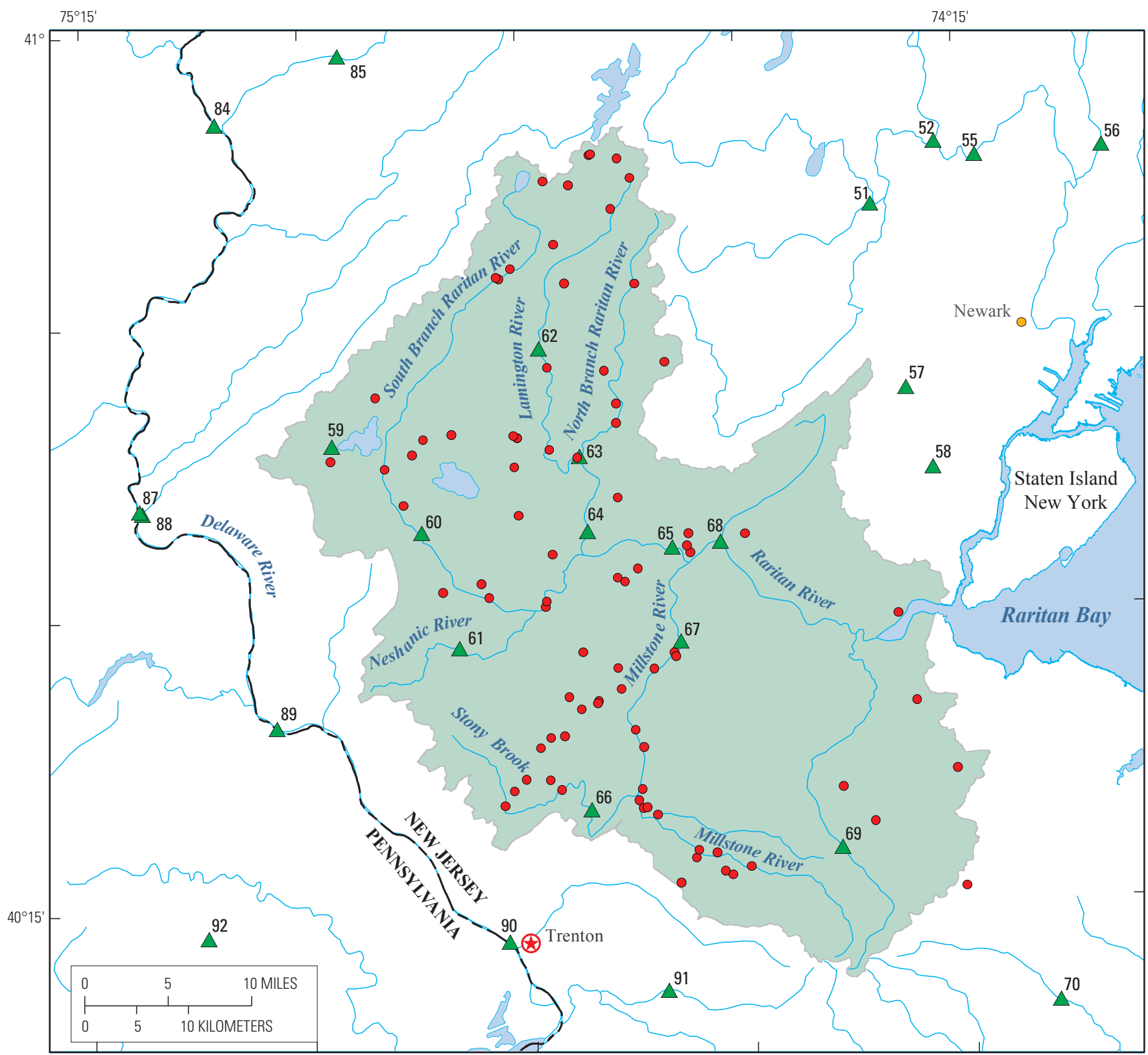

Base from U.S. Geological Survey Digital Data 1:100,000 Albers Equal-Area Projection

\section{EXPLANATION}

Raritan River Basin

59 USGS water-quality monitoring station, with station sequence number (table 5)

- Point sources that discharge nutrients

(4) State capital

City, over 250,000 population

Figure 23. Monitoring stations and point-source locations in the Raritan River Basin. 
41 percent of the stream load. During dry years, including 1992 and 1995, point-source loads of total nitrogen constituted more than 75 percent of the estimated annual stream loads (fig. 24A).

These estimates of point-source loads of total nitrogen as a percentage of total stream loads are similar to percentages for nitrogen constituents analyzed in the New Jersey study, which determined that attenuated contributions from permitted (point) sources accounted for 36 percent of the instream loads of total Kjeldahl nitrogen at the Raritan (Bound Brook) monitoring station during median streamflow, 100 percent during base flow, and 18 percent during high flow, during the growing season for the 1991-97 water years (Reiser, 2004 , p. 100, table 25). The New Jersey study reported that permitted sources accounted for 59 percent of the instream loads of nitrite-plus-nitrate nitrogen at this location during median streamflow, 100 percent during base flow, and 38 percent during high flow for the same period (Reiser, 2004, p. 107, table 29).

Trend results for the Raritan River at Bound Brook were generally similar for flow-adjusted concentrations of nitrogen constituents and for nitrogen constituent loads (tables 26, 27). No long-term or recent trends in either flow-adjusted concentrations of total nitrogen or loads of total nitrogen (fig. 24A) were detected. Long-term downward trends in flow-adjusted concentrations and loads of ammonia nitrogen and total Kjeldahl nitrogen were detected (fig. 24B). No recent trends in flow-adjusted concentrations or loads of ammonia nitrogen were detected (fig. 24B); trends in total Kjeldahl nitrogen were not evaluated for the recent period. A long-term upward trend in the flow-adjusted concentration of nitrite-plus-nitrate nitrogen was detected (table 26); however, no long-term or recent trends in load were detected for this constituent (table 27, fig. 24B).

Total point-source loads of phosphorus in the drainage area of the Raritan River at Bound Brook ranged from 16 to 99 percent of the estimated annual stream loads from 1990 to 1998 (fig. 24C). During years with above average annual mean streamflows, including 1994, 1996, and 1997, the point-source load of total phosphorus ranged from 16 to 34 percent of the stream load. In 1993 and 1998, when annual mean flows were near the long-term average, the point-source loads of total phosphorus constituted 40 and 29 percent, respectively, of the stream loads. During 1992, a dry year, the total pointsource load equaled the estimated total phosphorus load of the river (fig. 24C). Point-source data for total phosphorus were unavailable for 1995, also a dry year. These percentages are similar to percentages in the New Jersey study, which determined that attenuated contributions from permitted (point) sources accounted for 46 percent of the instream load of total phosphorus at the Raritan River at Bound Brook during median streamflow, 78 percent during base flow, and 31 percent during high flow, during the growing season for the 1991-97 water years (Reiser, 2004, p. 110, table 31). No longterm or recent trends in either flow-adjusted concentrations or stream loads of total phosphorus were detected for the Raritan River at Bound Brook (tables 26, 27; fig. 24C).

Annual loads for subbasins in the Raritan River Basin illustrate differences based on land use, population density, and numbers of point sources, and also illustrate the complexity of evaluating nutrient sources in drainage basins with multiple land uses. Comparisons among subbasins are complicated to some extent by differences in years and sources for data on population density and land use. Population density data for this report are from the 2000 census, and land-use data are from the 1992 NLCDe dataset (table 8, in back of report); consequently, the population density figures for areas that were undergoing increased urbanization during the 1990s may represent a more highly developed land-use condition than is indicated by the land-use percentages. In the report on stream quality and point sources in the Raritan River Basin, population density figures are from the 1990 census, and landuse percentages are based on 1996 data from NJDEP (Reiser, 2004 , p. 6, table 1). Consequently, population densities presented in this report are generally higher than population densities in the Reiser report, whereas total developed land-use percentages are generally higher in the Reiser report, which also shows relatively higher percentages of urban land and lower percentages of agricultural land for several subbasins.

Although the Raritan River Basin is in one of the most highly urbanized areas in the nation, one-third of the land in the drainage area was in agricultural uses in 1992 (table 8, in back of report), and most of the subbasins evaluated for nutrient loads had one-quarter to one-third of their land in agricultural uses. The overall population density for the Raritan River Basin in 2000 was about 650 people per square mile (table 8 , in back of report). Population densities for subbasins evaluated in this report range from about 200 per square mile in the Mulhockaway Creek drainage basin to about 800 per square mile in the drainage basin of the Millstone River at Blackwells Mills. Population densities for most subbasins are in the range of 450 to 600 per square mile. Point sources discharge to streams in many subbasins, including three with drainage areas that are less than $50 \mathrm{mi}^{2}$. The Neshanic River at Reaville is the only subbasin without point discharges evaluated in this report.

Point-source loads of nutrients, as a percentage of total stream load, are lowest in the Mulhockaway Creek Basin (station 59), which has no major municipal discharges (table 8 , in back of report). The Mulhockaway Creek Basin has the lowest population density (about 200 per square mile) and the highest percentage of undeveloped land (about 71 percent) of the Raritan subbasins evaluated in this report (table 8, in back of report). Annual point-source loads of total nitrogen and total phosphorus in this drainage basin represent an extremely small proportion of stream nutrient loads, less than 1 percent of the total stream load in each year for which point-source data are available.

The proportion of an estimated annual stream nutrient load derived from point-source discharges is generally, although not always, related to annual mean streamflow 

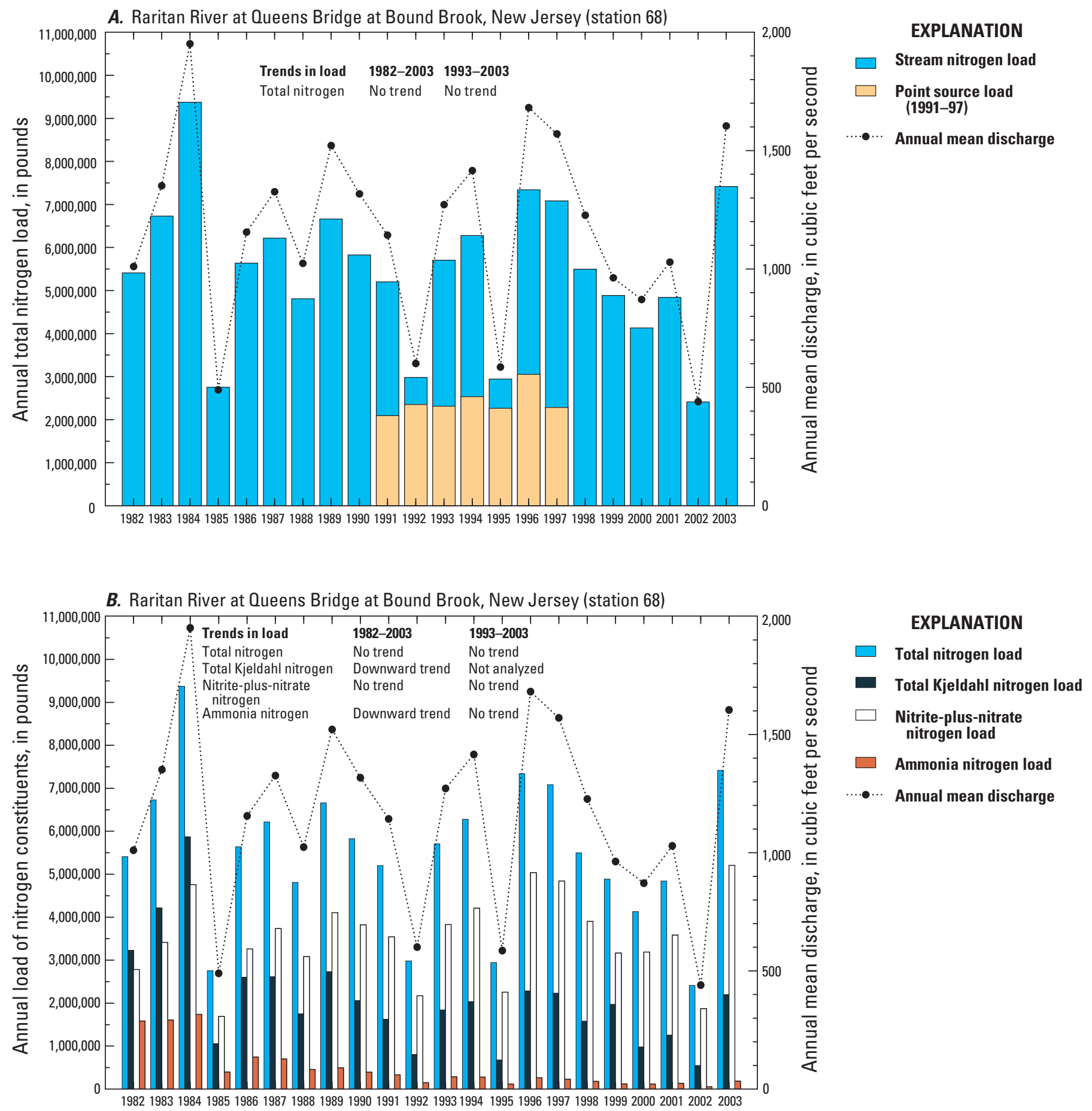

Water Year

Figure 24. Annual stream loads and point-source loads of nutrients in the Raritan River Basin. (A)Total nitrogen, Raritan River at Queens Bridge at Bound Brook, N.J., 1982-2003, (B) nitrogen constituents, Raritan River at Queens Bridge at Bound Brook, N.J., 19822003, (C) total phosphorus, Raritan River at Queens Bridge at Bound Brook, N.J., 1982-2003. Point source data unavailable for 1995, (D) total nitrogen, Lamington (Black) River near Pottersville, N.J., 1984-97, (E) total phosphorus, Lamington (Black) River near Pottersville, N.J., 1984-97, (F) total nitrogen, Millstone River at Blackwells Mills, N.J., 1991-2003, (G) total phosphorus, Millstone River at Blackwells Mills, N.J., 1993-2003, and (H) suspended sediment, Raritan River at Queens Bridge at Bound Brook , N.J., 1982-2003. 

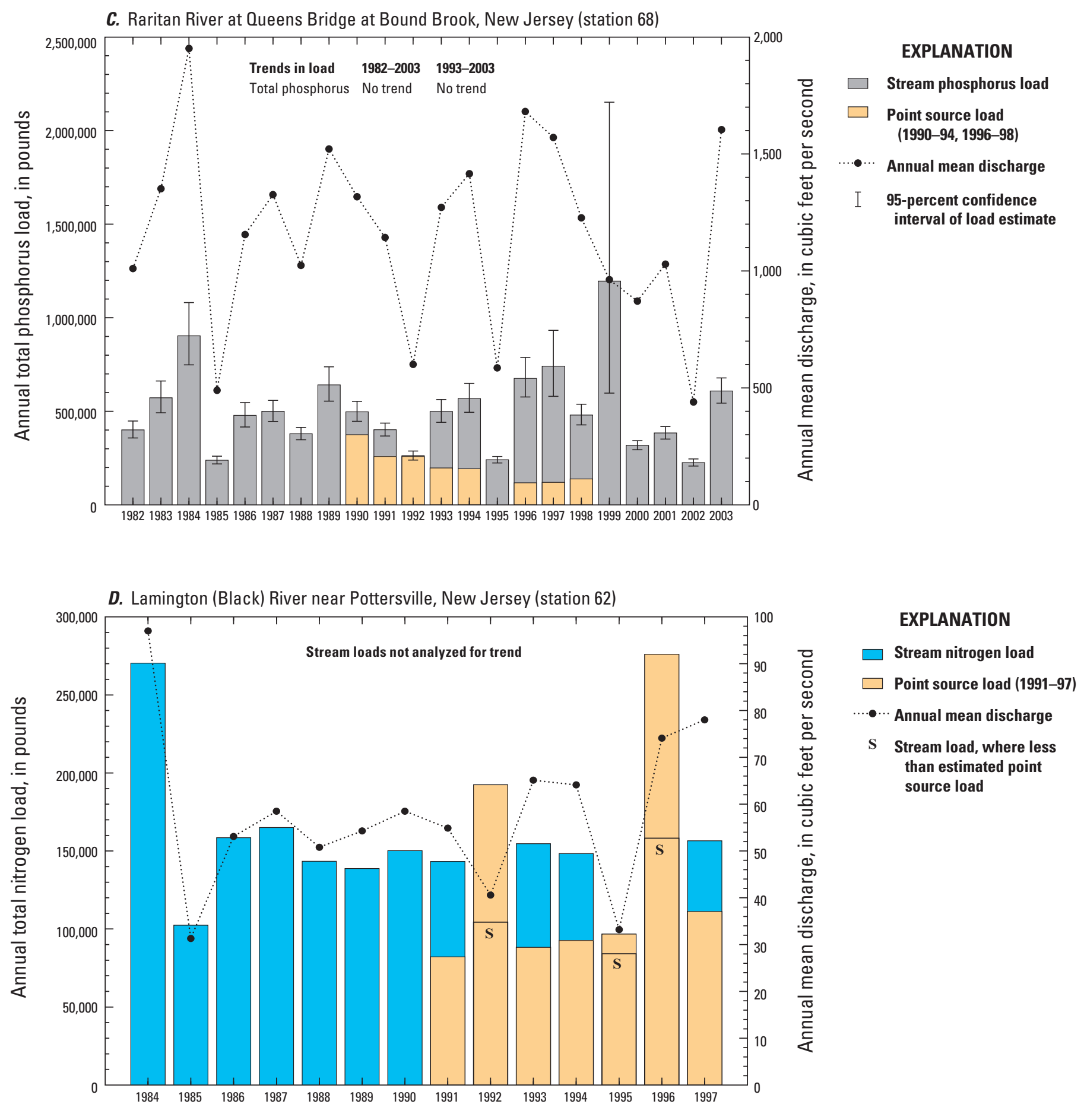

Water Year

Figure 24. Annual stream loads and point-source loads of nutrients in the Raritan River Basin. (A) Total nitrogen, Raritan River at Queens Bridge at Bound Brook, N.J., 1982-2003, (B) nitrogen constituents, Raritan River at Queens Bridge at Bound Brook, N.J., 19822003, (C) total phosphorus, Raritan River at Queens Bridge at Bound Brook, N.J., 1982-2003. Point source data unavailable for 1995, (D) total nitrogen, Lamington (Black) River near Pottersville, N.J., 1984-97, (E) total phosphorus, Lamington (Black) River near Pottersville, N.J., 1984-97, (F) total nitrogen, Millstone River at Blackwells Mills, N.J., 1991-2003, (G) total phosphorus, Millstone River at Blackwells Mills, N.J., 1993-2003, and (H) suspended sediment, Raritan River at Queens Bridge at Bound Brook , N.J., 1982-2003.—Continued 

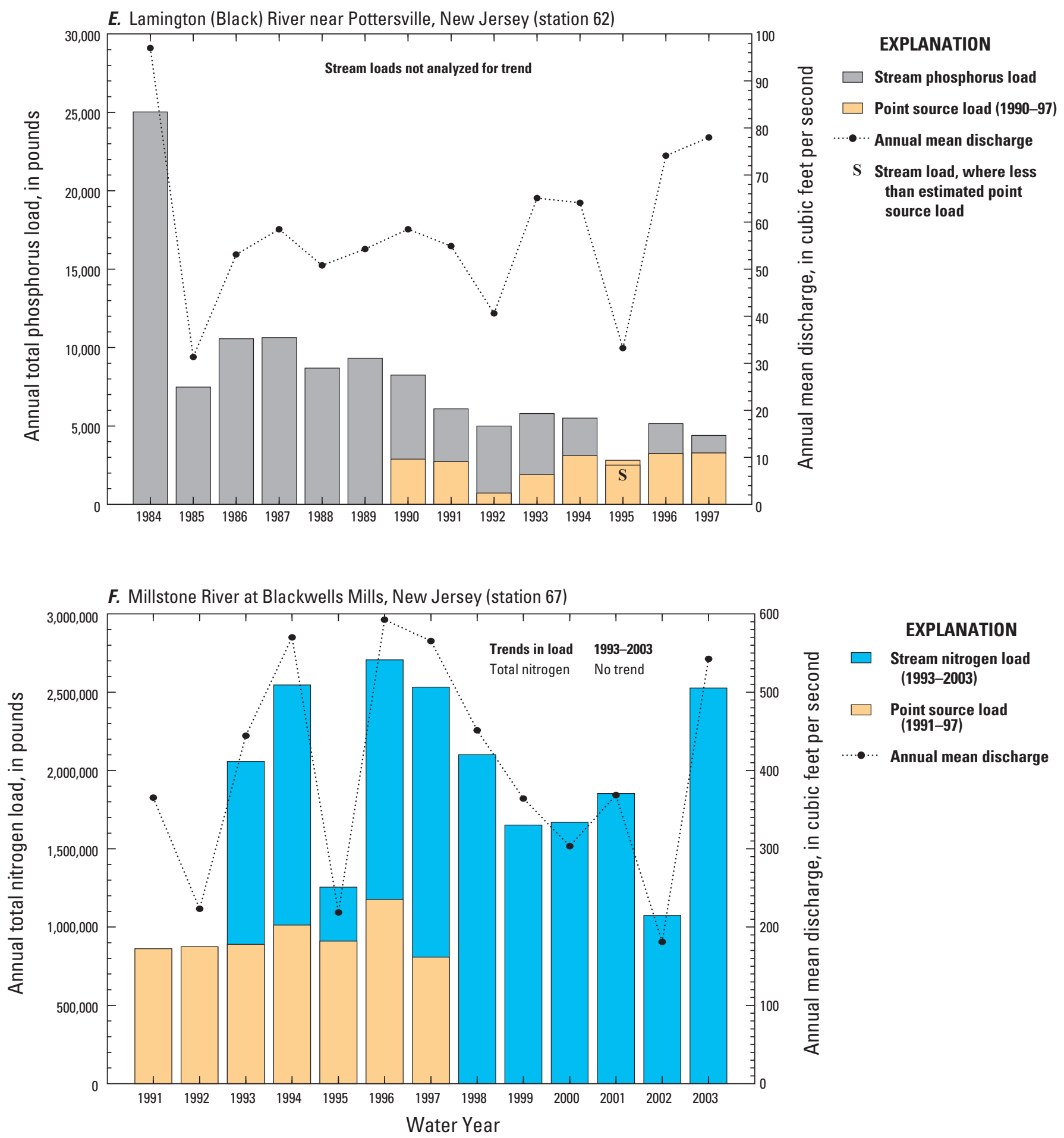

Figure 24. Annual stream loads and point-source loads of nutrients in the Raritan River Basin. (A) Total nitrogen, Raritan River at Queens Bridge at Bound Brook, N.J., 1982-2003, (B) nitrogen constituents, Raritan River at Queens Bridge at Bound Brook, N.J., 19822003, (C) total phosphorus, Raritan River at Queens Bridge at Bound Brook, N.J., 1982-2003. Point source data unavailable for 1995, (D) total nitrogen, Lamington (Black) River near Pottersville, N.J., 1984-97, (E) total phosphorus, Lamington (Black) River near Pottersville, N.J., 1984-97, (F) total nitrogen, Millstone River at Blackwells Mills, N.J., 1991-2003, (G) total phosphorus, Millstone River at Blackwells Mills, N.J., 1993-2003, and (H) suspended sediment, Raritan River at Queens Bridge at Bound Brook , N.J., 1982-2003.—Continued 

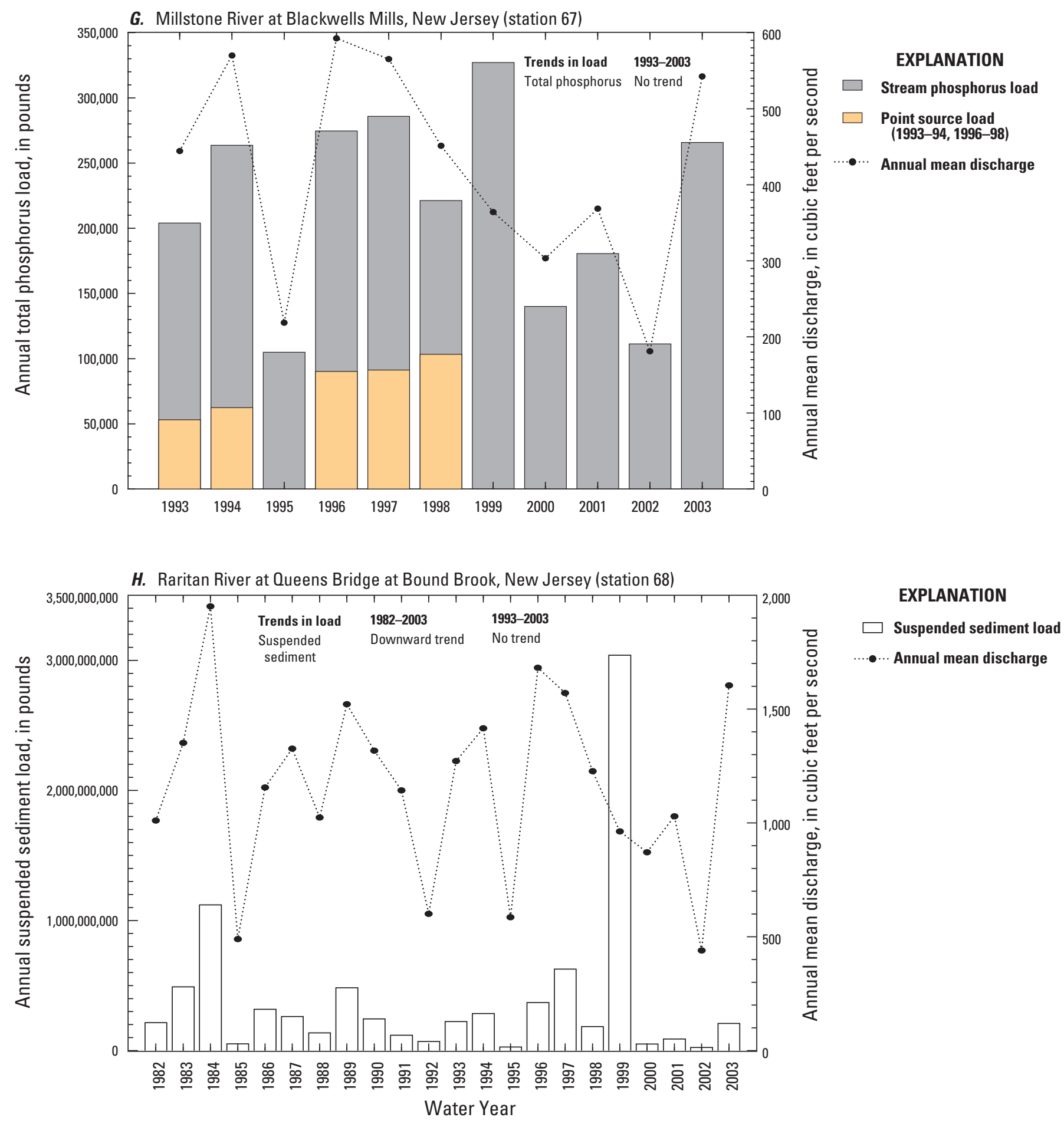

Figure 24. Annual stream loads and point-source loads of nutrients in the Raritan River Basin. (A) Total nitrogen, Raritan River at Queens Bridge at Bound Brook, N.J., 1982-2003, (B) nitrogen constituents, Raritan River at Queens Bridge at Bound Brook, N.J., 1982 2003, (C) total phosphorus, Raritan River at Queens Bridge at Bound Brook, N.J., 1982-2003. Point source data unavailable for 1995, (D) total nitrogen, Lamington (Black) River near Pottersville, N.J., 1984-97, (E) total phosphorus, Lamington (Black) River near Pottersville, N.J., 1984-97, (F) total nitrogen, Millstone River at Blackwells Mills, N.J., 1991-2003, (G) total phosphorus, Millstone River at Blackwells Mills, N.J., 1993-2003, and (H) suspended sediment, Raritan River at Queens Bridge at Bound Brook , N.J., 1982-2003.—Continued 
(figs. 24A, C). In several subbasins, point-source loads of nutrients generally constitute 10 to 20 percent of total stream nutrient loads in years with above average annual mean streamflows, and constitute 25 to 50 percent or more of stream nutrient loads in dry years. Annual point-source loads of nutrients were fairly constant during the 1990s in some subbasins, including the South Branch Raritan River at Stanton, the Raritan River at Manville, and Stony Brook at Princeton (not shown in fig. 24), whereas annual point-source loads varied considerably in other subbasins, including the Lamington River near Pottersville, and the Millstone River at Blackwells Mills (figs. 24D-G).

Point-source nutrient loads generally constitute a large percentage of annual stream loads for the Lamington River near Pottersville (station 62), a small drainage basin (almost $33 \mathrm{mi}^{2}$ ) with a high population density (about 600 per square mile; table 8 , in back of report). Point-source nitrogen loads represented 57 to 100 percent of stream nitrogen loads during the 1990s (fig. 24D). Point-source phosphorus loads represented 15 to 100 percent of stream phosphorus loads, and in most years constituted one-third to three-quarters of the stream load (fig. 24E). Estimated annual point-source nitrogen loads for the Lamington River exceeded estimated stream loads by a large amount in 1992 (a dry year) and 1996 (a wet year) (fig. 24D). Large interannual changes in point-source discharges of total nitrogen are caused primarily by changes at a single facility in the Lamington River Basin (R.M. Moore, U.S. Geological Survey, written commun., 2011).

Instream attenuation of nutrients may in part account for instances in which estimated point-source loads exceed estimated stream loads in the Lamington River Basin. Substantial attenuation of nutrients is likely in streams of the Raritan River Basin, more so than in some of the other basins evaluated for point sources, because many point sources are discharged into small streams where attenuation is likely to occur. Attenuation of nutrients discharged from point sources is likely for all years evaluated in the Lamington River Basin, because of the small size of the stream and because the three point sources are located in the headwaters of the drainage basin (fig. 23). Uncertainties in the estimation process or inadequacy of data also may contribute to the unusually large differences between stream loads and point-source loads for water years 1992 and 1996 in the Lamington River Basin.

Agricultural land as a percentage of total basin area exceeds urban land in seven of the eight subbasins for which nutrient loads were estimated (table 8, in back of report). Agricultural land is a major nutrient source in most subbasins, despite the urbanized nature of many subbasins and the numerous point sources that discharge nutrients to streams in the Raritan River Basin. A comparison of the Neshanic and Lamington River Basins, which are similar in size, illustrates this point (table 8 , in back of report, stations 61,62 ). The Neshanic River at Reaville (about $26 \mathrm{mi}^{2}$ ) is a predominantly agricultural drainage basin (about 60 percent agricultural land) with no point-source discharges and a low population density (about 340 per square mile) relative to other subbasins.
The Neshanic is the most highly agricultural and most highly developed of the subbasins (about 68 percent developed land). The Lamington River near Pottersville (almost $33 \mathrm{mi}^{2}$ ), an urbanized drainage basin with point-source discharges, has only half as much developed land (about 34 percent of the basin) as the Neshanic River, but the population density is higher (about 600 per square mile). Annual total nitrogen loads for the Neshanic River range from 130,000 pounds (lb) to $275,000 \mathrm{lb}$ for most years in the 1993-2003 period, with peak loads of about 300,000 pounds per year (lb/yr) in 1994 and 1996 (fig. 14C). By contrast, annual total nitrogen loads for the Lamington River are lower, generally ranging from 100,000 to $165,000 \mathrm{lb}$ for the 1984-1997 period, with a peak load of 270,000 lb in 1984 (fig. 24D). Annual total phosphorus loads for the Neshanic River range from 3,000 to 65,000 lb in most years, with peak loads of $115,000 \mathrm{lb}$ in 1994 and 400,000 lb in 1999 (fig. 14D). Annual total phosphorus loads for the Lamington River are much lower, generally ranging from 4,000 to $11,000 \mathrm{lb}$, with a peak load of 25,000 lb in 1984 (fig. 24E). Comparison of summary statistics for total phosphorus yields for these two similarly-sized basins shows that median and maximum yields for the Neshanic are an order of magnitude greater than those yields for the Lamington (table 21).

The Raritan River at Manville $\left(490 \mathrm{mi}^{2}\right)$ and the Millstone River at Blackwells Mills $\left(258 \mathrm{mi}^{2}\right)$ are the largest tributary subbasins of the Raritan at Bound Brook, together constituting 93 percent of the $804 \mathrm{mi}^{2}$ drainage basin. Comparison of point-source effects in these two major tributary subbasins is limited by the small number of years of readily available point-source data for nutrients, and the fact that the available years of water-quality data for stream load estimates, and the available years of point-source data, differ for the two stations. The Millstone River has the highest population density (about 800 per square mile), the highest percentage of urbanized land (about 19 percent), the second highest percentage of agricultural land (about 36 percent), and the second highest percentage of total developed land (about 55 percent) of the subbasins evaluated (table 8 , in back of report, station 67). The drainage basin of the Raritan River at Manville (station 65) has a population density of 526 per square mile, and about 49 percent of the drainage basin is developed, values that are similar to, though less than, those for the Millstone River Basin. Point-source loads of total nitrogen in the Millstone River Basin range from 32 to 73 percent of the stream nitrogen load, depending on annual mean streamflow, and point-source loads of total phosphorus range from 24 to 47 percent of stream loads (figs. 24F, G). No point-source data for total phosphorus are available for the Millstone River for 1995, a low flow year in which the point-source load is likely to represent a high percentage of the stream load. Point-source nutrient loads as a percentage of total stream loads are generally lower for the Raritan River at Manville (not shown in fig. 24). Point-source loads of total nitrogen generally range from 12 to 38 percent of stream loads, and point-source loads of total phosphorus generally 
range from 14 to 50 percent of stream loads. Comparison of total nitrogen and total phosphorus yields for these two subbasins shows that total nitrogen yields are similar, whereas total phosphorus yields in the Millstone River Basin are substantially larger than total phosphorus yields for the Raritan River at Manville (tables 20, 21).

Unusually high annual total phosphorus loads were estimated for 1999 for the Raritan River and several subbasins (figs. 24C, G). Annual mean streamflow for water year 1999 for the Raritan River at Bound Brook was slightly below average (less than the 25th percentile). Precipitation during water year 1999 had begun with a record dry period that extended from July to December 1998; extremely dry conditions prevailed again from April through July 1999, and streamflow declined to below normal levels during both of these periods (Reed and others, 2000, p. 2-3). Drought conditions ended in mid-September when Tropical Storm Floyd combined with a western storm system to produce as much as 14 in. of rain in New Jersey from September 15 to 17 (Reed and others, 2000, p. 2, 4). Record high streamflows were documented at several locations in the Raritan River Basin on September 16-17, 1999 , resulting in unusually high estimated annual total phosphorus loads and suspended sediment loads, relative to annual mean streamflow (figs. 14D, 24C, G, H). September 16, 1999, was the maximum annual peak flow recorded for the Neshanic River at Reaville (for the period 1931-2007), the North Branch Raritan River (1896-2007), and the Raritan River at Manville (1904-2007), and was the second highest annual peak for Mulhockaway Creek (1978-2007), the South Branch Raritan River at Stanton (1904-2007), and Stony Brook (1954-2007) (U.S. Geological Survey, 2009a). September 17, 1999, was the peak daily mean flow for the Raritan River at Bound Brook for the period 1982-2003.

The Raritan River at Bound Brook was the only station where a trend in suspended sediment load was detected, among four stations in the region evaluated for trends in suspended sediment load in the long-term period and eight stations evaluated for the recent period (tables 18, 27). A long-term downward trend in suspended sediment load was detected, and a long-term downward trend in flow-adjusted concentration of suspended sediment also was detected for this station (tables 26, 27). However, as can be observed in the plot of estimated annual suspended sediment loads for this station (fig. 24H), an extremely high estimated annual load (1999) can be produced by peak streamflow during a small number of days in any year, even when changes in a drainage basin may be contributing to an overall downward trend in load.

\section{Patuxent River Basin in Maryland}

The Patuxent River Basin, on the western shore of Chesapeake Bay, is in an urbanizing area of central Maryland, between Baltimore and Washington, D.C. (fig. 25). Of the watersheds selected for evaluation of point sources, the Patuxent River Basin has the highest percentage of urban land (about 19 percent, table 8, in back of report, station 114), and the highest percentage of agricultural land (about 38 percent), and the highest population density (about 1,000 per square mile). About 40 percent of the basin is undeveloped.

Annual stream nutrient loads were estimated for three monitoring stations in the Patuxent River Basin, all in Maryland. Trends in nutrient loads were evaluated and pointsource loads were estimated for one station, the Patuxent River near Bowie (table 8, in back of report, station 114, $348 \mathrm{mi}^{2}$ ). The Chesapeake Bay Program has identified 14 point sources with nutrient loads in the drainage area of the Patuxent River near Bowie. Seven of these point sources are identified as major (table 25).

Total point-source loads of nitrogen in the drainage basin of the Patuxent River near Bowie ranged from 25 to 82 percent of the estimated annual stream loads from 1990 to 2003 (fig. 26A). During years with annual mean flows that were above average, including 1996, 1997, and 2003, the pointsource load constituted 25 to 35 percent of the annual stream load. In 1998, a median flow year for the recent period, the point-source load of total nitrogen was about 34 percent of the stream load. During dry years and drought periods, including 1990-92, 1995, and 1999-2002, point-source loads of nitrogen constituted 45 to 82 percent of the estimated annual stream loads (fig. 26A).

Point-source loads of total nitrogen decreased during the early 1990s (fig. 26A), and then remained fairly constant from 1994 to 2003 , at about 500,000 to $600,000 \mathrm{lb} / \mathrm{yr}$. The decrease in the early 1990 s is probably the result of wastewater-treatment improvements. Seasonal biological removal of nitrogen was implemented at major wastewater-treatment plants in the Patuxent Basin between 1991 and 1993 (Darrell and others, 1999).

Highly significant downward trends in stream loads of total nitrogen, ammonia nitrogen, total Kjeldahl nitrogen, and nitrite-plus-nitrate nitrogen were detected for the Patuxent River near Bowie for the long-term period (table 27; figs. 26A, B); a downward trend in the stream load of ammonia nitrogen was the only trend in load detected during the recent period (table 27). Long-term trends in flow-adjusted nitrogen constituent concentrations were similar to trends in load, with downward trends detected for these four constituents (table 26). During the recent period, downward trends were detected in flow-adjusted concentrations of ammonia and nitrite-plus-nitrate nitrogen; total Kjeldahl nitrogen was not evaluated (table 26). The Maryland Department of Natural Resources has attributed large decreases in total nitrogen concentrations in the Patuxent River between the late 1980s and the mid-2000s primarily to the addition of an advanced treatment practice, biological removal of nitrogen, at wastewater-treatment plants (Maryland Department of Natural Resources, 2009).

Phosphorus load data are reported by the Chesapeake Bay Program for all seven major point sources. Phosphorus load data are not reported for four of the seven minor point sources, however, and the lack of data for these minor sources may affect this analysis. From 1990 to 2003, total point-source 


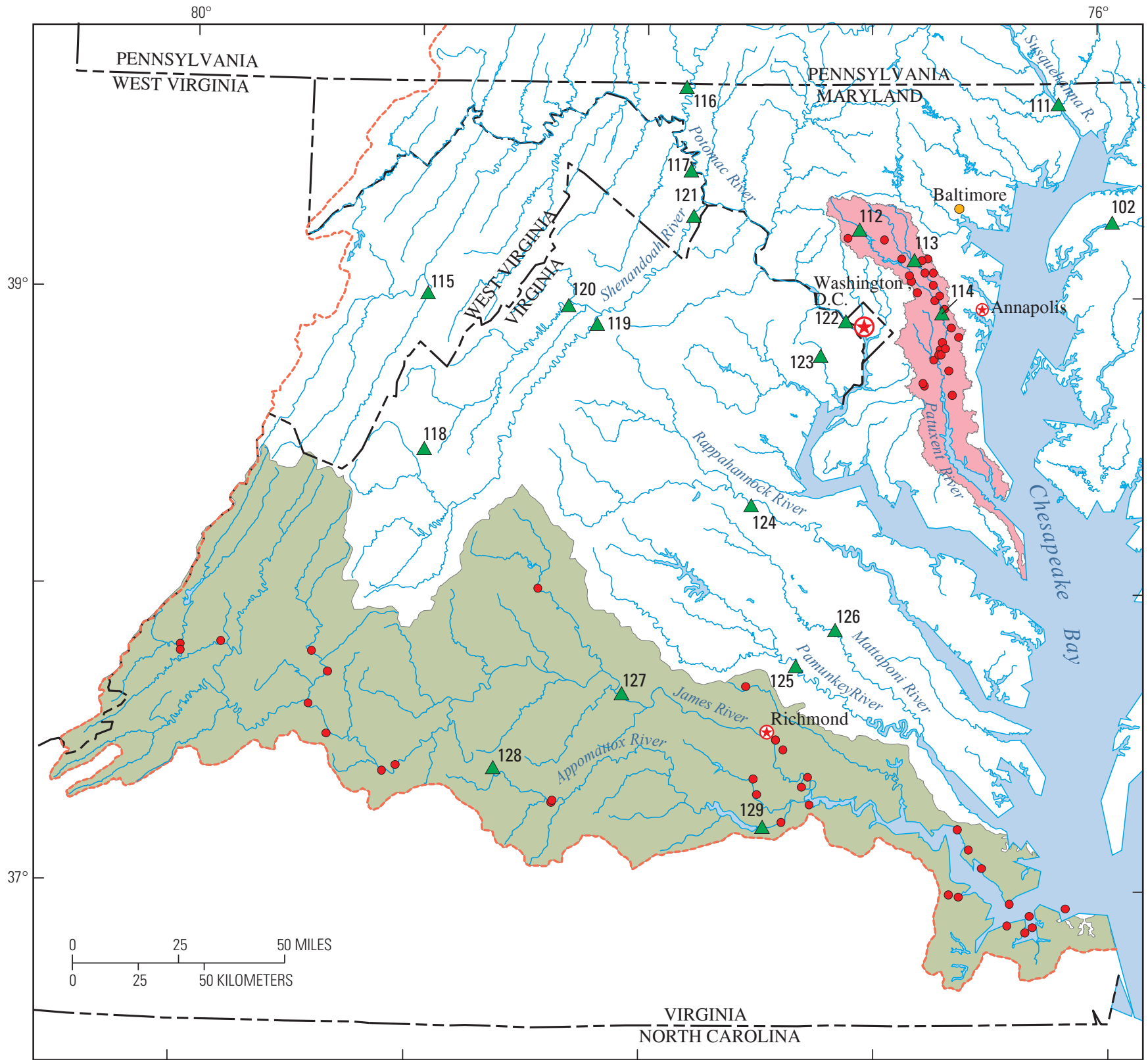

Base from U.S. Geological Survey Digital Data 1:100,000 Albers Equal-Area Projection North American Datum of 1983

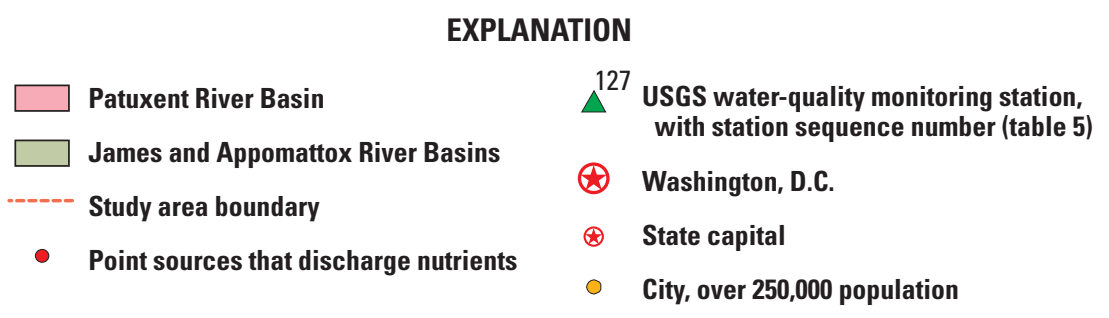

Figure 25. Monitoring stations and point-source locations in the Patuxent and James River Basins. 

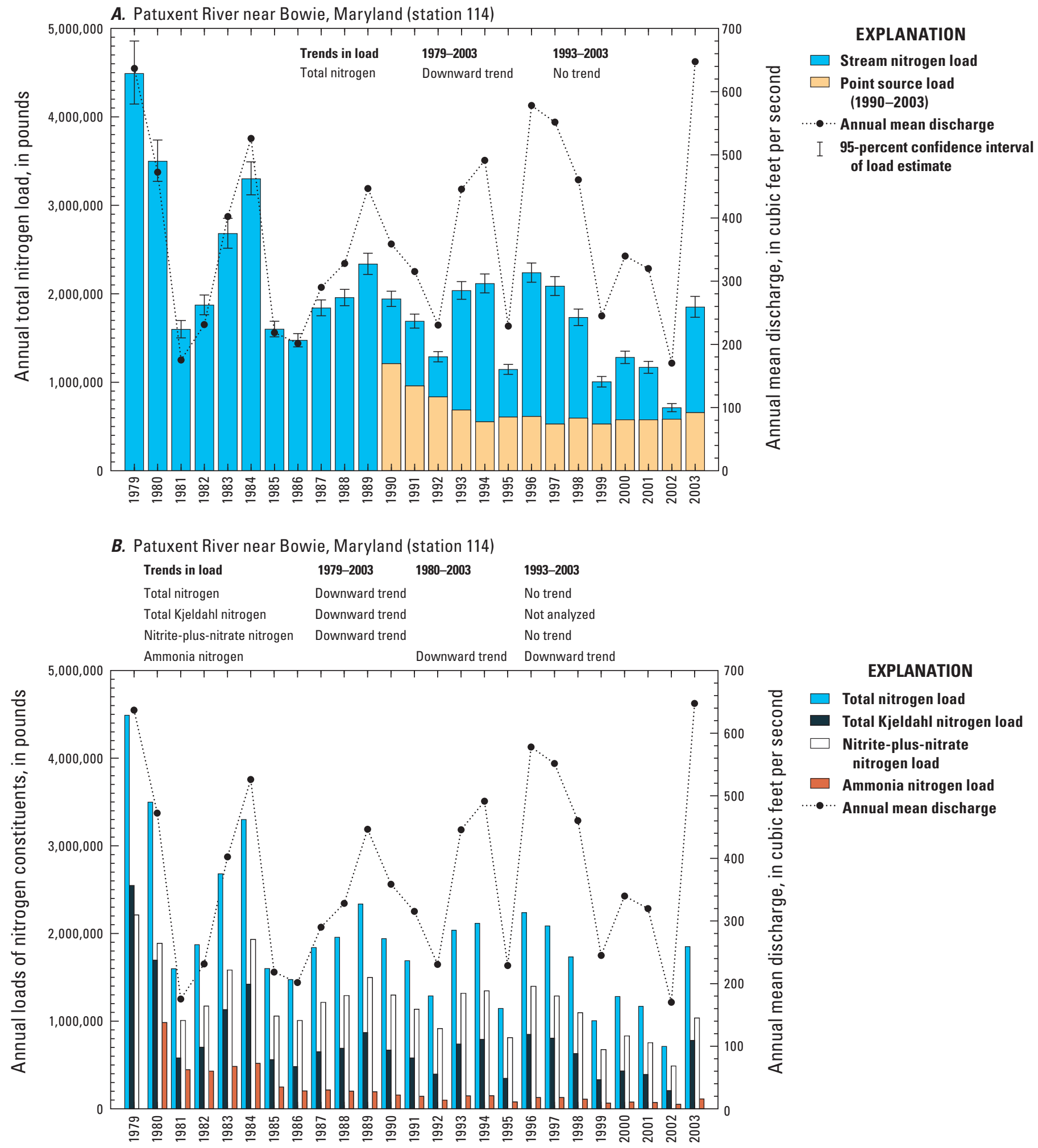

Water Year

Figure 26. Annual stream loads and point-source loads of nutrients in the Patuxent River Basin. (A) Total nitrogen, Patuxent River near Bowie, Md., 1979-2003, (B) nitrogen constituents, Patuxent River near Bowie, Md., 1979-2003, and (C) total phosphorus, Patuxent River near Bowie, Md., 1979-2003. 

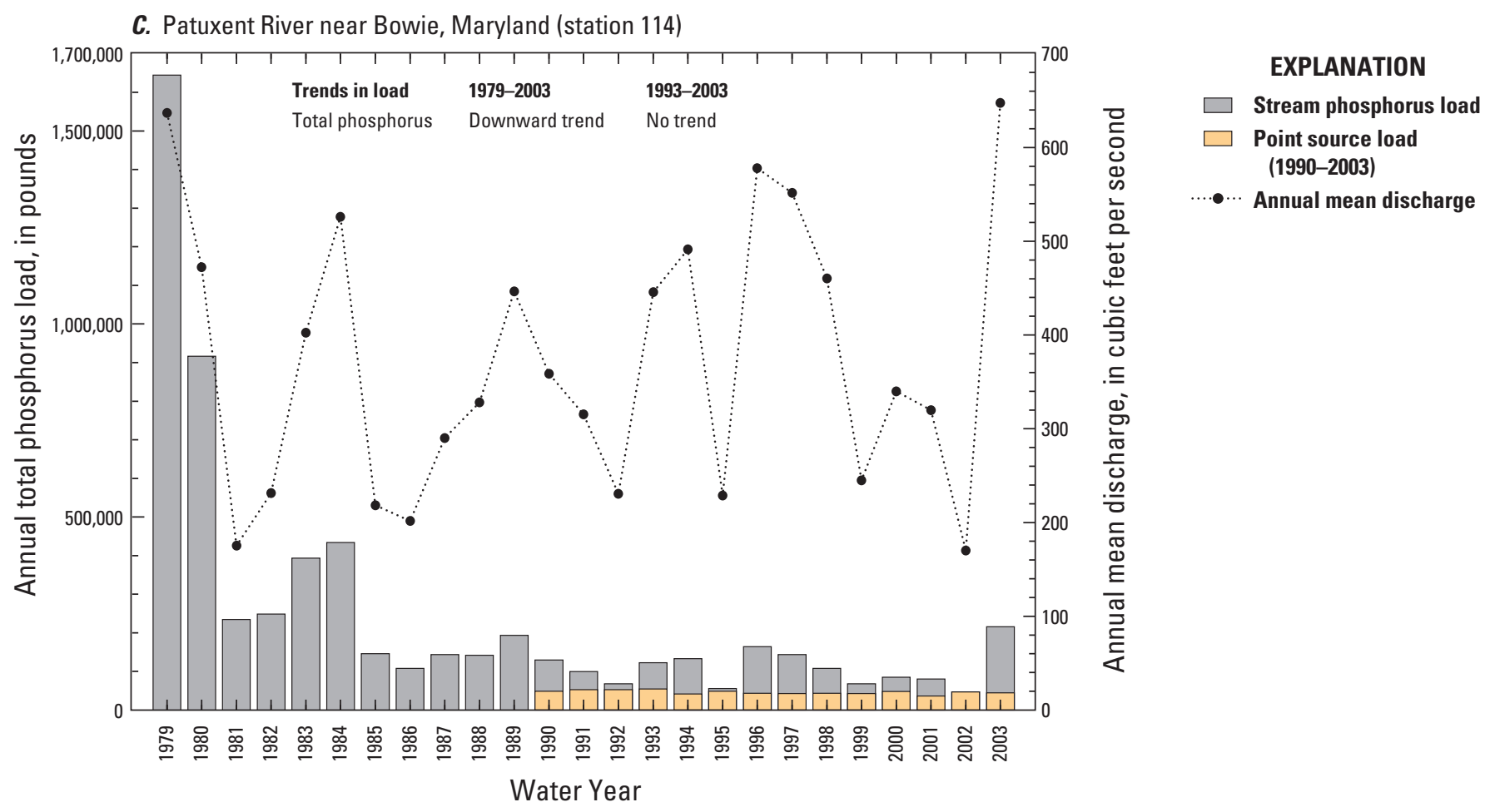

Figure 26. Annual stream loads and point-source loads of nutrients in the Patuxent River Basin. (A) Total nitrogen, Patuxent River near Bowie, Md., 1979-2003, (B) nitrogen constituents, Patuxent River near Bowie, Md., 1979-2003, and (C) total phosphorus, Patuxent River near Bowie, Md., 1979-2003.-Continued

loads of phosphorus in the drainage area of the Patuxent River near Bowie ranged from 21 to 100 percent of the estimated annual stream loads (fig. 26C). During years with annual mean flows that were above average, including 1996, 1997, and 2003, the point source load of total phosphorus constituted 21 to 30 percent of the stream load. In 1998, a median flow year, the point source load of total phosphorus was about 40 percent of the stream load. During dry years and drought periods, including 1990-92, 1995, and 1999-2002, point-source loads of total phosphorus constituted 38 to 100 percent of the annual stream loads, exceeding 50 percent of the stream load in six of the eight dry years (fig. 26C). The point-source load calculated for 2002, an extreme low-flow year, exceeded the estimated stream load, but was within the upper confidence limit for the stream load. Point-source loads of total phosphorus ranged from 36,000 to 53,000 lb/yr during the 1990-2003 period, with a mean of 46,000 lb/yr. Point-source loads were slightly higher in the early 1990s, but a pronounced change during the period is not apparent.

A highly significant downward trend in the stream load of total phosphorus was detected for the Patuxent River near Bowie for the long-term period (table 27; fig. 26C). During the recent period, however, an upward trend in flow-adjusted concentrations of total phosphorus for the Patuxent River may indicate processes or changes that are increasing nutrient delivery to the Patuxent River in recent years (table 26).

Long-term downward trends in flow-adjusted concentrations and loads of nutrients indicate progress in improving nutrient-related water-quality conditions in the Patuxent River. A substantial amount of this progress may be attributable to wastewater-treatment improvements, including biological removal of nitrogen, and implementation of phosphate detergent bans in Maryland in 1985 (Litke, 1999, p. 6, table 1). Based on the stream loads estimated for total nitrogen and total phosphorus for the period 1979-1989 (figs. 26A, C), it seems likely that some of the reductions in nutrients from wastewater-treatment plants took place prior to the period for which point-source data were available for this analysis.

Challenges to improving nutrient-related water-quality conditions remain. Stream load estimates and point-source estimates for nitrogen and phosphorus during the recent period indicate that most of the nutrients transported by the Patuxent River during dry years are from wastewater-treatment plants. As noted in the section on Modeled Instream Concentrations, recent total nitrogen and total phosphorus concentrations typically exceed proposed criteria in the highly developed Patuxent River Basin (table 15, in back of report). 


\section{James River Basin in Central Virginia}

The James River Basin in central Virginia, with a monitored drainage area of $6,252 \mathrm{mi}^{2}$, is the third largest streamflow and nutrient source to Chesapeake Bay, after the Susquehanna and Potomac Rivers (fig. 25) (Belval and Sprague, 1999, p. 5). Annual stream nutrient loads were estimated, trends in nutrient loads were evaluated, and pointsource nutrient loads were estimated for two monitoring stations in the James River Basin, both in Virginia: the James River at Cartersville and the Appomattox River at Matoaca (fig. 25, stations 127, 129). The Appomattox River is a tributary to the James River, but the confluence with the James is downstream from the monitored part of the James River (fig. 25). Consequently, nutrient conditions on the Appomattox River are not encompassed by the data for the James River, and the two are essentially separate drainage basins for the purposes of this discussion.

The Chesapeake Bay Program has identified 10 point sources, all of them major point sources, that contribute nutrient loads in the drainage area of the James River at Cartersville (table 8, in back of report, station 127; table 25). Of the watersheds selected for analysis of point sources, the James River watershed upstream from Cartersville is among the least developed and the most forested, with only 3.5 percent of the basin in urbanized land, 15 percent in agricultural land, and about 80 percent undeveloped (table 25).

The total point-source load of nitrogen upstream from the Cartersville monitoring station represents a small percentage of the estimated stream load during many years (fig. 27A). During wet years such as 1996, 1998, and 2003, when the annual mean flows were substantially greater than recent and long-term medians, the point-source load of total nitrogen was only about 10 to 15 percent of the annual stream load. However, the total point-source nitrogen load constituted from 33 to 100 percent of the estimated annual stream load during the prolonged dry period from 1999 to 2002. In 1997, a year in which the annual mean flow was close to long-term and recent median streamflow, point-source loads of total nitrogen were about 22 percent of the annual stream load. Annual pointsource loads of total nitrogen were fairly constant during the 1990-2003 period, ranging from 2.1 to 2.6 million pounds per year, with a peak annual load of 2.9 million pounds in 1994 (fig. 27A).

Long-term downward trends in stream loads of total nitrogen, ammonia nitrogen, and nitrite-plus-nitrate nitrogen were detected for the James River; a downward trend in ammonia nitrogen load also was detected for the recent period (table 27; fig. 27B). Trends in flow-adjusted concentrations of nitrogen constituents were similar, with long-term downward trends detected for total nitrogen, ammonia nitrogen, and nitrite-plus-nitrate nitrogen, and a downward trend in ammonia nitrogen detected for the recent period (table 26). However, an upward trend in the flow-adjusted concentration of total nitrogen was detected for the recent period (table 26).
No long-term or recent trends in flow-adjusted concentrations or stream loads of total phosphorus were detected for the James River (tables 26, 27; fig. 27C). The total point-source load of phosphorus is substantially less than the estimated stream load for the James River during most years (fig. 27C). During the wet years of 1996, 1998, and 2003, the point-source load of total phosphorus constituted about 10 to 18 percent of the annual stream load. During dry years from 1999 to 2002, however, the point-source load approached or equaled the estimated stream load (fig. 27C). Point-source loads of phosphorus increased during the 1990-2003 period, with annual loads ranging from 325,000 to $480,000 \mathrm{lb}$ from 1990 to 1997 , and annual loads ranging from 450,000 to 700,000 lb from 1998 to 2003 (fig. 27C).

The calculated point source load of phosphorus for 2002 exceeded the estimated stream load for the James River and also exceeded the upper confidence limit for the stream load. Instream attenuation processes may account in part for this difference, but uncertainties in the estimation process or inadequacy of data also may be involved. The point sources in this drainage basin are in the upstream part of the watershed (fig. 25). Instream biogeochemical processes affect the forms of nutrients transported, and may remove nutrients from streams. Nutrient processing and attenuation, and the differences in processes that affect nitrogen and phosphorus, may play a role in the observed differences between total point-source loads of nutrients and estimated stream loads of nitrogen and phosphorus. Phosphorus appears to undergo more in-stream decay (attenuation) than nitrogen. Concentrations of phosphorus are naturally high in some soils and rocks of the James River Basin (Belval and Sprague, 1999). The importance of this natural source relative to total stream loads has not been evaluated in this study.

The Chesapeake Bay Program has identified two point sources with nutrient loads in the drainage basin of the Appomattox River at Matoaca (table 8, in back of report, station 129; table 25). Both point sources are near the headwaters of the drainage basin, and one is identified as major, although total wastewater discharges are small relative to the other drainage basins evaluated. Instream nutrient processing may affect comparisons between total nutrient point-source loads and estimated stream loads, because of the distance between the point sources and the stream monitoring location. Of the drainage basins selected for analysis of point sources, the Appomattox River at Matoaca is among the least urbanized and the most forested (about 74 percent), with only about 2 percent of the basin in urbanized land, about 20 percent in agricultural land, and about 76 percent undeveloped (table 25).

Annual point-source loads of total nitrogen contribute only a small fraction of the estimated stream loads of total nitrogen for the Appomattox River, representing about 2 to 6 percent of the annual stream load from 1990 to 1999. Annual point-source loads of phosphorus contribute only a small fraction of stream phosphorus loads during most years, representing only 2 to 11 percent of the stream load 

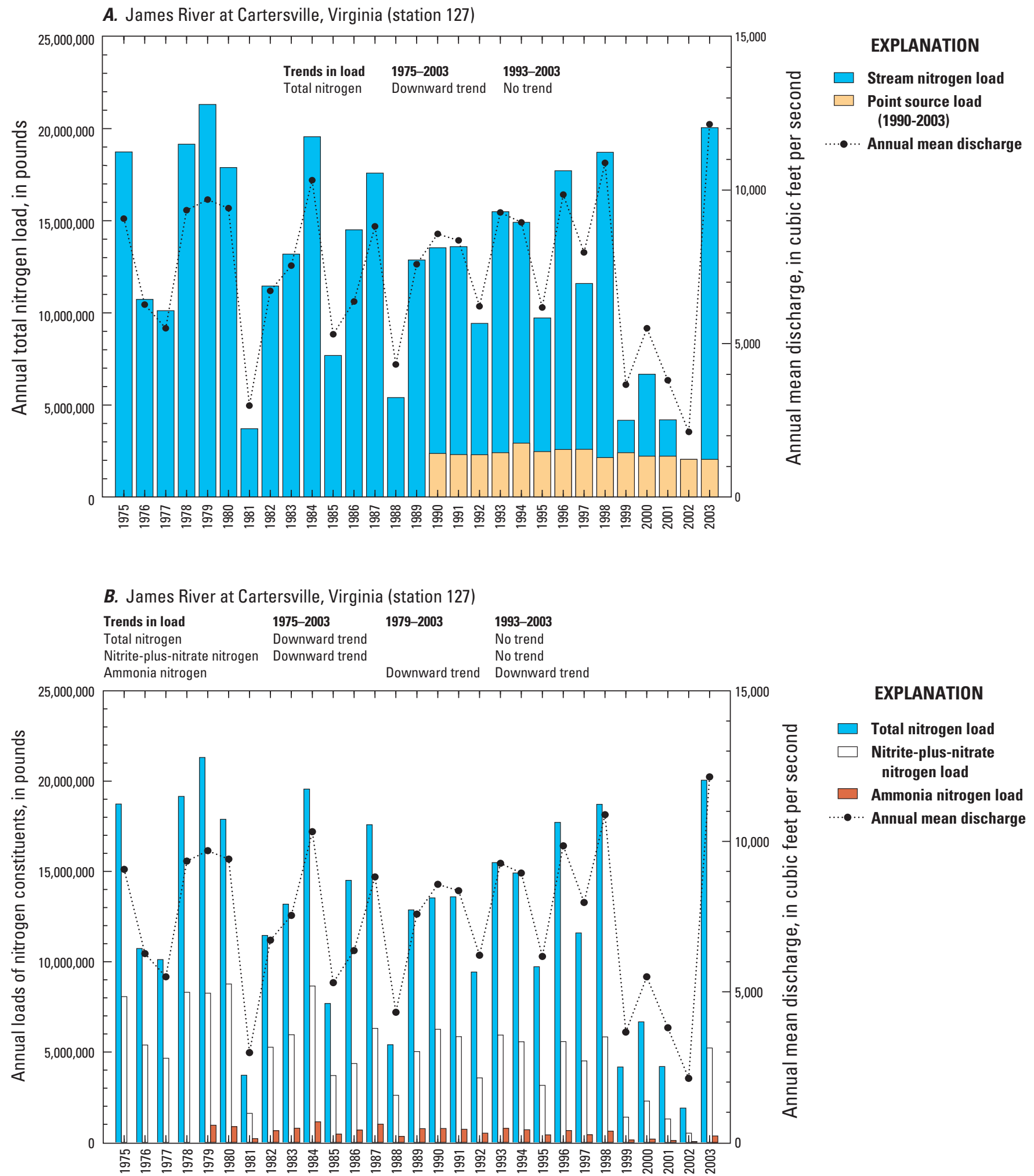

Water Year

Figure 27. Annual stream loads and point source loads of nutrients in the James River Basin. (A) Total nitrogen, James River at Cartersville, Va., 1975-2003, (B) nitrogen constituents, James River at Cartersville, Va., 1975-2003, and (C) total phosphorus, James River at Cartersville, Va., 1975-2003. 

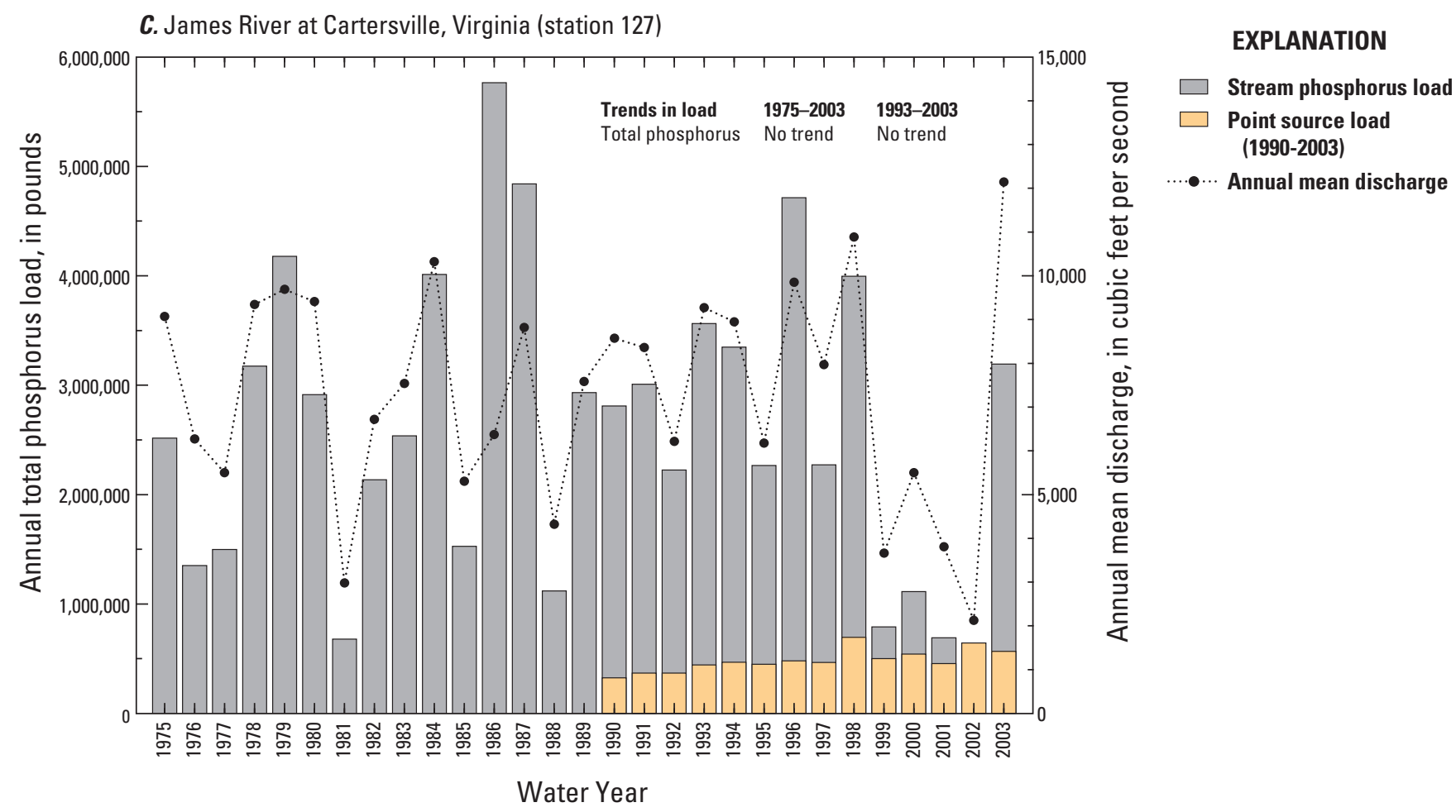

Figure 27. Annual stream loads and point source loads of nutrients in the James River Basin. (A) Total nitrogen, James River at Cartersville, Va., 1975-2003, (B) nitrogen constituents, James River at Cartersville, Va., 1975-2003, and (C) total phosphorus, James River at Cartersville, Va., 1975-2003.-Continued

in 13 of the 14 years from 1990 to 2003. In 2002, however, an extremely dry year in this part of the study area, pointsource loads of phosphorus represented about 45 percent of the stream load. This large percentage represents the low streamflow in 2002 rather than an increase in the annual point source load, which was similar to previous years. Point-source loads of total phosphorus did, however, approximately double during the period of analysis, from 4,000 to $5,000 \mathrm{lb} / \mathrm{yr}$ in the early $1990 \mathrm{~s}$ to 7,000 to $11,000 \mathrm{lb} / \mathrm{yr}$ in the late $1990 \mathrm{~s}$ and early 2000 s.

Few trends in stream nutrient loads were detected for the Appomattox River (table 27). No recent trends in any nutrient loads were detected, and no long-term trends in total nitrogen or total phosphorus loads were detected. Long-term downward trends in loads of ammonia nitrogen and nitrite-plus-nitrate nitrogen were the only significant trends in stream nutrient loads (table 27). Long-term and recent downward trends in flow-adjusted concentrations of ammonia nitrogen and nitriteplus-nitrate nitrogen were detected for the Appomattox River (table 26). No long-term trend in flow-adjusted concentrations of total nitrogen was detected; however, a recent upward trend was detected. A long-term upward trend in flow-adjusted concentrations of total phosphorus was detected, but no recent trend was detected (table 26). Increases in point-source loads of total phosphorus may be a factor contributing to the upward trend in total phosphorus concentrations.

Nutrient transport measured on the Appomattox River is affected by an impoundment on the river less than $3 \mathrm{mi}$ upstream from the monitoring station (Belval and Sprague, 1999, p. 6). Sedimentation of particles containing nutrients in the impoundment contributes to the relatively low nutrient yields on the Appomattox River compared to other major rivers flowing into Chesapeake Bay. 


\section{Summary, Conclusions, and Challenges for Management of Water Resources}

Water-quality problems resulting from excessive nutrients in freshwater and estuaries are among the most widespread and complex issues facing water managers in the northeastern United States. Effective action to address nutrient-related water-quality problems requires scientific information on the sources, distribution, cycling, and transport of nutrients in the environment.

The National Water Quality Assessment (NAWQA) Program of the U.S. Geological Survey (USGS) began regional studies in 2003 to synthesize information on nutrient concentrations, trends, stream loads, and sources. This report presents results of the nutrients study for river basins in the northeastern United States. The region extends from Maine to central Virginia, encompassing 166,000 square miles $\left(\mathrm{mi}^{2}\right)$ and a population of 59 million.

This report provides water managers, scientists, policymakers, and citizens with a regional perspective on the changes (trends) in nitrogen and phosphorus concentrations in streams of the northeastern United States; the nutrient concentrations observed in streams; the amounts of these nutrients (loads) transported by streams; and the sources of these nutrients in drainage basins. Specific objectives of the report were to present, evaluate, and synthesize (1) information on recent (1993-2003) and long-term (1975-2003) trends in nutrient concentrations; (2) observed and modeled instream nutrient concentrations relative to water-quality criteria and benchmarks; (3) recent and long-term annual nutrient load estimates, and information on trends in annual loads; and (4) selected information on nutrient sources, including regional land use and population density data, and point source information for a small number of drainage basins.

Nutrient data were evaluated for 130 USGS water-quality monitoring stations. Nutrient data were analyzed for trends in flow-adjusted concentrations, modeled instream (non-flowadjusted) concentrations, and stream loads for 32 stations with 22 to 29 years of water-quality and daily mean streamflow record during 1975-2003 (termed the long-term period), and for 46 stations during 1993-2003 (termed the recent period), by using a coupled statistical model of streamflow and water quality developed by the USGS. Recent trends in flowadjusted concentrations of one or more nutrients also were analyzed for 90 stations by using Tobit regression, which does not require a record of daily mean streamflow. Data for some stations were analyzed with both programs.

Annual stream nutrient loads were estimated, and annual nutrient yields were calculated, for 47 stations for the longterm and recent periods, and for 37 additional stations that did not have a complete streamflow and water-quality record for 1993-2003. Nutrient yield information was incorporated for 9 drainage basins evaluated in a national NAWQA study, for a total of 93 stations evaluated for nutrient yields.
Trends were analyzed and annual loads were estimated for total nitrogen, nitrite-plus-nitrate nitrogen, and total phosphorus for stations with sufficient data. Trend analysis and load estimation were performed for ammonia nitrogen, total Kjeldahl nitrogen, and suspended sediment for a small number of stations.

\section{Regional Data Integration}

A full regional synthesis of information on nutrient concentrations, trends, loads, and sources represents an unattained goal, in terms of continuity and consistency of waterquality data. Geographic coverage of the region by USGS water-quality monitoring programs is not complete, and consequently some major drainage areas of the region are not included in the analyses presented in this report. Many of the water-quality monitoring stations with the longest and most complete records were established in response to the Clean Water Act, and consequently many of these stations monitor waste-receiving streams. Comparable long-term monitoring is often lacking in drainage basins without point sources.

\section{Trends in Flow-Adjusted Nutrient Concentrations}

Numerous downward trends in flow-adjusted concentrations of nitrogen and phosphorus constituents during the period analyzed in this study indicate noteworthy regional improvements in nutrient-related water-quality conditions. Trends in streamflow were detected at only two stations, one in the 1993-2003 period, and one in the 1975-2003 period. Consequently, statistically significant trends in flow-adjusted concentrations are believed to represent changes in the delivery of nutrients to streams for most of the streams evaluated.

Flow-adjusted concentrations of total nitrogen decreased at about half the stations analyzed during the long-term period (18 of 32 stations), and 4 upward trends were detected. During the recent period, 12 upward trends and 15 downward trends in total nitrogen concentrations were detected, among 81 stations analyzed. During the long-term period, downward trends in flow-adjusted concentrations of ammonia nitrogen and total Kjeldahl nitrogen were detected at all six of the stations evaluated for these constituents. During the recent period, upward trends in ammonia nitrogen were detected at 2 stations and downward trends at 6 stations, among 15 stations analyzed.

Downward trends in flow-adjusted nutrient concentrations were more frequently detected than upward trends during both the recent and long-term periods, with two exceptions: nitrite-plus-nitrate concentrations during 1975-2003, and total phosphorus concentrations during 1993-2003. Flow-adjusted concentrations of nitrite-plus-nitrate nitrogen increased at one-third of the stations analyzed during the long-term period (11 of 32 stations), decreased at one-third of the stations (10 of 32), and had no significant trend at one-third of the stations. During the recent period, by contrast, only 1 upward 
trend in nitrite-plus-nitrate concentrations was detected, and 12 downward trends were detected, among 52 stations analyzed. Downward trends in flow-adjusted concentrations of total phosphorus were detected at more than half the stations analyzed (19 of 32 stations) during the long-term period; 3 upward trends were detected. During the recent period, however, most of the significant trends detected for total phosphorus concentrations were upward (17 upward and 6 downward trends among 83 stations analyzed), indicating possible reversals to the long-term water-quality improvements.

Progress has been made in reducing nutrient concentrations in the largest drainage basins of the region. Monitored drainage areas for the 11 largest drainage basins evaluated for trends (drainage areas greater than 1,000 $\mathrm{mi}^{2}$ ) encompass $72,275 \mathrm{mi}^{2}$, or about 44 percent of the region. One of these 11 large drainage basins was evaluated for the recent period only, and one for the long-term period only. Long-term downward trends in flow-adjusted concentrations of nutrients predominated at 7 of the 10 stations with long-term records; 20 downward trends were detected out of 35 analyses for these 10 stations. The 1993-2003 results, however, indicate recent increases in nutrient concentrations in some drainage basins. The preponderance of downward trends during the long-term period, viewed in conjunction with the absence of significant trends for about half of the analyses in these large basins for the recent period, may indicate that the largest reductions in nutrient concentrations took place prior to the 1990s.

\section{Instream Concentration Trends in Relation to Proposed Nutrient Criteria}

Trends in modeled instream nutrient concentrations for the long-term and recent periods were analyzed by using a coupled statistical model of streamflow and water quality. This method provides a modeled "reference concentration" for a constituent, that is, a typical concentration for the initial year of analysis that is not affected by seasonal variability or by fluctuations in annual streamflow conditions. Modeled reference concentrations, in conjunction with trend results, provide a useful indicator for assessing the status of instream water quality. Trend results for modeled instream concentrations and associated reference concentrations were evaluated relative to ecoregion-based criteria proposed by the U.S. Environmental Protection Agency (USEPA) for total nitrogen and total phosphorus.

Concentrations of nutrients in many of the streams evaluated in this study persist at levels that are likely to affect aquatic habitat adversely and promote freshwater or coastal eutrophication. Modeled reference concentrations for total nitrogen at the start of the 1993-2003 period exceeded proposed criteria by a factor of two or more at 21 of the 46 stations analyzed. Concentrations at 4 of these 21 stations exceeded proposed criteria by a factor of five or more. No trends in modeled instream concentrations of total nitrogen were detected during 1993-2003 at 17 of these 21 stations, indicating persistent elevated concentrations throughout the period of analysis at more than one-third of the 46 stations analyzed.

Modeled reference concentrations for total phosphorus at the start of the 1993-2003 period exceeded proposed criteria by a factor of two or more at 24 of the 46 stations analyzed for trends. At 4 of the 24 stations, modeled reference concentrations exceeded proposed criteria by an order of magnitude. No trends in modeled instream concentrations of total phosphorus were detected for 1993-2003 at 19 of these 24 stations, and upward trends were detected at 5 stations, indicating persistence of elevated instream total phosphorus concentrations throughout the period of analysis at about one-half of the 46 stations analyzed.

Evaluation of trend results and reference concentrations demonstrated mixed results in terms of instream nutrient conditions in the 11 largest drainage basins analyzed. Reference concentrations for total nitrogen or total phosphorus exceeded proposed criteria for several large rivers for the recent period, which may appear to contradict the water-quality improvements indicated by the many long-term downward trends detected for nutrient concentrations in large drainage basins. However, both analyses contain useful information. Substantial progress has been made in reduction of nutrient delivery to large streams in the region, as indicated by the long-term downward trends in flow-adjusted nutrient concentrations. The starting point of nutrient concentrations for these longterm downward trends was high, however, and modeled instream concentrations for the start of the 1993-2003 period, in conjunction with trend results for that period, indicate that instream concentrations still exceed proposed criteria for total nitrogen and total phosphorus in several major streams.

\section{Annual Nutrient Loads and Trends in Loads}

Stream discharge has varied substantially from year to year during the period of record evaluated, and annual nutrient loads have varied accordingly. During the recent period, annual mean flows varied substantially, with extremely low annual mean flows in 1995 and 2002, and high annual mean flows in 1996 and 2003, depending on the geographic area. In some parts of the region, particularly drainage basins in the southernmost areas, few annual mean flows near long-term median flow conditions were present in the 1993-2003 period, and consequently annual nutrient loads that represent typical conditions are less readily identified than annual loads during more extreme hydrologic conditions.

Annual loads of total nitrogen and total phosphorus in the recent period were generally substantially greater in 2003 than in 2002, particularly in southern parts of the region. Water years 2002 and 2003 represent the minimum and maximum annual nutrient loads, respectively, estimated during the recent period for some streams. Annual loads of total nitrogen or total phosphorus or both differ by an order of magnitude for those two years in some locations. 
Most of the long-term records available for load estimation and trend analysis are for streams with drainage basins that have large percentages of urban or agricultural land, and most of these drainage basins receive point-source discharges. Most of the significant trends in load have been detected in the more developed drainage basins of the region, where changes in land use and point-source loadings have a major effect on nitrogen and phosphorus delivery to streams. Trends in nutrient loads, coupled with similar trends in flow-adjusted concentrations, are likely to indicate long-term changes in the delivery of nutrients to streams in the region, because trends in streamflow were detected at only two stations.

Trends in nutrient loads were primarily downward during 1975-2003. Few statistically significant trends in nutrient loads were detected during the 1993-2003 period. Downward trends in total nitrogen loads were detected at more than one-third of the stations analyzed (12 of 32) during the long-term period; 1 upward trend was detected. Long-term trends in loads of nitrite-plus-nitrate nitrogen were detected at almost half the stations analyzed (15 of 32), with results about evenly divided between upward (7) and downward (8) trends. Long-term downward trends in ammonia nitrogen and total Kjeldahl nitrogen loads were detected at the six stations evaluated for these constituents. Three downward trends in loads of ammonia nitrogen were detected among nine stations evaluated for the recent period, and no upward trends were detected. All the streams evaluated for ammonia nitrogen and total Kjeldahl nitrogen receive point-source discharges. Downward trends in total phosphorus loads were detected at slightly more than half of the stations analyzed (17 of 32) during the long-term period; no upward trends in total phosphorus loads were detected.

The 10 largest drainage basins with long-term records (drainage areas greater than 1,000 $\mathrm{mi}^{2}$ ) had either downward trends in nutrient loads or no trends in load during the 19752003 period. No upward trends in nutrient loads were detected in these 10 drainage basins during either period of analysis. The 10 largest rivers with long-term records deliver the largest freshwater inflows and nutrient loads to major estuaries on the northeast coast, including Long Island Sound, Delaware Bay, and Chesapeake Bay. Consequently, long-term downward trends in nutrient loads represent critical regional waterquality improvements.

The Susquehanna, Potomac, Connecticut, Delaware, and James River Basins (in descending order of size) are the largest monitored basins for which long-term records were available for evaluation of trends in nutrient loads. Longterm downward trends in total nitrogen loads were detected for the Connecticut, Delaware, and James Rivers. No trend in total nitrogen load was detected for the Potomac River for either the long-term period or the recent period; however, the 1993-2003 period contains both extreme high and extreme low annual loads, and five of the six highest annual loads are in the 1993-2003 period. Although no trend in total nitrogen load was detected for the Susquehanna River for either period of analysis, a downward trend in total Kjeldahl nitrogen load and a highly significant ( $p$-value less than or equal to 0.01 ) downward trend in ammonia nitrogen load were detected for the long-term (1979-2003) period. Highly significant longterm downward trends in total phosphorus loads were detected for the Connecticut and Delaware Rivers. A downward trend in ammonia nitrogen load for the James River was the only trend in load detected for any nutrients for these five rivers during the recent period.

\section{Effects of Land Use and Population Density on Nutrient Yields}

Annual nutrient yields were used to compare the effects of major land uses in the region on stream nutrient transport. Annual yields were evaluated and summary statistics were calculated for 93 stations for total nitrogen and for 92 stations for total phosphorus, including stations with annual load estimates for all or some of the water years in the 1993-2003 period. Summary statistics for individual stations were further summarized into statistics for minimum, mean, median, and maximum yields for all stations and for four land-use categories (undeveloped, urban, urban/agricultural, and agricultural), on the basis of percentages of land uses in each drainage basin. Mean annual yields for nine basins in the region that were evaluated in a national study of undeveloped basins are included in the summary statistics for median yields for all basins and median yields for undeveloped basins.

Estimated yields for all drainage basins and years evaluated ranged over four orders of magnitude for total nitrogen and five orders of magnitude for total phosphorus. Estimated total nitrogen yields for the 1993-2003 period ranged from 41 to 32,000 pounds per square mile per year $\left(\mathrm{lb} / \mathrm{mi}^{2} / \mathrm{yr}\right)$. Minimum total nitrogen yields ranged from 41 to $15,000 \mathrm{lb} / \mathrm{mi}^{2} / \mathrm{yr}$, median yields ranged from 290 to $26,000 \mathrm{lb} / \mathrm{mi}^{2} / \mathrm{yr}$, and maximum yields ranged from 1,300 to $32,000 \mathrm{lb} / \mathrm{mi}^{2} / \mathrm{yr}$. Estimated total phosphorus yields ranged from less than 10 to $16,000 \mathrm{lb} / \mathrm{mi}^{2} / \mathrm{yr}$. Minimum total phosphorus yields ranged from 1.4 to $900 \mathrm{lb} / \mathrm{mi}^{2} / \mathrm{yr}$, median yields ranged from 12 to $1,900 \mathrm{lb} / \mathrm{mi}^{2} / \mathrm{yr}$, and maximum yields ranged from less than 100 to $16,000 \mathrm{lb} / \mathrm{mi}^{2} / \mathrm{yr}$.

Drainage basins classified as undeveloped in this report include small, largely forested and sparsely populated drainage basins, and also large drainage basins that meet the land-use criteria for undeveloped basins, but include urban areas and major point-source discharges. In 27 undeveloped (generally forested) drainage basins in the region, with undeveloped land ranging from 75 to 100 percent of basin area, median total nitrogen yields range from 290 to $4,800 \mathrm{lb} / \mathrm{mi}^{2} / \mathrm{yr}$, with a median of $1,300 \mathrm{lb} / \mathrm{mi}^{2} / \mathrm{yr}$, for the $1993-2003$ period. It is likely that even the most pristine drainage basins in the region have total nitrogen yields that are elevated relative to natural conditions, because of high rates of atmospheric deposition of nitrogen in parts of the northeastern United States. Maximum total nitrogen yields for 14 undeveloped drainage basins range from 1,300 to $6,400 \mathrm{lb} / \mathrm{mi}^{2} / \mathrm{yr}$. 
Median total phosphorus yields range from 12 to $330 \mathrm{lb} / \mathrm{mi}^{2} / \mathrm{yr}$ for the 26 undeveloped basins evaluated, with a median of $63 \mathrm{lb} / \mathrm{mi}^{2} / \mathrm{yr}$. Maximum total phosphorus yields range from 67 to $860 \mathrm{lb} / \mathrm{mi}^{2} / \mathrm{yr}$ for 14 undeveloped basins, with a median of $230 \mathrm{lb} / \mathrm{mi}^{2} / \mathrm{yr}$. Undeveloped drainage basins with maximum total phosphorus yields that exceed about $200 \mathrm{lb} / \mathrm{mi}^{2} / \mathrm{yr}$ are generally drained by streams that receive point-source discharges.

Total nitrogen and total phosphorus yields for drainage basins with 90 percent or more undeveloped land and no point sources provide an indication of nutrient yields under the least developed conditions in the study area, although this information is incomplete, in terms of both geographic distribution and years of record. Among the drainage basins evaluated in this study, the drainage basins that are least affected by human land-use and waste-disposal practices (although not totally unaffected) generally have median total nitrogen yields in the range of 300 to $1,700 \mathrm{lb} / \mathrm{mi}^{2} / \mathrm{yr}$ and median total phosphorus yields in the range of 30 to $100 \mathrm{lb} / \mathrm{mi}^{2} / \mathrm{yr}$. In large drainage basins that receive point-source discharges and have large percentages of undeveloped land, streamflow with low nutrient loads from relatively undeveloped headwater areas dilutes streamflow in the more urbanized downstream reaches, and dampens but does not eliminate the point-source "signal" of higher nutrient loads.

Although the northeastern United States is one of the most highly urbanized areas in the nation, agricultural land is a major source of nutrients. Nutrients derived from agricultural land contribute to some of the highest total nitrogen yields in the study area. Drainage basins with substantial agricultural influences on water quality are concentrated primarily in the central and southern parts of the study area. Total nitrogen yields are high on an annual basis in many agricultural basins. Several agricultural basins in the southern part of the study area have median total nitrogen yields that equal or exceed $10,000 \mathrm{lb} / \mathrm{mi}^{2} / \mathrm{yr}$. In some cases, periods of record are short, and additional years of record would be necessary to verify yield ranges and typical conditions. Median total nitrogen yields for 24 agricultural basins range from 1,700 to $26,000 \mathrm{lb} / \mathrm{mi}^{2} / \mathrm{yr}$, with a median for all 24 basins of $5,000 \mathrm{lb} / \mathrm{mi}^{2} / \mathrm{yr}$. Median total phosphorus yields range from 94 to $1,000 \mathrm{lb} / \mathrm{mi}^{2} / \mathrm{yr}$ for the 24 agricultural basins evaluated, with a median yield of $280 \mathrm{lb} / \mathrm{mi}^{2} / \mathrm{yr}$.

The maximum total nitrogen yield and maximum total phosphorus yield estimated for all stations in the region were both in small (less than $50 \mathrm{mi}^{2}$ ) agricultural drainage basins with no major point sources. The maximum total nitrogen yield, $32,000 \mathrm{lb} / \mathrm{mi}^{2} / \mathrm{yr}$, was estimated for East Mahantango Creek in Pennsylvania (about 55 percent agricultural land). The maximum total phosphorus yield, $16,000 \mathrm{lb} / \mathrm{mi}^{2} / \mathrm{yr}$, was estimated for the Neshanic River in New Jersey (about 60 percent agricultural land).

Nutrient yields in agricultural and urban/agricultural drainage basins generally increase with increasing percentages of developed land in a drainage basin, although there is a wide range in yields at most levels of development, and point-source effects in some basins complicate interpretations. Agricultural and urban/agricultural drainage basins dominate the highest maximum yields for total nitrogen (greater than the 75th percentile for all stations), whereas urban drainage basins are more numerous among the highest yields for total phosphorus. Agricultural land has been converted to residential developments and other forms of urbanized land in some parts of the study area during the 1993-2003 period for which nutrient yields have been analyzed. Consequently, annual nutrient yields are likely to have been affected by changing sources of nutrients in some drainage basins.

The Susquehanna and the Potomac River Basins are the largest monitored drainage basins in the region with complete records for the 1993-2003 period, and provide the largest freshwater inflows to the Chesapeake Bay. Although both drainage basins are more than 60 percent undeveloped, stream quality in both basins is affected by agricultural influences. The Susquehanna and Potomac River Basins are classified as agricultural drainage basins in this report, with about 28 and 34 percent agricultural land, respectively, and less than 10 percent urbanized land. Median total nitrogen yields for the Susquehanna $\left(5,200 \mathrm{lb} / \mathrm{mi}^{2} / \mathrm{yr}\right)$ and Potomac $\left(5,100 \mathrm{lb} / \mathrm{mi}^{2} / \mathrm{yr}\right)$ are close to the median (of all medians) for total nitrogen yields for all agricultural drainage basins $\left(5,000 \mathrm{lb} / \mathrm{mi}^{2} / \mathrm{yr}\right)$. The median total phosphorus yield for the Potomac $\left(280 \mathrm{lb} / \mathrm{mi}^{2} / \mathrm{yr}\right.$ ) is similar to the median (of all medians) for all agricultural basins. The median for the Susquehanna, by contrast, is somewhat lower (190 lb/mi²/yr), possibly because phosphorus tends to bind to sediment particles that settle and are retained in impoundments upstream from the monitoring station.

Urbanized drainage basins encompass a wide range of total developed land, and a wide range in the predominant type of urban development. Consequently, nutrient yields vary over a wide range in drainage basins classified as urbanized in this report. Conditions affecting nutrient yields in urbanized drainage basins include population density, percentages of urbanized versus undeveloped land, the presence or absence of point sources, the magnitude of point-source discharges relative to streamflow, and nonpoint source water-quality effects related to the intensity of the urbanized land development. Point sources have not been evaluated quantitatively for most drainage basins in the region; however, some general conclusions can be drawn. Urban drainage basins with the highest total nitrogen and total phosphorus yields are generally drained by streams that are receiving waters for major point discharges, and drainage areas for these streams are generally small, usually less than $300 \mathrm{mi}^{2}$ and in many cases less than $100 \mathrm{mi}^{2}$. Urbanized drainage basins with low total nitrogen and total phosphorus yields are generally larger drainage basins with point sources and a high percentage of undeveloped land; small drainage basins with presumed small point sources and a large percentage of undeveloped land; and small drainage basins with low-density development, no point sources, and a large percentage of undeveloped land. 
Median total nitrogen yields range from 1,400 to $17,000 \mathrm{lb} / \mathrm{mi}^{2} / \mathrm{yr}$ in 26 urbanized drainage basins, with a median (of all medians) of $4,000 \mathrm{lb} / \mathrm{mi}^{2} / \mathrm{yr}$. Maximum total nitrogen yields for urbanized basins range from 2,000 to $22,000 \mathrm{lb} / \mathrm{mi}^{2} / \mathrm{yr}$, with a median of $4,800 \mathrm{lb} / \mathrm{mi}^{2} / \mathrm{yr}$.

Median total phosphorus yields in 26 urbanized drainage basins range from 43 to $1,900 \mathrm{lb} / \mathrm{mi}^{2} / \mathrm{yr}$, with a median of $210 \mathrm{lb} / \mathrm{mi}^{2} / \mathrm{yr}$. Maximum total phosphorus yields for urbanized basins encompass a wide range, from less than 100 to more than $6,000 \mathrm{lb} / \mathrm{mi}^{2} / \mathrm{yr}$. Maximum total phosphorus yields exceeded $1,000 \mathrm{lb} / \mathrm{mi}^{2} / \mathrm{yr}$ in several urban basins.

The urbanized drainage basins with the highest nutrient yields are generally drained by streams that are receiving waters for major point-source discharges. For many small streams in the older urbanized areas of the northeastern U.S., wastewater discharges contribute a substantial part of the stream nutrient loads under most conditions. Total nitrogen yields are consistently high in several small drainage basins (300 $\mathrm{mi}^{2}$ or less) that have major urban influences on water quality in the form of large percentages of urbanized land, high population densities, or major point-source discharges. Minimum total phosphorus yields in urbanized drainage basins are high relative to other land-use categories. The maximum values for minimum and median total phosphorus yields are in urbanized drainage basins. Routinely high annual nutrient yields in urban drainage basins illustrate the challenges of managing nutrients in the older urbanized areas of the region.

Nutrient yields generally increase with increasing percentages of developed land in urbanized drainage basins where no major point sources are present, and where water quality is influenced primarily by nonpoint sources. This relation differs for total nitrogen and total phosphorus. High total phosphorus yields are common in small, highly urbanized drainage basins. Identification of specific urban nonpoint sources and land-use conditions may be necessary to address nutrient management in older urbanized areas.

Streams draining highly urbanized areas of the region are major nutrient sources, delivering nutrient loads to the main stems of major rivers and in some cases directly to estuaries and coastal areas. Smaller urbanized drainage basins (less than about $300 \mathrm{mi}^{2}$ ), including drainage basins with and without point sources, have some of the highest nutrient yields in the study area.

Urban and agricultural land use (more than 20 to 30 percent of a drainage basin) has increased median total nitrogen yields by factors of three to five and has increased median total phosphorus yields by factors of three to six, relative to undeveloped drainage basins in the northeastern United States, although the yield ranges for both constituents are large for all land use categories. The amount of developed land has a pronounced effect on the magnitude of nutrient yields. Where more than about 50 percent of a drainage area is developed, in either agricultural or urban land or both, the potential for very high yields is present. In 14 of 31 basins with more than 50 percent developed land, maximum total nitrogen yields equaled or exceeded 10,000 lb/mi' $/ \mathrm{yr}$. Most drainage basins with more than 50 percent developed land ( 23 of 31 basins) had maximum total phosphorus yields that exceeded $600 \mathrm{lb} / \mathrm{mi}^{2} / \mathrm{yr}$, and in 18 of these basins, maximum total phosphorus yields equaled or exceeded $1,000 \mathrm{lb} / \mathrm{mi}^{2} / \mathrm{yr}$. Major point-source discharges contribute to elevated nutrient yields throughout the study area, in agricultural, urban/agricultural, and forested basins, as well as in urban basins.

Annual nutrient yields varied considerably from year to year in response to changing hydrologic conditions. Large differences in maximum yields for total nitrogen and total phosphorus were observed between 2002, a very dry year throughout the region, and 2003, a very wet year in many parts of the region. Order-of-magnitude differences in yield between the two years were observed in several drainage basins in New Jersey, Pennsylvania, and Maryland; the Potomac River Basin; and all drainage basins in Virginia.

\section{Effects of Point Sources}

Four drainage basins were evaluated for the effects of point-source discharges: the Quinebaug River Basin in eastern Connecticut and adjacent areas of Massachusetts and Rhode Island, the Raritan River Basin in New Jersey, the Patuxent River Basin in Maryland, and the James River Basin in Virginia. Comparison of long-term and recent trends in flowadjusted nutrient concentrations, and trends in nutrient loads, indicates that in the basins evaluated, the major reductions in delivery of nutrients to streams, whether from point sources or other sources, may have taken place prior to the 1993-2003 period of analysis. The reduction in delivery of nutrients is consistent with the history of improvements in wastewatertreatment facilities in the region, although this relationship has not been documented quantitatively or in historical detail. A trend in stream discharge, for the 1975-2003 period, was detected at only one of the stations analyzed. Consequently, the trends in nutrient loads, for most stations, coupled with similar trends in flow-adjusted concentrations of nutrients, appear to indicate changes in the delivery of nutrients to streams, with long-term reductions detected for most nutrients evaluated.

The prevalence of long-term downward trends in nutrient loads in these four drainage basins indicates substantial improvements in nutrient-related water-quality conditions. Long-term downward trends in loads of ammonia nitrogen or total Kjeldahl (total-ammonia-plus-organic) nitrogen are consistent with wastewater-treatment processes that have reduced aquatic toxicity problems by converting ammonia to nitrate prior to discharge, and by removing organic material from wastewater. Long-term downward trends in total phosphorus loads are consistent with wastewatertreatment improvements and with the implementation of phosphate detergent bans in states of the region. The absence of downward trends in load for most constituents during the 1993-2003 period, coupled with modeled instream concentrations for the early 1990s that exceed proposed 
nutrient criteria in several of these waste-receiving streams, indicates that additional challenges remain in reducing the delivery of nutrients to streams from point sources.

At most of the monitoring stations evaluated in these drainage basins, long-term downward trends in nutrient loads were paired with long-term downward trends in flow-adjusted concentrations of nutrients, indicating reductions in the delivery of nutrients to streams. During the recent period, however, the following upward trends in flow-adjusted nutrient concentrations may indicate processes or changes that are increasing nutrient delivery to some streams in recent years: three upward trends in total nitrogen concentrations, two upward trends in ammonia nitrogen concentrations, and three upward trends in total phosphorus concentrations.

The interannual variation in stream nutrient loads was much greater than the interannual variation in the contribution of point-source loads to the stream, for most years at most monitoring stations evaluated in the Quinebaug, Raritan, Patuxent, and James River Basins; that is, the point source load was fairly constant from year to year. During dry years, however, nutrient loads contributed by nonpoint sources were minimal, and the total nutrient load from all point sources in the drainage area approached the level of the nutrient load transported by the stream. This general pattern was observed in all four drainage basins. The pattern was more pronounced in the more highly developed drainage basins, but was noticeable in less developed drainage basins in extremely dry years. The implication of this finding is that point-source loads are likely to be the predominant source of the nutrients in many rivers of the region during critical times. At times of low flow, the nutrient load from nonpoint sources is small, and less streamflow is available to dilute the point-source nutrients. Consequently, high nutrient concentrations, derived from point sources, are observed during times of low flow.

\section{Challenges for Management of Nutrients in the Northeastern United States}

Forested land cover generally constitutes 65 percent or more of the drainage area in the large drainage basins of the region, and cleaner streamflow from forested areas is a source of dilution for the more impaired waters in downstream urbanized reaches of major rivers. Development pressures in previously undeveloped forested areas of large drainage basins may contribute to future increases in nutrient yields, both through the increases in nutrient sources and the changes in hydrologic processes in headwater streams. Changes in land use have the potential to alter flow regimes substantially and to increase the delivery of nutrients to downstream reaches. These headwater changes may threaten long-term gains resulting from improved wastewater treatment along historically impaired main-stem reaches of major streams in the region.

Trend results for flow-adjusted nutrient concentrations, modeled instream nutrient concentrations, and nutrient loads show that over three decades, major gains have been made in controlling nutrient-related water-quality problems that result from point-source effluent in many streams of the region. Although nutrient concentrations are substantially reduced in many drainage basins, concentrations in many waste-receiving streams, including some of the major streams in the region, persist at levels that may promote freshwater or estuarine eutrophication and may adversely affect aquatic habitat conditions.

Small, heavily developed drainage basins (either urban or agricultural) have extremely high nutrient yields during high streamflows. Many small drainage basins with major pointsource discharges have consistently high nutrient yields during all streamflow conditions. These small drainage basins contribute large nutrient loads to major streams, and sometimes directly to estuarine areas.

Long-term nutrient data are sparse in many areas of the region for small, nonpoint drainage basins with a variety of land uses and a range of development intensity. Additional long-term monitoring, and regional modeling, will help to identify expectable nutrient yields from various land uses more accurately.

\section{Acknowledgments}

Information and assistance from the following U.S. Geological Survey (USGS) staff is appreciated: Jacob Gibs, New Jersey; Michael Langland, Pennsylvania; Doug Moyer, Virginia; Jeff Raffensperger, Maryland; Jonathan Kennen, New Jersey; Virginia de Lima, Jon Morrison, Craig Brown, and Karen Beaulieu, Connecticut; James M. Caldwell, Maine; Craig Johnston and Sarah Flanagan, New Hampshire; Laura Medalie, Vermont; Pat Phillips, New York; Robert Breault, Rhode Island; David K. Mueller and Lori Sprague, Colorado; Naomi Nakagaki, California; Michael Yurewicz, Office of Water Quality; Charles Crawford, NAWQA National Support. Thomas Trombley, Connecticut, provided spatial data analyses for maps in this report. Colleague review was provided by: David Lorenz, Minnesota, and Joel Blomquist, Maryland. Editorial review was provided by Lyn Osburn.

Paul Stacey, Connecticut Department of Environmental Protection, provided information on point-sources discharges in Connecticut. Kelly Streich, Connecticut Department of Environmental Protection, provided helpful comments on the report.

Information and interpretations in this report rely on streamflow measurements and water-quality data compiled during several decades by USGS hydrologic technicians and hydrologists in 13 states and 7 NAWQA study units, and on water-quality analyses by scientists at the USGS National Water Quality Laboratory in Denver, Colorado. Interpretations in this report would not have been possible without their efforts. 


\section{Selected References}

Alexander, R.B., Boyer, E.W., Smith, R.A., Schwarz, G.E., and Moore, R.B., 2007, The role of headwater streams in downstream water quality: Journal of the American Water Resources Association (JAWRA), v. 43, no. 1, p. 41-59.

Alexander, R.B., Slack, J.R., Ludtke, A.S., Fitzgerald, K.K., and Schertz, T.L., 1996, Data from selected U.S. Geological Survey National Stream Water-Quality Monitoring Networks (WQN): U.S. Geological Survey Digital Data Series DDS-37, 2 computer discs.

Alexander, R.B., Slack, J.R., Ludtke, A.S., Fitzgerald, K.K., and Schertz, T.L., 1997, Data from selected U.S. Geological Survey National Stream Water-Quality Monitoring Networks (WQN) on CD-ROM: U.S. Geological Survey Fact Sheet FS-013-97, 2 p.

Alexander, R.B., and Smith, R.A., 2006, Trends in the nutrient enrichment of U.S. rivers during the late 20th century and their relation to changes in probable stream trophic conditions: Limnology and Oceanography, v. 51, no. 1 (part 2), p. 639-654.

Ator, S.W., Blomquist, J.D., Brakebill, J.W., Denis, J.M., Ferrari, M.J., Miller, C.V., and Zappia, Humbert, 1998, Water quality in the Potomac River Basin, Maryland, Pennsylvania, Virginia, West Virginia, and the District of Columbia, 1992-96: U.S. Geological Survey Circular 1166, $38 \mathrm{p}$.

Ayers, M.A., Kennen, J.G., and Stackelberg, P.E., 2000, Water quality in the Long Island-New Jersey coastal drainages, New York and New Jersey, 1996-98: U.S. Geological Survey Circular 1201, 41 p.

Bachman, L.J., Lindsey, B.D., Brakebill, J.W., and Powars, D.S., 1998, Ground-water discharge and base-flow nitrate loads of nontidal streams, and their relation to a hydrogeomorphic classification of the Chesapeake Bay Watershed, middle Atlantic Coast: U.S. Geological Survey Water-Resources Investigations Report 98-4059, 77 p.

Belval, D.L., and Sprague, L.A., 1999, Monitoring nutrients in the major rivers draining to Chesapeake Bay: U.S. Geological Survey Water-Resources Investigations Report 99-4238, 8 p.

Bricker, S., Longstaff, B., Dennison, W., Jones, A., Boicourt, K., Wicks, C., and Woerner, J., 2007, Effects of nutrient enrichment in the Nation's estuaries: A decade of change; NOAA Coastal Ocean Program Decision Analysis Series No. 26, National Centers for Coastal Ocean Science, Silver Spring, Md., 322 p.
Castro, M.S., Driscoll, C.T., Jordan, T.E., Reay, W.G., Boynton, W.R., Seitzinger, S.P., Styles, R.V., and Cable, J.E., 2001, Contribution of atmospheric deposition to the total nitrogen loads to thirty-four estuaries on the Atlantic and Gulf Coasts of the United States, p. 77-106, in Valigura and others, eds., Nitrogen loading in coastal water bodies: An atmospheric perspective: Coastal and Estuarine Studies 57, American Geophysical Union, Washington, D.C., 254 p.

Center for Land Use Education and Research, 2009, Forest fragmentation in Connecticut: 1985-2006: University of Connecticut, $4 \mathrm{p}$.

Chesapeake Bay Program, 2002, The state of the Chesapeake Bay; a report to the citizens of the Bay region: U.S. Environmental Protection Agency, Chesapeake Bay Program Office; CPB/TRS 260/02, EPA 903-R-02-002, $60 \mathrm{p}$.

Chesapeake Bay Program, 2004, Chesapeake Bay: Introduction to an ecosystem: EPA 903-R-04-003, CBP/TRS 232/00, July 2004, 35 p.

Clark, G.M., Mueller, D.K., and Mast, M.A., 2000, Nutrient concentrations and yields in undeveloped stream basins of the United States: Journal of American Water Resources Association, v. 36, no. 4, p. 849-860.

Connecticut Department of Environmental Protection, 2001, Long Island Sound summer hypoxia: Hartford, Conn., 3 p., accessed December 18, 2007, at http://www.ct.gov/dep

Connecticut Department of Environmental Protection, 2008, 2008 State of Connecticut Integrated Water Quality Report, 321 p., accessed July 22, 2009, at http://www.ct.gov/dep/lib/ $\mathrm{dep} /$ water/water_quality_management/305b/2008_final_ct integratedwqr.pdf

Darrell, L.C., Feit-Majedi, B., Lizarraga, J.S., and Blomquist, J.D., 1999, Nutrient and suspended-sediment concentrations, trends, loads, and yields from the non-tidal part of the Susquehanna, Potomac, Patuxent, and Choptank Rivers, 1985-96: U.S. Geological Survey Water-Resources Investigations Report 98-4177, 39 p.

Ely, Eleanor, 2002, An overview of Narragansett Bay: Rhode Island Sea Grant, Narragansett, R.I., 8 p.

Ficke, J.F., and Hawkinson, R.O., 1975, The National Stream Quality Accounting Network (NASQAN) —-some questions and answers: U.S. Geological Survey Circular 719, 23 p.

Fischer, J.M., Riva-Murray, Karen, Hickman, R.E., Chichester, D.C., Brightbill, R.A., Romanok, K.M., and Bilger, M.D., 2004, Water quality in the Delaware River Basin, Pennsylvania, New Jersey, New York, and Delaware, 1998-2001: U.S. Geological Survey Circular 1227, 39 p. 
Fontaine, R.A., and Nielsen, J.P., 1994, Flood of April 1987 in Maine: U.S. Geological Survey Water-Supply Paper 2424, $50 \mathrm{p}$.

Forstall, R.L., 1995, Population of counties by decennial census: 1900 to 1990; compiled and edited by Richard L. Forstall, Population Division, U.S. Bureau of the Census; accessed August 22, 2008, at http://www.census.gov/ population/www/censusdata/cencounts/index.html

Freeman, M.C., Pringle, C.M., and Jackson, C.R., 2007, Hydrologic connectivity and the contribution of stream headwaters to ecological integrity at regional scales: Journal of the American Water Resources Association (JAWRA), v. 43, no. 1, p. 5-14.

Fuller, W.A., 1996, Introduction to statistical time series, second edition: New York, John Wiley and Sons, 728 p.

Garabedian, S.P., Coles, J.F., Grady, S.J., Trench, E.C.T., and Zimmerman, M.J., 1998, Water quality in the Connecticut, Housatonic, and Thames River Basins, Connecticut, Massachusetts, New Hampshire, New York, and Vermont, 1992-95: U.S. Geological Survey Circular 1155, 32 p.

Gilliom, R.J., Alley, W.M., and Gurtz, M.E., 1995, Design of the National Water-Quality Assessment Program: occurrence and distribution of water-quality conditions: Sacramento, Calif., U.S. Geological Survey Circular 1112, $33 \mathrm{p}$.

Helsel, D.R., 2005, Nondetects and data analysis, statistics for censored environmental data: Hoboken, N.J., John Wiley \& Sons, Inc., $250 \mathrm{p}$.

Helsel, D.R., and Hirsch, R.M., 2000, Statistical methods in water resources: Studies in Environmental Science 49, Elsevier, Amsterdam, 529 p.

Hem, J.D., 1985, Study and interpretation of the chemical characteristics of natural water; Third Edition: U.S. Geological Survey Water-Supply Paper 2254, 264 p.

Hickman, R.E., and Barringer, T.H., 1999, Trends in water quality of New Jersey streams, water years 1986-95: U.S. Geological Survey Water-Resources Investigations Report 98-4204, $174 \mathrm{p}$.

Hobbs, Frank, and Stoops, Nicole, 2002, Demographic trends in the 20th century: U.S. Department of Commerce, U.S. Census Bureau, Census 2000 Special Reports, CENSR-4, 222 p., accessed August 22, 2008, at http://www.census. gov/prod/2002pubs/censr-4.pdf

Insightful Corporation, 2002, S-PLUS 6.1 for Windows professional edition release 1, Insightful Corporation.
Jian, Xiaodong, Wolock, David, and Lins, Harry, 2008, WaterWatch-Maps, graphs, and tables of current, recent, and past streamflow conditions: U.S. Geological Survey Fact Sheet 2008-3031, 2 p.

Jorgensen, B.B., and Richardson, Katherine, eds., 1996, Eutrophication in coastal marine ecosystems: Washington, D.C., American Geophysical Union, Coastal and Estuarine Studies 52, $272 \mathrm{p}$.

Langland, M.J., 2009, Bathymetry and sediment-storage capacity change in three reservoirs on the Lower Susquehanna River, 1996-2008: U.S. Geological Survey Scientific Investigations Report 2009-5110, 21 p.

Langland, M.J., and Hainly, R.A., 1997, Changes in bottomsurface elevations in three reservoirs on the lower Susquehanna River, Pennsylvania and Maryland, following the January 1996 flood; implications for nutrient and sediment loads to Chesapeake Bay: U.S. Geological Survey Water-Resources Investigations Report 97-4138, 34 p.

Langland, M.J., Lietman, P.L., and Hoffman, Scott, 1995, Synthesis of nutrient and sediment data for watersheds within the Chesapeake Bay drainage basin: U.S. Geological Survey Water-Resources Investigations Report 95-4233, $121 \mathrm{p}$.

Langland, M.J., Raffensperger, J.P., Moyer, D.L., Landwehr, J.M., and Schwarz, G.E., 2006, Changes in streamflow and water quality in selected nontidal basins in the Chesapeake Bay Watershed, 1985-2004: U.S. Geological Survey Scientific Investigations Report 2006-5178, 75 p. [appendixes (on CD)].

Lindsey, B.D., Breen, K.J., Bilger, M.D., and Brightbill, R.A., 1998, Water quality in the Lower Susquehanna River Basin, Pennsylvania and Maryland, 1992-95: U.S. Geological Survey Circular 1168, 38 p.

Litke, D.W., 1999, Review of phosphorus control measures in the United States and their effects on water quality: U.S. Geological Survey Water-Resources Investigations Report 99-4007, 38 p.

Maryland Department of the Environment, 2008, 2008 Integrated report of surface water quality in Maryland, Part F5, Category 5 of the 2008 Integrated 303 (d) list, accessed August 21, 2009, at http://www.mde.state.md.us/assets/ document/2008_IR_Category_5_Waters(1).pdf

Maryland Department of Natural Resources, 2009, Long-term monitoring program shows improving nitrogen trends in Maryland's Rivers and Streams: Annapolis, Md., Maryland Department of Natural Resources, $2 \mathrm{p}$. 
Massachusetts Department of Environmental Protection, 2008, Massachusetts Year 2008 Integrated List of Waters, 221 p., accessed July 22, 2009, at http://www.mass.gov/dep/water/ resources/08list2.pdf

McMahon, Gerard, Tervelt, Larinda, and Donehoo, William, 2007, Methods for estimating annual wastewater nutrient loads in the southeastern United States: U.S. Geological Survey Open-File Report 2007-1040, 81 p.

Medalie, Laura, 1996, Wastewater collection and return flow in New England, 1990: U.S. Geological Survey WaterResources Investigations Report 95-4144, Bow, N.H., 79 p.

Medalie, Laura, and Smeltzer, Eric, 2004, Status and trends of phosphorus in Lake Champlain and its tributaries, 1990-2000, p. 191-219, in Manley, T.O., Manley, P.L., and Mihuc, T.B., eds., Lake Champlain: Partnerships and research in the new millennium: Kluwer Academic/Plenum Publishers.

Mueller, D.K., and Spahr, N.E., 2006, Nutrients in streams and rivers across the Nation-1992-2001: U.S. Geological Survey Scientific Investigations Report 2006-5107, 44 p.

Nadeau, T.L., and Rains, M.C., 2007, Hydrological connectivity of headwaters to downstream waters: Introduction to the featured collection: Journal of the American Water Resources Association (JAWRA), v. 43, no. 1, p. $1-4$.

Nakagaki, N., and Wolock, D.M., 2005, Estimation of agricultural pesticide use in drainage basins using land cover maps and county pesticide data: U.S. Geological Survey Open-File Report 2005-1188, 46 p.

National Research Council, 2000, Clean coastal waters: understanding and reducing the effects of nutrient pollution: Washington, D.C., National Academy Press, 405 p.

Natural Resources Conservation Service, 2009, Watershed Boundary Dataset (WBD) Facts, accessed March 16, 2009, at http://www.ncgc.nrcs.usda.gov/products/datasets/ watershed/facts.html

New Jersey Department of Environmental Protection, 2007, New Jersey Integrated Water Quality Monitoring and Assessment Report; 303 (d) list of impaired waters with priority ranking, accessed August 21, 2009, at http://www. state.nj.us/dep/wms/bwqsa/2006AppendixB303d.pdf

Patton, C.J., and Truitt, E.P., 2000, Methods of analysis by the U.S. Geological Survey National Water Quality Laboratory-Determination of ammonium plus organic nitrogen by a Kjeldahl digestion method and an automated photometric finish that includes digest cleanup by gas diffusion: U.S. Geological Survey Open-File Report 00-170, $31 \mathrm{p}$.
Pennsylvania Department of Environmental Protection, 2008, 2008 Pennsylvania Integrated Water Quality Monitoring and Assessment Report-Streams, Category 5 waterbodies, pollutants requiring a TMDL, accessed August 21, 2009, at http://www.depweb.state.pa.us/watersupply/lib/ watersupply/2008_integratedlist/streamscat5_createdaug1. pdf

Reed, T.J., Centinaro, G.L., Dudek, J.F., Corcino, V., and Steckroat, G.C., 2000, Water Resources Data, New Jersey, Water Year 1999; Volume 1, Surface-Water Data: U.S. Geological Survey Water-Data Report NJ-99-1, 293 p.

Reiser, R.G., 2004, Evaluation of streamflow, water quality, and permitted and nonpermitted loads and yields in the Raritan River Basin, New Jersey, water years 1991-98: U.S. Geological Survey Water-Resources Investigations Report 03-4207, 210 p.

Rhode Island Department of Environmental Management, 2008, 2008 Integrated water quality monitoring and assessment report, accessed July 22, 2009, at http://www.dem.ri.gov/programs/benviron/water/quality/ pdf/iwqmon08.pdf

Robertson, D.M., and Roerish, E.D., 1999, Influence of various water quality sampling strategies on load estimates for small streams: Water Resources Research, v. 35, no. 12, p. 3747-3759.

Robinson, K.W., Flanagan, S.M., Ayotte, J.D., Campo, K.W., Chalmers, Ann, Coles, J.F., and Cuffney, T.F., 2004, Water quality in the New England coastal basins, Maine, New Hampshire, Massachusetts, and Rhode Island, 1999-2001: U.S. Geological Survey Circular 1226, 39 p.

Robinson, K.W., Lazaro, T.R., and Pak, Connie, 1996, Associations between water-quality trends in New Jersey streams and drainage-basin characteristics, 1975-86: U.S. Geological Survey Water-Resources Investigations Report 96-4119, 148 p.

Rohm, C.M., Omernik, J.M., Woods, A.J., and Stoddard, J.L., 2002, Regional characteristics of nutrient concentrations in streams and their application to nutrient criteria development: Journal of the American Water Resources Association 38 (1): 1-27.

Runkel, R.L., Crawford, C.G., and Cohn, T.A., 2004, Load Estimator (LOADEST): a FORTRAN program for estimating constituent loads in streams and rivers: U.S. Geological Survey Techniques and Methods, book 4, chap. A5, 69 p.

SAS Institute, Inc., 2004, SAS OnlineDoc ${ }^{\mathrm{TM}}$ 9.1.2: Cary, N.C., SAS Institute, Inc. 
Schertz, T.L., Alexander, R.B., and Ohe, D.J., 1991, The computer program Estimate Trend (ESTREND), a system for the detection of trends in water-quality data: U.S. Geological Survey Water-Resources Investigations Report 91-4040, $72 \mathrm{p}$.

Seaber, P.R., Kapinos, F.P., and Knapp, G.L., 1987, Hydrologic unit maps: U.S. Geological Survey Water Supply Paper 2294, 63 p., 1 pl.

Slack, J.R., Lorenz, D.L., and others, 2003, USGS library for S-PLUS for Windows-Release 2.1: U.S. Geological Survey Open-File Report 2003-357.

Smith, R.A., Alexander, R.B., and Schwarz, G.E., 2003, Natural background concentrations of nutrients in streams and rivers of the conterminous United States: Environmental Science \& Technology, v. 37, no. 14, p. 3039-3047.

Sprague, L.A., 2001, Effects of storm-sampling frequency on estimation of water-quality loads and trends in two tributaries to Chesapeake Bay in Virginia: U.S. Geological Survey Water-Resources Investigations Report 01-4136, $44 \mathrm{p}$.

Sprague, L.A., Clark, M.L., Rus, D.L., Zelt, R.B., Flynn, J.L., and Davis, J.V., 2007, Nutrient and suspended-sediment trends in the Missouri River Basin, 1993-2003: U.S. Geological Survey Scientific Investigations Report 20065231, $80 \mathrm{p}$.

Sprague, L.A., Langland, M.J., Yochum, S.E., Edwards, R.E., Blomquist, J.D., Phillips, S.W., Shenk, G.W., and Preston, S.D., 2000, Factors affecting nutrient trends in major rivers of the Chesapeake Bay Watershed: U.S. Geological Survey Water-Resources Investigations Report 00-4218, 98 p.

Sprague, L.A., Mueller, D.K., Schwarz, G.E., and Lorenz, D.L., 2009, Nutrient trends in streams and rivers of the United States, 1993-2003: U.S. Geological Survey Scientific Investigations Report 2008-5202, 196 p.

TIBCO Software, Inc., 2008, TIBCO Spotfire S+ Version 8.1.1 for Microsoft Windows.

TRC Omni Environmental Corporation, 2001, Raritan River basin point source pollutant loading and attenuation rate analysis: Princeton, N.J., TRC Omni Environmental Corporation, $15 \mathrm{p}$.

Trench, E.C.T., 2000, Nutrient sources and loads in the Connecticut, Housatonic, and Thames River Basins: U.S. Geological Survey Water-Resources Investigations Report 99-4236, $66 \mathrm{p}$.
U.S. Census Bureau, 2000, Density using land area for states, counties, metropolitan areas, and places; Table 1. Land area, population, and density for states and counties: 1990; Released: March 12, 1996, Revised: June 26, 2000; accessed September 12, 2005, at http://www.census.gov/ population/www/censusdata/files/90den_stco.txt

U.S. Census Bureau, 2001, Census 2000 redistricting data (P.L. 94-171) Summary File and 1990 Census; Census 2000 PHC-T-2. Ranking tables for states: 1990 and 2000; Table 1. States ranked by population: 2000; Internet release date: April 2, 2001; accessed September 12, 2005, at http://www.census.gov/population/www/cen2000/briefs/ phc-t2/index.html

U.S. Environmental Protection Agency, 1986, Quality criteria for water-1986: U.S. Environmental Protection Agency Report EPA 440/5-86-001 [variously paged].

U.S. Environmental Protection Agency, 1998, National strategy for the development of regional nutrient criteria: U.S. Environmental Protection Agency Report EPA 822-R98-002, 30 p., plus appendixes.

U.S. Environmental Protection Agency, 2000a, Ambient water quality criteria recommendations: Information supporting the development of state and tribal nutrient criteria for rivers and streams in Nutrient Ecoregion VII; Mostly Glaciated Dairy Region: U.S. Environmental Protection Agency Office of Water Report EPA 822-B-00-018, 28 p., plus appendixes.

U.S. Environmental Protection Agency, 2000b, Ambient water quality criteria recommendations: Information supporting the development of state and tribal nutrient criteria for rivers and streams in Nutrient Ecoregion IX; Southeastern Temperate Forested Plains and Hills: U.S. Environmental Protection Agency Office of Water Report EPA 822-B-00019, 32 p., plus appendixes.

U.S. Environmental Protection Agency, 2000c, Ambient water quality criteria recommendations: Information supporting the development of state and tribal nutrient criteria for rivers and streams in Nutrient Ecoregion XI; The Central and Eastern Forested Uplands: U.S. Environmental Protection Agency Office of Water Report EPA 822-B-00-020, 28 p., plus appendixes.

U.S. Environmental Protection Agency, 2000d, Ambient water quality criteria recommendations: Information supporting the development of state and tribal nutrient criteria for rivers and streams in Nutrient Ecoregion XIV; Eastern Coastal Plain: U.S. Environmental Protection Agency Office of Water Report EPA 822-B-00-022, 25 p., plus appendixes. 
U.S. Environmental Protection Agency, 2000e, National water quality inventory-1998 Report to Congress: U.S. Environmental Protection Agency Report EPA841-R-00-001, Washington, D.C., 434 p.

U.S. Environmental Protection Agency, 2000f, Progress in water quality: An evaluation of the National investment in municipal wastewater treatment: U.S. Environmental Protection Agency Office of Wastewater Management Report EPA-832-R-00-008, variously paged.

U.S. Environmental Protection Agency, 2001, Ambient water quality criteria recommendations: Information supporting the development of state and tribal nutrient criteria for rivers and streams in Nutrient Ecoregion VIII; Nutrientpoor, largely glaciated Upper Midwest and Northeast: U.S. Environmental Protection Agency Office of Water Report EPA 822-B-01-015, 28 p., plus appendixes.

U.S. Environmental Protection Agency, 2002, Ecoregional nutrient criteria: U.S. Environmental Protection Agency Office of Water Fact Sheet EPA-822-F-02-008, 2 p.

U.S. Environmental Protection Agency, 2003, National primary drinking water standards: U.S. Environmental Protection Agency Office of Water Report EPA 816-F-03016, 6 p.

U.S. Environmental Protection Agency, 2004, Primer for municipal wastewater treatment systems: Office of Water, Office of Wastewater Management, EPA 832-R-04-001, $29 \mathrm{p}$.

U.S. Environmental Protection Agency, 2005, BASINS (Better Assessment Science Integrating point \& Non-point Sources): BASINS 3.1 description, accessed September 8, 2005, at http:/www.epa.gov/waterscience/ftp/basins/ system/BASINS3/

U.S. Environmental Protection Agency, 2006, What are water quality standards? Office of Water Science, accessed July 4, 2007, at http://www.epa.gov/waterscience/standards/about

U.S. Environmental Protection Agency, 2007, Total maximum daily loads: Office of Wetlands, Oceans, and Watersheds; accessed July 4, 2007, http:/www.epa.gov/owow/tmdl/ intro.html

U.S. Environmental Protection Agency, 2008, Water Compliance and Enforcement Data Systems used in Region 5, accessed October 22, 2008, at http://www.epa.gov/ r5water/weca/pcs.htm

U.S. Environmental Protection Agency, 2010, Overview of the National Water Program, accessed May 21, 2010, at http://www.epa.gov/water/programs/owintro.html

U.S. Geological Survey, 1999, The quality of our Nation's waters-Nutrients and pesticides: U.S. Geological Survey Circular 1225, 82 p.
U.S. Geological Survey, 2002, NWISWeb: New site for the Nation's water data: U.S. Geological Survey Fact Sheet 128-02, 2 p.

U.S. Geological Survey, 2009a, Surface water for New Jersey: Peak streamflow, accessed January 14, 2009, at http://nwis. waterdata.usgs.gov/nj/nwis/peak

U.S. Geological Survey, 2009b, USGS Water Data for USA; National Water Information System: Web Interface, accessed on multiple dates between March 1, 2005 and January 31, 2007, at http://waterdata.usgs.gov/nwis

U.S. Geological Survey, 2009c, WaterWatch-Current water resources conditions; accessed on multiple dates between July 20, 2005, and February 13, 2007, at http://waterwatch. usgs.gov/

Valigura, R.A., Alexander, R.B., Castro, M.S., Meyers, T.P., Paerl, H.W., Stacey, P.E., and Turner, R.E., eds., 2001, Nitrogen loading in coastal water bodies: An atmospheric perspective: Coastal and Estuarine Studies 57, American Geophysical Union, Washington, D.C., 254 p.

Virginia Department of Environmental Quality, 2008, Final 2008 305(b)/303(d) Water QualityAssessment Integrated Report, accessed August 21, 2009, at http://www.deq. virginia.gov/wqa/ir2008.html

Vogelmann, J.E., Howard, S.M., Yang, Limin, Larson, C.R., Wylie, B.K., and Van Driel, Nick, 2001, Completion of the 1990's national land cover dataset for the conterminous United States from Landsat Thematic Mapper data and ancillary data sources: Photogrammetric Engineering and Remote Sensing, v. 67, p. 650-662.

Vogelmann, J.E., Sohl, T.L., Campbell, P.V., and Shaw, D.M., 1998, Regional land cover characterization using LANDSAT thematic mapper data and ancillary data sources: Environmental Monitoring and Assessment, v. 51, p. $415-428$.

Wall, G.R., Riva-Murray, Karen, and Phillips, P.J., 1998, Water quality in the Hudson River Basin, New York and adjacent states, 1992-95: U.S. Geological Survey Circular $1165,32 \mathrm{p}$.

Yochum, S.E., 2000, A revised load estimation procedure for the Susquehanna, Potomac, Patuxent, and Choptank Rivers: U.S. Geological Survey Water-Resources Investigations Report 00-4156, 49 p.

Zimmerman, M.J., Grady, S.J., Trench, E.C.T., Flanagan, S.M., and Nielsen, M.G., 1996, Water-quality assessment of the Connecticut, Housatonic, and Thames River Basins study unit: analysis of available data on nutrients, suspended sediments, and pesticides, 1972-92: U.S. Geological Survey Water-Resources Investigations Report 95-4203, Marlborough, Mass., 162 p. 
Tables 8, 15 


\begin{tabular}{|c|c|c|c|c|c|c|c|c|}
\hline 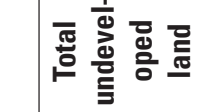 & 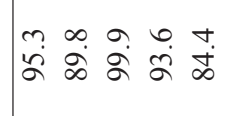 & $\frac{m}{\infty}$ & $\ddot{n}$ in & $\ddot{\infty} \stackrel{0}{\infty}$ & $\ddot{\infty} \underset{\infty}{i} \stackrel{\infty}{\infty} \frac{\eta}{\infty} \stackrel{\infty}{\Re}$ & 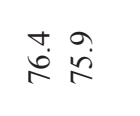 & के 犬ே. & 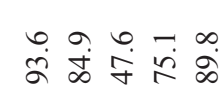 \\
\hline 홍 홍 & 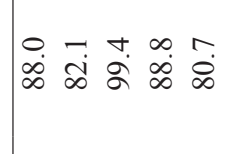 & $\stackrel{i}{i}$ & $\vec{b} \stackrel{m}{q}$ & $\underset{\infty}{\infty} \stackrel{\vec{n}}{i}$ & 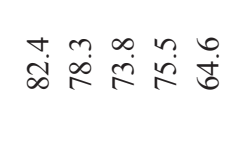 & $\stackrel{\infty}{a}$ aे & $\stackrel{n}{n} \underset{n}{n} \stackrel{\infty}{+}$ & 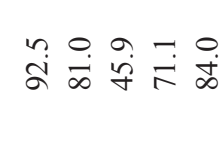 \\
\hline . & 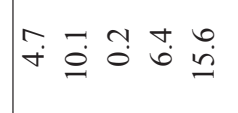 & $\stackrel{\circ}{\infty}$ & $\hat{a} \ddot{i}$ & 卞 $\stackrel{0}{-}$ & 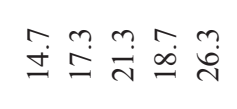 & $\stackrel{0}{\stackrel{i}{\sim}}$ & $\exists \stackrel{0}{\vec{\sim}} \stackrel{\infty}{\sim}$ & 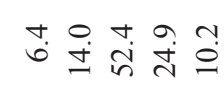 \\
\hline 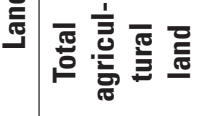 & $\mid \begin{array}{lllll}\forall & 0 & 0 & n & \infty \\
- & \dot{n} & 0 & m & \infty \\
& \infty & \infty\end{array}$ & $\hat{\sigma}$ & $\stackrel{9}{+}$ & $\vec{n} \stackrel{\nabla}{+}$ & 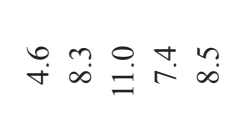 & $\hat{0} \stackrel{9}{=}$ & $\stackrel{+}{ \pm} \stackrel{0}{0} \stackrel{n}{=}$ & 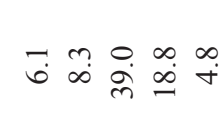 \\
\hline 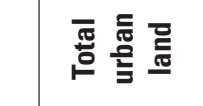 & 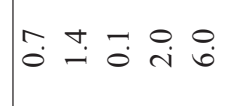 & $\stackrel{n}{=}$ & $\stackrel{n}{\stackrel{9}{9}}$ & $\begin{array}{ll}\infty & \infty \\
\infty & \stackrel{\infty}{n}\end{array}$ & 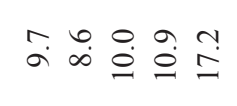 & 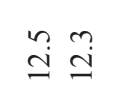 & กุ $\stackrel{0}{-} \stackrel{\infty}{0}$ & 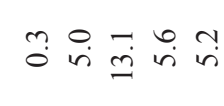 \\
\hline 它 욜 & 台々るる & $\mathfrak{s}$ & 占占 & 台占 & 甹々占台占 & 占占 & Z马ろ & Zろ ろろ \\
\hline 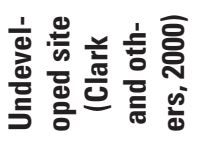 & $z z>z z$ & $\mathrm{z}$ & z Z & z z & z z z z z & z z & $z>z$ & $\lambda z z z z$ \\
\hline 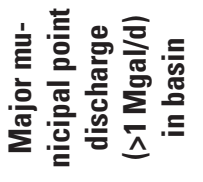 & $\stackrel{0}{\infty} \stackrel{0}{\infty} \dot{z} z$ & $\overbrace{}^{\mathscr{D}}$ & 之े & $\stackrel{\nu}{\infty}_{\nu}^{\infty}$ & 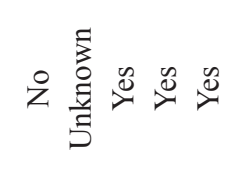 & $\sum_{>}^{\infty}$ & $\stackrel{0}{\infty} \dot{z}$ & 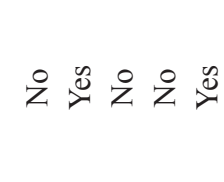 \\
\hline 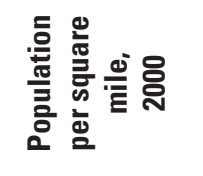 & 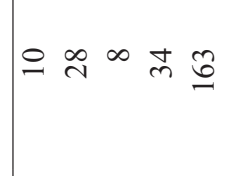 & त & $\begin{array}{l}n \\
\hat{2} \\
\hat{i}\end{array}$ & $\stackrel{n}{\sim} \stackrel{n}{n}$ & 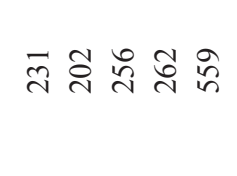 & 离志 & 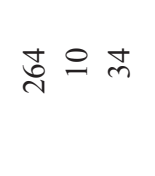 & 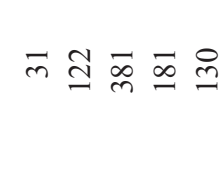 \\
\hline 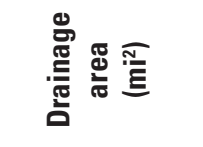 & 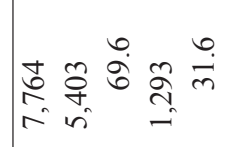 & 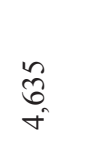 & $\vec{\sim} \nabla$ & ๙ั & ๙ิे & స్ల స్ స్ & $\frac{0}{\pi} \stackrel{\infty}{\infty} 8$ & 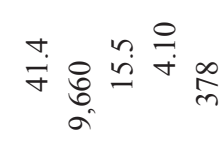 \\
\hline 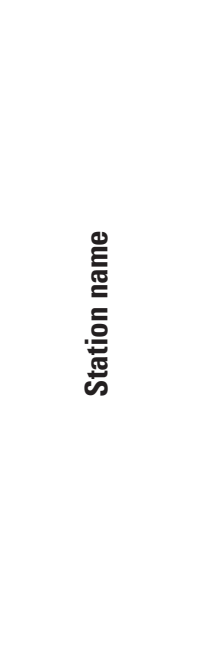 & 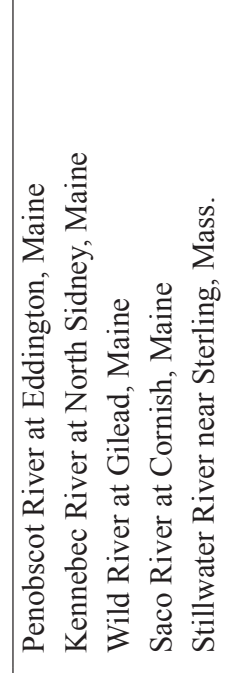 & 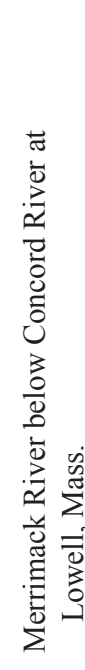 & 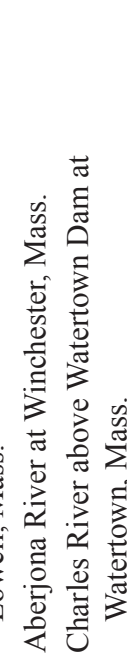 & 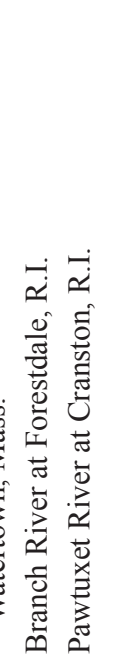 & 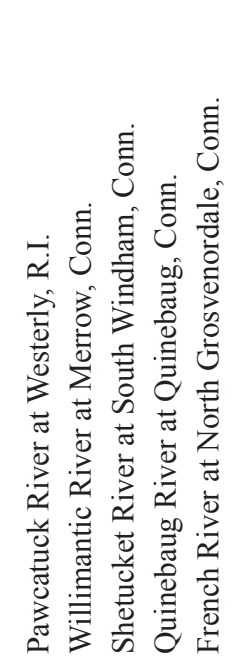 & 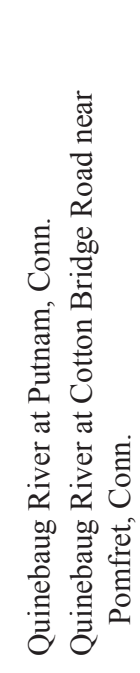 & 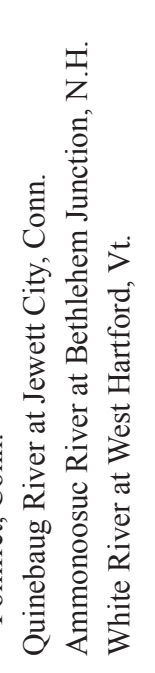 & 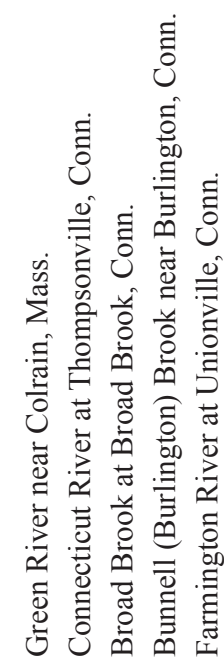 \\
\hline 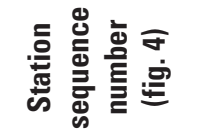 & $-N m+n$ & 6 & $\sim \infty$ & $a$ & $=\simeq \cong \pm \cong$ & $\stackrel{0}{ }=$ & $\stackrel{\infty}{2}$ ㄱ & $\vec{\sim} \approx \tilde{\lambda} \check{\lambda}$ \\
\hline
\end{tabular}




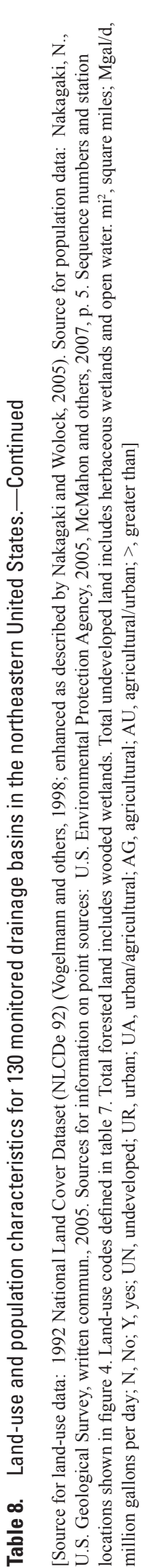

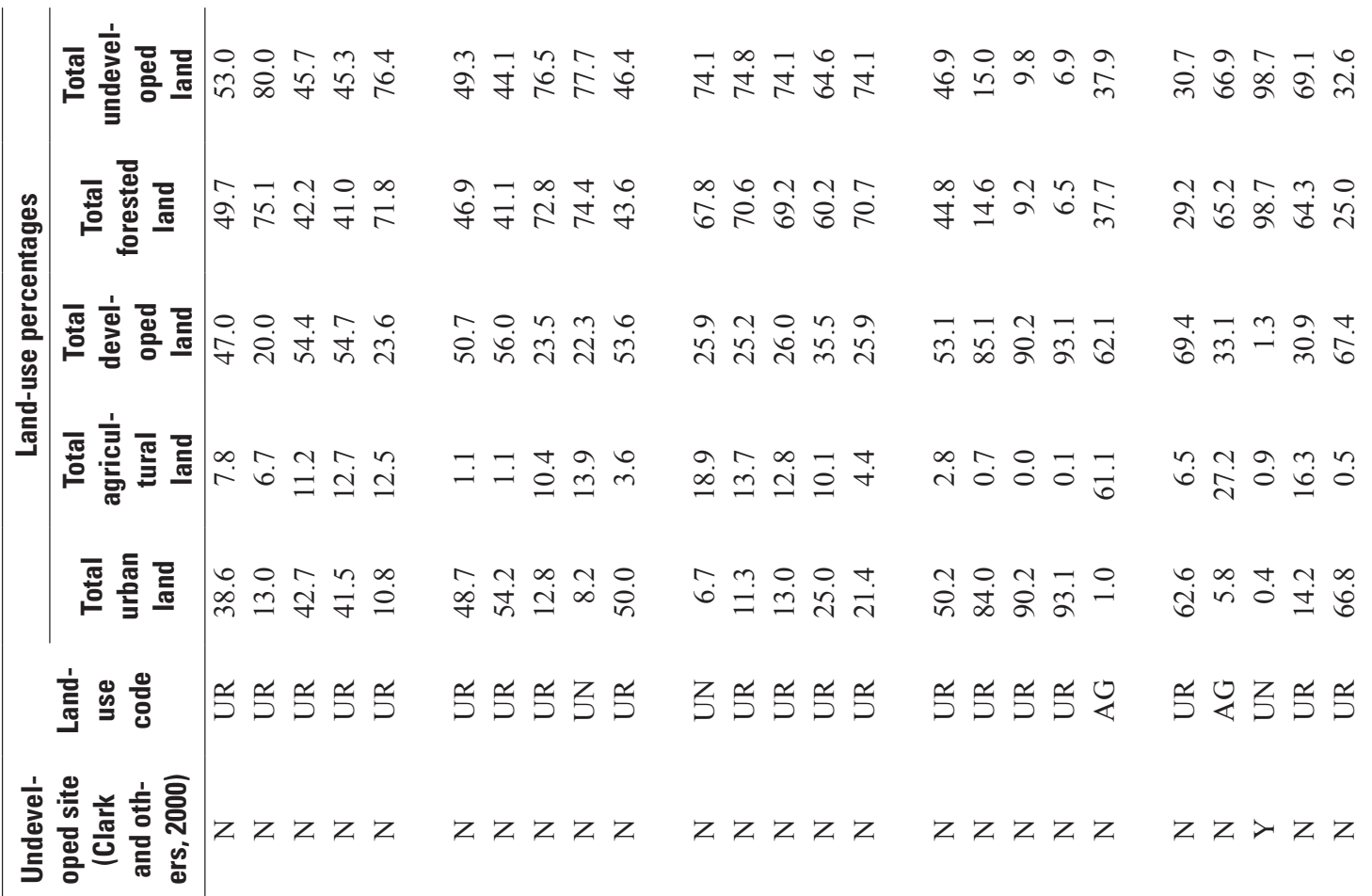

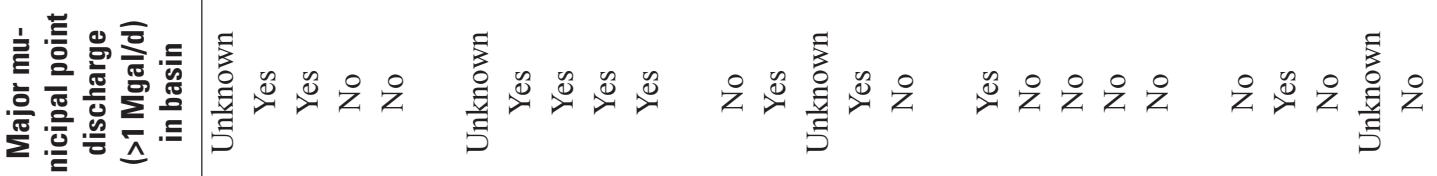

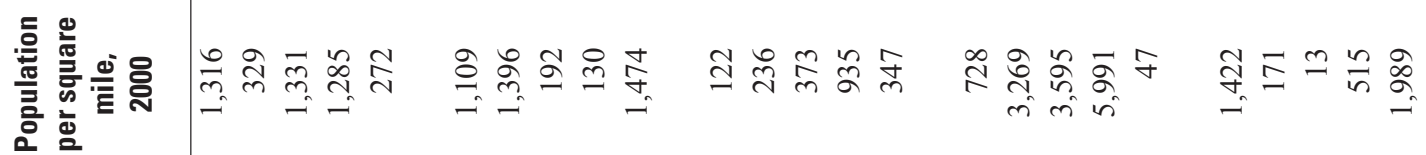

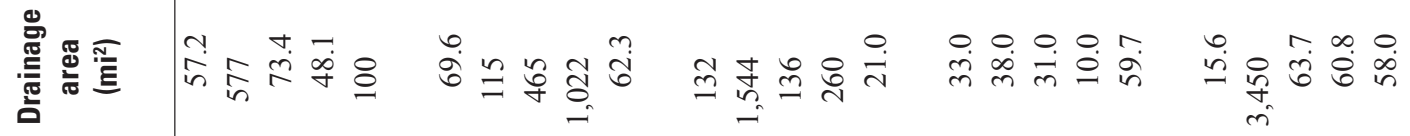
ठี่ 芒

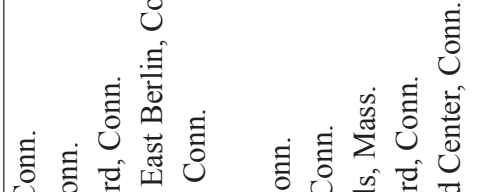

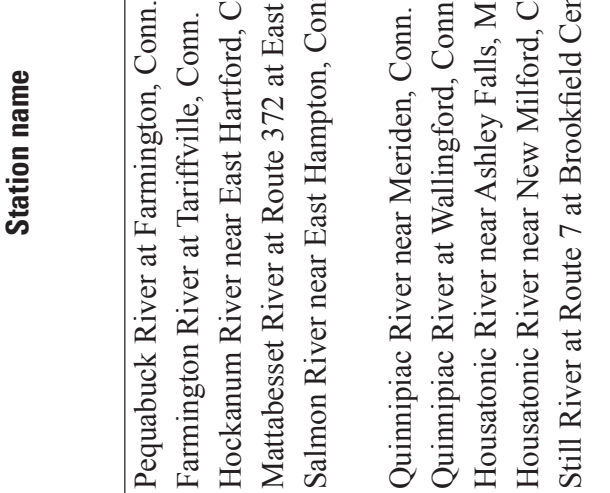

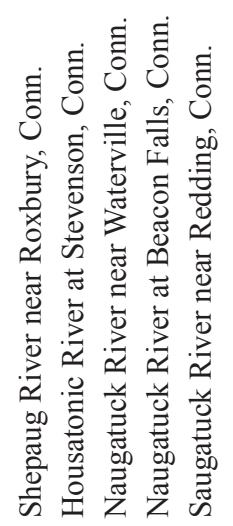

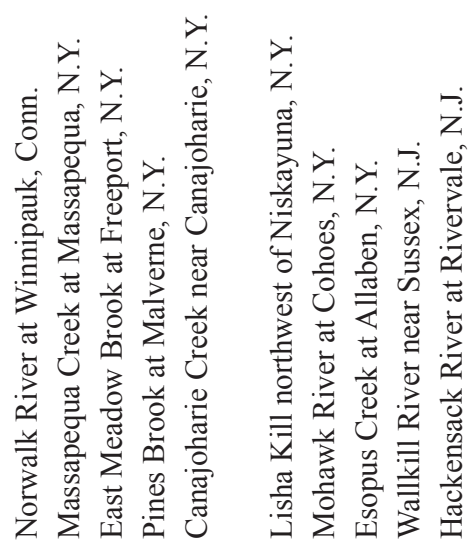




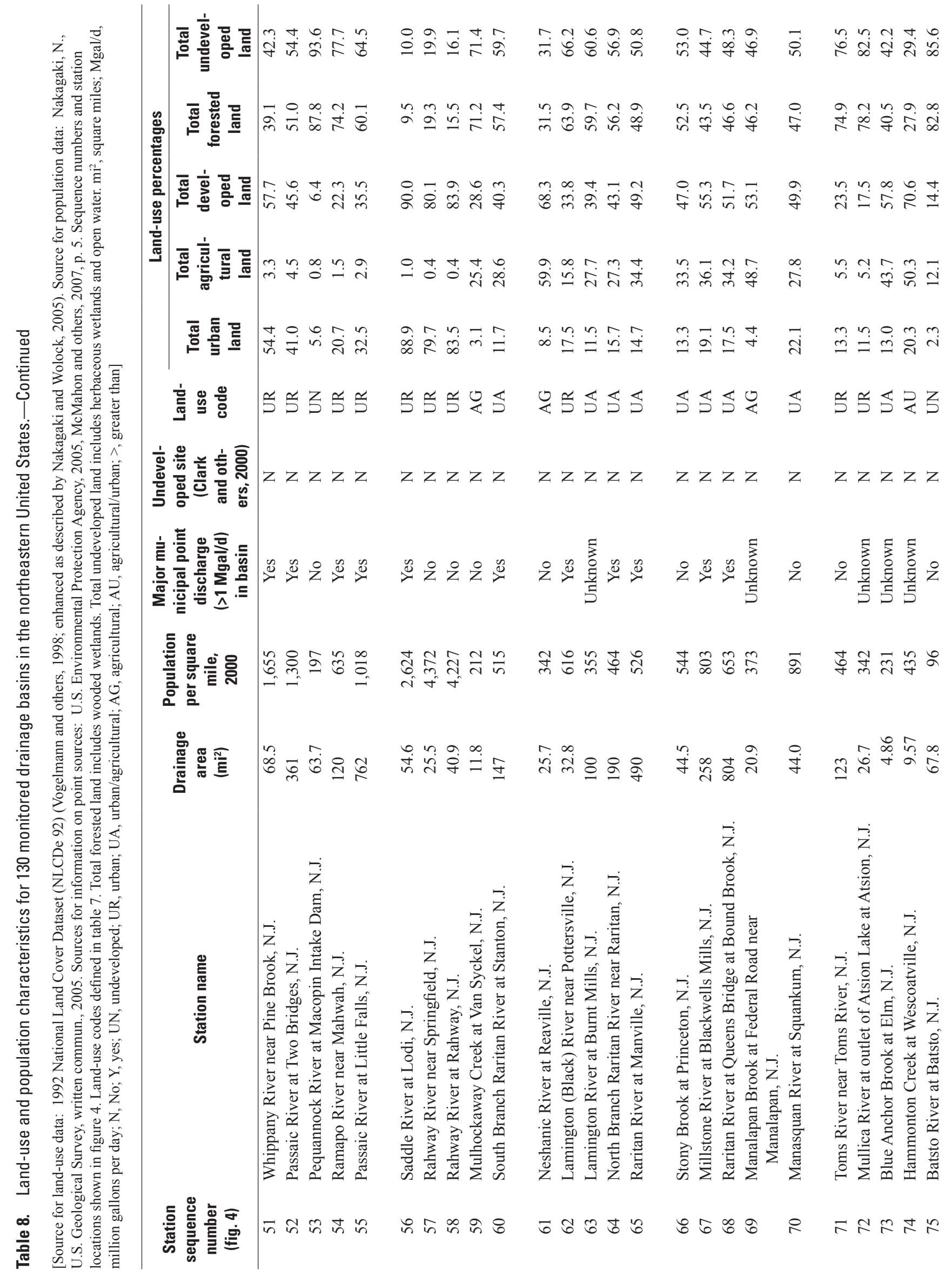




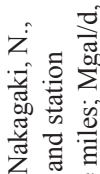

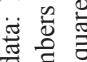

立

氹

형 궣

它的范

을

के ํำ

के क

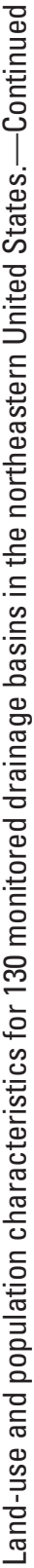

ते

응 뭏

흐

त $\sum_{5}$

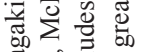

जै

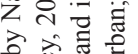

融

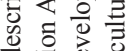

足皆

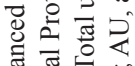

플

क

次. 흥

की

की

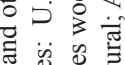

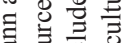

界

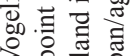

늠

สิ

宅造

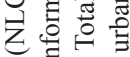

氙造

อั๊

흐응

is

च合焉

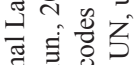

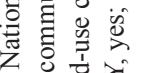

Zू चี

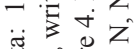

要余言

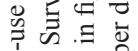

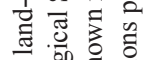

후음

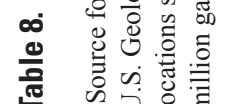

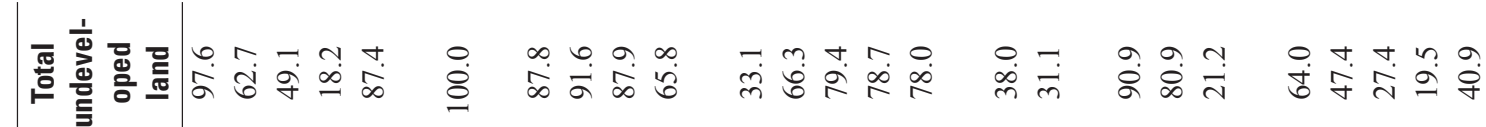

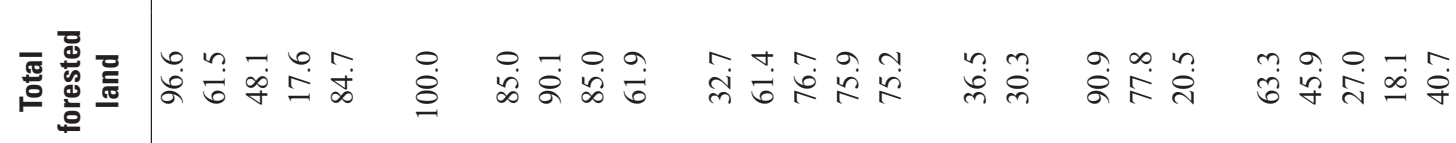

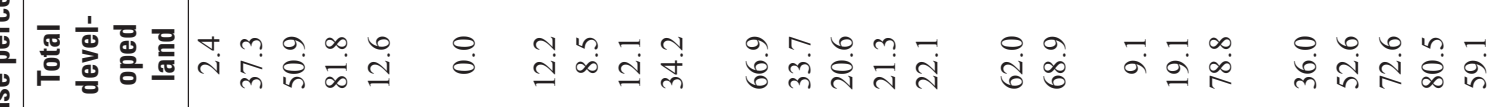

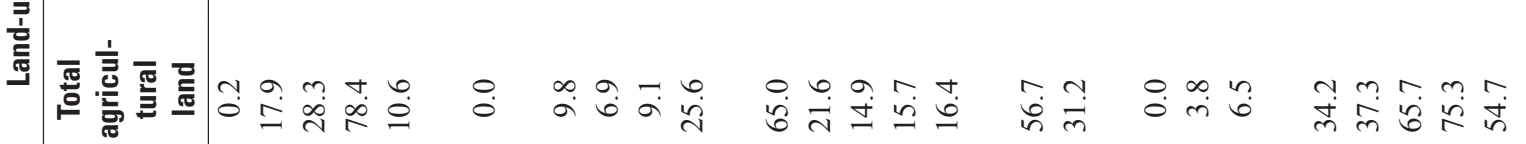

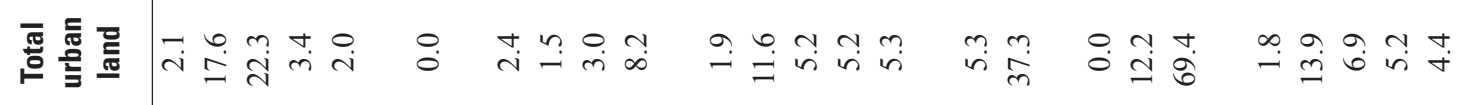

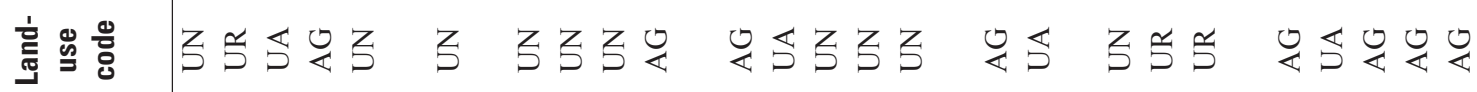

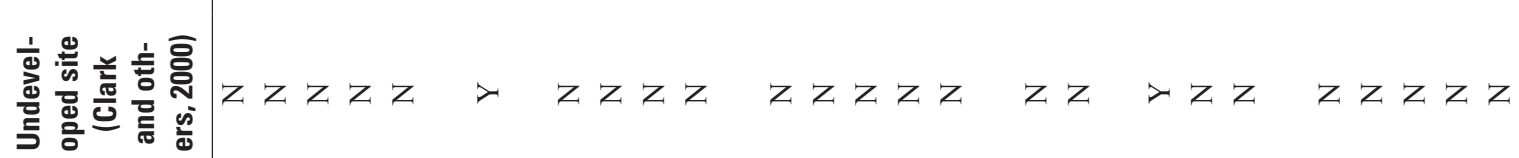

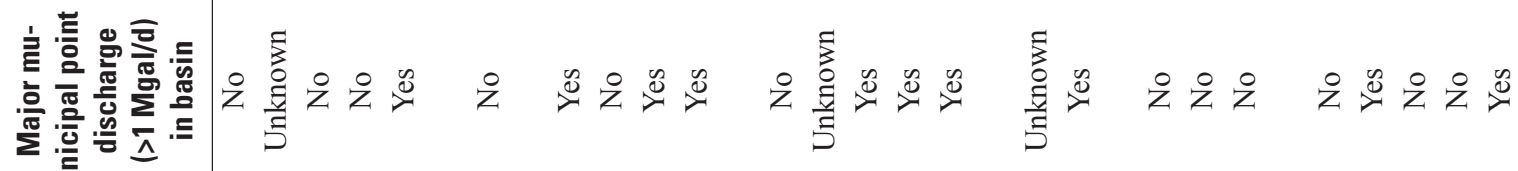

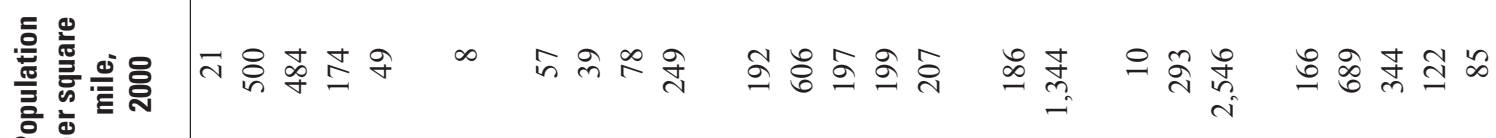

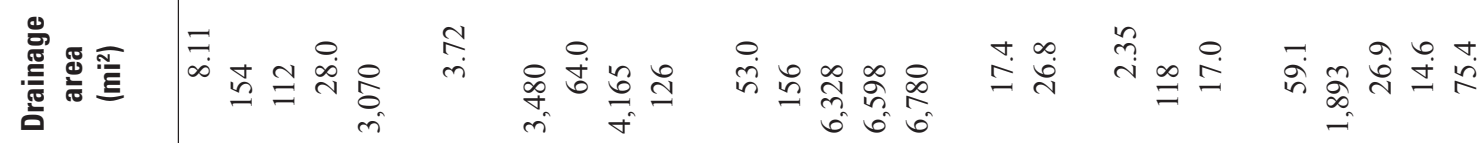

$\dot{z}$

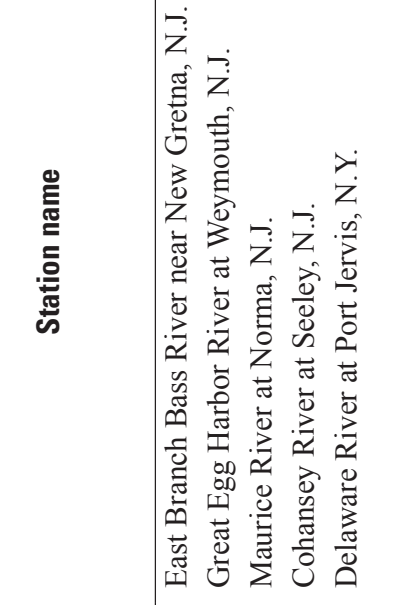

ᄃ r

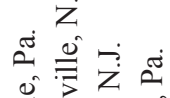

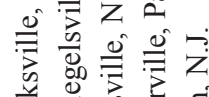

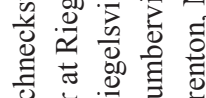

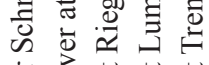

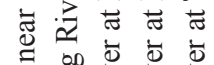

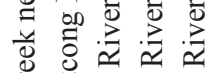

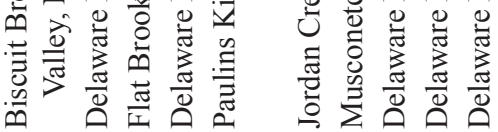

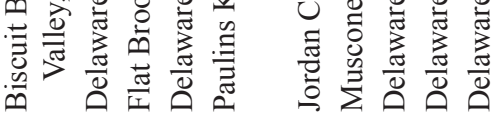

$\bowtie \infty \infty \infty \propto$
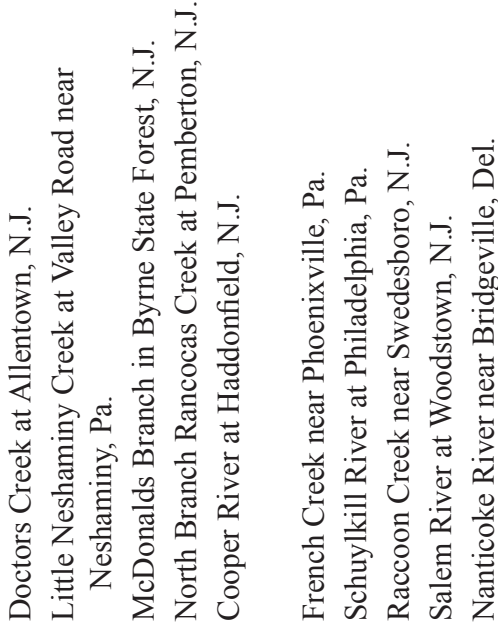


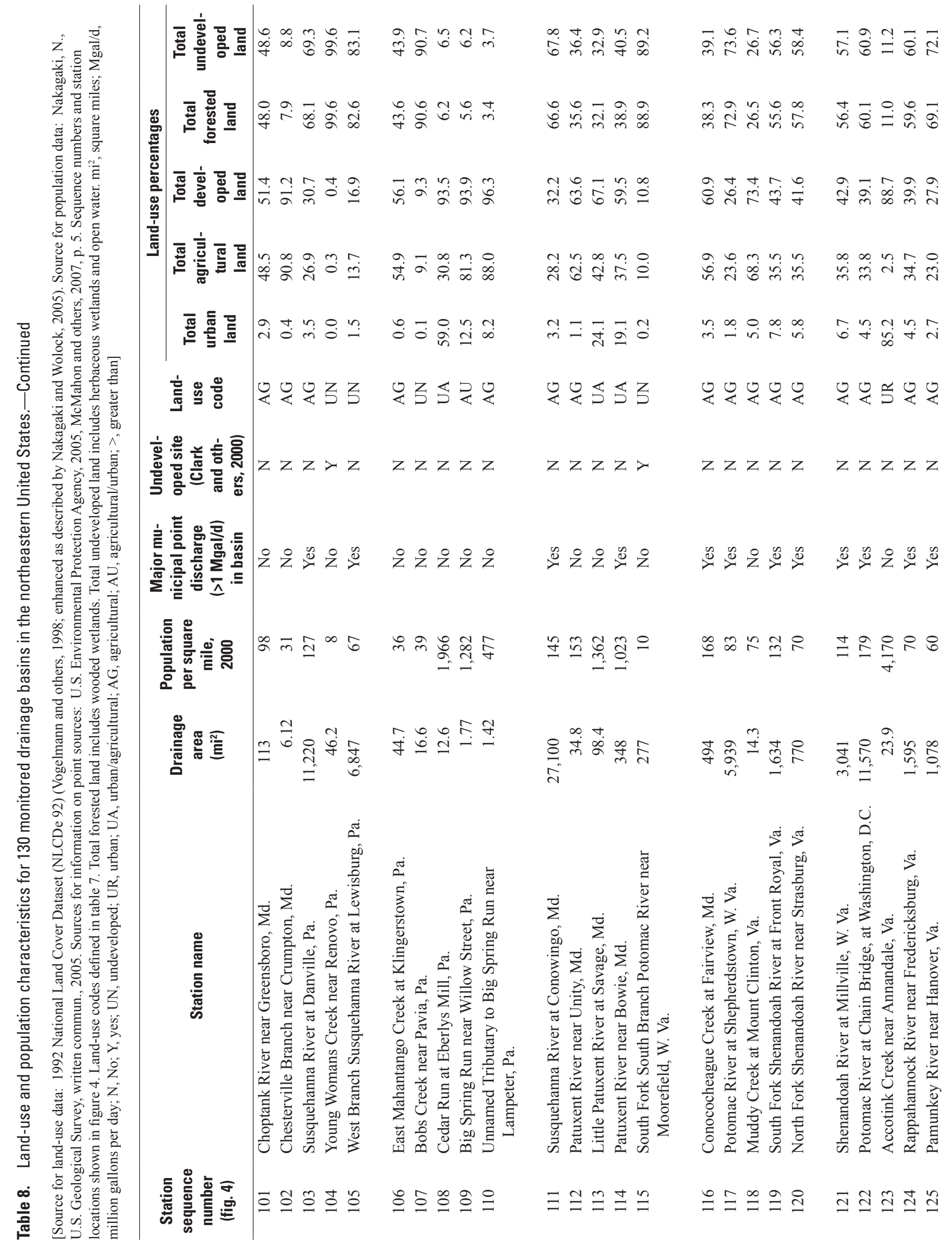




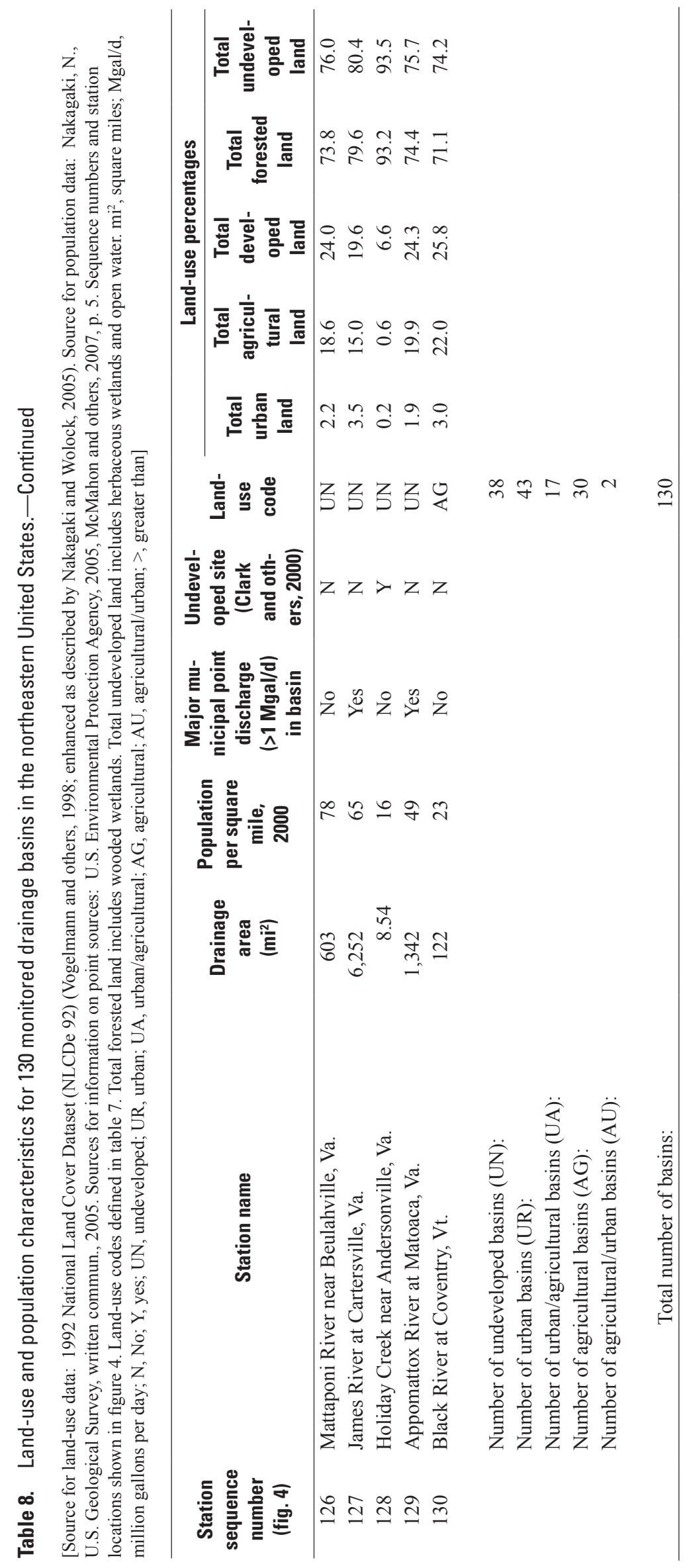




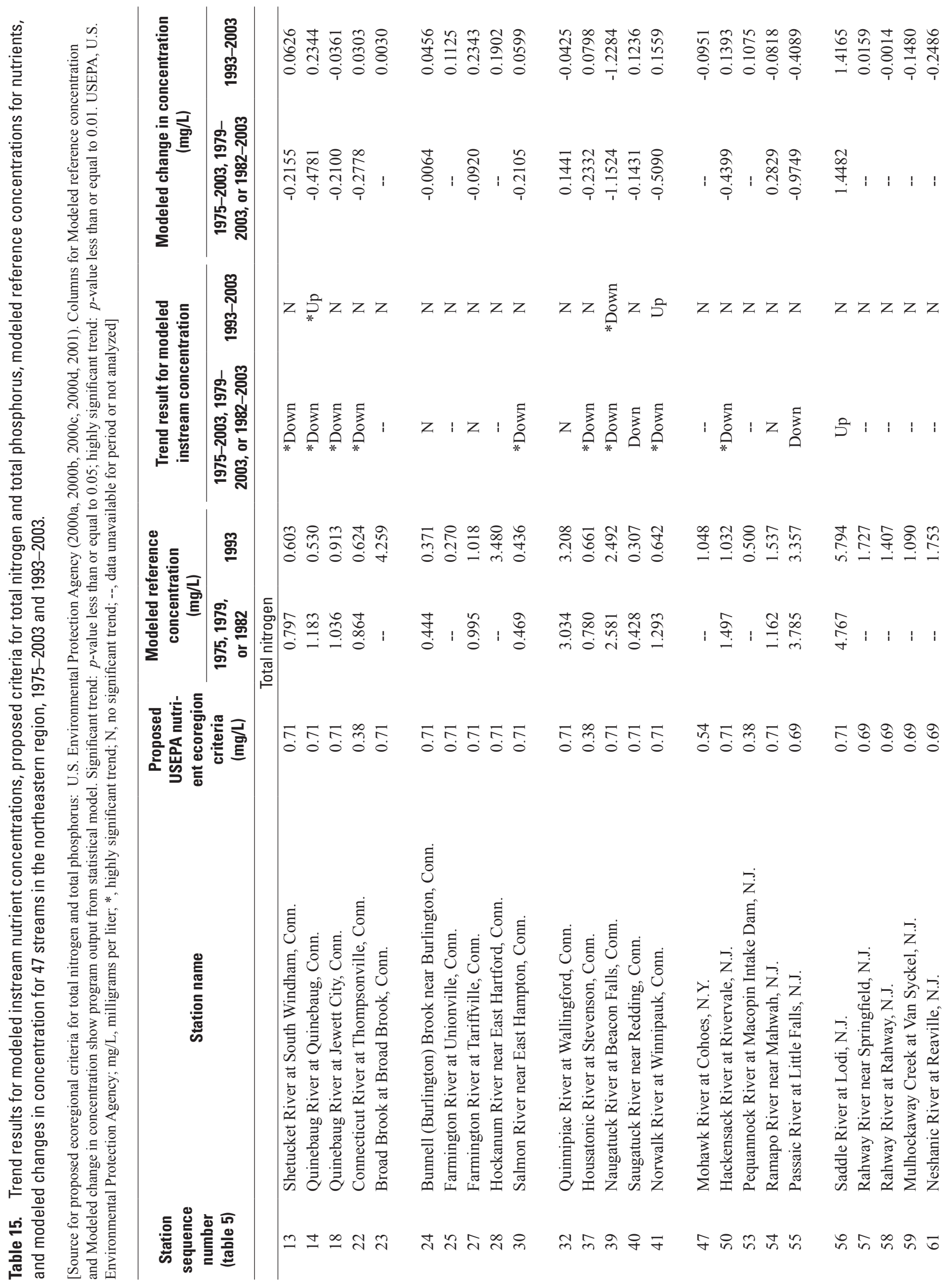




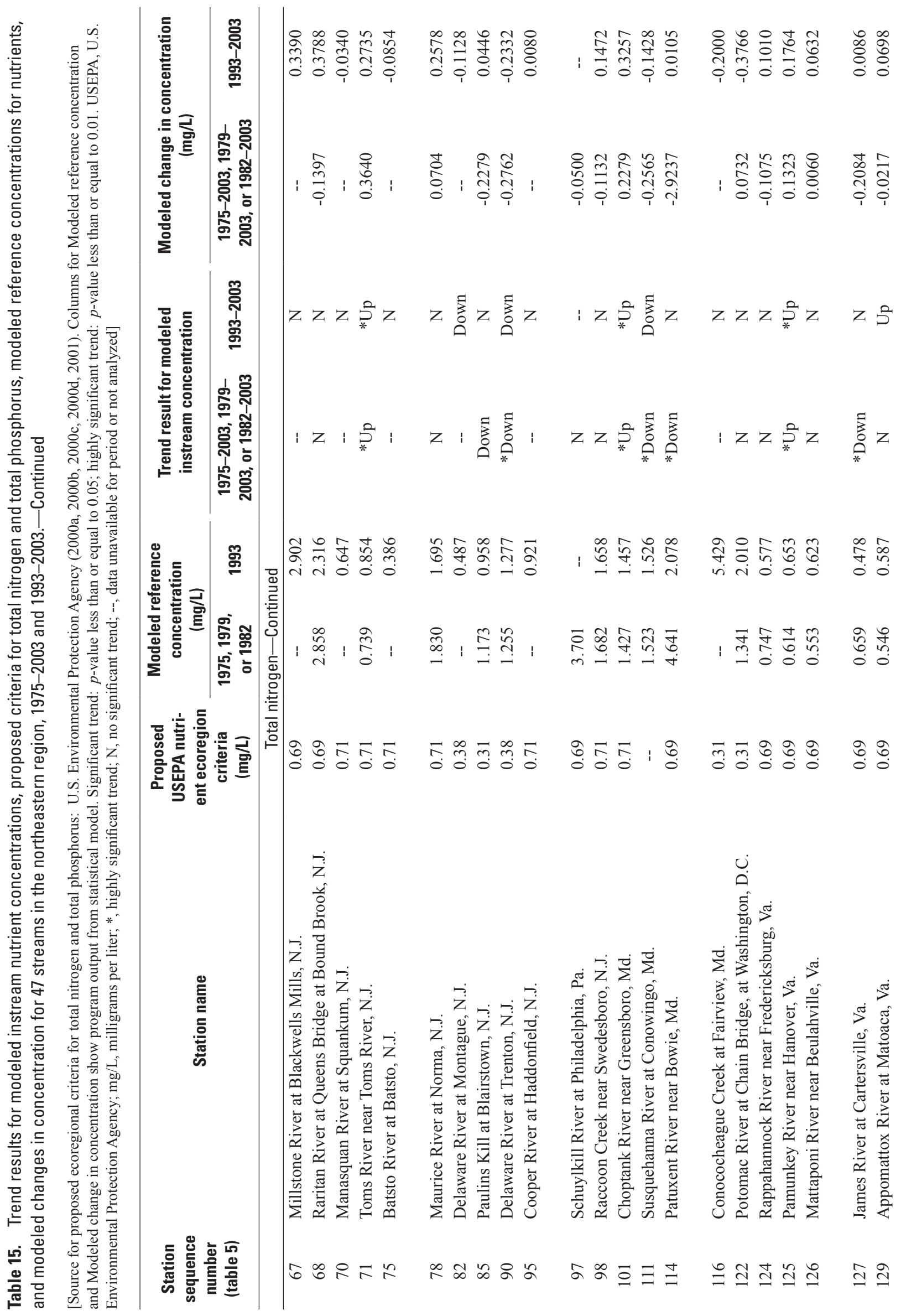




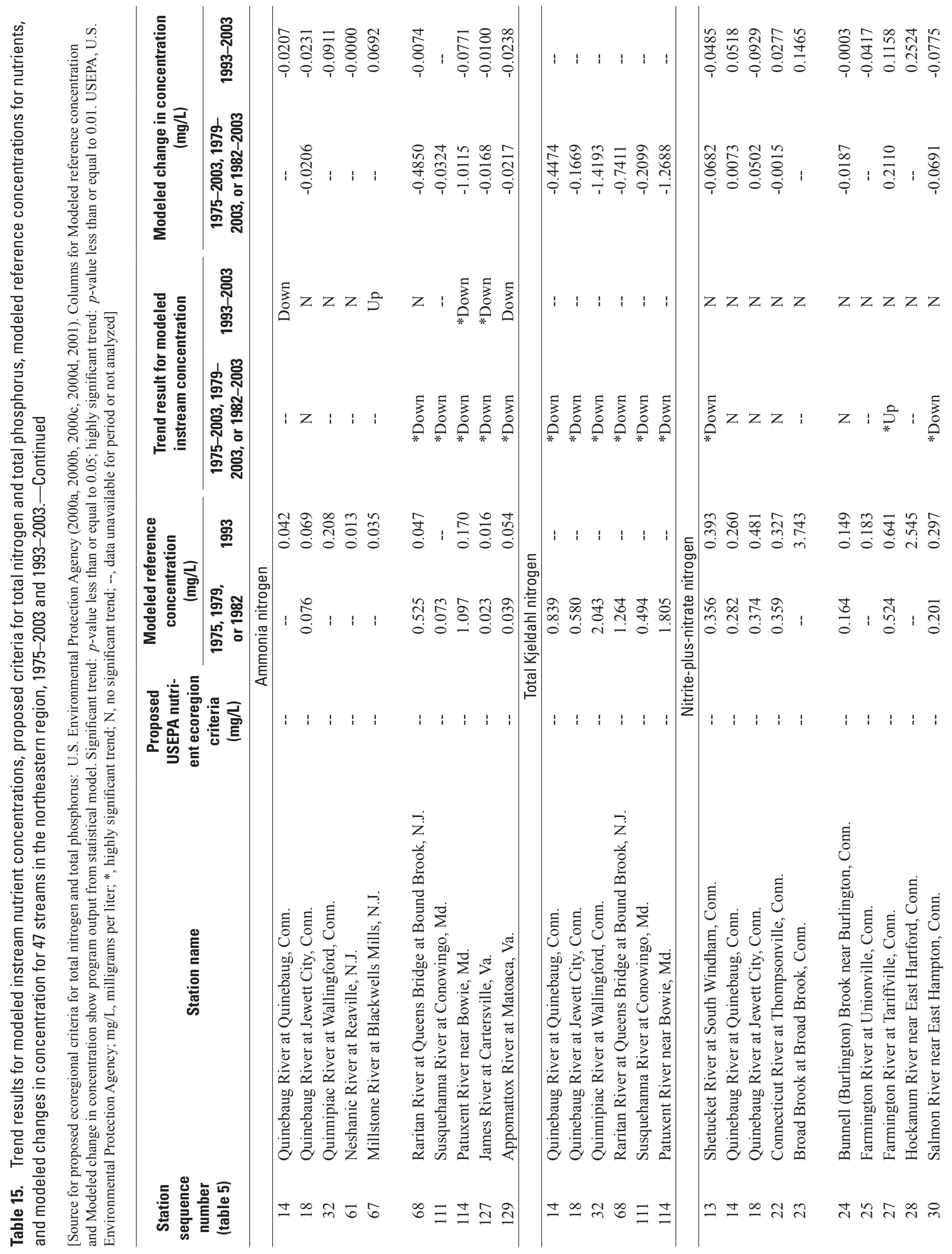




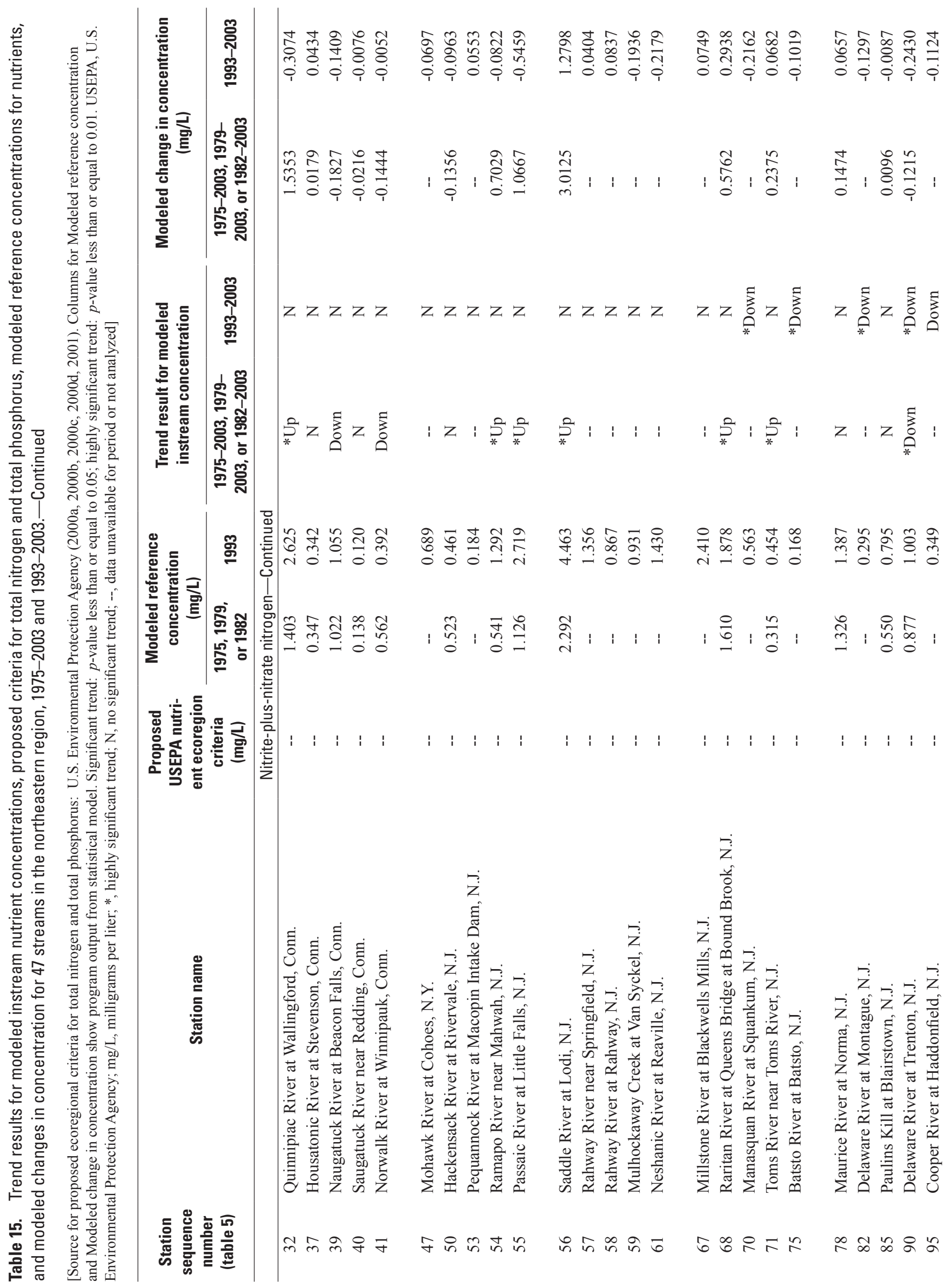




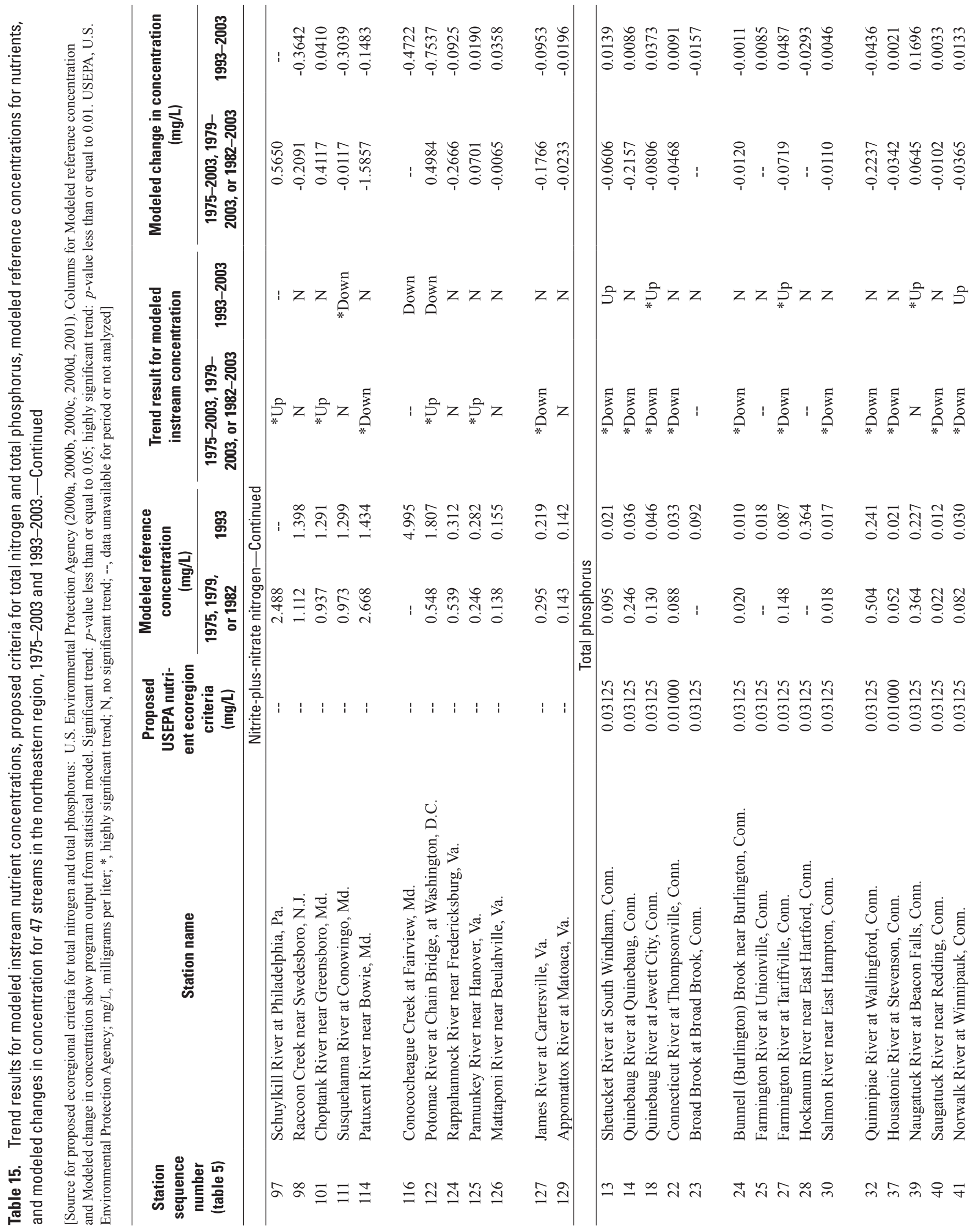




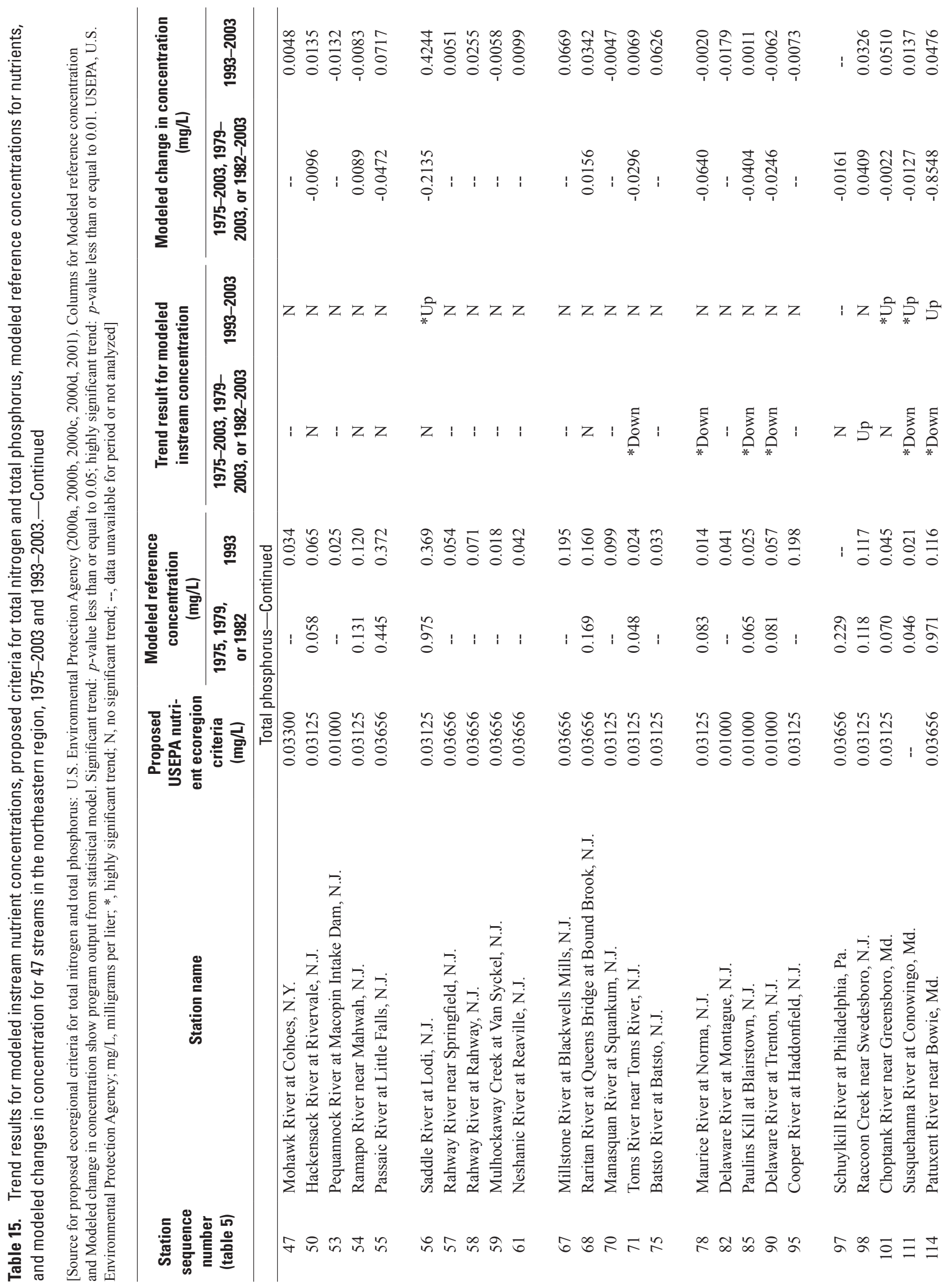




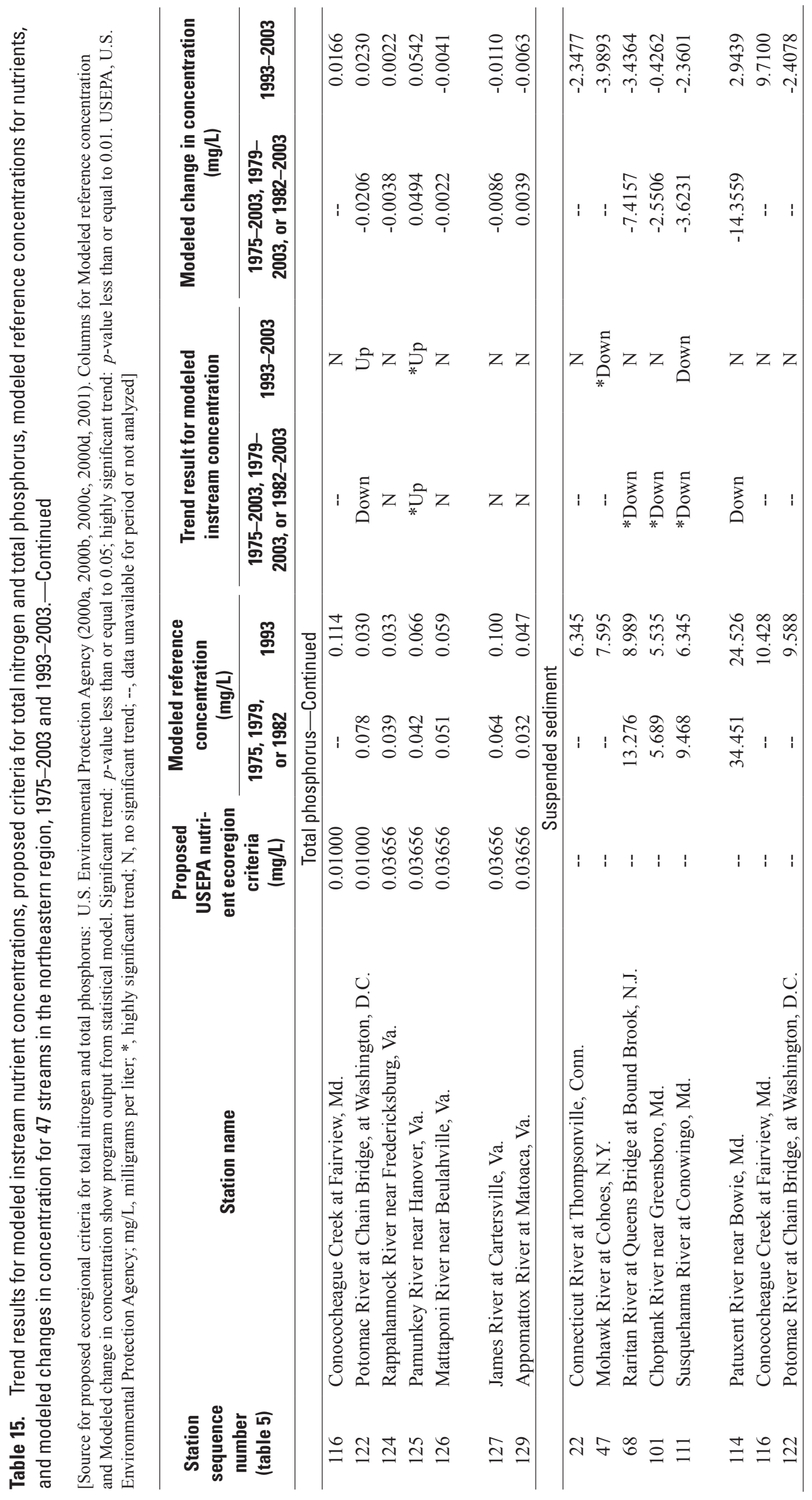




\section{Appendix 1. Methods-Data Retrieval, Screening, and Modification}

\section{Contents}

USGS Water-Quality Data Retrieval and Screening ..........................................................150

National Stream Water-Quality Monitoring Networks (WQN) Data ..............................150

National Water Information System (NWISWeb) ......................................................150

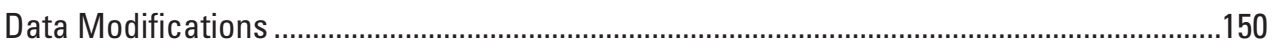

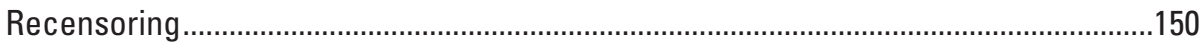

Parameter Codes, Calculated Values, and Order of Precedence for Use

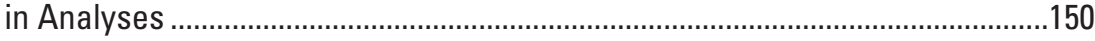

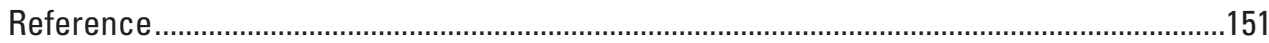




\title{
Appendix 1. Methods-Data Retrieval, Screening, and Modification
}

\author{
By R. Edward Hickman
}

\section{USGS Water-Quality Data Retrieval and Screening}

U.S. Geological Survey (USGS) water-quality data were obtained from National Stream Quality Accounting Network (NASQAN) and Hydrologic Benchmark Network (HBN) files, referred to collectively as the National Stream Water-Quality Monitoring Networks (WQN) (Alexander and others, 1997), and from online retrievals from the USGS National Water Information System (NWISWeb). These two datasets were merged.

\section{National Stream Water-Quality Monitoring Networks (WQN) Data}

Water-quality data were obtained from CD-ROMs containing data from NASQAN and HBN (Alexander and others, 1997). Data were retrieved from files for nutrients, major ions, and physical properties, and then merged.

\section{National Water Information System (NWISWeb)}

Stream water-quality stations were identified and retrieved on a state-by-state basis. A list of all surface-waterquality stations was retrieved for each state. Those stations in the study area (Hydrologic Regions 01 and 02) that had a drainage area of one square mile or more were identified. Water-quality data for these stations were retrieved. Data from all states were merged and duplicates records were removed.

\section{Data Modifications}

\section{Recensoring}

Water-quality constituents with recent values reported with laboratory-reporting limits (LRLs) were identified from the Laboratory Information Management System (LIMS) of the USGS National Water Quality Laboratory (NWQL). For each constituent, the value of each censored concentration was set to half the original value if the sample was collected after the date the NWQL started using LRLs for at least one method of analysis; these dates were available through LIMS. This procedure follows the recommendation of Helsel (2005).
Censored values of dissolved ammonia (parameter code 00608) prior to October 1, 1997, were reset to 0.02 milligrams per liter (mg/L) (as nitrogen), following NAWQA Program recommendations (D.K. Mueller, U.S. Geological Survey, written commun., 2004).

\begin{tabular}{lc}
\hline Water-quality constituent and parameter code & $\begin{array}{c}\text { Date when } \\
\text { NWOL started } \\
\text { reporting values } \\
\text { with laboratory- } \\
\text { reporting levels }\end{array}$ \\
\hline Dissolved ammonia (00608) & $10 / 1 / 1999$ \\
Dissolved nitrite (00613) & $10 / 4 / 2000$ \\
Dissolved organic nitrogen plus ammonia (00623) & $10 / 1 / 1998$ \\
Total organic nitrogen plus ammonia (00625) & $10 / 1 / 1998$ \\
Dissolved nitrite plus nitrate (00631) & $10 / 1 / 1999$ \\
Total phosphorus (00665) & $10 / 1 / 1998$ \\
Dissolved phosphorus (00666) & $10 / 1 / 1998$ \\
\hline
\end{tabular}

Parameter Codes, Calculated Values, and Order of Precedence for Use in Analyses

Total nitrogen was set equal to parameter code 00600 (see next table). If 00600 was unavailable, total nitrogen was calculated by combining parameters: $00625+$ nitrite-plusnitrate, or nitrite-plus-nitrate $+49570+00623$. In either case, total nitrogen was calculated by summing estimated or uncensored values; if the sum was less than $0.2 \mathrm{mg} / \mathrm{L}$ the value was set to $<0.2 \mathrm{mg} / \mathrm{L}$.

Ammonia nitrogen was set equal to 00608 .

Nitrite-plus-nitrate was set equal to one of the following parameters, if available, listed in order of precedence: 00631, 00630, 00618, or 00620.

Total ammonia-plus-organic nitrogen (total Kjeldahl nitrogen) was set equal to 00625 .

Total phosphorus was either set equal to 00665 or calculated from 00666 and 00667 by use of the following method (where " $r$ " is the remark code and " $p$ " is the constituent concentration value for that parameter code): 
If r00667 and r00666 are both not equal to "<", then $\mathrm{p} 00665=\mathrm{p} 00666+\mathrm{p} 00667$

If r00667 equals " <" and r00666 is not equal to "<", then $\mathrm{p} 00665=\mathrm{p} 00666$

If r00667 is not equal to " $<$ " and r00666 equals " $<$ ", then $\mathrm{p} 00665=\mathrm{p} 00667$

If r00667 equals "<" and r00666 equals "<", then $\mathrm{p} 00665=\mathrm{p} 00667$

Suspended sediment was set equal to 80154 .

\section{Reference}

Alexander, R.B., Slack, J.R., Ludtke, A.S., Fitzgerald, K.K., and Schertz, T.L., 1997, Data from selected U.S. Geological Survey National Stream Water-Quality Monitoring Networks (WQN) on CD-ROM: U.S. Geological Survey Fact Sheet FS-013-97, 2 p.

\begin{tabular}{|c|c|c|}
\hline $\begin{array}{l}\text { Water-quality constituents } \\
\text { and parameter codes }\end{array}$ & Description of water-quality constituent & $\begin{array}{l}\text { Calculated from or set equal to } \\
\text { (in order of precedence for use in analyses) }\end{array}$ \\
\hline \multicolumn{3}{|c|}{ (Remarks and values for the following) } \\
\hline PHOSPHORUS & Phosphorus, total mg/L & $00665,(00667+00666)$ \\
\hline 00665 & Phosphorus, total mg/L & \\
\hline 00667 & Phosphorus, particulate, $\mathrm{mg} / \mathrm{L}$ & \\
\hline 00666 & Phosphorus, diss, mg/L & \\
\hline NITROGEN & Total nitrogen, in $\mathrm{mg} / \mathrm{L}$ as $\mathrm{N}$ & $00600,(00625+00631),(49570+00623+00631)$ \\
\hline 00600 & Total nitrogen, in $\mathrm{mg} / \mathrm{L}$ as $\mathrm{N}$ & \\
\hline 49570 & Particulate-N, mg/L & \\
\hline TOT.ORG.N & $\mathrm{NH} 3+$ orgN, wu $\mathrm{mg} / \mathrm{L}$ as $\mathrm{N}$ & 00625 \\
\hline 00625 & $\mathrm{NH} 3+\operatorname{orgN}$, Total $\mathrm{mg} / \mathrm{L}$ as $\mathrm{N}$ & \\
\hline 00623 & $\mathrm{NH} 3+$ orgN, Diss mg/L as N & \\
\hline DISS.AMMONIA & Ammonia, Diss $\mathrm{mg} / \mathrm{L}$ as $\mathrm{N}$ & 00608 \\
\hline 00608 & Ammonia, Diss mg/L as $\mathrm{N}$ & \\
\hline NITRATE & Dissolved nitrate plus nitrite, in $\mathrm{mg} / \mathrm{L}$ as $\mathrm{N}$ & $00631,00630,00618,00620$ \\
\hline 00631 & Dissolved nitrate plus nitrite, in $\mathrm{mg} / \mathrm{L}$ as $\mathrm{N}$ & \\
\hline 00630 & Total nitrate plus nitrite & \\
\hline 00618 & Dissolved nitrate & \\
\hline 00620 & Total nitrate & \\
\hline 00613 & Dissolved nitrite & \\
\hline 00615 & Total nitrite & \\
\hline SUSPSED & Suspended sediment & 80154 \\
\hline 80154 & Suspended sediment & \\
\hline
\end{tabular}


THIS PAGE INTENTIONALLY LEFT BLANK 


\section{Appendix 2. Methods-Stations Used in Analysis of Discharge Conditions (CD-ROM)}

[In pocket]

\section{Table}

2-1. List of U.S. Geological Survey streamgages used in analysis of streamflow conditions, and summary of analyses performed 
THIS PAGE INTENTIONALLY LEFT BLANK 


\section{Appendix 3. Methods-Flow-Adjusted Trend Analysis with Tobit Regression in the S-ESTREND System}

\section{Contents}

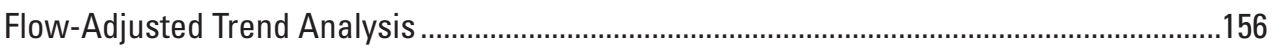

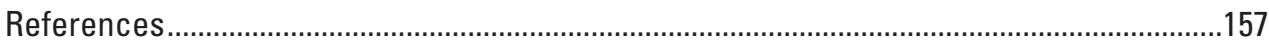




\title{
Appendix 3. Methods-Flow-Adjusted Trend Analysis with Tobit Regression in the S-ESTREND System
}

\author{
By R. Edward Hickman
}

\section{Flow-Adjusted Trend Analysis}

U.S. Geological Survey (USGS) water-quality stations were selected for analysis of flow-adjusted trends in total nitrogen and total phosphorus based on the availability of nutrient concentration data during water years 1993-2003 and the availability of a streamflow measurement associated with each water-quality value. Trends in dissolved nitrite-plusnitrate and dissolved ammonia were analyzed at stations in four basins selected for analysis of point source information, if sufficient water-quality data were available.

Trends were identified with the S-PLUS version of the ESTREND system (Slack and others, 2003). The ESTREND program (Schertz and others, 1991) was developed by the USGS to identify trends in water quality in streams. The program provides three methods to identify trends, and Tobit regression was the method selected to identify trends in this study.

Schertz and others (1991) recommend the amount of data required by the Tobit regression method to determine trends for periods longer than 5 years. First, a minimum of 10 detected observations are needed. Second, a minimum user-specified percentage of the total number of observations in the record must be detected observations; for this study, this minimum value was set to 20 percent. Third, a minimum of one observation per year had to be present in the beginning and ending fifths of the period. Additional requirements of (A) at least one measurement during water years 1996-2000, and (B) no more than four continuous water years with no observations, were used to screen out datasets with observations only at the beginning and end of the period.

Trend tests were conducted for periods ranging from 8 to 11 water years, depending on the availability and distribution of data. Trend test results for a nutrient at a station are reported where sufficient numbers of measurements were available to start the period of the trend test during either water years 1993, 1994, or 1995 and end the period of the test during either water years 2001, 2002, or 2003.

Relations between nutrient concentrations, year, streamflow, and season were developed with Tobit regression for each nutrient at each station with sufficient measurements. The general equation relating water quality to year, streamflow, and season is: where

$$
\begin{aligned}
C & =\text { concentration of nitrogen or phosphorus } \\
& \text { compound, } \\
B_{0} & =\text { intercept, } \\
B_{1} & =\text { coefficient for year, } \\
\text { Year } & =\text { year, } \\
B_{2} & =\text { coefficient for streamflow, } \\
\log & =\text { base-10 logarithm, } \\
Q & =\text { streamflow, in cubic feet per second, } \\
B_{3} & =\text { first season coefficient, } \\
\sin & =\text { sine, } \\
t & =\text { fraction of water year prior to month and } \\
B_{4} & =\text { day of measurement, } \\
\cos & =\text { second season coefficient, and }
\end{aligned}
$$

The term for streamflow was included in each test. The seasonal terms were included only if (A) seasonality appeared to be important based on an examination of a plot of residuals as a function of season, and (B) if the coefficients for the seasonal terms were significant at the 0.05 level.

Trends were identified if the coefficient for year $\left(B_{l}\right)$ was different than zero at the 0.05 level of significance. If $B_{1}$ was greater than zero, concentrations increased over time; if $B_{1}$ was less than zero, concentrations decreased over time. For each nutrient at each station, the magnitude of the change in concentration is reported in percent of mean per year.

Changes in the variance of the residuals over the years were considered as part of each trend test. The level of significance reported for the coefficient for year $\left(B_{l}\right)$ is accurate only if the variance of the residuals is constant over time. Results of a few tests were not reported if the level of significance of coefficient for year was close to 0.05 and if the variance of the residuals did not appear to be constant during the period of the test.

The effects of outlying measurements (outliers) on the results of the trend tests also were considered. For some tests, outliers were removed from the dataset and the dataset was then retested. In some cases, therefore, results presented do not include outliers.

$$
\log (C)=B_{0}+B_{1} * \text { Year }+B_{2} * \log (Q)+B_{3} \sin (2 \pi t)+B_{4} \cos (2 \pi t)
$$




\section{References}

Schertz, T.L., Alexander, R.B., and Ohe, D.J., 1991, The computer program Estimate Trend (ESTREND), a system for the detection of trends in water-quality data: U.S. Geological Survey Water-Resources Investigations Report 91-4040, $72 \mathrm{p}$.

Slack, J.R., Lorenz, D.L., and others, 2003, USGS library for S-PLUS for Windows-Release 2.1: U.S. Geological Survey Open-File Report 2003-357. 
THIS PAGE INTENTIONALLY LEFT BLANK 


\section{Appendix 4. Methods-Trend Analysis Using Coupled Statistical Model of Streamflow and Water Quality}

\section{Contents}

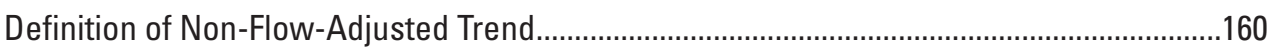

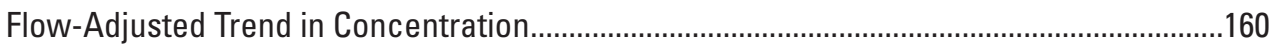

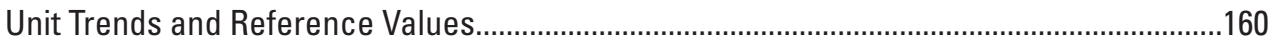

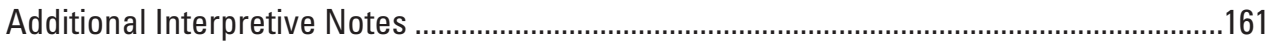

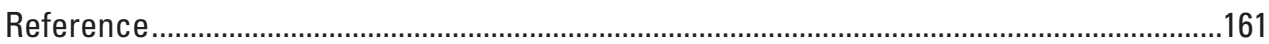




\title{
Appendix 4. Methods-Trend Analysis Using Coupled Statistical Model of Streamflow and Water Quality
}

\author{
By Gregory E. Schwarz
}

This appendix describes the use of coupled statistical models of streamflow and water quality to determine "flowadjusted concentration trends," "modeled instream concentration trends," and "trends in load" in support of the analysis of nutrient concentrations, trends, and loads in the northeastern United States. The modeled instream concentration trend, or non-flow-adjusted trend in concentration, is referred to as "total trend in concentration" in this appendix. Many other alternative descriptive titles are used for trend results of this nature, including: non-flow-adjusted trend, unadjusted trend, full trend, total parametric trend, and modeled instream concentration trend. The phrase "modeled instream concentration trend" has been used in this report to refer to the non-flowadjusted trend in concentration. The non-flow-adjusted trend in load is referred to as simply "trend in load" in this appendix and in this report.

\section{Definition of Non-Flow-Adjusted Trend}

Trend in load and total trend in concentration are defined as the percent changes in model-estimated, smoothed trend in load and concentration over the period of the water-quality record, divided by the length of the record. The modelestimated trend in load and concentration is determined by fitting separate trend models for streamflow and water-quality concentration. The streamflow model, estimated from all daily streamflow measurements available over the analysis period (water years 1993-2003, 1982-2003, 1979-2003, or 19752003 in this report), relates the logarithm of daily streamflow to an intercept, a linear trend term (measured by time expressed as a decimal), and sine and cosine seasonal factors (also functions of decimal time). The water-quality model, estimated from all water-quality measurements collected during the analysis period, relates the logarithm of constituent concentration to an intercept, possibly nonlinear functions of the logarithm of streamflow and decimal time, and to seasonal factors consisting of sine and cosine functions of decimal time. The smoothed trend in the logarithm of water-quality concentration is determined by the streamflow and time trend components of the water-quality model, where the smoothed trend in the logarithm of streamflow is substituted for the actual logarithm of streamflow in the streamflow component. Smoothed trend in the logarithm of streamflow is a simple linear function of decimal time, computed over the waterquality period of record, the function value being given by the average logarithm of streamflow over the water-quality period of record plus the product of the streamflow model trend coefficient and the deviation of decimal time from the mid-point of decimal time for the water-quality period of record. Total trend in concentration is obtained by transforming the modelestimated, smoothed water-quality trend from logarithm space to real space, computing the percent change corresponding to the first and last dates of the water-quality record period, and normalizing by the decimal time length of this period. Trend in load is computed similarly, except the smoothed trend in the logarithm of streamflow is added to the smoothed trend in the logarithm of water-quality prior to retransformation to real space. A formal mathematical description of this method is presented in Sprague and others (2007, p. 10-12), with additional discussion of the estimation of the streamflow and water-quality models, and an explanation of the associated statistical tests for trend.

\section{Flow-Adjusted Trend in Concentration}

The estimation of flow-adjusted trend in concentration is similar to total trend, the only difference being that the streamflow component of the water-quality model is not included in the determination of the smoothed water-quality trend; otherwise, the estimation methods are the same. The estimation of the trend in streamflow is based on the smoothed streamflow trend corresponding to the simple linear function of decimal time described in the previous section. The conversion of this smoothed trend to a trend estimate follows the same procedure described for total parametric trend, the only difference being that the period of the trend is defined by the beginning and ending dates for the flow record in the analysis period, rather than the beginning and ending dates of the water-quality record.

\section{Unit Trends and Reference Values}

The results also report estimates of unit trends - trends expressed in the units of load or concentration (for example, kilograms per year per year or milligrams per liter per year). The unit trends in load and concentrations are determined by multiplying the load and concentration trend estimates (either flow adjusted or total - depending on the trend concept being described, expressed as rates rather than in percentage) by appropriate reference values of load and concentration. The reference value for the logarithm of concentration is obtained by evaluating the water-quality model at reference conditions 
consistent with the trend in water quality at the beginning of the water-quality period of record. These conditions include setting the logarithm of streamflow to its smoothed trend value corresponding to the first day of the water-quality period, setting the trend term to the decimal equivalent of the first day of the water-quality period, and setting the sine and cosine seasonal factors to their average values over the full water-quality period. The logarithm value of the reference concentration is transformed to real space and a multiplicative retransformation factor is applied to correct for statistical bias arising from sample error in the water-quality model coefficients (Sprague and others, 2007). The reference load is computed similarly, except the logarithm of streamflow trend, as determined by the linear streamflow equation evaluated at the starting date of the water-quality period, is added to the logarithm value of the reference concentration prior to transformation to real space; also, a multiplicative constant is applied to convert the result to appropriate load units. The same reference concentration is used to derive total unit trend and flow-adjusted unit trend in concentration; the same reference load is used in the evaluation of unit trend in load and flow-adjusted unit trend in load.

\section{Additional Interpretive Notes}

Flow-adjusted trend, being independent of streamflow conditions, is best used to evaluate changes in water quality arising from changes in contamination sources or management activities in a watershed; conversely, total trend is indicative of the water-quality changes that riverine habitats have actually experienced. If no trend in streamflow is observed over time, the two estimates of trend will be equivalent. Because the water-quality model used to derive these trends includes streamflow as a predictor, the estimates of trend are immune to bias arising from preferential water-quality sampling during high-streamflow events. Care should be taken, however, in interpolating or extrapolating these trend estimates within or beyond the period of record for a site, or in making comparisons of trend across sites that have different periods of record. Because of the possible nonlinearity of trend, as arising from nonlinear specifications of the water-quality model streamflow or trend components, trends within the water-quality period, or trends experienced outside this period could be quite different from the trends reported here. The methodology used to evaluate trend is insensitive to changes in the variability of streamflow or to changes in the unexplained variability of water-quality, both changes potentially resulting in trends in water-quality arising from nonlinearity in the specification of the water-quality model. Accommodation of these uncertainty effects awaits future research.

\section{Reference}

Sprague, L.A., Clark, M.L., Rus, D.L., Zelt, R.B., Flynn, J.L., and Davis, J.V., 2007, Nutrient and suspended-sediment trends in the Missouri River Basin, 1993-2003: U.S. Geological Survey Scientific Investigations Report 2006-5231, $80 \mathrm{p}$. 
THIS PAGE INTENTIONALLY LEFT BLANK 


\section{Appendix 5. Results-Trends in Streamflow, 1975-2003 and 1993-2003 (CD-ROM)}

[In pocket]

Table

5-1. Trends in streamflow, and serial correlation of residuals, 1975-2003 and 1993-2003 
THIS PAGE INTENTIONALLY LEFT BLANK 


\section{Appendix 6. Results-Trend Analysis on Flow-Adjusted Nutrient Concentrations, 1975-2003 and 1993-2003 (CD-ROM)}

[In pocket]

Table

6-1. Results of trend analysis on flow-adjusted nutrient concentrations, using Tobit regression and coupled statistical model of streamflow and water quality, 1975-2003 and 1993-2003 
THIS PAGE INTENTIONALLY LEFT BLANK 


\title{
Appendix 7. Results-Annual Load Estimates, 1975-2003, 1993-2003, and Varied Periods of Record (CD-ROM)
}

\author{
[In pocket]
}

\section{Tables}

7-1. Annual load estimates, confidence intervals, and yields, 1975-2003, 1993-2003, and varied periods of record

7-1A. Annual load estimates, confidence intervals, and yields for total nitrogen, 1975-2003

7-1B. Annual load estimates, confidence intervals, and yields for total nitrogen, 1993-2003

7-1C. Annual load estimates, confidence intervals, and yields for ammonia nitrogen, 1975-2003

7-1D. Annual load estimates, confidence intervals, and yields for ammonia nitrogen, 1993-2003

7-1E. Annual load estimates, confidence intervals, and yields for total Kjeldahl nitrogen, 1975-2003

7-1F. Annual load estimates, confidence intervals, and yields for nitrite-plus-nitrate nitrogen, 1975-2003

7-1G. Annual load estimates, confidence intervals, and yields for nitrite-plus-nitrate nitrogen, 1993-2003

7-1H. Annual load estimates, confidence intervals, and yields for total phosphorus, 1975-2003

7-11. Annual load estimates, confidence intervals, and yields for total phosphorus, 1993-2003

7-1J. Annual load estimates, confidence intervals, and yields for suspended sediment, 1975-2003

7-1K. Annual load estimates, confidence intervals, and yields for suspended sediment, 1993-2003

7-1L. Annual load estimates, confidence intervals, and yields for total nitrogen, varied periods of record

7-1M. Annual load estimates, confidence intervals, and yields for nitrite-plus-nitrate nitrogen, varied periods of record

7-1N. Annual load estimates, confidence intervals, and yields for total phosphorus, varied periods of record 
THIS PAGE INTENTIONALLY LEFT BLANK 


\section{Appendix 8. Results-Trend Analysis on Nutrient Loads, 1975-2003 and 1993-2003 (CD-ROM)}

[In pocket]

Table

8-1. Results of trend analysis on nutrient loads, calculated by using coupled statistical model of streamflow and water quality, 1975-2003 and 1993-2003 
Prepared by the Pembroke Publishing Service Center.

For more information concerning this report, contact:

Director

U.S. Geological Survey

Connecticut Water Science Center

101 Pitkin Street

East Hartford, CT 06108

dc_ct@usgs.gov

or visit our Web site at:

http://ct.water.usgs.gov 


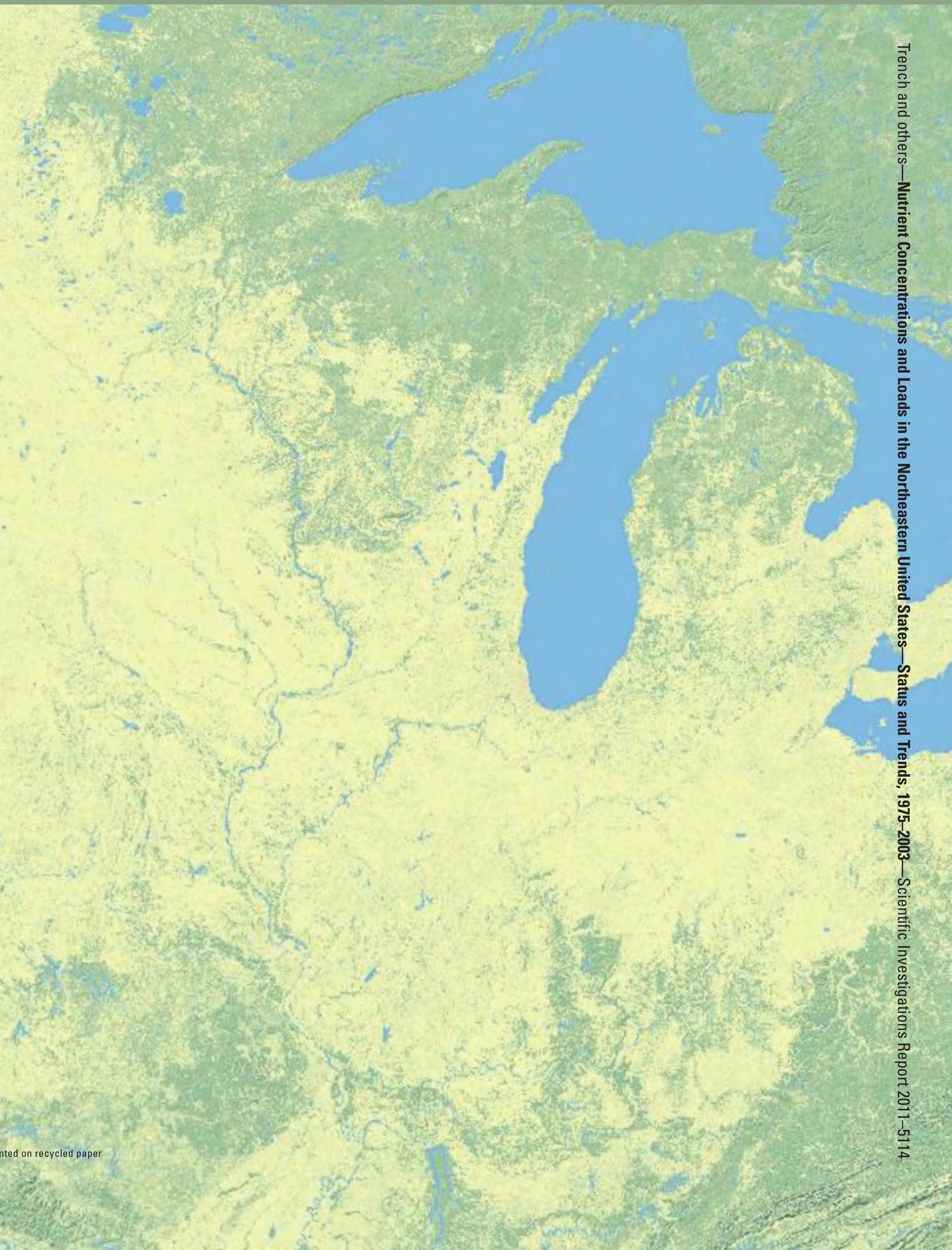

